\title{
A DIFFICULT NEIGHBOURHOOD
}

ESSAYS ON RUSSIA AND EAST-CENTRAL EUROPE SINCE WORLD WAR II 



\section{A DIFFICULT NEIGHBOURHOOD}

ESSAYS ON RUSSIA AND EAST-CENTRAL EUROPE SINCE WORLD WAR II

\section{JOHN BESEMERES}

Australian

National

University

PRESS 


\section{ANU \\ PRESS}

Published by ANU Press

The Australian National University

Acton ACT 2601, Australia

Email: anupress@anu.edu.au

This title is also available online at press.anu.edu.au

National Library of Australia Cataloguing-in-Publication entry

Creator: Besemeres, John F., author.

Title: $\quad$ A difficult neighbourhood : essays on Russia and East-Central Europe since World War II / John Besemeres.

ISBN:

9781760460600 (paperback) 9781760460617 (ebook)

Subjects: Russia--Relations--Europe, Eastern.

Europe, Eastern--Relations--Russia.

Russia--History.

Europe, Eastern--History.

Poland--History.

Dewey Number: $\quad 327.47$

All rights reserved. No part of this publication may be reproduced, stored in a retrieval system or transmitted in any form or by any means, electronic, mechanical, photocopying or otherwise, without the prior permission of the publisher.

Cover design and layout by ANU Press.

Cover photograph: Line of protesters at Dynamivska str. Euromaidan Protests. Events of 20 January 2014, by Mstyslav Chernov. Available at: commons.wikimedia.org/ wiki/User:Mstyslav_Chernov.

This edition (C) 2016 ANU Press

\section{CES Prize}

This publication was awarded a Centre for European Studies Publication Prize in 2015. The prize covers the cost of professional copyediting. 


\section{Contents}

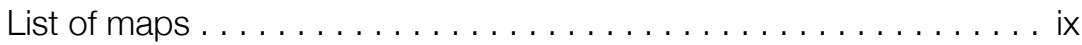

Acknowledgements ...................... xi

Introduction: Reclaiming the Empire $\ldots \ldots \ldots \ldots \ldots \ldots \ldots \ldots$

\section{Part 1. Twentieth-century Poland: War and Cold War}

1. Seven days that shook the world $\ldots \ldots \ldots \ldots \ldots \ldots \ldots \ldots . \ldots$

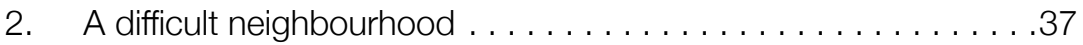

3. Jan Karski's valiant failures . . . . . . . . . . . . . . . . . . . . .49

4. The worst of both worlds: Captain Witold Pilecki between Hitler and Stalin . . . . . . . . . . . . . . . . . . . .63

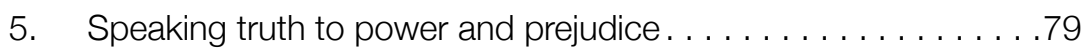

Part 2. Poland and Russia since the fall of communism: Drawing apart

6. Poland/Russia: Peace or ceasefire? . . . . . . . . . . . . . . . . . 91

7. Heading west, heading east: Impressions from Warsaw and Moscow . . . . . . . . . . . . . . . . . . 111

8. Poland at the polls: A win for pragmatism. . . . . . . . . . . . 129

9. Poland's EU presidency: Drawing the short straw . . . . . . . . 135

Part 3. Turning points in Ukraine and Belarus

10. Ukraine: A sharp turn eastwards? . . . . . . . . . . . . . . 141

11. In Belarus, the leopard flaunts his spots . . . . . . . . . . 167

Part 4. Russia and the former Soviet republics: Putinisation at home and abroad

12. Russia and its western neighbours: A watershed moment . . . 181

13. Russia's elections: Leaving little to chance . . . . . . . . . . . 201 
14. Putin's Ceauşescu moment . . . . . . . . . . . . . . . . . .207

15. Setbacks at home, successes abroad: The mixed fortunes of Vladimir Putin . . . . . . . . . . . . . . . . . . 219

16. Putin's phoney war . . . . . . . . . . . . . . . . . . . 229

17. Re-enter Putin, weakened and resentful . . . . . . . . . . . . 239

18. The real Mr Putin stands up . . . . . . . . . . . . . . . . .245

19. Towards a greater Putistan? Part $1 \ldots \ldots \ldots \ldots \ldots \ldots . . \ldots 255$

20. Towards a greater Putistan? Part 2 . . . . . . . . . . . . 269

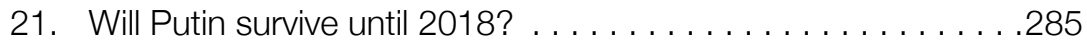

22. Putin's re-Sovietisation project and the Ukrainian jewel . . . . . 297

23. Vladimir Putin: Geopolitical wrecking ball . . . . . . . . . . . . 303

24. Putin's annus mirabilis . . . . . . . . . . . . . . . . . . . . . 307

\section{Part 5. Putin reverts to cold war: Changing the shape of Eurasia}

25. Putin's last territorial demand . . . . . . . . . . . . . . . . . . 329

26. Ukraine: Time to cut a deal? . . . . . . . . . . . . . . . . 335

27. Russian disinformation and Western misconceptions . . . . . . . 355

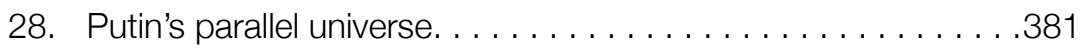

29. Putin's Westpolitik: Back to the USSR . . . . . . . . . . . . 401

30. Peace in our time . . . . . . . . . . . . . . . . . . 421

31. Ukraine conflict exposes Western weakness on Russia . . . . .437

32. Bling and propaganda in an ethics-free zone . . . . . . . . .443

33. Making nice and making enemies. . . . . . . . . . . . . . . 451

34. Ukraine, out of sight . . . . . . . . . . . . . . . . . 459

Select bibliography . . . . . . . . . . . . . . . . . . . .475

Further reading . . . . . . . . . . . . . . . . . . . . . . . . . . .493

Index . . . . . . . . . . . . . . . . . . . . . . . . . . . . . . . 507 


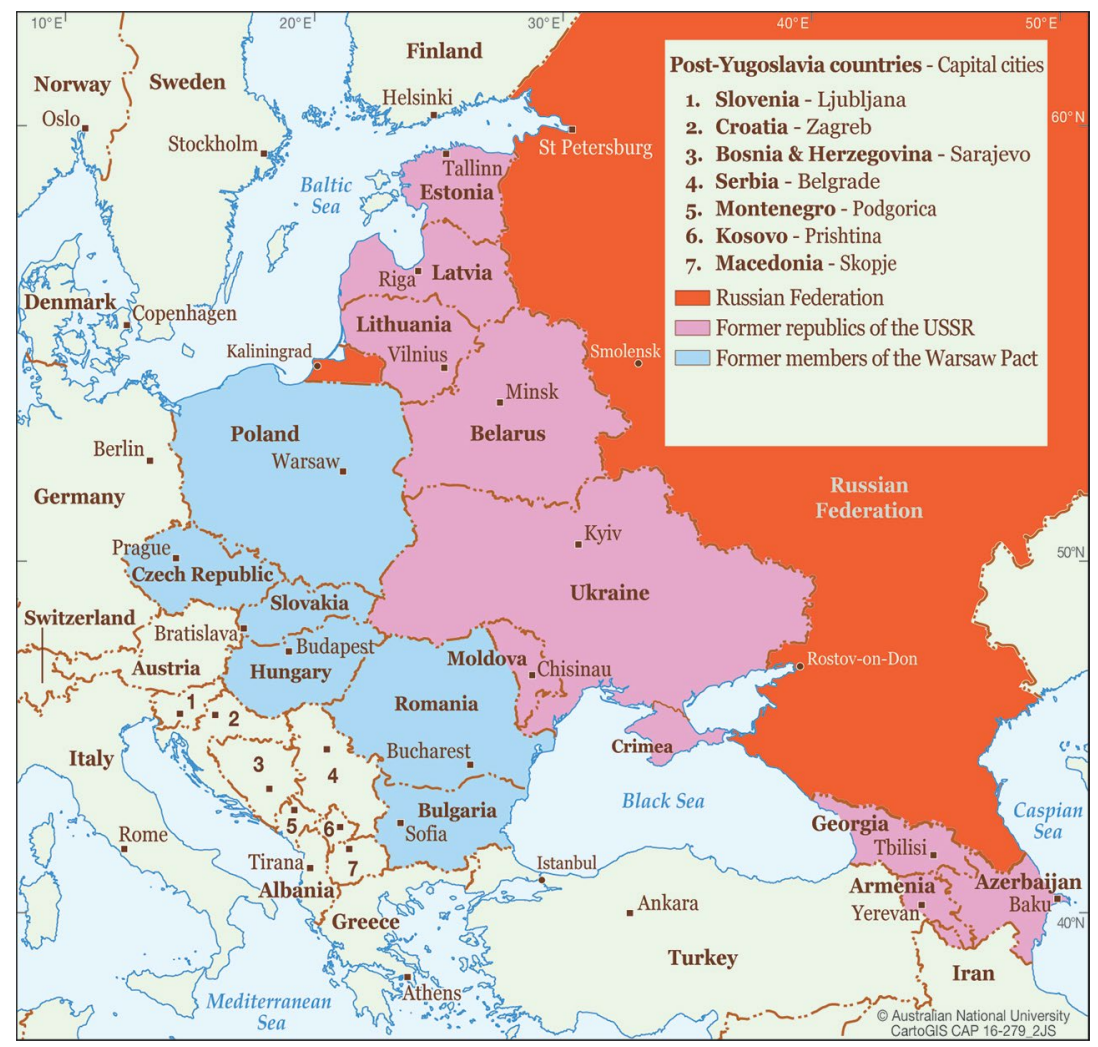

Map 1: Russia and its western neighbours.

Source: CartoGIS, College of Asia and the Pacific, The Australian National University. 



\section{List of maps}

Map 1: Russia and its western neighbours............ vii

Map 2: Ethno-linguistic map of Ukraine. . . . . . . . . . . . . 142

Map 3: The South Caucasian states: Armenia, Azerbaijan

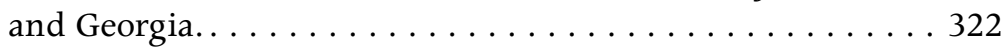





\section{Acknowledgements}

After more than 50 years of viewing Russia and Eastern Europe from different vantage points - academia, government service and living in or visiting the region - like any honest author, I should begin by conceding that a huge amount of such wisdom as I've accumulated is borrowed. Footnotes and bibliographies are a form of very partial acknowledgement, but the debt is essentially undischargeable. Nonetheless, I would like to pay tribute to a few of my more recent intellectual creditors.

But first I would like to warmly thank the staff and members of the Centre for European Studies at The Australian National University for their hospitality over the period in which these essays were being researched and written. In particular, I would like to thank Professor Jacqueline Lo, the Director of the Centre, and Dr Annmarie Elijah, the Associate Director, for their encouragement and support, including through the award of the ANU CES Publishing Prize. The Centre provides a relaxed and stimulating environment for research, and its staff members and visiting fellows past and present have contributed a great deal to maintaining that atmosphere. I thank them all. In addition, the Centre hosts a large number of academic visitors every year, many of whom have had impressive expertise relevant to the subjects touched upon in these essays.

I owe a very great debt to Associate Professor Kevin Windle, who read the manuscript at an advanced stage, making many invaluable suggestions on structure and presentation, as well as detailed content. With his remarkable knowledge of the languages, literatures and history of Europe, especially Russia and Eastern Europe, Kevin was the ideal consultant and adviser. 
Justine Molony and Mary Besemeres also read the entire manuscript, and very closely. With heroic patience they endured my serial cybermishaps, repairing their ravages with precision and great competence. I would also like to thank most warmly Emily Tinker and her colleagues at ANU Press; and Jenny Sheehan and colleagues at CartoGIS, ANU, for the maps. I am deeply grateful to them all. None of the above, nor indeed anyone else, should be held responsible for bloopers of any kind that I have managed to slip past them.

Among the people who have helped me to diagnose trends and assemble facts and arguments relevant to this book, I would particularly like to thank Kyle Wilson, David Wall, Bobo Lo, Stephen Fortescue, Robert Horvath, Peter Rutland, Csaba Nikolenyi, Marko Pavlyshyn, Igor Melchuk, Peter Reddaway, Bob Miller, Peter Browne, Martin Krygier, Janek Pakulski, Seweryn Ozdowski, Chris Cviić, Peter Hill, Saša Pavković, Stefan Markowski, Nina Marković, Halyna and George Koscharsky, Marek Heleniak and Genrikh Salata.

Finally, I would like to thank my wife, Anna Wierzbicka, whose extensive knowledge and love of things Russian as well as Polish have taught me much over decades, and continue to save me many a google. She introduced me to a circle of remarkable and lifelong Polish and Russian friends, with whom any conversation was always a pleasure, as well as a seminar. 


\section{Introduction: Reclaiming the Empire}

This book is not a history of Russia's relations with the former vassal states on its western borders. Most of the essays are snapshots taken between 2010 and 2016 that attempt to present some of the key developments in their interactions as they occurred. In addition, there are some more historical reflections on Poland's experience of German and Soviet dictatorship in the bloodlands ${ }^{1}$ during World War II, and its efforts to escape Moscow's legacy and integrate with Western Europe thereafter (Chapters 1-9). The historical chapters offer background to the story of Russia's recent efforts under President Putin to revive its imperial glories, and why those efforts are usually stoutly resisted by former subject nations, many of which have been through experiences not dissimilar to Poland's. From Chapter 10 on, the story of Russia's domestic evolution and its relations with its former subjects in Eastern Europe unfolds more or less chronologically.

Already from the early 1990s there were growing intimations of Russia's unhappiness with the post-1991 security settlement in Eurasia. The political class had assumed that they would enjoy early prosperity, full acceptance by the Western powers and a seamless

1 See Timothy Snyder, Bloodlands: Europe between Hitler and Stalin (New York: Basic Books, 2010). Snyder's book encapsulates something that Western observers often overlook about the extent to which Eastern Europeans (including the western former republics of the USSR) were the victims of the brutal and brutalising effects of three successive invasions by the vastly superior forces of two of the world's most sanguinary dictatorships in the twentieth century, Stalin's USSR and Hitler's Germany.

Angered by his treatment of Russia's aggression against Ukraine since early 2014, Russian propaganda has begun to target Snyder as an archenemy, wheeling out against him such distinguished historians as the pristine American Stalinist, Grover Furr. For Furr's views, see Ekaterina Blinova, 'Who controls the past controls the future: Why does West hate Stalin?', Sputnik, 25 Aug. 2015, sputniknews.com/politics/20150825/1026165590/why-does-west-hatestalin.html. 
continuation of the international importance they had once enjoyed. As they realised that much of this was not coming about, their resentment grew. Some Western observers began to fear the emergence of a 'Weimar Russia', resentful, revisionist and revanchist, with domestic policies in keeping with the external. While the later Yeltsin was prickly and difficult at times, and his Russia economically in disarray and democratically flawed, the Weimar fears were premature.

Most Western leaders accepted Yeltsin's abrupt withdrawal with equanimity or relief; and they looked to the early Putin with hope, despite his KGB background (his having been the first phone call to President George W. Bush after 9/11, and he having been the protégé of the reformist Petersburg mayor, Anatoly Sobchak). There was also satisfaction with Russia's sudden economic resurgence after 2000, and a feeling that this might lead to embourgeoisement and pressures for pluralist reform, producing another 'man they could do business with'. For their part, Western businessmen, particularly in the energy sector, were quick to grasp the expanding economic opportunities.

The contrary indications - Putin's appointments of KGB mates to most key positions, his use of energy diplomacy to coerce his neighbours (unequal contracts, arbitrary and punishing trade boycotts, extreme price discrimination on political criteria), his progressive destruction of the Gorbachev/Yeltsin democratic reforms, the deteriorating investment climate, the increasingly adversarial stance towards NATO despite Western efforts to engage and inform - should all have been warning signs.

By the time of his belligerent speech to the Munich Security Conference in February 2007, Putin was ready to forcefully spell out his resentments. But the West tried not to notice. At the conference itself, US Defense Secretary Robert Gates sought to allay the fears expressed by some that Putin was adumbrating a new cold war. ${ }^{2}$ Russia's cyberwar against Estonia in May of the same year, coupled with harassment of diplomatic staff and organisation of Estonia's large Russian community into concerted street demonstrations, were

2 See Oliver Rolofs, 'Ein Hauch vom Kaltem Krieg' [A breath of Cold War], Munich Security Conference, 2007, www.securityconference.de/de/ueber-uns/muenchner-momente/ein-hauchvon-kaltem-krieg/. 
a signal of 'hybrid wars' ${ }^{3}$ to come, against which NATO membership, as in Estonia's case, might not be an adequate defence. But few at that time outside the vulnerable capitals of Eastern Europe seemed to feel any great alarm.

In April 2008, with President George W. Bush pushing against Western European objections for Ukraine's and Georgia's strongly pro-Western reform governments to be given a NATO Membership Action Plan (MAP), Putin decided for the first time to attend the NATO summit in Bucharest. NATO was divided, a majority of the Ukrainian population at that time was against membership, and MAPs were withheld from both countries. Deeply worried by the implications for themselves and by the demonstration of Putin's lobbying capabilities in Europe, according to a senior EU official (personal communication), some new eastern members of NATO lobbied Merkel vigorously on their own account, which helped elicit a bland statement by NATO that Ukraine and Georgia would become members at some unspecified time. This assurance, however, carried little credibility.

Putin was reportedly furious with this addendum to the record, but in public spoke more moderately than at Munich and was probably pleased with the net outcome at Bucharest. ${ }^{4}$ Despite the vague assurances that Ukraine and Georgia would at some time become NATO members, it was clear from the reactions of 'old Europe' that further NATO expansion to former republics of the Soviet Union was off the agenda.

Putin soon had an opportunity to capitalise on his Bucharest success. In August 2008, Moscow's long campaign of aggression against Georgia and President Mikheil Saakashvili evoked an ill-judged attempt by Saakashvili to intervene with force against the ongoing expulsion of ethnic Georgians by Russia's South Ossetian proxies. Moscow had been goading Saakashvili to attempt such a thing for some time and was well prepared militarily to seize the opportunity presented by Saakashvili's rash own goal. Russian forces immediately

3 See Jānis Bērziņš, 'Russia's new generation warfare in Ukraine: Implications for Latvian defense policy', National Defence Academy of Latvia, Center for Security and Strategic Research, Policy paper no. 2, April 2014, www.naa.mil.lv/ /media/NAA/AZPC/Publikacijas/PP\%20022014.ashx.

4 See Steven Erlanger, 'Putin, at NATO meeting, curbs combative rhetoric', New York Times, 5 Apr. 2008, www.nytimes.com/2008/04/05/world/europe/05nato.html?_r=0. 
invaded much of the country, de facto annexing South Ossetia and Abkhazia, Russia's two protectorates within Georgia. In fact, Saakashvili had undertaken no action in Abkhazia, where massive expulsion of the ethnic Georgian majority in the province had occurred in the 1990s, facilitated by Russian 'peacemakers'. The West basically accepted Russia's successful fait accompli in Georgia. President Nicolas Sarkozy managed to negotiate a ceasefire with Russia on unfavourable terms, which Russia has also since violated with impunity.

In the years since, the de facto annexation of South Ossetia and Abkhazia has advanced further, with militarisation by Russia of both the territories. And Putin has unilaterally appropriated additional slices of land, taking him within easy range of vital Georgian strategic assets. None of these land grabs has evoked a serious response from the West. While Brussels has cautiously encouraged Georgia's efforts under the more pragmatic Ivanishvili regime to draw closer to the European Union, it seems increasingly unlikely that Putin will allow Georgia's integration with the European Union to proceed further. If and when he does put a stop to it by coercive means of one kind or another, it is far from certain that there would be any significant pushback from the West.

The new US administration of Barack Obama came in disavowing many of the policies of its predecessor. It moved quickly to 'reset' its relations with Russia to deal with Obama priorities, for which Russia's cooperation was deemed essential, like nuclear disarmament and containment of Iran's nuclear program. By implication, Putin would have taken the reset as tacit acceptance of his actions in Estonia and Georgia, as well as his 'energy diplomacy' with its coercive trade blockades against Russia's western neighbours.

A notable example of the latter was the Gas War against Ukraine in 2009, which forced Kyiv to accept a cripplingly high price for essential gas imports, further weakening the pro-Western Orange leadership, and helping to bring about its downfall. Moscow exports corruption as well as gas to target countries, and it is not any exculpation of Moscow to say that corrupt members of the Ukrainian political class were complicit in these outcomes. 
Simultaneously with these forward moves externally, Putin was strengthening his domestic 'power vertical' and advancing the patriotic conditioning of his subjects through heavy-handed propaganda in the education system and the media.

While views of the end of communism and the Soviet Union were more positive in the former Soviet republics, where the factor of national pride offset the disruptions and difficulties of the 1990s, in Russia much of the population came to see the transition to the market and democracy as the main source of their woes. Convincing them after decades of Soviet acculturation that the West was the cause of most of the ills that afflicted them was not difficult. Members of the political class were particularly susceptible to the idea that Russia was not being shown sufficient respect, indeed that the West had deliberately and consciously humiliated it.

Progressively under Putin, the old Soviet adversarial view of the world was restored, complete with a distinct view of the history of the years of perestroika to that held in the West or, indeed, in most of the rest of the Soviet empire. Mikhail Gorbachev and Boris Yeltsin had both become widely despised figures in the Russian public, a status that Putin cemented into place, though without taking punitive action against either of them. Yeltsin had chosen Putin as his successor on the understanding that his vital interests would be preserved. But the view of the 1990s that Putin successfully promoted throughout most of Russian society, depicting nothing but chaos and penury, ensured that the two former presidents' standing would not revive. In fact, the economic problems that blighted Gorbachev and Yeltsin's presidencies were largely the result of sustained low prices for oil and gas and their valiant and partly successful attempts to reform the Soviet economy. By contrast, the spectacular economic progress during Putin's first two terms owed a vast amount to a sharp increase in Russia's energy earnings, as well as the delayed positive effects of the reforms.

The parallel historical reality that Putinism has constructed (see Chapter 28, 'Putin's parallel universe') has laid the foundations for a renewed stand-off not dissimilar to the Cold War, but based on a new, anti-Western, highly nationalist ideology, which is ostensibly 'conservative', rather than Marxist-Leninist. While obviously more limited in its potential appeal to the main ethnic groups in the former 
vassal states, this ideological construct makes it easier for Russia to cultivate ethnic Russians and Russian speakers in neighbouring populations as fifth columnists.

The stopgap presidency of Dmitry Medvedev (2008-12) represented a mainly cosmetic though, in some measure, also real break from the Putinist narrative. But his influence on events was never strong enough to leave permanent marks. Even before Putin returned to the presidency in 2012, his neo-Stalinising influence from the prime ministership was palpable. And it has grown relentlessly since.

The essays in Parts 2 to 5 of this book pick up the story from early 2010, beginning chronologically with the presidential elections in Ukraine (see Chapter 10, 'Ukraine: A sharp turn eastwards?'). Thanks to the internal feuds and ineptitude of the pro-Western Orange leadership in Kyiv, and the destructive influence of the global financial crisis on the Ukrainian economy (which produced a 15 per cent decline in GDP in 2009), the populist Orange Prime Minister Yulia Tymoshenko lost the presidential election, though only by a surprisingly narrow 3 per cent margin to her pro-Russian rival, Viktor Yanukovych. Moscow contributed significantly to the downfall of the Orange forces by its 'energy diplomacy' and heavy propaganda in the more Russified eastern provinces.

But the Orange forces brought much of their fall from grace on themselves. The rashly anti-Moscow President, Viktor Yushchenko, alienated Putin and his pro-Russian Ukrainian sympathisers more than was wise, particularly during an economic crisis. During his last months in office, as his poll ratings fell into low single figures, he devoted most of his energy to supporting Yanukovych, hoping thereby to ensure that the Orange candidate, Tymoshenko, would lose. Yet it was Yanukovych's team who had earlier blatantly falsified the presidential contest of 2004 against Yushchenko himself, which in turn led to the outbreak of the Orange Revolution of 2004-05, forcing the rerun won comfortably by Yushchenko. Without Tymoshenko's charisma and rhetorical skills in mobilising the Orange crowds in 
2004-05, Yushchenko may well have not had a chance to assume the presidency. But in 2010, it was his perverse support for Yanukovych that tipped the balance against Tymoshenko. ${ }^{5}$

When the Orange incumbency ended in electoral defeat, Western leaders and commentators shed few tears. Insiders commented on a 'Ukraine fatigue' pervading relevant Western official circles. ${ }^{6}$ Paradoxically, the pro-Russian Yanukovych's victory over the Westernising Yushchenko was received in the West almost with relief and with hope for a better interlocutor. This response seemed curiously shortsighted. The genuine achievements of the Orange years in working towards Western integration, while consolidating democratic governance and media coverage in the country, were forgotten, and the extent of Yanukovych's contempt for democracy and his strong leaning towards Moscow seemed greatly underestimated in the West. Yanukovych's win would, I argued, impart strong momentum to Putin's restoration project for the former Soviet empire.

Ukraine fatigue had its own causes, but it was also part of a wider trend in Western attitudes in both the US and Europe. The economic problems of the GFC, coming soon after the big bang expansion of the European Union led to a growing reluctance by older EU members to accept the prospect of further enlargement to the East; so there was enlargement fatigue in general, and not just in relation to Ukraine. And, after the Bucharest NATO summit of 2008 and the Russian invasion of Georgia, there was a similar reluctance to accept new NATO members. Many core NATO members, both populations and political elites, feel reluctant to commit themselves to serious defence of new member states in the event of their invoking article 5 of the North Atlantic Treaty that calls for all NATO members to regard an attack on any one of them as an attack on all.

5 See Taras Kuzio, 'Yushchenko versus Tymoshenko: Why Ukraine's National Democrats are divided', Demokratizatsiya, vol. 21, no. 2 (Spring 2013): 215-40, www.taraskuzio.net/ Comparative\%20Politics_files/Kuzio_YuliaVersusViktor.pdf.

6 See, for example, ex-US ambassador to Kyiv, Steven Pifer, 'Curing “Ukraine fatigue"', New York Times, 9 Feb. 2010, www.nytimes.com/2010/02/10/opinion/10iht-edpifer.html?_r=0. 
Russia's growing belligerence towards NATO has strengthened that reluctance, ${ }^{7}$ while greatly increasing the anxiety both of existing new members like the Baltic states, as well as countries on Russia's borders who are not members but increasingly aspire to be. Moscow's hybrid warfare rehearsals in its cyberwar against Estonia in 2007, and its invasion of Georgia in 2008, reinforced those trends rather than suggesting any need for pushback against Russia. Many Western leaders responded to Putin's increased assertiveness by accepting his policies as the new normal and trying to moderate them by 'dialogue', concessions and conciliation. This, however, has seemed only to increase the Putin clan's anger, indignation and territorial and other ambitions.

Yanukovych's presidential victory in 2010 led to an almost immediate reversal of Ukraine's Western orientation. Kyiv's concessions to Moscow on security cooperation, in particular its agreement to extend Russia's access to naval facilities in Crimea to 2042, further consolidated Putin's position in Ukraine. NATO and the European Union by now seemed reluctant to issue any more enlargement challenges and, in the course of 2010, Putin had two further successes, in Poland and Belarus, though one of those successes, with Poland, differed from the usual directly coercive pattern, and, in the event, proved short-lived.

While still a relatively new member of the EU and NATO, under the skilful leadership of Premier Donald Tusk, Poland had begun to play a major role in European affairs with an agenda that, unsurprisingly, did not tend to favour Kremlin interests. As an EU member able to invoke the help of Brussels and Berlin, Warsaw could more effectively resist Russian pressures. Despite Yanukovych's tilt towards Moscow, Poland was also actively seeking to draw Ukraine closer to Brussels. At the same time, Tusk and his Civic Platform Party were less emphatically anti-Russian than their predecessors, the Kaczyński twins and their Law and Justice Party. Both the Russian and Polish governments seemed inclined to explore the possibility of a partial rapprochement,

7 On the (un)readiness of old Europe to come to the aid of a new member state under attack by Russia, see Katie Simmons, Bruce Stokes \& Jacob Poushter, 'NATO public opinion: Wary of Russia, leery of action on Ukraine', Pew Research Center, 10 Jun. 2015, www.pewglobal. org/2015/06/10/1-nato-public-opinion-wary-of-russia-leary-of-action-on-ukraine/. 
particularly on so-called 'difficult' historical issues like the Katyn massacre of some 22,000 Polish officers by the Soviet NKVD secret police during World War II.

When in April 2010 President Lech Kaczyński and 95 other Polish military and political leaders were killed in a plane crash near Smolensk on their way to a memorial service for the victims of Katyn, the tragedy paradoxically seemed to offer a chance for strengthening the rapprochement. Putin, who was hoping improved relations with Poland would dissuade it from seeking Brussels's support for its anti-Russian policies, went out of his way to seem reasonable. For a time there was sweetness and light and the expectation of more to come. A serious or sustained rapprochement, however, always seemed unlikely to those familiar with the history (see Chapter 6, 'Poland/ Russia: Peace or ceasefire?'); and it was not to be. When it became apparent that Putin's moments of partial truth in public about Russian war crimes against Poland were not going to yield sufficient rewards, Moscow rowed back from these concessions, and the relationship soured again. ${ }^{8}$

Politicised disputes in Poland about the causes of the crash and wild conspiracy theories surfacing from the Law and Justice side of politics - that the Polish Government had colluded with Russia to kill President Kaczynski and conceal their traces - were an important part of the story. But Moscow soon returned to form, withdrawing any support for an honest enquiry, refusing even to return the wreckage of the plane, and duly presenting its own tendentious findings that blamed the Poles entirely for the accident, and admitted no fault on the Russian side. Perhaps the main obstacle to maintaining the thaw in relations, however, was Poland's active engagement in initiating and advancing the EU's Eastern Partnership (EaP), which was aimed at drawing the former Soviet western republics, including Ukraine, into economic and political reforms, and a closer relationship with the European Union.

8 See Halya Coynash, 'Russia says Poland, not USSR, was Hitler's ally and responsible for Holocaust', Prava Lyudiny v Ukraini (Human Rights in Ukraine), 25 Sep. 2015, khpg.org/index. php?id=1443091855. 
Poland made particular efforts to interest the Belarus dictator Alexander Lukashenka in embarking on a reform course, offering him financial support through the European Union should he choose to do so. The Belarus economy was in bad shape, partly because Lukashenka had spent profligately in the hope of ensuring a clear win for himself in Belarus's December 2010 presidential elections. In the run-up to the elections, he had uncharacteristically permitted strong opposition candidates to challenge him at a time when he was at a low point in opinion polls.

Lukashenka was at this time flirting with the European Union, as he sometimes does when he feels he needs a hedge against Russian pressure. Putin, who despises Lukashenka, had been attempting to destabilise him by a scurrilous propaganda campaign accessible to Belarusian television viewers. To keep Brussels sweet and supportive, Lukashenka had allowed a little more freedom of expression in the run-up to the elections, which further strengthened the opposition challenge.

Lukashenka's performance in the poll appears to have been well below his expectations. ${ }^{9} \mathrm{He}$ decided to falsify the election results (implausibly claiming to have received four-fifths of the vote), abruptly reverse his mini-liberalisation program, suppress the resulting street demonstrations, and brutalise, arrest and imprison most of the opposition presidential candidates and many of their supporters (see Chapter 11, 'In Belarus, the leopard flaunts his spots'). This predictably led to sanctions and condemnation from the European Union, pushing Lukashenka back into Russia's grasp. In due course, Moscow helped him escape from his economic fiasco by generous subsidies and credits, but subject to certain conditions that would have enabled Russian investors to take over key strategic assets in Belarus. Lukashenka delivered on some of the conditions, but did his best to wriggle out of others, and has since wavered between greater and more limited compliance with Russia's wishes in exchange for handsome economic support from the Kremlin.

9 On this, see Andrew Wilson, Belarus: The last European dictatorship (New Haven, CT: Yale University Press, 2011), p. 231 and ff. 
Five years on, we are witnessing a not dissimilar scenario, with Lukashenka alarmed by Putin's invasion of Ukraine, worried about his own survival and that of Belarus as an independent country, and again seeking a mini-rapprochement with the West. So history seems poised to repeat itself in some form. But Lukashenka's crackdown on his domestic opposition in 2010, and his return to Moscow's embrace were undoubtedly a victory, if less than total, for Putin. Should Lukashenka persist with his current impertinence, a Ukrainian fate may well await him and his subjects sooner or later, at which point Western sympathy and support will doubtless again prove less than effective.

The Ukraine, Georgian and Belarus stories of 2008-10 illustrate the overall pattern of events in Russia's relations with its western neighbours: Moscow attempts to convert the economically based partial dependence of the former vassals into greater subordination by various forms of inducement and military or economic coercion, but the vassals resist. Often there is a strong nationalist or democratic, Westernising element in the resistance, but at a minimum there is a reluctance by any of them to sacrifice the sovereignty and independence that they had won with the collapse of communism and the break-up of the Soviet Union.

The Obama administration and most EU leaders were not initially greatly disturbed by Moscow's increasingly coercive policies towards its neighbours. But, under pressure from new member states fearful of the implications for their own security, NATO and the European Union slowly began to see Putin as representing a challenge that needed a response. With the partial exception of the western Balkan states (post-Yugoslavia plus Albania), enlargement has been effectively off the NATO table since the Bucharest summit of 2008. The outlook for new EU accessions has become similarly unpromising. The West has reached, instead, for less than adequate alternatives. The most prominent of these has been the EU's Eastern Partnership, in which Poland and Sweden were the key movers. After a long delay during which, in deference to Russia's sensitive feelings, NATO did nothing, it too has also finally resorted to policies of 'reassurance' for its new eastern member states on the Russian frontline, strengthening air patrols around the Baltic region, and increasing military exercises and small, non-permanent deployments of NATO forces in the East. 
In 2016, further modest measures have been announced or foreshadowed. On 10 February, NATO defence ministers agreed to strengthen their presence in Eastern Europe member states, though still on a rotational basis and not with the permanent boots on the ground that most new members have been wanting for years. The numbers to be deployed and from which NATO countries they are to come are still to be negotiated, but are likely to be relatively small, probably no more than 3,000. On 2 February, US Defense Secretary Ash Carter unveiled a US $\$ 3.4$ billion plan to increase prepositioned US heavy equipment in Europe, sufficient to equip a third US heavy armoured brigade to add to the two such units based in Italy and Germany. But, again, the US forces involved will be rotational, and mainly deployed to the Eastern members in small units for training purposes. For comparison, during the Cold War, NATO had 20 fully equipped divisions along the West German border with the Warsaw Pact countries, which is roughly the same length as the combined borders today of the Baltic states with Russia and Belarus (whose military is closely coordinated with Russia's). ${ }^{10}$

These measures, while welcome, are inadequate. A RAND study released on the same day as the Carter announcement reported that a series of wargames conducted in-house by RAND, in which Russian attacks were simulated against Baltic state targets, indicated that Russian forces could be in Riga and/or Tallinn within two to three days. Moreover, if US and Baltic forces tried to resist the Russian advance with the forces that they had available in theatre, they would be quickly overwhelmed and take heavy casualties. The study found that a force of at least seven brigades, including three heavy brigades, would be needed in the area to prevent such an outcome. ${ }^{11}$

Inadequate as they all have been, the softer alternatives to EU and NATO membership, and the cautious Western responses to Russia's increasingly threatening military posture have enraged the Russians as much or more than the original expansions of NATO and the European Union did. Russia has, to take the most obvious

10 John-Thor Dahlburg \& Robert Burns, 'NATO ministers approve new force for Eastern Europe', Globe And Mail, 10 Feb. 2016.

11 David A. Shlapak \& Michael Johnson, 'Reinforcing deterrence on NATO's eastern flank: Wargaming the defense of the Baltics', www.rand.org/pubs/research_reports/RR1253.html; Dan De Luce, 'If Russia started a war in the Baltics, NATO would lose-quickly', Foreign Policy, 3 Feb. 2016. 
example, fought numerous trade wars and, now, also a military war of choice against Ukraine over Kyiv's decision to sign an Association Agreement (AA) with the European Union. EU seniors never fail to emphasise that an AA is not a prelude to EU membership. In early March 2016, EU Commission President Jean-Claude Juncker declared that Ukraine would not be joining the European Union or NATO any time in the next 20-25 years. He may have been trying to help his Dutch colleagues cope with domestic unease about whether the Netherlands should ratify the EU's AA with Ukraine. But his casual comments will add to the demoralisation of Ukrainians generally, and the beleaguered government in particular. The authority of a Luxemburg EU politician, however senior, to speak on NATO's behalf is problematic, but Juncker's remarks probably reflect a strong and growing feeling among many in Brussels and the European Union of 'Ukraine fatigue' - that Ukraine is becoming one problem too many for them, alongside the migration crisis, Brexit and Syria. As Juncker often does with his statements relating to Russia, he certainly would have gladdened hearts in the Kremlin.

But, despite such reassurances, and even in tandem with 'resets' and periodic efforts to 'repair the relationship with Russia', Moscow presents AAs and other modest and peaceful forms of Western outreach as dire threats to its security though, in truth, the only countries whose security has been visibly threatened in recent years have been Russia's western neighbours.

In fact, the struggle over Eastern Europe since the 1990s has always been highly asymmetrical: reluctant expansion by Euro-Atlantic organisations (see Chapter 28, 'Putin's parallel universe') in response to insistent efforts to join by would-be new members, coupled with attempts by Western leaders to reassure Russia and draw it into some sort of broadly equivalent partnership in an unthreatening win-win situation. The problem, however, is that Russia doesn't believe in win-win situations, and responds with anger, threats and various forms of coercion. The West, in turn, then curtails further access to its Euro-Atlantic clubs, refuses increasingly desperate appeals from new members for some weaponry and significant forces to at last be deployed permanently on their territory, and offers concessions to assuage Russia - for example, cancelling particular ballistic missile 
defense projects, and inviting the Kremlin to help Brussels reconsider an EU AA that has allegedly damaged or offended Russia. But none of the above works.

If it all amounts to a cold war, it has been a cold war conducted, at least until very recently, by one side only. The West has been reluctant to view Russia as an adversary. And most of its interventions on behalf of the former republics and, arguably, also the new member states from the old Warsaw Pact, have been too little and/or too late. Putin behaves as though he is confident that, if Russia issues direct challenges to the post-1991 order, the West will not defend it with much unity or resolve.

While they do not say so overtly, some Western leaders in the European Union and Washington seem to believe that the post-1991 settlement in Europe is something about which the West should try to be flexible. Despite the shock at Russia's lightning invasion and annexation of Crimea, for example, and the sanctions that were imposed in response, the subject of Crimea seldom comes up. Similarly, despite US, UK and French signatures (as well as Russian) on the Budapest Memorandum on Security Assurances of 1994 assuring Ukraine of freedom from coercion of any kind in exchange for its divesting itself of nuclear weapons, that instrument has been dishonoured by all signatories and is not normally mentioned in official discourse.

Many Western commentators find a rich variety of reasons why Moscow deserves special compassionate treatment, unlike its escapees. It is often argued that Russia was treated unfairly and humiliated by the West at the end of the Cold War, ${ }^{12}$ and that it is time we showed more understanding for their 'legitimate interests' in wherever. Similarly, 'Russia' won World War II for us at tremendous cost to itself, and we should be eternally grateful for that (in this narrative, no credit is due to its western neighbours Ukraine and Belarus for that outcome, by the way - their contributions and sacrifices, which per capita were much greater than Russia's, remain invisible and Moscow's regularly expanding estimates of the USSR's war losses are routinely attributed to Russia alone). And other arguments are deployed: the

12 See Anne Applebaum, 'The myth of Russian humiliation', Washington Post, 17 Oct. 2014, www.washingtonpost.com/opinions/anne-applebaum-nato-pays-a-heavy-price-for-givingrussia-too-much-credita-true-achievement-under-threat/2014/10/17/5b3a6f2a-5617-11e4-809b8cc0a295c773_story.html. 
countries to Russia's immediate west are not real countries (Putin's view, but sotto voce accepted by many in the West); or not important countries; or certainly are less important than Iran, Syria, Iraq, or Islamic State; or belong to Russia's eternal sphere of influence; or are a bit, let's face it, fascist; or are strategically indefensible; or may irresponsibly trigger a nuclear attack on us of the kind Putin and his senior officials keep threatening us with; or would be far too costly to support economically, much less militarily; or mean far more to Russia than to us; and so on.

The threat posed by Putin's agenda of corralling as many former vassals as possible back into his sphere of influence through coercive means has become clearer to Western leaders and observers since he returned to the presidency in 2012. And it is a far-reaching agenda, which includes rehabilitating not just the 1945 Yalta settlement in Europe, but also the Molotov-Ribbentrop Pact, the incorporation of the Baltic states, the Winter war against Finland in 1939-40 and the apparently permanent Finlandisation of Finland and, both domestically and (more cautiously) externally, the rehabilitation of Stalin as a great if at times somewhat harsh leader who saved Russia and the world.

Recently, the Kremlin has again initiated some modest measures commemorating the victims of Stalinism in this or that locality. But this endless cycle of official de- and re-Stalinisation has been rolling on for many decades under various Kremlin incumbents. Moscow uses this mechanism instrumentally (as with Poland in 2010) and, when the dividends decline, it reverses course again. The present highly selective mini-thaw on Stalin's repressions is probably part of Putin's overall campaign (including by evoking the era of the grand wartime coalition with Stalin) to appeal to the West for sanctions relief, to achieve a favourable outcome in East Ukraine and, more generally, to revise the Eurasian security order in Moscow's favour.

Despite the increasing glimmerings of comprehension, the Western response continues to be marked above all by disunity, lack of leadership, notably from Washington but also from Europe itself, and irresolution. As a result, Russia's probing of the limits has progressively expanded and, on present indications will probably continue to do so, with occasional pauses for a peace offensive. 
With the invasion and annexation of Crimea and its hybrid war on eastern Ukraine, Moscow caught the West's attention more than with any of its earlier manoeuvres. The sanctions that were applied, initially not much more than symbolic, over time gathered in strength and bite. Though many influential Western leaders and governments, both to the left and the right, have wanted almost from the outset to phase out the sanctions, contrary to Moscow's reasonable expectations they have actually been expanded and extended. That was largely the fortuitous result of the shooting down of flight MH17 on 17 July 2014. Fortuitously again, but happily, the slump in energy prices and the consequent fall in the rouble and rise in inflation in Russia have greatly strengthened the sanctions' economic impact. The Russian leadership pretends that sanctions have not and will not lead to a change in its policies; and opinion polls in Russia suggest that Putin's high popularity has not yet been greatly affected. But there are numerous signs that he is eager to find a way to ease the sanctions, and that it is because of them that he has been holding back from bolder efforts to further extend his occupation of Ukrainian territory.

Nonetheless, over the longer run, Putin may not be satisfied with anything short of a compliant government in Kyiv, and control over a substantial part of Ukraine's eastern and southern regions such as would give Russia guaranteed access to Crimea and to Ukraine's battered military industrial complex. In the meantime, he will settle for a frozen conflict in Donetsk and Luhunsk provinces, and constitutional changes that would enable him through his proxies in the 'people's republics' to block any westward strategic integration by Kyiv.

He probably calculates that what he not unreasonably sees as the weak, divided and naïve leadership of the West will finally agree to a settlement largely on his terms. As the Georgian case has repeatedly demonstrated, a frozen conflict can be unfrozen and further land or sovereignty sequentially confiscated at short notice. And, if frustrated in his expectations of the negotiation process, and/or if the moment were propitious owing, for example, to a Middle Eastern contingency or a sharp rise in the oil price, Putin could yet risk violent destabilisation of further provinces, followed by hybrid military incursions to 'restore stability'. Even if such moves were not a military success, they might be enough to finally force Ukraine into bankruptcy and internal disorder, which, in Putin's mind, would 
be a great improvement on a Ukraine successfully reforming itself and integrating with Europe. It could also set the scene for further operations at a later date

The geopolitical tug-of-war over Ukraine has been at the heart of the broader contest between Russia and the West since Putin returned to the presidency. But there have also been skirmishes over other former republics, notably Georgia, Moldova and Armenia (see, in particular, Chapters 19 and 20, 'Towards a greater Putistan?', Parts 1 and 2; and, Chapter 29, 'Putin's Westpolitik: Back to the USSR'). Moreover, Russia has increased its efforts at destabilisation further afield, particularly in the Baltic/Scandinavian region: threatening overflights, military build-ups in adjacent territories, calls to ethnic Russian 'fellowcountrymen' (sootechestvenniki) to assert themselves, and financial and other support to anti-EU hard-right and hard-left parties.

But the main focus continues to be on the western former republics of the Soviet Union. Putin has been trying to build up counter-structures to the main European and Atlantic institutions, into which he would like to herd his balking former vassals, and over which he intends to maintain dominance and control. He would prefer to have in place in the former republics securely autocratic systems, preferably led by pro-Moscow strongmen who would be free to enjoy their own domestic power verticals but should, at the same time, respect the power vertical within Putin's new Soviet Union-lite.

Putin has apparently succeeded in pressuring Armenia back into the fold by playing on its justified fear of Azerbaijan's growing arms buildup. The most recent developments in Georgia and Moldova, the two former republics apart from Ukraine that are still actively pursuing European integration and which have been under pro-Western leaderships for over 13 and seven years respectively, will have given Moscow considerable encouragement. Its long campaigns against the ruling coalitions in both countries have eaten away at their popular support, while the poor economic performance of the European Union and the laborious process of integration reduce the attractions of the Brussels connection. The political elites have themselves undermined their cause by engaging in unedifying factional struggles and corruption. In Moldova, a sum equal to one-sixth of the country's GDP was spirited out of the banking system in one gigantic heist. These scandals and internecine jousts are typically murky, the hand of 
Moscow is often suspected, but the involvement of pro-EU politicians is also apparent, and the population certainly so perceives it. If a pro-Western course is to be maintained in either country, a good deal of luck and some dubious tactics may be required. Meanwhile, Brussels is losing enthusiasm for the struggle, and the onset of a similar fatigue in relation to Ukraine is also becoming apparent.

But Moscow is not finding things all smooth sailing, either, as is demonstrated by the difficulties it is experiencing in drawing the former republics into its network of institutions. These counterinstitutions, like erstwhile Soviet organisations, are made up to look like something they are not. The Eurasian Customs Union, the Eurasian Commission (EC) and the Eurasian Economic Union (EEU) or Eurasian Union are intended to simulate the appearance of EU institutions, even to the point of usurping acronyms. ${ }^{13}$ They are meant to seem as attractive and respectable as EU institutions, and are presented as constituent parts of Putin's broader vision of a multipolar world, with the EU, the Eurasian Union and China as three of those poles. To date, Putin's Customs Union has acted not as a trade-facilitating but as a trade-busting organisation, often highly prejudicial to the interests of the non-Russian members unless, as in Belarus's case, they are being specially favoured by Moscow. With the sharp slide in energy prices and the rouble, Eurasian Union members, particularly in the former Soviet Central Asian republics, have suffered further severe economic difficulties arising from their close connections with Moscow.

On the military/security side, there is the Collective Security Treaty Organization or CSTO, a poor man's successor to the Warsaw Pact. Currently only six of the former 15 Soviet republics are members of the CSTO, though Moscow continues to hope for foreign adherents. Under all of its leaderships, Ukraine has steadfastly refused to join the CSTO, and most other former republics have been similarly reluctant, or ambivalent at best.

What all these organisations share, apart from a strong whiff of Moscow's Soviet nostalgia and evident intent to dominate them, is a tendency either to shed members or to signally fail to attract them in

13 For a measured survey of some of these institutions, see Nicu Popescu, 'Eurasian Union: The real, the imaginary and the likely', European Union Institute for Security Studies Chaillot Papers, no. 132, 9 Sep. 2014, www.iss.europa.eu/publications/detail/article/eurasian-union-thereal-the-imaginary-and-the-likely/. 
the first place. Some of the Central Asians, poised between China and Russia and close to dangerous Islamist currents and disorder further to the south, feel more heavily dependent on Russia for security, as well as employment opportunities and remittances. While they broadly welcome China's burgeoning economic presence amongst them, they also want to be able to have a hedge against Beijing and, with Washington's diminishing profile in the region, Russia remains the only option for that role. But the western republics, even the less Westernising of them, have been more reluctant to sign up for Moscow's projects and, when they do join, are fairly determined not to be rubber stamps. So, in Putin's contest with the West, the acronyms have been less than a dazzling success. But getting all the former republics into the Eurasian Union nonetheless remains Putin's central objective, which he is pursuing with dogged, coercive and at times brutal determination.

Despite the evident unattractiveness of Russia's imperial structures, especially for its western neighbours, the East-West contest for Ukraine continues to be asymmetrical. Russia's military aggression against Ukraine has not elicited a response in kind from the West, even to the extent of providing Kyiv with some serious weaponry with which to reduce the military advantage the proxy forces enjoy.

Since early 2015, nonetheless, Russia's war in Ukraine has slowed, thanks to the increasing effectiveness of Ukraine's military, and the slump in the Russian economy stemming from the collapse in oil and gas prices, which has accentuated Moscow's fear of further sanctions. Another limit on the fighting has been the Minsk process, which has produced two ceasefire agreements, though both of them have been extensively violated, mainly by the Russian and proxy forces. Given its desperate economic plight, Ukraine badly needs that partial respite.

But Minsk I and II are flawed documents, which force Kyiv into accepting the partial legitimisation of the self-styled 'people's republics' of Donetsk and Luhansk (a designation that is strongly redolent of Soviet expansion into Eastern Europe at the end of World War II - something that passes curiously unnoticed in Western media and, one suspects, further up the line). Minsk also concedes legitimacy to the police states erected in the people's republics, and to the brutal militias and security formations they operate. Moreover, Minsk II requires that Kyiv should reach agreement with the 'people's republics' 
on various modalities of their operations, including their 'elections'. Minsk II seems to envisage this legitimation as a pre-condition for Ukraine's regaining control over its eastern border with Russia, which is currently largely controlled by the proxies, in cooperation with Moscow.

In the meantime, which may last for years or decades, Moscow is able to introduce military reinforcements and weaponry whenever it chooses to do so, while denying the purported enforcers of the agreements in the Organization for Security and Co-operation in Europe (OSCE) access to the area to observe what is going on. The Minsk agreements also require Kyiv to introduce constitutional changes to 'decentralise' their regional administration, which Moscow and its proxies are aggressively trying to interpret as 'federalisation'. Why an attacked country should be under pressure from the international community to change its constitution to accommodate its attackers remains a mystery. Minsk II additionally mandates that, despite its eastern regions having been devastated by Russian and proxy aggression, Kyiv should pay for the upkeep of the people remaining there whose lives and livelihoods have been disrupted by the fighting. (For more on the shortcomings and operations of the Minsk agreements see, in particular, Chapter 30, 'Peace in our time' and Chapter 34 'Ukraine, out of sight'.)

What the weak Western negotiation at Minsk and the even weaker enforcement of the agreements indicate is that Western support for Kyiv is half-hearted and, more generally, that the West under current leadership is not determined enough to defend the post-1991 security order (see Chapter 31 'Ukraine conflict exposes Western weakness on Russia'). As in the negotiations after Russia's invasion of Georgia, the Western response is primarily in the hands of the European Union, former French President Sarkozy in Georgia and now, in the case of Ukraine, German Chancellor Angela Merkel with President François Hollande of France as her 2iC. Merkel highlights the weakness of her position by repeatedly intoning that there can be no military solution to the conflict, despite the obvious fact that Moscow has repeatedly and successfully imposed military solutions of its own in Ukraine as well as elsewhere. Hollande, for his part, regularly betrays his eagerness for an early easing of Western sanctions in pursuit of a political 'solution'. 
Merkel has, however, shown determination in defending the sanctions, despite the wobbling on that subject in a number of EU countries as well as within German business lobbies and her domestic coalition partners, the Social Democrats. But she, too, seems at times to weary of the struggle and to wish to restore normal relations with Moscow.

On 4 September 2015, the Russian gas monopoly Gazprom reached agreements with a consortium led by two large German companies and one related Austrian company to build a second Nord Stream gas pipeline under the Baltic Sea. Like the first one, which was controversially sponsored by former German Chancellor and close Putin crony, Gerhard Schröder, this second gas pipeline has no economic justification. It will, however, increase Russia's ability to use gas deliveries (and pricing) as a weapon to coerce and economically damage Ukraine and other Eastern European states. It will enable some German as well as other big Western European energy companies to make money, but will also increase Germany and Europe's dependence on Russian gas. This appears to be in contravention of EU legislation and policies favouring diversification of energy supplies. Ukraine and Slovakia, among other countries, protested angrily against what Slovak Prime Minister Robert Fico, often a pro-Kremlin voice but in this deal a loser, described as a 'betrayal' ${ }^{14}$ It also appears to be flagrantly out of step with the EU's sluggishly ongoing anti-trust case against Gazprom. In short, this is Putin's 'business as usual' at its geopolitically most damaging, with German actors including Schröder and the ex-Stasi agent and close Putin crony, Matthias Warnig, prominently involved. ${ }^{15}$

For his part, President Obama has seemed happy to outsource this aspect of the Western agenda in large part to Merkel and Hollande, while the United Kingdom, which was once a Western leader, and Poland, which was active in resolving the Orange crisis in 2004-05 and in launching and maintaining the AA negotiations with Ukraine, are both sidelined from the process altogether.

14 See Georgi Gotev, 'Slovak PM calls Nord Stream expansion deal "a betrayal"', EurActiv, 10 Sep. 2015, www.euractiv.com/sections/energy/slovak-pm-calls-nord-stream-expansion-dealbetrayal-317531.

15 For a meticulous analysis, see Vladimir Socor's series of articles in The Jamestown Foundation Eurasia Daily Monitor, 10, 14, 15, 17, 21 Sep. 2015, www.jamestown.org/programs/edm/. 
Given the short-winded Western approach to the issues, Putin probably feels that a bit of patience and skilled manoeuvring on his part will be enough to get the sanctions off his back, without his making any major concessions on Ukraine. And now the long-running disaster in Syria and the European migration crisis have presented him with rich new possibilities to shift the agenda and undermine the fragile Western unity on Ukraine.

Putin is not just eager to restore Moscow's sphere of interest, but also to dismantle his opponent's. As he is reported to have told a NATO secretary-general, his interest is not in having a good relationship with that organisation but, rather, in destroying it. Brussels's growing set of crises and chronic governance dilemmas must give him hope of doing something similar with the European Union. In addition to driving wedges, as Moscow leaders have always done, between Western Europe and the United States, he is actively supporting all the disruptive Eurosceptic forces within the European Union to both right and left on the political spectrum.

Clearly Putin's military intervention into Syria has its own regional rationale - to defend the Assad regime, to strengthen the Russian presence in the Middle East and the Mediterranean, to demonstrate his capacity for loyalty to old allies (by contrast with the United States in Egypt, for example, another country that he is courting) and, perhaps, even to inflict some pain on Islamic State. But it is likely that any effort he makes against Islamic State will be intended to be sold as a service for which a large fee can reasonably be sought, including linkage to other issues, probably involving Ukraine and the security architecture of Europe. For its part, the present US administration, whose strategy for supporting 'moderate' Sunni forces to combat Islamic State in Syria has sustained serious reverses, seems prepared on occasion to accept Russian linkages, for example on missile defence, and to use Eastern Europe coinage to pay for them.

The refugee crisis in Europe is also manna from heaven for Putin. Anything that preoccupies, sorely troubles, divides and imposes costs on the European Union, is in his interest, and the migration issue does all of that handsomely. It is also likely to strengthen hard-right political forces within European countries with which he is keen to engage politically. The Schengen zone and mechanisms, to which former Western Soviet republics desire intensely to be granted access, 
are under threat, and Western Europe's enlargement fatigue is always prone to being exacerbated by signs of Polish plumbers or other undesirables swarming across European borders. Despite the looming threat from Russia and desperate lobbying from Eastern member states and would-be members, at the Riga EU summit in May 2015, visa-free travel agreements were not delivered or even clearly foreshadowed for Georgia and Ukraine; nor did the summit hold out any prospect of their becoming EU members. ${ }^{16}$

The chaotic procession of large crowds of people through successive countries on and just inside the EU perimeter has touched off a new round of recriminations between some western and eastern EU states, particularly Hungary. The Orban regime in Budapest is understandably seen as unattractive by other EU capitals, not least for its flirtation with Moscow and its backsliding from democratic values. But the fear of large, uncontrolled inflows of Middle Eastern migrants is not peculiar to Viktor Orban or Hungary. Many other countries in Eastern Europe have a similar reluctance to open their borders to elemental migration movements, especially from Muslim countries, and similar attitudes are widespread and growing in much of Western Europe, even in those countries once renowned for their liberal tolerance.

Unfortunately, the debate within Europe on what to do about the crisis quickly took on tones of recrimination, haughty condemnation and competitive moral beauty. Germany, proud of its Willkommenskultur, seemed to see an opportunity to finally put paid to its burden of historical guilt by making a dramatic gesture of atonement, with various remarkable figures for an annual intake in 2015 being invoked

16 Since then, there has been progress towards freer travel by citizens of both countries, who thus join Moldovans, who have had access to visa-free travel since 2014. But implementation for Ukraine and Georgia still has to be completed, and even then there will continue to be some restrictions and downsides. After the recent immigration turmoil in Europe, the prospects of any breakthrough to free movement may continue to be clouded (Robert Schwartz, 'Visa-free travel for eastern Europe, but with a lot of question marks', DW, 26 Dec. 2015, www.dw.com/en/ visa-free-travel-for-eastern-europe-but-with-a-lot-of-question-marks/a-18933243; Tamar Svanidze, 'Visa-free travel with EU: Green light to Georgia, but not for unlimited travel', Georgia Today, 29 Jan. 2016, georgiatoday.ge/news/2804/Visa-Free-Travel-with-EU\%3A-Green-Light-to-Georgia,but-not-for-Unlimited-Travel). 
with apparent confidence, though sober reflection has since started to kick in. ${ }^{17}$ In the event, the total figure for immigration into Germany in 2015 approached one million.

Eastern EU members and non-EU border states, in particular, were called upon to take fair shares of the burden. But virtually none of them have recent traditions of or infrastructure for major immigrant flows, and they are fearful of sourcing them from North Africa and the Middle East. ${ }^{18}$ Some smaller front-line countries proclaimed their noble intentions, but wilted when tens of thousands descended upon them. 'Old Europe' seemed at times hasty and overzealous with its moral indignation. Austria's President Werner Faymann condemned Orban for sending trainloads of would-be migrants off to camps to be registered, which, he declared, was comparable with the darkest pages in Europe's recent history; i.e. Orban was behaving like Himmler dispatching trainloads of people to Nazi death camps. ${ }^{19}$

The migration avalanche found the European Union unprepared, politically and organisationally. The public discussion seemed at times to lack considered ethical and pragmatic principles. It cannot yet be an internationally justiciable and inalienable human right that all citizens of the world should live in Germany if they so desire. Nor is it sustainable if they choose to do so in their hundreds of thousands by direct action in breach of the laws of various transit countries, with a chant of 'Germany, Germany, Germany' by way of an asylum application. Little is known reliably of the precise composition of the flows: some, perhaps many, may prove to be economic migrants from as far away as Pakistan or Bangladesh, and many others 'asylum shoppers', who have left safe but unattractive camps in Turkey, Jordan or Lebanon. Be that as it may, there is obviously an urgent

17 See Bojan Pancevski, “'Moral" Germany cracks as the world turns up on its doorstop', Sunday Times, 20 Sep. 2015.

18 For thoughtful reflections on the East/West divide within the European Union on this issue, see the article by the Austrian analyst Gustav Gressel, 'Understanding eastern European attitudes on refugees', European Council on Foreign Relations, 11 Sep. 2015, www.ecfr.eu/ article/commentary_understanding_eastern_european_attitudes_on_refugees4019; see also Radko Hokovský, 'What Central Europeans want to know about the refugee crisis', EU Observer, 18 Sep. 2015, euobserver.com/opinion/130321.

19 See 'Österreichs Kanzler vergleicht Orbáns Flüchtlingspolitik mit Holocaust' [Austria's chancellor compares Orban's migration policy with the Holocaust], Spiegel Online, 12 Sep. 2015, www.spiegel.de/politik/ausland/werner-faymann-ueber-ungarn-fluechtlingspolitik-erinnertan-holocaust-a-1052448.html. 
need to reduce the inflow to manageable proportions; and to pursue pre-emptive solutions, for example, by more generous international funding of UNHCR and refugee facilities in the region of origin. For the European Union to establish a well-crafted policy will take time, and less moral posturing. Germany may need to limit publicity for its generous Willkommenskultur to eliminate the huge pull factor that has been generated in the existing refugee camps of the Middle East. And much else will be required. Even the drastic solution of imposing compulsory migrant quotas on unwilling EU members by majority vote is inadequate to deal with the numbers who are already in Europe.

In the meantime, there will be a widely shared longing for a quick fix. And that is where Putin's Syria policies will enjoy further scope. For the Obama administration to again find much-needed support from Moscow in its struggle with another flailing Syria policy, and for the European Union to see some chance to stem the human tide will be strong temptations to do business with Mr Putin. Ukraine has been poised for some time already on the brink of bankruptcy and has received only modest direct support from the European Union, less than one-tenth that granted to Greece. The huge expense that the existing flow of migrants will generate will meanwhile weaken both the will and capacity for the European Union to do more. Putin will wish to exploit this opportunity to present Russia as the key to resolving all of the West's Syrian dilemmas in exchange for sanctions relief for his struggling economy, and a new approach to Eurasian security that recognises Russia's 'legitimate interests' in neighbouring states. ${ }^{20}$ If things were to develop along those lines, it will be even more difficult to maintain the present fragile status quo in Ukraine into the future, much less to resolve it in a way that will preserve Ukrainian independence and territorial integrity, and prevent other countries from sharing its fate. ${ }^{21}$

20 See Pavel Felgenhauer, 'Vyrastet li Yalta na oblomkakh Sirii?', Novaya Gazeta, 21 Sep. 2015, www.novayagazeta.ru/politicvs/70024.html?print $=1$.

21 The foregoing paragraphs on Putin's Syria involvement and the migration crisis in Europe, like most of this chapter, were written in September 2015. As with other chapters in the book, I have refrained from altering judgements, and have focused more on editorial adjustments for style, clarity and conformity with other parts of the text, as well as a few factual updates. There is further discussion of Syria to December 2015 in Chapter 33, 'Making nice and making enemies' and on the migration crisis, also to December 2015, in Chapter 34, 'Ukraine, out of sight'. 
The essays in this book will supply a longer and more substantiated version of the argument set out here about Russia's efforts to reclaim its Western neighbourhood. It should be noted that they were written not only at different times, but also for different audiences. Some were aimed at scholars, some at senior officials concerned with relevant policy matters, and some at the international affairs community more broadly. But some, probably most, are aimed at the general reader, who may follow international affairs regularly out of interest, while lacking a closer understanding of the particular countries under scrutiny. To avoid assuming too much knowledge, the basics about the people, places, conflicts and wider international backdrop involved were sketched in and recapitulated in sequential articles. The articles represent a mixture of genres: some are terser and aim to be punchier; some are longer, more measured, and spelt out in greater detail; some were footnoted or hyperlinked; while others, intended for journals of opinion rather than scholarly publications, were not.

There is inevitably some repetition. But, given the limited coverage of Eastern Europe in much of the West, and the fog of misunderstanding that skilful and intense Russian propaganda has succeeded in producing, especially in recent years (see Chapter 27, 'Russian disinformation and Western misconceptions'), some repetition may not be entirely a bad thing. I have in any case decided not to revise the original documents much, above all to avoid any suspicion of seeking to insert retrospective wisdom. Some minor inaccuracies, typos, infelicities and other lapses have been excised or corrected, but judgements have been left to stand, or not, the test of time.

The articles present the way it all looked when they were written. The overwhelming message of the story is that the largest country on earth has been bent for some time on righting what it sees as the wrongs of the post-Cold War settlement to the detriment of its western neighbours, of Europe as a whole and the West as a whole; and that the West has been doing too little to contain that threat.

Under Putinist rule, Moscow's objective has been explicitly to achieve a dominant position for itself on the Eurasian continent not as a modern, securely post-imperial and enlightened power, but as a hypernationalist neo-Soviet state with fascist characteristics, intent on preserving much of Stalin's legacy in the heart of a Europe that had hoped, and indeed assumed, that its follies and disasters of the 
twentieth century had been finally put behind it. Till very recently, the West was not paying enough attention to this undisguised challenge from Moscow, and perhaps either did not see, or refused to face up to, the blindingly obvious. It still fails to do so adequately. The West's sustained economic weakness since the global financial crisis, and the populism, short-termism and cumbersome and indifferent decisionmaking (think EU responses to Russian policy or the US Presidential election circus) that increasingly characterise its governance, all suggest that its performance is unlikely to improve any time soon.

It is to be hoped, that Kyiv's reforming coalition, which is wilting and flailing under the pressure of the war, the severe economic downturn of 2014-15 and its own declining popularity and internal divisions, can see out its travails, which will not end soon; ${ }^{22}$ and that Ukraine can rise above its colonial miseries, including the many millions dead as a result of Moscow's past policies, and escape into a decent, modern European normal, not yet another retrograde and reactionary version of Russian imperial domination. It can perhaps also be hoped, if not with much confidence, that Kyiv may even tug Moscow westward in its wake, rather than vice versa.

22 Since this was written, the Poroshenko-led governing coalition has reconfigured itself with Yatseniak being replaced as prime minister by Poroshenko's close ally, Volodymyr Groysman, a cautious reformer and observant Jew (Cnaan Liphshiz, 'Jewish wunderkind turned Ukrainian Prime Minister - who is Vlodymir Groysman?’, Haaretz, 14 Apr. 2016, www.haaretz.com/ jewish/features/1.714532). 



\section{Part 1. Twentieth-century Poland: War and Cold War}





\section{1 \\ Seven days that shook the world $^{1}$}

For many people, the fall of the Berlin Wall on 9 November 1989 was the moment when communism in Europe came to an end. But important events were still to occur, most notably the meeting between Soviet President Boris Yeltsin and his counterparts from Ukraine and Belarus in Belovezhskaya Forest on 7-8 December 1991, at which they proclaimed the end of the Soviet Union. And the main links in the causal chain had been fashioned years earlier.

In August 1980, the outside world watched with growing amazement as a wave of strikes swept across Poland. Such a comprehensive workers' revolt had not been seen before in the Soviet bloc, not even during the Hungarian uprising of 1956. The strikers maintained a remarkable discipline, avoiding violence or other provocations, and the huge support that they enjoyed throughout the whole country was palpable. On 21 August, just a week after the outbreak of the first strike in Gdańsk, the authorities sent senior party emissaries to negotiate with the strike leaders. Within a fortnight, several wideranging agreements had been reached with key regions; within a month, a national free trade union federation called Solidarity had been established under Lech Wałęsa.

1 First published in Inside Story, 15 Nov. 2010, insidestory.org.au/seven-days-that-shookthe-world. 
Events like these always seem inevitable in retrospect, and it's difficult for younger people, especially those without experience of tough regimes, to comprehend just what would-be reformers of communism were up against. Most people on either side of the iron curtain feared that serious reform would not come without terrible bloodshed. Many found the prospect either unimaginable or too terrifying to contemplate seriously.

All previous attempts at reform had ended badly: Berlin in 1953, Poznań in 1956, Budapest in 1956, Warsaw in 1968, Prague in 1968, and Gdańsk and other Polish Baltic cities in December 1970. These events - particularly the crushing of the national uprising in Hungary in 1956 and the suppression by Warsaw Pact armies of Alexander Dubček's 'socialism with a human face' in 1968 - left people feeling that all protest was ultimately futile. As a semi-dissident Polish group calling itself Experience and the Future said in May 1979, Poles had the 'bitter conviction' that, in the sociopolitical system in which they lived, 'radical change ... is absolutely necessary and at the same time totally impossible'. ${ }^{2}$

But the transformation of August 1980 was less abrupt than it seemed. Poles had a long tradition of uprisings against Russian authority and, since the bloody suppression of the spontaneous demonstrations on the Polish Baltic coast in 1970, small groups of workers and intellectuals had been working together to prepare for the next round. After the Gierek regime again put down workers' protests in several cities in 1976, dissident intellectuals formed the Workers' Defence Committee to offer advice and support to working-class leaders. In 1979, the recently elected Pope John Paul II (previously the Archbishop of Cracow) returned to his home country on a visit that produced gigantic crowds across the country. Already the eerie consensus and exceptional discipline of future Solidarity mass demonstrations were apparent.

2 Doświadczenie i Przyszłość: 'Raport o stanie Rzeczypospolitej i o drogach do jej naprawy' in Raport o stanie narodu $i$ PRL, Instytut Literacki, Paris, 1980, p. 31. 
In the year or so after the agreements of September 1980, as Poles revelled in their new freedoms while the economy staggered further into crisis, the regime was forced to cede ever more ground to society. The workers' demands, which were already expansive, became broader and more political. And the rest of Polish society joined in.

Communist one-party systems worked on a mixture of propaganda, intimidation, extreme concentration of power and the creation of elaborate structures of regime-controlled organisations that were designed to supplant and pre-empt genuine civil society. There were official trade unions, women's groups, writers' groups, student unions, publishing houses, professional associations and so on, all of them - with some Catholic exceptions - run by the party or its trusted nominees under tight central direction. Poland also had two parties ostensibly representing the peasantry and urban middle classes but in fact serving as top-down conveyor belts without diluting the oneparty reality in the slightest.

Many of these phoney bodies either were displaced by emergent Solidarity organisations or, in self-defence, began genuinely to represent their constituencies. Seeing these stooge organisations suddenly acquire real life was an odd experience, as unnerving - in the memorable phrase of the distinguished British journalist Neal Ascherson - as watching the ripening of wax fruit. ${ }^{3}$ The regime was progressively losing most of its instruments of power.

Even the party, security organs and army were influenced by the ferment, but they remained more securely under the leadership's control than other institutions. As Solidarity's demands for total democratisation became more insistent, the regime prepared its response. In October 1981, General Wojciech Jaruzelski, who was both Prime Minister and Defence Minister, became party leader as well. With impressive secrecy in a society that was by then awash with information and opinions, he prepared a massive counter-revolution. Declaring martial law on 13 December 1981, he closed down nearly all communications and media for several weeks and 'interned' thousands of Solidarity leaders from all over the country. Solidarity, which had

3 Neal Ascherson, The Polish August, Allen Lane, London, 1981, p. 31. 
always been essentially an open and nonviolent movement with little capacity for self-defence, was ill prepared for this turn of events and, for several months, seemed stunned.

But Jaruzelski, despite martial law, was not a gratuitously brutal leader or without patriotic scruples. In any case he realised, like János Kádár in Hungary after 1956, that the regime could only be rebuilt on the basis of some modus vivendi with society. As normality returned, Solidarity revived below the ground and later, increasingly, above it. A plethora of illegal, uninhibited publications burst forth. The movement's leaders were gradually permitted back into the public domain.

During the 1980s, the economy, as in much of the Soviet bloc, went from bad to worse. Poland looked like a country where crises and revolts were perhaps only a price hike away. And, with the accession of Mikhail Gorbachev to the Soviet leadership, glasnost and perestroika were added to the mix.

As public resentment began spiking again towards the end of the decade, Solidarity reasserted itself and, in 1988, launched strikes and issued demands. Though the situation was less explosive than in 1980, the regime was less able to resist or coerce. It agreed to commence in February 1989 what became known as the Round Table Talks, as a result of which partly free elections were held. Solidarity won with a crushing majority, which led by stages to the dismantling of the communist regime.

Solidarity radicals, a clear minority, were not happy that Wałęsa and his advisers agreed to a negotiated solution that allowed the communist establishment to escape reprisals, squirrel away funds and, before long, stage a political recovery as born-again social democrats. The post-communists went on in time to win democratic victories, in large part by criticising the economic 'shock therapy' that was adopted by the Solidarity Government to transform the command economy and tackle the hyperinflation and other economic crises the communists had left in their wake.

The argument about whether the conciliatory Round Table approach was the right course has continued ever since, through all the kaleidoscopic mutations of parties and personnel in Poland's volatile post-communist politics. But the results were good. The Polish 
communist establishment always had a strong liberal wing, which took to democratic politics skilfully and accepted the new dispensation. As a result, bloodshed was avoided both in 1989 and subsequently. But the argument among post-Solidarity politicians about who won the victory and who let the nomenklatura off the hook still rages.

As Poland became a more open society, the original raison d'être of Solidarity as a national, all-encompassing body faded. Like that of the Catholic Church, its political influence has waned from the high point of 1989. While a Solidarity-led government held sway for a time in the late 1990s, the organisation has shrunk to become more of a trade union than a national cause or party, though it participates vigorously in Poland's fractious politics.

So what is Solidarity's legacy? During last year's celebrations of the events of 1989, much public comment concurred that the decisive moment had been the spontaneous demolition of the Berlin Wall. But the fall of the Wall, though spectacular and cinematic, came about in part by accident when a senior East Berlin official, Günter Schabowsky, sent a mistaken signal to the East German population that the Wall was about to be thrown open. And its dismantling had, in any case, been largely pre-determined when Gorbachev made clear that he would not bring tanks to the rescue of the regime, and when Hungary's reformist communists decided to let East German tourists visiting their country escape en masse across the Hungarian-Austrian border.

In the downfall of communism there were, thus, many causes and many heroes, most of them unsung, and some of them, at first glance, unlikely or indeed unintentional, like Schabowsky, or only partially intentional, like Kádár. Kádár's decision to chart a liberal course after his brutal suppression of the uprising of 1956 enabled pluralism of a sort to develop in Hungarian society. Within Kádár's Hungarian Socialist Workers' Party, a strongly reformist leadership group emerged that helped ease him into retirement, proclaimed the need for a 'democracy without adjectives' and, quite consciously, set about undermining the East German regime.

Another partly unintentional hero, who remains, sadly, very much unsung in his own country, is Gorbachev, who came to reform communism, not to bury it. But it was his vision, political skill, 
courage, resolution and basic decency that not only transformed the system within his own country but also made it possible for reformers elsewhere, including in Poland, to achieve what they did.

Outside Russia, however, Solidarity's non-violent example (compare Czechoslovakia's velvet revolution and the Baltic states, for instance) was probably the largest single cause of the momentous events of the 1980s and early 1990s. Looking nostalgically back to Solidarity's glory days, many Poles mourn the passing of an era of great national idealism and unity. But Solidarity's contraction to more modest dimensions does not reflect tragic decay, just mundane democratic normality. And that, too, is an important part of its legacy. It would be good if all of Poland's post-Solidarity politicians accepted that the age of righteous heroism has passed and that sweeping pronunciamentos are no longer required. 


\section{2}

\section{A difficult neighbourhood ${ }^{1}$}

Poland's geopolitical location has seldom been an advantage in modern times. Caught between the Russian and Austro-Hungarian empires and the expanding Prussia of the Hohenzollerns, Poland disappeared from the map of Europe entirely between 1795 and the end of World War I, courtesy of a series of partitions of its territory by its neighbours.

World War I brought about the defeat of two of those partitioners and the downfall of their ruling houses, while the third collapsed into revolution and fratricidal confusion. Polish nationalists, who had kept the flame alive with frequent bloody sacrifices, seized the moment. Supported with some misgivings by France and Britain, which wanted to weaken the central European powers, and helped by US President Woodrow Wilson's Fourteen Points statement on the need for greater self-determination in the postwar world, an independent Poland re-emerged.

Border conflict was inevitable and occurred almost immediately. An adventurous foray by the new Polish state into Ukrainian territory in support of Ukrainian nationalists sparked an offensive by the Bolsheviks to seize back territory once held by Russia and to bring on a revolution in Europe. The Red Army reached the gates of Warsaw in August 1920, where it was defeated by Polish forces in a battle known

1 First published as a book review of Halik Kochanski's The Eagle Unbowed: Poland and the Poles in the Second World War (Allen Lane, 2012) in Inside Story, 2 Jul. 2013, insidestory.org. au/a-difficult-neighbourhood. 
to Poles as the Miracle on the Vistula. At the centre of this struggle were the disputed marchlands between Poland and Russia. The new state's western borders with Germany were contested, too, and the Poles had territorial disputes in the east and south with emergent national groups who viewed them in much the same way as they viewed Russia and Germany. Many of these border issues continued to simmer throughout the interwar period.

The new Poland was multi-ethnic, with large Ukrainian and Jewish minorities, substantial numbers of Belarusians and Germans, and other smaller groups. Successive governments had to deal with chronic, and sometimes violent, disaffection among these largely involuntary citizens. Official treatment of the minorities was often harsh, particularly under the authoritarian Sanacja regime led by Marshal Józef Piłsudski after his May 1926 coup d'état. As it struggled to unify three different legal, financial and administrative systems, the new state also had to tackle areas of severe economic backwardness, aggravated by the effects of the Great Depression, trade sanctions imposed by Weimar Germany, and Poland's own heavy budgetary outlays on defence.

These were among the factors which meant that by 1939, largely for reasons beyond its control, Poland was not well placed to respond to an invasion, much less a cataclysm. On 1 September, the German blitzkrieg machine was unleashed on Poland, which was quickly overwhelmed by the enemy's superior numbers and technology.

What happened next is a tragic and painful story, much of which has been told before in varying degrees of detail. But Halik Kochanski has done an impressive job of covering this huge and intricate subject in all its aspects. ${ }^{2}$ The Eagle Unbowed not only deals with the military and diplomatic history of this period but also, and more comprehensively than preceding accounts in English, draws in the stories of the millions of Poles who perished in or were displaced by the successive disasters that overtook their homeland.

2 Halik Kochanski, The Eagle Unbowed: Poland and the Poles in the Second World War (Allen Lane, 2012). 
The Poles' biggest miscalculation in 1939 was the expectation that their British and French allies would do something meaningful to support them. The French made only a symbolic incursion into a pocket of undefended German territory and withdrew within a matter of weeks. The main British response was to drop leaflets over German cities.

Meanwhile, in hasty pursuit of the territorial acquisitions they'd been promised under the Molotov-Ribbentrop Pact of August 1939, the Soviets invaded Poland from the east on 17 September, coordinating their actions with the Germans and meeting little resistance from the demoralised and isolated Poles. Unlike Germany, Moscow didn't bother faking an excuse to invade; it merely asserted that, given Poland had ceased to exist, it had to come to the aid of its East Slav brethren, the Ukrainians and Belarusians.

During the drôle de guerre that followed, Germany was able to prepare at relative leisure for other operations, and particularly for its attack on France, Belgium and the Netherlands in May-June 1940. The resistance of those three countries was broken in little more time than it had taken to defeat Poland. Polish forces that had reassembled in France were thrown into the fray to help delay the inevitable. As Kochanski comments:

The Polish army, so painstakingly built up in France, was squandered to facilitate the retreat of the French Army. It suffered 6000 casualties, including 1400 killed, and the majority of the troops became POWs or were interned in Switzerland. Only 19,000 soldiers and airmen were evacuated, representing under a quarter of the Polish Army in France at the start of the German invasion. ${ }^{3}$

This tended to be the pattern throughout the war: Polish forces were thrown into battles far from their homeland, with little hope that they were on the path to regaining it. Their rage at the Germans made them brave, sometimes foolhardy, fighters. Their valour and their contributions were often overlooked by their allies, however, and ultimately were to prove non-bankable. This was an experience that Polish patriots had encountered over centuries - fighting in the wars of others in the vain hope of winning back their national freedom.

3 Kochanski op. cit. p. 219. 
The Nazis' plan for Poland was to make way for German settlers by decapitating the intelligentsia, destroying Polish culture and education, Germanising the racially acceptable minority, and working to death or otherwise wiping out the rest of the population. They set about the task with vigour and, in the end, only a lack of time prevented them from achieving their objectives.

In addition to military casualties and mass executions of civilians, a million or so Poles were deported to work as slave labourers in the Reich, and some tens of thousands of children judged to have suitable racial characteristics were seized to be raised by German parents. Many of the labourers died in Germany and most of the children could never be recovered by their real parents. Large numbers of Poles also died from hunger, especially in labour and concentration camps. A recent estimate puts the total number of Polish citizens who died as a result of the German occupation at 5.5 million, some 3 million of them Polish Jews.

The Soviet occupation of eastern Poland between 1939 and 1941, though grimly brutal for many social groups, especially ethnic Poles, cast a few rays of light on others. The Soviet army and secret police set about Stalinising the area as soon as they arrived, seizing and deporting hundreds of thousands of people in inhuman conditions. Many others were imprisoned or executed, including the 22,000 who were murdered at several sites but who are collectively remembered by the name of one of them, Katyn. One estimate suggests some 150,000 may have died as a result of the two-year occupation. But, for Polish Jews, the Soviet occupation seemed to represent deliverance of a kind from Nazi Germany, while for Polish Ukrainians, at least temporarily, it seemed like a chance both to get even with the Poles and to secure rapid socioeconomic and national advancement.

Kochanski notes disagreements in the scholarly literature about how many people were deported into the Soviet hinterland. The attrition rate could be very high: of some 10,000 to 12,000 sent to the remote Arctic Gulag mines of Kolyma, only 583 were still alive by 1942 . At one time, the usual estimate was around 1.5 million Poles deported, of whom the majority were thought not to have survived the war. But since Soviet archives were partly opened in the 1990s, the standard estimate has fallen to half a million. Kochanski clearly has doubts about this lower figure. 
Hitler's attack on the Soviet Union in August 1941 made the situation even worse, particularly for the Jews. But the tide began to turn again in late 1943, and the prospect of another Soviet occupation loomed. Poland was at the heart of what Timothy Snyder has memorably termed the bloodlands, the swathe of the western Soviet Union and East-Central Europe that was subjected to three successive waves of Soviet-Nazi-Soviet murderous occupation, creating a cumulative brutalisation effect and forcing hapless populations to make repeated 180-degree turns just to try to survive.

Hobbesian conditions of lawless violence, ideological coercion and desperate poverty naturally brought out the worst in many people. Both the Nazi and Stalinist occupations created perverse incentives for their starving subjects to collaborate, and some doubtless seized the opportunity offered them with enthusiasm. Others were inspired to rise to great heights of heroism and compassion. But probably the vast majority simply kept their heads down and did whatever they thought they had to for their own and their family's survival, including unedifying or even repugnant things.

Through all this, the Polish state remained suspended. Unlike in most of occupied Europe, no significant Polish political organisations offered to collaborate with the Germans, a fact of which the Poles have always been proud. Kochanski is sceptical on this point, arguing that the Germans didn't really want to entrust anything to the Poles, but she does note that they did seek some weighty Polish collaborators, without success, in the early months of the war.

On the other hand, an underground state came into being soon after the German invasion and remained highly active throughout the war. An underground guerrilla force, the so-called Home Army (the Armia Krajowa, or AK), also quickly emerged. At its peak, the AK numbered some 400,000, the largest insurgent force in German-occupied Europe. There were also much smaller militia formations of the hard right and left that attacked the occupiers while pursuing their own agendas (anti-Semitic nationalist and pro-Soviet respectively) in defiance of the AK.

The Polish government-in-exile, a broad-based coalition, though excluding the Pilsudskiite Sanacja establishment, was based first in France and then in London. Widely recognised internationally as 
the legal successor to the Sanacja Government, its authority was also accepted by the Polish armed forces abroad and by the AK and the underground in occupied Poland, with which it maintained precarious contact using overland couriers and parachutists dropped behind enemy lines.

After Hitler's invasion of the Soviet Union in June 1941, and nudged by the British, Stalin agreed to re-establish relations with Poland. Polish deportees in the Soviet Union were amnestied from remote Gulag camps and collective farms, and the soldiers and surviving remnants of the officer corps were allowed to reconstitute a Polish army in the Soviet Union under one-time tsarist officer Władysław Anders. But Stalin was looking for collaborators among the Poles in Russia and, unlike Hitler, he found some. When Anders disappointed his expectation that the reconstituted Polish army would fight uncritically under his command, Stalin began to consider alternative solutions.

Because of growing disagreements between Stalin and the Allies about the size and use of Anders's army, Stalin grudgingly agreed that part of the army could be evacuated from the Soviet Union via Central Asia and Persia to join their comrades in other theatres. The troops were accompanied on a harrowing trek south by civilians, including women and children desperate to escape from their Soviet nightmare. Some 4,000 Jewish soldiers, including future Israeli leader Menachem Begin, either deserted or were given permission by Anders to leave their units and travel to Palestine. Meanwhile, Poles remaining in the Soviet Union were being subjected to increasing pressure and chicanery.

In April 1943, the Germans announced their discovery of the mass graves of Polish officers at Katyn and attributed the atrocity to the Soviets. To the Allies' dismay, the London Poles called for an International Red Cross inquiry into the massacre. Feigning outrage at this scandalous accusation, Stalin abruptly curtailed relations with the Polish government-in-exile. But, even before this convenient pretext presented itself, Stalin was starting to build within the Soviet Union the foundations of a future Polish government and army that were more to his taste. These shadow institutions were led by left-wing Poles who had chosen exile in Russia, and a small minority of officer POWs (headed by Zygmunt Berling) who had indicated a readiness to 
collaborate with Moscow after being captured in 1939, for which they were rewarded by comfortable living conditions in the capital instead of a bullet in the back of the head.

Polish servicemen abroad saw action on various fronts, making outstanding contributions, for example, during the Battle of Britain, where Polish airmen accounted for 15 per cent of German casualties, and during the siege of Monte Cassino in May 1944, where the Polish troops took heavy casualties. They also provided valuable input to Allied intelligence.

Poland's most notable espionage achievement - first shared with Britain in 1939 - was the cracking of the German Enigma codes, which eventually enabled the Allies to read much of the Axis powers' secret communications. In the view of General Dwight D. Eisenhower, this exerted a decisive influence on the course of the war. The Polish intelligence network in occupied Poland and beyond was also extremely productive. By one estimate, 48 per cent of the reports that British intelligence received from continental Europe came from Polish sources.

The AK and other resistance formations harassed and sabotaged German military and police resources, forcing Berlin to deploy around 500,000 military and security personnel in occupied Poland for most of the war. The biggest $\mathrm{AK}$ action was the valiant but quixotic Warsaw Uprising of August 1944, an unequal struggle that resulted in appalling loss of life (some 200,000 dead on the Polish side), the almost total destruction of Warsaw, and the dispatch of most of the survivors to camps or slave labour in the Reich.

The uprising formed part of Operation Tempest, a broader AK campaign to clear German forces from the areas of central-eastern Poland that the Soviet forces, with their Polish protégé army, were entering. The idea was to demonstrate to everyone, especially Stalin, that the AK was fighting to liberate the country independently and that he should, therefore, recognise Poland's sovereign existence.

Stalin had no intention of doing any such thing. The Soviet army and secret police refused to cooperate with the AK units that they encountered. They occasionally invited them to meetings, held ostensibly to discuss military coordination, but often as a treacherous prelude to arrests and summary executions. Nonetheless, the AK was 
encouraged by signs that Soviet forces were closing in on the suburbs of Warsaw east of the Vistula, and Soviet leaflets had been dropped over the city calling on all Polish patriots to rise up.

When they did, however, Stalin forbade his forces to support the AK until the uprising had been almost crushed; only in the late stages were units from General Zygmunt Berling's Soviet-subordinated army allowed to attempt (unsuccessfully) a crossing of the Vistula to link up with the AK. Moreover, Stalin refused to allow Allied aircraft to enter the area under Soviet control, which was essential if they were to deliver the supplies the AK desperately needed.

By this time, the leaders of the United States and Britain, acutely conscious of Stalin's growing de facto control of the east, were pressing the London Poles to seek an accommodation with the Soviets by accepting a massive revision of Poland's eastern border in Moscow's favour and engaging positively with Stalin's Polish allies. By now those allies were already being shoehorned by the NKVD (Soviet secret police) into administrative control of eastern parts of the proposed new Poland west of the Curzon Line. All this was anathema to the government-in-exile, though the Premier, Stanisław Mikołajczyk, sought to find ways to be flexible.

The AK leaders had a weaker sense of the emerging Realpolitik than did the government-in-exile. But they, too, felt that only some striking achievements on the ground could save them from being enveloped by yet another Russian occupation. The heroic Warsaw Uprising had achieved none of its objectives; on the contrary, it had done a great deal of Stalin's dirty work for him. Suppressing the ghostly remnants of the underground state and army in the capital would now be an easy task.

Stalin's gross cynicism over the uprising, the growing evidence of arrests and executions of AK soldiers, and the progressive enthroning of a communist-dominated puppet state in Poland were making Churchill increasingly uncomfortable about pushing his Polish allies to submit to Moscow. But push them he did. Roosevelt appeared to feel less discomfort. By then, his main concern in matters Polish seems to have been not to do anything that might lose him the potentially crucial Polish vote in the 1944 US presidential elections. 
The Yalta conference of the Big Three powers in February 1945 underlined the message that Britain and the United States had been trying to convey to Polish leaders for some time: the war was nearly over; Stalin was in control of Eastern Europe; and the Poles would have to swallow their bitterness and grasp whatever concessions might still be available.

The culminating humiliation for the government-in-exile was the 1946 Victory Parade in the British capital, to which the newly recognised, though unelected, Warsaw Government (still completing preparations for a Soviet-style 'election') was invited, while the London-based government was not. This led to a scandal and questions in the House of Commons. The Warsaw Poles then declined to come, whereupon hasty invitations were extended to senior military commanders of the Polish armed forces abroad. They also politely declined, so the march went ahead without any Polish representatives.

The London-based Premier, Mikołajczyk, tried to follow Churchill's often-angry advice, and returned to Soviet-controlled Warsaw after the war. Despite his enormous popularity and nominal presence in a heavily pro-Moscow 'coalition' government, which he agreed to under pressure, the emerging Polish police state progressively emasculated him and his party. In October 1947, he was forced to flee the country in fear for his life.

Some of Roosevelt's comments on the Polish dilemma in the last phases of the war now sound thunderously naïve to anyone familiar with Stalinism and the Soviet record. At times Churchill, too, sounds naïve about Moscow in his dealings with the Poles; at other times, cynical and bullying.

But without troops on the ground in numbers, there probably wasn't a great deal either leader could have done. As far as Poland's fate went, Stalin had the divisions, and he had them in the relevant places. He had no intention of making anything more than tactical concessions that could be withdrawn as soon as was convenient. Removing his proxy regime could only be done by armed force, for which no one except the Poles had the stomach once the war had ended, and they certainly could not do it on their own. 
Before The Eagle Unbowed was published, Kochanski was best-known as a military historian, and her formidable expertise in this field has clearly stood her in good stead. Although she doesn't appear to have published any major work on Poland previously, she has obviously acquired an impressive mastery of the country's modern history. Some minor factual inaccuracies have been pointed out by reviewers, but there has also been wide recognition that this is an unusually comprehensive treatment in English of a very large and complex subject.

For Kochanski, the form of whose name points to her British upbringing as well as her Polish family background, this was evidently a labour of love as well as a dauntingly large academic undertaking. Her family is present from the dedication to her parents at the beginning and thereafter throughout much of the book. Among the numerous apt eyewitness accounts she adduces are many skilfully and touchingly drawn from her own family sources to convey the human dimensions of the terrible events she is narrating.

Like Anders's army, many of her family members came from the Kresy (roughly, the eastern parts of prewar Poland and, in some Polish views, well beyond that also). These were the (ethnic) Poles who lost everything in the war, and were afraid or could not bear to return to the Muscovite Poland that the Yalta settlement offered them. Of the 80,000 Anders evacuees, only some 300 volunteered to be repatriated to Poland.

By any calculation, hundreds of thousands of ethnic Poles from the Kresy perished in the Soviet, German and renewed Soviet occupations. Some 60,000-70,000 civilians (some estimates go as high as 100,000) were also killed in the ethnic cleansing that was carried out in parts of the Kresy in 1943-44 by the Ukrainian Insurgent Army (usually known by its Ukrainian acronym UPA). This was an attempt to create geopolitical facts on the ground as well as indiscriminate and grossly disproportionate payback for the Sanacja oppression and territorial conflicts in the recent past. Despite the extent of the carnage, few general readers in the Anglo-Saxon world know much about it.

Kochanski's treatment of these under-reported massacres is understandably written from a Polish perspective. She refers, for example, to the local Ukrainians' 'disloyalty' to the Poles, without 
having adequately addressed the prior question of whether, in the light of recent history, the Poles could have expected loyalty. But the tragic story of the Kresy Poles deserves to be known better in all respects, and Kochanski tells it eloquently.

There has been some related criticism that, although Kochanski has read widely, her sources, which are nearly all Polish or English, reflect a certain Polonocentrism. The bibliography and footnotes confirm that there is something to this.

But she is most likely to be criticised, like any author stepping onto this sensitive terrain, for the book's treatment of Polish-Jewish relations. She devotes a separate chapter to the Holocaust, and there are many references throughout the book, often both fascinating and detailed, to the Jewish aspects of particular events and situations. But some readers will feel that one dedicated chapter on the Holocaust in 600 pages is not enough.

Despite her efforts to be fair, Kochanski seems at times to emphasise instances of positive behaviour towards Jews among ethnic Poles, while exhibiting reticence or offering extenuation in relation to examples of the opposite behaviour. There are things that can and should be said in extenuation, and she is justified in saying them. But, perhaps overall, she doesn't quite get the balance right.

As others have pointed out, Kochanski makes only modest use of recent research, mainly from scholars in Poland, presenting evidence of previously unpublicised incidents involving callous or brutal behaviour by ethnic Poles towards Jews during or soon after the war. She deplores the degree of polarisation that this new research has unleashed on all sides, but notes that this difficult debate will and should continue.

Nothing is comparable with the Holocaust, but alongside the 3 million Polish Jews killed were roughly as many ethnic Poles. Among many other things, this fine book is a moving memorial to their suffering, much of which is still a blank page in Western historical consciousness. 



\section{3 \\ Jan Karski's valiant failures ${ }^{1}$}

For Australians of my generation, the lives of World War II heroes and Poland produced many - seem almost superhuman. How could ordinary human beings set themselves against the rampant, satanic evil represented by German occupation in World War II?

Having narrowly escaped from hell, how could they find the strength and courage to expose themselves to it again and again on a daily basis for years at a time?

And how could they do so in the face of the almost equally inhuman force of Stalinism swamping them from the east, and proving to be just as barbarous, violent and treacherous as an ostensible ally as it had been as an enemy.

Many people succumbed to the crushing pressures of the GermanSoviet war in Europe by jettisoning their moral values and doing terrible things that, in a halfway normal life, most would never have done. Others responded with bleak resignation. Still others nurtured illusions that made their situation seem less desperate.

1 This article was originally an address given at the Polish consulate in Sydney on 29 November 2012, to mark the 70th anniversary of the presentation by the Polish governmentin-exile of its Note to the Allies on 10 December 1942 entitled 'The mass extermination of Jews in German-occupied Poland'. It was first published in Zachor (Apr. 2013) pp. 25-33 (Zachor is the journal of the Australian Association of Jewish Holocaust Survivors and Descendants). 
Few had many options. Some had no options at all. And yet, many succeeded in rising astonishingly to the occasion. Jan Karski was one such.

Jan Karski (Kozielewski) was born in 1914 and brought up in a strongly Catholic family in Łódź. His mother and much-admired older brother were also devoted followers of the agnostic Marshal Józef Piłsudski. They lived in a Łódź neighbourhood where there were many Jews with whom the young Karski had friendly relations.

After successfully graduating in law and diplomacy at Lwów University, further study in a military academy, then a couple of years as a cadet diplomat attached to Polish missions in Geneva and London, Karski began working in the Polish foreign ministry just before war broke out. Karski had graduated top of his class at both the military academy and in his foreign affairs training. He seemed destined for a brilliant diplomatic career.

At first glance, the bare facts of Karski's wartime experiences seem drawn from an overwritten adventure thriller. Deploying as a young lieutenant with his mounted artillery unit near what was to become known to the world as Auschwitz in south-western Poland, he and his unit were overwhelmed by the initial German onslaught.

Retreating in confusion towards Lwów in the south-east, Karski and many of his comrades were taken prisoner by invading Soviet forces who were bent on gathering the fruits of the Molotov-Ribbentrop Pact's secret division of territorial spoils.

Showing characteristic resourcefulness under pressure, Karski tricked his captors into believing he was not an officer and had himself included in a Soviet-German prisoner exchange. Though he didn't, of course, realise it at the time, he thereby escaped being murdered by a bullet in the head in an NKVD cellar. ${ }^{2}$

Escaping from a German cattle truck by persuading his fellow prisoners to throw him through a small window at about eye level while the train was moving, he picked himself up and set off on foot for Warsaw

2 Some 22,000 Polish officers, who were taken prisoner by the Soviet Union when they invaded eastern Poland, were murdered at Katyn and other locations in the western USSR in April and May 1940. Few escaped, and it is, therefore, highly likely that this would have been Karski's fate also. 
through a wintry and devastated Poland. After an eventful journey he arrived in the capital where, with his older brother's help, he soon joined the nascent underground movement.

In January 1940, he was sent as a courier by his underground superiors on a dangerous and circuitous journey via Slovakia and Hungary to Angers in France, where the emergent Polish government-in-exile was located during the drôle de guerre.

There he had many adventures, mainly of a political kind, including struggling to maintain cordial relations with feuding Polish factions and coping with grillings from senior ministers. He was also treated to a dressing down from the Prime Minister, General Władysław Sikorski, who viewed him as a supporter of the Pilsudskiite Sanacja regime, ${ }^{3}$ which Sikorski's government had effectively supplanted. It was not the last dressing-down he would receive from the general, though Sikorski came to deeply respect his skills and devotion to the cause.

After returning to Poland for a month in mid-1940, where he learned that his beloved older brother (a senior Sanacja official turned underground activist) had been seized by the Gestapo, he was dispatched on another liaison journey to France with much sensitive information in his head and a potentially incriminating microfilm on his person. Betrayed by a Slovak facilitator, he was arrested by the Gestapo and brutally and repeatedly tortured.

Fearing that he might eventually betray underground secrets, he attempted suicide by hacking his wrists with a razor blade that he had hidden in his boot before leaving Warsaw. Dismayed that they may lose valuable intelligence, the Germans dispatched him to be nursed back to torturable health in a prison hospital across the border in occupied Poland.

3 'Sanacja' is the term commonly applied to the political movement led by Piłsudski and the regime he set up after his armed coup in May 1926. The Sanacja regime lasted beyond his death in 1935 until the military defeat of Poland by Nazi Germany in 1939. The word 'sanacja' derives from the regime's declared intention of carrying out a 'moral cleansing' of the nation. For more on the Sanacja regime, see Antony Polonsky, Politics in Independent Poland 1921-1939 (Oxford University Press, 1972), p. 183 and passim; and, Rafal Pankowski, The Populist Radical Right in Poland: The patriots (Abingdon: Routledge, 2010), pp. 15-21. 
Here Karski became aware that some of the staff were underground sympathisers. He begged them either to help arrange his escape or to get him cyanide so that he could kill himself quickly and efficiently when his torture and interrogation resumed.

A unit headed by one of Karski's underground colleagues, Józef Cyrankiewicz, then a socialist leader, but later to become a prime minister of communist Poland, organised a remarkable 'Boy's Own Annual' escape from the prison facility. Karski was still gravely ill and was lucky to physically survive the adventure.

Later, the Germans shot over 30 people for their presumed involvement in the plot to rescue the high-value prisoner. This typical act of German retribution left Karski feeling bitter anguish for the rest of his life for having 'caused' these deaths.

Returning to Warsaw, he was deployed for a while in less torrid resistance activities with the underground state's Bureau of Information and Propaganda (BIP) where, among other things, he prepared and disseminated subversive literature aimed at German soldiers. Another aspect of the BIP's work was liaison with Polish Jews.

During this period, together with his BIP boss, Karski saved a Jewish couple, relocating them from Warsaw and protecting them from a Polish szmalcownik (ethnic Polish blackmailer of Jews), who accosted them at a Warsaw railway station. Sadly, at the country estate to which Karski had escorted them, where a wealthy sympathiser maintained a kind of safe house for the underground, they were later to be betrayed to the Germans by a peasant who worked on the estate.

In late 1942, Karski was chosen by the underground Delegate, ${ }^{4}$ Cyryl Ratajski, ${ }^{5}$ to undertake a high-level mission to the government-inexile and senior Allied representatives in London. The main priorities for his mission, in addition to liaison between the underground and the

4 The Delegate was the civilian leader of the Polish wartime underground organisation that had been formed and was subordinate to the Polish government-in-exile situated first in Angers and, from 1940, in London. The émigré government was a coalition formed from moderate prewar mainstream parties, but excluding Sanacja representatives. Ratajski, a pre-Sanacja politician of some note, represented a centrist party influenced by Catholic social teaching. On the Delegate's role, see 'Delegatura rzadu na kraj', Slownik historii Polski (Warsaw: Wiedza Powszechna, 1969). 5 See pl.wikipedia.org/wiki/Cyryl_Ratajski. 
government-in-exile, were the growing Polish concerns about Soviet intentions and the unfolding mass murder of Jews by the Germans in occupied Poland.

Since Hitler invaded the Soviet Union in June 1941, the Allies were pressing the Poles to be nice to Moscow, despite its having occupied much of Poland in 1939-41, murdered many of its people and deported many more hundreds of thousands in lethally inhuman conditions to Siberia and Central Asia. Karski's central task was to try to explain to all in London that the communist groups in Poland were not acting as allies of the underground movement but rather as Moscow's disruptive proxies.

His other key priority was to convey the uniquely hideous nature of the German crimes against the Jews, a message that was encountering some scepticism. Karski's lifelong sympathy for Jewish people made him a natural advocate for their desperate cause.

He had met the Polish Jewish Bundist leader Leon Fajner and a senior Zionist leader and listened at length to their briefings, fears and desperate proposals for international action. With Fajner, Karski made two covert entries into the Warsaw ghetto, where he was deeply affected by the doubtless routine horrors he witnessed, including a repulsive 'Judenjagd' by Hitlerjugend adolescents armed with rifles.

With the help of the Jewish underground, he also undertook a visit to what he believed to be the Bełżec death camp, where again he witnessed such sickening scenes of demonic cruelty that he was overcome and began to suffer a nervous collapse. Fearing that he might betray himself and his covert facilitators, the guide who was accompanying him hustled him out before suspicions were aroused.

After an eventful journey via Germany, occupied France, Spain and Gibraltar, including an initial period in British detention, Karski finally began his London mission in November 1942. From here on, his war service was to be political and bureaucratic at a high level, and he would not be allowed to return to Poland. 
In London, he had meetings with Prime Minister Sikorski and President Władysław Raczkiewicz, and with senior British officials and Foreign Secretary Anthony Eden. Karski sought an audience with Prime Minister Winston Churchill, but felt he botched his pitch on that score with Eden, who denied him the opportunity.

He also met Polish Jewish émigré leaders and a great many British celebrities. With his photographic memory, graphic eyewitness observations, linguistic facility, and his gaunt frame and face still ravaged by Gestapo torture, he again made a memorable impression.

Raczkiewicz, following Karski's suggestion, wrote a letter to Pope Pius XII, pleading with him to publicly denounce the German crimes against the Jews. Sikorski's government decided that a report on the German mass murder of the Jews, which was based in part on Karski's testimony and smuggled microfilmed materials, should be urgently presented to the Allies. This was done by Foreign Minister Edward Raczyński on 10 December 1942.

On 17 December 1942, at British initiative, the Allies did issue a declaration condemning the German murder of the Jews, though only after some reservations and amendments from the US State Department were received and incorporated.

On 18 January 1943, Raczyński presented further demands to the Allied Council, calling on them to bomb Germany in reprisal for the continuing atrocities against the Jews, to press Berlin to release Jews from occupied countries, and to press Allies and neutral countries in turn to accept them. Nothing much of substance, however, ensued as a result.

At the level of declaratory policy, Karski's message about the Holocaust seemed to have gone reasonably well. But the appeals he brought from the Jews of Poland for resolute action against German murder camps had changed little in the Allies' war strategies.

Karski's Allied interlocutors were reluctant to make saving the Jews who were still alive a priority. And they saw nothing but downsides in drastic responses. In their view, the best that the hard-pressed Allies could do (victory still seemed a remote and uncertain prospect) was to prosecute their war aims against the Axis forces with all their strength. 
In this dispiriting response there seemed to be an element of residual scepticism as to whether things were as bad as Jewish and Polish lobbyists were saying, and a failure of imagination and empathy, even a certain pusillanimity in the face of such a dire and unprecedented human emergency. They apparently did not see it as something at the heart of their national interests.

There had been, in fact, a strange and persistent reluctance, especially further away from the Central European ghettos and death camps, to recognise the enormity of what was happening. Yet innumerable reports from survivors and other witnesses had been filtering into the public domain. They were necessarily incomplete individually, but taken together, they added up to a fairly clear picture.

For different reasons, many Jews were also reluctant to accept the dire reports and warnings that were accumulating. Many, desperately hoping that they could not be true, convinced themselves that they were not; or, at least, that in the country or region of greatest direct concern to them, things would somehow not be so bad.

In 1943, the government-in-exile arranged for Karski to travel to the United States to take his message there. The line-up of dignitaries that he managed to speak to was even more impressive than in London, including Secretary of State Cordell Hull and President Franklin D. Roosevelt himself, together with numerous senior civilian and military officials.

He also met leading American Jews, notably Rabbi Stephen Wise, founder of the World Jewish Congress, and Supreme Court Justice Felix Frankfurter, who was a confidant and adviser to Roosevelt.

By this time, the Polish government-in-exile's main concerns were the looming threat of a return of the Soviets with plans to re-annex much of Poland's territory, and even to sponsor its own Polish government. The Katyn issue, which had been troubling the government for a long time, had meanwhile bubbled to the surface.

German occupation forces in the Soviet Union had discovered some of the mass graves of the Polish officers that were murdered by the NKVD secret police, and publicly invited the International Red Cross to send a delegation to investigate the site. At this point, while in no doubt about the German motivation behind making their discovery public, 
the London Poles could no longer accept Allied recommendations that they not 'provoke' the Russians by making public statements on the issue.

When they announced that they would support a German offer to allow a Red Cross team to investigate the site, Stalin denounced the government-in-exile and broke off relations with it. The Allies blamed the Poles for this and, of course, continued to pretend to be agnostic about the true authors of the Katyn crimes for decades afterwards.

In Washington, Karski's eloquence produced its usual animated response, and Roosevelt spoke with him for over an hour, though some of his comments and questions suggested that the desired messages were not getting through.

On the two main issues for Karski - opposing Soviet plans for Poland and responding more forcefully to the Holocaust - while Roosevelt listened attentively, he gave no sign that he was inclined to reconsider his position. Karski placed special emphasis on the Jews' terrible plight but, in conversation with Roosevelt, seems not to have mentioned his own direct observations in the ghetto and at the camp.

In a conversation a few weeks earlier with Justice Frankfurter after a dinner meeting during which Frankfurter had seemed faintly sceptical, Karski described to him in detail his own experiences in the Warsaw ghetto and at the camp near Bełżec. Frankfurter listened carefully, and seemed to be struck by the gruesome detail of Karski's eyewitness description.

But, after pacing up and down silently for a time, he resumed his seat, turned to Karski and said: 'Mr Karski, a man like me talking to a man like you must be completely frank. So I must say: I am unable to believe you.'

The Polish ambassador to Washington who was hosting the dinner protested that Karski was an absolutely truthful and trustworthy witness, to which Frankfurter responded: 'Mr Ambassador, I did not say this young man is lying. I said that I cannot believe him. There is a difference.'

Frankfurter's reaction reminds me of the wonderful Czechoslovakian film of the 1960s, The shop on the High Street, about wartime Slovakia's 'Aryanisation' program. A Slovak man is directed to take over an old 
deaf Jewish widow's sewing shop. He forms a warm attachment to her and, wanting to protect her, pretends to be a relative. When moves are imminent to deport all the Jews to a camp, he tries to explain to her why he must hide her.

Mrs Lautmann, beautifully played by the great Jewish actress the great Polish actress - Ida Kamińska, listens to his explanations with non-comprehension at first, but finally thinks she has understood. A look of horror passes across her face and she says one word: 'pogrom!' I still remember the sharp intake of breath in the cinema as she said it. The poignant, total inadequacy of that already terrible word to describe what was about to overwhelm her and her town sums up much of what we are talking about this evening.

So Karski's mission to the United States, while it produced quite a stir, from his own point of view ended in failure on the two central issues: Soviet perfidy and the German destruction of European Jewry. But if it was indeed a failure, it was a failure in the best Polish tradition of valiant failures.

He remained in the United States and, for a time, became a celebrity on the lecture circuit, publishing his book on the Polish underground Story of a Secret State (Tajne Panstwo) in 1944, well before the war ended, so that he had to self-censor extensively. The book was a bestseller but, when fame abated and the situation in Poland after the war went from bad to worse, Karski decided to settle in America permanently.

He completed a doctorate and became a lecturer at Georgetown University's School of Foreign Service in Washington, after an attempt to find work in the US State Department failed. While he became a popular and successful lecturer, and a patriot of his adopted country, the anguish of his wartime experiences and his failure to relieve the terrible suffering he had witnessed never left him.

After decades of silence on these subjects, Karski was drawn again, unwillingly, into public discussion of the Holocaust by Claude Lanzmann, the maker of the celebrated documentary Shoah. Lanzmann assured Karski that he would give due emphasis to efforts by Poles to help Jews, as well as their failures, their at times callous indifference and their all too frequent outright betrayals. He also undertook 
to cover Karski's efforts to alert the world. But, in fact, Karski's visits to the Warsaw ghetto and the camp figured prominently, and the rest scarcely at all.

In 1981, Elie Wiesel also 'discovered' Karski when organising a conference on the Holocaust, and managed to persuade him to speak in public about his wartime experiences. This led to a more general public discovery of him, and a new fame that, though it revived painful memories, must also have brought him some healing and satisfaction.

With his Polish-Jewish wife, the dancer and choreographer Pola Nirenska, he visited Israel, where he was recognised as one of the Righteous Among Nations at Yad Vashem Holocaust Museum. Other international honours came his way, including posthumously, when President Barack Obama awarded him the highest US honour, the Presidential Medal of Freedom, referring incongruously as he did so to 'Polish death camps'.

As the role that he had played during the war, and his views on things, became better known, some intra-Polish controversy arose. His association with Shoah, for example, which appeared in 1985, earned him hostile reactions from some Poles, who felt the film depicted Poles and Poland in an exclusively and tendentiously negative light.

His left-wing views also evoked suspicion. He had been inclined to support the Polish government-in-exile's Premier Stanisław Mikołajczyk's doomed efforts to reach a degree of accommodation with Moscow. ${ }^{6}$ In the underground, his sympathies were naturally with the left and against the anti-Semitic right though, as an emissary, he did his best to maintain harmonious contact with all.

One of his close colleagues in the underground had been Józef Cyrankiewicz who, in 1948, had subordinated his rump Polish Socialist Party to the communists to form the PZPR (Polish United Workers' Party), which was thereafter the ruling party of communist Poland. Some Poles were unpleasantly struck that, during a 1970s visit to Poland for research purposes, Karski had an apparently warm and emotional reunion with Cyrankiewicz, who was by then discredited

6 See pl.wikipedia.org/wiki/Stanis\%C5\%82aw_Miko\%C5\%82ajczyk; Janusz Gmitruk, Stanislaw Mikołajczyk: Trudny powrót (Warsaw: Muzeum Historii Polskiego Ruchu Ludowego, 2002). 
and out of power. Such a cordial meeting between them was perhaps more understandable given their wartime comradeship and the fact that Cyrankiewicz's group had saved his life.

But Cyrankiewicz's betrayal of his former underground colleagues had followed show trials of underground heroes, and the execution of such people as the Polish army officer and resistance fighter Witold Pilecki. Pilecki had volunteered to deliberately become a prisoner in Auschwitz, where he organised an underground group that collected and smuggled out intelligence about the crimes being committed there by the Germans. The work of Pilecki, a man with a background in Poland's often anti-Semitic nationalist right, contributed greatly to the message that Karski took to the Allies about the mass murders that Nazi Germany was committing behind a wall of stealth, lies and euphemism.

Karski never hesitated to reach across the barricades. Raised a Pilsudskiite, he became a faithful servant of the Polish governmentin-exile headed by Sikorski and other staunch adversaries of the Sanacja regime that Piłsudski had created, and which had, in the years after his death, veered in an increasingly anti-Semitic direction. Though of the Catholic left, Karski became an enthusiastic supporter of the right-wing Front for the Rebirth of Poland of Zofia Kossak. A distinguished Polish writer from a famous artistic Polish family, and an ardent Catholic, Kossak felt that Polish Jews often had little sympathy with Polish national objectives.

But when she became aware of the Germans' policy of genocide, she denounced it as an offence before man and God, and called on all Poles to resist and do whatever they could to rescue their suffering Jewish brothers and sisters. She was one of the original founders of the Polish underground organisation Żegota, which did more to save Jews during the German occupation than any other similar group in any country.

In his book The Terrible Secret (1980), the distinguished Jewish historian of Europe Walter Laqueur, no champion of Poland, makes it clear that the efforts of the Polish government-in-exile and its couriers, Karski in particular, deserve much of the credit for exposing the nature of the 'final solution'. And he comments aptly: 
That there has been a great deal of anti-Semitism in modern Polish history is not a matter of dispute, but it is also true that help was extended to the Jews after 1939 by some who had been their bitterest enemies before ... In view of the Polish pre-war attitudes towards Jews, it is not surprising that there was so little help, but that there was so much. ${ }^{7}$

Under communism, Poles were not exposed to much information about the misdeeds of ethnic Poles against Jews during and just after the war. The communist regime tended to absorb the uniquely horrible fate of Jews, including Polish Jews, within the overall story and statistics about Poland's wartime martyrdom, and to restrict discussion of grassroots Polish anti-Semitism. For a period in the 1960s, sections of the ruling regime even sought to incite and exploit anti-Semitism for crudely political purposes, with devastating effects on Poland's reputation.

Recent research inside Poland and abroad is now more openly addressing the darker sides of Polish-Jewish wartime relations. For many Poles, this is painful and some respond angrily and polemically, sometimes reviving the argument that Jews were disproportionately represented in the postwar communist regime and its brutal security forces who persecuted Poland's wartime Home Army (the Armia Krajowa) heroes. But, while there is some truth in this and other arguments that they deploy, they provide no justification for denial or suppression of the facts. It is a public discussion that has to happen, however painful it may be. If he were still alive, Karski would welcome it wholeheartedly.

Karski was a man of broad and undogmatic sympathies. Because of their history, Poles have tended to be hostile to their neighbours to the east and west, not without good reason. Any Pole who seems inclined to parley with them has often been quickly identified as a traitor. Shades of grey have seldom been Poland's strength. But while Karski had great moral clarity about the most important issues confronting his country, he was, for a Pole, unusually flexible.

In his later years, Karski became a friend and mentor to the new generation of post-communist Polish diplomats arriving in Washington. He struck them as being a classic representative of the traditional poszlachecka inteligencja (the patriotic Polish intelligentsia of the

7 Walter Laqueur, The Terrible Secret (New York: Owl Books, 1998), pp. 106-07. 
nineteenth and early twentieth centuries, typically deriving from the déclassé nobility of partitioned Poland): a gentleman diplomat, with a stylish home and manners and egalitarian attitudes.

His advice to them was explicitly unheroic: above all, be realists; avoid Polonocentrism; don't expect to be rewarded for your noble actions; don't expect anyone to write you a cheque for Solidarity; do all you can to get into NATO, but remember that once you're there, that's just the beginning. ${ }^{8}$

At Wiesel's conference, Karski struck an eloquent note of bitter elegy about his Jewish brothers and sisters of Poland and Europe:

The Lord assigned me a role to speak and write during the war, when - as it seemed to me - it might help. It did not ...

Furthermore when the war came to an end I learned that the governments, the leaders, the scholars, the writers did not know what had been happening to the Jews ... The murder of six million innocents was a secret ...

I am a practising Catholic. Although I am not a heretic, still my faith tells me the second Original Sin has been committed: through commission or omission, or self-imposed ignorance, or insensitivity, or self-interest, or hypocrisy, or heartless rationalization.

This sin will haunt humanity to the end of time.

It does haunt me. And I want it to be so. ${ }^{9}$

8 Ambassador Andrzej Jaroszyński, Polish ambassador to Australia, 2008-13, personal communication.

9 As quoted in E. Thomas Wood \& Stanisław M. Jankowski, Karski: How one man tried to stop the Holocaust (New York: Wiley, 1994), pp. 255-56. 



\section{4 \\ The worst of both worlds: Captain Witold Pilecki between Hitler and Stalin ${ }^{1}$}

In the late 1960s, during one of my first visits to Warsaw, I found myself travelling by public transport along Rakowiecka Street in the southern suburb of Mokotów with a young Polish woman named Sonia, who had been deputed by kind friends to look after their exotic and no doubt naïve visitor. At a certain moment she pointed discreetly at the forbidding walls of a building we were passing and whispered, with a tremor of dread in her voice, that it was a jail. Then, even more nervously, she explained to me that there were political prisoners inside. She sought my confirmation that there were such prisons in Australia too. I said there were not, which she obviously found incredible. By that time, there were far fewer political prisoners in Mokotów prison than there had once been. But, during the Stalinist period of Poland's postwar history, many wartime anti-Nazi resistance fighters were held there for extended periods of brutalisation and torture, and multiple executions were not uncommon.

Sonia was probably acutely aware of that period, and perhaps apprehensive that it might return and take an anti-Semitic turn. The politics of the ruling Polish United Workers' Party (PZPR) certainly

$1 \quad$ First published as a book review of Witold Pilecki's The Auschwitz Volunteer: Beyond Bravery (Aquila Polonica, 2012) in Inside Story, 3 Oct. 2013, insidestory.org.au/the-man-whovolunteered-for-auschwitz. 
seemed to be tilting in that direction. For historical reasons, Jews had been prominent in the Polish communist regime of the Stalinist era, including within its brutal security police. A hardline, anti-Semitic faction within the regime was seeking to exploit that fact in its bid to seize power and, in 1968, it launched an internationally conspicuous hate campaign against Poland's surviving Jews.

By that time, the notorious Jewish communists of the Stalinistera security establishment had been removed from office and, in some cases, punished, and the manoeuvre did not succeed. But its failure came only after a major crackdown on the opposition-minded intelligentsia, which also contained many Jews, had pushed half of Poland's surviving Jewry, including Sonia, into emigration.

It is unlikely that Sonia would have heard of the name, much less the exploits, of one of Mokotów's prisoners, the Polish cavalry captain Witold Pilecki, who was held and tortured there for nearly a year before being executed on 25 May 1948. For many decades following his judicial murder, Pilecki was an unperson, his heroic career unknown to the younger generation of his compatriots.

Pilecki features as one of the six most outstanding resistance fighters of World War II in the British historian Michael R.D. Foot's book Six Faces of Courage (1978). But because of the Western squint on the history of the war, Pilecki is not well known among Anglo-Saxon readers either. And that means any introduction of the remarkable book, The Auschwitz Volunteer, to English-language readers must also introduce its equally remarkable author.

Witold Pilecki was born in 1901 into a family that had been forcibly resettled to Tsarist Russia because of his grandfather Józef Pilecki's involvement in the Polish uprising of 1863, for which Józef had spent seven years in Siberian exile. As a boy, Witold moved with his family to the ethnically Polish (and Jewish) city of Wilno, now Vilnius, the capital of Lithuania. He joined the secret Polish scout movement, which led naturally to his teenage involvement in the Polish independence struggle during the latter stages of World War I, including the underground resistance to invading Bolshevik forces near Wilno. (Despite presenting themselves as the liberators of the Tsarist 'prison of the peoples', the Bolsheviks were in fact doing their best to restore the Russian empire, in a new 'proletarian' guise.) 
Following Poland's re-emergence as an independent state, Pilecki joined the newly formed national Polish army and took an active part in the Polish-Bolshevik war of 1919-20, notably in the defence of Warsaw in 1920. Still in his teens, he was twice decorated. After the war, he returned to civilian life, working to restore his family estate while remaining active both as a reserve officer and through charitable work, for which he was again decorated. By all accounts a devoted husband and father, he also engaged in musical and artistic pursuits, including painting and writing poetry. He was later to pen a poem in Mokotów Prison to his torturer-in-chief, the notorious Colonel Józef Różański.

In 1939, Pilecki was mobilised as a platoon commander in the Polish cavalry. Contrary to the hardy myth, his poorly equipped unit did not undertake quixotic charges on horseback against the advancing Germans, but it did succeed in destroying seven tanks and three aircraft. The Polish armed forces received no help from their Western allies and were soon outgunned by the enemy. Retreating to the southeast, Pilecki and his men were overrun by Soviet forces entering Poland to claim their share of the spoils of the secret clauses of the Molotov-Ribbentrop Pact, which carved up Eastern Europe between Germany and the Soviet Union.

Discouraged by Poland's isolation and the unequal struggle on two fronts, and feeling abandoned by the high command and political leadership who had retreated across the south-eastern border, many Polish armed units also headed west via the same circuitous route, but Pilecki's unit remained. Its last battles were fought as a partisan force.

In November 1939, Pilecki helped found a pioneering resistance group called the Secret Polish Army, which became one of the building blocks of the Home Army (Armia Krajowa, or AK), the biggest armed resistance formation in German-occupied Europe for much of the war. Pilecki's Secret Polish Army derived from the prewar nationalist right, which had numbered extreme nationalists and anti-Semites among its members. But Pilecki's simple personal and military code of God, Honour, Fatherland (Bóg, Honor, Ojczyzna), did not lead him in that direction. Under his leadership, the Secret Polish Army quickly accumulated thousands of followers. 
Hitler's occupation regime quickly began implementing its plan to decapitate the Polish intelligentsia, Polish culture and Polish education; to re-Aryanise any putative Germans; to seize children with promising Germanic traits for adoption by Germans; and generally to reduce the nation to a leaderless mass of slave labourers to be worked to death or deported to make Lebensraum for German settlers. Large groups of Poles were being arbitrarily seized and despatched to the Auschwitz concentration camp in the south-western Polish region of Silesia, which, with its mixed Polish-German population, had been annexed directly to the Third Reich.

The fragmentary but alarming reports about Auschwitz that reached the underground led Pilecki to propose to his superiors that he allow himself to be incarcerated in Auschwitz to organise a resistance movement there and send back intelligence. Pilecki seems to have been the only person who ever volunteered to become an Auschwitz prisoner. After his commanders agreed to the plan, he inserted himself in a German mass round-up in Warsaw. Along with some 1,800 other people seized in the round-up, he was transported to Auschwitz, where he was to spend two years and eight months in Auschwitz I, the Stammlager, or main camp, in the complex.

Auschwitz was not yet the mass-murder facility it was later to become, nor had adequate reports of the vicious conditions there filtered through to Warsaw. Even for someone as hardened to resistance as Pilecki, arriving at the camp after a nightmarish journey without food or water was nonetheless a severe shock. Brutally extracted from their freight trucks under blinding lights, beaten, kicked and rifle-butted by SS men and herded by snarling dogs into lines, the new arrivals were then marched into the camp. In his report, Pilecki described the scene as follows:

On the way, one of us was told to run to a post at the side of the road; he was followed by a burst of automatic weapons fire and mown down. Ten men were then dragged out of the ranks at random and shot with pistols as 'collective responsibility' for the 'escape' which the SS themselves had staged. All eleven of them were then dragged along by leg straps. The dogs were teased with the bloody corpses and set on them. All this to the accompaniment of laughter and joking. 
We approached a gate in a wire fence over which could be seen the sign 'Arbeit macht frei' ['Work makes you free']. It was only later that we learned to understand it properly.

Beyond the gate they were set upon by a horde of kapos (prisoner trusties) in the pyjama-like garb that was later to become so familiar throughout the world. Demanding in German to know what the newcomers had done in their former life, the kapos beat to death any who acknowledged they were educated professionals. The amplified voice of the Auschwitz deputy commandant, Fritz Seidler, could be heard promising the newcomers that they would be allowed to live no more than six weeks; any who did would be regarded as having stolen food, and for that they would be sent to a penal company where they could be quite certain they wouldn't survive long.

Pilecki himself endured two beatings, losing some teeth and only just managing to suppress groans of pain that might well have led to worse. Such was his introduction to Auschwitz.

The daily routine of the camp proved to be very like that welcome. Prisoners were systematically starved and deprived of sleep, sanitary facilities were grotesquely inadequate, and the daily labour was backbreaking. Unless they found a niche away from the everyday grind, prisoners would indeed die soon enough, even if they weren't killed for some alleged infringement of discipline or 'hygiene'. The day was made longer by repeated parades and rollcalls, and anyone failing to appear because of hunger, fatigue or disease was likely to be routed out and murdered on the spot to encourage the others to better behaviour.

Although some of the kapos and some of the German civilians employed at the camp showed some residual signs of human decency, most did not. The kapos were often the worst of all. Two ethnically Polish early arrivals at Auschwitz had ascended to the most senior kapo positions and were loathed and feared even more than the SS. Pilecki refers to the two contemptuously as 'ex-Poles'.

Pilecki's report describes the conditions in the camp in grim detail, with a keen eye for camp sociology, poignant scenes and brutal patterns of behaviour, and at times with black humour. Some of the time, things got worse; at others, they eased slightly. But throughout his lengthy stay, the remorseless attrition continued. Because the prisoners were 
given consecutive numbers based on the time of their arrival in Auschwitz (Pilecki was 4859), it became possible to determine attrition rates by counting the numbers who had survived from any group of one hundred. After two years, each group of Pilecki's approximate vintage had been reduced to fewer than 10 .

This was genocide, slow-motion genocide compared to the hideous mass-murder regimes instituted for Europe's Jews in the adjoining Auschwitz-Birkenau camp and elsewhere, but genocide nonetheless. And camp SS officials frequently reminded the prisoners that the purpose was to finish them all off in the end. Historians estimate that at Auschwitz alone, some 80,000-90,000 ethnic Poles perished, and over a million Jews.

Pilecki survived through a combination of physical fitness, resilience, exceptional resourcefulness, coolness under pressure and good luck. At one point he was allocated a skilled labourer's job by a junior camp official who was desperate to perform a private task for a superior. Despite not having the necessary skills, he inserted himself plausibly into the role. From there, one tradesman's job led to another and he escaped the worst of the barbarous camp conditions.

These jobs gave him the contacts, the relative freedom of movement and, above all, the longevity to build up his organisations of intelligence agents and soldiers-in-waiting. Through the networks they created, they were sometimes able to help themselves and others - or even save prisoners from impending disaster or exposure - and also to conduct guerrilla warfare against the worst of the camp administrators. (An example of the latter involved collusion with sympathisers on the staff of the prison hospital - itself typically a staging post to death or execution - to infect their hated tormentors with the typhus-carrying lice that were endemic in the prisoner population.)

Pilecki began organising this elaborate resistance structure very soon after his arrival, basing it on groups of five, no members of which, apart from himself, had a comprehensive sense of the extent or membership of the organisation as a whole. Though by no means the most senior military prisoner in the camp, his natural authority and remarkable flair for organisation enabled him to unify all the existing underground cells and groups in the camp under his leadership. The resulting Union 
of Military Organisation included activists from various points on the political spectrum of pre-war Poland who, in normal circumstances, would not have been prepared to shake hands with one another.

By recruiting collaborators from among inmates who had become camp functionaries of one sort or another, Pilecki's organisation was able to mitigate some of the worst features of camp life. It also gathered information about the crimes of the occupation regime and transmitted reports to the underground leadership via the occasional prisoners who were released from the camp (often thanks to large bribes offered to German officialdom in Warsaw or Cracow) or the very small minority who managed to escape.

Neither release nor escape were viable options for any of the Jews being caught up in the mass shipments to Auschwitz and other death camps. Pilecki's report describes how some time before Hitler's 'final solution' began to be implemented, Jews among the prisoners in Auschwitz I were forced to write letters to relatives throughout Europe describing the circumstances there as very favourable. Conditions were even eased for a time to facilitate this operation. The purpose, he later concluded, was to deceive the many thousands of Jews still to arrive at Auschwitz into believing that they were simply being resettled, and thereby to avoid mass panic or desperate rebellions as they were prepared for the gas chambers.

Pilecki's central objective was to ready an underground fighting force to rise up and overpower the camp administration in the event of an Allied or AK attack on Auschwitz. Sadly, this worthy and understandable ambition proved to be unrealistic. Despite the information provided by the Union of Military Organisation to the underground leadership, and through them to the Allies, about the mass torture, starvation, widespread murder and hideous conditions prevailing in Auschwitz, the Allies never undertook significant action to disable, much less liberate, the camp. And the AK was never strong enough to mount such an operation successfully on its own.

Even when the Germans began mass gassings at Auschwitz, initially and 'experimentally', of Soviet POWs, then increasingly of Jews - all of which Pilecki reported - there was a marked reluctance in Allied 
circles to believe the reports. As with the news of the Holocaust conveyed to the Allies by the legendary Polish courier, Jan Karski, they tended to be dismissed as exaggerated or inaccurate.

After more than two-and-a-half years in Auschwitz, Pilecki began to detect signs that the organisation could be in danger and that his own role could be exposed. If Pilecki, with his overarching knowledge of the underground structure in Auschwitz, had succumbed to extreme methods of interrogation the results for all his colleagues would have been disastrous. With two comrades, he therefore meticulously planned and staged a successful getaway, surviving gunfire from guards in hot pursuit and an encounter with an armed German patrol a little further along the way. For many readers, the gripping description of this adventure in Pilecki's report, extending over 50 pages, will on its own be worth the price of the book.

Over 800 inmates tried to escape from Auschwitz but only 144 succeeded. The failed escapees were invariably executed and, typically, the Germans inflicted collective capital punishment on at least 10 others, who may not have been involved in any way. Pilecki's organisation adopted a policy of discouraging escapes for that reason. At the time Pilecki and his companions decided to escape, however, while conditions in the adjoining Auschwitz-Birkenau death camp were even more hideous, the administration had become milder in Auschwitz I, and a successful escape a short time before had brought no collective punishment.

Having shaken off his pursuers, Pilecki made his way stealthily towards Warsaw. During the journey, by a bizarre coincidence, he met the real owner of the identity he and his underground colleagues had pilfered to forge the documents he had used for the round-up. The false identity helped to protect his underground colleagues and to save him from being blackmailed by threats to his family. The real owner of his nom de guerre was startled to meet him, but bore him no ill will and indeed invited him to rest and recuperate before continuing his journey.

Back in Warsaw he immediately resumed his underground activities in AK headquarters, where he was promoted from lieutenant to captain and deployed in the AK Sabotage Command. In his new post, he resumed his efforts to convince his superiors of the need to launch the 
attack on Auschwitz that he believed could have enabled the Union of Military Organisation to liberate the camp from within. He also prepared a report on Auschwitz, called the 'W Report' (later 'Witold's Report'), to be transmitted to the Allies, which formed the basis of the longer 1945 version that Jarek Garliński has now translated. The report was a key source of intelligence for the Allies on Auschwitz, but, regrettably, like others of its kind, it did not stir them into action.

On 1 August 1944, the AK leadership took its fateful decision to unleash the Warsaw Uprising against the German occupation of the capital. In nine weeks of fighting, over 200,000 Poles - men, women and children, civilians, underground soldiers, and medical orderlies alike - were killed. Hitler gave explicit instructions that the city should be razed to the ground in punishment for its outrageous impertinence. Despite his status as an officer, Pilecki volunteered for action as a foot soldier in the uprising. With casualties mounting rapidly, however, he accepted an officer's command, and led some particularly noteworthy acts of armed resistance against the vastly superior firepower of the enemy.

One in particular, in which his unit repeatedly took and retook a strategic building on the main east-west thoroughfare through the city, caused great frustration to the German side. Reviewing the episode, the eminent British historian Norman Davies comments that so long as Pilecki 'threatened this one vital pressure point, the German command was made to feel insecure. One is tempted to suggest that a single company could have won the Rising a fortnight's reprieve.'2

Time was perceived as vital by the uprising's leaders, who were calculating that the Allies would come to their assistance. But Moscow, having used its propaganda broadcasts to Poland to call for the insurgents to rise up, halted its advance on the other side of the Vistula River when they did so, and waited for Hitler to crush the insurrection. With it, Stalin calculated, the powerful national underground movement, which he wanted to replace with his proxy Polish forces, would also be crushed. Stalin even refused to allow the Western Allies to make use of airstrips under Soviet control to the east of the city in their attempts to deliver vital supplies to the insurgents.

2 Norman Davies, Rising '44: The battle for Warsaw (New York: Macmillan, 2003), p. 323. 
(Flight distances were too great for aircraft to deliver supplies to Warsaw without landing somewhere nearby and refuelling for the return journey to Allied airfields.)

When the leaders of the uprising finally surrendered, Pilecki was taken prisoner and spent several months in German POW camps. On being released in July 1945, he joined the main unit of the Polish armed forces in the west, General Władysław Anders's Second Polish Corps. He soon accepted a mission from Anders to return to Poland under yet another false identity to gather intelligence on the progressive communisation of Poland by the Soviet Army, the Soviet NKVD secret police, and their Polish equivalents. These Polish forces and nascent political structures had been recruited from deportees and exiles in the Soviet Union who had not chosen, or had not had the chance, to join Anders in his evacuation of Polish forces and their families from the Soviet Union to the West. By that time, they had been thoroughly immersed in Stalin's methods by their Soviet masters and fully subordinated to them.

Back in his homeland in October 1945, Pilecki again set about forming a resistance intelligence network. Early in 1946, the governmentin-exile in London, deflated by a complete lack of support from the Allies, who had supposedly guaranteed their sovereignty and declared war against Germany in their defence, decided further resistance to Sovietisation of Poland was pointless. They ordered all the partisans still resisting the new occupiers to abandon the struggle, conserve their remaining strength and return to a civilian existence in Poland or seek to escape to the West in readiness for some future reckoning. Pilecki ignored this directive, and also warnings that the Moscowcontrolled Polish police apparatus was closing in on him. He also declined to respond to an amnesty offered by the regime in 1947.

He was arrested in May 1947 and spent 10 months in detention while a show trial was prepared against him and a number of others accused of being members of his group. Like all political prisoners in the emerging Stalinist Polish state, he was treated with great brutality, and is known to have been subjected to 'interrogations' by some of the most notorious sadists in the Polish security police. In a final whispered aside to his wife and a family friend at his trial, he told them that in comparison with the communists' torture methods, 'Auschwitz had been kids' play' (igraszka). 
The trial of Pilecki and others from 'Witold's Group' began on 3 March 1948. Pilecki argued that his spying activities had been carried out on behalf of the Polish army in the West, of which he continued to regard himself as an officer bound by his oath of allegiance to God, Honour, Fatherland. Regime propaganda about the group on trial included the brazenly mendacious theme that they had collaborated with the Nazi occupation.

Pilecki was sentenced to death on 15 March 1948. At the show trial or in separate closed hearings, eight of his colleagues were also sentenced to death for spying against their own country, for which most of them had fought in shocking conditions throughout the German occupation. Two of the nine under sentence of death had their sentences commuted to life imprisonment. Thirteen others were sentenced to jail terms of from three to 15 years. The prosecutor and the president of the court that tried Pilecki had been members of the AK but, when the Soviets and their Polish allies arrived in the country making mass arrests among AK officers, they decided instead to forge careers in the new occupation regime.

Pilecki's wife and others made efforts to have his death sentence commuted, but Poland's communist President Bolesław Bierut declined to exercise his right to do so. Pilecki's supporters had hopes of intervention by the prewar Socialist leader Józef Cyrankiewicz, who had been active in the AK and also survived imprisonment in Auschwitz. Cyrankiewicz, too, had decided to collaborate with the new regime, and ultimately led the rump of his Socialist party into a 1948 merger with the communists to form the Polish United Workers' Party, which dominated communist Poland till 1990. As a reward, he was made Prime Minister of Poland (under communism an important but certainly not the top job) from 1947 to 1952 and again from 1954 to 1970. His alleged achievements as a resistance leader in Auschwitz were much trumpeted by Cyrankiewicz himself and the regime.

But when people begged him to do something to save the life of the doyen of all Polish Auschwitz survivors, he conspicuously declined to do so. ${ }^{3}$ Indeed, quite the reverse, he gave evidence against him. It has been plausibly argued that Cyrankiewicz saw Pilecki as someone who

3 Andrzej M. Kobos, 'Witold Pilecki w piekle XX wieku', www.zwoje-scrolls.com/zwoje09/ text02p.htm. 
could undermine his new propaganda persona as an Auschwitz hero and, for that reason, wanted him out of the way. Pilecki is reported to have told a fellow prisoner, Father Czajkowski, that 'if Cyrankiewicz finds out I' $m$ in here, I'll be killed for certain'.

Another source recalled that Pilecki had told her in 1946 he had heard Cyrankiewicz was preparing a speech glorifying his own role at Auschwitz. Pilecki told her he had written to Cyrankiewicz saying, 'I have a document in my possession regarding your time in Auschwitz. If you dare to speak about your role in the Auschwitz resistance, I will make that document public.' The speech was never given.

Cyrankiewicz played a more creditable role in the case of the legendary courier Jan Karski, but it seems likely that he engaged in dishonourable behaviour in Auschwitz, about which Pilecki had been reliably informed. It was characteristic of Pilecki that he did not hesitate to make an enemy of such a highly placed opportunist as Cyrankiewicz, and accepted the consequences. After Pilecki's death, the legend of Cyrankiewicz's doughty deeds in Auschwitz would remain unchallenged until he, too, was dead.

It was also characteristic of the communist modus operandi in Poland that they 'captured' and made use of prominent figures who had compromised themselves in some way. Two prewar Polish officers (Zygmunt Berling and Michał Rola-Żymierski) who were recruited to leading positions in Stalin's Polish communist army had been removed from the Polish army for embezzlement before the war.

On 25 May 1948, in Mokotów prison on Rakowiecka Street in Warsaw, Witold Pilecki, the only man known to have volunteered to be incarcerated in Auschwitz in the service of his country, and one of the few who risked immediate death to escape from it again, was executed as a traitor to his homeland with a shot to the back of the head, in the best NKVD tradition, by one Piotr Śmietański. This was a rewarding occupation for Śmietański, who was literally paid by the shattered head, and was kept busy.

From a window in his cell, an imprisoned priest, Jan Stępień, caught one of the last glimpses of Pilecki as he was being led to his death: 
I'll never forget that scene. There were two condemned men. Witold Pilecki was the first to appear. His mouth was bound with a white bandage. Two guards led him by the arms. His feet were barely touching the ground. I don't know if he was still conscious. He gave the impression of someone who had fainted. And then came the gunfire.

As with hundreds of other such executions, a jail functionary took the remains of the victim under cover of darkness and dug them into the ground near Warsaw's historic and atmospheric Powązki Cemetery. The terrain in question, known in police code as 'The Meadow', was at the time the location of a rubbish tip. Pilecki's final resting place was not known to his family for many decades, and is still not known exactly. He was not 'rehabilitated' until after the fall of communism in 1990, and only in 2012 was it possible for serious efforts to be undertaken to locate his remains.

Pilecki's manuscript was written as a military report to his superiors, not as a work of history, literature or journalism. It is direct and informal in style, with relatively little care taken to manicure the prose or mould paragraphs. The author had always been far too busy to find time to polish or contemplate publishing it.

As translator, Jarek Garliński has been at pains to retain the informal spontaneity of the original, including Pilecki's frequent use of German terms for camp institutions and the threatening language of the SS and the kapos. The son of the distinguished Polish émigré historian Józef Garliński, and himself deeply knowledgeable about the subject matter, Jarek Garliński also provides the reader with extensive and valuable aids to understanding the details of the text. Readers who find some of this detail (the numbers of the various Auschwitz blocks, and their previous designations, for example) superfluous to their requirements can easily bypass it.

The content is fascinating at a number of levels, whether in relation to Pilecki, camp life or the Third Reich in general. Parts of the book can also be read as a factional adventure story in the style of English classics like Eric Williams's The Wooden Horse (1949), but one with far greater depth and historical significance than most in that genre. For the outstanding American historian of Eastern Europe, Timothy Snyder, it is a document comparable with the works of Primo Levi and Tadeusz Borowski. 
When supplemented by a sketch of Pilecki's life before and after Auschwitz and a description of the fate of his homeland at the hands of both its enemies and its allies, the book conjures up the full tragedy and bitterness of Poland's wartime struggle. As Norman Davies says in his introduction, 'Only when one grasps the true horror of his fate can one comprehend what the Second World War in Europe was really about ${ }^{4}{ }^{4}$

It should not be said (though it sometimes is) that Pilecki's or Poland's struggle was entirely in vain. But it is understandable that some of the loyal rank and file who lived to tell the tale turned into sharp critics of their former leaders for allowing so much Polish blood to be shed in what was, they argued in retrospect, a futile cause. One can only conjecture as to whether hints of similar thoughts passed through Pilecki's mind in the last days before he was led away to be shot by a group of his fellow Poles. (He would probably have called them all 'ex-Poles', just as his compatriots took to contemptuously calling collaborators with the new regime 'acting Poles'.)

Inevitably, this account of Pilecki's life also raises again the old debate about which of the two great tyrannies of the era, Nazism and Stalinism, was the worse. Some participants in the debate, apparently trying to preserve the memory of Stalinism as an errant but nonetheless defensible part of the Marxist legacy, denounce any comparison as immoral. Those who opposed the introduction of communism into Eastern Europe, they sometimes argue, were fascists, anti-Semites, Hitler's pawns and so on, implying that they all got what they deserved. Most on the left take a more judicious view and, indeed, it was often writers from the left (Isaac Deutscher, George Orwell and others) who brought Stalin's crimes to Western attention.

Survivors' views of the two tyrants tend, for obvious reasons, to depend on personal experience. For some Ukrainians, for example, Hitler represented the hope, however illusory that proved to be, for a national life, even independence, and for deliverance from mass, deliberate starvation. They greeted his invasion naïvely with the traditional bread and salt of welcome. For Jews, by contrast, and for urgently compelling reasons, Stalin and Soviet communism represented deliverance from mass genocide and perhaps the promise

4 Pilecki, The Auschwitz Volunteer: Beyond Bravery, p. xiii. 
of a better life. The inhabitants of Snyder's 'bloodlands', ${ }^{5}$ notably the Poles and the Baltic peoples, typically experienced not one but three successive hideous invasions. Academic objectivity and exquisite moral judgement can be difficult for anyone with such life experiences.

'All the indications are that Soviet instruments of repression consumed more human beings than their Nazi counterparts', Norman Davies asserts confidently in his introduction to The Auschwitz Volunteer. Stalin's era and system lasted much longer than Hitler's so, on some interpretations of the statistical record Davies is probably right. Most contemporary historians of the period incline to the view that the Soviet statistics made available since Mikhail Gorbachev's perestroika point to a rather lower death rate under Stalinist rule than had previously been assumed. But the statistics may be imperfect - it was Stalin, after all, who suppressed the results of the 1937 Soviet census. Be that as it may, for most people there is something uniquely horrible about the death camps and industrialised mass murder of Nazi Germany, with which even the Gulag does not compare.

Snyder has weighed the pros and cons and come to the conclusion that, while initially Stalinism was worse, Nazism overtook it in brutality and became clearly the more evil of the two. ${ }^{6}$ What might Pilecki have thought of it after mature reflection in exile in the history department of an American university?

5 Timothy Snyder, Bloodlands: Europe between Hitler and Stalin (New York: Basic Books, 2010).

6 Timothy Snyder, 'Hitler vs. Stalin: Who was worse?', New York Review of Books Blog, 27 Jan. 2011, www.nybooks.com/blogs/nyrblog/2011/jan/27/hitler-vs-stalin-who-was-worse/. 



\section{5 \\ Speaking truth to power and prejudice ${ }^{1}$}

I first met Adam Michnik in Warsaw around 1970, when Jan Józef Lipski, one of the legendary figures of Polish resistance, took my wife and me to visit his young protégé in hospital, where Michnik was recovering from one of the many beatings he suffered at the hands of the communist security forces. The boyishly mischievous young man on the bed in front of us seemed totally undeterred by his experience, and his comments had all the overt defiance that made Poland such a difficult country for successive Russian imperial regimes to control.

Despite his youthful appearance, Michnik was already a veteran of seditious activity. In his early teens he had caught the eye of Lipski and another activist, Jacek Kuroń, and began taking part in their political discussion groups, which were duly disbanded by the regime. Before he turned 20, Michnik had been twice rusticated from Warsaw University. The first time was for circulating Kuron and Karol Modzelewski's Open Letter to the Party, a classic in the genre of Eastern European opposition literature, and the second for organising a discussion group with the famous Polish philosopher Leszek Kołakowski, who had just been expelled from the ruling party for his

$1 \quad$ First published as a book review of Adam Michnik's In Search of Lost Meaning: The new Eastern Europe (University of California Press, 2011) in Inside Story, 24 Oct. 2011, insidestory. org.au/speaking-truth-to-power-and-prejudice. 
outspoken criticism of the regime. The fact that Michnik was mingling with the elite of the Polish opposition at such an early age testified to his exceptional intelligence as well as his indomitable impertinence.

In March 1968 Michnik emerged as a leader of the student demonstrations, centred on Warsaw University, that were being staged against the increasingly hardline cultural policies of party boss Władysław Gomułka. Gomułka was a 'national communist' who had been ousted from the leadership in the late 1940s and later imprisoned for daring to defy Stalin, but was acclaimed by Poles as a national hero in 1956 when he was returned to power in defiance of Moscow's wishes. The regime's brutal reaction to the 'March events' was led by the anti-Semitic Partisan faction of the party, which had strong influence in the military and security establishment and whose leader, General Mieczysław Moczar, had ambitions for the top job.

Some of the student leaders, like Michnik, were the children of Jewish communists or ex-communists. They became the focus of the police actions and propaganda that were coordinated by the Partisan faction, which hoped thereby to curry favour with the public and destabilise Gomułka, whose wife was Jewish. For several months, the world was treated to the extraordinary spectacle of a communist regime, in a country that had involuntarily hosted Nazi death camps, conducting an overtly anti-Semitic crackdown and public disinformation campaign, sometimes employing language and cartoons reminiscent of the Third Reich. Many thousands of the small surviving Jewish community in Poland succumbed to strong official pressure to go into exile. The damage to Poland's international reputation and cultural life was severe and long-lasting.

For those of Michnik's young circle of rebels who had Jewish family backgrounds, it was a great surprise to find themselves identified as Jews and not Poles. Until then, they had not thought of themselves that way. Many involved in the protests, including Michnik, were expelled from the university and some were driven out of the country. As a key leader, Michnik was given a stiff prison sentence, but he was later released in an amnesty and allowed to resume his studies at another university. 
Happily for Poland, the Partisan faction's bid for control of the regime was unsuccessful. In December 1970, Gomułka's misrule came to an end when demonstrations against food shortages in Gdańsk and other Baltic cities were suppressed by mass shootings of unarmed protesters. In the crisis that followed, Gomułka was succeeded not by Moczar but by the relatively moderate Edward Gierek. It was no coincidence that the first powerful impulse to the Solidarity movement came from those same Baltic cities a decade later.

In that intervening decade, a gradually expanding milieu of opposition intellectuals built an extensive political underground in Poland, one of the central objectives of which was to forge links with the workers by giving them moral, legal and financial support while developing illegal publications and unauthorised teaching institutions. The success of their efforts became evident in the Solidarity revolution. Between repeated episodes of detention and police beatings, and a stint studying in Paris, Michnik managed to involve himself prominently in practically all the action, especially the writing, production and distribution of illegal publications. In August 1980, he was active in the Solidarity movement, again imprisoned, and only released when the authorities finally agreed to Solidarity's demands.

With General Wojciech Jaruzelski's introduction of martial law in December 1981, Michnik was placed in an 'internment' camp. When he refused to accept emigration as a condition for his release, he was imprisoned for three years without trial, including a lengthy period in solitary confinement, where he staged a hunger strike lasting several weeks. Amnestied in 1984, he was soon rearrested and sentenced to three years in prison, but then released after a year and a half in solitary.

Having become an adviser to Lech Wałęsa, he was involved in the Round Table Talks of 1989. These negotiations led to the peaceful transfer of power, by stages, from the communist regime to democracy, making Poland the first of the communist dominoes and the one that, in many ways, set the paradigm for the relatively bloodless revolution that progressively swept the Soviet bloc. It was the Round Table, however untelegenic, and not the fall of the Berlin Wall, that was the decisive moment in the dismantling of the Soviet empire. 
Throughout these turbulent events, Michnik maintained a highquality running commentary produced in extremely difficult conditions. He has always been a phrase-maker of rare talent with the ability to encapsulate complex historical truths or political strategies in a few words. Partly for this reason, no doubt, Wałęsa asked him to set up the legal, daily newspaper Gazeta Wyborcza (Electoral Gazette - which Michnik still edits) to present the Solidarity case in the runup to the first more or less democratic elections to take place in the Soviet bloc.

After winning the elections resoundingly - to the extent that the regime's rules permitted - Solidarity decided to make a bold move to take over the government while allowing Jaruzelski to remain in the presidency. In Gazeta Wyborcza, Michnik published an editorial with the impious title: 'Your president, our premier'. This boldness struck many in the West, as well as in official circles in Moscow and Warsaw, as a step decidedly too far. Yet the manoeuvre succeeded, and Jaruzelski accepted it.

This latest volume of Michnik's essays in English is a mixture of historical, literary and contemporary political commentary, much of which appears to have been written around the middle of the last decade. Looming large is Michnik's concern about the bitter internecine warfare that has often seemed to bedevil Polish political discussions. Even at times of great historic triumphs, as in the first years after Poland regained its independence at the end of World War I, or the years since the transition to democracy at the end of the 1980s, public life has been marred by furious accusations and mutual denunciations.

Though he scarcely mentions them by name, it is clear in the book that Michnik is particularly concerned with the behaviour of the main right-wing party of the past decade, Law and Justice, and its leaders, the late president Lech Kaczyński and his twin brother Jarosław, party leader and prime minister in 2006-07. That being so, Michnik would have been pleased with the result of Poland's parliamentary elections on 9 October 2011, when Law and Justice was soundly defeated again by the centrist Civic Platform party of Donald Tusk. 
The other concern that keeps resurfacing in the book, especially its last two chapters, is anti-Semitism. Michnik sheets home the responsibility for inflaming this sentiment both to the nationalist right in Poland in different periods and to the communist regime in the first decades after World War II. He has suffered at the hands of both groups, and so knows whereof he speaks.

Polish anti-Semitism is still alive, if seldom violent in the way that it has been in the past. Flagrant events, like the daubing of swastikas on a memorial to pogrom victims in the Polish village of Jedwabne during the recent election campaign, are relatively rare. The Kaczyńskis, it should be noted, have never appeared to be anti-Semitic, though some of their followers are. And it is not purely a story of tormentors and their victims: the troubled history of Polish-Jewish relations contains, for example, chapters that show why and how the postwar regime in Poland at times fanned those tensions, and why Poles had some cause to resent the role of Jews in Polish communism.

I recounted some of the highlights of an extraordinary life at the beginning of this review to show a number of things about Michnik - but, above all, that here is a historic hero of remarkable courage and dedication, as well as great intellectual and political gifts. So why have many Poles, including former comrades in the Polish underground, come to be so hostile towards him? (One critic, for example, wrote a book entitled Michnikism: A Medical History.) Much of Michnik's book is dedicated to showing that such people are in the grip of various unworthy prejudices, and that he is yet another in a long line of Polish public figures dragged through the mud by unjust critics and the gutter press. He is eloquent and usually convincing, but perhaps not always entirely objective in his own cause. Let me try to summarise a few of the salient points in the argument.

Michnik is attacked in newspapers aligned with Law and Justice primarily because he is their electoral enemy and the battlelines have been drawn. But they have specific complaints as well. He is particularly blamed for his cordial relations with and support for some of the old enemies; for example, General Jaruzelski, the imposer of martial law; ex-president Aleksander Kwaśniewski, once a minister in a communist government in the 1980s; and even the ex-head of the security apparatus in the martial law period, General Czesław Kiszczak. 
Michnik says of Jaruzelski that he acted partly from a justified fear of a Soviet invasion and that, after the Round Table, he stuck to the agreements even though they dismantled the communist regime and cost him his job. The agreements also led indirectly to his being charged with crimes against the Polish people and, despite his advancing years and poor health, subjected to lengthy legal proceedings - proceedings that Michnik opposed. In fact, the charges were only suspended this year on the grounds that Jaruzelski, who is now 88, is suffering from cancer. ${ }^{2}$

Michnik makes similar points about General Kiszczak: that although he managed an oppressive regime in the 1980s, he stuck honourably by the Round Table agreements when he could have caused a great deal of trouble for the new Solidarity Government had he chosen to try to undermine them. Many would agree with all of these points.

For his part, Kwaśniewski (president from 1995 to 2005) is widely seen, and not just by Michnik, as having been a successful and strongly pro-Western president, who defeated Wałęsa for the post in a fair election. Many of our Solidarity friends told us after Wałęsa's first term they had decided, with heavy hearts, that he was not up to the job and had voted for Kwaśniewski instead.

More broadly, Michnik argues that the Round Table was a brilliantly successful device for easing the transition to democracy without precipitating terrible bloodshed - a peaceful route that had once seemed impossible even to those optimists who dared to hope for an end to communism in Poland. It fostered goodwill and national unity, enabled the huge nomenklatura class to find a stake in the new dispensation, and provided an invaluable template for similar developments elsewhere.

Many of the nomenklatura class did indeed fall on their feet, but often with much corrupt appropriation of public property along the way, which caused great resentment in Poland. The austere and uncorrupt Kaczyńskis and their followers sought retrospectively to pursue some of these malefactors, and believe that Michnik has forgiven far too much and, indeed, become unpleasantly chummy with former regime figures. Law and Justice exponents also resent Michnik's close

2 Jaruzelski died on 25 May 2014, at the age of 90. 
relations with many people in Russia, and his ready acceptance of Russia's rapprochement overtures after the 2010 Smolensk disaster in which President Lech Kaczyński and many other Polish leaders died in an air crash in Russia. Again, he is too chummy for their taste.

But, in Russia, Michnik associates mainly with ex-dissidents and other free thinkers. While he did seem over-eager in responding to a conciliatory article by Vladimir Putin that was published in the Polish press last year, when he participated in a public forum with Putin during a visit to Russia soon afterwards, Michnik took him to task over the Khodorkovsky case, causing Putin some rare discomfiture. Michnik speaks fluent Russian and gives forthright interviews to opposition-friendly Russian media outlets (these agencies continue to be regarded with suspicion by the Law and Justice party). And he describes himself as an anti-Soviet Russophile, which seems a defensible position to me, but is probably overdoing it for many Poles.

But, 20 years after Poland's successful transition to market democracy, surely these are differences of opinion and perception rather than matters of national treachery. One of the problems of the Polish right is that it tends to have some difficulty in adequately distinguishing between the two.

The other big issue on which Michnik has increasingly angered many on the Polish right is his strong support for efforts to expose past violence by Poles against Jews. One of his old comrades-in-arms from the events of March 1968, Jan Tomasz Gross, after a spell in a communist jail, emigrated to the United States, where he became an academic expert on Poland, specialising in the sufferings of the Poles at the hands of occupation regimes. During the last decade or so, Gross has turned his attention to the suffering of Polish Jews at the hands of ethnic Poles during and just after World War II. In collaboration sometimes with his former wife, Irena Grudzinska Gross (the editor of the book under review), Gross has published a series of books and articles on those subjects. 
The first of these books, Neighbors (2001), ${ }^{3}$ describes a pogrom in the Polish village of Jedwabne in 1942 that culminated in survivors being locked in a barn that was then incinerated. The book caused an enormous stir in Poland, with many people trying desperately to discredit it. Over time it has come to be accepted in Poland that these events did occur much as described, but not without a fair bit of denial, reluctance and extenuation along the way. President Kwaśniewski delivered an apology on behalf of the Polish people at an official commemorative ceremony in Jedwabne in 2001, but that did not lay the issue to rest. This year Jan and Irena Gross published another book, Golden Harvest, which describes how during and just after the war, some Poles desecrated Jewish corpses in search of valuables while others murdered or betrayed for gain Jewish compatriots who were fleeing or hiding from the Nazi occupation. ${ }^{4}$ This latest book has again excited great anguish and controversy.

During the communist period most such topics were glossed over in official discourse and education, and it is only in the last few years that many Poles have been forced to come to terms with them. Having been raised to think of themselves as having a prior claim to martyr status in their own country, they have found this process of re-education difficult.

Such sensitive Polish-Jewish issues are the subject of the last two items in Michnik's book. One, the essay on the Kielce pogrom of 1946 , is particularly gripping. While clearly relating strongly to the events he describes - as a Jew who lost many of his family in the Holocaust - Michnik also makes an effort to see it from an ethnic Polish perspective. He goes to some trouble to place the ugly events at Kielce in the context of a time when Poles emerged from one brutal occupation only to be overrun by another in which, especially in the early, Stalinist years, Polish Jews played a prominent role. But of course the pogrom was inexcusable.

Michnik's critics on the right are not necessarily classifiable as antiSemites, even though they reproach Michnik for making too much of such horrible incidents. But some of the critics have, for example, used

3 Jan T. Gross, Neighbors: The destruction of the Jewish community in Jedwabne, Poland (Princeton University Press, 2001).

4 Jan Tomasz Gross \& Irena Grudzinska-Gross, Golden Harvest (New York: Oxford University Press, 2012). 
dubious formulations like 'true Poles' (prawdziwi Polacy) to draw a line between approved and non-approved categories of Polish citizens. The Agora company, which publishes Gazeta Wyborcza, has pursued in court some of those who use such language, which in turn has led to accusations that Michnik is using the judicial system to suppress free speech about difficult and contentious matters.

The issues of Polish-Jewish relations are more complex than they might at first appear, and Michnik's essay on Kielce goes a fair way towards evoking some of those complexities. Broadly, critics argue that Gross's (and, by extension, Michnik's) approach is selective; that too little attention is paid to the demoralising effect of occupation and the brutalising presence of the German military and security forces; that Poles were at risk of terrible collective punishments for whole families and more if they did not cooperate with the occupiers; that extreme poverty made them desperate and prepared to do anything to keep themselves and their families alive; that, after the war, many Jews who returned to Poland did so 'on Russian tanks' as members of a Moscowled and trained imported Polish regime, which took vengeful action against Polish resistance fighters who had stayed in the country; that this in turn greatly aggravated traditional Polish stereotypes about Jews and communism (there is usually a subtext lurking but left unsaid here that Michnik's father was a senior communist before the war, and his half-brother a Stalinist judge who condemned Polish resistance fighters in the postwar years); and that, anyway, on top of all this, Poles often behaved heroically to save Jews at great risk to themselves and their families, because of which they are the most numerous national group represented in the Garden of the Righteous Among the Nations at the Yad Vashem Holocaust Museum in Jerusalem. They also argue that Gross's books feed the unjust stereotypes of Poles, present in some quarters, as all being mothers'-milk anti-Semites.

But, despite all such arguments - and there is some merit in many of them - the problem remains. It would seem that there is no alternative for Poland and the Poles but to investigate any more such dark episodes as may yet emerge and face them with full acknowledgement and without flinching.

Not only has Michnik never shrunk from controversy, he continues to thrive on it. And his brilliant pen has a sharp edge. At the end of the day, however, anyone who has made such a huge contribution to 
the liberation of his people and at such great cost to himself, while he should obviously not be above criticism, should at the very least be cut a fair bit of slack by his domestic adversaries. Michnik is a great representative, indeed a great hero of the Polish nation, and at the same time a great Polish Jew. The time is surely past when the two should be seen as mutually exclusive. 


\section{Part 2. Poland and Russia since the fall of communism: Drawing apart}





\section{6 \\ Poland/Russia: Peace or ceasefire? ${ }^{1}$}

Poland's presidential elections, which concluded on 4 July 2010, were brought on by the air disaster near Smolensk on 10 April, in which 96 died, including the Polish President Lech Kaczyński and many other members of the Polish political and military elite. Also on the plane were representatives of the families of victims of the mass shootings in 1940 at Katyn and elsewhere in the Soviet Union of some 22,000 Polish officers by the NKVD secret police. In response to the crash, Russian Prime Minister Vladimir Putin, who had a few days earlier attended a landmark joint ceremony with his Polish counterpart Donald Tusk to mark 70 years since the massacre, became even more conciliatory towards Poland.

Russian state-controlled television twice showed the great Polish director Andrzej Wajda's graphic film on the mass murder (it had never previously screened in Russia to a commercial or television audience). This was all the more striking in that in recent years, Moscow had again been flirting with the old Soviet lie that the murders were committed by Nazi forces. There followed a remarkable outburst of popular sentiment in both Russia and, to some extent, also in Poland,

1 First published as 'Can Poland and Russia get along at last?', Quadrant, vol. 54, no. 9, Sep. 2010: 50-57. 
with many Russians leaving flowers at the Polish embassy in Moscow, and some prominent Poles, including Wajda, calling for demonstrations of sympathy for Russian war dead buried in cemeteries in Poland.

During the election campaign, the late president's identical twin brother and former prime minister, Jarosław Kaczyński, who stood as the Law and Justice party's candidate to succeed his brother, seemed to give the lie to his well-deserved reputation as robustly antiRussian by directing a YouTube video to the Russian people calling for reconciliation between the two nations. Even more remarkably for a politician who was hitherto unremittingly hostile towards Tusk's centre-right Civic Platform (CP) party, Jarosław also called for an end to what he called the war of Poles against Poles. The narrow victory of the $\mathrm{CP}$ candidate, former parliamentary Speaker Bronisław Komorowski, over Kaczyński seemed to confirm that Tusk's CP-led coalition government's policy of cautious rapprochement with Moscow would be strengthened, with the threat of presidential opposition now removed.

Is this really an outbreak of sweetness and light between Warsaw and Moscow? To answer the question, we need to look at Poland's intensely partisan politics and the factors influencing the conciliatory trend in Moscow.

After the Kaczyńskis and their right-wing Law and Justice (LaJ) party came from behind to defeat $\mathrm{CP}$ in the 2005 parliamentary and presidential elections, they adopted strongly nationalist and anticommunist policies. In the absence of any explicitly communist political parties in Poland itself, their efforts were directed not so much against the post-communist Democratic Left Alliance (usually known by its Polish acronym SLD - Sojusz Lewicy Demokratycznej) party that was previously in power and that had just been crushed in the elections, as against LaJ's post-Solidarity rivals in CP. When CP declined to join LaJ as junior partner in a new coalition, the Kaczyńskis began to denounce it more fiercely, claiming that only LaJ truly represented Solidarity, anticommunism and Polish independence. $\mathrm{CP}$, they maintained, was little better than the post-communists, having in earlier incarnations helped the communists to survive and reinvent themselves as democrats and business tycoons. 
LaJ saw much of what had happened since the victory of Solidarity in 1989 as a betrayal by sinister forces who had sold out to the communists and allowed them to take control of a post-communist establishment (uklad) in which CP and others were culpably implicated. They vowed to purge these evils from the body politic by creating a 'fourth' republic (in contradistinction to the third republic: post-communist Poland from 1989 up to their victory), free of communist influence. On economic issues, however, they were nearer the Democratic Left Alliance, favouring retention of increasingly unaffordable social security entitlements and opposing efforts to privatise inefficient communist-era mega-enterprises.

Externally, LaJ was resolutely opposed to Russia and nearly all its works, seeing Putin's heavily ex-KGB leadership group as continuing most of the policies of the Soviet Union in a new guise. The Kaczyński twins were also prickly towards Germany, despite efforts by Chancellor Angela Merkel to maintain Berlin's policy of reconciliation with Poland. On one occasion, Lech Kaczyński took umbrage at a German newspaper article likening him and his brother to potatoes, cancelled his attendance at a trilateral summit with Merkel and French President Jacques Chirac, and demanded an official apology.

LaJ took a dim view of the European Union generally, regarding it as having abandoned the traditional values of the Christian (that is, Catholic) Church, and as a threat to Polish sovereignty. The Kaczyńskis also vigorously supported the efforts of post-Soviet countries like Ukraine and Georgia to build their future free of Russian influence and pressure. Strongly Atlanticist, and popular in President George W. Bush's Washington, the LaJ administration quickly became viewed with impatience and at times anger in Europe, as they used or threatened to use their veto against a variety of pending EU decisions that otherwise enjoyed a consensus.

In 2007 CP, led by Tusk, convincingly won parliamentary elections and formed a new governing coalition, ousting LaJ and its somewhat disreputable coalition allies, the League of Polish Families and the Self-Defence party. The League of Polish Families is a clerical, conservative party, more Eurosceptic and xenophobic than LaJ itself, and linked to the at times audibly anti-Semitic Radio Maryja radio 
station. Self-Defence is a left-leaning, rural-populist party, headed by the notorious populist, Andrzej Lepper, who has on several occasions been charged with criminal offences.

Tusk quickly sought to mend fences with Germany and the European Union. Without conceding on basics, he also tried, as far as possible, to normalise bilateral links with Russia, which had taken a sharp turn for the worse under LaJ. Even before then, Polish-Russian relations had hit a low point when the SLD President Aleksander Kwaśniewski took a leading role in securing a re-run of the rorted presidential elections in Ukraine in 2004, which brought the pro-Western Orange leadership of Viktor Yushchenko and Yulia Tymoshenko to power. Putin had overtly involved himself in the first presidential campaign on behalf of the pro-Moscow candidate Viktor Yanukovych and his Party of Regions, and was furious with the revised outcome.

Tusk and his colleagues did what they could to smooth relations with Russia and to ease Moscow's politically motivated trade boycotts against Poland, notably by improving Warsaw's standing in Brussels and thus gaining greater support from EU leaders for Poland's position. The $\mathrm{CP}$ Government also sought to tackle the sensitive historical disputes that regularly inflamed bilateral relations by setting up with Moscow a joint Commission for Difficult Matters (Komisja dla Spraw Trudnych), a group of experts tasked with working towards accommodations on those issues. The most difficult of these was Katyn, about which Putin had again chosen to obfuscate the truth to punish Poland for its involvement in the Orange Revolution.

Whilst continuing, like all post-communist Polish governments, to support former Soviet republics in their efforts to join the European Union and NATO, the Tusk Government de-emphasised Poland's relationships with Ukraine and Georgia. At the time of the Georgian war in 2008, when Lech Kaczyński impulsively flew towards Tbilisi to express his solidarity with President Mikheil Saakashvili (and was widely reported to have tried unsuccessfully to persuade his pilot to land in the war zone), Tusk had tried to forestall what he saw as a quixotic mission. But on most issues, Tusk has stood firm against Russian pressure - notably the proposed US missile defence installations in Poland and the Czech Republic. 
He also opposed Russia's Nord Stream project, which secured German assistance for building a gas pipeline under the Baltic that would partially bypass the existing gas transit lines in Poland, Belarus and Ukraine. This would threaten transit revenues and, indirectly, the energy security of all three countries. When completed, Nord Stream would make it easier for Russian 'energy diplomacy' to cut off gas flows to any of the three transit countries, while still delivering gas via Nord Stream to preferred customers like Germany. On the other hand, the Tusk Government has been prepared to negotiate a long-term extension of its gas supply contract with Moscow (the deal has not been finalised). For this and other policies Tusk has been severely criticised by the LaJ opposition as being soft on Russia, a dangerous criticism in Polish politics.

Despite LaJ's decisive loss in the 2007 parliamentary elections, as president in a situation of cohabitation, Lech Kaczyński used his constitutional powers to the maximum to block $\mathrm{CP}$ domestic and foreign policies for which Tusk had a fresher electoral mandate, but to which LaJ were opposed. Tusk patiently worked with or around the president, gradually improving Poland's standing in Berlin, Brussels and Moscow.

In September 2009, Putin accepted an invitation to attend the 70th anniversary of the Polish defence against Nazi forces of Westerplatte, near Gdańsk, in the early days of World War II. In doing so, Putin was in effect obliquely acknowledging that, because of the 1939 MolotovRibbentrop Pact, which secretly divided Eastern Europe between Germany and the Soviet Union, Poland was left to face the German attack in isolation. Shortly thereafter, Soviet forces had invaded and occupied eastern Poland. At the Westerplatte ceremonies Putin spoke in a broadly conciliatory tone, though without fully recognising the validity of Poland's grievances about the period.

But the real breakthrough in Russian acknowledgment of responsibility for Soviet behaviour came with Putin's invitation to Tusk to attend a joint commemoration of the Katyn massacre on 7 April 2010. Putin spoke expansively at the ceremony, condemning the massacre and Soviet 'totalitarianism', though there were also some exculpatory accents. Following the crash three days later, he was even more forthcoming. And Moscow initially went to great lengths to involve 
Polish officials in the investigation into the crash, no doubt fearing with good reason that sections of the Polish public were likely to blame Russian officialdom for the disaster.

For LaJ, the compromises with historical truth that the joint ceremony involved were unacceptable, and they maintained their sharp criticism of the government. President Kaczyński had not been invited to the joint commemoration and his ill-fated flight to Katyn on 10 April with many LaJ and military leaders on board looked like a riposte to Tusk for having accepted Putin's invitation to attend a joint commemoration. While the president's prepared speech, never delivered, contained one or two conciliatory accents towards Russia, LaJ leaders felt Moscow was still stopping short of full acknowledgment, and might again revert to denial and obfuscation.

In the wake of the disaster, the bilateral relationship took a sharp turn for the better. But the presidential campaign soon brought the pressures of electoral politics to bear at the Polish end. Within days of the crash there was an unseemly dispute over the dead president's funeral arrangements. It was announced that he and his wife would be buried in Wawel Castle in Cracow, the final resting place of many of Poland's kings and great national poets, but not hitherto its elected presidents. Opponents of the decision were reluctant to make the point sharply, given the stunned consensus that briefly prevailed after the crash. But for $\mathrm{CP}$ sympathisers, this was an unfair use of the period of national mourning by LaJ, with the support of the custodian of Wawel, the Archbishop of Cracow, to wrap the Kaczyńskis in the national flag and impart a Catholic blessing to LaJ's presidential campaign.

For Lech Kaczyński, regardless of whether, as many believed, he may have somehow pressured the pilot into landing in hazardous conditions, the crash was a huge posthumous boost to his standing. His chances of re-election had seemed decidedly slender as his approval rating dropped below 30 per cent. After the crash, polls indicated more than half found him retrospectively a great president. Riding on a wave of public sympathy, Jarosław began the campaign in a low-key mode, presenting himself as a born-again moderate but, as the shock of bereavement abated, he found his old pugnacious voice. 
LaJ played into a strong Polish mood, which is inclined to see the crash as another example of murderous Russian perfidy. For Poles, Katyn will always be a powerful symbol of all they have suffered at Russian hands. The extraordinary circumstance of a 'second Katyn' again wiping out much of the Polish elite on Russian territory seems to many too fateful to be coincidence. Russian hostility to LaJ and the Kaczyński twins has always been obvious so, for those so inclined, it was not wholly paranoid to posit a motive.

Even the key sound sequences used in referring to the crash are irresistibly suggestive: Katyn and katastrofa, the first syllable of both of which, kat, is also the Polish word for executioner. Fragments of evidence have been adduced - not always plausibly for an outsider to build complex conspiracy theories pointing to Russian involvement. Despite desperate Russian attempts to rebut such suspicions by involving Poland at every stage of the investigation, the conspiracy theories run on, with periodic baroque additions to adjust to new evidence. This is a state of Polish mind in which LaJ populism excels, and it seemed to pose a serious danger to the CP candidate, now President Komorowski, as his initial lead of over 20 per cent was progressively whittled away.

It also seemed to threaten the fragile bilateral rapprochement. Russian media, not noted for its objectivity on things Polish, began to react, with signs of another revival of the myth of Nazi involvement in the Katyn massacres. And there was initially strong Russian indignation about Polish statements that Russian security units had been involved in robbing one or more of the crash victims of their credit cards and using them for fraudulent purposes. The reports were essentially true, though the people involved were conscripts, not security officials as a Polish spokesman had erroneously asserted.

If $\mathrm{CP}$, having scraped into the presidency, can maintain its control of the political agenda, the thaw may still be maintainable on the Polish side. But parliamentary elections are looming next year, LaJ again looks strong and mobilised in opposition, and the conspiracy theories about the crash and tensions over other bilateral issues are not about to die away. 
Indeed, since the presidential elections, Jarosław Kaczyński has sidelined his moderates and sharpened his message further, accusing $\mathrm{CP}$ of 'criminal' responsibility for the death of his brother and the others who 'fell' (the military terminology is deliberate) near Smolensk. ${ }^{2}$ LaJ supporters even speak of a conspiracy between Putin and the Tusk Government, and the party seems, in fact, to want to make the causes of the disaster the main election issue at local elections in October and the parliamentary elections due next year.

Meanwhile, Moscow's initially forthcoming attitude towards sharing documents has given way to a typical Russian obstructionism. As LaJ's approach to the issue has become more politicised, Russia has become less cooperative. Major plane crashes usually have a multitude of primary and secondary causes, as well as predisposing circumstances. Russian aviation has a poor safety record, and the airport at Smolensk was far from cutting-edge. Moscow's growing reticence suggests that their inquiries have revealed things to them that they would not like to see subjected to LaJ's remorseless and far from impartial scrutiny. A conspiracy seems highly unlikely, but in Russian conditions a cockup is always a strong possibility. Their attempts latterly to stall the Polish investigators are bound to increase Polish suspicions. Jarosław Kaczyński is a skilled tactician, and the latest hardening of his line suggests he may be on to something. Even if the Russians are not hiding anything of great note, despite a rise in public support in Poland for rapprochement, the torrid political atmosphere will certainly keep relations with Russia under strain.

\section{Russia's stake in improved relations}

While Tusk was the initial demandeur, Moscow has latterly had its own reasons for pursuing rapprochement. Recognising Poland's increasing strength within EU and NATO councils, it has accepted reluctantly that bullying Poland with arbitrary trade sanctions and threatening

2 Back in power since 2015, LaJ is again trying to enforce public acceptance of the idea that those who died in the disaster 'fell' (polegli), as if on the field of battle, not in a tragic accident. Anna Dabrowska, 'Prof. Bralczyk: Słowo "poległ” w kontekście smoleńskiej to nadużycie', Polityka, 14 July 2016. 
military exercises (staple policies towards former subordinates) had become counterproductive. Poland is now a country with which it needs to be circumspect.

The severe impact of the global financial crisis on Russia (where GDP declined by some 8 per cent in 2009) has reduced Putin's earlier swagger and inclined Moscow to rein in some of its adversarial attitudes towards the West. Moreover, US President Barack Obama's 'reset' policy seems to offer greater incentives and dividends for its doing so. With energy prices down, and its gas exports clouded by reduced European demand and major developments in gas extraction technology, Russia is again more conscious of its economic shortcomings. And the relentless rise of its giant neighbour, China, increasingly concentrates its mind.

More promisingly from Moscow's perspective, Poland's relations with Belarus and Ukraine have frayed under the pressure of President Alexander Lukashenka's oppression of the dwindling Polish minority in Belarus, and the policy chaos and occasional abrasive nationalism in Kyiv under President Yushchenko. Moscow was also pleased by Tusk's restrained approach to the Georgian crisis. If Poland was becoming less active in coaxing former Soviet republics in the direction of Brussels and Washington, this was a trend that Moscow wished to encourage.

More generally, President Dmitry Medvedev has been trying to sell a comprehensive revamp of European security aimed at weakening NATO and transatlantic unity, and hopefully giving Moscow an effective veto on regional security issues. So far Medvedev's proposals have had limited impact, but a number of European countries, notably Germany and France, seem ready at least to discuss them. At the Russo-German bilateral in Meseberg on 6 June 2010, Merkel and Medvedev agreed on a memorandum calling for the creation of a joint EU-Russian committee on security and foreign policy, to be chaired by Russian Foreign Minister Sergey Lavrov and his asymmetrical EU opposite number, Catherine Ashton.

Certain prominent German figures and influential commentators in the United States are declaring that expansion of NATO may not have been a good idea, or proposing that Russia should be invited to join it. In return for modest help on key US priorities like Iran and Afghanistan, Russia is hoping that its gains in Ukraine and Georgia and its claim to a 'sphere of privileged interests' will be tacitly accepted in 
Western capitals. In this broader context, having good relations with a one-time bitter adversary like Poland is a useful diplomatic asset for the Kremlin.

There is also a domestic factor at play in Moscow. While Putin remains the paramount leader, Medvedev has been pushing a kind of miniperestroika, a campaign given some impetus by the difficulties caused for Russia by the GFC. Medvedev's amorphous 'modernisation' agenda includes a role for obliging Western investors to open their doors and pockets for Russia, despite the latter's often cavalier treatment of Western business partners under Putin. In parallel, Medvedev and others in the elite have been trying to reverse the recent trend towards partial rehabilitation of Stalin. These trends intersected with the Katyn commemoration and related events.

A sharp beam of light was shed on all this by the leaking in May 2010 of a document prepared by the Russian Foreign Ministry in response to a directive from Medvedev, which sets out the rationale for a new direction in external policies. Putin's KGB-led regime does not leak much, but this document looks plausible and its authenticity has not been disputed. Russki Newsweek, which published it, also ran an article drawing on sources in the Foreign Ministry, from which further plausible details emerge.

The main thrust of the document is that Russia should focus pragmatically on all itsforeign relationships toadvanceits modernisation agenda. While all partners can contribute in some way (and a plan was developed for each), some are deemed particularly desirable, notably the European Union and the United States. The document calls in effect for renewed détente with the West to replace the 'new Cold War' of the second half of Putin's presidency. But the accompanying article emphasises that Putin and his own foreign policy team, led by Yury Ushakov, ambassador to Washington from 1999 to 2008, were closely involved in this change of direction; and that the damage wrought by the GFC was the catalyst.

There are still characteristically Putinist accents in the report. For example, it is recommended that special attention be devoted to the Baltic states: weakened as those economies are by the GFC, the document recommends that Russian companies should be encouraged to acquire as many key companies there as possible. In Ukraine, 
widespread Russian acquisition of major industries is recommended; there and in Central Asia, the acquisition of companies from the former Soviet military-industrial complex gets special mention. In other words, despite the emphasis on economic modernisation, there is to be a strong strategic focus on restoring imperial influence where possible, in this instance by 'banks not tanks'.

Russki Newsweek claimed that the shift in policy towards Poland, though within the framework of the new doctrine, was a special case. The Russian embassy in Warsaw had, according to Russki Newsweek, sent a telegram directly to Ushakov in Putin's administration pleading for a new approach. Simultaneously, a senior Russian business executive of Polish ancestry had been lobbying Putin directly on behalf of Polish business colleagues. The embassy had reportedly argued that warmer relations with Poland were needed to enable Russia to achieve a breakthrough with the European Union, as Poland now had the standing within the European Union to frustrate Russia's efforts. Putin was convinced, the article claims, and sent the Foreign Ministry a directive mandating a sharp change of policy towards Poland beginning with a joint ceremony at the Katyn memorial.

Better relations with the United States, Western Europe or Poland would obviously not be advanced by restoring Stalin to the pantheon of Russian statehood. Recognising this, Putin seems to have accepted the need for another adjustment to the party line on Stalin. But it was clearly a matter of dispute within the leadership. The durable and stridently nationalist mayor of Moscow, Yury Luzhkov, was keen for the 65th anniversary of Victory Day on 9 May to be celebrated with prominent posters of the great Stalin displayed on Red Square and elsewhere, as in the good old days. ${ }^{3}$ This initiative would have strong support in the population at large, where Stalin continues to be revered by many, and his monstrous rule widely admired.

After some mixed signals, the push for Stalin to be honoured on Victory Day was quashed. The leadership decided to invite numerous representatives of the Western world to come to Moscow for the event and for units of their military to participate, unprecedentedly, in the parades. Poland was one of the invitees and accepted. Despite extreme

3 See www.telegraph.co.uk/news/worldnews/europe/russia/7650172/Moscow-backs-downfrom-Stalin-poster-plans.html. 
domestic pressure and conflicting events (a vital and threatening election in North Rhine-Westphalia) on the same day, Merkel also accepted. Der Spiegel reported that Merkel had made it clear she would not attend if Stalin was looking down on proceedings. ${ }^{4}$

The events surrounding the Katyn commemoration played an important role in making a flirtation with another partial Stalinist restoration very untimely. By denouncing the Katyn massacre publicly in the presence of Tusk and his delegation, Putin made it harder though not impossible - for himself or anyone else to yet again revise Moscow's line on Katyn or Stalin.

\section{A watershed moment for Poland?}

Sustained warmer relations with Moscow would be at odds with some of the most basic maxims of Polish strategic thought. After the eighteenth-century partitions by Austria, Prussia and Russia that obliterated Poland from the map for over a century, Polish national leaders oscillated between revolutionary romanticism and realism. Periodic national uprisings broke out, particularly against the Russian imperial power, despite their predictably bloody endings. Poles fighting for independence often sought alliances with other would-be nations that shared their stateless condition - hence, for example, General Tadeusz Kosciuszko's adherence to the struggles of the independence movement in the American colonies. They fought hopefully in wars or social upheavals of varying provenance under the banner of 'for our freedom and yours'. The French Revolution, the Napoleonic wars, the ferment of 1830 and 1848 - all were seen as opportunities to pursue the goal of independence.

More pragmatic nineteenth-century Polish patriots saw these struggles as doomed to disaster. Far better, they argued, to make an accommodation with the temporal power and seek to advance the national cause by 'organic work', developing Poland's economic, educational and cultural resources without provoking retribution in unequal military struggle. This realist vs romantic debate continued in

4 See Christian Neef \& Matthias Schepp, 'The return of Uncle Joe: Crisis-stricken Russians nostalgic for Stalin', Spiegel Online, 6 May 2010, www.spiegel.de/international/world/thereturn-of-uncle-joe-crisis-stricken-russians-nostalgic-for-stalin-a-692971.html. 
Aesopian language into the communist era, with allusions to the many disasters and the occasional shining triumph of the past. And traces of it are still evident, especially in discussions of Poland's 'Eastern Policy' (polityka wschodnia).

'Eastern policy' has also been a bone of contention between LaJ and CP. Since at least Marshal Józef Piłsudski's time, many Polish strategists have dreamt of building a grand alliance with other nations in the marchlands between Russia and Poland as a common defence against Moscow. This strategic orientation is variously referred to as Prometheist, Jagiellonian (referring to the medieval Polish dynasty that ruled over the relevant lands) or Giedrojc's Eastern Policy (after Jerzy Giedrojc, the editor of the influential émigré journal of the communist era, Kultura, published in Paris).

Polish dissidents schooled in smuggled copies of Kultura were very influential in Solidarity's strategic thinking before and after the fall of communism. This led to early recognition by the first Solidarity Government of the independence of western republics of the Soviet Union, and strenuous efforts by Warsaw to bury the acrimonious feuds of recent history that had bedevilled Poland's relations with those peoples. The policy was extended also to former republics further afield like Georgia, which, after the Rose Revolution, was seeking acceptance into NATO and the European Union. Nearly all post-communist Polish governments have pursued this objective, including the former communists of SLD, to Moscow's great irritation.

Clearly there are echoes here of the romantic notions of 'for our freedom and yours'. Tusk's policy, by contrast, is more one of realism and 'organic work'. ${ }^{5}$ While he maintained support for the eastern neighbours (for example, pushing successfully for a special EU program of assistance to them, the so-called Eastern Partnership), he puts greater emphasis on achieving whatever is possible from the bilateral relationship with Russia. This shift is exemplified by the

5 'Organic work' (praca organiczna) refers to the tradition in Polish political theory and practice of working pragmatically towards socioeconomic development in the Polish lands rather than risking all in desperate efforts to seize back Polish sovereignty by revolutionary action. The idea developed in the 1830s following the crushing of the 1830 November Uprising against Russia. 
personal evolution of the current Foreign Minister, Radosław Sikorski, once a strongly anti-Russian LaJ defence minister, now a member of $\mathrm{CP}$ and more moderate.

Lithuania, Belarus and Ukraine, for historical reasons, are key to this debate. Having with great anguish relinquished all claims to its prewar territories there, including to cities like Vilnius (Wilno) and Lviv (Lwów) where Poles had once been dominant, Poland feels it is entitled to expect more reciprocity. The perils of this approach are illustrated by the Możejki case. In pursuit of 'our freedom and yours', the LaJ administration pushed through the purchase in 2006 by the big Polish firm PKN Orlen of the Możejki (Mazeikiai in Lithuanian) oil refinery in Lithuania in an effort to prevent it from falling into the hands of a Kremlin-controlled Russian firm, thereby, as they saw it, saving the Lithuanians from Moscow's potential energy blackmail.

Instead, the Polish owners themselves became the victims of the blackmail. When its bid for the refinery failed, Moscow refused to supply the refinery with crude oil, and to make the point clearer, successive 'accidents' were organised on the main supply pipeline from the east (which is still not repaired as of 2010), ensuring that Orlen had to obtain oil at greater expense elsewhere. Yet, according to Polish accounts, the Lithuanians have not supported the new Polish owners, who have sustained serious losses. At the same time, the surviving Polish minority in Lithuania continues to experience cultural discrimination, pushing them politically into the arms of the local Russian minority (with whom they are often assimilating).

In Belarus, all efforts by Poland and its EU partners through inducements and persuasion to reform the Lukashenka regime have achieved little. Recently, there has been another acrimonious dispute over repression of Belarus's long-suffering Polish minority. Though Lukashenka needs hedges against Russian domination, this has not benefited Poland, and Lukashenka's dictatorship continues unchecked.

In Ukraine, also, the Poles have felt that their support and friendship since independence, particularly during the Orange Revolution, have not been adequately rewarded. Their Orange allies did not make a success of their five years in power, but before losing it, caused Poland some grief through their repeated gas wars with Russia and occasional nationalist gestures. Now that the Orange leadership has been 
supplanted by President Yanukovych, who is building a close strategic relationship with Russia and has ruled out NATO membership, Poland is again left alone on NATO's eastern front line.

Many Poles were particularly aggrieved by Yushchenko's according of the title of Hero of Ukraine to Stepan Bandera (1909-59), a Ukrainian nationalist and insurgent leader. While Bandera was in Nazi detention during the war, some of his followers were involved in massacres of Jews and ethnic Poles in the former Eastern Poland. Polish members of the European Parliament, led by CP deputies, responded angrily to the award by pushing through a resolution condemning Kyiv for the decision. This resolution led to a damaging breach between Poland and its erstwhile Orange allies, for whom Bandera, who was murdered in 1959 by a KGB operative in Munich, was above all a hero of Ukraine's national liberation struggle against Moscow.

As Yanukovych, much more pro-Russian than any of his post-1990 predecessors, strengthens his grip on Ukraine, the chances of Moscow gathering together most of the territory between itself and Poland in a Russian-led alliance of Soviet-nostalgic autocrats increase. There may not have been much Warsaw could have done to forestall this. But the Tusk Government may yet regret Ukraine's strategic reorientation.

While CP has not abandoned its eastern neighbours, it sees more to be gained economically and strategically by moving into the EU mainstream through such groupings as the Weimar Triangle with Germany and France. As the Tusk Government has trodden further along this path, its view of Russia has begun to shift towards the positive approach to Moscow typified by Berlin.

If $\mathrm{CP}$ remains in power and the crash investigation does not throw up major sensations, Poland's cautiously conciliatory policy will probably continue. But many Poles feel deep and historically well-founded suspicion towards Moscow. Issues will continue to arise that inflame bilateral tensions. LaJ will remain eager to exploit any such differences. For the moment, CP seems to have all the key instruments of power in its hands. But if it now finally tackles the painful economic reforms it has long proclaimed necessary, it could alienate the electorate and its coalition partners, and open the way for LaJ to return to government after next year's parliamentary elections. 


\section{Russia: The limits to Slavic brotherhood}

There are also some large 'ifs' on the Russian side. The residual logic of the Jagiellonian Eastern Policy will probably ensure that the Poles continue to look for ways to strengthen EU and NATO influence to the east - for example, as recently, by pushing hard for a stronger NATO military presence in the Baltic states and other eastern member countries that are regularly subject to Russian pressure. Poland's eagerness to attract US assets into the country, such as this year's Patriot missile deployment (a consolation prize for cancellation of the missile defence project), quickly led to angry questioning from Russian Foreign Minister Lavrov.

Moreover, Poland is eager to build up its own military capability, preferably with US military assets and technology, which Moscow also objects to. The Kremlin logic seems to be: we liberated you from the Germans and now we've apologised for Katyn and you're still treating us as an enemy. Given the two countries' joint history, it should hardly be surprising that Poland wants strong defences, but Moscow still has trouble accepting that its former satellites now wish to make their own sovereign decisions about security. Some Western commentators are sympathetic to Moscow's point of view on such matters. So none of these irritants is likely to go away soon.

Russia has evidently had a change of mind about Poland, but it's not clearly had a change of heart. The warm outpouring of sympathy among ordinary Russians after the crash was touching, but Russian policy is seldom shaped by popular sentiment, which Russian leaders see as something to be manipulated rather than followed. And they have formidable skills in this area.

On 22 July 2010 the official Russian paper Rossiiskaya Gazeta published a forceful article by establishment commentator Sergey Karaganov, praising the decision to acknowledge Katyn, and declaring that 'the whole of Russia is one big Katyn'. Karaganov called for all these unmarked graves of the victims of Stalinism to be given proper monuments, and more generally for a full reckoning with the evil legacy of Stalinism at home as well as abroad. Coming from the at times hawkish Karaganov, this seemed a clear and very welcome signal that the Kremlin has decided the time is ripe for another round of de-Stalinisation. But just a few days after Karaganov's article appeared, 
the Russian parliament passed a law strengthening the repressive powers of the KGB's domestic successor, the FSB (Federalnaya Sluzhba Bezopasnosti - Federal Security Service) a measure that Medvedev has publicly claimed as his own initiative. And it was the same Karaganov who declared two years ago that the Poles had a 'Katyn complex' for which they should seek a cure.

So while it would be wonderful if we were about to witness the final exorcism of Stalin from Russian public life, it may still be too early to sound the hosannas. Since Nikita Khrushchev's sensational but selective denunciation of Stalin in 1956, Moscow has passed through numerous phases of de- and re-Stalinisation. If the Kremlin judged it desirable in six months' time to unwind the Russian people's increased awareness of what had been done in their name at Katyn or anywhere else, this would not be beyond its capacity.

Russia remains unhappy with the loss of its empire after the collapse of communism and eager to reverse as much of that as it realistically can. At a minimum, it would like to restore control over Belarus and Ukraine and some other parts of the old Soviet Union, while striving for a dominant influence in most of the rest. The Kremlin probably accepts that the countries of Eastern Europe will retain their independence, but it would certainly hope to increase its influence there by a mixture of courtship, economic penetration, occasional threats and coercive energy diplomacy. The attitude to Poland before the recent warming of relations reflected that approach, and is unlikely to alter permanently as a result of it. While Russian leaders are friendly towards Poland at the moment, they do not typically regard smaller neighbours with great respect, seeing them as less than fully 'sovereign' in the special meaning that Russian discourse gives to that word.

In Europe, more generally, they are working in traditional mode to divide Europe from the United States and, within Europe, to aggravate divisions by cultivating links with those European countries that are more pragmatically or even warmly disposed to them, and isolating those that are not. They want to revise the post-communist European security system in their favour, and have grounds for thinking that some European governments will be prepared to meet them part of the way. 
Despite Medvedev's efforts to 'modernise' Russia and his occasionally trenchant criticisms of the state of the nation, the strength of his commitment to serious reform remains unclear and, in any case, he is unlikely to be able to make his writ run far. Opinion polls regularly show that a large majority of Russians believe he does not have the decisive say in the direction of his nation's affairs and it is hard not to agree with them.

Despite its current tilt towards the West, Russia seems likely to remain, at least for some time yet, the relatively closed, enigmatic and authoritarian system that it has nearly always been and that Putin has largely restored. The GFC has probably now done its worst, but while there has been some slight weakening of Putin and Medvedev's stellar popularity ratings, the system still looks pretty secure. If Putin chooses to return to the presidency in 2012, he could have a further 12 years in office in which to consolidate his 'power vertical' at home and extend it to the former republics. Russia's corrupt oligarchic economy meanwhile seems as far from genuine market reform as ever.

Across Russia's western borders things are broadly similar. While it is experimenting with economic reform, Belarus is not becoming any more democratic; and Lukashenka is under growing attack from Moscow, which wants to discipline him or replace him with someone more amenable. In Ukraine, Yanukovych looks well on the way to restoring a more authoritarian system than has existed at any time since before perestroika. And Moldova, though turning westward again after elections, is under severe pressure from Russia (now with support, not opposition, from Ukraine). Moscow has slapped another boycott on Moldovan wine (wine constitutes 40 per cent of its total exports), and continues to manipulate the issue of its client regime in the secessionist territory of Transnistria. Further afield, in Georgia, heedless of credible (by regional standards) elections that President Saakashvili's party wins easily, Moscow has been overtly grooming two opposition politicians as his potential successors.

Secretary of State Hillary Clinton's 5 July visit to Tbilisi and her public statements calling for Russia to withdraw from the territory it is occupying in Georgia may have reassured Tbilisi and disappointed Moscow (though reaction there was muted). Soon after, French Foreign Minister Bernard Kouchner chose Bastille Day to visit Tbilisi, where he also called for a Russian withdrawal. But Russian forces remain within 
40 kilometres of the Georgian capital, and Georgia's dismemberment appears to have been tacitly accepted by most Western leaders. More generally, in pursuit of 'reset' or 'strategic' or 'modernisation' partnerships, both the United States and the European Union seem, for the moment, disposed to take Russia as they find it. Poland may be moving part of the way towards a similar accommodation.

Like the Polish-Russian rapprochement, and for similar reasons, any new détente between Russia and the West will remain insecure while the values gap continues as at present, or widens, as it has done for most of the time under Putin. Until Russia confronts its Stalinist past squarely and consistently, and draws the necessary conclusions from doing so, its relations with the United States and much of Europe may continue to oscillate between the fragile and the fraught. 



\section{Heading west, heading east: Impressions from Warsaw and Moscow ${ }^{1}$}

During a fortnight divided between Warsaw and Moscow, from where we have just returned, my wife and I were struck by the similarities and contrasts between the two cities. Anna is Polish, and we spent three years together in Warsaw during the communist era, returning many times since then for weeks and sometimes months. Both of us have also visited Moscow many times over the past few decades.

Both countries have legislative elections later this year that promise to be interesting, but will hardly be game changers. While there have been losers from the economic transformation in each capital, both are enjoying a relative prosperity that is quite striking after the privations of communist times. After decades of empty roads, traffic is roaring, with considerable collateral damage and terrifying effects for those, like us, who - while they still remember sardine class in public transport - once found crossing a road not too stressful. Shopping, once a time-consuming and frustrating battle against the odds, has become relatively straightforward. The abusive and contemptuous attitudes of salespeople and service personnel have

1 First published in Inside Story, 11 Aug. 2011, insidestory.org.au/heading-west-headingeast-impressions-from-warsaw-and-moscow. 
largely disappeared. The aggressive and unhelpful attitudes that were once almost universal in public places have been replaced by courtesy, even cordiality.

Marxism-Leninism is probably beyond resuscitation in either country, though in Russia there are dismaying signs of nostalgia for Stalin. Freed at last from the inhibitions of official communist ideology, nationalism is running hot in both countries, which makes the recent tentative rapprochement between them all the more fragile. Religion has also been freed from those constraints, leading to a sharp rise in the visibility of Orthodoxy in Russia, though in Poland, paradoxically, there's been a noticeable decline in the Catholic Church's moral authority.

But, for all the superficial similarities, and despite the tactical warming of bilateral ties, these are two countries that, in political and civilisational terms, are headed in diametrically opposite directions. And each is trying to draw the countries that lie between them along with it. After centuries in which Russian domination was superimposed over an earlier Polish sway in much of the territory between them, a competition between Moscow and Warsaw for cultural influence in the region is on again. Warsaw tries not to be too blatant about its efforts to tug its Eastern neighbourhood towards Europe, but Moscow of course sees what's going on and deeply resents it.

For those like Anna and me, whose sympathies are Polish but who have very good Russian friends and a great love of Russian language and culture, the mutual hostility and suspicion are painful. At the interpersonal level, Russians and Poles have much in common. To my Anglo-Saxon perceptions, both are extraordinarily warm and hospitable. They are courageous and resilient, and have a strong streak of human kindness. In particular, their respective intelligentsias (in the Eastern European sense of the word) remain deeply impressive in their intellectual seriousness and civic courage.

But, despite the tentative signs of reconciliation between the two nations at the popular, intelligentsia and governmental levels since 1990, their developmental trajectories seem set to diverge further. The elections in Poland on 9 October will almost certainly see Premier Donald Tusk's centre-right Civic Platform win its third successive election victory. Its main adversary is the right-wing nationalist and 
anticommunist Law and Justice Party of Jarosław Kaczyński, the surviving twin of ex-president Lech Kaczyński, who was killed with 95 other members of the Polish elite in a plane crash near the western Russian city of Smolensk in April last year.

Tusk has sought better relations with Russia, but he is even more intent on strengthening Poland's standing within the European Union and doing what he can to bring Ukraine, Belarus, Moldova and even Georgia and Armenia towards European integration. If by some strange chance Jarosław Kaczyński and his party have a sudden resurgence in the polls sufficient to win government, relations between Warsaw and Moscow will take a nosedive.

Poland, which holds the presidency of the European Union for the second half of this year, has largely shed its old streak of Euroscepticism. The peasants have been won over by generous cohesion fund payouts and, despite its doubts about the secularism and sexual liberationism of Western Europe, the Church has now largely accepted the EU choice. Even Law and Justice has mellowed in its attitudes towards Brussels and its German neighbours. As Poles become more aware of the huge financial benefits of EU membership and increasingly see gaining greater influence within EU corridors of power as their primary objective, the earlier strong ties with the United States have weakened.

In Russia, meanwhile, developments in recent weeks have made it even plainer that Vladimir Putin's autocratic system is being reaffirmed domestically; and a string of characteristically aggressive statements and manoeuvres suggests a return to the assertive anti-Westernism of the later years of Putin's presidency (2000-08). During our visit, there was a press 'leak' citing government sources to the effect that Putin had made up his mind to take the presidency back from Dmitry Medvedev. As Medvedev and his followers have been responsible for most of the more liberal domestic and foreign policy pronouncements of the last three years, his departure from the presidency would be seen by most Western chanceries as a bad sign.

But, for many observers of Russian politics inside and outside Russia, the tandem political game during the period in which US-Russian relations were 'reset' has come to be seen as a bad joke anyway. Medvedev has been unable to convert virtually any of his more 
resounding reformist declarations into reality. During our time in Moscow, Mikhail Khodorkovsky's business partner and fellow prisoner Platon Lebedev had his appeal for early parole contemptuously dismissed by an obscure provincial court near Arkhangelsk in northern Russia. This was despite Medvedev's having repeatedly indicated publicly that the key member of that duo, Khodorkovsky, represented 'no threat' to Russia.

An attempt to reopen the investigation into the death of Sergey Magnitsky, a lawyer working for the Western firm Hermitage Capital Management, was also recently brushed aside by the Russian Interior Ministry. Magnitsky was jailed and allegedly murdered in custody for investigating corruption by Russian officialdom affecting his Western employers. Pleas from Medvedev's presidential Human Rights Council for a thorough investigation and repeated representations by Western governments had no evident impact. While another arm of the Russian Government is reportedly opening its own enquiry into the Magnitsky case, official reactions so far (including promotions and awards for some of the officials involved) are not encouraging.

In response to pressure from the US Congress, the State Department has announced that it has placed individual sanctions on a lengthy list of the officials identified as connected with Magnitsky's mistreatment. Washington's move seems to have been an attempt to forestall legislative action in the matter by Congress, which might have endangered the 'reset'. Moscow's rubber-stamp Duma, in a move richly redolent of Soviet times, responded to the bill in Congress by threatening to legislate for counteraction against US officials.

The key figure in Hermitage Capital is William Browder, an American businessman resident in Britain, who is ironically the grandson of a former leader of the US Communist Party. For many years, he was a very big and determined investor in Russia and a strong supporter of Mr Putin. Increasingly outraged by the corruption and bureaucratic obstruction that he encountered in his business dealings, Browder attempted to expose those involved. This seems to have sealed Magnitsky's fate.

The Lebedev and Magnitsky cases typify some of the growing strains in the US-Russian relationship, which have intensified in the last few months, as Medvedev's always forlorn bid for real influence has 
come up against Putin's overt re-emergence as the paramount leader. With the parliamentary and presidential elections scheduled for 4 December 2011 and 4 March 2012 respectively, this trend could strengthen. Though Moscow often tries to pursue better relations with European countries while enjoying Cold War-style stoushes with the United States, the Lebedev and Magnitsky cases also typify the kinds of issues that will ultimately stultify the Russian relationship with Europe, including Poland.

When we arrived in Warsaw, the main event on the RussianPolish agenda was still the Smolensk air disaster of April 2010. The investigation of the crash by the Russian-led Intergovernmental Aviation Committee had abruptly reported last January that the blame lay entirely on the Polish side. After lengthy delays, as of late July the parallel investigation headed by Poland's Interior Minister, Jerzy Miller, was about to report its findings. The report was a hot potato both domestically and bilaterally.

Conspiracy theories have repeatedly been generated by the Law and Justice camp, which has suggested in effect that the crash was a 'second Katyn'. (The late President Kaczyński and his party had been travelling to Russia to attend a commemoration of the massacres of some 22,000 Polish officers by Stalin's NKVD secret police at Katyn Forest and other sites in 1940.) In other words, it has been darkly hinted, Moscow had in some way deliberately caused the deaths of Poland's president and many of his closest colleagues in the crash, with the complicity never clearly explained - of Poland's government. During our visit, we encountered the latest of these conspiracy theories, which asserted that the plane had somehow been mysteriously disabled before it hit the ground - and that this proved it was all a zamach, an assassination operation.

The Miller report, which was finally released on 29 July, found no basis for such lurid theories. Not surprisingly, though, it did come up with plenty of evidence of sloppiness by Russian as well as Polish officials. The main emphasis was on Polish errors - and indeed its publication led swiftly to the resignation of the Polish Defence Minister, with the prospect of other high-level casualties to follow. But the Miller report's partial exoneration of the Russian side was sufficient for the Russiancontrolled committee to issue an immediate rebuttal of those parts of the report that suggested any degree of Russian culpability. 
The Russian committee was no doubt antagonised by the interminable and hostile discussion of the case in parts of the Polish media and among the political elite. After initially cooperating with the Poles, it had become increasingly evasive, and then brought down and is now resolutely defending a one-sided finding. This is typical of what is wrong with judicial and quasi-judicial enquiries of all sorts in Russia, which are often all too clearly subject to 'justice by telephone' (that is, political direction). Conversely, the fact that the Miller inquiry came up with what seems like a reasonably balanced assessment - an assessment that, despite intense domestic pressure, criticises Poland's role - is more in keeping with an open democracy and the rule of law. In a way, the two enquiries epitomise where the two countries currently seem headed.

As on all our visits since Poland's transition to democracy, we found Warsaw looking slightly more orderly, prosperous, contented and mainstream European than on the previous visit. Not everyone has benefited, but most people have, and Poland's strong economic progress continues, with over 4 per cent growth expected this year. Like Australia, it was one of the few Western countries to stay out of negative-growth territory during the global financial crisis. It has also had the good sense not to fast-track its mandatory entry into the eurozone. And while neither its public finances nor the present government's approach to debt are impeccable, it seems unlikely to join the growing list of EU countries directly affected by the euro debt crisis.

One of Poland's many achievements is the decline of the petty corruption that used to mark many everyday transactions. One small subset of these involved travellers, especially foreigners, at Warsaw's airport. Once known simply as Okęcie, it has now been ponderously renamed the Fryderyk Chopin Airport. It's much bigger and slicker, and the swarms of illegal or amateur taxi drivers that used to surround the airport looking for huge mark-ups have gone.

But their spirit still lingers. We took a taxi from a company recommended by our family. Although the car seemed roadworthy and the driver was pleasant and courteous, he took us on a circuitous route into another zone, which allowed him to double his fare. But it was a small enough surcharge to pay for the pleasure of staggering, 
jetlagged, straight into a waiting taxi whose doors closed properly and that then ran smoothly and swiftly though the dense traffic. And while the meter was rigged, at least it had one.

There was a time when this and most other human needs had to be satisfied 'on the left-hand side' - corruptly and often expensively. In communist Poland, petty corruption was almost universal; though it was maddening, in a way it was what made life bearable and innumerable difficulties soluble. As Poles used to say: 'In Poland any problem can be fixed (U nas nie ma nic nie do załatwienia).'

Shopping is now a delight for any visitor who recalls the communist era. Goods are no longer rationed by queues. The network of commercial outlets for all goods and services seems adequate, where once they were as undersupplied as the goods and services themselves. The absence of an obscene excess of choice between brands is a bonus. And the rude contempt with which one was greeted at the end of the wait in the queue is also long since gone.

We stayed with family in the outer suburb of Miedzeszyn, a sleepy village during the later communist era (though, curiously, the site of a regime installation where former leader Władysław Gomułka and his wife were held in detention - separately - during Gomułka's disgrace in the 1950s) with a few urban dwellings dotted among the fields and woods and a small group of modest semi-detached units. Once a relative luxury by Communist standards, the semi-detacheds have been increasingly outclassed by huge, often fortified villas, with 'beware of the dog' signs. Gone are the picturesque, rustic wooden houses nestling among the pine trees. Gone, too, are the last of the prewar signs on the small concrete commercial premises, which have now been joined by larger, slicker competitors.

The new public politeness is well established in Miedzeszyn. In one shop I spotted a tag on the tunic of the young woman at the cash register that read, 'How can I help?' Once or twice I did things in the shop that were obviously not part of the received order, but without any anger or moral disapproval the proper method was smilingly pointed out to me. And on leaving came the phrase, 'Thank you and please come again (Dziękujemy bardzo i uprzejmie zapraszamy jeszcze raz)' - a little cloying, perhaps, like 'Have a good day', but a vast improvement on what used to take place. 
Miedzeszyn traffic also reflects the broader transformation. Sealed roads have replaced the potholes that had endured for decades. And the once sporadic traffic is now intense on the main roads running through the suburb. Even on the side streets, one must be more vigilant. There are pedestrian crossings, but woe betide the visitor who takes them at face value. The same was true elsewhere in Warsaw, of course. And similar principles apply in Moscow, though we felt that the murderous exuberance with which the post-communist Russian nouveaux riches used to drive through pedestrian crossings may have diminished slightly.

Road fatalities in Poland currently stand at 14.7 per 100,000 people per year, and 28 per 100,000 cars. Russian fatalities are 25.2 per 100,000 people. I could find no figure for Russian fatalities per 100,000 cars, but the Polish statistics suggest that - given the roughly equivalent levels of motorisation in the two countries - the Russian figure for 100,000 cars is probably over 50. The equivalent figures for Australia, for comparison, are 5.2 per 100,000 people and 6 per 100,000 cars.

In the past, vital links in the public transport system in Poland, like in many other communist countries, were the small kiosks selling newspapers, toiletries, small toys and tickets for the chance to fight your way on and off the bus. They kept long hours, and, in a shopper's hell, they were a great boon. This time, looking for a popular newspaper one day, I went to four kiosks before I could get served. The first three had helpful signs displayed in the window that brought memories flooding back: 'Kiosk not open, try the one nearby' (there wasn't one); 'Temporarily closed' (but with no indication of when it might open); and 'Pause - receiving goods' (the proprietor could be seen through the glass walls doing something about four feet away, but after five minutes I realised that the pause might be a long one).

Public transport in Poland, always good if one was young and strong, now seems simply wonderful. The buses and trams are seldom crowded, private buses are offering better and quicker services, there is an urban train service and the beginnings of a metro, and it is all still relatively cheap and reliable. The reason for the new comfort is, of course, the fact that many passengers have bought cars. Traffic on the roads is much heavier, and korki (jams) are not infrequent. Tokyo it isn't, but why so many prefer their cars when public transport is such a good option is a mystery. 
Warsaw's historic main drag, which extends for several kilometres from Wilanów Palace to the scrupulously restored Old and New Towns (both date back to medieval times) and Royal Palace, still looks splendid. Commercialisation is held in check and for the most part is well matched to the premises. Why some visitors call Warsaw ugly is another mystery, though it obviously wouldn't win in a competition with Cracow or Prague. The visual amenity tends to fall away quickly the further you get from the historic centre, though more striking new buildings are multiplying among the Stalinist stodge.

The people on the streets look mainstream European, with many stylish young women (as there always were, even when I first visited in the 1960s), and rather less stylish though well-to-do everybody else. Drunks and beggars seem less in evidence, which might reflect favourable underlying social trends. Poland has always been a harddrinking country, but the statistics (always difficult in this area) seem to have improved after the Solidarity revolution of 1980 and to have held steady since.

Flower shops - flowers were once an absolute and indispensable staple for anyone visiting anyone at almost any hour - are harder to find. Another striking and ubiquitous feature of communist Poland, the gentlemen (of all ages) kissing the hands of ladies (of all ages) on greeting and parting, seems to be in decline. The polite third-person mode of address also seems to be ceding ground to the familiar secondperson singular. Worshipper numbers are down and the numerous churches are now usually locked to casual visitors during ordinary hours. With communism gone, some of its most cherished social objectives seem at last to be coming within reach.

Our Polish friends and relatives had varying views about Polish politics, but we noticed a certain weariness of the topic. The endless febrile discussion of the Smolensk tragedy had exhausted the patience of many. There was also a widespread scepticism about the radical rightwing politics of the Law and Justice Party, which in government had set about radically transforming Poland's democratic institutions on the grounds that they were still dominated by a sinister establishment composed of former communists and 'collaborators'. Even Lech Wałęsa and other prominent Solidarity figures were contentiously characterised in this way by Law and Justice-controlled institutions. 
The polls suggest that, as a result of their experience of Law and Justice rule in 2005-07, many Polish voters see Law and Justice as a slightly scary, even subversive party. Without necessarily feeling great enthusiasm for Civic Platform, which seems headed for a further four years in government after the October elections, they want to cast a negative vote against Law and Justice. Our contacts often fell into that category

Our superficial observations of Moscow at street level were similar to those of Warsaw. Much of our daily movement was in a relevantly affluent area on the architecturally charming and charmingly named Ostozhenka Street (a pre-communist name, now restored, deriving from the word for haystack), and this may have coloured our impressions. Among the many nineteenth-century buildings on the street was a recently renovated house with a classical façade where the novelist Ivan Turgenev once lived, and which is now the Turgenev Museum. A few doors further down was another mansion with a plaque on the front wall indicating that it had once been inhabited by another distinguished figure from Russian history, Kim Philby.

Near the Philby residence one already warm morning we were disturbed to see a young, well-dressed man lying in the grass by the side of the road, apparently unconscious. People were hurrying past him without paying any attention. When we lived in Warsaw we often rang the ambulance service to advise them of drunks lying in snow and in danger of freezing to death (a very common cause of death in Moscow). In summer we felt less alarmed, but there was something about the young man's appearance that worried us. We went into a pharmacy a few yards away to draw it to their attention. The chemist looked very uninterested. Like Poland, but more so, Russia has a severe alcohol problem. In recent decades it has also acquired a terrible and multi-faceted substance abuse problem, including a sinister designer drug known as krokodil. Pharmacists - and Russians generally have probably become grimly blasé about it all.

Alcohol statistics are always a bit dubious but, by any standards, Russia is up there with the heaviest drinkers: by one estimate 15.7 litres of pure alcohol equivalent per capita per annum (compared to Poland's 13.25 litres). Both those estimates allow for substantial amounts of illegal booze (Russian samogon and Polish bimber are both basic words in the respective vocabularies), but that is an especially 
fraught area. According to the Public Affairs Chamber of the Russian parliament, alcohol was responsible in one way or another for 500,000 deaths in Russia in 2009. Successive leaders have tried to tackle this demographic and social scourge, including the sober Putin, who sets an excellent example in this respect. But success has been elusive.

The Putin years have seen a big increase in prosperity that has primarily been fuelled by high energy prices, but with major expansion of agricultural production and consumer goods and services. Studies have shown that income differentials in Russia are high, but living standards overall have improved greatly, and poverty is much less apparent on the streets of inner Moscow than was once the case. Shopping has improved in much the same way as in Poland, and the atmosphere of mutual hostility between consumers and shop employees seems to have largely disappeared. There are more shops and service outlets and the queues are much smaller. In fact, the queues I saw didn't compare with those in typical large Australian supermarkets.

But we saw or heard about both major and minor signs of traditional Russian disorder. In one shop, for example, I noticed bottles of once fresh milk on ordinary non-refrigerated shelves, though the temperature during our stay did not fall below 20 degrees at night and 30 degrees in the middle of the day. At the same time, there were radio warnings to Moscow residents to be wary of consuming dairy products brought from shops as refrigeration in the city's transport and supply networks was said to be unable to cope with the exceptional summer heat.

Russia was still righteously maintaining its extended bans on all fruit and vegetable imports from European countries (especially those like Poland, which it wanted to punish politically), because of the much earlier German E.coli scare, which hadn't occurred in the countries still under sanction in the first place. Moscow has imposed innumerable trade boycotts on its neighbours in recent years, ostensibly on phytosanitary grounds, though often in fact for visibly political reasons.

We were in Moscow in the immediate aftermath of the sinking of the pleasure cruiser Bulgaria, in which over 100 people died, including many children; Moscow continues to be a world leader in disasters of this kind. Plane crashes are also still quite common, though a senior 
Western businessman friend who travels a lot by air assured us that Aeroflot is no longer the 'Aeroflop' of legend and now has a good safety record, compared to some of its newer and smaller competitors.

Moscow's public transport is also good, in a way that is similar to Warsaw's. The Metro was much less crowded than it used to be (even allowing for the summer holiday season) but traffic on the roads is much denser and the probki (jams) more challenging than in Warsaw. The Metro has a much better reputation than Aeroflot, and deservedly so. But to record a trivial example of a more general problem in Russian life, at one point, for no reason, a computerised turnstile at the entrance to a Metro station identified me as an interloper with an invalid ticket (I was innocent) and sent a metal bar thudding down on my knee. An attendant, manifestly unsurprised by this turn of events, told me in a kindly second-person singular simply to bypass the turnstiles via the space he was guarding.

Medvedev has endorsed a plan for Moscow's further development in which, to relieve congestion, much of Moscow's central government business would be moved to the outer regions of an expanded capital territory. Our friends were sceptical that this would happen, illustrating among other things the widespread expectation that anything Medvedev proposed was almost bound to fall through.

People are visibly better off. The women are usually quite stylish, though at times young would-be vamps achieve an over-the-top effect of Lady Gaga proportions. The once ubiquitous babushkas in black selling sundry goods are much sparser than they once were. The new mayor of Moscow, Sergei Sobyanin, who last year replaced the corrupt long-term mayor Yury Luzhkov (and his equally corrupt wife), has conducted a blitz against informal merchandise outlets, which may have contributed to the disappearance of the babushka, but it's probably also a demographic and economic trend. As for the new mayor, he and his wife have also recently become embroiled in allegations of possible corruption.

While Putin has put the non-print media through the 'blander', some Russian papers are still worth a read and there are a couple of radio stations that are listenable. A lot of interesting books are available on cultural and even political themes. Outside television, the autocratic system relies more on selective bans and sanctions than blanket 
controls in the publishing and scholarly domains. The internet is still lively, though there are ominous signs that the authorities would like to control it closely in the way that their much-respected Chinese 'strategic partners' do.

We were in Moscow for Anna to receive a prize named after the famous Russian mathematician Roland Lvovich Dobrushin. This was a gratifying but slightly unsettling award given that Anna is a linguist rather than a mathematician. Our worry was that the choice of a linguist might prove to be some sort of excruciating misunderstanding. The fact that Anna's acceptance address was scheduled as the first paper at the mathematics conference in which the Dobrushin celebrations were embedded seemed to increase the chances that questions from the audience would assume high mathematical competence.

But our anxieties were misplaced. Anna's work often deals with Russian semantics and has been widely published in Russia and in Russian. Her semantics paper was well received, no one wanted to ask impossible questions, the discussion was good and everyone seemed pleased with the event. The fact that a foreigner spoke fluent Russian and so obviously loved the language and understood its subtleties was enough to ensure approval. But it is probably also the case that in Russia, compared to the Anglo-Saxon world, the barrier between C.P. Snow's 'two cultures' is less rigid.

There was something slightly sad about the fact that this distinguished group of mathematicians, many of them survivors from the Soviet scientific elite, appeared to be ageing and a bit depleted. Many Russian academic stars spend a good deal of their time at foreign universities while retaining links with the profession in their home country. Young people no longer want to study science as the pathway to prestige in the way that they did in Soviet times. At the outset of the post-Soviet era, able young people typically wanted to go into business, above all to make money. Now they often tell sociological researchers that they want to join the bureaucracy to make money, reflecting the growing blight of corruption and bureaucratisation. And recently came the startling official news that, over the past three years, some 1.25 million 
people had emigrated from Russia, including disproportionate numbers of the young, educated and entrepreneurial. ${ }^{2}$ Opinion polls suggest many more would do so if they could.

Like the mathematicians, friends and other people we met demonstrated again the exceptional warmth and hospitality of Russian people. Smallish tables in smallish flats were covered with an impossible array of food, and people were crammed in around the table for several hours of eating, drinking and togetherness (obshchenie). Conversations of impressive erudition raged, usually several at once and in competition, people interrupted, contradicted and outshouted one another unceremoniously, and no one took offence. Less fluent speakers of Russian like myself were at a serious disadvantage, but again the discussants showed a remarkable tolerance.

Those we met who spoke of politics were divided sharply into those who were broadly happy with the Putinist dispensation and those who were deeply unhappy with it. The opposition remains hopelessly fragmented and the regime, in any case, uses various devices to deny its opponents access to public media or the chance to compete in elections. Whether and to what extent the opposition might be more popular in a more democratic framework is hard to judge. People who deplore Russia's rejection of a more Western course feel beleaguered, much as they did before Mikhail Gorbachev and perestroika. And polls suggest that the popularity of Putin and the ruling United Russia party, though it has fallen significantly, is still fairly high by democratic standards.

Yet, as prosperity returned after the sharp downturn during the financial crisis, Putin and the regime's ratings might have been expected to stay as high or even climb further. The fact that they haven't suggests that there is considerable resentment at the regime's large and widening democratic deficit. In particular, there are strong indications that Russians are deeply unhappy about what is perceived to be growing official corruption up to the highest levels.

2 See Simon Shuster, 'Why young entrepreneurs are fleeing Russia', Time, 18 Jul. 2011, content.time.com/time/world/article/0,8599,2080414,00.html. 
The very popular anti-corruption blogger, Aleksey Navalny, coined a phrase for the United Russia party that has had wide resonance: 'a party of swindlers and thieves (partia zhulikov i vorov)'. ${ }^{3}$ We noticed the word vor (thief) and its derivatives vorovstvo (theft) and vorovat' (to thieve or steal) recurring in our conversations, often used with great passion. This is a concern for a regime that worries chronically about 'colour revolutions' and has certainly noted the Arab Spring. Navalny, though not an easy target for the authorities because of his strong nationalism, is now being subjected to legal harassment.

Another subject that greatly distressed many of our Russian contacts was the continuing respectability, indeed popularity, of Stalin, including among the young. Putin has done a lot to contribute to Stalin's partial rehabilitation, ensuring, for example, that a 'balanced' view of the murderous despot was mandated for school textbooks. Medvedev has struggled hard to get a new wave of de-Stalinisation launched in Russia, but to date the results, as with nearly all his projects, have been modest. One interlocutor described Russia in this context as a 'gravely ill society'. Another angrily asked us why, given Stalin's standing in Russia, and the fact that the country was now run by the KGB, which even the communist party had never permitted, so many Western governments and businessmen were tumbling over one another to deal with it as if it were a normal country. If Hitler had anything remotely like that status in Germany, he said, the world would be in uproar.

Putin's response to Medvedev's pleas for a second term as president has been a combination of economic populism aimed at various voting blocs, macho public displays, occasional anti-Western rhetoric and revival of the old Soviet tactic of the national front, in this case the 'all-Russian National Front' (Russian acronym ONF). Taken together, these manoeuvres look very like a pre-election campaign. Whole organisations have been recruited into the ONF, often after minimal consultation with their members. Putin even found it necessary at one point to remind the organisers of the Front that they should not overdo things.

3 See Russian election: Hundreds rally against Putin in Moscow, BBC News, 5 Dec. 2011, www.bbc.com/news/world-europe-16042797. 
We may see on 4 December how successful the ONF manoeuvre has been (though whatever happens, the intended electoral results will be achieved). But it is evident that Russia is again taking a turn away from most of the rest of Europe. It is true, as our interlocutor charged, that to date Russia has been cut a lot of slack in Europe. But Putin's credibility may be wearing thin even in countries like Germany, where he has been held in greater esteem.

Recently, a high-profile German NGO, Quadriga, announced that they were awarding one of their prestigious annual prizes to Putin, apparently for his leadership of Russia and his services to RussoGerman relations. The annual prize, which is described as being intended for people who are in some way role models for Germany, has in the past been awarded to various luminaries, including former Czech president Václav Havel. On hearing of the proposed award to Putin, Havel threatened to send his own prize back. His intervention added to a growing groundswell of concern within Germany itself, and the group decided to cancel all its awards for 2011. That incident might suggest that even Germany's resolutely positive engagement with Russia at the level of business and government may be coming under some strain.

This may be good news for Medvedev. Putin and his advisers may decide that they still need Medvedev in the ostensibly top job as a front man who goes down well with Western leaders. We shall see, but recent events seem to confirm that whether Putin or Medvedev or some third person ends up in the presidency might not affect the country's real direction much anyway.

So Poland is headed west while Russia, alas, seems headed east. This is more than a bilateral matter. Depending on the outcomes in countries like Ukraine, Belarus and Moldova, there is a fair chance of a new division appearing in Europe on the current eastern border of the European Union. It will be less ideological than the last one, but there are certain defining characteristics nonetheless: on one side, open societies, human rights, free markets and democracy, if at times flawed; on the other, autocracy, whether softer or harder, economies marked by heavy corruption and state intervention, the absence of rule of law, and a tendency to look to the People's Republic of China as the best developmental model. 
In the shadow of growing 'enlargement fatigue' in Europe and the seemingly never-ending financial crisis in the West, and given Russia's heavy pressure on wayward former republics, the EU's chances of convincing its eastern neighbours to adopt its civilisational model seem less than assured. 



\section{8 \\ Poland at the polls: A win for pragmatism ${ }^{1}$}

Poland's parliamentary elections on 9 October 2011 saw Premier Donald Tusk's centrist Civic Platform party emerge with the largest number of seats. Elections in the former communist countries of Eastern Europe typically produce a decisive swing of the pendulum, but this time the governing party bucked the trend - indeed, Civic Platform has now won three successive national elections (two parliamentaries and one presidential). Tusk will be asked by President Bronisław Komorowski to form a new government, and he is almost certain to form a coalition with the Polish People's Party again.

The results are a further major setback for the main parties on the right and left of Polish politics. On the right, this was a sixth successive loss in elections of varying kinds for the nationalist Law and Justice Party of Jarosław Kaczyński. On the left, the post-communist Democratic Left Alliance (usually known by its Polish acronym SLD), once the dominant party, came in fifth.

The big sensation was a strong showing by an aggressively secular party, the Palikot Movement, which broke away from Civic Platform after the leaders of that party found the amusing but controversial antics of the movement's eponymous leader, Janusz Palikot,

\footnotetext{
$1 \quad$ First published in Inside Story, 14 Oct. 2011, insidestory.org.au/poland-at-the-polls-a-winfor-pragmatism.
} 
an increasing liability. Provocatively anti-clerical, even anti-religious, and provocatively opposed to Kaczyński's party - indeed, provocative in every way, and a successful producer of alcoholic beverages into the bargain - Palikot says he wants to turn Poland into a truly modern state.

By this he means not just liberal abortion laws, for instance, but also gay rights and some legalisation of prohibited drugs. For Poland this is all very strong stuff. But to judge by the electorate's reaction - Palikot secured 10 per cent of the popular vote and seems assured of some 40 seats out of 460 in the Sejm, the lower house of the parliament it seems to be an idea whose time has come.

There is an important message here for the Church, for Law and Justice, and apparently also for the post-communist and more respectably secularist SLD, whom Palikot upstaged with his much more strident language.

Civic Platform's victory will have been a big relief for the celebrated Polish public intellectual, Adam Michnik, who has largely devoted himself in recent years, both as a writer and as editor of the leading Polish daily Gazeta Wyborcza, to ensuring Law and Justice never returns to power. Shortly before last weekend's elections, fearing that a poor turnout might disproportionately favour Law and Justice, which seemed to be making a late surge, Michnik wrote a typically passionate column entitled 'Get out and vote! Take pity on Poland'.

His sentiments would have been shared in most European capitals and in Moscow. Law and Justice has a well-deserved reputation for xenophobic populism. Had it won, Poland's relations with Germany and Russia in particular would have slumped sharply. With Poland currently holding the rotating six-monthly presidency of the European Union, many in Brussels and elsewhere feared that a Law and Justice win could disrupt the work of the presidency at a time when the euro crisis was already causing quite enough disruption. Tusk and his team are well respected in EU circles, and few European leaders feel any nostalgia for the days of Law and Justice government.

Measured, courteous and fluent in German, Tusk has an excellent relationship with German Chancellor Angela Merkel. Merkel's efforts to woo the Law and Justice leaders - the late President Lech Kaczyński and his brother Jarosław, who was prime minister at the time - were 
abruptly rebuffed in 2006-07, and the party's anti-German strand lingered. Just a few days before last weekend's elections, Jarosław Kaczyński made the bizarre allegation that Merkel had been promoted into the chancellorship with the aid of the East German secret police, the Stasi, an organisation disbanded more than a decade before her accession. It was all the stranger because Merkel, with her direct experience of communism as a citizen of the former East Germany, appears to be about as well disposed towards Poland as any German leader is ever likely to be.

Kaczyński has been equally acerbic towards Moscow. Since the tragic air crash near Smolensk in April 2010 in which his brother Lech and many Law and Justice leaders and members of the Polish military elite perished, party figures have maintained a stream of dark hints that this was a massacre engineered by Russian agents - abetted in some unspecified way by the elected Polish Government, no less. At one point, Kaczyński described Poland as a 'Russo-German condominium'. But the Tusk Government's policy towards Russia, while taking pains to minimise tensions, has been firm, and the warming of relations after the Smolensk disaster has partly dissipated.

Law and Justice refused to accept the victory of Civic Platform's Komorowski in the mid-2010 presidential elections, despite the fact that numerous international observers declared the poll to be free and fair. After the election, Jarosław Kaczyński declared that he would not shake his victorious opponent's hand and repeatedly referred to him publicly as Mr Komorowski (Pan Komorowski - the Polish sounds much less respectful than the English) rather than President Komorowski. During the current campaign, Kaczyński and his party refused to take part in any of the scheduled televised debates with the other parties, demanding instead that Civic Platform and its coalition partner should present at the Law and Justice headquarters for a televised grilling on their performance in government.

Back in 2005-07, when Law and Justice held both the presidency and the reins of government, it set about creating a 'fourth Polish Republic', making extensive personnel changes in the public service and regulatory agencies. It took over leadership of the Institute of National Memory, a body whose role includes exposing people in public life who have not acknowledged their collaboration with communist Poland's security police. The institute was felt by many 
to have become extremely politicised and overzealous: it produced, for example, a book denouncing the communist-era dissident leader Lech Wałęsa as a secret police collaborator.

Given Wałęsa's public record, and the dubious quality of the communist secret police files adduced as evidence, this seemed less than plausible as well as highly divisive. But it was part of a broader Law and Justice narrative, which affirmed that, despite all external appearances (15 plus years of democratic elections, frequent changes of government, the entry of Poland into NATO and the European Union), Poland continued to be ruled by a sinister crypto-communist uklad (establishment) in active cahoots with Moscow.

Having taken government in 2007, Civic Platform proceeded to reverse these policies. This process has accelerated since Civic Platform's Komorowski succeeded Lech Kaczyński in the presidency, which eliminated the threat of a presidential veto. Not perhaps without some justification, Law and Justice supporters now complain that they, in turn, have been unfairly discriminated against in various domains of public life.

Law and Justice has a strong orientation towards the Catholic Church, which has been reciprocated at various levels, from bishops to parish priests. Though Polish bishops differ in their political outlook, some are indeed Law and Justice supporters, even ardently so. A streak of narrow patriotism can sometimes emanate from the parish pulpit, particularly in rural areas, reflecting the traditional stereotype of 'PoleCatholic', and not without at times a trace of anti-Semitism. To take an example that has attracted a degree of notoriety, the radio station Radio Maryja, which is run by the Redemptorist priest Father Tadeusz Rydzyk, presents a mix of popular devotional programs and explicitly pro-Law and Justice material that often verges on the xenophobic.

In recent years, the Polish national church has sometimes seemed to lack the wise and decisive leadership that it once enjoyed. While Poland has become a much more secular and pluralist society, the Polish Church, always conservative, seems to have become even more so. In addition to the strong current of overt support for Law and Justice, there is a strong emphasis on 'lifestyle' issues like abortion and contraception (staples in communist times, too), but also the role of women in the church, state and society, the use of in vitro fertilisation, and gay rights. 
The Church has been dismayed to find that its moral directives on such matters, once largely accepted, are increasingly being questioned. In response, it continues to claim the sacrosanct and privileged position it once enjoyed in Polish society. Encountering growing scepticism, it falls back on the reliable support of Law and Justice. But doing so may compound its problems. Certainly, the Church's assumptions about its special role are increasingly challenged if not resented. Palikot's success last Sunday and Law and Justice's latest defeat may lead to some sort of rethink in both the Church hierarchy and in the party's highly centralised leadership. But in recent times both have seemed unresponsive to signals from public opinion.

Despite Poland's huge economic and political successes under varying governments, Polish politics continues to be bitterly contested. The degree of venom in public life seems to bear little relation to the new realities that are apparent to the rest of Europe, where Poland is widely seen as having come of age as a successful market democracy that has joined the inner circle of the most influential EU member states. What makes it seem all the stranger to outside observers is the fact that the leaders of both main parties were comrades-in-arms in the struggle for democracy and national independence.

While Tusk has achieved pretty good results domestically, certain difficult reforms have tended to be postponed on the grounds that the president might veto them or that an election was coming up. Further reforms are needed in such areas as privatisation, pensions and public finances. Civic Platform now holds the presidency and a secure parliamentary majority, so it has run out of excuses for any further postponements.

Tusk and Foreign Minister Radosław Sikorski's external policies have been largely successful. Though controversies arise from time to time, Poland's international standing is high and its relations with most of its neighbours much improved. But one key area where it may be hitting a brick wall is in the so-called Eastern Partnership (EaP). Formally an EU initiative, though largely promoted by Poland and Sweden, the partnership is aimed at drawing six former republics of the Soviet Union - Ukraine, Belarus, Moldova, Armenia, Azerbaijan and Georgia - into closer relations with Europe. Poland would like to see at least some of these countries, particularly its large neighbour Ukraine, become fully integrated partners or even members of the European Union. 
Despite Poland's assiduous efforts, the future of the EaP still looks uncertain. The sums of money being spent by Brussels on the project are relatively modest, EU members are preoccupied with the euro crisis, 'enlargement fatigue' is growing within the European Union, and the behaviour of some of the most important of the putative partners has been often unedifying.

Belarus's economy is in freefall, and its president of 17 years, Alexander Lukashenka, has dealt brutally with the growing mood of opposition in the country as his approval ratings have sunk to an unprecedented low of 20 per cent. Periodically, he makes gestures towards the West by releasing some political prisoners, but then takes offence at something else and resumes denouncing the West's 'hypocrisy'. He is still hoping for an International Monetary Fund loan to bail him out and save him from total dependency on Russia, but the logic of his regime and his economic model seems to be driving him further into Moscow's arms.

The Ukraine of President Viktor Yanukovych is similar in many ways. Eager to escape Moscow's tight control, despite his pro-Moscow instincts, Yanukovych has been pushing hard for an Association Agreement (AA) with the European Union that would give him a free trade deal and progress towards visa-free people movements. At the same time, though, he has been pursuing opposition leaders through the courts in what look very like political prosecutions. On 11 October 2011, the heroine of the Orange Revolution of 2004-05, Yulia Tymoshenko, who nearly defeated him in last year's presidential elections, was sentenced to seven years' imprisonment. Polish leaders have repeatedly warned Kyiv that this might cost it an agreement with Brussels, but it remains unclear whether Yanukovych will somehow facilitate her release.

Poland managed to secure a summit of EaP and EU leaders in Warsaw on 29-30 September, but it was not an obvious success, and there is a danger that, when Poland vacates the presidency, achieving progress on that front will become harder. Tusk has certainly fought the good fight, but success remains elusive. He will continue to try to build Western European influence in the countries to Poland's east, as far as possible without unnecessarily alienating Russia in the process. But that would be difficult at the best of times. Unfortunately, with EU governments in the grip of crisis and a confident and strategic Vladimir Putin back at the helm (which he never really left), these are not the best of times. 


\section{9 \\ Poland's EU presidency: Drawing the short straw ${ }^{1}$}

Imagine you have been allocated a kind of Buggins's turn at presiding for six months over the exclusive business association you've only fairly recently joined. Like the rest of the city, the Occidental has hit bad financial trouble, and the fear is spreading that some members, or even the club itself, hitherto a pillar of solvent respectability, might be facing bankruptcy. Other new members, who joined at the same time as you did, have already had their turn at the rotating presidency, but some senior members weren't impressed by their performance and, indeed, had been sceptical about their joining the club in the first place. One had muttered audibly that the newcomers didn't seem to know when to shut up. ${ }^{2}$ Another had reproached the new members collectively for their 'bad manners'.

Once the colder financial winds started to blow, some establishment members were quick to point their fingers at the newcomers, suggesting that their shiny trousers and unsafe business practices would only bring discredit to themselves and financial damage to the club as a whole. But, luckily, the new members proved financially more resilient than some of the older ones. This was a relief in one way,

1 First published in Inside Story, 5 Dec. 2011, insidestory.org.au/polands-eu-presidencydrawing-the-short-straw.

2 A reference to French President Jacques Chirac's criticism of some new members for not supporting his and German Chancellor Gerhard Schröder's lead in criticising the US-led invasion of Saddam Hussein's Iraq. 
but some establishment figures were now in such strife that it seemed the whole club might go down the gurgler, at which point degrees of culpability might seem less relevant. The president's role had been downsized a bit after the new boys joined, but you still felt a heavy weight of responsibility when you assumed the mantle.

The two most senior members, ${ }^{3}$ who had traditionally run the club's affairs de facto, were feuding publicly about what was to be done. Despite their disagreements, they organised crisis meetings, to which you and most new members were often not invited. You tried to speak up for the excluded members, but it was an invidious position from which to try to broker a solution.

On the other side of town, meanwhile, the rival Eurasian Club, ${ }^{4}$ of which you and other new boys had once been reluctant members, is staging something of a comeback after years of crisis and disintegration. You and some of the other new members feel that the Eurasian's resurgence is likely to take the form of hostile, legally dubious takeovers and even standover tactics, for which that club's Mr Big 5 has long been notorious. Two big neighbouring firms ${ }^{6}$ who had defected from Mr Big and have been showing interest in your association are under heavy and increasing pressure from Mr Big to go back to him.

You are very conscious that some of the influential older members of your own club ${ }^{7}$ feel $\mathrm{Mr}$ Big deserves more respect and attention from them than you think he does. You try hard to establish polite and productive relations with $\mathrm{Mr}$ Big, but you are far from convinced that he is a reformed character. So, to prevent his again becoming a dominant force in the city's politics, and especially in your immediate neighbourhood, you are doing your best to persuade your mid-town neighbours to come over to your side. Though schooled in the same tough neighbourhood as Mr Big, while wary of him, they seem unable to make up their minds.

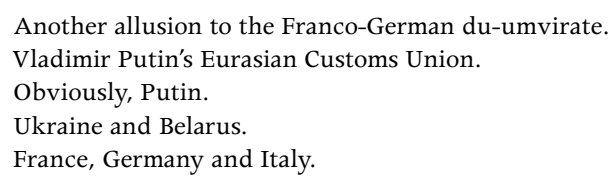


Many senior club members are preoccupied with their own problems and have lost interest in attracting new members. One was even heard to snort from his deep chair in the members' bar that riff-raff like would-be members $\mathrm{B}-$ and $\mathrm{U}-{ }^{8}$ would be better off with Mr Big: 'Let him sort them out.' Despite these discouraging signals, you work on the seniors to keep the membership doors open. And you keep trying to persuade the wannabes to press their claims as persuasively as possible, almost in spite of themselves.

But suddenly one neighbour you were trying to sneak past the ethics committee gets involved in a dismaying spectacle of street violence, ${ }^{9}$ which convinces most of your club members that he is totally unworthy of a place in their midst. Even after that you don't give up, but wipe the egg from your face and organise a very attractive rehabilitation package for him in exchange for a show of penitence. But he treats the offer you made on behalf of your club with public contempt and, to make matters worse, publicly abuses your club's hard-working CEO in highly colourful language. ${ }^{10}$ You strongly suspect that Mr Big's emissaries have nobbled him.

Then your other nearest neighbour ${ }^{11}$ also makes fresh trouble. Despite some increasingly visible peccadillos in his own life, he had been skilfully buttering up your senior members. You have done all you could to strengthen his commitment to your club's values. But he seems to have a split personality. While one half of him seems genuinely to want to become a member, his behaviour at home suggests exactly the opposite and risks his being imminently blackballed. And you know that he is also talking with the Eurasian Club about joining them.

Suddenly, he too becomes involved in nasty public violence against a business rival ${ }^{12}$ who evokes strong sympathy among your club members. You beg him to desist, fearing that your colleagues will recall reports of similar behaviour by him earlier in his career. ${ }^{13}$

\footnotetext{
8 Belarus and Ukraine.

9 Alexander Lukashenka's crackdown on the protesters against his rorted re-election in December 2010.

10 In May 2011, Lukashenka said publicly: 'On the subject of bastards like Barroso and others - who is Barroso anyway? There was a Barroso in Portugal. But they kicked him out and put him to work in the European Commission ... European officials ... are all crooks.'

11 Viktor Yanukovych.

12 Yulia Tymoshenko.

13 Yanukovych's criminal record, see, for example, 'Profile: Ukraine's ousted President Viktor Yanukovych', BBC News, 28 Feb. 2014, www.bbc.com/news/world-europe-25182830.
} 
Despite everything, you keep meeting with him, imploring him not to sink his chances of club membership and all the respectability and business advantages that could provide. You desperately want him to be given the nod by the club's management committee before your term as president expires. And you still have the support of the club's external liaison manager, ${ }^{14}$ despite her doubts about his suitability.

As that date approaches, you feel more and more desperate. You have nightmares he will suddenly appear on TV with Mr Big vowing his total commitment to the Eurasian Club. Or that one of your fellow club members will tell you in quite explicit terms that, regardless of what your neighbour finally decides, they will veto him anyway.

But your biggest worry is the most senior and influential member of your association, by tradition the CEO of the most powerful company in town; a position currently held for the first time by a woman ${ }^{15}$ - and from the other side of the tracks, which raised quite a few eyebrows at the time. She's a brilliant negotiator and can work a committee room far better than any of her male detractors. You've cultivated close links with her and have a healthy respect for her company. But you feel strongly that, because of some unhappy episodes in the company's history, on key issues affecting regional business confidence she's got the wrong end of the stick. Finally you summon up your courage, and during a visit to her head office, launch a carefully calibrated but sharp critique of her whole approach to the regional economy. ${ }^{16}$ And now you're anxiously awaiting the outcome of this risky manoeuvre.

Spare a thought for Premier Donald Tusk, President Bronisław Komorowski and Foreign Minister Radek Sikorski. They don't have an easy life. And yet, despite all the troubles they are grappling with, reportedly not always in perfect unison, they are still getting a pretty good press abroad, as well as the usual bucketing at home from their domestic opponents. They must be doing something right.

\footnotetext{
14 Cathy Ashton.

15 Angela Merkel.

16 Radek Sikorski's celebrated speech in Germany, saying that he was more concerned about Germany's inactivity than about what it does do. The speech evoked much comment in Germany, not on the whole unfavourable.
} 


\section{Part 3. Turning points in Ukraine and Belarus}





\section{0 \\ Ukraine: A sharp turn eastwards? ${ }^{1}$}

The victory of the pro-Russian candidate Viktor Yanukovych in the recent Ukrainian presidential elections elicited curiously little concern in the West. Senior Western figures, from President Barack Obama down, were quick to offer their congratulations. NATO and EU representatives expressed confidence that they would work together with the new president to build on the strong cooperation that already exists. And the markets reacted favourably. ${ }^{2}$

In Moscow the reaction was euphoric, but discreetly so. After then President Vladimir Putin's counterproductive intervention in the 2004 election that helped trigger the Orange Revolution, Russian leaders were especially careful not to call the race until others had done so. They had been studiedly neutral before the first round, except towards outgoing President Viktor Yushchenko, who by then was so low in the opinion polls as to present little danger to them. And, during the run-off campaign between Yanukovych and Prime Minister Yulia Tymoshenko, they maintained their decorum. Tymoshenko had herself tilted towards Moscow in the months leading up to the poll and, from Moscow's point of view, either candidate would represent improvement. But it was clear that Yanukovych's ultimate success was very welcome.

1 First published in ANU Centre for European Studies Briefing Paper Series, vol. 1, no. 1 (May 2010), politicsir.cass.anu.edu.au/sites/politicsir.anu.edu.au/files/documents/2010-1_A-SharpTurn-Eastwards-Besemeres.pdf.

2 'Ukraina razvernulas' reitingom vverkh', Kommersant, 15 Mar. 2010. 


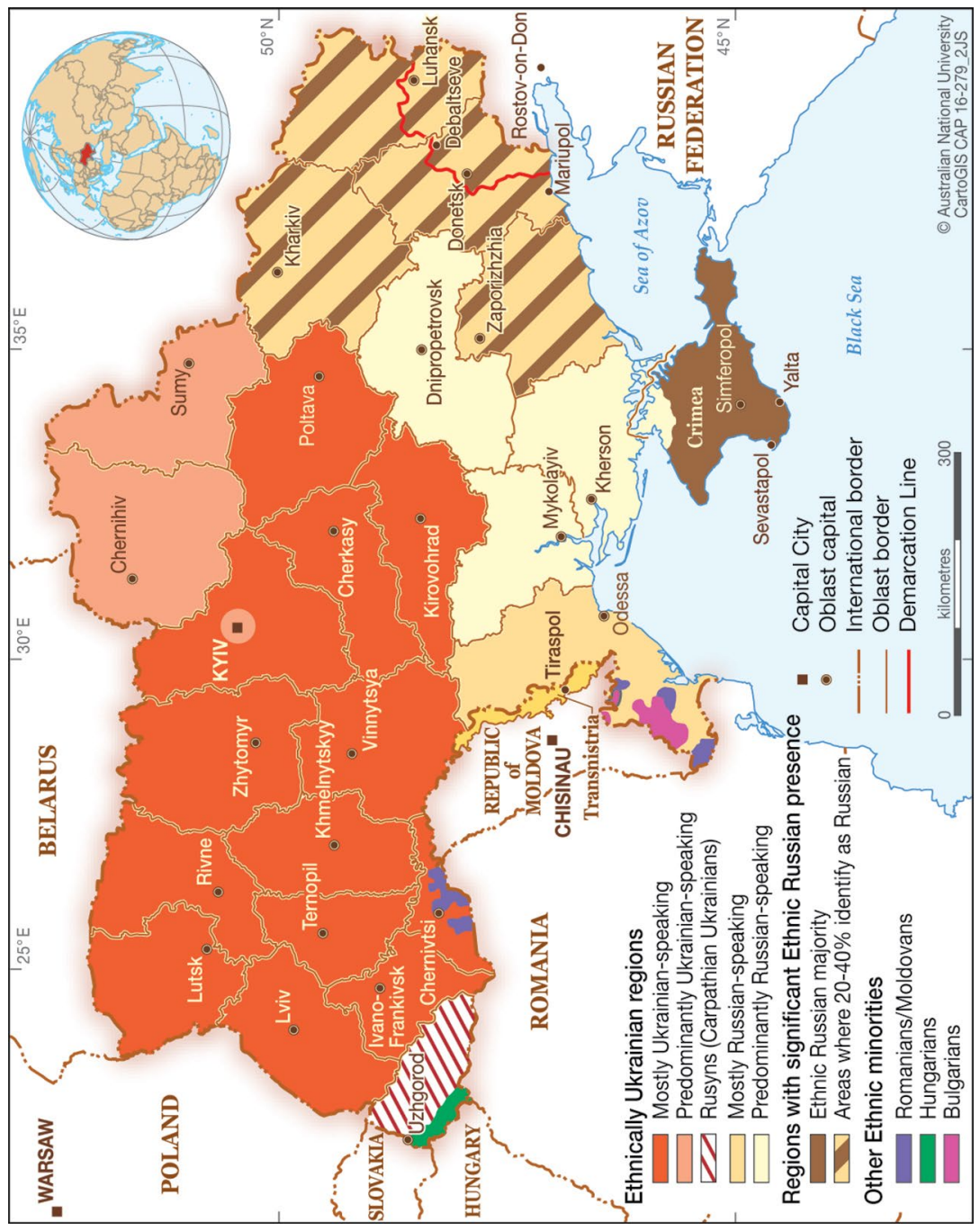

Map 2: Ethno-linguistic map of Ukraine.

Source: CartoGIS, College of Asia and the Pacific, The Australian National University.

Some commentators have suggested that the outcome will not greatly affect the Russian-Ukrainian relationship one way or the other. $^{3}$ And Western leaders are saying that they look forward to full cooperation with the new president, implying that that is their

3 See, for example, the appraisal by the experienced Ukraine observer Adrian Karatnycky, ‘Reintroducing Viktor Yanukovych', Atlantic Council, 8 Feb. 2010, www.acus.org. 
judgement also. The fact that the new president travelled to Brussels ahead of his first trip to Moscow has been widely cited as confirmation of his declarations that he will seek to have equally good relations with Russia, the European Union and the United States. But he has said very different things to his East Ukrainian constituents and Moscow interlocutors.

Why did the Orange Revolution fail? Why has its defeat evoked so little dismay in the West? And is it true that Yanukovych will not change Ukraine's strategic direction?

\section{'Ukraine fatigue'}

By the end of the Orange period, there was considerable impatience with Ukraine in most Western capitals; a sentiment often referred to, including by officials, as 'Ukraine fatigue'. ${ }^{4}$ It must be acknowledged that the Orange forces had done themselves few favours. From the outset, their two leaders, Yushchenko and Tymoshenko, were at loggerheads. Within months of the Orange Revolution, Yushchenko seemed to find more in common with Yanukovych and his Party of Regions than with Tymoshenko, the crowd-stirring heroine of the Orange events. Having appointed her as prime minister, he dismissed her again within a year. Tymoshenko had adopted populist policies that Yushchenko, the former central banker, rightly feared would be disastrous. But there was also an element of jealous rivalry that grew as time passed until, in his last months in office, Yushchenko seemed to be expending much if not most of his remaining capital on ensuring that their erstwhile common adversary Yanukovych would win the presidency.

In the run-off campaign in 2010, Yushchenko called on all his supporters to vote against both the run-off candidates (which the ballot papers facilitated). Over a million did so, more than Yanukovych's winning margin. And many voters in Orange strongholds stayed at home. It's plausible to argue that Yushchenko's campaign against Tymoshenko made the crucial difference. When Yanukovych used a coalition he had cobbled together in the fractious Ukrainian parliament to move

4 See 'Curing "Ukraine fatigue"', by former US ambassador to Kyiv, Steven Pifer, in New York Times, 9 Feb. 2010. 
the goalposts by revising the electoral laws three days before the poll, Yushchenko signed the bill with indecent alacrity. Earlier there had been not entirely implausible suggestions that Yushchenko had done a deal with Yanukovych ${ }^{5}$ to support him in the run-off, in exchange, it was claimed, for high office for Yushchenko himself and for some of his followers after Yanukovych's victory.

Yushchenko's actions can be explained partly by his reservations about Tymoshenko's at times populist and economically irresponsible policies as prime minister. But Yushchenko has himself been inclined to populism and, in the last phase of his presidency in particular, he pursued divisive, nationalist policies on sensitive issues relating to language and recent history. It can be argued it was reasonable for him to push the question of Stalin's possibly genocidal intent in instigating the Ukrainian famine of the early 1930s that killed millions (the order of magnitude as well as the precise motives remain disputed); to try to advance the cause of Ukrainian as the national language (it had long been discriminated against by rulers from Moscow); and perhaps also to push for some re-evaluation of the role of the Ukrainian nationalist groups involved in the bloody events of the 1930s, and 1940s in western Ukraine and prewar Eastern Poland. ${ }^{6}$ But the way Yushchenko went about these objectives was divisive and, ultimately, self-defeating.

His decree in the dying days of his, by then, deeply unpopular presidency proclaiming the western Ukrainian nationalist leader Stepan Bandera a Hero of Ukraine was a case in point. Militias associated with Bandera (who was then in German detention) had been involved in massacres of civilians during World War II. While Bandera's personal responsibility for these events is disputed, he is viewed with great hostility in much of Russian-speaking Ukraine. ${ }^{7}$ The main short-term effect of the award was to damage Ukraine's international standing in influential quarters and to stir bitter controversy within Ukraine itself.

5 See, for example, Taras Kuzio, 'Yushchenko and Yanukovych forge an electoral alliance', Jamestown Foundation Eurasia Daily Monitor, 5 Jan. 2010.

6 On these developments, see Orest Subtelny, Ukraine: A history (Toronto, 1988), chpts 22-23; Timothy Snyder, 'The causes of Ukrainian-Polish ethnic cleansing 1943', Past and Present, vol. 179, no. 1 (May 2003): 197-234.

7 For a more sympathetic view of Bandera's career and context, see Andriy Semotiuk, 'The Stepan Bandera quandary', www.kyivpost.com/news/opinion/op_ed/detail/64386. See also, on Yushchenko's approach to the Bandera issue, Snyder's New York Review of Books blog article at blogs.nybooks.com/post/409476895/a-fascist-hero-in-democratic-Kyiv. 
The European Parliament passed a resolution in which it condemned Yushchenko's decree. ${ }^{8}$ And steps were quickly undertaken in the Yanukovych camp to reverse it.

While Yushchenko may have done more to launch their feud, Tymoshenko responded in kind, at times herself cooperating with Yanukovych to frustrate the President. Her populism reached its apogee during 2009 when her failure as prime minister to meet the terms of an International Monetary Fund (IMF) bailout led to its suspension. During that same period, she also made a lurch towards Moscow, at one point negotiating for a US $\$ 5$ billion loan. The talks fell through, but she gave ammunition to Yushchenko's attempts to discredit her as a stooge of Putin.

Tymoshenko can certainly claim extenuating circumstances. Ukraine was in diabolical trouble as a result of the global financial crisis: its economy shrank in 2009 by 15 per cent. Any prime minister in her place would have been desperate to get money anywhere and have felt tempted to keep turbulent voters happy by maintaining unaffordable social security handouts - any prime minister, and particularly one who was a frontrunner in a forthcoming presidential election. But during all this she, like Yushchenko, sorely tested the patience of her Western partners and creditors. In their prompt endorsement of Yanukovych's narrow win (despite his notorious track record), one sensed not only a desire to affirm promptly their recognition of an election result deemed basically fair by the many international observers present, ${ }^{9}$ but also a wish to forestall or undercut the expected challenge to the result by the Tymoshenko campaign.

The Orange forces have been justifiably blamed by outside observers for the dismal state of the economy, and particularly for their populist resistance to the rigours being demanded of them by the IMF. But, despite its relatively modest resource endowment (nothing like Russia's), Ukraine's economic growth had outstripped that of its larger neighbour almost throughout the noughties. ${ }^{10}$ The nosedive in 2009

8 European Parliament P7_TA-PROV(2010)0035, 'Situation in Ukraine', 25 Feb. 2010.

9 See, for example, 'Ukraine: l'OSCE reconnaît la bonne tenue de l'élection', Le Monde, 8 Mar. 2010. The OSCE and Council of Europe expressed full support, as did key Western leaders, including EU High Representative for Foreign Affairs Catherine Ashton. Given the closeness of the result and the winner's track record, the speed and unanimity of the response was striking. 10 Andrew Wilson, The Ukrainians: Unexpected nation, 3rd edn (Yale University Press, 2009), p. 313. 
was an extreme product of the global crisis, but not without parallels elsewhere, both west and east (Ireland, Latvia). Orange Ukraine was particularly at risk because of the rapid - and political - increase in the cost of its oil and gas imports from Russia, and the deep slump in the price of steel, its staple export. Even if one were to accept Russia's argument that its gas prices were merely being raised to market levels (although other customers have been paying much less, especially former Soviet republics), the hikes were abrupt and particularly hard on Ukraine, whose economy is heavily gas-dependent. In brief, the Orange forces were a bit unlucky to be caught when the music stopped.

Western governments and creditors have been hoping that, if Yanukovych takes over decisively, pursuing consistently the stability he has proclaimed as his prime objective, the basket case may start to recover, requiring less external attention and largesse. And gas deliveries to Western Europe should continue, undisturbed by the gas wars that had become almost an annual event during the Orange ascendancy. Some Western commentators have suggested that the one essential and lasting legacy of the Orange forces is that they were themselves deposed by a free and fair election. Yanukovych's make-over as an EU-friendly democrat (substantially the work of his US public relations advisers) ${ }^{11}$ encourages them to pronounce him a safe pair of hands for restoring rational governance, while - as they cautiously hope - carrying forward the democratic transformation of Ukraine.

\section{Enlargement fatigue}

More broadly, much of Western Europe feels that the reasonable limits of EU and NATO expansion have now been reached. The poor performance of some countries involved in the most recent large expansion of the European Union, in particular Romania and Bulgaria, has led to impatience and cynicism in Brussels. Hostility towards enlargement has seeped into many EU electorates as well, sometimes because of fears of uncontrolled immigration, some of which has come from or through Eastern Europe. The United States under President George W. Bush urged further expansion, in particular to

11 Yanukovych has had a number of make-overs in his career. See Konrad Schuller, 'Neuer Schnee auf altem Schmutz', Frankfurter Allgemeine Zeitung, 15 Feb. 2010. 
NATO, and had support for this in a few European countries, but the predominant mood in Europe has become markedly more sceptical. And governments have become less inhibited about expressing their scepticism. Exceptions may ultimately be made for some small Western Balkan countries, largely for security reasons, but not quickly. The disruptions caused by the global crisis in core Europe have reinforced the mood, and the recent sharp economic downturns in the Baltic states and Hungary have added to it.

The fact that the troubles have now affected the long-term EU member Greece, and are threatening to spread to other existing members, does nothing for the status of supplicants further east. In the absence of any realistic prospects for eager would-be members like Georgia or Ukraine, the EU has offered various halfway houses. NATO is even warier - membership action plans for Ukraine and Georgia have been firmly deflected into the blue beyond. ${ }^{12}$ The prospects for absorption of more members into Euro-Atlantic structures currently look bleak.

This broader scepticism about enlargement has contributed to the souring of attitudes towards Ukraine and the pro-Western Orange forces. Similar considerations apply to countries like Moldova and Georgia. Many Western Europeans see the Georgian war as a warning against further eastern entanglements. In that respect, Ukraine raises even more worrying possibilities than Georgia. Yanukovych's victory will offer reassurance that no alarming crises over the Russian Black Sea Fleet or similar Crimean issues are now likely to arise. In fact, not the least of Yanukovych's advantages is that, while he says he wants to join the European Union at some point, he may be less committed to it than he claims. And as for NATO, he has made it clear that he won't be seeking an entrance ticket.

There is in fact, since the Georgian war, a strengthening feeling in some key European governments that flirting with Kyiv or Tbilisi about possible NATO membership will damage relations with Russia, engagement with which should have priority. ${ }^{13}$ This kind of

12 See, for example, Andrew Wilson, 'Dealing with Yanukovych's Ukraine', European Council on Foreign Relations Policy Memo, Mar. 2010, p. 4.

13 As a former senior State Department official in the Clinton administration wrote recently, 'you don't have to go very far in Europe to hear whispers that some kind of new "Finlandization" might be a good compromise for countries like Ukraine and Georgia'. Ronald Asmus, 'Finlandization of Georgia and Ukraine', Moscow Times, 3 Mar. 2010. 
thinking, together with domestic economic considerations, has led the French Government to negotiate to sell four advanced Mistral-class amphibious assault vessels to Russia. The prospective sale of these ships, of which a senior Russian military commander has said that having them in its armoury would have enabled Russia to deal with Georgia much more expeditiously, is causing acute alarm not only in Georgia but also in new NATO members located on the Baltic Sea. ${ }^{14}$ Meanwhile, a group of former senior German officials (including a defence minister) has called for Russia to be invited to join NATO. ${ }^{15}$

The United States, for its part, is keen to secure the support of Russia on issues of prior concern to the Obama administration like Iran, Afghanistan and nuclear disarmament, and does not wish to antagonise it unnecessarily. So, pressure from that quarter for enlargement is much diminished. And Ukrainian public opinion itself seems to be reciprocating. The West's growing scepticism towards them did not help the Orange forces domestically or in its pro-Western foreign policy aspirations. Support for NATO membership was always in the minority, something that Yushchenko's ineffective and divisive leadership may have accentuated. But public support for EU membership has also been declining and is for the moment a minority preference. ${ }^{16}$

\section{Yanukovych's mandate}

Some misplaced commentary about a stunning victory notwithstanding, Yanukovych's starting position seemed weak. He is the first Ukrainian president to have been elected with less than 50 per cent of the votes cast, and that in an election where turnout was well below 2004 levels. His total vote was down on last time by hundreds of thousands and his majority of 3.5 per cent was much less than had once seemed likely, given the impact of the GFC on the

14 Pavel Felgenhauer, 'France fears the loss of Mistral sale', Eurasia Daily Monitor, 4 Mar. 2010; J. Marone, 'Russia's interest in warships worrisome', Kyiv Post, 4 Mar. 2010, www.kyivpost.com/ article/content/ukraine/russias-interest-in-warships-worrisome-61057.html.

15 Walter Mayr, 'Walking the thin line with Catherine Ashton', Spiegel Online, 8 Mar. 2010, www.spiegel.de/international/europe/european-union-foreign-policy-walking-the-thin-linewith-catherine-ashton-a-682339.html.

16 A survey by the European Council on Foreign Relations showed only 34 per cent of Ukrainians supporting EU membership in 2009. See Alina Inayeh, 'Ukraine and the EU: A family portrait', The German Marshall Fund of the United States Focus on Ukraine, 27 Jan. 2010, www. gmfus.org/publications/ukraine-and-eu-family-portrait. 
economy. Tymoshenko was evidently gaining on him. In her, he has a determined opponent, who has promised to fight him at every turn. Moreover, the powers of the presidency had been reduced by the constitutional deal that accompanied the Orange victory ${ }^{17}$ - and which, in large measure, led to the unproductive internecine political struggles of the Orange period.

Yanukovych's win is, in any case, the proverbial poisoned chalice. While the economy is showing signs of stabilising after its freefall, there is a long way to go, and he will have to meet some tough (though very different) demands from the IMF and Moscow if he is to get the help he will need to overcome the crisis. The necessary measures will be hard to get through the fractious parliament, and politically damaging to anyone attempting to implement them.

More generally, any Ukrainian leader has to reckon with the tribal divisions in Ukrainian society and politics. Voting patterns in this election were as regionally divided as ever, with Yanukovych winning big in the Russophone east and south, and Tymoshenko easily carrying the Ukrainian-speaking west and centre, winning 17 of Ukraine's 27 administrative regions. Yanukovych also has to keep sweet the strongly pro-Moscow Communist Party within his coalition (this is essential to his majority), while continuing to balance the various clans and more and less Russophile factions within his Party of Regions.

\section{What can we expect from a Yanukovych presidency?}

The early portents suggest that Yanukovych will consolidate his authority by liberal use of what in Moscow is called 'political technology'. After changing the electoral laws just before the runoff in his own favour, he then used his improvised majority to have himself and his chosen government confirmed by essentially that

17 See Wilson, The Ukrainians, pp. 320-21, for domestic aspects of the compromise; International Centre for Policy Studies, 'Yanukovych uncovered', Inside Ukraine [special issue], Feb. 2010, pp. 8-9, for the foreign policy aspects. 
same majority, in a way that was widely seen as unconstitutional. ${ }^{18}$ The tainted majority - achieved by seducing defectors away from other parties by alleged bribery ${ }^{19}$ - was also used to postpone inconvenient local elections that were scheduled for May. And the new ministers and presidential administration staff whom he has put in place offer little encouragement to those who expected him to make concessions to the strong opposition forces in parliament. ${ }^{20}$

The opposition appealed to the Constitutional Court against the way in which the new government was formed. To no one's great surprise, the court rapidly reached the conclusion that the new government's formation was in keeping with the constitution, despite having previously ruled against allowing single deputies to defect to form a government. Tymoshenko had claimed that Yanukovych was exerting heavy pressure against the court. If so, he would not have been the first president to do so. Similarly, this is not the first time that the court has seemingly capitulated to political pressure. ${ }^{21}$

Many have expected Yanukovych to be a president like Leonid Kuchma (president from 1994 to 2004). Kuchma won the presidency by campaigning 'from the east', but then made elaborate efforts to rule from the centre, including by making efforts to improve his Ukrainian.

The curious thing is that all three of the current protagonists are actually easterners by birth and upbringing. Yushchenko came from the east but, after studying in western Ukraine, was bitten by the nationalist bug, acquired good Ukrainian and later used it and advanced it officially wherever possible. Tymoshenko comes from

\footnotetext{
18 The 2004 constitutional compromise included provision for an 'imperative mandate' prescribing that parliamentary deputies who left the party on whose proportional representation ticket they had been elected would cease to serve. This was meant to prevent the kind of crossrecruitment that had been taking place up to then, often with a strong hint of corrupt inducements. This was the provision that Yanukovych almost certainly breached in putting together his coalition just before and after the presidential run-off. For a discussion see Andreas Umland, "“Tushki" and the decline of Ukrainian representative democracy', Kyiv Post, 24 Mar. 2010, www.kyivpost.com/ article/opinion/op-ed/tushki-and-the-decline-of-ukraines-representative--62429.html.

19 The leader of the People's Self-Defence party, Yuriy Lutsenko, one of the more honest of the Orange politicians, described the process as one of 'buying deputies both wholesale and retail': 'Lutsenko o koalitsii: Pokupka deputatov optom i v roznitsu'”', glavred.info/print/news/274642. prn (accessed April 2010, article no longer available).

20 See the section 'Towards a Donetsk "power vertical"?', below.

21 Taras Kuzio, 'Judges mock justice with their useless or corrupt rulings', Kyiv Post, 8 Apr. 2010, www.kyivpost.com/article/opinion/op-ed/judges-mock-justice-with-their-uselessor-corrupt--63477.html.
} 
Russophone Dnepropetrovsk (the home base of Leonid Brezhnev's leadership clique) but she, too, earnestly enhanced her Ukrainian and uses it widely. This was a winning card for her in the Orange events, and has helped moor her main base in the centre and west, despite her periodic conciliation of Moscow.

By contrast, Yanukovych is an Easterner in sentiment, style and language. Many Ukrainians of Russian heritage in the east see themselves as both Russian and Ukrainian and perceive no difficulty in doing so. A minority identify simply as Russians. It would not be politically wise for Ukrainian politicians of national ambitions to present themselves as Russian in this latter sense, and Yanukovych of course does not. He has made some efforts to improve his Ukrainian, but orally challenged in general, he seems not to relish speaking it. He has little rapport with the over 20 million who prefer to speak Ukrainian, many of them militant nationalists in the western provinces. He appears comfortable in the company of his Russian counterpart, Dmitry Medvedev, and certainly will be much more at home in Moscow than in Brussels or Washington. He may even feel more comfortable in his native Donetsk than in Kyiv, where Western sentiment and the Ukrainian language have made some inroads since Soviet times, when Russian was dominant both officially and unofficially.

Yanukovych has been presenting himself as a competent pragmatist, who is not Moscow's man but, rather, a European who wants to have good relations with Moscow and the West alike. He says he will put an end to the political squabbling, ineffective economic management and corruption that have cost the average voter so dearly. In his inauguration speech on 25 February, Yanukovych lamented the present state of the nation and the dismal economic outlook. He promised reform of governance with a cabinet of professionals, working transparently in tandem with the president. On foreign policy he pledged neutrality, and said he would seek the best and most advantageous relationships equally with Russia, the European Union and the United States. ${ }^{22}$

Consistent with this even-handed pitch, his first foreign trip was to Brussels on 1 March, four days before his first visit to Moscow, a fact that was widely commented on with satisfaction in the West. But, according to the liberal Moscow paper, Kommersant, already on 13 February, 
the head of the Russian Presidential Administration (and reportedly former KGB official), Sergey Naryshkin, had visited Yanukovych in Kyiv and spent six hours with him one on one, discussing matters of mutual and evidently urgent interest. ${ }^{23}$ Naryshkin is a longstanding colleague of Prime Minister Putin and is seen by some as Putin's man in Medvedev's entourage.

Some of Yanukovych's other actions and pronouncements on the campaign trail and since the election have been less reassuring than his Brussels visit, where he certainly talked the EU talk (though he did not visit NATO). He said, for example, he would renegotiate the gas contract with Russia in a way that seemed likely to restore murky middlemen to the transactions, one of the murkiest of whom, Dmytro Firtash, is one of his key backers. Firtash's allies have now been appointed to high office. Yanukovych also said he would seek to create a consortium, including a one-third share for Gazprom, to run Ukraine's gas transit system. (It is a basic principle of Putin's 'energy diplomacy' that Gazprom should gain control of as much as possible of other key countries' oil and gas infrastructure.) Both of these Yanukovych policies were ones that Tymoshenko, to her credit, had opposed.

Yanukovych was obviously hoping that such concessions to Russia would give Ukraine's desperately cash-strapped gas importer Naftohaz some pricing relief and make it easier for the national economy to stay afloat. He also hoped these moves might dissuade Russia from diverting much of its gas exports from the Ukrainian pipelines (through which 80 per cent of Russia's exports to Europe are currently channelled) to the controversial Nord Stream and South Stream pipeline projects, which seem aimed at bypassing Ukraine. These projects represent a severe economic and strategic threat to Ukraine, and advance Russia's policy of seeking a potentially coercive stranglehold over energy supplies to Europe whilst gaining greater leverage over former vassal states to its west. It always seemed unlikely that Russia would agree to any such quid pro quo.

Yanukovych also indicated more than once that he would consider favourably extension of the lease of the Russian Black Sea Fleet in Crimea, which is due to expire in 2017; an extension that Yushchenko

23 'Konfeta po-Kyivski', Kommersant Vlast, 22 Feb. 2010, www.kommersant.ru/doc/1323691. 
had vigorously opposed. The Crimea is strongly Russophone and Russophile, and the issue has been a source of great tension in bilateral relations and within Crimea. For many Russians, especially those in Crimea, there is bitter regret that, in 1954, the Soviet leadership decided to mark a historic anniversary of Russo-Ukrainian unification by transferring the Crimean province from the Russian to the Ukrainian republic within the USSR. The move seemed purely symbolic at the time, but acquired a new significance with the collapse of the Soviet Union, and the emergence of Ukraine as a sovereign state in its existing borders.

The gas price and Black Sea Fleet issues have now apparently been resolved in tandem by a package deal announced by Yanukovych and Medvedev at a bilateral summit in Kharkiv on 21 April. Under the agreement, Ukraine extended the lease by 25 years from 2017 and, in return, received a rebate on its gas purchases of 30 per cent on the current (above-market) price contracted by then Prime Minister Tymoshenko with Putin in early 2009 to bring an end to the gas wars. There will be European countries who will share Moscow's satisfaction at this development. But some observers worry that any such deal as that now struck could threaten Ukraine's sovereignty. ${ }^{24}$

On NATO, Yanukovych has envisaged continuing existing cooperation in the near term, while ruling out accession. But, despite the frequent comparisons, he seems to have much less enthusiasm for NATO than President Kuchma did. In fact, he has recently dismantled some longstanding governmental structures that were meant to prepare for any possible future accession by Ukraine to NATO. On the European Union he has been much more positive, and clearly hopes to benefit as much as possible from economic cooperation with it. Whether he is seriously intent on becoming a member is less clear. His declared readiness in the past to consider joining Moscow's rival customs union between Russia, Belarus and Kazakhstan (for which Putin suddenly last year demanded the right to negotiate entry into the World Trade Organization (WTO) as a unit) threw some doubt on his personal commitment to either the European Union or even the WTO, of which

24 James Sherr, 'Ukraine's elections: Watershed or new stalemate?', Chatham House REP Paper 2010/01 (Feb. 2010), www.chathamhouse.org/sites/files/chathamhouse/public/Research/ Russia\%20and\%20Eurasia/pp0210ukraine.pdf. For further discussion of the deal, see the section entitled 'A sharp turnaround?', below. 
Ukraine is already a member. Despite this, some EU members and the European Parliament, for their part, have held out the prospect of future membership and, in the meantime, offer the possibility of an Association Agreement (AA), with a free-trade deal and visa-free travel for Ukrainians, which are all big attractions.

On the campaign trail, Yanukovych indicated that he wished to make Russian the second official state language. To quietly reverse some of Yushchenko's vigorous boosting of Ukrainian, including in areas where Russian is strongly dominant, would ease tensions in Party of Regions constituencies and be not unreasonable. Elevating it to the status of a second official language is more controversial and, as the extension of the Black Sea Fleet's lease appeared to be, on the face of it politically and constitutionally difficult. While the constitution as such may not be a major obstacle for Yanukovych, since becoming president he has distanced himself from any such formal proposal, whilst trying to reassure his Russophone supporters that their expectations will be met in other ways. But that is probably a change of tactic rather than a change of heart. Certainly the opposition expects that, in government circles, Russian will become the de facto official language.

On the day of his inauguration, Yanukovych accepted a blessing from the Moscow Orthodox Patriarch Kirill, a provocative gesture towards Ukraine's Greek Catholics and followers of the two Ukrainian Orthodox churches. Kirill has been an active and adroit supporter of the Russian imperial interest in Ukraine and, despite his large following there, especially in the east, his visits to the country have not been uncontroversial. Symbols like these may point to Yanukovych's likely choices over the longer term. They may also be damaging to the country's fragile internal balance.

Very controversially, Yanukovych has in the past intimated that his government might recognise the 'independence' of South Ossetia and Abkhazia. If it were indeed to do so, Ukraine would join a select group of countries that includes (apart from Russia) Venezuela, Nicaragua and Nauru. It would not thereby improve its own international standing, and be unlikely to do much for that of the two breakaway statelets sponsored by Russia. In particular, any such move would damage Ukraine's relations with Western countries from which it needs and will seek financial and other support. Moscow has been lobbying hard and offering substantial rewards to countries prepared to offer recognition. Compared with the other three recognising states, 
Ukraine would be a huge prize. Not even Alexander Lukashenka's Belarus has yet succumbed to Moscow's blandishments. Recognition by Kyiv, if it happens, would certainly be confirmation of a new strategic trajectory for Ukraine.

Yanukovych will probably offer Russia other opportunities. Russian businesses and investors will be favoured more than at present, provided that they do not walk all over Yanukovych's Ukrainian oligarch backers, who are increasingly interested in Western markets. Purveyors of Russian language and culture will be made very welcome in the media and elsewhere. Yushchenko's efforts to check Russian espionage and penetration are likely to become a thing of the past. Military access in the Crimea and elsewhere, despite Yanukovych's professions of neutrality, may be extended. Ukraine's links with Georgia and other Russian bêtes noires will be phased down or out. Security cooperation with NATO will be scrutinised far more critically than under Yushchenko. And so on.

Finally, and more broadly, there is the question of the extent to which Yanukovych will preserve the gains of the Orange Revolution. Notwithstanding some recent commentary, these are actually considerable, and can't be reduced to the judgement that the presidential and other elections on Yushchenko's watch have been pretty clean. On a range of international indices of sociopolitical progress, Ukraine has improved its position in the first years after the Orange Revolution, whereas Russia declined.

On the Bertelsmann Transformation Index (which examines a range of socioeconomic and governance issues), Ukraine went from 44th place in 2003 to 37th in 2010 (Russia from 41st to 65th). On Freedom House's freedom of the press index, Ukraine went from 68th in 2004 to 55th in 2009 (Russia from 67th to 80th), and other related indices recorded a similar pattern. For comparison, Reporters without Borders indices had Ukraine on 51 in 2004 ( 0 would be ideal), and 22 in 2009 (whilst Russia declined from 51 to 61). Even on one index of corruption, for which Ukraine is acquiring proverbial status, not without reason, Ukraine comes out ahead of Russia, with Georgia, incidentally, markedly better again. ${ }^{25}$

25 On all of the indices cited above, see 'Russland in politikbezogenen länderrankings', Russland-analysen, no. 197, 26 Feb. 2010, www.laender-analysen.de/russland/pdf/Russland analysen197.pdf. 
The point of adducing these various findings is not to suggest that they are free of all bias and 100 per cent reliable. But, clearly, they depict a pattern that is similar to the pattern agreed on by a variety of less systematic observers. While Ukraine is corrupt and chaotic (though not uniquely so), it has made great progress in the last few years in important respects. It is for this reason that a number of prominent Russian journalists, who have been frozen out of the public space in Russia, have departed to Ukraine to practice their craft. And it is also for this reason that Putin has seemed chronically worried about the threat that Russian politics may become 'Ukrainianised'.

Putin's worries may be over. Despite some of his recent pronouncements, Yanukovych is not one of nature's democrats. He is also facing difficult problems. The temptation to cut corners will be great. Already he has been doing so, by riding rough-shod over constitutional restraints. More such manoeuvres by Yanukovych seem likely to follow. He is, for example, talking about preparing a package of constitutional measures to resolve the conflicts between executive and legislature of recent years. Clearly he thinks they shouldn't be hard to get through by one means or another. Yanukovych was, after all, the man who sought to steal the 2004 presidentials and has never expressed any regret for having done so. At the very least, it seems a safe bet that the next presidential elections will be less democratic than the ones just past.

\section{Towards a Donetsk 'power vertical'?}

Despite the structural pluralism of Ukrainian society, Yanukovych is already more in charge than anyone has been for a number of years. While his Party of Regions has its own clans and factions, it is operating with more cohesion than the other Ukrainian parties. All the key instruments of power appear now to be in the president's hands or those of his close allies.

Yanukovych is often presented as being the creature of his patrons and handlers. And he is routinely mocked for his gaffes and inarticulate presentation, not only in his laboured Ukrainian, but also in Russian. He once referred to the great Russian playwright Anton Chekhov as a Ukrainian poet, and identified the equally celebrated Russian poet Anna Akhmatova publicly as Anna Akhmetova (the tasty irony in this being that his biggest backer is Ukraine's richest man Rinat 
Akhmetov). But all the gibes about Yanukovych overstate the case. He is clearly a capable politician, who has successfully maintained the cohesion of his diverse party. Given that diversity, where Russophile zealots mingle with pragmatic moderates, his choices of key officials are important as pointers to his intentions, to the strength of different factions and thus to likely policy directions.

Yanukovych's first appointments (on the day of his inauguration) were to his Presidential Administration (PA). ${ }^{26}$ His first nominee, Serhiy Lyovochkin as head of the PA was not encouraging. Lyovochkin has links to Firtash and the intermediary companies formerly involved as middlemen in the gas trade from Russia through Ukraine to Europe, in murky arrangements that are widely seen as facilitating corruption and damaging to Ukraine. Yanukovych had wanted to return to those old arrangements, which Tymoshenko finally succeeded in dismantling, but they may have been bypassed in the Kharkiv deal. Yanukovych's choice of Iryna Akimova as a first deputy head of the PA may be a more favourable signal. Only 40, she is a respected economist who has worked in Poland and Germany, and has publicly rejected suggestions that Ukraine should join Putin's Eurasian Customs Union. She is linked to Ukraine's most powerful oligarch, Rinat Akhmetov, one of those who favour nurturing trade with the European Union. But Yanukovych's new Premier, Nikolai Azarov, has declared, to the outrage of women's groups, that economic reform is not women's business. He has no women in his cabinet of 29 .

Other senior appointees to the PA are a mixed bunch. Most are, like Lyovochkin, veterans of the later, more autocratic and Russianleaning Kuchma period, and/or old mates of the president, one of them reportedly having had a role in Yanukovych's electoral headquarters at the time and place where the fraudulent results were manufactured in 2004. The most surprising choice is that of former journalist Hanna Herman, who has an unusual component in her background for a Regions politician, namely a period working in Radio Free Europe/Radio Liberty in Germany, from which she was recruited by Yanukovych after she had interviewed him in 2004. Feisty, articulate

26 For a description of the initial appointees, see www.kyivpost.com/content/ukraine/ yanukovychs-top-management-team-60473.html. 
and fluent in Western languages, she is likely to be a more liberal voice and called on to serve as the public face of the new administration in Western capitals. But she is unlikely to mould policy.

After winning the run-off, Yanukovych named Serhiy Tyhypko, Nikolai Azarov and Arseny Yatseniuk as his three preferred frontrunners for the prime minister's position. Tyhypko and Yatseniuk are both political technocrats with past exposure at the top, who performed strongly in the first round of the presidential elections, presenting themselves as a 'third force' between the opposing sides. Either as prime minister would have been a sign that Yanukovych indeed wished to rule from the centre. Tyhypko was given a deputy prime ministership, despite having freely criticised his former ally, the new president, on a number of issues. ${ }^{27}$

But Yanukovych's choice for the top job fell on his very close and longstanding ally, Azarov, a diehard Regions politician, and Soviet-style financial manager. He came to Ukraine from his native Russia only in his 30s, does not speak Ukrainian and, as a deeply pro-Russian figure, has alienated the Orange constituencies.

The cabinet appointed to serve under Azarov is uninspiring. Few appointees are remarkable for their competence. Thirteen of the 29 ministers are either from Donetsk province (Yanukovych's home base) or the neighbouring Donbas province of Luhansk in the Russianspeaking east. Eastern oligarchs are particularly heavily represented, including the Gazprom-friendly Firtash group, to which the gas sector has been entrusted. Bizarrely, the gas lobby has also been given charge of the State Security Service. The new head has denounced his Orange predecessor for having opened too many Soviet-era files, declaring that under his control the agency will concentrate on guarding secrets, not exposing them. And he has called for radical extension of his right to tap phones, without the need for court approval. ${ }^{28}$ The new Minister

27 Tyhypko had even condemned the unconstitutional way in which the government he joined had been constituted. Like Akimova, he has been criticised by Regions stalwarts and, although he has a strong public following, may not last long in the government. He has claimed to the media that one of the conditions he stipulated on joining the government was openness. He promised he would continue to state his views publicly, and virtually foreshadowed his own future departure from the government. 'Tyhypko poprosiv, shtob iomu ne zakrivali rot', Unian, 16 Mar. 2010.

28 'Bad decisions', Kyiv Post, 18 Mar. 2010, www.kyivpost.com/opinion/editorial/bad-decisions $-62055 . \mathrm{html}$. 
for Education, Dmytro Tabachnyk, is a well-known pro-Moscow figure who has declared in the past that the west Ukrainians are not really Ukrainians at all. His appointment has predictably outraged the western provinces. And the Deputy Prime Minister for Humanitarian Affairs has called for discussion of a possible union of Russia, Belarus and Ukraine. ${ }^{29}$

None of this looks like ruling from the centre. In fact, Yanukovych's appointments and his government's first steps and pronouncements look very much like a sharp turn towards both Moscow and winner take all. The Orange opposition, meanwhile, true to form, is fragmenting and squabbling with itself, as the steady trickle of defectors into Yanukovych's generous embrace continues.

\section{Better to rule in hell than serve in heaven}

Yanukovych's native Donbas was a loyal region of the Soviet Union, and Yanukovych a typical product of it. His instincts, behaviour and most of his policy declarations thus far all point to his origins. And Russia will be directing all its efforts towards drawing him into a close, cooperative and preferably subordinate relationship. Few Russians can accept the idea of Ukraine as a separate country. ${ }^{30}$ As Zbigniew Brzezinski has written, Russia without Ukraine ceases to be an empire. But with an eastern-led Ukraine more or less obediently at its side, nationalists in Russia, who include many in the present regime, could again aspire to imperial status. Theirs would be an entity of nearly 200 million, with much of its old Soviet-era military potential again fully under its control. Belarus, and other fragments of Moscow's former domains - and not just South Ossetia, Abkhazia and Transnistria - might then feel more impelled to fully embrace its leadership. The geopolitics of the region could be transformed in Moscow's favour.

29 'Semynozhenko wants discussion of idea of union of Ukraine, Russia, Belarus', Kyiv Post, 28 Mar. 2010, www.kyivpost.com/content/ukraine/semynozhenko-wants-discussion-of-idea-ofunion-of--62662.html.

30 As Putin is widely reported to have said to George W. Bush, 'You don't understand, George, that Ukraine is not even a state'. James Marson, 'Putin to the West: Hands off Ukraine!', Time, 25 May 2010, www.time.com/time/world/article/0,8599,1900838,00.html. Many Russians, including senior political figures like Moscow mayor Yury Luzhkov, share Putin's opinion. 
There can be no doubt that many in Russia and a smallish but active minority in Ukraine feel drawn to this vision. Even if he nurtured such impulses himself, however, Yanukovych would understand that to set off down that path could lead to serious turbulence within his domain that could threaten his own undoing. Cordial fraternal ties with Russia would seem to be as much as the market could comfortably bear.

In any case, few in positions of power wish to embrace a diminution of their own role. Even Lukashenka, the dictator of Belarus (who calls his KGB the KGB, who for most of his tenure has run his country like a Soviet theme park, and whose population is much more Russified than Ukraine's), has been increasingly defiant towards Moscow of late. ${ }^{31}$

But Ukraine's economic frailty and Yanukovych's own ethno-political inclinations present Russia with serious possibilities for strategic gains. Given this prospect, Western leaders are offering some belated gestures of hospitality, welcoming the new president with elaborate respect and the prospect of economic and political advantage if he measures up to their expectations. The European Union quickly responded to the election outcome by declaring its readiness to work with the new administration towards greater Euro integration. The US administration, though its focus is elsewhere, has also been positive. President Obama made time in his schedule to meet Yanukovych during the nuclear summit in Washington on 12-13 April. Hence the paradox that the removal of the ardently pro-Western Orange forces has led to a warmer welcome in the West for their pro-Russian opponents than they themselves have ever received.

Russia knows its target far more intimately than its Western rivals ever will. Provided it can restrain its frequent impulse to treat its prodigal little brothers with imperial arrogance, it should be able to make some solid headway over the next few years. One thing it will not be doing is encouraging the new Ukrainian leadership to lovingly preserve the fragile democratic gains of the Orange Revolution.

31 Lukashenka's latest gesture of defiance towards Moscow was to offer hospitality to the ousted dictator of Kyrgyzstan, Kurmanbek Bakiyev, who infuriated Moscow by accepting a large Russian loan, on the understanding that he would expel the United States from the air base at Manas (which is vital for resupply into Afghanistan), then allowing it to remain there for a much higher rent. For more background on Lukashenka's anti-Moscow manoeuvres, see David Marples, 'The great game', Eurasia Daily Monitor, 31 Mar. 2010. 


\section{A sharp turnaround?}

Yanukovych's first official visit to Moscow on 5 March produced few immediately visible results. But he struck a different tone to the one he had adopted in Brussels a few days before, foreshadowing a 'sharp turnaround' (krutoi povorot) in bilateral relations. ${ }^{32}$ He reaffirmed that joining NATO was off the agenda, that he looked forward to strategic partnership with Russia, and that the question of the Black Sea Fleet could be resolved to the mutual satisfaction of both countries. He also promised to rescind Yushchenko's decrees declaring Bandera and a key associate Heroes of Ukraine. Rather ominously he praised Russia's political stability and spoke disparagingly of Ukrainian politics and politicians. ${ }^{33}$ And he issued an invitation for President Medvedev to visit Ukraine before mid-year. The sides agreed to set up a joint commission to examine bilateral issues in the meantime.

Both Yanukovych and Azarov (on a subsequent visit) desperately sought lower gas prices for Ukraine, which is currently paying more than most other European customers in the east or west. Recently, Gazprom has felt obliged to relax its tough contractual terms to meet the needs of key Western clients, in recognition of the fact that the spot price has declined markedly and that the European market is increasingly influenced by falling demand and greater and more diversified supply. But Russian responses offered little encouragement. Putin at one point suggested publicly that to get better gas prices Ukraine should join his Customs Union. Clearly Moscow felt they could hold out for more.

According to Kommersant, the Ukrainian side was already under pressure to move on a number of 'delicate' questions during Yanukovych's first visit. ${ }^{34}$ The Russians reportedly raised the matter of an agent of the Russian Federal Security Service (FSB - the KGB's

\footnotetext{
32 'Vyrvi gaz', Kommersant, 5 Mar. 2010.

33 'I think that the Russian people probably do not yet completely understand the price of the stability that exists in Russia ... I am deeply convinced that there are sufficient numbers of instigators and - as they are called - politicos everywhere, including in Russia. If we gave you a small number of these politicos from Ukraine, you would understand what political maneuvering means.' The quote is from a conversation with Putin recorded on Putin's official website, as quoted in Kyiv Post, www.kyivpost.com/content/politics/yanukovych-envious-ofpolitical-stability-in-russi-61162.html.

34 'Viktor Yanukovych vygliadel vazhnym i politicheskim', Kommersant, 6 Mar. 2010.
} 
domestic successor organisation) being held in a special security prison in Kyiv. And Moscow was said to be seeking the removal of CIA agents from Ukraine, of whom, according to an unnamed Ukrainian diplomat quoted by the paper, 'we have many'. At the same time, according to the paper, the Russian side wanted the FSB to be able to resume its work with the Black Sea Fleet (Yushchenko ordered the FSB's expulsion late last year), and made clear to the Ukrainian delegation that it expected all military cooperation with Georgia to cease. Earlier, even before Yanukovych's inauguration, it was reported in Russia that in the northern autumn of this year, Russia and Ukraine would conduct their first joint air and air defence exercises for a long time ${ }^{35}$ How Kyiv handles these matters will further test Yanukovych's purported 'neutrality'.

Reporting on the spate of bilateral visits in both directions that followed Yanukovych's first trip, despite the Russian hardball, seemed to reflect a growing intimacy between the two governing milieus hardly surprising given the formal relationship of partnership that exists between the Party of Regions and the ruling United Russia party. On 5 April, a week ahead of his first trip to Washington, Yanukovych made another, supposedly private visit to Moscow, where he again met with President Medvedev.

Then on 21-22 April, Yanukovych met with Medvedev in Kharkiv and unexpectedly announced that, in effect, Kyiv was selling some surplus sovereignty for a gas discount. This development again seems to be in breach of the Ukrainian constitution, which precludes the stationing of foreign forces on Ukrainian soil. There is, however, also a 'transitional' provision that permits the use of an existing base for temporary stationing of foreign forces. ${ }^{36}$ Stretching this provision, which was seemingly meant to tide the Russians over after the breakup of the Soviet Union to as far ahead as 2042 with an option for at least a further five years, seems a bit radical. Despite that, the sides agreed further that their respective parliaments would ratify the accord in unison on 27 April, expeditious even by Soviet rubberstamping standards. Clearly they wished to forestall any discussion of the strategic surprise by the Ukrainian population. This agreement,

35 Mariusz Zawadzki, ‘Janukowycz: Ukraina będzie bliżej UE’, Gazeta Wyborcza, 11 Feb. 2010, citing the Moscow paper Komsomol'skaia Pravda and sources in the Russian Defence Ministry. 36 'Viktor Yanukovych razrubaet morskoi uzel', Kommersant, 23 Apr. 2010. 
now ratified without dissent in Moscow but amid turbulent and not always edifying scenes in Kyiv, seems likely to be seen as a major turning point in the bilateral relationship over the two decades since the collapse of the Soviet Union.

Continuing the fast pace, Putin travelled to Kyiv for a working visit on 26 April. Whilst there he continued to press for more radical measures to closely align the two countries' nuclear energy, aviation and shipyards industries. On his form to date, Yanukovych would seem likely to respond positively to these proposals if the commercial interests of his key oligarch backers are safeguarded.

The Kharkiv deal suits Yanukovych's short-term interests. It gives him enough relief to be able to present the IMF with a plausible budget without the need to resort to serious austerity or reforms. It keeps him sweet with his gas-guzzling oligarch supporters, whose main products are rendered profitable again. It may contribute to Ukraine's incipient recovery and make average voters see the new president as having brought about palpable improvements to their lives; already he is offering to increase salaries and pensions. And it closes off any question of NATO membership for several decades.

For his part, Medvedev was scarcely able to contain his delight. As a Moscow newspaper commented, it enabled Russia to extract a geopolitical concession from Ukraine of which until recently it could not have even dreamed. The same newspaper quoted Yanukovych as saying that if all bilateral meetings were going to end with such decisions as these, the recent freeze in bilateral relations would soon be compensated for. At this point one of the Ukrainian journalists present was reportedly heard to whisper 'and we'll become part of Russia'. ${ }^{37}$

The Russian media had reported shortly before the agreement that Russia's defence ministry was planning to strengthen the Black Sea Fleet presence in Crimea with new submarines and other vessels. ${ }^{38}$ The earlier 'temporary' agreement on a 20-year lease, which was agreed in 1997 in Kuchma's time, did not permit replacement of existing vessels

37 Vladimir Solovyov, 'Iz Ukrainosti v krainost', Kommersant, 22 Apr. 2010.

38 Nezavisimaia Gazeta, 21 Apr. 2010. 
in the fleet without Kyiv's consent. ${ }^{39}$ While the Ukrainian Foreign Minister has declared that Russia would continue to be bound by that requirement, Yanukovych is hardly likely to withhold his consent.

Early discussion of the very non-transparent gas deal includes suggestions that the murky middlemen will be allowed to return to the process; and that the cost to Russia will be modest when all factors are taken into account. According to one source, Moscow is allegedly seeking that Kyiv offer concessional access to Ukraine's entire oil and gas infrastructure to a degree amounting to 'energy occupation' ${ }^{40}$ And there have been media reports of rumours of further concessions having been offered and deals struck in addition to the gas-for-base accord. The chair of Ukraine's parliamentary committee on European integration (and twice its foreign minister in the past) Borys Tarasiuk has claimed that the Russians are still insisting that Ukraine join Russia's Customs Union, integrate with the Commonwealth of Independent States, and make further concessions on national values and historical memory. ${ }^{41}$

Attending a meeting of the Parliamentary Assembly of the Council of Europe (PACE) after Putin's visit, Yanukovych publicly rejected the Customs Union as inconsistent with Ukraine's WTO membership. But, on the same occasion, he hinted again at possible recognition of Abkhazia and South Ossetia, effectively withdrew from active PACE consideration Yushchenko's thesis of genocide against Ukraine during the famine of the 1930s, and declared that he favoured strategic relations with Russia 'in all spheres'. ${ }^{42}$ On another front, he has gladdened Moscow's heart by agreeing to joint celebrations of Victory Day with Russia in Moscow, Kyiv and the Crimea on 9 May.

After such divisive measures and pronouncements as these, Yanukovych may find it expedient over the coming months to allay the fury of the Orange forces by some conciliatory gestures. But he probably feels at this point that he has their measure. For its part, to

39 Pavel Felgenhauer, 'Jubilant Medvedev praises Yanukovych and threatens Lukashenka', Eurasia Daily Monitor, 22 Apr. 2010.

40 See Andrzej Kublik, 'Rosja podbija Ukrainę', Gazeta Wyborcza, 28 Apr. 2010.

41 'Tarasiuk: Russia proposes terms contradicting Ukraine's interests in exchange for reduction in gas price', Kyiv Post, 20 Apr. 2010, www.kyivpost.com/content/ukraine/tarasiuk-russiaproposes-terms-contradicting-ukrai-64522.html.

42 'Viktor Yanukovych proyavil mnogovektornuyu priznatel'nost', Kommersant, 28 Apr. 2010. 
ensure that the Black Sea Fleet deal sticks and is not denounced by a future Ukrainian government of different persuasion, Russia is now likely to make an even bigger investment in ensuring that Yanukovych stays in power. This may not always take the form of conciliatory gestures. From Russia's point of view, an acrimoniously divided and even unstable Ukraine is not necessarily a bad thing. Moscow has been operating on a similar basis to keep pro-Western forces in check in Georgia and Moldova, and in general often finds instability in its former vassals creates a congenial terrain for pursuing its interests.

Yanukovych seems prepared to meet Moscow much more than halfway on matters relating to hardcore security, language, culture, sentimental ties and what might be loosely termed identity politics. On economic issues, though conciliatory, he will not be such a soft touch, and will want to keep the door open to Western trade and investment. The West's best option at this stage - perhaps its only one - for maintaining a foothold in Kyiv may be to talk nicely, offer incentives, and hope that Putin oversteps again, as he did in 2004. 



\section{1 \\ In Belarus, the leopard flaunts his spots ${ }^{1}$}

Even before the polls closed in Belarus's presidential election on 19 December, supporters of opposition candidates were planning their protests. Although the conduct of the campaign was remarkably liberal by recent standards, opponents of Alexander Lukashenka's regime confidently expected another rorted result, so no one was surprised when, late on polling day, the president claimed an implausibly huge victory. His return to authoritarian form was dramatically displayed when the government's security forces beat up protesters rallying in the centre of the national capital, Minsk. At least 640 people were arrested, including seven of the nine opposition candidates.

The leading opposition candidate, Vladimir Neklyayev, was seized and bashed on his way to the demonstration, suffering severe concussion. He was taken to hospital, where a group of plain-clothes thugs burst into the ward, dragging him off to jail. Neklyayev, who has serious vascular problems, has been denied treatment and there are fears for his life. Another leading opposition candidate, Andrei Sannikov, also injured, was stopped by traffic police and pulled out of a car on his way to hospital. His wife tried to hold on to him, for which she was also assaulted. Beatings in jail are reported to be widespread, and some protesters have been forced to recant, Iranian-style, on television.

\footnotetext{
1 First published in Inside Story, 4 Jan. 2011, insidestory.org.au/in-belarus-the-leopardflaunts-his-spots.
} 
Just over a week later, in Moscow, came the conviction of Russian oligarch Mikhail Khodorkovsky and a fellow Yukos Oil executive for allegedly stealing and laundering the proceeds of most of the oil produced by their own company. A few days earlier, well before the verdict, Russian Prime Minister Vladimir Putin met a handpicked audience to respond to pre-approved questions. Asked about Khodorkovsky, he said that 'a thief should stay in prison', putting paid to any idea that calls by President Dmitry Medvedev and his entourage for respect for the rule of law would be heeded. Khodorkovsky's real offence before his first show trial in 2003 had been to try to play a role in politics and even contemplate standing for the presidency against Putin. He has now been convicted a second time, in effect, for that same offence.

Meanwhile, in Ukraine, the regime of President Viktor Yanukovych, who narrowly defeated the former prime minister, Yulia Tymoshenko, in the presidential elections in early 2010, has recently charged his rival with various criminal offences, warning her that she may not leave the country. On 26 December one of her former ministers, Yuriy Lutsenko, was arrested while walking his dog, taken to jail and charged with embezzlement. Lutsenko, an anti-corruption campaigner of long standing, was the latest in a long list of former Orange Government ministers and senior officials jailed or indicted for such offences.

The contrast with the way the Orange leadership treated Yanukovych and his allies, who blatantly rorted the presidential election in 2004 then lost on the re-run forced by the Orange Revolution, couldn't be greater. The Orange President, Viktor Yushchenko, even appointed Yanukovych to the prime ministership for a time. Yanukovych and his Party of Regions were able to regroup and successfully contest the 2010 presidential elections, which were widely accepted by international observers as free and fair. But, since his election, Yanukovych has not reciprocated that generous treatment, having systematically abused the Ukrainian constitution to set up a centralised autocracy while persecuting his former opponents through a corrupted court system.

In other words, the authorities in each of the Slav-dominated former republics of the Soviet Union - Russia, Belarus and Ukraine - are displaying overt contempt for democratic norms. The curious thing is that they are doing this precisely at the time when each of them is seeking closer relations with the European Union. In Russia's case, the 
declared motivation is to pursue a 'partnership for modernisation'. In Ukraine's case it is a pitch for trade concessions and visa-free travel, but ostensibly with an ultimate aspiration to join the European Union. For Belarus, the 'last true dictatorship of Europe' as Condoleezza Rice once said, it has been a flirtation with Brussels to hedge against growing pressure from Moscow.

For Brussels, the primary motivation is to use 'engagement' to improve relations with each of these three difficult neighbours, encouraging transparency, good governance, financial probity and democratic norms. With Ukraine and Belarus there is the additional objective of succouring their independence against attempts by Moscow to resubordinate its smaller Slavic neighbours in some kind of Russianled quasi-federation or close alliance.

After years of frustration in pursuing this objective, Moscow has latterly been making progress. Yanukovych's victory last February more than restored the close relations between Russia and Ukraine that existed before the Orange Revolution of 2004. Political, security, ethno-linguistic and economic ties have all been greatly strengthened. When Putin began to press forcefully for a takeover of the commanding heights of the Ukrainian economy, Yanukovych's key Ukrainian oligarch supporters felt their vital interests were threatened, and Kyiv's resistance stiffened. But the two governments remain very much closer than they were a year ago.

As with the Ukrainian presidential elections, Moscow looks to be the biggest winner from the recent spectacle in Belarus, which suggests that the friction between the two countries has begun to lift. And, in the last year or two, there have been encouraging developments for Moscow elsewhere in the 'near abroad', notably in Georgia and Kyrgyzstan. In various ways, Russia is bringing some of its wayward former provinces back home.

But Belarus has never been regarded as one of the more wayward former republics. So how did the recent conflict between Lukashenka and Moscow come about?

Despite a brief flowering of national independence on either side of the fall of communism, Belarus once again became virtually a Russian province in the years after Lukashenka won the presidency in 1994. He set about creating a neo-Soviet autocracy at the same time that the 
Russian President, Boris Yeltsin, was starting to retreat from his earlier westward tilt. The neo-Soviet trends in the two countries strengthened after Putin came to power in 2000. For a time, it even seemed likely that the 'union-state' of Russia and Belarus, proclaimed in 2000, might become a reality.

But in recent years, as Russia reduced its energy subsidies to Belarus, as for other former republics, while pushing to secure control of their key economic assets, Lukashenka became anxious. He might have gone along with a Russo-Belarus confederation, but only if it guaranteed a prominent role - perhaps even the presidency - for him. As Russia's intentions and Putin's distaste for him became more evident, however, he began to seek and welcome EU overtures.

Under courtship but also pressure from Brussels, Lukashenka looked to improve his image and the country's foreign investment climate, which now sits well above that of Russia or Ukraine on international rankings. More surprisingly, he eased his notoriously repressive regime, presenting himself almost as a born-again liberal reformer and allowing opposition politicians to gain official acceptance as presidential candidates for the December 2010 poll. In early November 2010, the German and Polish foreign ministers promised Lukashenka support for a large International Monetary Fund (IMF)led loan package on behalf of the European Union, as well as progress towards free trade and visa-free entry for Belarusians if he agreed to democratise his country.

Relations with the United States also improved for Belarus. In pursuing its 'reset' policy with Russia, the Obama administration has placed less emphasis than its predecessor on promoting democracy in the former republics of the Soviet Union, though it continues to welcome any moves in that direction. For his part, like Yanukovych earlier in 2010, Lukashenka has courted American approval by offering to eliminate his stocks of highly enriched uranium, a key priority for President Barack Obama. He was still sending out some positive messages to the United States in meetings with visitors from Washington think tanks just a few days before the crackdown.

While this opening towards the West was taking place in the months before the elections, Russia was increasing its pressure on Belarus. Moscow was angered by Lukashenka's efforts to resist increases in 
energy prices and even more by his failure to support key Russian projects. In particular, Lukashenka was reluctant to adhere to the latest stage of Putin's Eurasian Custom Union integration project, into which Moscow was keen to inveigle other former republics, especially the fraternal Slav states of Belarus and Ukraine. Nor would he recognise the 'independence' of breakaway territories South Ossetia and Abkhazia, after Russian forces 'liberated' them during its 2008 war against Georgia. When Russia applied its usual tactic of manipulating energy trade to enforce compliance - suddenly and sharply reducing gas deliveries to Belarus in June 2010, for instance - Lukashenka responded by seeking further credits and subsidised energy elsewhere, including from China, Venezuela and Iran.

Responding in July 2010, state-controlled Russian television ran a series of denunciatory documentary programs about Lukashenka, depicting him as an autocrat with a contempt for human rights, referring to the violent deaths and disappearances among his opponents, and highlighting a comment he had allegedly made in praise of Hitler. Much of the material was not far off the mark, though it was also eerily applicable to Putin's Russia.

But, with the violent crackdown on 19 December, both the proWestern and anti-Moscow trends in Belarus policy seemed to have been abruptly reversed. The leopard's familiar spots were again fully in evidence. Having blitzkrieged the domestic opposition that he had tolerated for months, Lukashenka belligerently dismissed Western concerns, saying he would put an end to 'senseless democracy'. The president's swashbuckling, bullyboy style, which was evident at a news conference after the violence, recalled Putin at his most colourful. It also recalled Lukashenka himself after the previous presidential elections, when he'd threatened to wring oppositionists' necks 'as one would a duck'.

Such language and behaviour are typical for Lukashenka. It has been reported that when the openly gay German Foreign Minister Guido Westerwelle and his Polish counterpart Radosław Sikorski were visiting Minsk in November to offer aid in return for democratisation, they enquired about Belarus's treatment of sexual minorities. 'We don't have people like that here,' the President allegedly responded, 'but if we did, we'd put them in cattle wagons and ship them off to camps.' 
Nonetheless, despite his well-known track record, both the brutality of the crackdown and the aggressive rhetoric seemed deliberately intended to alienate his erstwhile Western interlocutors.

What brought about the change? Essentially, it was the sustained Russian pressure. While he remained defiant in response to Moscow's campaign against him during the course of the year, Lukashenka was keenly aware that Belarus's economy depends heavily on Russia, with which about half of its foreign trade is still conducted, including some 70 per cent of its machinery exports and 90 per cent of its exports of food products. In particular, Belarus's relatively steady growth under Lukashenka has owed a great deal to the continued inflow of heavily subsidised Russian oil and gas. Even with that support, the economy was heading for trouble under the stress of the global financial crisis. Belarus has a serious and dramatically worsening balance of payments deficit, by one estimate likely to reach US\$7 billion for 2010 . This has led, in turn, to a sharp increase in its foreign indebtedness. Belarus's debt repayment obligations are set to worsen in the next few years, threatening an uncontrollable spiral.

Lukashenka probably always knew that Moscow could ultimately draw the noose as tight as it chose, until finally he would be left with little recourse. The European Union was offering him less, and with the price tag of a democratisation agenda that might ultimately have cost him power. By contrast, Russia was 'only' seeking to reduce his country's national sovereignty and might well accept his continued grip on power if he were more cooperative. In similar circumstances earlier in the year - facing growing energy bills and debts to Russia as the financial crisis bit deeper - Ukraine's Yanukovych opted to reach a deal to extend Russia's lease on its Crimean naval facilities to 2042 in exchange for a reduction in the price of gas imports. Lukashenka has apparently now made a similar choice.

At the height of Moscow's anti-Lukashenka campaign, some observers speculated that Russia was seeking regime change in Minsk, but it was probably always more likely that Russia would be happy to reach a compromise on energy if Belarus toed the line on its neo-imperial agenda. On 9 December, 10 days before the election, Lukashenka met with the Russian leadership in Moscow and agreed to enter the Common Economic Space with Russia and Kazakhstan. At the same time he reached an agreement for an effective reduction in the price of 
imported Russian oil that will save Belarus an estimated US $\$ 4$ billion a year, more than the one-off IMF credit that the EU emissaries had been talking about.

By election day, with the bilateral deal with Moscow more or less settled, Lukashenka no doubt felt that he could afford to treat his domestic opponents and the West with contempt. For its part, though it was mildly irritated by the fact that some Russian journalists had been caught up in the wave of detentions and weren't immediately released, Moscow was quick to express its satisfaction with the conduct of the election.

While there is no mystery behind the reasons for Lukashenka's volteface, it is curious that he struck out against his opponents with such venom, even though this was bound to damage his relations with his Western interlocutors. It may be that he was responding to the fact that the elections went rather worse for him than he was prepared to acknowledge. Independent polling in the relatively free atmosphere before the ballot showed his support slipping and suggested that, in a fair fight, he might only get somewhere between 30 and 50 per cent of the vote, and would need to go to a second round to win.

Applying his usual tactics - stacking the voting booths with trusties (excluding all but a few token opposition representatives), abusing the bizarre system of 'preliminary voting' by people employed in government institutions who are ferried en masse to cast early votes, and common-or-garden ballot-stuffing - would probably have given him a comfortable victory anyway. But he could well have faced the embarrassment of the solid opposition support becoming visible and contrasting sharply with his sweeping majorities on previous occasions. The Polish Foreign Minister, Sikorski, has suggested this as an explanation for the fury of his attack on the protesters, citing information that he had attracted no more than 40 per cent of the vote rather than the nearly 80 per cent officially claimed. ${ }^{2}$

But thuggery is Lukashenka's style and always has been. He is a deeply Soviet figure, even more devoted to the less edifying aspects of the Soviet tradition than is Putin himself, who tends to view him as

2 See 'Belarus Elections in the Focus of Polish Press', Belarus Digest, 29 Dec. 2010, belarusdigest.com/2010/12/29/belarus-elections-in-the-focus-of-polish-press. 
a naïve provincial bumpkin. So perhaps his response reflected, above all, exuberant relief that the pretence of a mini-democracy could be flung aside once concessions had been wrung from Moscow, and that smarming up to the West was no longer necessary. After the people power revolutions in Georgia, Ukraine and Kyrgyzstan, all postSoviet autocrats, including Putin, feel a slightly irrational fear that despite their popularity (in some cases) and their elaborate security/ propaganda empires (in all cases) they could suddenly be pitchforked out of office by an angry mob. They see such events not as largely spontaneous domestic revolts but as sinister plots orchestrated in the West.

This mindset may help explain Lukashenka's violent reaction and anti-Western rhetoric, but there is also evidence that the crackdown was carefully choreographed. Provocateurs reportedly encouraged protesters to ignore their leaders' calls for restraint, and broke windows in government buildings to provide the pretext for the crackdown. This line of interpretation sometimes goes further, arguing that from the beginning Lukashenka's contacts with the West were an elaborate feint meant to extract a better deal from Russia, which, once it was in his pocket, meant that 'stupid democracy' and his tiresome opponents could at last be dispensed with.

Whatever his thinking or instincts in discarding the Western card, Lukashenka may have done himself a mischief. Moscow can, if it so desires, retract its concessions or find other ways of pressuring him whenever it likes. Lukashenka might be calculating, probably correctly, that Western governments will eventually swallow their pride and lift any sanctions against him, allowing him to resume tactical manoeuvres on both the eastern and western fronts. But in the meantime, he may need to reach an accommodation with Moscow, without the benefit of other options.

He could probably live with that. He detests democracy and impertinent challenges to his autocratic supremacy. In a close embrace with Putin's Russia, he can be sure of one thing: that he will be under no pressure to introduce democratic reforms. And for Moscow, a stable 'power vertical' (Putin's term for concentrated top-down power) in Belarus to match Russia's own would not cause any great distress, except in some liberal circles that still cleave to the fading hope of a Medvedev-led perestroika. 
The two regimes will continue to have their differences. But for the time being they will be reconciled, and Moscow will feel it is making progress towards Putin's objective of at least partially repairing what he regards as 'the greatest geopolitical catastrophe of the twentieth century', the break-up of the Soviet Union. Putin will also be pleased that there are no longer any democratic experiments in Ukraine and Belarus that might conceivably turn the heads of his own constituents.

After a period of perhaps one or two years of indignation, and some sort of sanctions against Belarus, many or most Western countries will probably conclude that sanctions are only isolating Lukashenka unproductively, and will again look for ways of engaging the dictator. And, having made his point, Lukashenka may well again display interest in any fresh inducements. Western policy does not seem to have many viable alternatives in these situations. Despite Russia's seizure of parts of Georgia in 2008, its contemptuous dismissal of Western objections, its breach of French President Nicolas Sarkozy's ceasefire agreement and so on, within a few months the reset button had been pressed in Washington, and the European Union and NATO were both offering their own peace overtures to Moscow.

The main drivers of the current conciliatory trend in Western policy are the United States and Germany. For the Obama administration, the new policies relate not so much to Russia or Europe as to other concerns, especially nuclear disarmament, Iran and Afghanistan. WikiLeaks revelations have confirmed that official Washington has no illusions about Moscow, but Obama is still eager to establish the best possible bilateral relationship to advance other priorities.

Germany's conciliatory policy towards Russia has a long history, but the main factors at the moment are probably its huge and profitable economic relationship with Russia (including an element of energy dependency); Germany's memory of its Ostpolitik towards the Soviet Union in the 1970s, which it feels led to détente, perestroika and German reunification; fear of provoking Russia by adopting too forceful a policy in relation to former Soviet and Soviet-bloc territories; and, probably, an element of historic guilt for the barbarous Nazi occupation of Soviet lands during World War II. Berlin still feels grateful for reunification, in particular, and believes that other Western countries pushed Moscow too far after Mikhail Gorbachev had conceded so much. Germany is the main conciliator, but there are 
others, notably France under former president Jacques Chirac, and increasingly also under Sarkozy, Italy under Prime Minister Silvio Berlusconi, Spain and Greece.

Between them, the United States, Germany and France have done much to pursue engagement with Russia. At the Lisbon summit of NATO on 19 and 20 November 2010, to which Medvedev was invited as an honoured guest, the rhetoric of both sides was extremely positive, despite the important differences that continue to divide them. Before the Lisbon summit there was a high-level meeting on 18 October involving Germany, France and Russia - but not the United States - at Deauville in France, at which security issues were discussed in a positive atmosphere. France has now confirmed it will sell Mistralclass amphibious assault vessels to Russia, despite the objections of Baltic NATO member states and the desperate would-be member Georgia. Paris has justified this unprecedented sale with the surprising reasoning that if NATO wishes to engage Russia on security and other issues it should be prepared to display trust towards it.

Given these determinedly positive atmospherics, it would be surprising if the developments in Belarus were to derail East-West rapprochement for long. Yet, for all the talk of engagement, modernisation, renewed security architecture and so on, the current situation is rather different from the détente of the 1980s. In Gorbachev, the West had a leader with whom it could indeed do business, a leader seeking to meet Western expectations at least halfway and to achieve domestic reforms that would make the Soviet Union a more democratic, transparent and normal society.

In Putin they have someone who bitterly regrets most of what happened under Gorbachev and Boris Yeltsin, and who is heading to a large extent in an anti-Western, even xenophobic direction certainly domestically, and usually externally as well. Medvedev represents a different strain of thought within the elite, but though it might suit the Putin leadership that Medvedev presents a smiling face to the world, he seems unable to make his writ run on virtually any important issues. 
The easy passage of New START through the US Senate will give the overall East-West dynamic some momentum. Sooner or later, however, the key US-Russian relationship will keep snagging on issues like Belarus, as Moscow continues its determined pursuit of restoring Russian great power status and recapturing former dominions.

What of Belarus itself? Will its society be content to accept Lukashenka's latest diktat without demur? If there is resistance, will it seriously threaten the ex-collective farm chairman?

Generally speaking, the degree of resistance by vassal states to Moscow's domination during the Soviet period, and the development of stable and prosperous democracies since then, have depended on the strength of national sentiment and the maturity of civil society in each country or region. Despite some revival of civil society in the last couple of years, Belarus has not been one of the stronger post-Soviet states in either respect. The national language - close to Russian - has not had a secure hold in most of its territory in recent times. Russian is now dominant in most of Belarus. A small minority speaks Belarusian by preference, but Russian is overwhelmingly the language of public discourse. (In this respect it is unlike Ukraine where, in the west and much of the central regions, Ukrainian is dominant or holds its own.)

Although it had its own representation at the United Nations when it was part of the Soviet Union, Belarus was essentially a loyal Soviet province rather than a recognisable nation or centre of nationalist resistance like the Baltic states, for example, or even Ukraine. Despite rediscovering Belarusian nationalism when it suited his interests, Lukashenka is probably still a typical Soviet Russian as much as he is a Belarusian. Though he recently startled an audience by speaking fluent Belarusian in public, he does so seldom and appears to care little about its status or future. Nationalists and some oppositionists try to keep the language alive, but they are up against not only the Russifying policy of the authorities but also the apathy of most of the population.

Belarus suffered far greater casualties and devastation than Russia during World War II. The once large and culturally influential Jewish and Polish minorities have been devastated by war, genocide, Stalinism and discriminatory policies in the later Soviet period. Eighty per cent of Belarusians are now Orthodox, like the Russians, and the 
Jews and Catholic Poles have been replaced by a large (12 per cent) Russian, mainly immigrant, population fostered by Moscow. So the population is now ethnically and religiously largely homogeneous and increasingly Russified.

Moreover, most of the country fared relatively well in the later Soviet period, receiving a disproportionate share of industrial investment. And conservative economic policies and Russian subsidies since 1990 have helped Belarus avoid some of the disruption in living standards seen elsewhere in former republics. All these factors have meant that the population is broadly pro-Russian in outlook. Indeed, some of the leading opposition candidates in the presidential elections were rumoured to be accepting support from Moscow, and they certainly explicitly favoured better relations with Russia, as well as with the West.

Discontent with Lukashenka's rule has been growing in recent years, as was evident during the last two presidential election campaigns. And, even if some Russian support is reinstated for now, Belarus is heading for a difficult period. As harder economic times set in, Lukashenka's stocks could sink further. But neither democratisation nor a colour revolution by the spirited but divided opposition seems likely any time soon.

Since the crackdown, Lukashenka has purged his leadership, appointed a new prime minister and issued a decree ordering further liberalisation of the economy, which suggests that he is looking to Chinese rather than European economic models. Furthering links with new friends like China and Venezuela will also help him to hedge against overbearing behaviour by Russia. They have the additional advantage that they won't be asking tiresome questions about human rights and democracy. 


\section{Part 4. Russia and the former Soviet republics: Putinisation at home and abroad}





\section{2}

\section{Russia and its western neighbours: A watershed moment $^{1}$}

Russia's relationships with Belarus, Ukraine and Poland are delicately poised at present, as indeed is the domestic situation within Russia itself. How these relationships and Russia's internal politics play out in the near future will go far towards determining whether Russia pursues a path towards democratic normality, or reaffirms its recent trajectory towards corrupt, anti-Western autocracy, taking Belarus and Ukraine with it.

For a few years before his deeply flawed re-election on 19 December 2010, President Alexander Lukashenka of Belarus had been flirting with the European Union in search of financial backing and a hedge against Russia. In an attempt to meet EU expectations, he had even allowed a presidential election campaign to proceed that bore some faint resemblance to the real thing. Then suddenly on election night, in response to a large opposition demonstration against the implausible result announced by the regime, his security forces unleashed a brutal crackdown, arresting hundreds, beating up many (including most opposition presidential candidates) and charging over 40 opponents with crimes against the state; some have already been sentenced,

1 First published in Inside Story, 21 Apr. 2011, insidestory.org.au/russia-and-its-westernneighbours-a-watershed-moment. 
others remain incarcerated. In this way, despite his burgeoning economic problems, Lukashenka opted to cut himself off from any further support from the West.

Belarus's economic crisis is now galloping downhill. Lukashenka continues to perform a dance of economic death to stave off devaluation, inflation and mass panic-buying, but a denouement cannot be far off. Moscow is offering Lukashenka a short-term bailout, but subject to conditions that could threaten his sovereignty. The sinister terrorist strike in Minsk during peak-hour traffic on 11 April 2011, which resulted in 13 deaths and over 200 injured, has no logical explanation; but it will give Lukashenka a further excuse to brutalise his already cowed opposition. He seems bent on attributing the attack both to them and to their putative paymasters in 'Strasbourg', by which he presumably means the European Union. Doing so will further deepen his alienation from the West but won't necessarily shore up his position against a Russia that wants to buy his strategic economic assets in exchange for keeping him afloat a while longer.

Ukraine, meanwhile, seemed to gravitate rapidly towards Moscow after Viktor Yanukovych's election as president in February 2010. But now, having quickly conceded nearly all of what Russia wanted on security, national identity, religious matters and 'historical policy', Yanukovych is digging his heels in and trying to defend his economic independence against pressure and economic inducements from Moscow. Russia is competing with the European Union for influence in Kyiv, seeking to draw Ukraine into the customs union it has created with Belarus and Kazakhstan. The European Union is offering negotiations on a free-trade agreement as a stage towards possible membership in the future. Ukraine is trailing its coat in both directions, hoping to get the economic benefits of each without having to choose between them.

Yanukovych has erected a system of autocracy strikingly similar to the system Vladimir Putin established in Russia after succeeding Boris Yeltsin as president. But he has repeatedly emphasised that economic integration with Europe, rather than the Russian-sponsored Eurasian Customs Union, remains his priority. Now Russia is raising the stakes, playing on Ukraine's economic vulnerability after the global financial crisis. (In 2009 alone, it suffered a 15 per cent slump in GDP.) On 12 April, Putin visited Kyiv seemingly at short notice. During the 
visit, he promised his Ukrainian counterpart that joining the Customs Union would entail savings of between US $\$ 6$ billion and US $\$ 9$ billion a year on Ukraine's gas bill. He also warned that not choosing the Customs Union would mean that Russia (Ukraine's main trading partner) would have to impose heavy duties on Ukrainian exports. Moscow will maintain its pressure in an attempt to drag Ukraine fully into its sphere of influence.

Poland's Western choice is probably accepted by Moscow. But it would like to strengthen bilateral ties to avoid Poland's using its growing influence in the European Union against Russian interests. The plane crash that killed President Lech Kaczyński and many other members of the Polish elite near Smolensk on 11 April 2010 seemed to greatly strengthen an incipient warming of relations between Poland and Russia. But the strongly anti-Russian main opposition party, led by the dead president's brother, Jarosław, refused to accept the rapprochement. With little evidence, Kaczyński blamed the Polish Government and Russian officialdom for the crash; he has since maintained a barrage of criticism, hinting at conspiratorial links to conceal the 'true' causes of the disaster.

Now, one year after the event, the issue of the Smolensk disaster and its real and purported links with the Katyn massacre - the subject of last year's apology by Moscow - has risen to the surface again. Just days before the Polish President was due to pay an anniversary visit to the site of the crash, Russian officials decided to remove a commemorative plaque placed there a few months ago by a Polish opposition delegation, on the grounds that the wording on the plaque was offensive to Russia. Buoyed by this fresh affront, the anti-Russian camp of Jarosław Kaczyński, has returned to the offensive with renewed vigour.

\section{Russia: De-Stalinisation?}

Russia's 'tandemocracy', which involves President Dmitry Medvedev making the pronouncements and Prime Minister Putin calling the shots, is showing serious strains. Recently Medvedev has taken to challenging his mentor, even appearing at times to dress him down. 
The most widely noticed challenge was Medvedev's rebuke to Putin on Libya. Putin had declared that any attempt by outside powers to interfere in Colonel Gaddafi's military onslaught against his own population would be illegitimate and reminiscent of the medieval crusades against Islam. Putin made this typically neo-Soviet statement, repeating arguments deployed by Gaddafi himself, in a missile factory where he was talking up the need for Russia to rapidly expand its strategic arsenal to deal with external threats. Expressing what he called a personal opinion, Putin denounced UN Security Council Resolution 1973 that provided the legal basis for the French-led intervention to create a no-fly zone in Libya, an objective that was endorsed by the Arab League.

Russia chose not to use its veto in the UN Security Council, allowing the resolution to pass with five abstentions, including China, Russia itself and Moscow's preferred EU interlocutor, Germany. Foreign policy is ostensibly the prerogative of the president, as Putin acknowledged and, within hours, Medvedev responded. He reaffirmed his view that the abstention was appropriate and reproved those who referred to 'crusades' for risking a 'clash of civilisations', which he characterised as 'unacceptable'. A spokesman for Putin then repeated publicly that the president was responsible for foreign policy matters. Even more remarkably, Putin's earlier statement, initially given wide coverage, abruptly disappeared from the media.

Putin's and Medvedev's public declarations have long diverged in spirit and, at times, their spokesmen have exchanged sharp words. But, between the tandemocrats themselves, a certain decorum has always been maintained. Typically, Medvedev makes a speech or places text on one of his websites full of liberal phrases and calls for reform and 'modernisation'. Either there is no policy response or Putin issues an oblique rebuttal. Over the three years of Medvedev's presidency, observers hoping for democratic reform have become accustomed to this choreography, and disappointment and cynicism have set in.

But, recently, the challenges from the junior tandem partner have become more overt, even strident, and the liberals are daring to hope for another thaw along the lines of Mikhail Gorbachev's or Nikita Khrushchev's. There is a feeling in certain quarters that the Putin era 
may be approaching some kind of crisis, though the strong price of oil and the still very high, though declining, public approval ratings for Putin seem to suggest otherwise.

Still, the policy skirmishes between the two camps continue thick and fast. The Medvedev camp's hopes of burying Stalinism once and for all and the Federal Security Service's (FSB - the KGB's domestic successor) proposal to ban the use of foreign-based internet services like Skype, Gmail and Hotmail are two recent examples. In both cases Medvedev's view is clear: he has been at the rhetorical forefront of the anti-Stalin drive and he uses some of the internet services in question himself. Although the presidential administration has only mildly opposed the internet plan, Medvedev is unlikely to favour major restrictions.

By and large Putin has hitherto tolerated blogging dissent. Computer attacks on foreign enemies like Estonia and Georgia have been plausibly attributed to pro-Putin Russian youth groups in the past, a use of the internet of which Putin would certainly see the value. But lately some domestic bloggers have been getting close to the bone with corruption stories aimed at Putin. There have been reports this week of extensive hacking attacks on opposition blogs, suggesting that some uses of the internet will prove to be more equal than others.

On Stalin, the proposals emanating from the Medvedev camp are essentially that Stalin should be removed from any honourable place in the public domain, that memorials to his many victims should be erected across the length and breadth of the country (there are remarkably few at present) and that officials who deny his crimes should be dismissed. The tentative steps towards de-Stalinisation were accelerated after Moscow reacknowledged during 2010 that Soviet forces were responsible for the Katyn massacres in 1940.

Stalin's standing in Russia is particularly relevant to the relationship with Poland, but it also affects relations with the Belarus and Ukrainian leaderships, both of which hold the late dictator in rather higher esteem than does Medvedev.

Another long-running and increasingly obvious difference between the two Russian leaders concerns Medvedev's campaign against official corruption. Putin has made occasional populist gestures in the same direction but, during his presidency, corruption greatly increased, and Putin himself is believed by many to be an extremely wealthy man. 
At first, Medvedev's moves against corruption seemed no more serious than Putin's. He instituted, for example, an ultimately absurd ritual of requiring all officials, including himself and the Prime Minister, to make annual income declarations. Unsurpisingly, the published results have lacked credibility.

But, recently, Medvedev has announced sharper measures aimed at creating a better investment climate and has set out a series of goals for the government to achieve by an early deadline. Most strikingly, he has demanded that senior government officials withdraw from the high-ranking positions they often have in large state-run or ostensibly private companies.

Among other things, these measures involve removing Putin's key silovik ally, Deputy Prime Minister Igor Sechin, from the position of president of Rosneft, the Russian oil giant. Rosneft was directly involved in, and benefited from, the stripping of the assets of jailed tycoon Mikhail Khodorkovsky's Yukos empire. Sechin, often seen as the de facto number two in the regime after Putin, has obediently withdrawn from his position in Rosneft. Whether this will reduce corruption or the politicisation of the most important commercial decisions of big Russian companies remains highly doubtful. But on the face of it, this was a remarkable intervention by Medvedev, especially when compared with earlier efforts that disappeared without trace.

What are we to make of this belated search for relevance by Medvedev? While most observers have long agreed that Putin was the dominant partner in the tandem, interpretations of the relationship have varied significantly. Some saw no serious political differences between the two and believed that the different shadings of emphasis that sometimes seemed to emerge were minor nuances in a wholly harmonious and functional political partnership. Others maintained that the differences were completely phoney, all part of an elaborate charade intended to deceive and manipulate observers and interlocutors, especially naïve foreigners ready to be duped by a good-cop, bad-cop routine.

Others again held that the differences were psychologically real and potentially even important politically, but that Medvedev had no hope of making his writ run on any of the disputed issues. He had always been in Putin's shadow and would remain so unless the global financial crisis or some other external shock reshaped the political chessboard. 
When the crisis failed to deliver any perceptible destabilisation or liberalisation, these observers concluded that Medvedev would never challenge his mentor.

It seems unlikely that Medvedev does expect to overcome Putin and his governing United Russia party, senior figures in which are overtly sceptical of the president's recent moves. Nor would he expect to tame the security establishment, of which Putin is the paramount leader. Medvedev has never belonged to either of these key structures in the power elite. In fact, his assertiveness of late might be the boldness of desperation. But hope springs eternal, especially in the minds of politicians, so it should not be ruled out that he really believes he can convince enough of the elite and the public to be given a second term as president.

Even if he is resigned to being nudged out of the top job, it seems clear that at a minimum, whatever the views of Putin and his camp, he wants to set out clearly where he thinks the country should head. He may calculate that if he is rejected for a second term he will at least be awarded a worthy post from which to keep his career alive while waiting for some game-changing shock. When the oil price slumps again or something else crystallises latent public discontent, he might hope to return as the man whose time has come.

\section{Belarus: Re-Stalinisation?}

While the situation in Ukraine, which has more than four times the population, is of greater strategic significance, events in Belarus have certainly been more newsworthy. Since the mass detentions after the presidential elections on 19 December 2010, there has been a steady stream of reports of new arrests, use of torture, suppression of media, denunciations of the West and threats against the opposition. Then, on 28 March 2011, the Central Bank in effect devalued the currency by 10 per cent, amid reports that Belarus was lurching towards disaster. On 19 April, the bank further loosened the exchange rate.

Lukashenka has maintained much of the old Soviet command economy and, thanks to generous Russian subsidies on oil and gas imports, till recently the system worked nicely. By avoiding reform, he also avoided some of the pain encountered elsewhere in post-communist 
economies. But Lukashenka, despite his loyalty to Soviet Russian traditions, did not wish to subordinate himself to the Kremlin. He is popular in Russia itself, especially with die-hard Stalinists and Soviet nostalgics, of whom there are many. Indeed, he has sometimes seen himself as the natural leader of Russia and Belarus. His vanity and insubordination irritate Putin, who may even feel threatened by him. And Moscow became tired of subsidising him. So, in recent years, they have been forcing him to pay something nearer to market prices for his energy imports.

Instead of adapting to his new station in life, Lukashenka essentially continued with a Soviet-style economy and sought to stave off the need for reform by obtaining loans, whilst hiking public sector wages extravagantly in preparation for the 2010 elections. The trade deficit deteriorated sharply, nearly all of it owing to trade with Russia, with foreign debt increasing by 30 per cent last year. Foreign currency reserves are naturally slumping rapidly towards zero, declining by 20 per cent in January/February 2011 to US $\$ 4$ billion, and they are under further pressure. Goods shortages and inflation have set in and Belarusians are afraid that if a large devaluation occurs their savings and assets will be dissipated. Naturally, they have sought to obtain foreign currency as a hedge, increasing the drain on reserves. Bizarrely, amidst all this, GDP is supposedly continuing to grow by over 7 per cent a year, but much of what is produced is unsaleable and simply consigned to warehouses, another traditional Soviet practice.

The economy was beginning to show the strain last year, but this year all these processes have accelerated. Economists are expecting a 40 per cent devaluation, whether acknowledged or de facto. The government meanwhile is thrashing around with ad hoc bans and prohibitions. Having slammed the door on the International Monetary Fund (IMF), Lukashenka's best chance of relief, probably his only one, is to secure the US $\$ 3$ billion in loans being offered by Russia. But Moscow, too, is insisting on conditionality. It wants to see some economic reform measures adopted in Minsk. And it also wants its own state and crony capitalists to be able to buy up some of Belarus's best and most strategic industries. Even if the US\$3 billion is forthcoming, without sharp reductions in state expenditure - and hence in wages - a hefty devaluation and other painful reforms, it won't postpone a severe crisis for long. 
In this deepening economic gloom, the mysterious terrorist attack in the double subway station in Minsk during peak-hour traffic at $6 \mathrm{pm}$ on 11 April 2011 looks like a bright ray of light for Lukashenka. The president summoned together his security forces, headed by the sentimentally named KGB, and exhorted them to seek the support of their Russian counterparts and find the culprits without delay. The KGB, in keeping with its best traditions, had cracked the case inside 36 hours. 'At 5 am this morning', reported the President proudly on 13 April, 'the crime was solved.' Having earlier hinted that the first detainee was of swarthy appearance, the authorities later corrected themselves to say that the five arrested terrorists were all Belarusians from the same provincial town. So efficient was the KGB that, within these same 36 hours, the malefactors had also confessed to two earlier bomb incidents in 2005 and 2008 in which there were no fatalities, though some 50 people were injured in each.

Those two earlier incidents had been most unusual in a country with no tradition of terrorism and, unlike Russia, no Islamist insurgency or significant Islamic minority or other well-documented violent groups. Apart from announcing comprehensive success in the investigation, Lukashenka and his security chiefs were very sparing with details. The event seems incomprehensible. There is no evidence that has been made public that adequately explains it, though it has been suggested by an anonymous source in the investigation that the main perpetrator is a psychopathic sadist. But the timing, adroit execution, and use of explosives claimed by the regime to be unique in the world all suggest a degree of planning, even professionalism, that is scarcely credible in Belarus.

Moreover, the fact that the bomb was stuffed with lethal metal shrapnel suggests a malign violence totally uncharacteristic of the opposition and indeed of any group in Belarus society, with the possible exception of Lukashenka and his security forces. He and his administration are the only people who stand in any sense to gain from the disaster. But at this stage there is little evidence to point to anyone other than the detainees, one of whom was reportedly identified on a security camera.

Lack of evidence is not, however, constraining the President from suggesting that a vast conspiracy of all his enemies is involved. He has demanded an exhaustive enquiry into 'all statements by activists and 
politicians ... Question them all, regardless of democracy and the cries and groans of their foreign sympathisers'. ${ }^{2}$ And he has darkly hinted that the domestic criminals have employers beyond the country's borders.

Almost before the noise of the explosion had abated, opposition spokesmen were gloomily predicting a fresh wave of arrests, interrogations and repression. And already there are reports of security forces zealously carrying out the president's requirement that all 'politicians' (that is, oppositionists) be called in for questioning.

Coming on top of the rorted elections and the sudden economic freefall, this latest dismaying event has reportedly shaken the population in the capital and probably further afield as well. But for Lukashenka, the bomb blast is a splendid way of changing the subject. Clearly people must now forget about petty economic tribulations or political disputes and prepare for the iron discipline that the President is promising them. Any contacts with the evildoers to the West should be eschewed forthwith. Backsliders and panic-merchants will deserve any punishment they get. In a word, the scene seems set for repression and rigid controls in all spheres of life.

Some speculative explanations turning on machinations within the Belarusian security apparatus with possible Russian involvement have been launched. The cui bono test and the location of the metro station next to the presidential compound may be consistent with theories of Belarusian KGB involvement. But though terrorists active in Russia may conceivably have passed on some of their skills and modus operandi to the perpetrators, it seems unlikely that Russian officials or agents would have been involved. Moscow now has plenty of other more conventional means at its disposal to influence events.

More liberal-minded figures in the Moscow leadership will deplore Lukashenka's resort to further repression. But most, regardless of whether or not they feel that the President is a primitive throwback to an earlier era, will feel strong satisfaction that Belarus's flirt with

2 See Michael Schwirtz, 'Belarus says suspects confessed to subway bombing', New York Times, 13 Apr. 2011, www.nytimes.com/2011/04/14/world/europe/14belarus.html?_r=0. 
the West has been decisively curtailed and that the task of bringing Lukashenka to heel as his economy sinks begins to look much more manageable.

\section{Ukraine: Leaning east, but keeping a European option open}

After coming to the presidency in February 2010 by a narrow margin, Yanukovych quickly re-established autocratic rule in a country that had seen five years of turbulent but democratic rule by the leaders of the 2004-05 Orange Revolution, ex-president Viktor Yushchenko and ex-prime minister Yulia Tymoshenko. It had, moreover, been devastated by the global financial crisis, sustaining a 15 per cent drop in GDP in 2009 alone. By dubious constitutional means and with some alleged bribery of backsliders from other parties, Yanukovych set up something similar in Ukraine to Putin's 'power vertical', centred on his own Russophone and realtively Russophile home province of Donetsk. In the year since he has further consolidated his domestic control, though as he has sought to grapple with Ukraine's continuing economic problems, his popularity has declined sharply.

His domestic regime is now widely seen as becoming progressively more undemocratic. Judicial independence has become a mockery and selective prosecutions, typically on trivial or dubious charges, have been pursued against many senior members of the former Orange governments, including, in particular, Tymoshenko. This has resulted in many cases in the accused being held in pre-trial detention; that is, jailed, for months at a time. One of the former ministers so threatened has successfully sought political asylum in the Czech Republic. Pressure has been exerted against the media, particularly non-print media, to toe the line. Television now almost exclusively depicts the doings of the government, with little coverage of other views. Freedom of assembly has also been subjected to significant restrictions.

These trends have not passed unnoticed by international monitoring agencies like Freedom House. The US State Department and the European Union have both expressed official concern and Ukraine has been warned by senior EU representatives that backsliding on democratic norms would not assist its progress towards EU integration. 
In foreign policy, Yanukovych moved quickly to restore warm relations with Russia. Moscow had felt uncomfortable about the freewheeling democracy in Orange Ukraine (many Russian journalists, for example, moved to Kyiv to ply their trade, including with hardhitting commentary on Russia). And the Kremlin hated the Orange leadership's nationalist policies, in particular its desire to join not just the European Union but also NATO as quickly as possible. This latter prospect Moscow had been particularly determined to prevent. Yanukovych was quick to oblige them by explicitly ruling out NATO membership, something none of his post-communist predecessors had done. In many other ways he soon showed himself to be a loyal Russophile ex-Soviet citizen, like much of the rest of the population in the Russified eastern and southern provinces of Ukraine.

Yanukovych promptly cancelled Yushchenko's efforts to secure international recognition of the deliberate starvation of over 3 million Ukrainians by Stalin in the 1930s as an act of genocide. He appointed an extremely Russophile Education Minister, celebrated for his public contempt for Ukrainian-speakers, who set about reversing all the Orange policies aimed at removing the Russian and Soviet bias from the educational system. He also cultivated close relations with the Moscow Patriarch Kirill, a deeply divisive figure in Orthodox Ukraine, where the Kyiv Patriarch has a larger flock than his Moscow counterpart. Kirill has made a special personal project of trying to Russify the Ukraine Orthodox Church. And there was much more of the same. Ukraine seemed to be heading rapidly back into Moscow's orbit.

After an initial flurry of economic agreements and numerous bilateral visits in both directions, however, Moscow began to push too hard on the economic front, proposing to take over many of Ukraine's most significant enterprises. In particular, in keeping with Putin's 'energy diplomacy' (using energy supplies and acquisition of neighbours' energy infrastructure to establish a potentially coercive control over their key decision-making options), they proposed that the Russian gas giant Gazprom should 'merge' with (that is, take over) its much smaller Ukrainian counterpart, Naftohaz. This would have obviated the need for any more 'gas wars' of the type that created havoc in Ukraine and many countries further west in January 2009. 
For Yanukovych and his governing Party of Regions, in which many of Ukraine's biggest oligarchs have a strong involvement, this was a step too far. The bilateral ardour suddenly cooled and, in recent months, contacts have dropped off somewhat. Relatively few new cooperative agreements have been concluded lately, though Russia has continued trying to achieve a decisive breakthrough in drawn-out negotiations on the gas sector.

In parallel with its dealings with Russia, Kyiv has also been working on negotiating an Association Agreement (AA) and, within that framework, a Deep and Comprehensive Free-Trade Agreement (DCFTA) with the European Union. The DCFTA is particularly important for Yanukovych and his oligarch supporters, as the European Union is, after Russia, Ukraine's largest trading partner. The European Union, for its own strategic reasons, is eager to encourage Ukraine's waning Western orientation and, while it has been critical of Ukraine's progressive slide away from democratic norms, it has tried to be flexible in advancing the negotiations. Moscow seems to have become aware recently that there was a serious danger the free-trade deal might materialise before the end of the year and has unleashed a threat-and-charm offensive to stave it off.

Russia has been pushing its own counterblast to the European Union, the Eurasian Customs Union, to which so far only Belarus and Kazakhstan have signed on (though Kyrgyzstan has just announced it will join the group next year). Moscow is particularly keen to inveigle Ukraine into the arrangement, partly as a way of kneecapping the DCFTA. The European Union has declared, and recently confirmed, that Ukraine could not proceed further with the free-trade agreement if it joined the Customs Union.

Ukraine has been officially cool on the Customs Union, but it still has serious economic problems and associated domestic discontent, and Moscow's short-term threats and promises are potentially persuasive to both political and business leaders. The fact that the gas-pricing formula is in itself highly contentious, and that Ukraine has been charged by Moscow more for its gas than nearly all other customers, cannot, however, be reassuring for the Ukrainians who might accept the bribe and then find that it is again confronted with an unpalatable pricing ultimatum some time in the future. 
Moreover, Moscow is vigorously pushing a project to build another bypass route for its gas exports to Europe (called South Stream, mirroring the one already well advanced in the north, known as Nord Stream). Both projects are intended to avoid Ukraine and thereby cost it valuable transit income. They will also make it possible for Moscow to cut off gas supplies to Ukraine to enforce its will on any disputed bilateral issue without in the process cutting off its customers further west. Yanukovych probably assumed that Ukraine's highly cooperative approach to Moscow should have led to the abandonment of the scheme, which was originally employed as a weapon against the Orange leadership. He has protested against South Stream repeatedly, but in vain. Some observers believe that South Stream will prove unviable, but Kyiv can't be sure of that. In the meantime, the Nord Stream/South Stream pincer movement is another weapon that Moscow can hold to its fraternal neighbour's head and is therefore probably another element in the bilateral negotiations.

Despite its coolness towards the Customs Union and its frequently reaffirmed preference for the free-trade agreement with the European Union, Ukraine's final decision cannot yet be confidently predicted. The benefits of doing a deal with Russia are short-term, whereas the European Union is promising some initial pain and only then larger mid-term benefits. Politicians in volatile domestic circumstances are always looking for short-term advantage, and so it may yet prove in this case. Moreover, the Ukrainian leadership is divided on the issue and there are some out-and-out Moscow sympathisers in their midst, as well as those, seemingly including Yanukovych, who want to keep a door open in both directions.

The Yanukovych Government's expressed preference for the EU option is not a choice of the heart. In most ways, Yanukovych feels more naturally at home with Russia. His interest in the EU is purely pragmatic. Kyiv does not relish criticism of its democratic shortcomings from Brussels and, though it does throw up propaganda smokescreens and claim to be committed to democratic norms, one suspects that despite the protestations of an intention to ultimately join the European Union, it would be happy to settle for the DCFTA and an agreement on visa-free bilateral travel, without the lectures on democracy. 
Recently the Ukrainian prosecutor-general, a self-confessed old crony of the President, initiated proceedings against the former president, Leonid Kuchma, in connection with the murder of a prominent independent journalist, Hryhorii Gongadze, whose headless body was found in a forest near Kyiv in 2000. One of Kuchma's bodyguards had secretly taped and then leaked some of the president's intimate political conversations, in one of which he appeared to be calling in colourful language for Gongadze to be somehow removed from the scene.

Yanukovych was Kuchma's anointed successor in the fraudulent presidential election of 2004, the results of which were ultimately overturned. Their relations have since frayed somewhat but, after years in which for whatever reason even the Orange leadership did not pursue the Gongadze case effectively, it was curious that Kuchma should now apparently be prosecuted at the behest of his former ally. Part of the explanation for this enigmatic development could be that Yanukovych wanted to give the lie to the widespread conviction in the West that he was practising at best selective justice against his Orange enemies. Going after, or even pretending to go after, a big fish from nearer his own side of politics, like Kuchma, might get EU critics of his democratic credentials off his back.

On balance, Yanukovych's heart says Russia and the Customs Union, while his head says the European Union and the AA. Having thus come to a fork in the road, Yanukovych might simply wish, as was once said of Bill Clinton, to take it. While reaffirming his commitment to the EU negotiations, Yanukovych has also been pitching for $3+1$ trade negotiations with the three Customs Union members: Russia, Belarus and Kazakhstan. Deputy Premier Serhiy Tyhypko, one of the relatively few committed liberal economic reformers in Yanukovych's team, has argued that the European Union's huge market would be a decisive advantage over the longer term, and that eastern countries who've joined the European Union have usually done very well economically as a result. Tigipko advocates integration with the European Union and 'friendship' with the Customs Union, which is another version of $3+1$.

This difficult choice is about much more than trade. As Oleksiy Kolomiyets, an independent Kyiv think-tanker has said: 'The Customs Union is a camp of authoritarian regimes, and our political system would follow the economic logic if we became part of it.' 
Acknowledging that Yanukovych has publicly rejected the Customs Union, he added: 'There is intense political struggle over this issue, and it's only just beginning. Ukraine's economy is very fragile and extremely vulnerable to Russian blackmail. ${ }^{\prime 3}$

Moscow remains keen to re-establish some latter-day incarnation of the Soviet Union, and the Putinist version of that would likely be much as Kolomiyets described - unless, that is, Russia again reverses course and pursues the more reformist path that Medvedev and his followers are trying to lay out. But on form to date, that looks a long shot.

\section{Poland: An uneasy rapprochement}

The sudden warming of Polish-Russian relations at governmental level that followed the Smolensk air disaster of 11 April 2010 has more or less survived the following year, though with occasional discord, mainly relating to official investigations into the causes of the accident. The Russian enquiry, which suddenly announced its findings without having previously offered them to their Polish colleagues for comment or proposed amendments, placed all the blame for the accident entirely on the Polish side. Polish officials accepted that the blame lay more on the Polish side (for which view a good deal of evidence has emerged from both the Russian and the Polish enquiries), but emphasised with some heat that there was contributory negligence on the Russian side as well and submitted a long list of objections to the Russian report. As the months went on, Warsaw also increasingly blamed Russian authorities for being slow to respond to requests for information from the Polish enquiry.

But at the level of public opinion, particularly on the Polish side, relations have been more torrid. The main Polish opposition party, the right-wing nationalist Law and Justice (LaJ), headed by Jarosław Kaczyński, has continued its campaign against the Polish Government for having allegedly been complicit in covering up malfeasance both by themselves and the Russian authorities. Over the last year, Kaczyński and his followers have fought elections and daily political

3 See Fred Weir, 'Ukraine struggles to balance lure of Europe, pull of Russia', Christian Science Monitor, 13 Apr. 2011, www.csmonitor.com/World/Europe/2011/0413/Ukraine-struggles-tobalance-lure-of-Europe-pull-of-Russia. 
battles largely on this issue, hinting darkly at alleged conspiracies by Polish and Russian authorities to somehow cause the accident, then conceal their traces.

As evidence has accumulated pointing, not surprisingly, to some typical Russian disorder at the provincial Smolensk airport on the day, and as the Russian side has increasingly sought to play down or deny any fault of its own (partly in response to the endless accusations of mass murder from some Polish press and politicians), LaJ have seized every opportunity to renew their accusations or devise fresh ones. The anniversary last week produced a fresh crescendo. In the absence of any solid evidence to substantiate the more extravagant conspiracies, senior LaJ politicians have become carefully vague in their assertions: 'President Lech Kaczyński had to die because he was a true Pole', and similar.

Without seeking the agreement of local Russian authorities, LaJ sympathisers, including some of the bereaved, had laid a memorial plaque that the Russians removed from the crash site last November. The plaque, which was only in Polish, had linked the crash to Katyn by saying that President Kaczyński and the other passengers had been on their way to commemorate the 70th anniversary of the 'Soviet genocidal war crime' committed against Polish officers in 1940. The Russians were reportedly unhappy about the word 'genocidal'. They currently acknowledge that the massacre was a crime, but maintain that Stalinism committed similar and worse crimes against people of all ethnic groups, including above all Russians, and that therefore this was not a case of genocide.

The argument is unpersuasive to a Western ear, but there is a further aspect to the case. Medvedev's campaign for de-Stalinisation has acquired some of its current momentum from the decision to restore the Yeltsin position of apologising for Katyn, a decision taken in the first instance primarily for foreign policy reasons. For Medvedev to meet President Bronisław Komorowski of Poland on the anniversary, as was planned, and lay flowers on a plaque in Polish, of unofficial Polish composition and including the words 'Soviet genocidal war crime', would be severely embarrassing for him at a delicate time in the ongoing struggle over Stalin's place in Russian history. In the event, the two sides agreed that the presidents would instead jointly 
lay wreaths under a birch tree at the site of the crash, not on the Russians' new, blander and bilingual plaque, hopefully thereby postponing the issue until a better moment.

None of this satisfied LaJ, which denounced it as yet another sign of Polish official servility towards Moscow. While the governing Civil Platform party of Premier Donald Tusk and President Komorowski has maintained a clear lead over LaJ over the last year, with LaJ sometimes looking electorally marginalised by its own anti-Russian obsessions, recent events seem to have contributed to a revival in LaJ support and a lessening in that of Civic Platform. The national elections, which are expected in October this year, could yet prove difficult for Civic Platform and, in the run-up to them, Kaczyński will not be holding back from his denunciations of the government's 'eastern policy'.

Though they overstate the case and are given to implausible conspiracy theories, there is justice in some of LaJ's reproaches. The Polish Government has, for example, concluded in the last year a long-term agreement on gas supplies from Gazprom, which seems disadvantageous to Poland, placing it in a state of high dependence on the one problematical supplier, at high cost (US\$336 per thousand cubic metres) and for a seemingly unnecessarily long period. Warsaw has been working towards creating LNG import infrastructure as a partial alternative to Russian gas. Moreover, while this was not fully apparent in the earlier stages of the negotiations, Poland is reportedly on the cusp of developing its extensive shale gas deposits. ${ }^{4}$ So the pressing need for such an expensive, long-term deal was not obvious.

The Gazprom agreement was also at odds with Warsaw's campaign within the European Union in recent years for diversification of gas imports away from Russia as a politically motivated, often expensive and unreliable supplier. Ironically, Poland was only rescued from reaching an even worse deal with Gazprom by the intervention of the EU energy commissioner, who insisted on becoming involved in the negotiations at the 11th hour to ensure that Poland complied with the European Union's new legal requirements. The so-called EU third energy package insists inter alia on competitive market access of

4 Since this article was written, evaluations of the extent and economic viability of Poland's shale gas deposits have become more pessimistic, and exploration and investment in them have declined markedly. See Andrew Kureth, 'Polish shale gas hits a dry well', Politico, 8 July 2015, www.politico.eu/article/polish-shale-gas-hits-a-dry-well/. 
other suppliers to energy infrastructure, like, in this case, Gazprom's gas pipelines to and through Poland, which the final draft of the deal had not ensured. In the last stages of the negotiations, various improvements were introduced, including scaling back the date of termination of the agreement from 2037 to 2022.

The Polish Government did its best to keep key details of the negotiations out of the public domain, but they have recently been exposed in the leading conservative newspaper Rzeczpospolita. ${ }^{5}$ The government's reticence on this matter is understandable. The deal was disputed within the government, and it is difficult to believe it would have gone ahead with it, were it not for the rapprochement it had reached with Moscow. The late President Lech Kaczyński opposed the deal and, as prime minister before 2007, Jarosław Kaczyński would hardly have negotiated one like it.

In retrospect, given the bilateral difficulties that have arisen, LaJ's criticism that Poland was not sufficiently energetic about seeking a greater direct involvement in the enquiry into the Smolensk disaster also seems persuasive, and their explanation that the Warsaw Government did not want to ruffle Russian feathers may not be far off the mark.

But, in general, the endless harping of LaJ politicians on the subject and the extreme polarisation of political life that they have thus engendered may be a double-edged sword for them electorally. Opinion polling indicates that a majority of Poles disapprove of LaJ's partisan exploitation of the tragedy. For as long as the issue remains alive, there is great potential for the Polish-Russian détente to run aground. Other bilateral disputes could well arise and there are plenty of longstanding differences between the two countries that will continue to generate tensions of their own. If, at the parliamentary elections in October, through a strong performance at the polls and adroit coalition manoeuvring, LaJ were to regain a place in government, the bilateral relationship would come under great strain.

5 See Igor Janke, ‘Igor Janke o kulisach pertraktacji z Rosja w sprawie gazu', Rzeczpospolita, 2 Apr. 2011, beta.rp.pl/artykul/636014-Igor-Janke-o-kulisach-petraktacji-z-Rosja-w-sprawiegazu.html. 
Summing up, there is some prospect of liberal and more pro-Western policies gaining greater traction in Russia, but their chances of doing so are tied closely to the weak-looking reed of Medvedev's aspirations for a second presidential term.

Belarus is heading from provincial neo-Stalinism to something much worse in the short term, after which it is likely to fall under stronger influence from Moscow. This, however, depending on how things play out in Russian politics, could conceivably be a moderating factor and might, together with Lukashenka's declining popularity and the economic meltdown, lead to a change in the Belarus leadership. But in such an event, any new leader would have to be to Moscow's taste.

Ukraine is at a crossroads, torn between its current leadership's strong preference for the ethno-political comfort zone of Russia and its recognition that its future economic health can probably be best assured if it keeps some essential links with Europe alive.

Poland is likely to see the moderate Civic Platform party returned to power later this year. This will help to maintain Poland's increased status in Europe as it undertakes its first rotational presidency of the European Union in the second half of this year. It will also shore up the fragile rapprochement with Russia, which should in turn reassure the Russian governing elite that its apologies for Katyn were not a misplaced political investment. Such an outcome would be a positive, though not decisive, factor favouring continuation of the latest de-Stalinisation tendency in Russia itself and a more constructive course in Russian external policies generally. 


\section{3}

\section{Russia's elections: Leaving little to chance ${ }^{1}$}

Russia's parliamentary and presidential elections are scheduled for 4 December this year and 4 March next year respectively. Opinion polls suggest that ordinary Russians, habituated to expecting little from elections, don't see themselves as having much say in these ones either. And the authorities have been even more assiduous than usual in seeking to ensure that voters don't have much to be excited about. The most plausible opposition party, the People's Freedom Party, was prevented from registering on a technicality, and Prime Minister Vladimir Putin has reached for an old Soviet-bloc expedient - the All-Russian National Front, into which whole organisations have been press-ganged holus-bolus - to maximise the pro-government vote.

Most interest internationally has turned on whether the relatively liberal and Western-friendly Dmitry Medvedev would again contest the presidency, or whether Putin, the senior partner in the so-called ruling duo or tandem, would return to the office he occupied between 2000 and 2008. If Putin does return, it will be for a recently constitutionally revised term of six years rather than four, with the prospect of a further six years after elections in 2018. That could mean a quarter-century of de facto Putin rule in Russia.

$1 \quad$ First published in Inside Story, 8 Sep. 2011, insidestory.org.au/russias-elections-leavinglittle-to-chance. 
Fearing this prospect, more liberal figures within the regime have pushed vigorously for a second presidential term for Medvedev. Most Western governments would also have a clear preference for Medvedev rather than Putin. And Medvedev himself would like the job. But it appears that even the decision to stand is not his to make, as Medvedev himself has more or less acknowledged. Earlier this year, following the 8 per cent decline in GDP and other severe economic symptoms of the global financial crisis in Russia, and with popular dissatisfaction rising, the Medvedev camp seemed to be issuing a serious challenge to Putin's paramount leadership. Medvedev made a series of critical statements about the existing direction of the government, and some of his prominent supporters went out on a limb to make strident demands for his re-election.

Then, in May, Medvedev called a press conference at Skolkovo Russia's would-be answer to Silicon Valley, which the computersavvy President has been promoting - where many believed he would formally declare his intentions. But the event proved to be a fizzer. There was no announcement and, apart from a couple of sly digs at Putin (including a suggestion that no one should wish to be in power for 20 years), Medvedev again assumed the respectful protégé role that has been his usual posture since he first worked with Putin in the Petersburg city administration in the 1990s.

Although Medvedev is still making it known that he wants the presidency, or at least something nice in lieu, he seems to accept that he needs Putin's support to get anything. Nearly four months on, he has still made no announcements, unilateral or otherwise. The rumour mill is again suggesting that an announcement on the presidency is imminent. But it's far from clear that the decision about who stands for the job matters all that much.

Even in May, many Russian and foreign observers had become somewhat jaded by the tandem couple's drawn-out game of hide-and-seek over the presidency. Subsequent events were to make them more so. On the same day as the Skolkovo press conference, it was announced that the leader of the Kremlin-approved A Just Russia party, Sergey Mironov, who had been increasingly stroppy and critical of the government in parliament, had been ousted. Putin has effectively eliminated all 
overtly oppositionist parties from the parliament, but the parties that are still allowed to get in, like A Just Russia, sometimes take their role more seriously than was intended.

A Just Russia seems likely to be eased out of parliament in the forthcoming elections. Mironov will be replaced as speaker of the Federation Council, the upper house of parliament, by a close Putin associate, former Petersburg governor Valentina Matviyenko, who is expected to ensure that greater decorum is observed in the chamber. For her part, Matviyenko was translated into the parliament by a series of deceptive by-election manoeuvres that were exceptional even by the standards of Putinist 'managed democracy'.

The reason for these exertions was that she had become extremely unpopular in the home town she shares with most of the Putin leadership. St Petersburg is the fourth largest city in Europe, and the Kremlin is naturally keen to secure the best possible election outcome there. To do so, it needed a more locally popular politician to head the Petersburg campaign of the governing United Russia party. Matviyenko, a reliably loyal Putinist, could be of more use in charge of the slightly restive law-makers in the Federation Council.

Simultaneously, a great many other manipulations have been in progress in preparation for the polls. These broadly conform to the pattern of 'political technology', as it's known in Russia, or 'virtual politics', to use the term coined by the distinguished British expert on the post-Soviet scene, Andrew Wilson. What these terms indicate is a determination by the authorities to ensure by any means that they get the kind of election results they want.

This is not to say that the Putin regime is deeply unpopular, or that it is unresponsive to signals of popular discontent. The authorities pay very close attention to the opinion polls and commission polls themselves. Even the more independent polls consistently show both Putin and Medvedev with the sort of ratings that would make almost any Western prime minister green with incredulous envy. (Medvedev's results, though also very good, always seem to be slightly lower as if in deference to Putin's, and lately have sagged slightly.)

Russians expect less of their politicians than most Western voters do of theirs. However, Putin, in particular, is seeking to please, with his recent macho displays, including the remarkable dive in the Black Sea 
where he miraculously happened upon two ancient and extremely valuable Greek amphoras. Following on from last year's Playmatesstyle calendar produced by student volunteers in support of Putin, a group of well-endowed young women known as Putin's Army has recently recorded videos of its activities, in which by graphic example their members call on other young women to tear off their tops for Putin. ${ }^{2}$ On a more serious note, Putin has been at pains to identify himself as the main person responsible for the expenditure of large sums on defence, security and social welfare, all of which are very popular with key constituencies.

Not to be outdone, the Medvedev camp has come up with its own group of engagingly attired young women to organise happenings aimed at boosting Medvedev's flagging fortunes. And Medvedev still makes some public statements aimed at rallying his troops. For the most part, though, his heart doesn't seem to be in it, and Putin's return to the presidency has been looking increasingly likely.

But, the line-up at the top may yet be rearranged in surprising ways. Medvedev's international popularity has become an important asset for a Russian leadership keen for the moment to cultivate good relations with the wealthier and technologically more advanced countries. Even domestically, it has been suggested that if the ruling United Russia party nominates Medvedev as their candidate for the presidency at their congress on 23-24 September, it will draw in the liberal-reform constituency in support of the party in time for the parliamentary polls in December.

So a return to the presidency by Medvedev with the true pecking order privately but clearly reinforced can't be ruled out. Nor can a Medvedev prime ministership. But power does not reside in the prime ministership as a matter of course in Russia: many prime ministers since the fall of the Soviet Union have been minor figures, now forgotten or relegated to lesser roles. It has been a dominant position recently only because Putin has been occupying it.

2 See Julia Ioffe, 'Taking it off for Putin', The New Yorker, 21 Jul. 2011, www.newyorker.com/ news/news-desk/taking-it-off-for-putin. 
Medvedev might be dropped to a dignified but much less prominent role as president of the Constitutional Court (not anywhere near as politically important as Australia's High Court) or as chief executive of Skolkovo. But wherever he ends up, he is unlikely to be numero uno or even numero due. Under Putin, the latter position has been occupied and continues to be occupied, de facto, by Igor Sechin, an ex-KGB or ex-GRU officer and old colleague of Putin's, whose formal role is as deputy prime minister responsible for energy matters. 'Energy diplomacy' - using Russia's vast energy resources to exert geopolitical pressure and influence on other countries, especially its near neighbours - is vital to Putin's overall approach to foreign and strategic policy.

In one of his assertive interventions earlier this year, Medvedev issued a decree requiring senior government ministers and officials to withdraw from leading positions in large corporations. This forced Sechin to make what was seen by many as a humiliating retreat from his concurrent position as chief executive of Russia's biggest oil corporation, Rosneft. Rosneft was formed largely from the dismembered Yukos corporation of the Russian businessman Mikhail Khodorkovsky, whose long prison term was recently extended further on the basis of unusually implausible charges. Medvedev has said publicly several times that Khodorkovsky presents no threat to the Russian state, implying that he could or should, therefore, be released. But he is still in jail. And when Rosneft and the US giant ExxonMobil recently struck what has been described as the biggest Russian energy contract with a Western company ever, it was Putin and the ostensibly rusticated Rosneft chief executive Sechin who presided, beaming, over the signing of the deal.

Among other things, the Exxon-Rosneft joint venture illustrates that Mr Putin is nothing if not pragmatic. For much of the time since his ascent to the presidency in 2000 he has displayed the strongly antiWestern instincts that his KGB past always led observers to expect. Since more overtly resuming his dominant position in the tandem this year, those anti-Western instincts have been on frequent display. Recently, for example, he referred to the United States as a parasite on the world economy. While Medvedev can also take a hard line sometimes when trying to impress the establishment with his readiness for high office (recently, for example, he called for Georgian President 
Mikheil Saakashvili to be placed before an international criminal court), in recent months he has been increasingly drowned out by his senior partner.

Regardless of whether Medvedev gets a senior role in the new disposition, Putin may well seek to maintain some of his younger protégés more Western-friendly approach to international issues. And, domestically, he has in the past tinkered with economic reform and may do so again. He has retained competent people in key economic portfolios and clearly respects their advice, despite the more liberal inclinations that some of them (Finance Minister and Deputy Prime Minister Aleksei Kudrin, for example) occasionally display. Even with a fully dominant Putin back in the presidency, Russian domestic and external policies may not shift far - not least because the Medvedev camp's efforts to tilt Russia in a more liberal direction didn't achieve very much in the first place. 


\section{4 \\ Putin's Ceauşescu moment ${ }^{1}$}

On 21 December 1989, Romania's neo-Stalinist dictator Nicolae Ceauşescu called a mass rally in Bucharest to shore up a brutal regime under pressure from galloping reform in the communist states of Eastern Europe. The unthinkable happened: the crowd herded into the city square to endure yet another tedious address suddenly morphed from cheering to jeering. Television cameras recorded the look of horror and disbelief that spread across Ceauşescu's face, as if he were glimpsing the apocalypse. And, in a personal sense, he was. In those few seconds, the latent brittleness of his tyranny was exposed. Events accelerated and, within a few days, his regime had fallen and he and his wife had been executed.

Vladimir Putin's recent experiences might be less drastic, but he must be aware of the unsettling parallels. Opinion polls have been pointing to growing discontent within the Russian population, particularly among the urban middle classes. Official media - especially television, from which 80 per cent of Russians derive most of their information - betray little of this. But the blogosphere is full of robust discussion about the regime's failings. And with over 50 million Russians now using the internet, cyberspace - of almost negligible political significance when Putin came to power - has become a serious threat to regime stability.

1 First published in Inside Story, 9 Dec. 2011, insidestory.org.au/putins-ceausescu-moment. 
While Putin's personal approval ratings have fallen markedly in recent months, they remain enviably high. Those of his governing United Russia party, on the other hand, have been declining further and faster, and more or less collapsing in some major urban centres. But Putin seemed brimming with self-confidence until quite recently, staging macho electioneering displays, offering sharp and contemptuous comments on the West's economic travails ('the little hamster' - the European Union - 'has bitten off more than it can chew'), and announcing grandiose plans for a new Eurasian Union to embrace much of the former Soviet empire.

In announcing the job-swap with Medvedev, whereby Putin would resume the presidency while magnanimously passing the prime ministership to his Petersburg protégé, the pair told voters that the two of them had agreed on this manoeuvre several years before to enable Putin to return to the top job. This patrimonial approach to the highest, ostensibly elective, offices in the land showed a self-confidence about the public's compliance bordering on the solipsistic.

Many observers believe that this 'castling' (rokirovka) manoeuvre by the pair, and the manner in which it was announced, were important factors in exhausting the patience of the long-suffering Russian public. And there were other surprising lapses in judgement by Putin - for example, when he told members of a group of partly Western interlocutors what a great leader his old friend Silvio Berlusconi had been, describing him as one of the last of the Mohicans of European politics. Coming on 11 November, this was not the most opportune moment for Putin to be referring to his and Berlusconi's high mutual regard.

Pride goeth before a fall. Just 10 days later, Putin had his Ceauşescu moment. At a martial arts contest between a Russian champion in indifferent form and an American opponent, who some said had been carefully chosen to give the Russian a certain victory and the Premier another suitably macho electoral photo opportunity, Putin entered the ring to congratulate the burly Russian on his victory. When he began to speak, booing and jeering broke out in the crowd. Putin managed to complete his remarks and beat an orderly retreat, but the damage had been done. His aura of invincibility had suddenly been pierced, like Ceauşescu's nearly 22 years before. The Kremlin went into damage control, seeking to argue that the crowd had been booing the 
American for putting up a poor fight. But few believed it, and many of the fans present went to the trouble of posting their real views on the subject online, including on the American's own website, where they assured him of their utmost respect.

The warning signals were evident earlier in the campaign when attempts by the ruling party to tie United Russia's campaign to the public appearances of popular Russian celebrities had ended in public irritation and heckling. But, for Putin himself to suffer such a public indignity was unprecedented. He was clearly shaken, and though he is typically now a confident public performer, he began avoiding potentially hazardous public appearances in the run-up to the elections for the Duma (parliament) last weekend.

Under Putin, the Kremlin has closely followed and itself commissions public opinion surveys. The regime's nervousness about the elections was palpable. Despite the steeply tilted playing field and the strenuous exercise of what is known euphemistically as 'the administrative resource' (including ballot-stuffing, intimidation and bribery of voters, and requiring key officials, employers, university rectors and so on to reach a required target vote for the ruling party in their bailiwicks), the results appear to have been worse than the regime feared. Putin's brief public appearance to claim victory at party headquarters displayed none of his usual panache.

United Russia had not only lost its two-thirds constitutional majority, it was also struggling to reach a simple majority of votes cast. Exit polling suggested a vote for the party of somewhere between 46 and 48 per cent. Some observers guestimated that the real figure may have been well below that. In Moscow, St Petersburg and some other big cities, United Russia was running in the low 30s, or lower, according to exit polling, though official results were sometimes massaged upwards.

By various means, Putin has effectively excluded most serious opposition parties from participating in Russian elections or the public media. In their absence, the three tame parties that are tolerated in parliament (the Communist Party, the grotesquely misnamed Liberal Democratic Party of the chauvinist buffoon Vladimir Zhirinovsky, and the left-leaning A Just Russia party, which the regime had been hoping to oust) all did very much better than before. They had campaigned 
with more vigour than usual, and benefited from the fact that many 'illegal' oppositionists had called on their followers to vote for any party other than the ruling party.

The Central Electoral Commission, headed by the faithful functionary Vladimir Churov, has indicated that United Russia's vote will be sufficient to give them 238 seats, a narrow absolute majority in the 450-seat Duma. This result probably owed something to outright manipulation in the commission and elsewhere. In the indigenised tyranny that is Chechnya, for example, there was reportedly a truly Soviet turnout of over 99 per cent (compared with 60 per cent nationwide), of whom we are told 99 per cent voted for United Russia. Indeed, the party was heavily dependent on Russia's Caucasian regions, many of which are experiencing an ongoing armed insurgency, to reach its bare majority of seats.

Despite periodic rhetorical flourishes, the tolerated parties haven't represented a major threat to United Russia's dominance of the Duma. Notwithstanding their sharply increased numbers, the situation is probably still manageable for the regime, barring any further increase in turbulence. Nonetheless, the spate of unusually large demonstrations in Moscow and St Petersburg in recent days suggests further troubles may lie ahead in the run-up to presidential elections on 4 March. What was expected to be a shoo-in may prove unpleasantly exciting for the anointed candidate, though in the end it's hard to see him not winning.

In the meantime, Putin will probably work on shoring up support from the other three parties by offering them perks and sinecures, and maybe even some minor and safe portfolios. Despite its recent feud with the regime, A Just Russia has already indicated it would be prepared to cooperate in the new parliament. Zhirinovsky and his chauvinist mates have been under Kremlin control since their first emergence on the scene in the early years of Boris Yeltsin's reign, and will surely continue to support the government. Even the communists shouldn't find it hard to sign on to more state largesse for various underprivileged groups, a big military buildup and stoking tensions with the West.

Until now Putin has had a dream run. Plucked from a modest eminence in the Petersburg city apparatus to serve in Yeltsin's administration in Moscow in March 1997, he made a giddy ascent. Starting as deputy 
chief of staff to Yeltsin, in less than three years he progressed through ever more senior posts to become successively head of the Federal Security Service (FSB - the domestic successor to the KGB), secretary of the Security Council, deputy prime minister, prime minister, acting president and finally the elected president of Russia. Yeltsin had decided that this young man - Putin was not yet 50 - could best guarantee his legacy and his family's vital interests.

That was just the beginning of his good fortune. Despite enjoying only modest public recognition, he quickly converted his standing as president into genuine popularity. This was based, above all, on three factors: unlike his predecessor he was young, healthy, sober and intelligently articulate; he had relaunched the war against the armed Chechen rebels and done so with apparent success; and, most importantly, the price of oil and gas had soared following a lengthy slump under Yeltsin. After the hardships of Russia's feel-as-you-go transition from a command economy with a huge ballast of imperial defence expenditure to a market economy via a corrupt privatisation process, GDP stabilised from its steep decline in the 1990s and then took off through the early to mid-noughties.

Putin reaped the political benefits of this turnaround. As he set about rolling back the political freedoms of the Yeltsin era, the Russian public seemed to be happy to accept a bit of traditional Russian autocracy as long as their pay kept increasing and arriving on time. Nor were they averse to the strongly anti-Western edge to Putin's foreign policy. Like him, they had been reared to hate the West, and the tribulations of market democracy had inoculated them against the pro-Western euphoria that had briefly swept over the Russian political elite and the population at large in the Gorbachev and early Yeltsin years.

Then came the global financial crisis. At first, Putin seemed convinced that this downturn for his Western adversaries must be good for Russia, which, he confidently expected, would sail through the turbulence with all flags flying. But in 2009 the Russian economy shrank by 8 per cent. The painful downturn must have dented Putin's reputation as an economic manager. While his stellar approval ratings stood up pretty well at first, they later began to decline, and surprisingly continued to do so even as the economy partly recovered. That trend 
has accelerated in 2011. While overall economic performance has been solid, opinion polling this year has consistently pointed to progressive erosion of Putin's, Medvedev's and the ruling party's standing.

What we can expect next from a chastened Putin is probably a little bit of carrot and rather more knout. On the carrot side, there have already been big concessions on salaries and social security expenditures, but we may now see more such budgetary largesse. With former finance minister and close Putin ally from the Petersburg years Aleksei Kudrin disciplined for having questioned the proposed ballooning of military expenses, there will be less effective resistance to any such dubious fiscal measures. Thanks to Kudrin's legacy, Putin has a better starting point from which to commit fiscal vandalism than most European leaders.

The big buildup in military expenditure is a carrot that will please the military and nationalist lobbies, both of which are large and powerful. Unlike the security organs, the military have not had an easy time of it under Putin, who has sanctioned a long-running effort to move the military establishment from its traditional reliance on a large conscript army towards something smaller and more high-tech. Expenditure on personnel has been pared back to make funds available for more sophisticated weaponry; the oversized officer corps has been thinned out. All of this has been painful for the military and resisted by many senior officers. Compensatory salary hikes for the military were already on the table.

But Putin may decide to conciliate it further with a change of leadership in the defence portfolio, as well as intensified anti-Western themes in his foreign and security policies. A winding back of the 'reset' with the United States, further shrill criticism of NATO, support for Iran, Syria's Bashar al-Assad, Kosovo Serbs and so on, and more anger and indignation about the proposed missile defence installations in Eastern Europe could all be on the agenda. There have been rumours in the Russian press that the intensely abrasive Russian ambassador to NATO, Dmitry Rogozin, who has been in Moscow recently for discussions on military matters, could be appointed defence minister.

Articulate and combative in several European languages, and reportedly the son-in-law of a KGB general, Rogozin's appointment would be a fairly robust signal in itself to Washington and Brussels. 
If he stayed in the job, it is likely he would deliver further robust signals at regular intervals. None of this would necessarily diminish his popularity with much of the Russian public, who liked the cut of his jib when he headed an earlier Kremlin-backed party called Rodina (Motherland), which the Kremlin dismantled because its strident nationalism was becoming too electorally competitive.

Still on the carrot side, we can expect some conspicuous and condign punishment for unpopular officials. Medvedev, who is actually still president despite recent appearances, has already called for a reckoning with provincial governors who failed to deliver sufficient votes for the ruling party in their domains. Despite his liberal leanings, Medvedev has a much more off-with-their-heads style with allegedly erring subordinates than Putin, and we can expect to see it in action. Putin prefers to dress down his senior colleagues on prime-time television without necessarily replacing them, and we can expect some of that as well when he recovers his balance. To what extent that will placate the public remains to be tested.

The Kremlin's political manipulator-in-chief, Vladislav Surkov, has been speaking since the elections of the need to create a right-wing opposition party to broaden the Putinist system's bizarrely skewed political spectrum. Surkov was working on such a party some months back, using a once semi-authentic right-wing party called Right Cause as the building block. But the Kremlin-designated leader of the revived party, oligarch Mikhail Prokhorov, threw himself into the project with too much enthusiasm, leading Surkov, doubtless in consultation with Putin, to organise a coup against him.

Prokhorov then resigned with a clatter, publicly denouncing the 'puppet-master', Surkov. None of this conformed to the script and was itself a sign of a new current of unpredictability beneath the glossy surface of Putin's 'managed' or 'sovereign' democracy. Whether Surkov will have any more success with his new project than he had with the earlier one remains to be seen, but similar activity to provide the appearance of more democracy can be expected.

There have been signs that Putin will try to adjust his own image for something more modern and consultative. After 12 or more years in the public eye, though, he has a rather fixed persona. He may find it easier to project a new image through prominent appointees who 
have greater reformist credibility. He may, for instance, set up a new body to tackle corruption with a relative cleanskin at the head of it. The Public Chamber, an advisory body attached to the parliament, may be called on to look at pre-trial detention and other such issues. In extremis, he may even order a review of Mikhail Khodorkovsky's case, despite his consuming hatred for the imprisoned businessman. But public scepticism won't easily be overcome.

Putin and his inner circle will also place a very high priority on bringing an unruly public back into line. The Moscow and Petersburg demonstrations against the election results have made visible a massive police presence in the two capitals and led to over 1,000 arrests. Among those arrested and sentenced to 15 days' detention was the extremely popular anti-corruption campaigner, Aleksey Navalny. A lawyer by trade and a highly skilled blogger by avocation, Navalny's website and other cyber pronouncements have built his following. In particular, his coining of the now universally quoted phrase 'the party of crooks and thieves' did more to bring about the downturn in United Russia's fortunes than almost any other single factor.

Navalny has launched an increasingly forceful challenge to Putin in the blogosphere, and Putin has probably decided he needs to meet it head on. People like Navalny have sometimes been killed or maimed in the past by 'unknown assailants'. But he is something of a nationalist, which together with his fame and popularity makes him harder to deal with than most traditional opposition figures. Before Alexandr Solzhenitsyn was driven into exile in 1974, he told a Western interviewer that, despite death threats he felt safe: not a hair would fall from his head or the heads of any of his family without the consent of the KGB, he said, because they knew they would be blamed for it. On that logic, the Kremlin may wish to avoid making a martyr of Navalny, but they will increase their pressure on him.

More generally, harassment and punishment for obdurate opposition figures is likely to increase, quite possibly in parallel with calls for a new spirit of dialogue and discussion in the public sphere. Putin controls the security organs and has made their senior workforce, the siloviki (securocrats), central to the functioning of the state, the economy and society. $\mathrm{He}$ is unlikely to come under pressure from that quarter. Insofar as the organs have - as they surely must - heightened professional concerns about stability, which is one of Putin's most 
cherished political values (and one he reaffirmed in his very brief victory remarks on election night), he can easily make gestures in their direction, and indeed may now be eager to do so.

In July this year, the FSB called for the introduction of restrictions on the internet to counteract 'terrorism'. Medvedev - who has made a thing of advancing computerisation of Russian society, is personally cyber-adept, and uses social media to broadcast his views and policies - quickly let it be known that he opposed this initiative. Putin who by contrast is cyber-challenged, offered no immediate public reaction, but in early September was reported as declaring publicly that in 'modern states' internet access should not be restricted.

That affirmation should not be taken too seriously. Hacking and denial-of-service attacks in or from Russia, which have looked very likely to be officially inspired, have been occurring for years. During the acrimonious dispute between Russia and Estonia in 2007, the tiny Baltic nation's highly sophisticated and extensive national internet systems were the subject of coordinated attacks sourced from Russia, which were widely believed to have been sanctioned by the Kremlin.

There have been intermittent attacks against websites in Russia in recent years, though never massive or sustained. But before, during and after last weekend's parliamentary elections, hackers temporarily crippled a large number of oppositionist websites, and even legally sanctioned media outlets that were deemed too independent. In particular, attacks were launched against an NGO called GOLOS ('voice' or 'vote' in Russian), which, like Navalny, had particularly infuriated the Kremlin in the months leading up to the elections. GOLOS maintains an interactive site known as Karta Narushenii (Map of Violations), on which were recorded all reports they have received of 'the administrative resource' being deployed to skew the elections in United Russia's favour.

Putin has expressed particular hostility towards GOLOS because he has been trying to limit or even squeeze out independent international election monitors, and GOLOS, though a Russian volunteer monitoring organisation, has received funding from Western sources. He has referred recently to GOLOS volunteers as 'Judases', and further action against them seems likely. Putin's regime has long been deeply anxious about the possibility of a coloured revolution, like those that took 
place in Georgia and Ukraine. Until now any such popular uprising in Russia has seemed highly unlikely, and probably for the time being remains so. But where there is fear within a regime like this one, oppressive measures may not be far away.

In present circumstances, the Kremlin may decide that its hacking resources are not a sufficient defence against the burgeoning menace from the blogosphere. If so, they may look again at the successful measures their strategic partner China has applied to filter and control the internet. Any such policy initiative by their former boss would of course be warmly welcomed and enthusiastically applied by the FSB, who have been pressing for just such a crackdown.

While he feels some distaste for the provincial enthusiasms of the Belarus dictator Alexander Lukashenka, Putin may even look more closely at how Lukashenka has succeeded in crushing major unrest in his country, despite an unfolding economic disaster that has reduced Belarusians' real incomes by more than half. Any president who can keep that kind of situation in check must be well worth bailing out which is precisely what Putin has recently done for Lukashenka.

In considering his next steps, Putin needs to decide what to do with Medvedev. When they swapped jobs, the younger man was also given the task of heading the United Russia election campaign, a curious assignment, constitutionally speaking, for a president and, moreover, one who wasn't even a member of the party. It seemed at the time that Putin was thereby flicking his tandem partner a hospital pass. United Russia's ratings were known to be floundering. Now that Medvedev has predictably failed to revive them, he could be punished for having sought for a few months in early 2011 to assert himself against the paramount leader. Putin might even have been thinking of reneging on his promise to appoint Medvedev as prime minister when he resumes the presidency.

If so, he may now be reconsidering. His own position has been weakened, and any attempt to scapegoat Medvedev might lead to more trouble. In a sense, the events of the last few days in Petersburg and Moscow are fuelled by a loss of illusions among those who had dared to hope for improvements during a second Medvedev term. Better perhaps to appoint him as prime minister, allow him to resume enunciating his more liberal opinions and, perhaps, even to make 
a few liberal ministerial appointments and actually to do a few things. The problem with trying to deploy Medvedev as a carrot is that Medvedev, in meekly agreeing to vacate the presidency for Putin without visible resistance, has lost most of the credibility he had gained by his liberal pronouncements, perhaps irretrievably. Either way, what happens to Medvedev should be a sign of things to come.

Despite the recent turbulence, in the short to medium term any further major increase in levels of unrest seems unlikely. So, net emigration outflows, disproportionately of the best and brightest, look set to continue, though that will not be as a matter of deliberate policy choice aimed at ensuring 'stability'. The presidential elections on 4 March will be a worrying time for the regime, but candidate Putin has not allowed serious rivals to present themselves, and any who were to emerge at this late stage would be expediently dealt with. But if he manages to restore calm by whatever combination of knout and carrot, and thereafter chooses not to make any serious concessions to growing opposition sentiment, tensions could rapidly surge again.

Since the Bolshevik revolution, Moscow has most typically dealt with unrest or opposition by severe repression and emigration. In the last decade, 1.25 million people have left Russia, many of them young and highly qualified. Opinion polls suggest that some 20 per cent of Russians would currently like to emigrate despite the economic improvements of the Putin era. Putin worries about Russia's grim demographic situation, and is unlikely to welcome a major outflow. But he also wants a deal on mutual visa-free travel with the European Union, and reintroduction of Soviet-style border controls seems unlikely.

In the longer run, that leaves comprehensive democratic reform or repression as the central policy dilemma for Putin 2.0. Putin's instincts are undoubtedly hardline; and they will have been reinforced by his recent humiliations. Up until now his autocracy has been based more on manipulation and delivery of tangible benefits than brute force. But his violent crackdown in Chechnya and surrounding regions, and the stark language he has often used in public about domestic adversaries suggest that, in the interests of domestic stability and Russia's return to great power status, if thwarted and defied, he may see harsher measures as necessary. If he does, the Arab Spring scenarios that some domestic critics have foreseen may indeed start to come into view. 
A DIFFICULT NEIGHBOURHOOD

After a decade of Putin's increasingly predictable restorationism, Russia has entered another period of flux and uncertainty. If the hamster's struggles with the euro crisis prove unsuccessful, we may see another sharp economic downturn in the West. Putin's impulse will first be to rejoice. But another 2009 will be the last thing he needs. 


\section{5}

\section{Setbacks at home, successes abroad: The mixed fortunes of Vladimir Putin ${ }^{1}$}

Vladimir Putin will be viewing his date with the Russian voters on 4 March 2012 with some apprehension. The presidency seemed his for the taking, and it still seems most unlikely that anyone will be allowed to defeat him. But what should have been another victory lap before a grateful public is starting to look more like an ordeal, in which he is on a hiding to nothing. The first-round victory that he took for granted may slip beyond his reach unless Vladimir Churov, the 'magician' (Dmitry Medvedev's term) of the Central Electoral Commission, can pull off another miracle. Opinion polls are suggesting that Putin's percentage of the votes in the first round will be only in the 40s. The veteran Communist boss Gennadi Zyuganov, who is again standing for the presidency, may well pick up some of the anti-Putin protest vote, making him a likely second-round opponent. A run-off against Zyuganov more than 20 years after the fall of communism could prove uncomfortable from various points of view.

But the candidates of the officially tolerated 'establishment' parties, which have the resources (and the privileged access to the media) to run a presidential campaign, are unlikely to go all out against Putin.

1 First published in Inside Story, 22 Dec. 2011, insidestory.org.au/setbacks-at-home-successesabroad-the-mixed-fortunes-of-vladimir-putin. 
The billionaire Mikhail Prokhorov is offering himself ostensibly as a non-establishment candidate, but many have their doubts about how genuine an oppositionist he is. The A Just Russia party has put forward its leader, Sergey Mironov, who has made conciliatory noises to the Kremlin since the ruling United Russia's reverse at the parliamentary polls on 4 December. Many in and outside the party would have preferred to see the much more popular Oksana Dmitriyeva from A Just Russia's Petersburg machine stand for the top job.

The growing numbers of voters who are sceptical about Putin do not have an obvious alternative in view. For its part, the Kremlin will do whatever is necessary to keep potentially dangerous wild cards, like the charismatic anti-corruption blogger Aleksey Navalny, out of the contest. One way or another, Putin should get over the line in the second round, even if Churov is unable to award him victory in the first.

After he was publicly booed at a martial arts event on 21 November, Putin postponed his annual televised Q\&A session until after the elections. When it was finally held on 15 December, he appeared less assured than usual. He was certainly very angry, however, especially with Hillary Clinton for her criticism of the conduct of the elections. While he made a show of accepting that the protesters on the streets of Moscow and St Petersburg were moved by honest democratic emotion, he also asserted that many of them were working for or inspired by Western governments, and made his usual suggestion that such people were traitors.

Putin expressed particular passion, and compassion, about the tragic fate of Libyan leader Colonel Gaddafi, for whose death he blamed US drones. And he returned to his obsession about 'colour revolutions' (like the Orange Revolution in Ukraine) instigated by sinister forces abroad. In other words, he seems unable to accept that many of his constituents might simply be getting sick of him. None of this bodes well for a peaceful resolution of the situation if the unrest and dissatisfaction with Putin's re-election plans persist.

Since the severe crackdown on the first post-election demonstrations, the regime has pursued a more moderate approach. It avoided repressive measures against a big Moscow protest on 10 December, and permitted some more honest media reporting. But there is no sign of any serious 
move towards reconciliation or reform. It appears, rather, that the regime simply wants to avoid provoking public opinion while it waits for the protest momentum to subside.

On 20 December a website owned by one of Putin's extremely wealthy friends published transcripts of one of the leading opposition figures, Boris Nemtsov, making derogatory remarks about a fellow oppositionist in a private phone call obviously tapped by the security organs. Nemtsov apologised, his apology was accepted and the two made an amicable joint appearance. While the opposition is notoriously divided, this incident was hardly helpful, although the restive urban intelligentsia may not be impressed by the regime's nakedly dirty tactics.

If the opposition cannot get substantial numbers out on the street at the next big demonstration on 24 December, however, the regime will start to breathe more easily. For the moment they are comparing the demonstrators with the international Occupy movements, which may prefigure the kind of endgame they are planning.

On 22 December, Medvedev unveiled a package of electoral reforms, which included easing the criteria for forming a new party and restored elections for the position of regional governor. This looks very much like dangling a few carrots to weaken the protesters' resolve, especially as the reforms are not to take effect until after the presidential election on 4 March and Putin has said that candidates for the governors' positions will still need to be approved by the President (that is, him). And, above all, these proposals come not just from a lame-duck president, but from one who has repeatedly called for reforms that have never eventuated. Medvedev's undertakings have lost all credibility since he declared publicly that he had only served as a placeholder while Putin took leave from the job. Medvedev also said that there must be no threats to stability - that troublemakers and 'extremists' would not be tolerated, particularly those who have foreign connections. The intention is transparent, but if it gets a few people off the streets then it will have served its purpose.

In the two months between his 23 September announcement of his intention to resume the presidency and the booing incident on 21 November, Putin had seemed full of self-confidence and eager to pursue his key foreign-policy objectives, notably restoring strong 
Russian influence over the former Soviet republics. His trademark truculence towards the West, perceptibly distinct from Medvedev's more emollient approach, was again in evidence. He took great pleasure in making allusions to the West's economic difficulties, particularly the euro crisis. And recently he has been able to chalk up quite a few successes.

Putin has always deeply regretted the collapse of the Soviet Union and said so again in his Q\&A session. He has always tried to do whatever he can to create and advance multilateral structures that bring as many as possible of the former republics together under Moscow's leadership. His 'energy diplomacy' involves manipulating the supply and pricing of Russia's abundant oil and gas exports to favour the cooperative and punish the others. Similar trade practices involving commodities like wine, and even mineral water, exploiting sometimes imperial monopsony rather than monopoly, have been routinely deployed against recalcitrants like Georgia and Moldova. Nor have these tactics been confined to the former republics or non-European Union members. Poland and the Baltic states, for example, have often been on the receiving end.

Fearing, with good reason, that Moscow's leadership will mean domination, some former vassals have sought safety in the European Union, where possible, or have at least avoided joining the various trading or security acronyms that Russia has established. In consequence, progress for Moscow has been slow. But now, with the European Union less able to attract and less willing to accept new members, and with Washington under President Obama pursuing more pressing priorities elsewhere, Moscow's opportunities have expanded.

The most recent of the multilateral bodies that Moscow is pressing on its neighbours are the Eurasian Customs Union and the newly minted Eurasian Union, a concept Putin elaborated soon after announcing his intention of resuming the presidency. Very roughly, he envisages the Eurasian Union as a kind of European Union to the Customs Union's Common Market. In addition to former republics of the Soviet Union, Moscow has spoken about the desirability of attracting countries that are traditionally sympathetic to Russia and its culture; for example, Venezuela and Cuba, Serbia and Montenegro, and even Finland and Hungary. 
Putin is also declaring that the Eurasian Union, as the final step in the process, would seek collegial relations, trade agreements and so on with China on the one hand and the European Union on the other. Moscow clearly expects that Russia will dominate its union far more than Germany, for instance, dominates the European Union. And it will undoubtedly continue the policy, extending back to Soviet times, of seeking to divide EU members the better to influence them and weaken transatlantic ties. Presumably, too, Putin would wish to establish international arrangements that would preclude any contact between these supposedly friendly blocs in the new multi-polar world that might lead to greater electoral transparency or more coloured revolutions.

To date, Belarus and Kazakhstan have signed up to the Customs Union and Kyrgyzstan and Tajikistan have expressed interest. Moscow is working on other republics to join, but is focusing particularly on Ukraine, potentially the jewel in the crown. The biggest country in Europe (if European Russia and France's overseas territories are excluded), it has large Russian, Russian-speaking and Russophile communities, and is seen by most Russians as the historic core of Russia and quite simply 'ours'. Together with the largely Russianspeaking Belarus, and Kazakhstan, which is the most Russified of the 'Stans', this would give Russia a kind of Slavonic Union, the dream of many Russian nationalists, and a unit with well over 200 million inhabitants, and most of the resources and industrial capacity of the old Soviet Union.

But even the Yanukovych administration, the most pro-Russian in Kyiv in the post-Soviet era, has been reluctant to join the Customs Union, preferring instead to continue its predecessors' quest for an Association Agreement (AA) with the European Union, which would incorporate a comprehensive free-trade agreement. Negotiations for such an agreement were finalised in the last days before the UkraineEU summit in Kyiv on 19 December. Some months ago it seemed likely that the AA would be initialled at the December summit and possibly come into force in 2012. The European Union was keen for this to happen, though some lingering scepticism remained about Ukraine's suitability. But it was not to be, at least not yet, and not perhaps for quite some time to come. 
Yanukovych has long been under fire for eroding the democratic gains of the Orange Revolution of 2004. But what comprehensively undermined his standing with the European Union was his decision to launch a criminal prosecution against Yulia Tymoshenko, the Orange leader and ex-prime minister, whom he narrowly beat for the presidency in 2010. Tymoshenko was charged with exceeding her powers as prime minister in concluding an allegedly unfavourable deal on gas prices with Moscow in early 2009, a deal meant to end a punishing 'gas war' that was threatening to freeze much of Western Europe. On 11 October, she was sentenced to seven years' jail, disqualified from public life for a further three years beyond that, and ordered to 'repay' US\$186,000,000. Innumerable representations were made to Yanukovych by senior EU figures making clear that this decision could block his EU aspirations. Kyiv's response was to prepare a further nine (sic) criminal cases against Tymoshenko and to subject her to various other chicaneries.

The Tymoshenko/gas deal saga is part of a complex story. Much has been made of the argument that Kyiv was convicting Tymoshenko to show Moscow that the current gas deal was 'illegal' and should therefore be renegotiated. Some were impressed by an alleged Putin preference for Tymoshenko over Yanukovych as an opposite number, despite her strong Western sympathies. Others have claimed that the poor president is powerless in the face of an overwhelmingly strong pro-Moscow lobby in his ruling Party of Regions. Much of that seems increasingly implausible as the persecution of Tymoshenko continues.

Concurrently with its EU bid, Ukraine has been pursuing sometimes acrimonious negotiations with the Russian gas giant Gazprom (essentially an instrument of Kremlin policy), seeking lower prices for its vital gas imports. The current prices for Ukraine are higher than for most Western European customers, some of whom have succeeded in getting price concessions from Gazprom in recent months.

It does seem, however, that Yanukovych was not using the EU bid simply as a bargaining chip in his negotiations with Moscow. Ukraine's trade with Russia and the European Union is roughly equal, and a majority of Ukrainians and many heavyweight local oligarchs now want EU integration. But his pursuit of Tymoshenko in the face of all the warnings does make one wonder how serious Yanukovych's commitment really is. To compound matters, in the last weeks 
before the summit he began to demand that the AA provide a clear 'perspective' of EU membership down the track. Had it not been for the Tymoshenko case and some others like it, this might conceivably have been doable. As things stood, it was just the kind of negotiating gambit to raise EU hackles even higher. In the end, a drafting fudge was devised to get past that problem. But while the agreement was ready, it was not even initialled at the summit, though another fudge was deployed to hold out the prospect of that happening in the early months of 2012.

And so the long-running story of Ukraine's two-faced relations with Russia and the European Union remains open. But the balance has swung markedly towards Moscow. There have been hints lately that a deal on gas prices is imminent. Some expect this will be paid for by the surrender of more sovereignty by Kyiv, perhaps in the form of conceding Gazprom a controlling interest in Ukraine's gas pipelines, which is a key objective of Putin's energy diplomacy. Russia is also eager to take over Ukraine's struggling and much smaller Gazprom equivalent, Naftohaz. But despite both inducements and threats from Moscow, whatever else he concedes, Yanukovych is likely to continue holding out against joining the Customs Union, aware that joining would preclude integration with Europe.

Ukraine's northern neighbour, Belarus, provides some oblique insights into Yanukovych's dilemma. Since the brutal crackdown in December 2010 on the large demonstrations in Minsk against falsified election results, Belarus has experienced spectacular economic decline, thanks partly to irresponsible election promises by the incumbent, with average purchasing power declining by about 50 per cent. President Alexander Lukashenka has responded to the resulting discontent by thoroughgoing neo-Stalinist repression, proscribing even 'silent protests' by tiny groups of people. This has worked well for him, and his loyal security organs, headed by the local KGB, ensured that only small numbers of people turned out on the first anniversary of the crackdown, 19 December, to renew the protest.

But Lukashenka has decided that his own stalwart defence of Belarusian sovereignty (which translates essentially into defence of his own power and importance) should not be taken to pedantic extremes. The European Union had offered him generous inducements to repent, but they also demanded some democracy and human rights in return, 
which Lukashenka decided he would prefer to do without. Having failed also to win unconditional sympathy from the International Monetary Fund (IMF), which had demanded the quid pro quo of serious economic reforms, he decided to throw in his lot with Moscow. As a reward he was given a very generous package consisting of loans and a much reduced gas price of US $\$ 165$ per thousand cubic metres, a long way below market rates. This deal by one estimate is worth in total more than US\$14 billion. ${ }^{2}$ In exchange, Lukashenka sold off to Gazprom the rest of Belarus's gas pipelines, hitherto rightly regarded as a vital strategic asset, and became much more cooperative and respectful towards Moscow on other issues.

This reward was also intended as bait for Ukraine, which, even with its discount granted for extending Russia's lease of Crimean naval facilities, is currently paying US $\$ 400$ per thousand cubic metres for gas, with the prospect of further hikes ahead. By that reckoning, membership in the Customs Union must look much more attractive to the leadership in wintry Kyiv.

Moscow's pacts hold other attractions for distressed autocrats. At its August summit this year, the Collective Security Treaty Organization (of which Ukraine is not a member) discussed proposals to use the organisation to strengthen the defences of all member states against colour revolutions or any spillover of the Arab Spring. Lukashenka seemed particularly interested in this idea, which he and others saw as an invaluable security guarantee for any member leader under domestic threat.

Another leader who was reportedly keenly interested in this issue was President Nursultan Nazarbayev of Kazakhstan, immediate past chairman of the Organization for Security and Co-operation in Europe. In power for over 20 years, Nazarbayev has in recent days put down a workers' uprising in a town in the west of his country by armed force and a total blockade of telecommunications in the region. Initial reports spoke of at least 10 fatalities, but the information blackout has effectively reduced the flow of reliable news. How far the ideas under consideration in the Collective Security Treaty Organization will go

2 See Andrew E. Kramer, 'Gas deal with Belarus gives control of pipeline to Russia', New York Times, 25 Nov. 2011, www.nytimes.com/2011/11/26/world/europe/in-deal-with-belarus-russiagets-control-of-yamal-europe-pipeline.html?_r=0. 
towards becoming a new Brezhnev doctrine remains to be seen. ${ }^{3}$ If so, it could be very attractive to some potential new members as well as veterans like Lukashenka and Nazarbayev.

Moscow has had some successes on other fronts. In Kyrgyzstan, for example, a strongly pro-Russian President, Almazbek Atambayev, came to power last October. One of his first public statements was to foreshadow that he would terminate US access to the Manas air base, a vital supply link with Afghanistan, when the lease runs out in 2014. Observers take differing views about how serious a threat this is. But should Moscow ever wish to apply pressure to their 'reset' partners in Washington, having such a president as a warm and cooperative Eurasian Union colleague in Bishkek would clearly be advantageous. Atambayev's predecessors were much less accommodating towards Moscow in that respect.

Putin's energy diplomacy received a big public boost with the 8 November opening of the Nord Stream gas pipeline to Germany. The pipeline, in which Putin's key collaborator has been his close friend the former German Chancellor, Gerhard Schröder, bypasses Belarus, Poland and Ukraine and gives Russia a capacity to cut off gas supplies to those countries temporarily without incommoding their more important customers further west. It also serves as a warning to Ukraine and Belarus that they can expect to earn much less for transit fees in future.

Despite desperate assurances from Yanukovych of his readiness to cooperate in delivering gas exports for Gazprom, Moscow has also persisted with its plans to develop a southern equivalent called South Stream, which would further deprive Kyiv of income and energy security. The objective of South Stream, which would be much more expensive than any purely economic alternatives, is to draw countries of south-eastern Europe into closer energy links with Russia, and at the same time to pre-empt the Nabucco project.

3 The Brezhnev doctrine was an ex-post facto ideological doctine developed after the Sovietled military intervention in Alexander Dubček's Czechoslovakia in 1968 that other 'socialist' countries in the Warsaw Pact had the right to deliver fraternal support to (read: invade) any member state where socialism was threatened. 
Nabucco is a planned strategic pipeline intended by the United States and the European Union to weaken the Kremlin's strong grip not only on gas exports to southern Europe, but also on potentially competitive gas supplies originating in Azerbaijan and Turkmenistan. Nabucco has had a chequered career thus far, with many EU members and would-be members quite happy to conclude bilateral deals with South Stream that ignore Brussels's endorsement of Nabucco as vital for EU energy security. Nabucco has suffered a few defeats in recent months and Moscow will certainly see all these as important victories in its long-running South Stream campaign.

Putin might well have felt satisfied with the way his domestic and foreign priorities were shaping up in the weeks before the booing. As another noted Russian leader once said, life had become better, life was becoming more cheerful. But then came the domestic setbacks, which revealed again Putin's very strong anti-Western instincts. With his overt takeover of Medvedev's supposed bailiwick, foreign policy, we have seen a growing inflexibility and sharpness of tone in relations with the West, reminiscent of pre-Gorbachev times.

Putin is worried about China, but he tries to keep it well hidden. He never uses the belligerent, mocking or contemptuous accents with Beijing that have become almost routine in his public comments about the West. After 11 years it is perhaps time to say that this is the real Putin standing up. Strong rumour has it that he will appoint the obsessively anti-Western ultra-nationalist ambassador to NATO, Dmitry Rogozin, as defence minister. With a resentful Putin convinced that his domestic troubles are all a Western conspiracy in the presidency for at least another six years, expect strains in EastWest relations to increase further. 


\section{6 \\ Putin's phoney war ${ }^{1}$}

Since the governing United Russia party's setback at Russia's parliamentary elections on 4 December 2011, Vladimir Putin has been struggling to regain the initiative against a chaotic, hydraheaded opposition. With high energy prices sustaining the economy throughout his 2000-08 presidency, and buoyed by a bounce-back in prices since 2010, Putin's luck seemed to be holding. His subordinate, President Dmitry Medvedev, was there to take the worst of the blame for Russia's 8 per cent slump in 2009. Then, after a few ineffectual efforts to present himself as worthy of a second term, Medvedev meekly proposed Putin as the regime's officially endorsed candidate for this Sunday's presidential elections (4 March 2012). Magnanimously, Putin responded by indicating that he would, in turn, appoint Medvedev as his prime minister.

But then came the shock rebuff at the December 2011 parliamentary (Duma) elections. The result revealed a growing irritation among many Russians, particularly within the urban middle-class intelligentsia, at being taken for granted by their rulers. The job-swap that Putin and Medvedev brazenly announced in September - quickly labelled 'the castling' (rokirovka) by chess-playing Russian intellectuals - was rightly seen as a display of contempt for the voters. The prospect of Putin returning for up to two further terms of six years each suddenly struck many people as intolerable.

1 First published in Inside Story, 1 Mar. 2012, insidestory.org.au/putins-phoney-war. 
Putin seemed ill-prepared for the electoral reverse. The regime's initial reaction was to arrest and jail some of the participants at a large postelection protest held against the rigging of the vote, which had been exposed more clearly than previously by internet sources.

Then, realising the strength of the protests, the authorities adopted more nuanced tactics, allowing a second and larger rally to proceed without hindrance on 10 December. A mini-thaw began to seep into public life, which, in the following weeks, started to resemble the early phases of Gorbachev's glasnost and perestroika. Opposition figures, who had been banned for years from the state-controlled television, made brief reappearances; liberals within the establishment spoke out in seemingly unscripted ways, calling for new budgetary priorities, greater 'dialogue', and even the release of the jailed oligarch Mikhail Khodorkovsky, a sentiment likely to enrage Putin.

Senior politicians appeared to be repositioning themselves, and even expressing some personal opinions. Medvedev announced a set of proposed electoral reforms, including restoration of the direct election of regional governors and the removal of onerous restrictions on who is eligible to run for the presidency or the Duma. But it quickly became clear that these reforms were not to be brought into effect until after the presidential poll in March, and were thus years away.

Medvedev's proposed reforms were seen as too little, too late by the protesters, who were demanding, among other things, a re-run of the Duma elections and the dismissal of Putin's devoted ally, the Central Election Commission chairman Vladimir Churov. (Medvedev had, it will be recalled, described Churov as 'the magician' after he announced United Russia's wafer-thin majority in the new Duma.) Despite the promises of future reforms, these opposition demands have not been met, and responsibility for securing a win for Putin in this weekend's presidential poll still remains in Churov's capable hands.

Even Vladislav Surkov, the puppetmaster and leading ideological phrase-maker in the Kremlin, emerged from the closet as a born-again liberal, for which he was soon demoted from deputy head of the presidential administration to the much less significant post of deputy prime minister in charge of 'modernisation'. 
But the most significant deviation from the party line came from Putin's old friend, Aleksei Kudrin, who had in the 1990s helped Putin to transfer from Petersburg to Moscow and to launch his dazzling career. Kudrin was Russia's finance minister and a deputy prime minister for many years, but resigned from government after a public argument with Medvedev over planned budgetary expenditures, notably a huge buildup in military spending. In fact, his differences were probably more with Putin. Since Kudrin's resignation, Putin has reaffirmed that he would like to see him back in a senior position, but also that he plans to greatly expand the defence budget. Kudrin, for his part, has tried to position himself between the authorities and the demonstrators. He has called for new elections in 18 months (not immediately, like the opposition), attended the 24 December rally and addressed the crowd - to a mixed reception - and has offered to mediate wide-ranging discussions between the Kremlin and the street.

Most opposition leaders view Kudrin with respect, but there are suspicions that what he really wants is to return to power as prime minister. If Putin were to renege on his promise to appoint Medvedev and instead choose Kudrin, it isn't clear that any major political liberalisation would follow. On budgetary matters, Kudrin would certainly be at least as determined a defender of fiscal good sense as he has always been as finance minister. But for that very reason, given his expansive plans for military expenditure, Putin may be reluctant to have him back.

Outside the Duma, the conditions for opposition forces have been difficult. The Kremlin has systematically harassed them and worked to keep them fragmented. Although opposition leaders have often contributed to their own ineffectiveness by their constant disputes, in recent months they have played down their differences and worked to organise the big protest marches that have imparted such dramatic public visibility to social discontent. The ostensibly oppositionist parties tolerated in parliament and public life are essentially parts of the Putinist system and can safely be ignored for most purposes. But they have performed a useful function for the real opposition since the leading rebel blogger, Aleksey Navalny, popularised the tactic of calling on everyone to vote for anyone other than Putin. This worked well in the Duma elections, but may not be sufficient to force Putin to a second round this Sunday. 
Since the high point of the 24 December demonstration, the opposition has sustained a certain loss of momentum. Anti-Putin sentiment is still alive on the internet, often in forms that would be deeply wounding to any politician, much less an alpha-male autocrat like Putin. But it now seems likely that Putin will win and, at least as recorded by Churov, win well and in the first round. With temperatures falling below minus $20^{\circ} \mathrm{C}$ and remaining there over an extended period, Generals January and February - traditional allies of Russian leaders - have contributed to deterring political ardour on the streets.

Sardonic attacks on Putin and his system have continued in cyberspace, but the opposition has not managed to devise a political formula to encapsulate its objectives. It has not put forward a candidate for president (though had it sought to do so, any nomination would certainly have been blocked by the redoubtable Churov). The usual suspects from the three tame opposition parties are in the presidential race yet again, two of them - the communist leader Gennady Zyuganov and the populist court jester Vladimir Zhirinovsky - running for the fourth time. The only candidate who looks slightly more interesting is the billionaire Mikhail Prokhorov, who has made some independent remarks but has been unable to fully convince the opposition that he is any more than a Kremlin project.

Meanwhile, the regime is engaged in visible preparations to get out the vote and rig it where necessary. Social security officials have revealed that they have been called on to collect as many votes as possible through 'facilitated voting', where officials help grateful pension recipients to cast their votes at home. Governors and military commanders understand that they will be held responsible for any poor outcomes in the election. And the Chechen tyrant Ramzan Kadyrov will no doubt be looking to improve on his 99 per cent result for the regime in the Duma elections.

Although he seemed a bit at a loss just after the Duma elections, Putin quickly regained his composure. In a series of statements and programmatic articles, he has repeatedly evoked the spectres of internal subversion and external military threats, while promising generous budgetary support to all at considerable cost to Russia's financial stability. Putin was also generous with other people's money, publicly demanding Russian airlines offer free passage for Russian football fans to attend European Cup matches in Poland and Ukraine. 
One of the articles made a pitch to rekindle a kind of Soviet notion of Russian nationalism - one that ostensibly welcomes all those who speak Russian and see Russia as their home. While seemingly condemning Russian chauvinism as well as other shades, the article clearly sees Russians as having pride of place - a pitch to xenophobia both internal and external, part dog whistle, part explicit. As one legacy of their Soviet past, ordinary Russians already have a tendency to ethnic intolerance and jingoism, and opinion polls have detected an increase in these sentiments in the run-up to the presidential elections.

Increasingly, the regime is seeking to organise counterblasts to the opposition demonstrations. Groups of core constituents from factories, government agencies, provincial cities and Kremlin-controlled youth organisations have been bussed into demonstrations in support of Putin. And despite conciliatory noises emerging from the Kremlin, there has been a strong hint of artificially fanned class warfare, often promoted by Putin himself. In this neo-Soviet narrative, the honest workers and ordinary citizens of Russia are pitted against the wealthy and pampered layabouts of Moscow and St Petersburg - people who seem to think that they are the creative classes, when it is the workers who built a giant dam or a new railway line who are truly creative. According to this view, the spoilt rich of the capitals are traitors who are prepared to sell out their country for a few pieces of silver offered by the CIA, et cetera.

These are somewhat shop-soiled methods and storylines. While they still work up to a point, the air of fatalistic acceptance at pro-Putin gatherings contrasts sharply with the unmistakable exuberance of the opposition crowds. Participants in the Putin rallies often openly tell journalists that they were pressured or bribed to be there.

Putin's autocratic rule has been relatively consensual to date, and neither gratuitously violent nor ideologically rigid. Compared to Alexander Lukashenka's Belarus, for example, it has been a haven of pluralism. But that may be about to change. Putin has been reluctant to suppress opposition activities or aggressively pursue their leaders during the trimester between the elections for fear of provoking a backlash. Once he is safely ensconced back in the presidency, he may well remove the gloves. Already there have been some ominous signs that the phoney war is about to end. Some of the key opposition media outlets have been subjected to various forms of attack, either 
directly via the compliant law enforcement and judicial systems, or through pressure on owners already known for their responsiveness to Kremlin requirements.

The celebrated Moscow radio station Ekho Moskvy (Echo of Moscow), one of the few independent non-print outlets with any reach (currently over a million listeners daily), has recently come under pressure from its two-thirds owners, Gazprom-Media. As the name suggests, this is an offshoot of the huge parastatal company that is a willing executor of Moscow's 'energy diplomacy', frequently making decisions of dubious economic rationality that happen to serve the Kremlin's strategic interests. Putin has usually taken a semi-tolerant approach to the station, but in a meeting with media figures a few weeks back he angrily reproached its editor-in-chief, Aleksei Venediktov, for retailing rubbish from morning till night and pouring shit all over me'. Now Gazprom is moving to reshape the station's board, which Venediktov has described as an attempt to reshape its editorial policy.

There have been other such attacks. Novaya Gazeta (New Gazette), the leading independent newspaper, has lost four of its bravest and most eminent journalists, including Anna Politkovskaya, to murder, typically by 'unidentified assailants'. Now the Central Bank, no less, is conducting an investigation into the business affairs of its part-owner, the controversial but seemingly independent oligarch and ex-KGB officer Alexander Lebedev (Mikhail Gorbachev is also a partowner); last week, as a result, Novaya Gazeta was reportedly unable to pay its staff's salaries.

Some of Putin's key personnel decisions in recent weeks also point to a looming policy adjustment. The anti-Western ex-ambassador to NATO, Dmitry Rogozin, has been appointed deputy prime minister responsible for defence, and the hardline Vyacheslav Volodin has been elevated into the vacancy left by Surkov in the presidential administration. Putin's rhetoric against opposition members - whom he has repeatedly labelled national traitors in foreign pay - has been consistently venomous through the election period. While the charges would be ridiculous if they were not so ominous, his anger is not simulated. If and when he feels he can deal with this dangerous threat to Russia's sovereignty and, coincidentally, to his own political survival, he may well take severe measures. 
His relatively benign treatment of most Russians has not extended to all his subjects. He came to power and popularity fuelled not just by oil and gas price surges but also by a brutal war against the Chechen rebels, a war that is still not over and has increasingly become a jihadist insurgency as it has spread to neighbouring Muslim-populated regions. That war was partly justified by a sudden spate of mysterious apartment bombings in Russia in 1999, when Putin was prime minister. The last event in the sequence appeared to bear the fingerprints of the Federal Security Service (FSB), not Chechen terrorists as has always been officially maintained. Some of those who investigated the events and wrote about them have subsequently been assassinated, including Alexander Litvinenko. ${ }^{2}$

And now we have this week's remarkably well-timed official reports of an assassination plot against Putin, in which Caucasian terrorists (one with reported British connections) have been found to be implicated. The bruised and bleeding body of one of the arrested men has already been displayed on TV, leaving little doubt as to what the judicial futures of the group members will be. In the meantime, they may have a variety of instructive roles to play. For the moment their arrest is clearly meant to boost Putin's election result.

It is noteworthy that these culprits were nabbed with the assistance of security forces from Ukraine, where that well-known Europhile, President Viktor Yanukovych, recently appointed two ethnic Russians with strong Soviet Russian (and in one case KGB connections) to head the key ministries of defence and internal security. Perhaps this valuable cooperation will improve the troubled bilateral relationship; and, who knows, it may even help get Yanukovych a desperately needed gas price discount.

None of this necessarily means that Putin is preparing to declare a state of emergency, though such a development at some point can't entirely be ruled out. Barring a steep economic downturn or some other event that sharply elevates domestic tensions, however, it seems much more likely that we will see incremental repressive steps to restrict the internet, immobilise the main centres of opposition and sever the protesters' links to the broader population.

2 Alexander Litvinenko \& Yuri Felshtinsky, Blowing up Russia: Terror from within, Geoffrey Andrews and Co (trans.) (London: Gibson Square Books, 2007 (2002)). 
Putin has been politically damaged by the recent outburst of popular resistance, and by the withering mockery to which he has been subjected in Russia's cyberspace. He is coming under some pressure even from hitherto loyal business circles, and possibly other quarters in the elite, to consider declaring his intention not to seek a further sixyear term in 2018. It may be that popular resentment and resistance will continue to mount even if, or indeed perhaps because, he unleashes a crackdown against his tormentors. According to one recent line of argument, Putin's 'power vertical' - his centralised control over all parts of the Russian establishment - was always a mirage, and he is really no more than a chairman-like figure, precariously balanced over a whirlpool of conflicting silovik and oligarch groupings all of them pursuing separate corrupt interests and largely out of his control. ${ }^{3}$

It is certainly true that Putin's position has been damaged, and also that any autocratic power structure is likely to have a latent vulnerability that can precipitate an abrupt collapse if habits of obedience and compliance are suddenly punctured. But there is a big gap dividing potential brittleness from hapless impotence. It still seems likely that Putin retains the confidence of the military and security establishments, even if the doubts of some of its denizens about this or that may be growing. He hasn't recently given them all a massive pay increase for nothing. If we are seeing the beginning of the end of Putin's reign, it may take quite some time yet to run its course.

Pointers to key imponderables will probably be evident soon. If Putin appoints Medvedev prime minister, as promised, or if the apparent coolness between them in recent months means that Deputy Prime Minister Igor Shuvalov or former deputy prime minister Kudrin gets the job, we might expect the more moderate elements in the elite to have continued influence. But if there were a surprise appointment, now or in a few months, of someone like Volodin or the Moscow mayor Sergei Sobyanin, we could see a more self-willed and hardline Putin, unconstrained by liberal reformers in his midst.

What will he do to curb the internet? He doesn't use it much or have a good understanding of it, but he has recently been made painfully aware of what it can do to him. His past assurances about internet

3 See Stephen Holmes \& Ivan Krastev, 'The weakest strongman', The New Republic, 11 Jan. 2012, www.newrepublic.com/article/world/magazine/99527/strongman-putin-march-kremlin. 
freedom were never credible, given the regime's regular deployment of computer hackers to advance government policies domestically as well as externally.

Will he continue his sharply anti-Western rhetoric of recent months? It's all vintage Putin, but how will it affect his relations with the West in the years ahead? Will he further strengthen his 'strategic partnership' with China in order to make the world safe for the Assads and their like and to finally expunge the ugly threat of coloured revolutions from the post-Soviet scene?

Or will we see, as some have argued, unpersuasively in my view, a more relaxed and confident Putin, prepared to seek economic and other reforms and dialogue and reconciliation with the opposition and the West? We shouldn't have too long to wait. 



\section{7 \\ Re-enter Putin, weakened and resentful'}

While he presented himself throughout his campaign as the 'stability' candidate who could not only snorkel down to priceless ancient artefacts, but also save the country from the disintegration plotted by sinister Western agencies, Vladimir Putin's return has in reality added an extra layer of instability to a situation already piled high with new uncertainties. Until recently, his popularity was sinking in the opinion polls, not as rapidly as that of his ruling United Russia party, but steeply nonetheless.

His win in the presidential elections on 4 March is being rejected as illegitimate by the opposition. So the attacks on him in the cybersphere can be expected to become even denser and more sardonic in his third term in the presidency, as internet use in Russia climbs further having already overtaken Germany in absolute numbers in September $2011 .^{2}$ This is a key reason why many pundits, even within the Russian establishment, are starting to hint at the likelihood of his not seeing out his new six-year term in the top job.

1 First published in three parts in The Interpreter, 8-9 Mar. 2012, www.lowyinterpreter.org/ post/2012/03/08/Putins-Pyrrhic-victory.aspx; www.lowyinterpreter.org/post/2012/03/09/Reenter-Putin-weakened-and-resentful.aspx; www.lowyinterpreter.org/post/2012/03/09/PutinFor-Russians-the-thrill-is-gone.aspx.

2 See 'ComScore releases overview of European internet usage in September 2011', 14 Nov. 2011, www.comscore.com/Insights/Press-Releases/2011/11/comScore-Releases-Overview-of-EuropeanInternet-Usage-in-September-2011. 
His 64 per cent first-round victory looks convincing enough on paper, but it must be remembered that this was a contest against a carefully restricted line-up of compliant losers and Kremlin projects. Genuine opponents were kept out of the race by various expedients. None of the leaders of the new opposition even bothered to seek approval to stand, knowing it would be refused by Putin's loyal allies in the Central Electoral Commission. State television, from which the majority of Russians continue to derive their news and views of the world, has been heavily, often fawningly, skewed in Putin's favour for over a decade.

And, while the installation of nearly half a billion dollars' worth of webcams in the 90,000 polling stations across the country and the deployment of a large number of new opposition recruits as election observers made vote-rigging harder (New York Times, 5 Mar. 2012), the regime apparently rose to the occasion. Teams of 'Vote early and vote often' supporters, equipped with large supplies of absentee voting forms, were bussed around from polling station to polling station to build up the numbers ('carousel voting' in current Russian jargon). Many instances of electoral fraud were reported ${ }^{3}$ and the official Organization for Security and Co-operation in Europe (OSCE) observer group criticised the conduct of the elections.

Nonetheless, even GOLOS, the leading independent election monitors (helpfully ejected from their headquarters a few weeks before the poll) acknowledged that Putin probably scored just over 50 per cent of the vote. So a win is a win is a win. Or is it?

In budgetary terms, this has been a Pyrrhic victory for the regime. Even before the election campaign, Putin had secured a budget full of goodies for almost all sectors of the electorate: big pay rises for doctors, academics, teachers, security organs, armed forces, and enhanced payments for pensioners, mothers (especially the more fecund), and students. He also arranged for unpopular but necessary price hikes for basic utilities to be postponed till later this year. Then he added further to the burden by extravagant promises during the campaign. ${ }^{4}$

3 See Tom Balmforth, 'Election observers claim fraud, intimidation in Russian vote', Radio Free Europe/Radio Liberty, 4 Mar. 2012, rferl.org/articleprintview/24504685.html.

4 Jason Bush, 'Price of victory may be too high for Putin', Reuters, 5 Mar. 2012, www.reuters. com/article/2012/03/05/us-russia-election-promises-idUSTRE8240EQ20120305. 
Putin will be able to appoint a prime minister to take the blame for this profligacy. On the eve of the election he reaffirmed his earlier promise that Medvedev is to be his nominee for the position, and Medvedev is certainly abundantly well qualified for this subordinate role. Apart from that, Russia's current fiscal position is sound by European standards thanks to high prices for its energy exports and the legacy of tough fiscal orthodoxy left by Putin's longtime ally the former finance minister and now semi-dissident Aleksei Kudrin. But, particularly if European economies slump further and/or there is a dip in the price of oil and gas, Putin is going to have to severely disappoint some of his core electorate.

This could lead to a renewed decline in his popularity ratings. Putin has run into the dilemma familiar in more genuine democracies of being the politician that people have become sick of, and have largely stopped listening to. His grossly inflated campaign rhetoric about sinister Western enemies, the break-up of the Russian Federation, attempts by the mild-mannered, middle-class protesters to stage a coup, and so on, may have helped him to energise some of his own supporters but probably alienated many others. To maintain the support of the faithful, he needs to deliver on his promises and, to recapture some of the lost sheep, he needs to somehow reconcile the urban intelligentsia.

But it is hard to see how he can do the former and how he would ever want to do the latter. A key part of his campaign was to contrast the limp-wristed arty-farties of Moscow and St Petersburg with the saltof-the-earth working classes of the provinces. In a late-night video link-up with workers in a remote armaments factory, he told them: 'You showed who the Russian people are, the Russian working man ... You showed you are a head higher than any layabout, any old windbag. ${ }^{5}$

In fact, Putin has been roundly insulting the urban middle class since the protests broke out after the parliamentary (Duma) elections on 4 December last year. Then he compared their white ribbons with condoms in an anti-AIDS advertisement, and asserted that they were only out on the streets because the US State Department had bribed

5 See 'Emotional Putin wins election as opposition cries foul', EurActiv, 5 Mar. 2012, www. euractiv.com/europes-east/emotional-putin-win-election-opposition-cries-foul-news-511273. 
them to be there (another apparent case of Freudian projection, like the plot to murder one of their own attributed to the opposition). He has maintained a similar tone ever since.

Putin has for some years lived in intermittent terror of a 'colour revolution' in Russia, unlikely as that prospect has always seemed to most outside observers. He sees the Rose Revolution in Georgia in November 2003 and the Orange Revolution in Ukraine in 2004-05 as the prototypes of externally devised and imposed conspiracies that have little to do with rorted elections or popular dissatisfaction within those countries, but everything to do with the almost unlimited capacity of foreign intelligence services to impose their will. He sees these developments as of a kind with the much more palpable involvement of external agencies in the overturning of the Gaddafi regime in Libya, and other Arab Spring phenomena. Not normally a man with a gift for human empathy, Putin seems to strongly identify with Colonel Gaddafi and President Hosni Mubarak of Egypt, whose fate he has referred to more than once.

Putin returns to the presidency angry with his domestic adversaries and their supposed foreign backers, and seemingly bent more on repression than on reconciliation. Already before the election there were attacks on a number of the most prominent of the tolerated independent media voices, either through criminal investigations or pressure on their owners. In a characteristic outburst, Putin publicly denounced one such editor for 'pouring shit over me from morning till evening ${ }^{\prime}{ }^{6}$ Not surprisingly, the owners of that media outlet took the hint and went into action a short time later to reshuffle the station's board of directors. ${ }^{7}$ More such measures seem highly likely.

The big question is whether he will take on the internet purveyors of excrement. Putin is not internet-savvy, but he is probably thinking something along the lines of the wit who said, on being reproached for overstepping the boundaries of his competence: 'I can't lay an egg, but I certainly know when I get a bad one.' While he has more than once claimed to believe that Russia's internet should remain free, it has

6 Benjamin Bidder, 'Controlling the press', Spiegel Online, 17 Feb. 2012, www.spiegel.de/ international/world/controlling-the-press-echo-of-moscow-under-pressure-in-russia-a-815731.html. 7 'Ekho Moskvy editor says reshuffle aimed at "controlling" election coverage', Radio Free Europe/Radio Liberty, 14 Feb. 2012, www.rferl.org/content/gazprom_wants_to_dismiss_radio_ board/24483318.html. 
not been entirely free to date. Cyber-attacks from mysterious sources commonly linked to Kremlin-backed youth movements like Nashi (sometimes referred to derisively as Putinjugend) have often been deployed both on foreign and domestic enemies.

But Putin may well feel now that strong measures must be undertaken against the bloggers. In addition to that, he can be expected to rein in some of the glasnost that has been spreading in the more orthodox media outlets.

Putin's fears of a ruthless colour revolution notwithstanding, Russia's oppositionists are basically civilised, and not too formidable. Though impressed by the example of the Arab Spring, they are not desperate members of a huge youth unemployment bubble moved by a transcendental ideology that offers them the certain hope of eternal joy in the hereafter and a release for their burning resentments now. The Russian opposition wants dignity and respect, a chance to have a say about how they are governed and, more generally, greater opportunities to realise their professional talents.

If they are denied these, they can always head for the exits, as many of their like-minded fellow countrymen have been already doing. According to Sergey Stepashin, a senior Russian official and one-time prime minister, over 1.25 million Russians have emigrated in recent years, including many young, highly qualified professionals. Twenty per cent of respondents told the independent Levada opinion polling agency that they would like to emigrate. ${ }^{8}$ If obstreperous oppositionists chose not to do so voluntarily, it might prove necessary for them to be selectively encouraged to do so.

Putin should, however, beware of believing his rhetoric that it's only the urban middle classes with whom he has a problem, and that ordinary Russians remain as supportive of him as ever. One forms the impression that for many of them, too, the thrill has gone and that they see him more as inevitable than as necessarily desirable. At this stage his popularity is probably several time zones wide, but only an inch or two deep.

8 Sergei Loiko, 'Russians are leaving the country in droves', Los Angeles Times, 14 Nov. 2011, articles.latimes.com/2011/nov/14/world/la-fg-russia-emigration-20111115. 
People of all milieus are angry at being taken for granted and infuriated by the ubiquitous corruption, both petty and spectacular, blighting Russian life, for which they blame 'the party of crooks and thieves'. ${ }^{9}$

Putin has a serious problem on his hands. But some Western commentators may be getting ahead of themselves in describing him as an already spent force, presiding over a dysfunctional and ineffective 'power vertical'. ${ }^{10}$ The 'end of Putinism', proclaimed an article in the Washington Post on 5 March. 'Russia's incredible shrinking Prime Minister', read Time magazine's front cover for 24 February 2012, with apt graphic reinforcement. But, at a time when many countries in its region are doing rather worse, the Russian economy will get by with sensible management for some time yet, even without the serious reforms that many recommend. ${ }^{11}$ And, while the coercive structures of the state may conceal some structural weaknesses, the opposition would be unwise to test their mettle too much.

Whilst maintaining his own hardline stances, Putin may also continue his longstanding arrangement of having the unthreateningly reformist Medvedev issue forth liberal pronouncements and initiatives from time to time to keep the opposition's hopes up and make favourable headlines in the Western media. If under real stress, he might move Medvedev to another post and bring back the strong-willed Kudrin as prime minister, while making clear to him that his primary task was to maintain economic stability, not propose early elections or other dangerous liberal ideas.

Putin may be looking more mortal than the swaggering figure of the noughties with his astronomical approval ratings. But he has his 64 per cent, however acquired, and this may dispirit the opposition in the months ahead, whilst discouraging potential opponents within the so-called political elite from contemplating a palace coup. His brand is tarnished and he seems to have no plausible platform for tackling many of Russia's real problems. But the obituaries are premature.

9 See 'Russia election: Hundreds rally against Putin in Moscow', BBC News, 5 Dec. 2011, www.bbc.com/news/world-europe-16042797.

10 See Stephen Hoffman, 'The power vertical and its chilling effect on democracy', Human Rights in Russia, 5 Mar. 2012, www.rightsinrussia.info/archive/blog/hoffman/power-vertical.

11 See, for example, the article by the eminent British economist Philip Hanson in the Chatham House report 'Putin again: Implications for Russia and the West', Feb. 2012, www.chathamhouse. org/sites/files/chathamhouse/public/Research/Russia\%20and\%20Eurasia/r0212_putin.pdf. 


\section{8 \\ The real Mr Putin stands up ${ }^{1}$}

Both before and since the poor showing of the ruling United Russia party in the December 2011 parliamentary elections, there have been commentators who expected to see Vladimir Putin return as a reformist for his third term as president. Some looked back to the first-term Putin, who surrounded himself with competent economic officials like German Gref (Economic Development and Trade Minister) and Aleksei Kudrin (Finance Minister), and introduced a few sensible economic reforms. Some looked back further, to the 1990s, when Putin's boss was the reformist mayor of St Petersburg (and his former university law professor) Anatoly Sobchak, who was supposed to have inspired in him a deep respect for the law - a kind of counterpoint to his KGB training.

With high oil and gas export prices delivering fewer windfall benefits, and years of high budgetary outlays weighing heavily on the budget, it has also been suggested that, in his third term, Putin will have little choice but to be an economic reformer. Moreover, with popular dissatisfaction growing and his and the regime's opinion-poll ratings in decline, some have maintained that he would need to introduce liberal economic reforms to stave off impending Brezhnevian stagnation (zastoi) and secure his place in Russian history. With liberals in the

1 First published as 'Vladimir Putin, the waiting game', in Open Democracy, 29 Mar. 2012, www.opendemocracy.net/john-besemeres/vladimir-putin-waiting-game. 
establishment also calling for such reforms, it was argued that Putin would need to ensure, as the chairman of the regime factions, that such views were reflected in decision-making.

Some observers have discounted the sharply anti-Western tone of Putin's second term as president from 2004 to 2008 as an understandable reaction to the West's failure to respect Russia's sovereignty. NATO and EU leaders, they felt, should have rejected the desperate efforts of former Soviet vassals in Eastern Europe to join their organisations. This line of analysis sometimes declares that the Obama administration's 'reset' of US-Russian relations has created a more stable bilateral and international environment, in which Putin finds it less necessary to defend Russia from external meddling.

There is a subset of this school of thought, however, which is disappointed by Obama's policies towards Russia, seeing Washington as having lost yet another of the opportunities since the late 1980s to establish cordial and cooperative relations with Moscow. Prominent among them are the distinguished historian of the Soviet period Stephen F. Cohen and his wife, Katerina van Heuvel, proprietor of The Nation, and also a group of thinkers, some of Russian background, associated with the influential Washington journal, The National Interest. While their bottom line is usually summarised in such reasonable-sounding formulations as 'all Russia is really asking for is to be treated with respect as an equal partner', after two Bush administrations and two Democrats in the White House, it begins to seem that, in their view, US administrations of whatever colour are fatally flawed and that their policy advice may never be sufficiently heeded.

Most of these critics focus primarily on what they maintain is the hypocrisy and unrealism of Western policy towards Russia, which they see as far more aggressive and misplaced than Russia's towards the West. As for Moscow's domestic policies, their view is typically that Putin's Russia is a vast improvement on Boris Yeltsin's, and that Western critiques of Putinism are selective, unfair and a reflection of Cold War attitudes that their exponents are still unable to shed.

Both those who predict Putin will return a born-again reformer and those who say he deserves a better press and warmer response from his Western counterparts seem likely to be disappointed by his third term. It is doubtful that Putin will make the domestic changes that 
would validate the more optimistic views. And the pessimists who have waited so long for better Western policies probably won't be too surprised to see Obama II (a fortiori Romney I) letting them down yet again.

But March 2012 has actually seen what The National Interest school might think are positive signs for the troubled US-Russian reset. Addressing a Congressional committee earlier this month, a senior US Defense Department official foreshadowed that the United States might share sensitive data about its European ballistic missile defence shield in an effort to reassure Russia that it could not possibly threaten its nuclear deterrent.

In addition, the Russian press has reported that Obama unexpectedly changed the venue for the forthcoming G8 meeting on 18 May from Chicago to Camp David. This would enable Putin to attend the G8, then give the NATO summit a miss without his absence being too conspicuous. However, the change of venue may seem like a modest concession, and almost any concession on the missile-defence shield is unlikely to satisfy Russia, which has been clinging to its grievances in the matter with remarkable tenacity.

More recently, the world has overheard Obama at the Seoul nuclear summit on 26 March asking Dmitry Medvedev to pass on to presidentelect Putin a request for a little bit of bilateral understanding. Unaware the microphone was still live, Obama asked that Medvedev let Putin know he hoped to be able to offer Russia some greater flexibility on the missile defence shield once the US presidential elections were out of the way. Medvedev can be heard assuring Obama that he would pass the message on to 'Vladimir'. This microphone mishap instantly became an election issue in the United States, which may now make for further bilateral difficulties. But none of the above supports the view of The Nation or The National Interest that US administrations are remorselessly harsh towards Putin.

\section{A troubled reset}

In the meantime, however, some earlier positive signals must have been favourably received in Moscow. On 14 March, Foreign Minister Sergey Lavrov announced that the Russian Government would consider 
allowing US and coalition forces to use an air base near Lenin's home town of Ulyanovsk to transit troops and supplies into Afghanistan. Lavrov sought to reassure offended patriots in the Duma that this was an investment in Russia's own security against terrorists and illegal drugs coming in from the south.

This is a valid argument, but not one that would appeal greatly to many Russians in either official or unofficial circles. Resupply to Afghanistan, one of the fruits of the reset, has been permitted through Russia since 2009, but this would be the first time use of a Russian facility has been offered to NATO in this way. That such an outrage might be perpetrated in a town named after Lenin will strike many Russians as sacrilegious.

These gestures are all the more noteworthy because they followed months in which Putin repeatedly denounced the West and especially the United States for interfering in Russia's elections and undermining stability more generally. Along with other Kremlin figures, he described street protesters as traitors in the pay of the US State Department and Hillary Clinton.

Clinton and other Western officials were critical of the conduct of the Duma elections in December, and milder reservations were also expressed about the presidential elections on 4 March by some official outsiders, including the electoral observer team from the Organization for Security and Co-operation in Europe (OSCE). But Clinton, to the dismay of the Russian opposition, acknowledged that Putin was the 'clear winner' this time around. The European Union made a similar pronouncement. So, perhaps, a degree of normality is now returning to Russia's relations with Western countries after an unusually torrid election season.

But any such normality is relative. The reset has been in trouble for some time. Apart from cooperation on Afghanistan and successful US efforts to secure Russia's entry into the World Trade Organization (overcoming both Georgian objections and Russia's ambivalence), progress has been modest. Relations with NATO have been increasingly cool and unproductive - hence Putin's desire to skip the summit. And relations with the European Union are not much better; EURussia summits have also become strained and light on substance. 
The lack of enthusiasm for the prospect of another Putin presidency was palpable throughout much of the Western world. Obama, for his part, took several days to respond to his counterpart's 'clear' victory. The most conspicuous exceptions were Putin's close friends Gerhard Schröder and Silvio Berlusconi. The former German chancellor Schröder pronounced Putin still a 'flawless democrat', and Berlusconi skipped a planned TV appearance to visit Russia and congratulate Putin in person.

Obama seems to have poor personal chemistry with Putin, and his administration has made a policy of dealing preferentially with Medvedev, with whom relations are warmer. While there have been obvious protocol reasons for dealing with Medvedev during his period as president, Washington seemed almost to be hoping thereby to contribute to building his authority. Other Western leaderships also seemed happier dealing with the more emollient Medvedev. Whatever their motivations, after Putin's inauguration on 7 May they will be deprived of that option.

Russia's relations with Western countries are still snagged, however, over a number of international issues, including Libya and Syria, the US ballistic missile defence shield, the UN's 'responsibility to protect' doctrine and national sovereignty, Russia's purported zone of privileged interests, energy security and Arctic resources. But Russian domestic developments and the commentary that they have attracted in the West have generated much of the East-West tension since Putin's bloody counter-insurgency in Chechnya and his dismantling of the Gorbachev-Yeltsin democratic reforms. What course Putin decides on domestically in his third term will do much to shape his relations with the West.

\section{Between past and present}

While he did show some liberal leanings in his first years in power, that phase in Putin's life now seems far behind him. He may enact some pragmatic reforms to strengthen Russia's dismal investment climate, but nothing in his election campaigning suggested he was about to institute 'democracy without adjectives' in Russia. 
Putin is not normally given to public displays of empathy or emotion. His glistening eyes at his victory address to the well-organised multitude in Red Square were really for himself. They recall another occasion in 2000 when he was seen to shed a tear or two at the funeral of his jurisprudential guru and career facilitator, ex-mayor Sobchak. But his sentimental regard for Sobchak is evidently coming under some strain now.

Putin is widely believed to be the godfather of Sobchak's daughter Ksenia, who has become a glamorous TV personality and prominent member of the Putin-era glitterati with a huge Twitter following. During recent months, however, she has resoundingly aligned herself with the opposition, regularly attending their rallies. Her political chat show was removed from state-controlled TV after she invited opposition leader Aleksey Navalny to make an appearance. She also attracted official notice by appearing in a viral YouTube video satirising a series of TV spots recorded by prominent public figures - sometimes, reportedly, under official pressure - declaring why they intended to vote for Putin.

Ksenia Sobchak has since been accused by a Kremlin-connected media outlet of attacking and taking hostage two of its reporters. She claims that she had them ejected from her restaurant because they were attempting to film her in a private conversation. But her restaurant was visited soon after by Russia's sanitary inspectorate, headed by one Gennady Onishchenko, who has loyally fought many a trade war - involving such things as wine, mineral water and cheese - for the Kremlin against stroppy former Soviet republics and other difficult partners. The deployment of such heavy artillery suggests that the president-elect's godfatherly patience has been exhausted.

There must be some doubt also about Putin's commitment to strengthening normal market mechanisms in Russia. For much of his 12 years at the top, things have been heading in the opposite direction, towards high-level corruption, heavy concentration of ownership in inefficient parastatals controlled by political allies, a form of 'corporate raiding' that amounts to mega-larceny with menaces, and a general lack of the rule of law. 
As for transparency, Sergey Ivanov, a long-time KGB colleague and ally of Putin, has said that surveys of investment conditions like those produced by Transparency International are biased against Russia, and that Russia should therefore produce its own. Ivanov was recently named head of the presidential administration, a decision not likely to have been made by the current nominal incumbent. Medvedev actually got the nod to keep Putin's place warm for him in 2008 ahead of Ivanov, who had been widely seen as Putin's most likely successor.

Most of the liberal and democratising reform proposals that have emerged in recent years have emanated not from Putin, of course, but from Medvedev. He has proposed reversing Putin's abolition of direct elections for regional governorships, for example, and the removal of the severe restrictions Putin had placed on forming parties and standing for public office. But Putin quickly made it understood that he would expect selection of gubernatorial candidates to be coordinated with the President.

The Duma is now processing the relevant reform legislation on formation of parties with unusual haste, and it is expected to be signed soon while Medvedev is still in office. There are indications that it will be shaped in such a way as to produce a proliferation of parties and yet, at the same time, it will remain possible for the Kremlin to disallow parties it doesn't like by deploying other objections against them.

Medvedev also announced a review of the imprisonment of Mikhail Khodorkovsky (something advocated publicly within his entourage for some time). No one who has followed Putin's past pronouncements on this subject, however, could feel confident that the review will produce results. Putin's press secretary Dmitry Peskov probably got it right when he noted pointedly, in response to a question, that the order to review the conviction was under the competency of the current President, declining any further comment.

While many are sceptical of Medvedev's motives, he probably sincerely believes most of the liberal sentiments he has launched into public discussion during his presidency. But one must have very grave doubts about whether he can make any of them fly. 


\section{The president's dilemma}

Putin has reaffirmed that he will nominate Medvedev for the job of prime minister in May. This may be a gesture towards the liberal wing within the leadership group, which felt energised by the protest movement. But Putin's instincts lie clearly nearer the other end of the spectrum. And the satirical buffeting he has received from the opposition in the streets and on the internet is not likely to awaken the flawless democrat in him any time soon. In fact, his main motive for putting Medvedev forward is probably not any perceived need for a liberal gesture, or loyalty to the job-swap deal with his old colleague, but rather his confidence that, as prime minister, Medvedev will not challenge him any more effectively than he has ever done as president.

If liberalising change is to come to Russia under Putin, it will have to come more despite him than because of him. While economic pressures will push him towards reforms of a sort, these will probably only be pragmatic-technocratic, not political-democratic. This brings us back to the opposition. While discouraged and diminished for the moment, they are a new factor in the mix, which Putin will find it hard to neutralise. Their spontaneous irruption from the margins to centre stage in December will be hard to completely reverse, though Putin will give it his best shot.

Their chronic ideological divisions, and the lack of an agreed, realisable program or any dominant, charismatic leader, make the opposition vulnerable to counter-attack. So does the current tendency of some of their leaders to seek confrontation on the streets in the hope of artificially maintaining the rage. Russians have a well-based fear of revolutionary ferment, something that Putin successfully played on during his election campaign. If the courageous, but not always judicious, Navalny tries to lead them on marches to the Kremlin in present circumstances, the crowds will thin out further and be easily dealt with.

Putin has a contempt for most of his Western counterparts. He thinks they are weak and unstrategic, and that they can be readily outmanoeuvred. He relishes the protracted economic crisis in the West and hopes that it will persist, without getting too severe, believing that this should give him the opportunity to pursue restoration of Russian influence in the post-Soviet space. But, after eight years of presiding 
over economic success as president, Russia's own 8 per cent downturn in GDP in 2009 reminded him of his country's economic vulnerability. And he recognises the need for Western investment and know-how, and this is the key factor leading to the tepid rapprochement with the West of the past couple of years.

This being the case, Putin is unlikely to embark on a major crackdown even if or when looming economic problems trigger a renewed wave of public opposition. Despite the violence of his language under stress in recent months, he has not generally been a gratuitously violent autocrat, except in relation to the North Caucasus insurgencies. Selective repression of individuals, and attempts to curb the independent media and the internet are more likely.

To wedge the opposition, he will probably also cultivate a few pseudoindependents from the tame parties, or popular apolitical public figures, perhaps by offering them ministries of door frames and silly walks. He may even try to co-opt some susceptible opposition figures hungering for positions of importance. Consultative bodies may be formed with fanfare. But short of bringing back his old friend and colleague Kudrin as prime minister, none of it is likely to amount to much. Kudrin is the only politician currently on the scene with not just the economic competence, but also the necessary personal and political clout, determination and international standing to push Putin nearer genuine reforms. And he has given some indications of sympathy for the opposition and their political program.

\section{The return of politics}

Despite Russia's huge resource endowment, high energy-export prices and minimal indebtedness (a legacy of Kudrin and his colleagues' good management), the Putinist model is heading for serious trouble. In the last five years or so, despite Kudrin, the budgetary situation has become more unstable. Where an oil price of US $\$ 28$ a barrel was not so long ago sufficient to balance the Russian budget, now the figure is over US $\$ 100$, and rising. Kudrin has warned that even a price of US $\$ 80$ would precipitate a crisis. Given the risk of a worsening slowdown in Europe, its main customer, Russia's fiscal position is potentially fragile. It was over this issue, in particular the extravagant defence program slated for the next few years, that Kudrin resigned. 
While Russia desperately needs increased expenditure on infrastructure, health and education, money continues to be poured not just into defence and internal security, but also into high-profile extravaganzas like the Sochi Winter Olympics in 2014, the football world cup in 2018, and the Asia-Pacific Economic Cooperation (APEC) meeting in Vladivostok later in 2012. Putin's ambitious project to coax often reluctant former Soviet republics into his new Eurasian Union also threatens to be very expensive.

The election campaign has added to the fiscal overhang. It has been estimated that the campaign promises Putin made on the fly will cost the budget a further US $\$ 161$ billion over his next term in office. And the economy has other severe problems. Labour productivity and the investment to GDP ratio are significantly lower than in most other comparable countries. It will be difficult, if not impossible, to restore the high growth of the early Putin years because, for demographic reasons, the labour force will be shrinking sharply over the next few years while other key demographic indicators - the dependency ratio, for instance - will continue to deteriorate markedly. It is doubtful whether Putin, in his third term as president, will be equal to all these challenges.

It seems, therefore, highly likely that economic troubles will trigger renewed unrest at some point in Putin's term, possibly even as early as mid-2012 when the utility-price hikes that were postponed until after the election season are scheduled to be introduced. In the meantime, the increasingly articulate, sophisticated and demanding urban middle classes are not going to remain passive. After the Putinist idyll of the noughties, politics could be returning to Russia. 


\section{9}

\section{Towards a greater Putistan? Part $1^{1}$}

The months between early December last year and late October this year may come to be seen as a time when the Slavonic core of the former Soviet Union took a further, and perhaps decisive, turn away from European democracy. In December 2011 and March 2012, Russia held parliamentary and presidential elections that seem, after a season of excitement, to have confirmed Vladimir Putin's grip on power for at least another six years and initiated a trend towards a police state. Parliamentary elections are scheduled in Belarus for 23 September and in Ukraine for 28 October, and although Belarus's are a formality, Ukraine's are much less so. Both, however, are likely to confirm autocratic continuity with distinct downside risks.

Outside the Baltics and one or two other former Soviet republics, elections in the successor states of the Soviet Union don't normally count for a great deal. The results are usually predictable, and the events themselves elaborately stage-managed. Nonetheless, they can at times cause a boilover of sorts, as occurred in December 2011 when Russia's parliamentaries, despite all the rigging on a sloping deck, saw a shockingly bad result for Putin's ruling United Russia party, which lost 77 of its parliamentary seats. While United Russia failed to get an absolute majority of votes, it did manage still to win a slim absolute

$1 \quad$ First published as 'Towards a greater Putistan?' in Inside Story, 17 Sep. 2012, insidestory. org.au/towards-a-greater-putistan. 
majority of seats over the largely docile opposition parties that are permitted representation in the legislature. It has used that majority to pass a series of repressive laws aimed at neutralising the opposition and minimising their activities on the street and the internet.

At 64 per cent, Putin's winning vote in the presidential poll in March 2012 was more convincing. Despite the considerable unrest, mainly affecting the urban middle classes, this comfortable margin was not surprising given his near complete control of television (where most Russians get their information) and of who might be allowed to run against him. Observers saw evidence of extensive fraud on the day, but nearly all felt that, regardless, Putin would have scraped over the line in that first round.

Belarus's last elections - the presidential contest in December 2010 - produced a similar surprise to the recent Russian electoral cycle - a phoney outcome leading to an outburst of popular anger, then a crackdown. The preordained winner, Alexander Lukashenka, was duly declared to have secured a fourth straight victory with a totally implausible 80 per cent of the vote. Nine candidates had been permitted to run against him and were given slightly less restrictive conditions than usual in an effort to mollify the European Union as a hedge against Moscow.

A few days before the poll, Moscow ironed out its bilateral dispute with Minsk by renewing subsidies for Belarus's energy sector worth, according to Putin, over US\$4 billion per annum. Seeing no further need to hold out an olive branch to the European Union, Lukashenka unleashed a ferocious crackdown on the peaceful crowd that had gathered to protest the results on election night. Many were manhandled, 639 were arrested, including several of his fellow presidential candidates, and dozens of people were ultimately sentenced to lengthy jail terms. Conditions for political prisoners in Lukashenka's jails are particularly harsh: they are often, for example, put together with murderers and other difficult inmates.

Despite the regime's brutality, opposition on the streets continued for many months afterwards. In response, Lukashenka progressively sharpened his legislative provisions to the point where people could 
be arrested for applauding in a public place, or even for being silent in a public place. The regime has essentially maintained the crackdown ever since.

In 2011 the national economy had fallen into a severe slump, which was largely caused by Lukashenka's reckless pre-election spending. As a consequence, opinion polling showed the president's real support falling to around 30 per cent.

Like Putin, Lukashenka had enjoyed a considerable degree of real popularity in earlier years and, like Putin, he had now been given a clear signal by popular unrest and opinion polling that he would need to take sterner measures to maintain himself in power. With the opposition cowed by the regime's unrelenting repression, and the economy picking up considerably thanks to further increases in Russian subsidies, the parliamentary elections on 23 September will almost certainly result in a win for the regime.

When it comes to repression, Lukashenka is meticulously thorough. In July a group of Swedish activists managed to get a light aircraft into Belarus and drop a few hundred teddy bears holding a freedom of speech message in their paws. Lukashenka was so incensed that he expelled the Swedish ambassador, closed the Swedish embassy, sacked his foreign minister and the head of his airforce, sacked another general for good measure, and had arrested a young man who placed an image of the bears on his own website.

Judged by neighbourhood standards, Ukrainian elections are less predictable and its politics a little more pluralist. Governments and policy directions have changed more than once since the fall of the Soviet Union. In November-December 2004, when Ukraine's current President, Viktor Yanukovych, was implausibly declared the winner of the presidential election despite widespread reports of gross irregularities, public indignation was so great and effective that the result was finally overturned. Yanukovych was defeated in the re-run by Orange Revolution leader Viktor Yushchenko.

The coalition of Yushchenko and firebrand orator Yulia Tymoshenko, who became prime minister, soon fell apart. After a giddying series of political changes and a severe slump in 2009 because of the global financial crisis, popular support for the Orange forces fell away. At the next presidentials in early 2010, Yanukovych made a comeback, 
narrowly defeating Tymoshenko in the run-off. The Orange leadership, with its endless internal feuds and failure to implement promised reforms, had been a great disappointment to its supporters at home and abroad. And the disappointment was magnified by the deep economic slump caused by the Global Financial Crisis. But the Orange leaders had at least established and maintained a large degree of democratic freedom and propriety, as Yanukovych's victory itself demonstrated.

On taking power in March 2010, Yanukovych and his Party of Regions quickly converted a narrow victory into a near stranglehold on power by highly dubious means. Democratic freedoms were whittled away and opposition parliamentarians were bribed into joining the government coalition, enabling it to control the parliament. The powers of the presidency have been expanded with the compliance of the judiciary, whose independence has been systematically undermined. Key opposition leaders have been jailed on trumped-up charges to prevent them from presenting any kind of threat at future elections.

Yanukovych, who above all represents the more Russified east and south-east of the country, has taken several big steps towards closer alignment with Moscow. At the same time, he has continued to assert that membership of the European Union is his prime economic objective, and that he will not accede to the various post-Soviet multilateral organisations that Putin is pressing him to join. But the constant abuses of democratic principles have effectively put significant progress towards Europe out of the question, despite the technical negotiations for an association and free-trade agreement having been successfully concluded. The imprisonment of Yulia Tymoshenko, who is now being threatened with a further series of implausible charges, including one for alleged conspiracy to murder, is only the best-known of these abuses.

Despite Yanukovych's consolidation of autocratic control and his free use of administrative resources and legal chicaneries to neutralise the battered Orange forces, it still seems possible that the elections on 28 October could produce another changeover in parliament. Opinion polls show the Party of Regions and the united opposition party list, led by Tymoshenko and former foreign minister Arseny Yatseniuk, running neck-and-neck. Much will depend on how successfully the 
regime can use its access to the machinery of government to massage the vote, and whether other parties that win seats choose to ally with Regions or the opposition.

Money often buys support in Ukrainian politics, and Regions has more of it at its disposal. One smaller party, Forward Ukraine, which broke away from Tymoshenko's bloc, has been running an intellectually vacuous campaign ('new people for a new country') backed by extremely expensive advertising. It has latterly recruited as a candidate Andriy Shevchenko, Ukraine's world-class soccer star, who joined the party soon after an audience with Yanukovych. The party leader, Natalia Korolevska, claims that they are a true opposition party, but it is far from clear where their money is coming from, and most expect them to do a deal with the Party of Regions as soon as the elections are over.

Another sporting hero, world heavyweight boxing champion Vitali Klitschko, is also leading a party that seems destined to win quite a few seats. Klitschko sounds more oppositionist than Korolevska, but he has maintained some ambiguity about his future intentions.

If Yanukovych is able to cobble together a clear win in the elections, or assemble a financially lubricated coalition after them, it seems likely that what remains of Ukraine's democracy will be under serious threat.

In Moscow, after the humiliations and anxieties of the parliamentary and presidential elections, during which he was booed in public and street demonstrations became almost commonplace, the old Putin has re-emerged with most of his customary self-confidence restored.

The recovery in his demeanour was slower than might have been expected. His formal inauguration was held during a quiet time in early May, with his motorcade's route to the Kremlin sealed off from ordinary Moscow residents and protesters. The televised event made the city of some 13 million look eerily like a ghost town. Elsewhere in the city, scuffles broke out between smallish groups of opposition supporters and police, as had happened on the day preceding the ceremony.

Since then, though, the Kremlin has undertaken a consistent campaign to cow the opposition and get its members permanently off the streets. Prosecutions, house searches and confiscations of property relating to 
the May street clashes are continuing. Despite its own embarrassments, the ruling United Russia party has regained its vigour and resumed doing what it does best, guaranteeing that legislation required by the Kremlin is passed in quick time with scant regard for procedural niceties. Some members of the tame parties that are allowed into the Duma have put up a bit of a fight but have been swept aside.

Draconian penalties (US $\$ 9,000$ - roughly equivalent to the average Russian's yearly income) were legislated for anyone participating in an unauthorised public demonstration, or breaching the conditions of authorisation. The new penalties for organisers are even more severe, rising to US\$30,000 for any groups involved.

Libel and slander have been recriminalised, a rebuff for Dmitry Medvedev - former president, now prime minister - on whose watch such offences had been decriminalised only a few months earlier. Like many Russian laws, this is likely to be an instrument of 'selective justice', wielded against those identified as enemies of the regime.

Another new law subjects the internet to close invigilation and sanctions, including the summary closing of websites, ostensibly to protect the young and vulnerable from pornography and the like, but with ample scope to be used against websites critical of the regime. And any NGOs that receive money from abroad must register and declare all such sources, and identify themselves publicly as 'foreign agents'. With its strong Stalinist redolences, this tag should suffice to make most Russians wary of having anything to do with them. Other such measures are reportedly under consideration in United Russia's suddenly hyperactive law-making circles.

Putin's determination to stamp out opposition was also reflected in the recent trial of three members of Pussy Riot. The arts and entertainment communities have turned against him in recent years, and the Kremlin clearly judged that the group was a suitable target to be made an example of. Putin's faithful allies in the Orthodox hierarchy (Patriarch Kirill is widely believed to have been a collaborator of the KGB since Soviet times) called for the young women to be punished appropriately, and most of Russian society also strongly disapproved of their antics in the Moscow Cathedral of Christ the Saviour. In fact, 
the three young women disported themselves there for only 40 seconds before cathedral officials removed them; most of the impertinence was spliced in later.

As time went on, the public, including Orthodox believers (not a huge group within the Russian population - many identify as Orthodox, but only a small minority are devout or observant) began to feel that the accused should not be punished too severely. The legal basis for the trial was manifestly shonky and international condemnation became intense. Even Putin himself, who was undoubtedly angered by their call on the Virgin Mary to 'drive him away', seems to have had second thoughts - or at least affected to have second thoughts as he observed international reactions - and expressed the disingenuous hope that they might not be punished too severely. Whatever the propaganda value domestically, the trial was clearly becoming severely damaging internationally. As Stephen Sestanovich, the distinguished Russian expert and former senior official in the Clinton administration remarked in commentary on the trial, 'Russia has not seemed as unattractive or unappealing as an international player in a long time'. ${ }^{2}$

Another target of Putin's wrath has been Ksenia Sobchak, the daughter of his former boss and close friend, Anatoly Sobchak, the Yeltsinera mayor of St Petersburg. Ksenia is widely rumoured to be Putin's goddaughter (though she has denied it). A glamorous and successful media personality and socialite, she has in recent months emerged as an oppositionist. As a reward for this public-spirited makeover she has been removed from her roles in the state-controlled media, but has become a star on the internet, gradually overcoming the initial mistrust of other, more longstanding, opposition activists.

Along with other leading opposition personalities, she was subjected to a sudden house search by police early on the morning of 11 June 2012. The police, who were obviously expecting to find her current live-in boyfriend present, read aloud love letters they found in her flat and confiscated over US\$1 million in cash.

2 See Stephen Sestanovich, 'What's at stake in Putin's Culture War' (interview with Jeanne Park), Council on Foreign Relations, 17 Aug. 2012, www.cfr.org/russian-federation/stake-putinsculture-war/p28814. 
The purpose of this operation was to show the Russian public that oppositionists are very wealthy, probably thanks to their treacherous contacts with Western organisations, and that they lead enviably dissolute lives. There is a Russian saying to the effect that a peasant is happy to be poor as long as his neighbour doesn't prosper; envy has been one of the emotions Putin's election campaign and recent policies have used to excite popular resentment against his middleclass opposition.

Putin's longstanding family friendship with the Sobchaks makes it likely that Ksenia's selection as a victim of this operation was cleared with Putin; Ksenia's mother, Lyudmila Narusova, is the widow of Putin's former mentor, the one-time mayor of Petersburg Anatoly Sobchak, at whose funeral he publicly wept. Narusova is a member of the upper house of the Russian parliament, where she too is under official fire for opposing recent authoritarian legislation.

Repressive action has also been launched against two other leading oppositionists: Aleksey Navalny, the anti-corruption blogger and author of the politically effective phrase 'party of swindlers and thieves' to describe United Russia; and Gennady Gudkov, a Duma deputy from the tolerated opposition party A Just Russia. Navalny has been charged with stealing a large amount of timber in a period when he was working as an adviser to a liberal and ex-dissident provincial governor. The charges have been used against him in the past but collapsed, even in Russia's accommodating judicial system. This time they may be forced to succeed, leaving Navalny facing a possible 10 years' imprisonment.

Gudkov, who has been the most active oppositionist in the Duma, has been charged with owning a private business - which has suddenly become an offence for public officials - even though he divested himself of any managerial responsibility. Many United Russia deputies are known to be in the same position, but no charges have been laid against them. Gudkov, curiously, is an ex-KGB colonel like Putin, but his recent activities would have struck the president as a case of inexcusable treachery to his former service.

Internationally, a major factor contributing to Russia's image problem has of course been the Kremlin's determination to protect the Assad regime in Syria as it continues to slaughter its domestic 
adversaries in a sectarian cause. More generally, Putin has continued the anti-American and anti-Western animus of his election campaign pronouncements. Disregarding the fiscal objections of his old comrade, self-exiled former finance minister Aleksei Kudrin, Putin has returned to his election theme of a huge arms buildup with a new/old twist: as in the Stalin years, to which he often looks back with nostalgia, he argues that a buildup would catalyse a new flowering of industry and technology in the country.

Even with oil prices as high as they currently are, Russia's public finances are vulnerable; in the absence of any plausible enemy, the buildup makes little financial or strategic sense. Yet Putin is planning to sink an additional US $\$ 970$ billion into defence equipment by 2020 , with an increase in overall defence expenditure of about one third by 2014 .

Western leaders enjoyed the four-year holiday from Putin while the more emollient and liberal-sounding Medvedev was supposedly the custodian of Russian foreign policy. Some even appeared to genuinely believe that this was the case, or at least to behave as though it were, in the hope that this would somehow help Medvedev to grow into the job. But he either could not or chose not to.

Following on from his humiliation last September, when he had to announce publicly that he would vacate his post in favour of Putin because of Putin's superior merits, Medvedev has now had to endure attacks on his courage and competence in handling the outbreak of hostilities with Georgia in August 2008. In an internet documentary marking the fourth anniversary of the war, a group of retired generals blame him for his allegedly slow and hesitant response which, they claim, cost lives. They take the opportunity to praise Putin for having administered a kick to those in Moscow who were holding the high command back from getting on with the task. Putin has also made public statements implying that, though he was away at the Beijing Olympics at the time, he nonetheless stayed in touch with (read: in control of) events by telephone.

Though he is still prime minister, Medvedev's position looks weaker than ever, as Putin builds his Presidential Administration into a dominant force that is able to second-guess or overrule ministers and ministries as required. Some economic liberals still remain in the 
upper reaches of the elite, and many in governing circles are thought to be unhappy about Putin's repressive course domestically and his belligerence on the international scene. But for now they don't seem to be exerting much influence.

So Western leaders are stuck with Putin, possibly even for 12 years, and while there is not a great deal they can do about it, they clearly are not enjoying the prospect. Even Germany - where Putin spent his only foreign posting with the KGB (in Dresden, East Germany) and where his interpersonal skills and strong command of the language won him a good deal of initial sympathy after he became president - seems to be tiring of him. The economic links will undoubtedly remain very strong, but Chancellor Angela Merkel and President Joachim Gauck, both East Germans, clearly find him distasteful. And the German press has become sharply critical. Der Spiegel reported that, on his last trip to Germany, Putin forced Merkel to wait for an hour for a meeting with him. This curious form of discourtesy towards foreign interlocutors seems to have become more frequent - he recently infuriated the Ukrainian leadership by keeping Yanukovych waiting for five hours in Kyiv for a bilateral meeting while he met with a group of Russian nationalistic bikies in Crimea.

US ambassador Mike McFaul, a key architect of Obama's 'reset' policy towards Russia, was subjected to months of crass harassment earlier this year, clearly officially inspired and publicly and coarsely endorsed by the Russian Foreign Minister. If Obama is returned to office, and Putin's belligerence towards the United States persists, Washington's approach to Russia may become cooler, particularly once the US drawdown of forces from Afghanistan (for which Russian cooperation is important) is well advanced. If Obama is defeated, a Republican administration's approach is likely to be very different, as the team behind presidential candidate Mitt Romney has already signalled.

Having embarrassed their reset partner Obama with sustained public anti-Americanism through the Russian election season and since, Putin and his spokesmen have now joyfully grasped Romney's tough campaign pronouncements about Russia, which were made in response, as proof that they were right to see the United States as a dangerous enemy in the first place. 
Moscow was recently buzzing with excitement about a new report produced by the Minchenko Consulting Group, based on interviews with experts and well-placed figures in the elite, which sought to analyse how Putin's inner leadership circle operates. According to the report, this 'politburo', as it is described, contains key oligarchs and others who are hardly household names in the Western media. Putin is described as a primus inter pares - first among equals - an arbiter who settles all disputes that arise between the various competing clans and factions but does not enjoy a position of complete dominance. Surprisingly, the consensus of the Minchenko group seems to be that Medvedev remains a significant player with some prospects for regaining greater influence.

The biggest sensation in the report, perhaps, was that the inner circle allegedly envisages the possibility of a crisis arising in which it might become necessary to change the leadership. Depending on the circumstances, the decision might be to entrust the country and the elite's joint fortunes either to former finance minister Kudrin, an economic dry and political moderate, or to the belligerently antiWestern Deputy Premier responsible for defence industry matters, Dmitry Rogozin, a talented populist with KGB connections and strong support from Soviet nostalgics and hardline nationalists. On the face of it, Kudrin is still out in political no-man's land, running a think tank that produces statements and reports critical of the regime and calls for dialogue with the opposition. Rogozin's likely approach as leader would be the diametrical opposite of Kudrin's.

Some might think that the report underestimates Putin's position, while overestimating Medvedev's. Putin is more than an arbiter deriving his power from his role in keeping powerful warring clans apart. Russia has a history of powerful supreme leaders into which Putin fits nicely. Capo di tutti capi, or boss of bosses in a disreputable gang, would probably be a more accurate term than primus inter pares, with its prime ministerial connotations. One also wonders whether a change of leadership could really be brought about coolly and rationally in quite the way suggested by Minchenko. But the report is probably indicative of a certain turbulence close to the surface of Putin's third term. 
Will the move against the opposition result in mass repression, or only the imprisonment of some on trumped-up criminal rather than explicitly political charges? Outside Chechnya and its neighbours in the mainly Muslim-populated region of the North Caucasus, where there is a slow-burn insurgency, Putin has largely sought to avoid bloodshed in dealing with domestic opponents. Inconvenient individuals have frequently been killed by 'unknown assailants' and the crimes never satisfactorily explained or resolved. And at the very beginning of Putin's ascendancy in Moscow, just after his period at the head of the Federal Security Service (FSB), the main successor to the KGB, a series of mysterious bombings of apartment buildings in Russia, officially attributed to Chechen terrorists, caused heavy loss of life. These events remain murky. Many observers have concluded they were a provocation staged by the FSB.

Generally, though, Putin's rule has been a soft or consensual autocracy resting on his authentic popularity as well as on manipulation and coercion. Now that his popularity seems to be fluctuating downwards, a greater degree of force may be deemed necessary to strengthen the 'power vertical'. ${ }^{3}$ My sense is that Putin will try to make telling examples of particular individuals who have earned his wrath but will avoid mass repression. It is hard to feel confident, though. There are anxious rumours circulating, for example, that recent steps taken or threatened against officials with private businesses or property abroad could morph into a wider purge of the bureaucracy.

Putin's recent political travails have left him eager, at the very least, to reinforce his power and end the indignities that he's been forced to suffer in the past year or so. As his legislation moves from autocracy towards the police state paradigm, the leader too may transition from autocrat towards dictator. Fear is never too far away in Russia, and many once venturesome public commentators can now be seen hedging their bets with respectful references to Mr Putin as a very intelligent man, who may, they hope, decide to become another Stolypin, and so on. ${ }^{4}$ Putin seems to like this comparison (despite the fact that Stolypin's career ended in assassination), so those seeking his

3 See Andrew Monaghan, 'The Russian Vertikal: the tandem, power and the elections', Jun. 2011, Chatham House Russia and Eurasia Programme Paper, www.chathamhouse.org/sites/files/ chathamhouse/19412_0511ppmonaghan.pdf.

4 Pyotr Stolypin was the Tsarist prime minister, 1906-11, who ruthlessly suppressed disorder, but pursued small ' $\mathrm{l}$ ' liberal reforms. 
favour probably see it as the way to his heart. But on his record, one would have to say that just as Dan Quayle was no Jack Kennedy, Putin is no Stolypin.

Commenting recently on Putin's latest macho stunt (assisting a group of threatened Siberian cranes to return to the wild), Gleb Pavlovsky, a one-time insider, observed that the optics of this operation were unfortunate. Bloggers had been unkind, one insider even claiming that some of the cranes had died or been injured during preparations for the hang-glider flight, though this item was quickly removed. In Pavlovsky's view, Putin should have been advised against making this mistake. But 'now there is no one who would tell him "Ne nado Vladimir Vladimirovich" ["Best not, Vladimir Vladimirovich"]'. Pavlovsky's comment about the absence of any effective opposition to Putin's political impulses within the regime is probably applicable to all issues, not just endangered cranes.

Putin is clearly increasingly exercised by the growing tensions in society. One matter of particular concern to him is Islamic militancy. In recent weeks the once nationalist, but now increasingly Islamist, turbulence that is endemic to the North Caucasus region has suddenly manifested itself in violence against moderate clerics in Tatarstan, a mixed but mainly Muslim-populated republic on the Volga in the Russian heartland. Tatarstan has been regarded till recently as a multicultural success story, where Russians and Tatars lived together in harmony.

This is an ominous development for Putin and for Russia. If pressed, Putin might well argue privately to a European critic of his domestic regime that Russia, with its 15 per cent Muslim population and other potential ethnic stresses, faces a much more serious problem of social cohesion than any Western European states. The presence of Muslim immigrant communities in Western Europe that are much smaller than Russia's, he might argue, has nonetheless led to the emergence of virulent anti-immigrant movements and parties that have sometimes entered governments. Should Russia proceed along that path, he might ask rhetorically.

5 See 'Gleb Pavlovskii: Putin stavit kakoi-to novy spektahl', Vlasti.net, 11 September 2012, vlasti.net/news/149409. 
But the radicalisation of Muslim ethnic minorities in Russia has been greatly facilitated by the brutal war in Chechnya and indiscriminate use of force in the North Caucasus region generally during Putin's ascendancy. Moreover, in the past Putin has often flirted with Russian nationalism in various forms. Lately it has become clear that he sees some dangers in enfranchising that phenomenon. Nationalism, however, remains a pillar of his domestic support and one that could be exploited by potential rivals like Rogozin if Putin seemed to be renouncing or downplaying it. While continuing to push Russian 'patriotism', he is trying to soften its edges, and is increasingly inveighing against nationalist extremism of any sort. The country's burgeoning right-wing Russian extremist movements have at last been encountering more pushback from the security services. But the genie seems to be out of that bottle.

Domestic developments in Russia do not seem particularly propitious at present for a smooth transition to a more open, pluralist and tolerant society, despite the growing pressure for such an evolution coming from the urban middle classes. Similarly, a more authentic 'Europeanisation' of Russia, despite the greatly increased people-topeople contacts of the last 25 years, does not seem to be imminent. As well as his domestic policies, Putin's foreign policy seems to stand in the way. And the unending eurozone crisis or crises have done much to reduce Europe's attraction as a role model. Europe's declining influence is evident not only in Putin's periodic slighting public references, but also in the attitudes of his counterpart autocrats in Ukraine and Belarus. 


\section{0}

\section{Towards a greater Putistan? Part $2^{1}$}

Since announcing his intention to reclaim the Russian presidency, and especially since the outbreak of public demonstrations in late 2011, Vladimir Putin has been pursuing a hard line both domestically and externally. At home he is strengthening his 'power vertical' by reinforcing his instruments of control and repression at all political levels and doing away with the wishy-washy liberal rhetoric of his placeholder predecessor as president, Dmitry Medvedev. Externally he is pursuing the anti-American and anti-Western line that he adopted in his second term as president (2004-08), also stripped of the more emollient accents of Medvedev.

The urban revolt against Putin and his system has largely run out of steam for the time being. Discouraged by the failure to win any concessions from Putin, and probably deterred by the recent spate of repressive legislation, dwindling numbers are turning out for street demonstrations. Though in his last months as president, Medvedev tried to respond to the unrest with liberal reforms to the electoral system, his successor has gutted virtually all of them.

\footnotetext{
1 First published in Open Democracy, 4 Oct. 2012, www.opendemocracy.net/john-besemeres/ towards-greater-putistan.
} 
But Putin and his system are no longer sacrosanct, and dissidence continues to spread on the internet and in local communities fed up with the Kremlin's incompetence and venality. A further crackdown on the internet is likely (a move to ban YouTube from Russia is mooted, for example). But, despite the growing repression, unrest could be reignited by a sharp economic downturn, some spectacular scandal or disunity within the elite (an outbreak of overt conflict between Putin and Medvedev's more liberal government, for example). If that occurs, Putin could respond harshly.

A particularly important, if not the most important, foreign-policy objective for Putin is to build the existing rather feeble post-Soviet multilateral institutions into something he has called - by misleading analogy with the European Union - the Eurasian Union. Within this proposed bloc, Putin wants Moscow (led by his St Petersburg coterie) to play the role of both Brussels and Berlin. His aim is to bring in as many former republics as he can muster by using a mixture of persuasion and coercion (mainly economic, but he is also embarking on a very ambitious military buildup).

Kazakhstan, with its large Slavonic minorities, has joined the Customs Union and has maintained productive relations with Russia, but is also strengthening its ties with China and the West. Russia continues to have hopes of greatly expanding its influence in other former republics, such as Georgia; hopes that have been boosted by the parliamentary elections on 1 October in which the strongly proWestern and anti-Russian government of Mikheil Saakashvili was defeated (and a similar outcome could occur in the elections of 14 and 28 October in Lithuania).

A struggle for influence is taking place in Moldova, where the proWestern coalition government is making a determined effort to seek integration with Europe. On 11 September, Moscow delivered a public warning to the visiting Moldovan Prime Minister, Vlad Filat, that, if Moldova wanted to pay less than the current US $\$ 392$ per thousand cubic metres for its gas, his government would, in effect, have to renounce its Western orientation. Moscow is also holding Moldova responsible for the US $\$ 3.5$ billion gas debt of Transnistria, a breakaway pro-Moscow province, which Russia has been cosseting, supporting and controlling for the last two decades. The European Commission President José-Manuel Barroso quickly responded to Moscow's 
ultimatum with a declaration that an Association Agreement (AA) between the European Union and Moldova could be signed by 2013. Meanwhile, Moldova's opposition pro-Moscow Communist Party is pressing for a referendum on joining the Eurasian Union.

Moscow is fighting a long-term positional battle for influence in most of the other former republics, with mixed and fluctuating fortunes. But the possibility that it will consider applications to join the Eurasian Union from countries further afield cannot be ruled out. There is some sentiment in both Russia and Serbia in favour of Serbia's becoming a member. The new president and government that came to power in Serbia earlier this year are markedly more pro-Russian than their predecessors. While for economic and electoral reasons they continue to emphasise their desire for European integration, this project could come unstuck over Kosovo or some other issues.

Both Serbia's President Tomislav Nikolić and Prime Minister Ivica Dačić have interesting pasts - Dačić as former president Slobodan Milošević's party spokesman and Nikolić as deputy leader of an extreme nationalist party - but both emphasise they are now proEuropean. Nonetheless, during his two visits already to Moscow since becoming president in May 2012, Nikolić has embarrassed some of his fellow countrymen with his expressions of love for Russia. 'The only thing I love more than Russia is Serbia', he announced at one point. This and other Nikolić statements - including his apparent denial of the Srebrenica genocide - could yet cause serious trouble in Brussels, potentially opening the way for increased Russian influence.

But, within Putin's plans, a crucial role is accorded to the two Slavonic former republics of the Soviet Union, Ukraine and Belarus, which have many ethnic, political and cultural links with Russia. If they were to form a stable alliance or, better still from Putin's point of view, confederation with Russia, Moscow would be at the head of some 200 million people, with much of the industrial capacity of the old Soviet Union again under its leadership. Individually and as a group, these three countries pose thorny dilemmas for Western policymakers.

And none more so than Russia. Even when Moscow doesn't deliver on such important issues as Iran and Syria, the United States still sees the need to struggle for its support in the UN Security Council. Because of its difficult relationship with Pakistan, Washington's forces in 
Afghanistan rely on logistic support both from Russia and from former Soviet republics Kazakhstan, Kyrgyzstan, Tajikistan and Uzbekistan - where any American presence evokes strong objections in Moscow. And Obama's nuclear-disarmament agenda, which is a high priority for the President though not for Putin, depends crucially on Moscow's cooperation.

The US administration has played down the differences over Russia's incursion into Georgia in 2008 and the role of human rights in the bilateral relationship, and has modified its missile defence plans for Eastern Europe in deference to Russian sensitivities. But Moscow continues to argue that the missile plans are a deadly threat that is forcing it to rearm comprehensively, at the same time declaring that it could easily dispose of the installations and will target them preemptively in any future conflict.

The Kremlin has also threatened former vassal states that make decisions about their own defence of which Russia disapproves. And both the chief of the general staff, Nikolai Makarov, and (less bluntly) Putin recently threatened Finland with retaliation in the event of its pursuing any degree of military cooperation with NATO. Makarov even queried why Finland should have military exercises on its territory at all, demanding to know against whom such exercises were directed and asserting that Finland should instead cooperate militarily with Russia.

Finland and the other Nordic states have been disturbed by the increased regional deployments and exercises that Russia has undertaken under Putin's ascendancy, as well as by its frequently threatening language. They were also unfavourably impressed by the heavy pressure unleashed against Estonia in April 2007 - including an apparent cyber-attack on Estonia's highly computerised government infrastructure - when the government in Tallinn had the temerity to relocate a statue commemorating the Soviet 'liberators' of Estonia from a central square in the capital to a military cemetery.

Washington has responded to pressure of this kind by acceding to Eastern European requests for a more visible NATO military presence. Again in deference to Russian sensitivities reflected in the 1997 NATO/Russia Founding Act, Washington and NATO long refrained 
from placing significant hardware or conducting military exercises in the region, but that policy has now been modified. The Obama administration has also been reluctant to export arms to Georgia since the conflict with Russia, despite the fact that Moscow has been militarising the territories it detached from Georgia after its invasion.

Back home, the Obama administration has done its best to persuade Congress to repeal the Jackson-Vanik Amendment - a restrictive trade provision routinely waived by the President - in accordance with World Trade Organization rules, now that Russia has finally joined the organisation. (US support and assistance, including helping to short-circuit a threatened Georgian veto, helped facilitate Russia's membership.) And it has sought to head off the strong pressures in Congress for sanctions against Russia over a spectacular case of corruption involving high-level officials acting against a foreign-owned company in Moscow; and over the imprisonment and suspected murder of Sergey Magnitsky, a Russian lawyer employed by the company, who blew the whistle on the affair.

While he was still in the presidency, Medvedev made a typically ineffectual attempt to look into the Magnitsky case. But that led nowhere, and the Kremlin has responded to international complaints with bluster and threats of counter-sanctions. Unwisely perhaps, though also not surprisingly, Congress has dug in its heels and still not repealed Jackson-Vanik. For his part, Mitt Romney has come out in favour of introducing Magnitsky sanctions as a precondition for repealing the amendment. More bilateral turbulence on this and other issues can be expected.

On 19 September, Moscow announced that it was expelling the US Agency for International Development (USAID) from Russia, demanding that it close its doors by 1 October; i.e. in less than a fortnight. USAID supports some 57 Russian NGOs concerned with human rights, election monitoring, Aids prevention, disability support, governance and environmental issues. GOLOS (Voice), the Russian volunteer election-monitoring group that earned Putin's rage and indignation during the electoral season, is among the organisations funded by USAID, and will find its work much more difficult without its support. Russian oligarchs will not be risking their fortunes to support them or any of the others. USAID activities and outlays in Russia have been declining under the Obama administration and the 
administration's response to this development was characteristically mild and forbearing. But this looks like yet another Putinist punch in the eye for the 'reset' in relations between the two countries.

In Europe's relations with Russia, the central underlying geopolitical issue is probably the fact that, to a greater or lesser degree, Russia has still not accepted the sovereignty of the countries that it used to dominate in Eastern Europe. Given their historical experience of Moscow's attentions, those countries feel understandably anxious, and have very often sought reassurance in EU and/or NATO membership and support. To the extent that they are successful, Russia declares itself threatened and takes countermeasures; and so the cycle continues.

Russia wants to re-establish influence, if not control, over as much as it can of the territory it once dominated; and it is prepared to do so by political infiltration, using its energy exports as a geopolitical tool, exploiting Russian minorities or applying military pressure, at times including nuclear intimidation. It is an awkward neighbour.

Moscow's energy diplomacy is best exemplified by the operations of its national gas corporation, Gazprom. Gazprom's primary role is not to make a profit, though it has often done that, but rather to set prices, build or dismantle pipelines, and satisfy or not satisfy customers, all in such a way as to further the president's geopolitical objectives. It is a subject close to Putin's heart: in a remarkably short time in the mid1990s, he wrote (or as some have suggested, commissioned) a thesis on the optimal management of national resources. Energy diplomacy has brought both Belarus and Ukraine to heel in the recent past, and Moscow is doing all it can to ensure that it remains an effective weapon.

But now it has begun to encounter some pushback. The European Union and individual EU countries cooperated with Gazprom projects for many years, and some still do. But in 2004, with the acceptance into the European Union of former Soviet-bloc countries that are heavily dependent on Russian energy imports, the tide began to turn. Moscow's subsequent 'gas wars', especially those against Ukraine in 2006 and 2009 with their collateral damage for Western European consumers, increased Europe's disquiet about Gazprom's hardball tactics. 
On 27 September 2011, European Commission officials raided a series of Gazprom-connected firms in 10 EU countries, seeking evidence that Gazprom was in breach of anti-trust laws. A sensational sequel came when Brussels announced on 4 September 2012 that it was launching an anti-trust case against the Russian giant. Gas is not the only commodity that Russia uses as a geopolitical weapon, but it is the main one; so this is a significant volley across its bows. The prima facie case seems strong: Gazprom's prices in Europe vary wildly, reflecting Moscow's view of the country in question. The prices are often discreetly withheld from public view, but Belarus is understood to be paying around US\$165 per thousand cubic metres while Poland, for example, is paying well over US $\$ 500$.

Putin has responded to the announcement with characteristic pugnacity, declaring that Russia would not subsidise Eastern European countries on behalf of Brussels, and issuing a hasty decree forbidding Gazprom or other 'strategic' Russian enterprises from providing information to EU authorities on any such matters without the regime's explicit approval. He also announced, with heavily implied menace: 'In Asia they are waiting for us.'

Putin has deployed threats to redirect Europe's gas to Asia many times before, but of course Russia's pipelines (Gazprom has been very slow to embrace LNG) are not easily redirected. And Putin knows all too well that his 'strategic partner', China, has been wary of allowing itself to become dependent on Russian energy, and also drives a much tougher bargain than any European country. It is clear, however, that Russia's relations with the European Union on this and other topics could be in for another torrid time.

Where do Ukraine and Belarus fit into this pattern? Russia's attitude can be summed up very briefly: it wants them back. Putin once said, very quotably, that the collapse of the Soviet Union was 'the greatest geopolitical catastrophe of the twentieth century'. Many ethnic Russians living both inside and outside Russia would agree with him. Though large numbers of them migrated to Russia from the former Soviet republics after 1991, there is still a heavy concentration of Russians and Russian speakers in several former republics, including Ukraine and Belarus. 
In Ukraine, a little over 8 million of the country's 45 million (or 18 per cent) identify as ethnic Russians. But a larger proportion (around 30 per cent) give Russian as their native language to censustakers, something approaching half tell researchers that they use Russian at home, and a much larger percentage again are fluent in Russian. Of Belarus's 9.6 million, about 8 per cent identify as ethnic Russians and fully 70 per cent acknowledge Russian as the language they speak at home. In both countries, Orthodoxy is clearly the strongest religion. Despite the turbulence and violence of the region's history, public attitudes towards Russia remain broadly positive, reflecting much common experience and shared culture. Putin has enjoyed very high popularity ratings in both countries, higher at times than any local politicians.

But there are important differences between the two countries. In Ukraine there is a much stronger attachment to the native language and to the country's distinct cultural traditions. Most Ukrainians tell enquirers that they are not religious or do not clearly identify with a particular group. Those who identify as Orthodox are divided among the Moscow Patriarchate (about 30 per cent), the more nationalist Kyiv Patriarchate (formed in the early 1990s after independence 40 per cent) and the Autocephalous Ukrainian Orthodox Church (about 3 per cent). Greek Catholic or Uniate Christians (15 per cent) are concentrated in the west of the country, where historical connections to Russia are weakest and attitudes generally hostile to Moscow.

A strong majority of Ukrainians tell pollsters that they favour Ukrainian independence (which they voted for resoundingly in 1991). But Ukraine is also the country Russians most regret losing, with Kyiv widely regarded as the historic heartland of their state and of national culture. As President of Russia, Boris Yeltsin found it politically expedient to agree to the secession of Ukraine and Belarus in December 1991, but most Russians probably still find it absurd that Ukraine has somehow become a separate country, complete with the Crimean peninsula and access to Russia's Black Sea Fleet. As Zbigniew Brzezinski once said, also very quotably: 'without Ukraine, Russia ceases to be an empire'. ${ }^{2}$

2 See Zbigniew Brzezinski, 'The premature partnership', Foreign Affairs, Mar./Apr. 1994, www.foreignaffairs.com/articles/russian-federation/1994-03-01/premature-partnership. 
Putin has been at pains to draw Ukraine back into close communion with Mother Russia. In 2004, he overtly interfered in the presidential election, strongly supporting Viktor Yanukovych who, as he rightly judged, was much more pro-Russian than his Western-leaning rival Viktor Yushchenko. But Yanukovych's fraudulent victory was overturned by popular resistance, with some involvement from the judiciary and - mediated by the Polish and Lithuanian presidents from the European Union. This treacherous involvement of former vassals enraged Putin, who always sees a political reverse anywhere in the former Soviet Union as the product of Western plotting, not popular will. He had nonetheless learnt a lesson: during the 2010 presidential election in Ukraine he kept his distance, at least on the surface, and Yanukovych won with full international acceptance.

In the current election cycle in Ukraine, both Moscow and Putin personally have been discreet, though their sympathies are obvious. Yanukovych awarded Russia a series of major unilateral concessions early in his term as president, most notably striking a deal on allowing Russia guaranteed access to its naval and security facilities in Crimea until the 2040s. But Putin has mixed feelings about Yanukovych because, when it became apparent that Russia was not planning to reciprocate with more than a temporary cut in the price of its gas, he became stubborn and started playing his Western/EU card more frequently, something Ukrainian leaders often do to ward off Russian pressure or strengthen their leverage.

As the price of gas resumed climbing, reflecting the rising cost of oil (the two typically being linked in Gazprom contracts), Ukraine desperately sought further price relief. Innumerable meetings have been held to discuss the subject, but each time Russia has insisted that concessions would only come if Kyiv agreed to sell its gas pipelines to Russia and join Moscow's Eurasian Customs Union (to which only Belarus and Kazakhstan have signed up so far). Putin continues strongly encouraging Kyiv to consider how much it is paying as a nonmember of the union (US $\$ 425$ per thousand cubic metres) contrasted with how much Belarus pays (US\$165).

Meanwhile, Moscow continues to push its South Stream gas pipeline project, which, like the Nord Stream pipeline under the Baltic, is designed to bypass Ukraine and other unfavoured states. Moscow's purpose is to deprive these governments of their transit fees and 
negotiating leverage, and to ensure that Russia is able to cut off their vital gas supplies to enforce its will while still servicing important customers like Germany and Italy further afield.

I recall a prominent Russian economist recounting how he and others like him had sought to remonstrate with Russian policymakers about the huge and, as they saw it, unnecessary costs of the bypass gas pipelines to north and south. They were told emphatically to back off; this was 'strategic'. The total costs are undoubtedly much greater than the alternative, an upgrading of Ukraine's and Belarus's ageing pipelines. But the Russians have turned a deaf ear to Yanukovych's pleas that they desist from constructing the new pipeline and invest instead in upgrading a friendly pro-Russian neighbour's infrastructure.

As the elections and South Stream's construction draw nearer, Yanukovych has shown signs of capitulating to Russian pressure. In August, he introduced a major change to Ukraine's language policy that greatly strengthens the position of Russian (something Moscow has long demanded, but which is extremely divisive within Ukraine). And, on 25 August 2012, on the margins of a meeting with Putin, he hinted broadly at his readiness to make unspecified concessions in exchange for cheaper gas.

One of Yanukovych's biggest problems is that he has all but burnt his bridges with the European Union, which further undermines his bargaining position with Moscow. Determined to rig the parliamentary elections in October more effectively than he did during his presidential bid in 2004, he has used his manufactured majority in parliament to change the electoral act to disadvantage the opposition and has restricted freedom of the media, particularly television.

To make doubly sure, he has prosecuted several of the previous government's ministers, including, above all, the former prime minister Yulia Tymoshenko (whom he only narrowly defeated for the presidency in 2010) and the former interior minister Yuriy Lutsenko. After lengthy periods in pre-trial detention that were disproportionate to the flimsy charges against them, both were duly convicted and sentenced to long prison terms. After both then appealed to the European Court of Human Rights, further charges were laid to ensure 
there would be a legal pretext for keeping them out of circulation beyond the elections if the court demanded their exoneration on the earlier charges.

The jailings are a misstep by Yanukovych on two grounds. While they have kept a formidable campaigner, Tymoshenko, off the hustings, they have also restored some of her erstwhile popularity and stimulated the opposition to work harder and cooperate better. And they are the clearest possible red line for the European Union and its member states. Brussels has repeated over and over again that the association and free-trade agreements laboriously negotiated and initialled with Kyiv will not be signed while Tymoshenko and Lutsenko remain behind bars.

But winning the election by whatever means was clearly more important to Yanukovych and his party than EU integration, despite his repeated claims that this was Ukraine's primary objective. He may be calculating that once his Party of Regions gets over the line he can make some magnanimous gestures to bring the deals with the European Union back to life. But if he does win the election by one means or another, he may decide his next objective should be to ensure that the opposition is disabled more permanently, which would attract a further reaction from Brussels.

Ukraine's difficult economic position means that it desperately needs financial support from somewhere. It was granted a US $\$ 15$ billion credit by the International Monetary Fund (IMF) in 2010, to be dispensed in several tranches, but the agreement was suspended because of compliance issues after disbursement of the second tranche and has not been renewed. Kyiv continues to try to extract further credits from the IMF, but without meeting the fund's tough conditions. Doing so would have affected the government's domestic popularity in the run-up to the elections. Again, this may be a matter that Yanukovych plans to come back to after the elections.

In the meantime, Ukraine is developing a number of credit arrangements with China that may, if all come to fruition, serve as a partial substitute for the IMF, as well as a warning to Moscow that Kyiv has other and worrying options. Russian banks (no doubt in consultation with the Kremlin) have also been more forthcoming than the IMF, providing Ukraine with credit facilities to help pay for its expensive gas imports 
from Russia. But clearly such loans have the effect of helping secure Ukraine's head in Gazprom's noose. Yanukovych knows he could get more from Russia if he were prepared to sell more sovereignty. While so far he is holding out, he seems to be weakening.

Belarus's President Alexander Lukashenka has also tried repeatedly, and with some success, to strengthen his freedom of manoeuvre by playing the European Union off against Russia. But despite intermittent family quarrels with Moscow, he has always been closer to Russia than any of his Ukrainian counterparts. And now he has backed himself into a corner. During the economic crisis into which his mismanagement plunged the country in 2011, he finally agreed to sell Gazprom the rest of Belarus's gas pipelines. He also appears to have agreed in principle to further privatisations of big Belarusian companies in favour of Russian purchasers. And he has not returned to the testy, even hostile relations with Russia that prevailed in the period leading up to the December 2010 presidential elections.

Since Boris Yeltsin's time in the later 1990s, Belarus and Russia have ostensibly been working towards some kind of unification. The Union State of Russia and Belarus, created under a different name in 1996, has passed through several mutations, but it has never amounted to much. Russia has always expected subordination, whereas Lukashenka, for all his Russophilia and intermittent enthusiasm for the project, was clearly only prepared to agree to unity if it involved a very senior position for him, perhaps even as president of the new entity. There is activity and enthusiasm from Lukashenka again on this front, however, and it can't be ruled out that progress might be made.

Lukashenka's flirting with the European Union has probably always been entirely cynical, intended only to gain ad hoc goodies and greater leverage in his dealings with Russia. Periodically, Brussels has held out inducements for him to embrace democracy, rule of law, human rights and so on, but with little success. Lukashenka's domestic regime has been so retrogressively Soviet that even Putin, himself something of a Soviet nostalgic, views both the President and his regime as slightly pathetic. Ideally, Lukashenka would like to see the return of some Soviet world in which he was the leader and the resources of the entire bloc were available for import into Belarus at bargain prices. 
In their bilateral dealings, Putin has usually tried to pursue Russia's pragmatic national interests. His recent resumption of generous subsidies for Belarus's unreformed economy, which extracted it from its 2011 slump, was timed to pull Lukashenka back onto the reservation. But in the near future, Minsk will be under great pressure to sell its crown jewels to Russia and embrace some Russian-led economic reform. At that point, Lukashenka may revert to holding out his cap to Brussels, but it could be hard for him to play that game again.

During the first half of 2012, Belarus's export performance and balance of payments position underwent a mysterious improvement. Lukashenka also chose again to distribute wage increases to voters to improve the pre-electoral atmosphere. It seems that this further apparent economic top-up to what Moscow's tactical generosity had already given him resulted from a scam Lukashenka had employed against his Russian benefactors. Having access to Russian oil imports free of export duties at preferential prices for domestic consumption, Belarus had been processing and refining a substantial proportion of the oil and re-exporting it at a big mark-up, disguising it as solvents and diluting agents. When it became apparent that Moscow was onto this scam, Lukashenka appears to have attempted a similar manoeuvre in exports to Ukraine.

But the game is up. As the relatively independent Nezavisimaya Gazeta commented:

Moscow is dealing with this problem quietly ... but is not intending to let Lukashenka off the energy hook. His dependency will be longterm, and he must settle accounts for the subsidies he has received either by selling property in a best-case scenario, or in a worse one by surrendering his own grasp on power and the independence of his country. ${ }^{3}$

The scam, like the teddy-bear invasion, taps into the rich strain of farce, sometimes dark, that runs through public life in Lukashenka's Belarus. Speaking of farce, the parliamentary elections on 23 September have predictably resulted in yet another resounding win for Lukashenka's regime. Opposition representatives, who have been excluded from parliament since 2004, were again prevented from taking any

3 See 'Minsk prikidyvayet kak obmanut' soyuznika', Nezavisimaya Gazeta, 5 Sep. 2012, www.ng.ru/cis/2012-09-05/7_minsk.html. 
effective part in the contest. Some of Belarus's brutalised opposition parties decided to boycott the election from the outset; others did so demonstratively in the last days before the poll.

The Organization for Security and Co-operation in Europe (OSCE) observer mission severely criticised all aspects of the conduct of the election. A rival Moscow-led observer mission pronounced it fully kosher. It would be tedious to enumerate even the main abuses but, by way of example, over one quarter of all registered voters cast their votes before election day in voting precincts where there was often no independent supervision. Opposition groups said the turnout was overstated by about 20 per cent.

But for Lukashenka the splendid victory demonstrates that the deep economic and social malaise and the political unrest of 2010-11 have been overcome. And in a sense they have been - thanks to a mixture of Russian economic subsidies, relentless repression and society's own relapse into passive resignation. The only threat to Lukashenka's power at this point comes from Moscow. But that is a real one, with which no doubt he will now be forced to come to terms.

Lukashenka's regime is more dictatorial than Yanukovych's or even Putin's, though Putin's current course suggests Russia may be taking more and more leaves from the Belarusian book. What is clear is that the three regimes are moving progressively further away from the democratic and national promise of the early 1990s towards deepening autocracy, marked by high levels of corruption and repression, muffled public discourse, increasing estrangement from their European neighbours, and a regrouping - if at times acrimonious or reluctant around Moscow as their shared cultural capital.

Neither Lukashenka nor Yanukovych wants to be a provincial administrator in a Russian-dominated Eurasian Union. But that is the unavoidable logic of Lukashenka's attitudes, political system and unreformed economy. Yanukovych still tolerates greater pluralism at home, defends his independence more stubbornly and displays more interest in achieving some sort of European orientation. But that interest does not extend to European values. For him, as for Lukashenka, the most precious thing that Moscow offers is an external guarantee for his autocracy. Both of them also look with interest to 
China's potential as another munificent patron, whom they could hope to play off against Moscow without having to endure any hectoring about human rights and the like. China is displaying interest in these and other post-Soviet states and significantly building up its trading links with them. But that may still be a hedge too far.

Over the past two decades the European Union has managed, with a remarkable degree of success, to use the attraction of its model to integrate most of post-communist Eastern Europe. And, despite deepening 'enlargement fatigue', it is continuing to work with the tougher cases of the former Yugoslavia and the non-Baltic western republics of the former Soviet Union. It does not want - and its most eastern members emphatically do not want - to share a border with prickly autocracies falling in behind a rearming and increasingly nationalist Russian Federation.

Brussels has consistently left the door open for erratic wannabe members to turn over enough of a new leaf to qualify for some level of integration, and even potentially membership. It is prepared to reward those who show a commitment to taking on EU values and the acquis communautaire. It also reproves and sometimes sanctions countries that flout those principles. But as the new cases get harder and the European Union continues to struggle with its long-running internal crisis, its power to attract and the force of its sanctions become weaker, and Ukraine and Belarus seem to slip further away from its outstretched hand.

Some would argue that the European Union should try to reduce the two countries' dependency on Russia by bending its rules as far as it takes to draw them into some kind of integration, in the hope that the values might start to filter in at a later date. But, given the behaviour of the two regimes, it's highly unlikely that such pragmatic agreements, even if they could be reached, would be ratified by all EU members. For the moment a weakened Brussels seems to have no good options.

Conditions for Putin to pursue his ultimate goal of a Eurasian Union are currently about as favourable as they are ever likely to be; and they are particularly favourable in the Slavonic core. The European Union is in crisis and Putin has pro-Russian autocrats in place in Kyiv and Minsk who need his support and for whom Russian is their native language and Russia a second homeland. Gas prices are under 
some economic and political pressure internationally but, for the time being, gas blackmail is still a strong weapon. Oil prices, though always volatile, have so far been holding up well. And all three regimes seem to be headed very much in the same direction.

But, since 1991, the non-Russian former Soviet republics have become used to being their own masters, and drawing them firmly into the post-Soviet orbit and keeping them there has been like herding cats. In that respect, the culturally and linguistically close Ukrainians and Belarusians have not been much more amenable than the others. Keeping them all in the tent will probably involve long-term retention of expensive subsidies, which Putin's successors may find unattractive.

For their part, Russian generals, diplomats, intellectuals and political leaders seem to have been unable to restrain themselves from being alltoo-nakedly imperious and imperial. And the urban populations of all three have a growing desire for dignity, democracy and respect. It's not yet an overwhelming majority taste, but there's enough of it around to make any structures Putin succeeds in launching or propping up more than a little unstable. 


\section{1}

\section{Will Putin survive until 2018?}

The standard narrative about the last year and a half in Russian politics runs roughly as follows. In late 2011, Putin and his ruling United Russia party's ratings were sliding. The fact that the party performed so poorly at the December 2011 parliamentary elections was a shock, though not wholly unexpected. But the largely spontaneous popular demonstrations against the falsification of the results gave Putin a serious fright. Until he managed to engineer himself a win in the first round of the presidential elections the following March, he was very much on edge. The tears in his eyes on election night bore eloquent witness to the strain he'd been under.

Since then, however, Putin has recovered his usual confidence and belligerence. He has charted a course towards increasing repression at home and increasing assertiveness abroad, displaying particular venom towards the United States. The opposition has largely subsided and failed to press home any advantage it had. Putin is securely in the saddle for the next six years, until 2018, and possibly for 12 . We should prepare for more of the same.

The standard narrative isn't necessarily wrong, but important qualifications need to be made. Though the strength of Putin's position shouldn't be underestimated, as oppositionists tend to do, it is less stable than it looks, and certainly less stable than it once was.

$1 \quad$ First published in Inside Story, 27 Mar. 2013, insidestory.org.au/will-putin-survive-until-2018. 
Putin's legitimacy has been seriously damaged, and the chorus of criticism on the internet and in the remaining independent media is shrill. The urban middle classes are disheartened but also alienated. Efforts at creating a coherent opposition leadership have had only modest success, and numbers at demonstrations are down, but when an issue does mobilise people, the opposition can still get a crowd out on the streets. (In January 2013, for instance, over 50,000 marched 'against the scoundrels' over the banning of adoptions of Russian children by US citizens.)

Opposition is taking various forms, typically via the internet, and can sometimes draw blood. Anti-corruption campaigner Aleksey Navalny's current campaign of exposing prominent hardliners in the parliament for offences against Putin's new strictures on property ownership by officials has demoralised the ruling party and led to a spate of resignations.

An opposition campaign is also being launched online against the widespread practice within the Russian elite of acquiring academic decorations by resort to ghostwriters and plagiarism. The opposition has already claimed some scalps and reportedly has something like 20 'investigations' in train. This trend is the more threatening because Putin himself is vulnerable on this count. Much less flagrant cases of plagiarism than seem to be common in Russia have led to ministerial resignations in Germany, which is a comparison commentators are making.

Although the Russian economy looks solid compared to much of Europe, it is underperforming for a country with such a huge resource endowment. In the last quarter of 2012, growth slipped to the equivalent of an annual rate of 2 per cent. Collateral damage from the Cyprus banking crisis permitting, that rate will probably recover somewhat in the course of 2013, but the current trend rate of between 3 and 4 per cent compares very unfavourably with rates of around 7 per cent during Putin's previous terms as president.

To win re-election, Putin promised everything to everyone, placing a heavy and long-term burden on the state budget. The oil price at which the Russian budget breaks even had already been rising rapidly and has now reached US\$117 a barrel. And there are looming threats to Russia's dominant position in energy export markets from, for example, US shale gas. 
While Putin's 'power vertical' - his consolidation of centralised power in the Russian state - came together well enough to see off the immediate challenge from political opponents, there are signs of instability within the elite that are being accentuated by Putin's actions. Hardline factions, to which Putin has always been closer, are tending to escape control in the way they did during the period before he handed the presidency to Dmitry Medvedev in 2008. The elite as a whole has moved to the silovik (securocrat) right and there may be challenges from that quarter.

The strong neo-Stalinist tendency within the elite has an able and popular potential leader in Dmitry Rogozin, the combative former ambassador to NATO. Recalled to Moscow last year, Rogozin is now a highly visible deputy prime minister responsible for the defenceindustrial complex. He has called for a renewed wave of military industrialisation - as in the Soviet Union in the 1930s - claiming implausibly that this could revitalise the entire manufacturing sector. He also supports renaming Volgograd as Stalingrad, and - perhaps attempting to outshine Navalny - has called for severe punishment for anyone found to be involved in corrupt activities. This populist platform has considerable appeal to much of both the elite and the general population.

Even the occasionally excessive zeal of the United Russia deputies in the Duma seems to be causing Putin some anguish. While the Kremlin has undoubtedly initiated the many legislative attacks of recent months on the opposition, some of the new laws have risked becoming caricatural in the hands of Duma zealots competitively eager to please the leadership. Putin initially tried to moderate their proposed total ban on US adoptions, for example, and rubbed some of the harsh edges off their draft laws prohibiting Russian officials from owning property or bank accounts abroad. But this, too, was a Putin initiative aimed at curbing the tendency of the Russian elite to denounce the West for domestic political purposes while owning property, schooling their children and in general disporting themselves in Western countries.

Another clear sign of dog-fighting under the carpet is the public struggle by conservative forces within the regime against the government of Prime Minister Medvedev. Putin has himself been openly critical of the government, and the attacks by conservative media sources have been frequent and abusive. Although liberals have tended to gather 
around Medvedev as prime minister, he is an even weaker reed in that role than he was as president. Putin is making costly demands - for huge military expenditure and the further concentration of energy industries at huge expense in the hands of his de facto number two, Rosneft chair Igor Sechin, for example - and it is left to Medvedev and his government to square any resulting fiscal circles.

This form of intra-elite instability may not be of long duration. Putin can easily turn Medvedev into a scapegoat to be sacked at a time of his choosing. In the meantime, Medvedev is being treated with contempt in public by the siloviki, including via an online documentary ${ }^{2}$ accusing him of weakness in capitulating to the West over Libya.

A similar, earlier video showed former senior military officers denouncing Medvedev for alleged indecision just before the outset of the Georgia war in 2008, while praising Putin, then prime minister, for having demanded more resolute action. While backbiting and policy squabbles have never been entirely absent from Putin's rule, these are unusually public and explicit expressions of the tensions.

The fact that Medvedev is under such heavy attack may be more than just a reflection of his unpopularity with the dominant siloviki or their hostility towards some government policies. As prime minister, Medvedev would be in constitutional line to act as president should Putin die or be incapacitated. The rumours swirling in late 2012 that Putin may be suffering a potentially debilitating injury or illness evoked speculation about possible succession scenarios, and may explain some of the urgency in hardline attempts to tip Medvedev out of his prime minister's chair.

Putin has always been a practitioner of what was known in Leonid Brezhnev's time as 'stability of cadres'. Bureaucrats in autocratic systems do not appreciate constant sackings and other such disruptions, much preferring to get on with feathering their nests undisturbed. And this they have been able to do spectacularly well under Putin, their numbers multiplying as well as their rapacity. But with the opposition scoring telling points by exposing their corruption, Putin now feels he must be seen to act, at least symbolically. Hence the strictures against

2 See www.youtube.com/watch?v $=$ zrtcVd1LASc\&feature $=$ youtu.be. 
members of the elite living a double life, denouncing the West at home while enjoying its fleshpots at every opportunity. These new rigours have been termed Putin's 'nationalisation of the elite'.

Putin's drive to repatriate elite assets from Western boltholes has multiple targets. It is meant to stave off opposition attacks on 'swindlers and thieves', ${ }^{3}$ to increase the leadership's purchase on its sometimes unresponsive bureaucracy by making an example of some of them, to reduce exposure to malign Western influences and reduce the West's capacity to punish the regime by using selective sanctions against top officials of the kind launched under the US Magnitsky Act, ${ }^{4}$ and to address the burning issue of capital flight from Russia to Western destinations.

A particularly striking example of this capital flight, an unknown but not insubstantial proportion of which is illegal or downright money laundering, is the vast flow of funds from Russia to Cyprus and back again. Bizarrely, that tax haven (population 800,000 ) is responsible for about a quarter of foreign investment in Russia, and itself attracts about a quarter of Russian investment abroad. While most of this financial round tripping involves at least tax evasion, some observers believe that what's mainly involved is the need Russian investors feel to escape the dismal investment climate in their own country.

The European Union's decision that the solution for Cyprus's banking crisis should include a compulsory contribution from the wealthiest of its account holders will certainly hit Russians and Russia hard. The angry protests from Putin and Medvedev are likely to be supported by many Russians, including people who would normally be on the other side of the barricades. Led by Germany, the decision is both an opportunity and a costly blow for Moscow. With more plausibility than usual, Putin can blame the West for nefarious conspiracies to damage the homeland. And it gives an unexpected fillip to his campaign to repatriate Russian capital to the homeland where he can more readily get access to it for his own patriotic plans.

3 Ellen Barry, 'Rousing Russia with a phrase', New York Times, 9 Dec. 2011, www.nytimes. $\operatorname{com} / 2011 / 12 / 10 /$ world/europe/the-saturday-profile-blogger-Aleksey-navalny-rouses-russia. html?_r=1\&.

4 See www.govtrack.us/congress/bills/112/hr6156. 
But being forced to put their often dubious earnings where their patriotic mouths are will stir great resentment in the elite. To make things worse, Putin also seems inclined to inflict collective punishment on the United Russia party as a whole for its poor performance, shifting his support instead to the All-Russian National Front, which he set up to support the regime in the parliamentary/presidential election cycle of 2011-12. There is even speculation that Putin may dissolve parliament to help purge and punish the hapless United Russia. These are all uncharacteristically risky manoeuvres for Putin, suggesting that, for whatever reasons, he is agitated about the current state of affairs in Russia.

The turbulence within the elite, which he is exacerbating, may make it more difficult for Putin to continue to maintain his role as the arbiter of last resort between the different factions. But he has always been closer by background and temperament to the Petersburg siloviki than the Petersburg tsiviliki (civilian lawyers and economists) who, together, form the core of his elite support. Despite presiding over a country with some of the greatest socioeconomic inequalities in the world, he continues to pretend, quite successfully, to be a man of the people, a champion of the working class, a resolute supporter of the Russian military and patriots generally, and a determined adversary of the petty-bourgeois Russian intelligentsia.

Simultaneously, he manages to present himself as a social conservative, a devout Orthodox churchgoer, and the scourge of unpopular minorities, including (sotto voce) Muslims and pushy sexual minorities. (Internationally he has even managed to market himself successfully to Hugo Chavez and other latter-day state socialists as their like-minded ally.) These representational skills, which owe something to his KGB training, have been in prominent display in his repression of the street protests of 2011-12.

Putin's crackdown on the opposition was initially tempered by the fading liberal gestures of Medvedev's last even lamer duck months as president. But since Putin returned to the presidency formally in May 2012, the tempo has increased sharply. With impetuous speed, the Duma has passed a series of harsh new laws that create or extend criminal offences and provide for draconian fines and, often, prison terms. This takes Russia back to a level of repression not seen since before Gorbachev's perestroika. These new legislative initiatives: 
- penalise those who organise or participate in 'unauthorised' demonstrations

- require all organisations that receive any foreign money to proclaim themselves 'foreign agents'

- ban anyone holding foreign citizenship from working in an NGO in Russia or expressing views that are damaging to Russia's interests

- recriminalise 'slander', which was decriminalised by Medvedev a few months earlier

- propose a new offence of insulting religious feelings (the bill is still under consideration in the parliament)

- expand the criminal offence of treason

- place restrictions on freedom of expression on the internet, ostensibly to protect minors (with more restrictions apparently under consideration).

A number of further such measures have been proposed in the Duma, most xenophobic and some bizarre, like the suggestion from the Duma's longstanding court jester and kite-flyer, Vladimir Zhirinovsky, that foreign words be banned from use in Russian media, and a proposal that cinemas be penalised for showing too many foreign films.

Many leading opposition figures have been singled out for dawn raids on their apartments, indicted for offences carrying heavy penalties, or subjected to character assassination in television 'documentaries'. And reports suggest a big legal case is being mounted against 20 or so demonstrators who were involved in the Bolotnaya (Muddy) Square case, ${ }^{5}$ which arose out of a demonstration on 6 May last year, just before Putin's inauguration.

In the view of most independent observers, the physical confrontation that broke out that day was the result of provocation by police. Last week, a man claiming to have been a secret government operative surfaced on YouTube asserting that he had been offered money to cause an outbreak of violence at the demonstration. Regardless of the plausibility of the witness or his story, it does seem clear that the regime intends to use the event to prosecute and jail a significant number of alleged offenders.

5 See 'Anti-Putin protesters march through Moscow', The Guardian, 5 Feb. 2012, www. theguardian.com/world/2012/feb/04/anti-putin-protests-moscow-russia. 
So far, however, the regime has not vigorously pursued many of the new police-state laws. They are very repressive on paper, but their implementation remains more consistent with the soft authoritarianism that has characterised Putin's rule to date.

Many of the putative offenders, particularly the better known ones, have still not been locked up, and some continue to defy the regime. Despite facing multiple charges that could attract lengthy sentences, Navalny has been particularly active. (The charges look thin, but conviction rates in Russian courts are close to 100 per cent even in non-political cases.)

Will Putin now tighten the screws and make an example of some of these 'offenders'? The Muddy Square case and the raids in recent weeks on hundreds of NGOs suggest that the repression may be now starting to gather momentum. But tightening the screws would be risky, and not just in terms of Russia's international 'reputation deficit'. A few martyrs might re-energise and refocus the opposition.

More heavy-handed tactics, on the other hand, might cow the critics, but at the cost of causing an exodus of talent that Russia can ill afford. Surveys have long pointed to high percentages of younger urban Russians wishing to leave the country and, in recent months, emigration has again become a buzzword among the creative classes.

But, in another sense, Putin's repressive measures have been more carefully and skilfully managed than their hasty adoption and their repugnance to a Western sensibility might suggest. From the outset of the protests, he sought to identify himself with the ordinary person out in the sticks, for whom these intelligentish $k i^{6}$ poncing about in the capital had little appeal. He seized on one such salt-of-the-earth type, an industrial foreman in Siberia called Igor Kholmanskikh, as the epitome of this healthy core of society. During a TV call-in program in December 2011, Kholmanskikh offered to bring some mates to Moscow to help Putin sort out the arty types on the streets. Kholmanskikh was rewarded soon after for his sturdy good sense by being made the polpred (presidential representative) to Eastern Siberia, a job for which he appeared to have only very modest qualifications.

6 A contemptuous word used for intellectuals by anti-intellectual Russians, often in power. 
At Putin's first big press conference after the elections in December 2011, he compared the white ribbons worn as symbols by the protesters to condoms. And he didn't refrain from hinting that the protesters were sexual deviants of some kind. The aim was evidently to accentuate divisions in society, often drawing on the mass propaganda and ideologised education of Soviet times.

To make sure a wedge was driven between the urban middle-class protesters and the ordinary people, opposition leaders were presented as wealthy and corrupt, with even Navalny, the volunteer scourge of official corruption, being depicted as corrupt. Navalny's low ratings in public opinion polling suggest the counterattack, however crude, has been effective. In any European country with free media and a mature democracy this tactic would hardly have worked, but it does still in Russia. From this point of view, the Pussy Riot trial was a gift to the regime, as were any efforts by opposition figures to try to prevent the victimisation of homosexuals, against whom a repressive campaign has also been conducted with growing intensity.

The Kremlin closely studies the Russian public's attitudes and knows how to target its conservatism. Opinion polling frequently appears to demonstrate that this or that repressive measure undertaken by the regime is wildly popular with a majority of respondents. While the timing and methodology of such enquiries may at times be dubious, it would seem that Putin's tactics are effective. In short, he has developed a set of policies with which a transplanted Pauline Hanson would be more than happy.

Nina Andreyeva (the putative author of a neo-Stalinist article in Sovetskaya Rossiya in 1988 denouncing perestroika) would probably also be pleased with Putin's attack on the United States for supposedly bribing the demonstrators and funding monitors who cast doubt on the honesty of the elections. 
She would be even happier with Putin's efforts to restore 'balance' to the official assessment of Stalin and revise school history textbooks to preclude undue emphasis on such difficulties as purges, concentration camps and mass starvation. In February 2013, the independent public opinion polling organisation Levada published results of surveys showing that the number of people who see Stalin in a positive light has increased significantly on Putin's watch, and is now almost 50 per cent of the population.

After the street demonstrations of 2011-12, the Kremlin launched a strident campaign against their 'reset' partners in the United States, starting with a campaign of harassment of the reset's key architect, the then incoming US ambassador Mike McFaul, and continuing through to its extreme reaction to the Magnitsky Act.

The hasty passage in a highly patriotic atmosphere of Herod's Law, as it has been called, banning any adoptions of Russian children by American parents, featured bizarre statements by some deputies to the Duma. These included the assertion that the United States wanted Russian children in order to harvest their organs for resale, or to use them as cannon fodder in a future war against Russia.

What all this points to is the fact that, while Russian foreign policy is undoubtedly the product of many factors, it is currently being shaped substantially and at times decisively by domestic politics and by the mindsets, phobias and propaganda tactics of the people who dominate it.

The combination of increasingly repressive policies, adroitly selective use of left-wing rhetoric and simultaneous appeals to the public's conservative mindset seems to be working well for now. But some opinion surveys suggest that Putin's popularity is again slipping (though no alternative to him is in sight). And the domestic political situation is certainly less stable than it was before Putin and Medvedev swapped jobs in September 2011. The urban middle classes are unhappy, the economy is more fragile, and the balance between intraregime factions is more tenuous, in considerable measure as a result of Putin's own actions.

To complicate matters further, the ever-present threat of militant Islamism concentrated in the North Caucasus continues to bubble along, with a disturbing tendency to metastasise to areas not 
previously much affected, notably the Central Volga regions of Tatarstan and Bashkortostan. Keeping all these factors under control till 2018 and beyond will be a challenge.

Although Putin's repressive domestic policies and strident external policies will probably be maintained, and possibly strengthened, there are some important exceptions to this general picture. In some areas of domestic policy, for instance - in macroeconomic policy in particular, which has been in competent and responsible hands and whose importance Putin recognises - good sense will continue to prevail.

But it would be surprising if that competence and good sense were allowed to extend in any serious way towards tackling corruption (in which the regime is heavily implicated), ${ }^{7}$ improving the dismal investment climate or reducing the inefficient gigantomania of favoured economic enterprises. The recent prominence of Putin's neoSoviet economic adviser, Sergey Glazyev, and the pronouncements of Putin and Rogozin on the need for a massive 1930s-style defenceled industrialisation suggest that the effectiveness and independence hitherto of the key economic policymakers may come under threat.

The stridency of external policies could also be checked by signs of progress in relations with the United States and the European Union. If, for example, Washington were indeed to offer greater flexibility on missile defence (as Obama audibly promised Medvedev at the Seoul nuclear summit last March), Moscow might tone down its rhetoric.

But even that may be too much to hope for. While for reasons that are not yet fully clear, Moscow has muted somewhat its denunciations of the EU-imposed bailout, the fallout from Cyprus is likely to further inflame relations with the European Union. And when Defense Secretary Chuck Hagel announced on 15 March that Washington would not be proceeding with stage four of its proposed European missile defence

$7 \quad$ Putin is widely believed to be personally involved in corruption and to have become a wealthy man as a result. Numerous plausible articles have been written on this subject. But, until the Putinist system starts to crack, direct documentary proof will be difficult to come by. And, in the meantime, publishing the evidence that exists about Putin and his cronies' involvement is not easy, even in the West, as the publication history of Karen Dawisha's Putin's Kleptocracy (New York: Simon \& Schuster, 2014) illustrates. The book was earlier offered to Cambridge University Press, who declined it for fear of the legal implications. See Anna Arutunyan 'Book Review: Putin's Kleptocracy' by Karen Dawisha, Wall Street Journal, 30 September 2014, www. wsj.com/articles/book-review-putins-kleptocracy-by-karen-dawisha-1412118992. 
shield (a feature of the plans that the Russians had particularly objected to), the reflex action from senior Russian spokesmen was immediately and overwhelmingly negative. If the Putin regime hangs on, whether under Putin or, for example, his old ex-KGB colleague Sergey Ivanov, it could be a tough 12 years for East-West relations. 


\section{2 \\ Putin's re-Sovietisation project and the Ukrainian jewel ${ }^{1}$}

Largely unnoticed by the media in Australia, a lengthy geopolitical tug of war has been taking place for dominance in Eurasia. Though he and his propagandists periodically deny it, President Vladimir Putin is clearly bent on restoring some kind of successor organisation to the Soviet Union that Moscow (he) can control. The European Union took a long time to react to this development, and the Obama administration seems to pay only modest attention to it.

Just before retiring as secretary of state, Hillary Clinton labelled Putin's efforts an attempt to re-Sovietise the region. ${ }^{2}$ The high priority these words seemed to imply for Washington has not been particularly apparent since. But alarmed by increasingly bellicose rhetoric from Putin, the cyberwar fought by Moscow against Estonia in 2007, ${ }^{3}$ the shooting war in Georgia in 2008 (provoked by Moscow and its South Ossetian proxies and unwisely triggered by Georgia's pro-Western President Mikhail Saakashvili), some Eastern and Scandinavian EU members lobbied successfully for some EU (and NATO) pushback.

\footnotetext{
1 First published in The Interpreter, 21 Nov. 2013, www.lowyinterpreter.org/post/2013/11/21/ Putins-restoration-project.aspx?COLLCC $=2000020440 \&$.

2 See 'Clinton Calls Eurasian Integration An Effort To "Re-Sovietize"', Radio Free Europe/ Radio Liberty, 7 Dec. 2012, www.rferl.org/content/clinton-calls-eurasian-integration-effort-toresovietize/24791921.html.

3 See 'Estonia hit by "Moscow cyber war"”, BBC News, 17 May 2007, news.bbc.co.uk/2/hi/ world/europe/6665145.stm.
} 
In Brussels, this led to the Eastern Partnership (EaP) initiative, which was aimed at the former western republics of the USSR: Ukraine, Belarus, Moldova, Azerbaijan, Armenia and Georgia. Launched in 2009, the EaP is an attempt to integrate these countries into the European Union via trade and enhanced bilateral contacts in exchange for their undertaking reforms to bring them into line with EU values and practice. Many within the elites in those countries are in fact minded to head in a European direction, though some would prefer to go just far enough to secure advantages for themselves and a hedge against Moscow.

The NATO equivalent has been November 2013's 'Steadfast Jazz' exercise, involving over 6,000 NATO troops (only 250 of them from the United States). This was a response to an aggressive Soviet-style exercise called Zapad (West) 2009, led by Moscow with participation by troops from Belarus, and another Zapad exercise this year that, according to some accounts, saw up to 70,000 troops deployed. Zapad 2009 turned on what Moscow identified as a 'terrorist' scenario involving the suppression of an uprising by a 'national minority' group in Belarus and culminating in a simulated nuclear strike on Poland.

Fearing the EaP might produce a reprise of 'the greatest geopolitical catastrophe of the twentieth century', ${ }^{4}$ Moscow has set up a rival project of a Eurasian Customs Union aimed at the former Soviet republics, which is to develop over time into a Eurasian Union. ${ }^{5}$

This is presented as a benign EU equivalent ostensibly aimed at forming a cooperative building block together with the European Union and China of a new multi-polar Eurasian security structure. The former republics have mostly been sceptical of Putin's insistent invitations to join Moscow's various new multilateral bodies, including the Customs Union, seeing them as a thinly disguised device for restoring Moscow's dominance. Even those that have joined the Customs Union (Kazakhstan and Belarus) or signalled their intention

4 See Claire Bigg, 'World: Was Soviet collapse last century's worst geopolitical catastrophe?' Radio Free Europe/Radio Liberty, 29 Apr. 2005, www.rferl.org/content/article/1058688.html.

5 See 'Putin calls for "Eurasian Union" of ex-Soviet republics', BBC News, 4 Oct. 2011, www. bbc.co.uk/news/world-europe-15172519. 
of doing so (Armenia, Kyrgyzstan, Tajikistan) continue to cultivate links with one or more of the European Union, United States and China, and resist many of Moscow's initiatives.

Putin has had to resort to press-gang tactics to herd the reluctant former republics into his Customs Union and away from the European Union. Meanwhile, the EaP has been pushed ever closer towards the moment of decision, with a special EU summit to take place in the Lithuanian capital, Vilnius, on 28-29 November 2013. Lithuania, which currently occupies the rotating six-monthly EU presidency, has been active in promoting the EaP, and the Lithuanian President Dalia Grybauskaite, a one-time Soviet party official, has been one of its most forceful advocates.

It has been expected that at Vilnius, the key EaP candidate, Ukraine, would sign an Association Agreement (AA) with the European Union, giving Ukraine freer trade with Europe while falling short of foreshadowing full EU member status.

It has also appeared increasingly likely that if President Viktor Yanukovych finally committed unequivocally to signing the AA, the European Union would respond with economic aid to save Ukraine from pending crisis and protect it from the effects of the punitive trade sanctions Russia has been overtly threatening. But recently, the autocratic Yanukovych, who has been tacking west strongly for several months, seems to be hedging or even reconsidering his options. In particular, he has failed to free his domestic archenemy, ex-premier Yulia Tymoshenko, whom he narrowly beat for the presidency and who has been in jail since 2011. If she is not released under reasonable terms or pardoned outright, the chances of an AA being ratified by EU members will be slim.

Which side of the mountain Yanukovych finally lumbers down will be of great strategic significance. After European Russia, Ukraine is the largest European country by territory, and the fifth largest by population ( 45 million), with a substantial resource endowment and great economic potential. It was a vital part of the Soviet military-industrial complex, and Russia is keen to regain full control of those assets. 
The strange thing about the geopolitical struggle for the heart of Eurasia is that Moscow seems to be the only contestant taking it fully seriously. The European Union is divided and, though its resolve has been stiffened somewhat by Putin's bellicosity, it still is not resolutely determined to prevail. Putin, on the other hand, is very focused. For many Russians, including Putin, Ukraine is a wayward and rather comical provincial backwater of Russia itself, occupying areas that the Russians regard as vital to their military strength and cultural and historical identity.

The Russian leadership, whatever weaknesses it may have, is always closely attentive, almost obsessively so, to its strategic advantage. Putin thinks about these matters intelligently, carefully and constantly. Unlike his democratic Western counterparts, many of whom he views with at times ill-concealed contempt, he has plenty of experience in the job, plans much more of the same in the future, and is capable of thinking long and to good effect. He can fine-tune his coercive 'energy diplomacy' manoeuvres, skilfully dividing and manipulating his target counterparts. And no one ever calls him to account.

Western leadership and unity, by contrast, does not present well. Obama had (and largely still has) rockstar status with European publics, and therefore with their leaders, but has made very little use of it to repair the rifts of the Bush years.

Irritated by its European allies' miserly and declining spending on defence (by contrast, Putin has embarked on a US $\$ 700$ billion rearmament program over 10 years, ${ }^{6}$ and will, on one estimate, increase his defence spending by a quarter next year alone), Washington is 'pivoting' away from Europe to Asia, and calling on its European allies to do more for themselves. The protracted economic stagnation and resulting social stresses, the growing divergence in strategic perceptions, even the long-running Snowden media entertainment skilfully promoted by Kremlin impresarios all greatly weaken Western effectiveness. The Transatlantic Free-Trade Area negotiations are a welcome light in the distance, but the journey towards it could prove long and arduous.

6 See Matthew Bodner, 'Putin tightens grip on Russian defense industry', Moscow Times, 10 Sep. 2013, www.themoscowtimes.com/business/article/putin-tightens-grip-on-russian-defenseindustry/506803.html. 
Against this none-too-promising backdrop, how the EaP project turns out is all the more important. It's not an easy thing for Brussels for a number of reasons. Ukraine's Yanukovych may in the end decide not to sign an AA but rather to accept another bribe from Putin, as he did in 2010 when he extended the Russian Black Sea Fleet's leasehold on naval facilities in the Crimea for 30 years, in exchange for a lowering of Moscow's extortionate price for Kyiv's gas imports. Even if Yanukovych signs, and the EU ratifies, he may well subsequently renege on the political and economic reforms agreed as a quid pro quo. He is likely, in any case, to continue trying to play off Moscow against Brussels and vice versa.

Accepting Ukraine at this stage cannot be seen as a reward for its adoption of 'European values'. It can only be justified on strategic grounds as a step aimed at ensuring that those values may have a greater chance of being implemented some time in the future.

On the other hand, it does seem highly likely that if Yanukovych is shown the door by Brussels this time, he will rebound into the arms of Moscow. In that event he would seek and probably receive enough economic and political support to win re-election in Ukraine's 2015 presidential elections, if necessary by jailing as many of his opponents as he chooses, and doing whatever else is required to meet the objective. Moscow would certainly not object or withdraw aid in protest.

Yanukovych would not then become a complete vassal of Moscow, any more than the leaders of Belarus and Kazakhstan are at present. But Ukraine would nonetheless become the jewel in Putin's neoimperial crown, the indispensable province restoring the proud Soviet patrimony he recalls nostalgically from his days as a patriotic schoolboy when the world stood in awe and fear of the mighty Soviet Union.

Putin's vision is that this area of 'stability' and 'traditional values', which he latterly presents in almost Huntingtonian terms as true Orthodoxy, should stand steadfastly against decadent Western values as part of a new geopolitical balance in Eurasia, in which Russia and its satellites would become one pole of at least equivalent weight, in Putin's eyes, to the other two. 
The sharply anti-Western propaganda he has stepped up domestically since the lèse-majesté he suffered on the streets of Moscow in 2011-12 fits well with this external strategy of creating a Russian-dominated autocratic entity between Europe and China. His own pivot to the East is focused above all on the strategic and economic partnership he proclaims and promotes with his like-minded counterparts in Beijing.

It must be doubted that Russia has the economic, ideological, political or even the demographic strength to sustain itself as an equivalent pole to Europe, much less to China, on the Eurasian continent. Already some of the former Soviet Central Asian states are increasingly looking to China, particularly for trade and investment purposes, but also to some degree as a hedge against Moscow. In the longer term the real threat to Russia's standing and influence is from China, not from the hated West. But while a concealed anxiety about China's rise occasionally shows through, much more often Putin seems to see getting closer to his giant Eastern neighbour as in some way increasing his strategic weight in relation to the United States.

If a new line of demarcation is drawn on the Eurasian landmass that is intended to ensure that democracy, human and minority rights, free markets, decent governance, and freedom of expression and assembly are shut out beyond the eastern borders of the European Union, it will be a major strategic defeat for the West.

Nor will those EU members nearest to that line necessarily be secure from attempts at subversion or penetration. Putin wants to reverse the outcome of the Cold War. Western absent-mindedness and pusillanimity have helped him significantly in his endeavour thus far, and could yet come to his aid again. 


\section{3 \\ Vladimir Putin: Geopolitical wrecking ball ${ }^{1}$}

With his crude but effective intrusion into Kyiv's strategic decisionmaking, Russia's President has comprehensively destabilised Ukraine with unpredictable consequences and triggered a reprise of the 'Orange' events of 2004-05.

As a candidate in the 2004 presidential elections and with Putin's overt support, Viktor Yanukovych had deployed 'administrative resources' to rig the ballot. Mass street protests, with some brokering from Western emissaries, forced a re-run, which Yanukovych lost decisively to the pro-Western Viktor Yushchenko, a humiliating reversal that has haunted both Yanukovych and Putin since.

While Moscow has always strongly resented the idea that Ukraine should join NATO, it has seemed more relaxed about former Soviet republics having closer economic ties with Europe. But, in 2013, when a number of them seemed likely to conclude Association Agreements (AA) with the European Union, Moscow's reaction became more emphatic.

Punitive trade boycotts were unleashed against Ukraine and Moldova, and Armenia was threatened with a withdrawal of Moscow's security guarantee against Erevan's archenemy Azerbaijan. After a sudden trip

1 First published in The Interpreter, 21 Feb. 2014, www.lowyinterpreter.org/post/2014/02/21/ Vladimir-Putin-Geopolitical-wrecking-ball.aspx. 
to Moscow to see Putin, Armenian President Serzh Sargsyan abruptly announced his country was trashing years of negotiations toward an AA and had decided instead to join Putin's Eurasian Customs Union, a kind of ersatz USSR.

Then, after two secretive meetings with Putin, Yanukovych announced Ukraine too was 'suspending' its long-running negotiations, only a week before it was to sign an AA at the Vilnius EU Summit of 28-29 November 2013.

On 17 December, after another Putin-Yanukovych meeting, it was announced that Russia would purchase US $\$ 15$ billion worth of Ukraine's wilting Eurobonds (to stave off any possible default), and reduce the price Gazprom charges Kyiv for its gas imports by a third. To keep Yanukovych honest, the US\$15 billion would be dispensed in tranches, and the gas deal would run for 18 months, reviewed quarterly.

Before his sudden about-face, Yanukovych had shown every sign of firming up on an AA in response to Moscow's economic coercion (gas price hikes, trade boycotts and the construction of gas pipelines bypassing Ukraine). Kyiv's abrupt and totally opaque 180-degree turn shocked Ukraine's citizens even more than it shocked Brussels. For months, polling had shown solid, even decisive majority support for the AA. Ordinary Ukrainians, not just in the centre and west, saw the AA as the key to their becoming citizens of a 'normal' country, like the EU countries that they had visited or seen on their screens, free of the rampant corruption, cronyism and sustained economic stagnation of their homeland. Hence the large crowds on Kyiv's Maidan Nezalezhnosti (Independence Square) that have persevered through three months of winter.

Yanukovych's instinct was seemingly to make few concessions and wait for winter to do its work. But, several times, he has attempted violent dispersal of the protesters. He was probably being pushed in that direction in part by Kremlin economic blackmail. After the first US $\$ 3$ billion tranche had been disbursed, Russia suspended the program because of the resignation, in response to Maidan pressure, of Ukrainian Prime Minister Mykola Azarov (a Russian immigrant to Ukraine), a decision of which Moscow clearly disapproved. The latest crackdown earlier this week was launched immediately after a second 
tranche of bond purchases worth US $\$ 2$ billion was announced. Yanukovych had had a discreet meeting with Putin in Sochi a few days earlier, where quid pro quos for a second tranche may well have been discussed.

Until recently, the Maidan protesters maintained remarkable levels of discipline and organisation, despite growing regime violence, casualties and disappearances, some of which were carried out by hired thugs (titushki), not regular police or security units. Opposition leaders like Vitali Klitschko and Arseny Yatseniuk have consistently called for calm but, unsurprisingly, militant groups have lately grown more prominent, and some of them have managed to acquire weapons.

The Kremlin's line, since the days of Stalin, has been that western Ukrainians are all 'fascists', and this hyperbole has been given undue prominence by poorly informed Western commentators. If antiRussian Ukrainians, many of whom would have lost relatives to the holodomor (Stalin's enforced mass starvation policy in Ukraine in the 1930s), are 'extremists', what is one to say of the unreconstructed Ukrainian communists and Yanukovychites in the east demanding the protests simply be crushed?

In a conversation with the uncensored Maidan TV station Hromadske (Community), the eminent US historian of the region, Timothy Snyder, aptly referred to this attempt to disqualify the protest movement as 'abuse of history'. Now Yanukovych, Putin and the European Union have an entrenched polarisation and potential civil war on their hands, all essentially flowing from Putin's attempt to foist his geopolitical dreams on the Ukrainian public, most of whom do not want his Customs Union.

Recently, Moscow voices have begun talking of 'federalisation' projects, a theme that has also been taken up by pro-Moscow groups in, for example, Crimea and Kharkiv. As it has done elsewhere, the Kremlin may support breakaway pro-Russian enclaves and proclaim an obligation to protect 'fellow countrymen' it has liberally issued with Russian passports. Any such manoeuvres with a large country like Ukraine would be far more destabilising than similar tactics in Georgia. 
What's needed, ideally, are fresh elections, hopefully yielding a new, competent and legitimate leadership with the wisdom to rule for both ends of the country. An EU-US economic package with enough noughts to compete with Putin's offer and a renewed International Monetary Foundation support deal would also be highly desirable, if not essential.

It's hard to be optimistic about any of this. Until recently the US leadership has been focused elsewhere, and many influential EU leaders believe Russia is best not provoked, and that Ukraine is a basket case they should shrewdly avoid taking on. They seem to view the emergence of a Putinist anti-Western empire flush on their borders with remarkable equanimity.

The EU's responses so far have tended to be too little, too late. With the Sochi Winter Olympics out of the way, and given his conviction that the West is in terminal decline, President Putin may be prepared to throw some more weight around to win the battle for Kyiv. 


\section{4}

\section{Putin's annus mirabilis ${ }^{1}$}

Many foreign observers have joined with pro-regime commentators in Russia to declare Vladimir Putin's performance on the world stage during 2013 a triumph. Russians of dissident persuasion have tended to acknowledge his successes, too, while accentuating the downsides in the hope of descrying a trend, and I will be attempting to do something similar.

But first the triumphs. The one that has attracted most international applause, some of it grudging, is Syria, where Putin stalwartly defended his ally Bashar al-Assad as he continued to use what are ostensibly national defence assets to massacre large numbers of his own population. Until the conflict broke out, Western observers were making favourable comparisons between Bashar, once a respectable London ophthalmologist, and his father, Hafez al-Assad (though the son was considered not as astute). Even when Bashar far outstripped his ruthless father's repressive death count, Putin's support never wavered. Vetoes, watered down UN resolutions, smokescreens to throw doubt on evidence that Assad's regime used chemical weapons on its people - no exertion by the Russian diplomatic and propaganda apparatus was spared to defend its Syrian allies.

1 This article was published as 'Putin's annus mirabilis: Changing the shape of Eurasia', in ANU Centre for European Studies Briefing Paper Series, Vol. 5, No. 1 (Apr. 2014), ces.anu. edu.au/sites/ces.anu.edu.au/files/2014/2014-1\%20Putin \%27s\%20Annus\%20Mirabilis \%20 -\%20Changing \%20the \%20Shape \%20of\%20Eurasia.pdf; it was first published in Inside Story, 24 Jan. 2014, insidestory.org.au/putins-annus-mirabilis-changing-the-shape-of-eurasia. 
Correctly assessing that Western allies were reluctant to risk becoming involved in another unpredictable Middle Eastern conflict, Putin proposed that the United States and Russia lead a push to rid Assad of his chemical arsenal. This project, while worthy enough in itself, has served brilliantly to change the subject and get Assad off the hook.

Unabated are the slaughter (over 130,000 dead to date), the floods of refugees ( 6 million internally displaced, over 2 million seeking refuge in neighbouring states and beyond), the destabilisation of the entire region along the Sunni-Shia faultline, and the opportunities for al Qaeda and other extremisms to flourish. Meanwhile, Assad's minority Alawite regime, with armed assistance from Hezbollah and continuing military and diplomatic support from Russia, has avoided meaningful negotiations and restored its military advantage.

Post-communist Russia presents its continued support for militant, anti-Western regimes favoured by Soviet rulers - those of Saddam Hussein, Colonel Gaddafi, the Assads and the Teheran mullahs, for example - as part of its effort to curb Islamist infiltration of Caucasian terrorist groups in Russia and a contribution to the international 'war on terror'. And many in the West accept that line of argument. It is certainly true that the insurgencies in Russia's North Caucasus are becoming more Islamist as time goes on; and it is true that Moscow is increasingly confronted with a serious problem, of both intractable internal insurgency and recurring terrorist attacks aimed at civilian targets in the Russian heartland.

But it is also true that the Caucasian insurgencies were initially secular independence movements responding to generations of brutal Soviet and Tsarist oppression. The Tsarist conquest of the North Caucasus in the nineteenth century caused mass casualties, and Stalin's wartime deportation in inhuman conditions of the entire Chechen population (and other national groups) led to a fatality rate estimated at one in four. Yeltsin's and Putin's wars to suppress Chechen independence after the fall of communism killed tens of thousands of combatants, mainly Chechens, and tens of thousands more civilians (including many ethnic Russians).

In Chechnya itself, Putin finally opted for 'indigenisation', and the Chechen Republic has now been largely pacified by the brutal dictatorship of the former insurgent, Ramzan Kadyrov, with generous 
funding from Moscow. Putin has also tried more conciliatory policies of economic development in the wider region, but without great success. The insurgency that was once centred in Chechnya has spread to neighbouring Muslim entities and acquired increasingly Islamist overtones. But the connections between Caucasian insurgents and Middle Eastern insurgencies should not be overstated; and, in any case, they have come about largely as a result of failed repressive policies by Moscow.

Russia has also been active diplomatically elsewhere in the Middle East. In Egypt, for example, American disapproval of the military coup against President Mohamed Morsi and the Muslim Brotherhood gave Putin a chance to regain a foothold in a country where Russian influence has been minimal for decades. In Iraq, Putin has been courting the Shiite dominated regime of Prime Minister Nouri al-Maliki in pursuit of lost oil contracts, also securing in 2012 a US\$4 billion deal on the sale of arms to Baghdad. Western commentators largely agree that Russia is now 'back' in the Middle East.

\section{The Snowden windfall}

One of Putin's most dazzling triumphs over the United States seemingly, or supposedly, just fell in his lap. Edward Snowden's illegal release of tens of thousands of secret documents from the United States and many of its allies, including Australia, has been hailed by many Western intellectuals and politicians as a triumph for human rights protection. The issues raised incidentally by the leaks are no doubt a worthy topic for public debate, and wariness about the growing power of all states in the cyber age is entirely understandable.

What is less understandable is why such a doughty fighter for human rights as Snowden would seek refuge first in Hong Kong, where he was reported to have been accorded hospitality by an organisation linked to Chinese security, ${ }^{2}$ then in that exemplary international champion of human rights protection, Putin's Russia. Whether and how much Snowden has advanced the protection of citizens' rights is not yet clear. But what is clear is that the steady drip-feed of documents,

2 John R. Schindler, 'Snowden in the U.S-Russian "SpyWar"', The National Interest, 27 Jun. 2013. 
often seemingly chosen to embarrass, divide and damage Western democracies, has severely strained the effectiveness and cohesion of the Western strategic community. To take one example, Der Spiegel recently reported that the German federal prosecutor has declared that there is sufficient evidence 'to open a politically explosive investigation into NSA spying on Chancellor Angela Merkel's mobile phone'. ${ }^{3}$ Such developments strike the Russian foreign/security elite as great victories for itself.

Exactly when Putin became aware that this huge espionage windfall, perhaps the most copious if not the most crucial in the history of EastWest relations, was being deposited in his lap is unclear. But for Putin, with his intensely zero-sum approach to the United States, NATO, the European Union and the West generally, it is a gift that keeps on giving. No Soviet 'active measures' to drive wedges through the transatlantic consensus have ever been so spectacularly and publicly successful.

As has been often noted - and usually overemphasised - Snowden's presence in Russia is not without its embarrassing aspects for Putin. While the Schadenfreude is delicious, it has enraged Washington to a possibly greater degree than Putin would have wished. It does, moreover, raise the question in some minds as to whether Snowden may now have become, if he was not before, a Kremlin project. Recent allegations that Snowden was also a guest of the Russian special services in Hong Kong before his departure to Moscow, for example, are stirring interest in the US Congress. ${ }^{4}$ Perhaps most seriously, from Putin's perspective, the massive publicity surrounding Snowden in the West could conceivably leak sufficiently into Russian awareness for a copycat Russian Snowden to emerge to haunt the Kremlin. ${ }^{5}$

But these dangers, such as they are, all seem manageable. In deference to US sensitivities, Putin went through an elaborate show of reluctance before granting Snowden asylum for a year, claiming publicly that, while he was enjoying Russian hospitality, Snowden would need

\footnotetext{
3 'Top German prosecutor considers NSA investigation', Spiegel Online, 20 Jan 2014.

4 Michael Bohm, 'The 5 biggest events that shaped Putin's 2013', Moscow Times, 30 Dec. 2013.

5 For an examination of the case for the Snowden leaks having been a Kremlin project, see Edward Lucas, The Snowden Operation (Amazon Kindle Single, 2014). For another view see the book by former Guardian correspondent in Moscow, Luke Harding, The Snowden Files (London: Vintage, 2014).
} 
to refrain from damaging the interests of 'our American partners'. He maintains a similar tone whenever the subject of Snowden comes up in press conferences, implying that the whole matter is largely out of his hands as Russian justice takes its majestic course. Washington is unlikely to be persuaded, but gratuitous offence is avoided.

As far as damage to the Snowden brand goes, it would seem that the international cult of Snowden's personality is proof against any tarnishing by association with Putin's Russia. He has been proposed for a Nobel Peace Prize and, even more incongruously, was shortlisted for a Sakharov Prize from the European Parliament. As for the danger of a Russian Snowden suddenly bursting on the international scene, a state led by former KGB professionals can probably ensure that the chances of this happening remain minimal.

\section{Ukraine: Restored to its rightful owners}

But Putin's greatest success, and probably the one closest to his heart, came in November. Ukraine's President Viktor Yanukovych, after years of laborious work towards reaching an Association Agreement (AA) and free-trade treaty with the European Union, suddenly suspended those negotiations just before the finishing line. Then, on 17 December 2013, following a series of secretive bilateral meetings, Putin and Yanukovych announced that they had reached a comprehensive rapprochement under which Russia would give Ukraine various shortterm economic subsidies that would stave off the severe financial crunch Kyiv seemed to be facing.

Though its largely unreformed economy has been struggling for many years, Ukraine has large industrial and agricultural resources. With a population of 46 million and the largest landmass of any country in continental Europe, it is a geopolitical prize to be fought over. In recent years, this has been precisely what Russia and the European Union have been doing. Putin is, of course, the author of the much-quoted tag, 'the collapse of the Soviet Union was the greatest geopolitical catastrophe of the twentieth century'. He is also quoted as having said on another occasion that 'whoever doesn't regret the downfall of the Soviet Union has no heart, but whoever thinks it can be restored has no brain'. Despite that disclaimer, though, neo-imperial restoration efforts are central to his foreign policy. 
The gas wars with Ukraine in 2006 and 2009, the shooting war with Georgia in 2008, the cyberwar with Estonia in 2007, the blatant interference in Ukraine's presidential election in 2004 (in which he supported Yanukovych, whose fraudulent victory was, however, overturned by the 'Orange Revolution'), the manipulation of 'frozen conflicts' in the former republics of Moldova (Transnistria) and Georgia (Abkhazia and South Ossetia) - these and numerous other salient features of Putin's approach to the 'near abroad' admit of no other interpretation. He may indeed recognise that the USSR cannot be resurrected in a unitary state, but what he wants is the closest possible reintegration of the Soviet patrimony under Moscow's domination.

For Putin and most Russians, Ukraine is the indispensable link in this chain, not just because of its size, population and resources, but also because Russians see Ukraine as Russia's historic heartland. For many Russians, the Ukrainians - including those mostly in western Ukraine who prefer Ukrainian and avoid using Russian - are country Russians who just need to be taught to speak properly. And, in fact, many Ukrainian citizens from the Russified east of the country speak only Russian, and identify with Russia, and Soviet Russia at that. The many millions of Ukrainians who have migrated or been deported to Russia proper over the centuries have never been allowed to have a network of cultural or educational institutions of their own, and this remains the case despite the existence of a legally sovereign and independent Ukraine.

\section{The tug of war for Eurasia}

Within the alphabet soup of post-Soviet institutions, the key component aimed at achieving Putin's restorationist objectives is the Moscow-led Eurasian Customs Union, which, by 2015, is slated to blossom into a Eurasian Economic Union. Moscow presents this multilateral project as being modelled on the European Union - a bridge, in what it claims to see as the multi-polar world of the future, between Europe and China, when the United States will at last be reduced to being, at most, one pole among others. In a sense, the Customs Union is a pre-emptive organisation that is not unlike the old Soviet-bloc trade unions, writers' unions, communist youth groups and so on, corralling its members in such a way that there is no danger 
they will form or join organisations that might authentically express their aspirations. Specifically, the Customs Union is meant to forestall integration with Europe through AAs, free-trade agreements or, worst of all, what Brussels calls a 'European perspective', or the prospect of full membership of the European Union.

The European Union and NATO have done a great deal to integrate the former communist states of Eastern Europe into European and Atlantic structures. Both organisations had a powerful appeal to the newly independent governments of East-Central Europe, which wanted security from Russia and the chance to catch up with EU living standards. They saw the NATO umbrella (even with a minimal military presence) and EU aid funding, market access and technical assistance as vital to their futures, even to their survival as sovereign states. Moscow made clear its great hostility to NATO expansion, in particular to any accession by former republics of the Soviet Union, and often claims that it was promised that such outrages would never occur.

But they occurred because the countries in question emphatically wanted them. NATO and the European Union were often skittish or reluctant and, in recent years, have been operating something close to a de facto prohibition on further enlargement into post-communist countries outside the western Balkans, largely in deference to Russian objections. To allow Russia to block further accessions from its 'sphere of privileged interests' would be to concede Moscow a permanent right of veto over the decisions of ostensibly sovereign states.

In 2004, the Baltic states managed to sneak into NATO past Russia's opposition. But, by the NATO summit in Bucharest in April 2008, it was clear that Russia's emphatic objections to accession bids by the Georgian and Ukrainian governments had been internalised by key member states, notably Germany and France. NATO's pronouncements on the issue at the summit were ambiguous, reflecting the divisions within its membership, but it was clear that, for the foreseeable future, no further applications opposed by Moscow would be accepted.

After the Bucharest summit, Moscow stepped up its goading of the pro-Western Georgian leadership of President Mikheil Saakashvili through its proxies in the pro-Russian enclaves of Abkhazia and South Ossetia. In August 2008, responding to further expulsions of 
ethnic Georgians from South Ossetia, Saakashvili unwisely decided on direct action. This gave Moscow a splendid casus belli to invade and convert the breakaway territories into supposedly independent proxy statelets (still unrecognised by virtually any other significant countries, even close Moscow allies like Belarus). The war in Georgia served to reinforce the message to nervous EU and Eastern European capitals alike that Moscow was best not provoked.

Further EU expansion into Russia's 'near abroad' was by now becoming problematical too, even though Russia long maintained that it was NATO membership rather than EU membership that it found truly objectionable. Particularly with the burgeoning internal EU problems triggered by the global financial crisis, growing 'enlargement fatigue' in core EU countries was clearly going to make it difficult for any other former Soviet republics to achieve acceptance into the club.

Some of the relatively newer EU members, especially Poland, Sweden and the Baltic states, wanted to strengthen the European Union's relations with the former Soviet republics nearest their eastern borders. Recognising that the prospects for any of these countries joining the European Union, much less NATO, were slight, they developed a project known as the Eastern Partnership, or EaP, which gained acceptance in Brussels. Inaugurated officially by the European Union in 2009, the EaP was a kind of Clayton's enlargement, expanding economic and cultural links with the former Soviet republics Belarus, Ukraine and Moldova in the west of the post-Soviet space, and Azerbaijan, Armenia and Georgia in the Transcaucasus region. Where possible, the EaP sought to reach AAs with those of the six who were inclined to do so, the centrepiece of which would be a Deep and Comprehensive FreeTrade Agreement (DCFTA).

Other prominent objectives included the encouragement of economic reform, rule of law and better observance of human rights, and the facilitation of travel and wider human contacts. Azerbaijan and Belarus (both notorious abusers of human rights) were never serious candidates for AAs, though the European Union did try to engage Belarus's President Alexander Lukashenka, who chose to flirt for a time with Brussels in search of financial inducements, a hedge against Moscow and other practical advantages. The other four states seemed to pursue the negotiations more seriously but they were troubled by the fact that Brussels was unable to offer them a 'European perspective', 
because doing so would have worried EU members suffering most from enlargement fatigue. Even Ukraine, under the pro-Moscow and very post-Soviet Yanukovych, was interested in concluding an AA and joining the Deep and Comprehensive Free-Trade Area. As the EaP began to look serious, Putin's hostility towards the idea became more overt, and his manner and tactics more peremptory, even bullying. For a time, this seemed merely to increase Yanukovych's ardour for the Brussels connection.

\section{Ukraine's U-turn}

By mid-2013, Moscow's anxiety about the EaP had reached acute levels. The planned EU summit on 28-29 November in Vilnius, under the rotating presidency of the Lithuanians (in itself an affront for Putin), was drawing close, and four of the six 'partners' - Ukraine, Armenia, Georgia and Moldova - seemed determined to sign AAs with Brussels at that event. In Ukraine's case, Yanukovych's numerous breaches of human rights and departures from democratic rectitude (in particular his habit of locking up his opponents for long jail terms), gave Moscow reasonable confidence that the European Union would not sign, or at least not ratify, an AA. But as Yanukovych made concessions, releasing lesser figures from the former government from prison, Brussels began bending over backwards to accommodate him, thereby triggering anxiety attacks in the Kremlin.

According to a plausible-looking document leaked to the Ukrainian press, Moscow had prepared a master plan to torpedo Kyiv's moves towards an AA. ${ }^{6}$ In July and August 2013, it unleashed yet another round of arbitrary trade sanctions against Ukraine, particularly targeting business interests that were known to be supportive of the EU connection. Ukrainian trade is about equally balanced between Russia's Custom Union and the European Union. While an AA would give Ukraine increased access to a market some eight times the size of the Customs Union, it would also expose it to potentially challenging competition.

6 See Yevhen Solonyna, 'Russia's plan for Ukraine: Purported leaked strategy document raises alarm', Radio Free Europe/Radio Liberty, 20 Aug. 2013, www.rferl.org/content/russia-ukraineleaked-strategy-document/25081053.html. 
Moreover, as Yanukovych was acutely aware, Ukraine could not afford to abruptly lose much of its trade with Russia, which would particularly affect the president's own constituencies in the east of the country. And Moscow, unlike Brussels, could devastate Ukraine's foreign trade balance and bring the country to its knees if it were to apply severe trade sanctions over a sustained period. When Moscow blocked Ukrainian exports to Russia for over a week in August 2013, it left lengthy queues of transport vehicles stranded at the border and forced many Ukrainian exporters to postpone or cancel dispatches, particularly of perishable goods.

Usually, such measures against insubordinate ex-vassals are justified by alleged dangers to health discerned by Russia's Kremlin-compliant chief sanitary inspectorate, the Rospotrebnadzor, which findings are typically shown to be baseless. Moscow's actions in these cases - and there have been scores of them against neighbouring states, including EU members - are almost certainly inconsistent with World Trade Organization (WTO) rules. (After long hesitation, Russia joined the WTO with vital US support in August 2012.) WTO dispute mechanisms are complex and usually take a long time, however, and in the meantime Ukraine could be forced into default.

In trying to balance between two large neighbours competing for its loyalty, Kyiv knows that nothing similar to this kind of pressure would threaten from the EU side. If you are courted by one entity that behaves according to the rule of law and another that is ready to break laws in order to punish you, you may resent the latter more, but you are likely to give it priority in any tug of war.

And so it was with Ukraine in 2013. But, not only did Moscow have excellent sticks to wield and no legal or other scruples about doing so, Putin and his intimates are also able to decide to deploy generous carrots at short notice without any public scrutiny or parliamentary or legal restraints. On 21 November last year, after his secretive tête-à-têtes with Putin and just a week before the Vilnius EU summit, Yanukovych suddenly announced that Kyiv was suspending negotiations with the European Union and pursuing improved relations with Russia. It became apparent that Yanukovych and Putin had reached a deal including termination of the trade sanctions, at least for the time being, and the promise of much cheaper gas imports from Russia and the purchase by Russia of US $\$ 15$ billion worth of Ukrainian bonds. 
The money for this purchase was to be drawn from Russia's National Welfare Fund (a sovereign wealth fund). In strictly economic terms, this procedure, which will greatly ease Ukraine's desperate financial situation, is highly questionable for Russia and, indeed, illegal under Russian law. But none of that will restrain Putin in his pursuit of geopolitical objectives. The gas discount, if sustained, will greatly improve Ukraine's balance of payments, although it is worth noting that Kyiv will still be paying far more for gas under Gazprom's highly political pricing policy than does its neighbour, the Customs Unionmember Belarus. These generous gifts will be dispensed in tranches to keep Yanukovych from welshing on any aspect of the deal.

Exactly what Yanukovych has promised in exchange for Putin's munificence remains a secret, like most other features of the negotiations. Various rumours are abroad on the subject, including that Yanukovych has promised to lock his country into Russia's embrace by joining the Customs Union. If he has, it is vital that it be kept quiet for the time being, as any public acknowledgement of such a massive capitulation would excite even more unrest in Ukraine. It has also been speculated that Russia has agreed to do whatever it takes to ensure that Yanukovych wins next year's Ukrainian presidential elections, something that will again be in Putin's interest, as it was in 2004.

But, perhaps the most crucial undeclared clauses in the deal became apparent on 16 January when, in a farcical pseudo-legal coup d'état, Ukraine's parliament passed what Swedish Foreign Minister Carl Bildt has described as 'the most solid package of repressive laws I've seen enacted by a European parliament in decades'. ${ }^{7}$ The bills were rushed through with grotesque haste and with no sign that the successive shows of hands were even counted.

These laws bear Putin's unmistakable stamp; for example, any organisation with foreign funding or investment is required to identify itself as a 'foreign agent'. Unauthorised street demonstrations will attract elaborate punishments, the offence of slandering public officials has been introduced, and the characteristically Putinist legal concept of 'extremism' is freely deployed. In just a few minutes, Ukraine was converted into a police state by the ruling party's loyal 
deputies. In doing so, as Snyder points out, they may have done themselves out of a job, as the institution of parliamentary immunity was also cancelled. ${ }^{8}$

Since these measures passed, riot police have been deployed to disperse the entrenched and, at times, huge street demonstrations in Kyiv against the regime's abrupt lurch towards Moscow, which is rightly seen by the protesters as the prelude to all-out Putinisation of their country. The totalitarian coup and subsequent police actions were undertaken in a country where opinion polls had been showing a strong preponderance of support for the EU AA over the Customs Union.

The high approval ratings for the AA reflect not only widespread Ukrainian resentment of Russia's tactics and its frequently contemptuous attitude, but also the fact that the AA with Brussels was something on which, to all outward appearances, the opposition and Yanukovych's ruling Party of Regions had been in basic agreement. Outside the Russophone and Russophile heartland in the east and south-east of the country, most Ukrainians see the EU countries as a model for their own country. Many Ukrainians travel to Poland, for example, sometimes to work for short periods, and they like what they see and what they can earn. Since 1990, when the two countries were broadly on the same level economically, Poland has advanced to three times Ukraine's GDP per head, and has benefited enormously from EU trading opportunities, funding and expertise.

\section{Brussels upstaged}

Though some in the European Union suspected a double cross, Kyiv's 21 November announcement that it was suspending negotiations came as a great shock, as have many subsequent events - the PutinYanukovych deal, the size and ardour of the pro-EU demonstrations (garnering up to hundreds of thousands of participants, who were scrupulously well-ordered and non-violent until very recently), and now the Yanukovych coup d'état.

8 Timothy Snyder, 'Ukraine: The new dictatorship', New York Review of Books Blog, 22 Jan. 2014. 
Trying to rescue something from their policy fiasco when Yanukovych changed direction, Brussels spokespeople tried to maintain that 'the door remained open' up to and beyond the Vilnius summit. Showing impressive chutzpah, and despite the outburst of people power on the streets of Kyiv, Yanukovych attended the summit and Ukrainian leaders made increasingly extravagant bids for financial support from the European Union. Clearly they already had something solid in their pocket.

Brussels should not have been so surprised. Yanukovych may have been angered by Russia's efforts to use gas pricing and pipeline construction to isolate Ukraine and keep its industries under pressure. And, like many other post-Soviet leaders, he has often been offended by Putin's personal displays of contempt. On one occasion, Putin kept him waiting for several hours for a bilateral summit while he made an unforeshadowed visit to a group of macho-chauvinist Russian bikies in the Crimea known as the Night Wolves. It would have been hard for Putin to have found a more insulting way of spending that time. It was probably also meant as a crude reminder to the Ukrainian leader that Russia could stir up very serious trouble for him by manipulating the uber-Russian patriots of Crimea into questioning Ukraine's territorial integrity.

But Yanukovych is from the Russophile province of Donetsk and is a native speaker of Russian who does not know any Western European languages. $\mathrm{He}$ is an adherent of the patriotically Putinist Moscow Patriarchate of the Russian Orthodox church, and is in many ways a deeply Soviet person who has been running a 'power vertical' (autocracy) in Ukraine that is very similar to Putin's system in Russia.

In his first months in power in 2010, he granted some huge concessions to Moscow to repair bilateral relations after the pro-Western reign of the Orange President Viktor Yushchenko. He quickly restored full cooperation with Russian security organisations, which Yushchenko had been trying to phase out, and extended Russia's lease of Crimean naval facilities for its Black Sea Fleet from 2017 to 2042. He also moved not long after to improve the position of Russians and the Russian language within Ukrainian public life. At this time, Yanukovych seemed more clearly pro-Moscow than any of his post-1990 predecessors. It was always on the cards that, if Putin were to deploy more of either stick or carrot, Yanukovych would back off from his 
'strategic choice' of Europe. As a senior Polish official once explained, given Yanukovych's natural leaning eastward, 'Putin's contemptuous attitude towards Yanukovych and Ukraine is the best thing going for us to keep him on track for Brussels'. ${ }^{9}$

There had also been clear warnings in the preceding months. On 3 September, Putin summoned Armenia's President, Serzh Sargsyan, to Moscow, where Sargsyan, without the backing of any detectable political process in his homeland, declared that he was forthwith reversing years of negotiations with Brussels for an AA and would join Putin's Customs Union. ${ }^{10}$ With a long Christian tradition, the Armenians very much see themselves as European. They had also sought better relations with the European Union in the hope of material gain and to secure a hedge against Moscow's domination.

But, they are squeezed between their mortal enemies, Turkey and Turkic-speaking Azerbaijan, part of whose territory - the largely Armenian-populated Nagorno-Karabakh - they had seized by armed force after the collapse of the Soviet Union. Since then, Azerbaijan has been using its oil and gas riches to build up a huge military preponderance over Armenia, which is totally dependent on Moscow for cheap arms imports and an effective security guarantee. A few months before Sargsyan's volte-face on the AA, Putin reached an arms sales agreement with Azerbaijan worth US $\$ 4$ billion, a very clear shot across Armenia's bows.

\section{Moldova and Georgia under pressure}

Moscow had also made strenuous efforts to turn the other two candidates for AAs, Moldova and Georgia, away from the European Union. The war with Georgia in 2008 had effectively destabilised Saakashvili's pro-Western leadership. Despite signs of division on the issue within the Russian leadership, Moscow desisted from sending its troops the last few kilometres into Tbilisi. But, having extensively damaged Georgia's infrastructure and taken roughly half of its Black

9 Private personal communication with the author, 2012.

10 Szymon Ananicz, 'Armenia turns away from the EU', Centre for Eastern Studies (Warsaw) Eastweek, 4 Sep. 2013. 
Sea coastline, it did all it could to discredit Saakashvili and ran, for example, a determined campaign to convince ill-informed Western publics that he was mentally unbalanced if not deranged.

With Russian 'peace-keepers' not far from his capital, and under severe economic pressure from the global financial crisis, Saakashvili began to contribute to the Russian propaganda campaign by taking repressive measures against his domestic opponents. His main target and most dangerous adversary was the so-called Georgian Dream coalition, a loose formation funded and organised by Bidzina Ivanishvili, a Georgian oligarch who had made his US $\$ 5$ billion fortune in Putin's Russia without ever falling foul of the Russian leader. Some felt Ivanishvili could not have achieved that without incurring some indebtedness to Putin and his entourage.

Saakashvili and his officials were thus strongly suspicious that Ivanishvili was not just someone who could buy and sell the entire country (the GDP of Georgia was US $\$ 15.8$ billion in 2012, just three times his fortune), but also that he was in some sense a Kremlin project. Some Georgian opposition politicians clearly were, and Ivanishvili strongly emphasised the need to mend bridges with Russia while blaming Saakashvili exclusively for causing the 2008 war. In doing so, he has used arguments that closely resemble Moscow's. After coming to power, and just one day after his neighbour Sargsyan's about-face on the AA with the European Union, Ivanishvili declared that he was studying the Customs Union and might consider joining it if that seemed desirable. None of this is particularly reassuring.

The fact that the Georgian Dream was able to win the elections and summarily remove Saakashvili's United National Movement from offices across the country is perhaps the best indication that, for all its imperfections, Georgia was clearly the most democratic (as well as the most effectively reformed) post-Soviet country outside the Baltic states. Ivanishvili has repaid this democratic behaviour by pursuing criminal charges against several key United National Movement leaders, and repeatedly threatening to do the same to Saakashvili.

But regardless of any personal views that Ivanishvili might hold about the Customs Union, or any concerns he may feel for the safety of his fortune in Putin's Russia, he has deferred to the strongly pro- 
EU orientation of most Georgians and, at the Vilnius summit last November, Georgia was one of the two former republics in the Eastern Partnership that initialled the agreement.

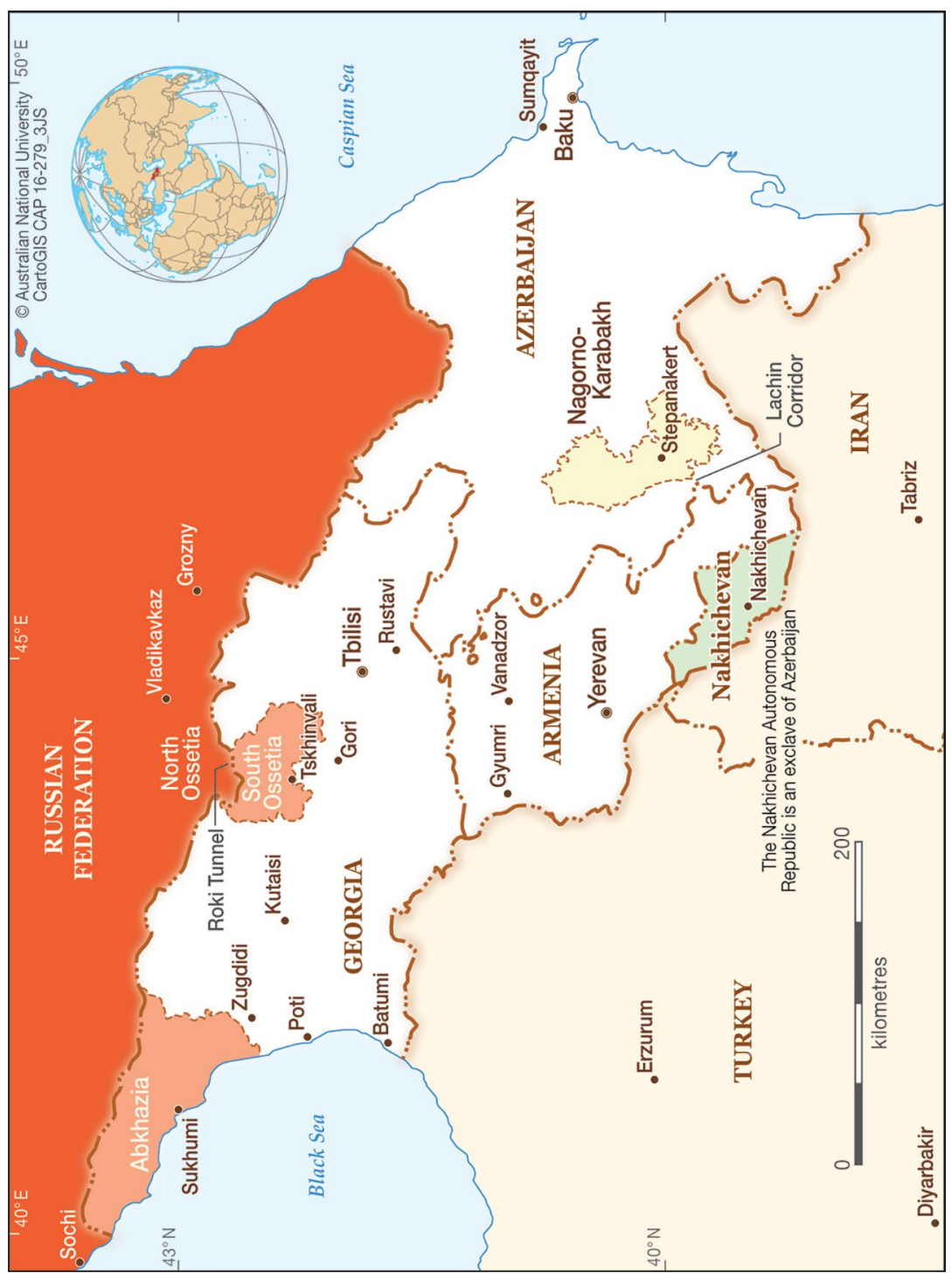

Map 3: The South Caucasian states: Armenia, Azerbaijan and Georgia.

Source: CartoGIS, College of Asia and the Pacific, The Australian National University. 
The other was Moldova, a much-disputed territory sandwiched between Ukraine and Romania, with a mainly Romanian and Romanian-speaking population that is Orthodox, poor and socially conservative. It also has substantial minorities, which mostly speak Russian and have pro-Moscow inclinations. And there is a strongly Moscow-sponsored breakaway territory within Moldova's internationally recognised borders called Transnistria, where Russian 'peacekeepers' are deployed. Transnistria is basically manipulated by Moscow in various ways to block moves by Moldova towards any form of Western integration. Moscow also supports the largely unreformed Moldovan Party of Communists (still known by that name), which was previously in government but is currently in opposition.

In recent years, Moldova has been ruled by a fractious and unstable coalition, the pro-Western Alliance for European Integration. Because the Alliance has been in power during the European economic crisis, and because of its inherent instability, the communist-led opposition has latterly been making gains in the opinion polls. Moscow would like to see the government overturned. Most of the population probably thinks of itself as European rather than Eurasian, and many Moldovans travel to EU countries in search of work. The statistics are tricky but even more probably travel to the Russian Federation. Remittances, both from west and east, are a vital part of the vulnerable Moldovan economy, and represent between a quarter and a third of GDP, with some three-fifths of all remittances stemming from Russia. ${ }^{11}$

During 2013, Russia repeatedly threatened to block any further economic immigration from Moldova, and even to expel Moldovan labourers. The political message was clear: join our Customs Union and you will be entitled as of right to come to Russia; don't join, and we can bring your economy to its knees any time we like. Moldova is also heavily dependent on wine exports to, as well as gas imports from, Russia, either of which can be summarily curtailed. Russian Deputy Premier Dmitry Rogozin, who is responsible for defence industries but also has a special brief on Moldova, visited the country in September

11 See Simion Ciochina, 'Moldovan migrants denied re-entry to Russia', Deutsche Welle, 21 Dec. 2014, www.dw.com/en/moldovan-migrants-denied-re-entry-to-russia/a-18144394. 
2013 and publicly threatened a cut-off of gas deliveries, declaring 'energy supplies are important in the run-up to winter. I hope you won't freeze. ${ }^{\prime 2}$

By such subtle means as these, Moscow was hoping to build up the pro-Customs Union constituency in the country, which is strong for obvious, pragmatic reasons. Moldovans want to eat and not to freeze, and sense that one side holds effective weapons in its hands and will not hesitate to use them. The outcome in Ukraine must also suggest to them that the European Union is unlikely to win any struggle that develops in their case. But, despite these highly intimidatory threats, Moldova went ahead at the Vilnius summit with initialling the AA that they had negotiated with the European Union.

The Vilnius initialling still leaves Georgia and Moldova some distance from signature. Chastened by their experience with Ukraine, EU leaders announced on 20 December 2013 that they would work towards signature with Georgia and Moldova by no later than the end of August this year. Whether Russia will accept that timetable remains to be seen.

The Moldovan ruling coalition has been in precarious shape for some time, and it would not be surprising if Moscow's huffing and puffing, trade manoeuvres or manipulation of the Transnistrian issue led to another political crisis there. That could leave Georgia as the last surviving remnant of the EaP dependent on the political will of the erstwhile Russian oligarch, Ivanishvili, who might perhaps then revisit his thoughts of joining the Customs Union should the context seem right.

\section{Germany clings to Ostpolitik}

There have always been strong forces, especially among the older EU members, who are sceptical not just about Georgia and Moldova, but also about Ukraine and the whole enlargement agenda. Far from

12 See Andrew Silke, 'EU embrace of Ukraine fuels Russia tensions', BBC News, 15 Oct. 2013, www.bbc.com/news/world-europe-24532292. 
evoking in them stern resistance to Moscow's thuggish tactics, the fiasco of the EaP seems to have strengthened their desire to 'build a better relationship' with Russia.

The key country in all EU issues is now, of course, Germany. Under Chancellor Angela Merkel, an East German, that country has taken a more sceptical view of Russia than under her predecessor Gerhard Schröder. In his last days in office, Schröder used his position as chancellor to arrange a big credit for Russia's Nord Stream gas pipeline, an expensive project of dubious economic and ecological value, but an important geopolitical instrument for Putin, with which he has greatly increased his coercive influence over Ukraine and other former Soviet subordinates. The other pincer, the South Stream gas pipeline, will complete Ukraine's energy encirclement, impeding if not nullifying the European Union's struggling efforts to develop its 'southern corridor' pipeline system, which is designed to diversify supply and reduce the European Union's dependence on Gazprom. South Stream was actively, personally and skilfully promoted by Putin.

In sharp contrast to Schröder, who continues to hobnob socially with Putin and accepted a lucrative role as chair of the Nord Stream Board immediately after his departure from the chancellery, Merkel clearly does not enjoy Putin's company nor approve of his policies. Even less so does German President Joachim Gauck, another East German, who was one of the first world leaders to announce he would not be attending the Sochi Winter Olympics. But Germany is heavily invested, both figuratively and literally, in the bilateral relationship, and the relatively pro-Moscow establishment is powerful in Germany, in the foreign ministry, in business circles and elsewhere.

Merkel's Christian Democrats scored their best result in over 20 years in last September's Bundestag elections but, by contrast, their centrist partners, the Free Democrats, had their worst result ever, failing to reach the 5 per cent threshold for parliamentary representation. This forced Merkel into renewing the 'grand coalition' with the Social Democrats. Under the coalition agreement, Frank-Walter Steinmeier of the Social Democrats regained the foreign minister's position, replacing the Free Democrats' Guido Westerwelle, who was a strong supporter of the EaP and an often forceful critic of the democratic failings of Russia, Ukraine and Belarus. In his earlier time in the job 
in 2005-09, Steinmeier was markedly more positive towards Russia than Merkel, and it is already apparent that he will adopt a similar approach again now.

Perhaps even more significantly, Germany's special coordinator for Russia, Andreas Schockenhoff, a vocal critic of Putin's anti-democratic policies and human rights abuses, has been replaced by Steinmeier's close ally Gernot Erler, a key author of the 'modernisation partnership' with Russia that was drawn up during Steinmeier's tenure in 2005-09. Despite the innumerable recent displays of Putin's overt contempt for the West, Steinmeier and Erler seem bent on resuming their earlier approach. Even before Merkel reluctantly agreed to confirm him in the post ${ }^{13}$ Erler went on the record to criticise the European Union for its 'misjudgements' on Ukraine. In Erler's view, the launching of the $\mathrm{EaP}$ itself was one such misjudgement. It is clear from his statements that he regards any EU policy that Russia strongly objects to as being best discarded. In justification of this stand, he cited the invaluable cooperation that Russia has provided on Syria and other matters. ${ }^{14}$

With German policy again led by this kind of anachronistic Ostpolitik, the chances of Europe adopting the kind of policies that would seriously threaten Putin's restoration project in the former Soviet republics diminish further. For its part, the administration of Obama seems remarkably untroubled by the prospect of Moscow's step-bystep dismantling of the post-communist and post-Soviet settlement of the early 1990s. Putin's year of triumphs in 2013 may be followed by more of the same. While it will probably be an unstable restoration, there seems a good chance that an eastward-oriented bloc of nations will be re-established, led by thuggish kleptocracies that are intent on retaining power and happy to accept subsidies funded by Moscow's 'energy diplomacy' in order to do so. On the other hand, as against all of the above, at least things are going splendidly in Syria.

13 See Valentina Pop, 'Merkel caves in on Russia appointment', EU Observer, 10 Jan. 2014, euobserver.com/foreign/122680.

14 Rachel Herp Tausendfreund \& Bettina Vestring, 'On Ukraine, the EU has made too many misjudgements', Deutsche Gesellschaft für Auswartige Politik, 12 Dec. 2013, ipjournal.dgap.org/ en/article/24666/print. 
Part 5. Putin reverts to cold war: Changing the shape of Eurasia 



\section{5}

\section{Putin's last territorial demand ${ }^{1}$}

In just over three weeks, the Kremlin has invaded and seized control of Ukraine's Crimean peninsula, installed a local government headed by a pro-Russian politician with a criminal past, enacted legislation through its well-trained Russian parliament facilitating annexations of other people's territories, supported the conduct of a hasty plebiscite at the point of a gun that achieved truly Soviet results (allegedly 97 per cent in favour), and commenced the accelerated approval of an appeal from Crimea to be annexed.

The procedure was crassly illegal from start to finish, secured virtually no support from the international community and effectively disenfranchised the Crimean Tatar community, whose grandfathers' generation had been brutally deported by Stalin towards the end of World War II with a fatality rate of up to 50 per cent. The survivors and their families were allowed to filter back to the peninsula only 45 years later. Not surprisingly, they decided to boycott the shotgun poll.

The model thus demonstrated has proved so attractive that Transnistria, a Russian-supported and largely Russophone enclave in mainly Romanian-speaking Moldova, which shares no common border with Russia, has also indicated its wish to be annexed.

1 First published as 'Say nyet now - or watch Putin's appetite expand', in The Australian, 22 Mar. 2014. 
The West has so far responded to this machine-gun fire of facts on the ground with shock, disapproval and non-specific warnings of 'costs' and 'consequences'. But, when the United States and European Union presented parallel programs of targeted sanctions on 18 March, these scarcely made a dent in the triumphalist mood of Vladimir Putin's celebratory annexation speech in the Grand Kremlin Palace the next day.

Further US sanctions announced on 20 March do, however, land some telling blows against some of Putin's KGB and judo billionaire cronies. One in particular, Gennady Timchenko, is widely believed to be Putin's personal bagman. But sanctions, to be truly effective, must emanate from the European Union, the source of most of Russia's fading prosperity.

Further steps are under discussion, and some European leaders, including German Chancellor Angela Merkel, seem at last to be seized of the matter. But the pain for both sides of serious trade sanctions, and the continuing divisions in EU circles, suggest nothing too dismaying for Moscow is likely to emerge.

In 1904, Russian Interior Minister Vyacheslav Plehve justified his support for the Russo-Japanese war by arguing that, to avert a revolution, Russia urgently needed a 'short, victorious war'. Since launching his Crimean triumph, Putin's ratings have gone up 10 per cent.

The Russian President has an obsessive fear of popular revolts that can take over the streets and topple autocrats. Twice he has seen it happen in Ukraine, in 2004-05 and again in 2013-14. And, just ahead of 'the greatest political catastrophe in the twentieth century' (the fall of the Soviet Union), he saw it, unnervingly, at first hand in the streets of Dresden in East Germany, where he was posted as a middle-ranking KGB officer.

Lately, the Russian economy has been in increasing trouble, with growth down to 1 per cent and further decline likely, particularly given Putin's extravagant US $\$ 700$ billion rearmament program for the current decade superimposed on the defence budget. 
Unproductive expenditure on his vast and ever expanding security forces and corrupt civil bureaucracy has led to cuts in health, education and infrastructure, all of which urgently require greater investment.

But Crimea is an alluring symbol for the 80 per cent of voters who depend on Russia's increasingly mendacious and xenophobic state television programs for their news and views. Thanks to the blanket propaganda from official media, the proportion of opinion-poll respondents who favour Russian interference in Ukraine has increased from a minority to an overwhelming majority within a month.

While Putin is simultaneously cracking down further on his domestic opponents, right-wing super-patriotic extremists are increasingly setting the tone for Russia's public life, ${ }^{2}$ and the surviving moderates in the President's entourage are marginalised. In seeking rational explanations, even justifications, for Putin's behaviour, commentators sometimes forget the basic principle that an autocracy's foreign policy will depend in large measure on the head noises of the autocrat and his current circle of favourites.

Crimea has been a splendid achievement for Putin, but he will not now want to stop there, unless he is very energetically resisted. He has invested a great deal in destabilising the eastern provinces of Ukraine, sending in volunteers and probably also, as in Crimea, spetsnaz (special forces) in mufti. Together with local Russian patriots, the newcomers have provoked repeated clashes with supporters of the government in Kyiv, seizing public buildings and trying to install 'popular governors'. These struggles are probably meant to create a fresh casus belli for Russian military intervention.

Such clashes are not typical of Ukraine, where, despite their differences, eastern and western Ukrainians have got along pretty well. But Moscow has run the narrative that its 'fellow countrymen' in Ukraine generally, as in Crimea, are at risk of terrible and violent persecution, which supposedly imposes on Russia an R2P (responsibility to protect) obligation. This is largely rubbish, as the Russians have not

2 See Robert Horvath, 'Putin's fiasco', Inside Story, 11 Dec. 2014, insidestory.org.au/putinsfiasco. 
been in danger and are, in fact, close to a majority in the cities of the south-east. But under the radicalising stress of invasion and further threatened incursions, it could become a self-fulfilling prophecy.

Putin will not withdraw those irregular forces until he has gained a good return on his investment. He will have had time to assess the Western response. Putin is known to hold Western leaders in contempt, viewing their cumbersome decision-making processes as dysfunctional. He will have been observing the internal disputes about sanctions and policy towards Russia in the European Union, and the frequent transatlantic disputes triggered by the dripfeed of Kremlin-friendly leaks from the idealistic Edward Snowden - safely ensconced in that mecca for human rights, Moscow. Unless Western leaders can suddenly reverse the momentum of recent months and set him back on his heels with some resolute decision, he will feel a strong impulse to move on to more venturesome scenarios.

If Moscow can maintain a state of disorder in south-eastern Ukraine, it may try to settle for a federalisation scenario. In a curious echo of NKVD secret police strategies in Eastern Europe in 1944-48, Russia has this week proposed that a 'support group' be created to oversee a rewriting of Ukraine's constitution to overcome the 'crisis' in the country and replace the 'illegitimate' government. The new constitution should, among other things, provide for a federative structure, with extensive autonomy for the provinces where Russians are allegedly under threat; ensure the country be permanently neutral and precluded from joining NATO or the European Union; prevent Ukraine from again adopting a 'neo-Nazi' ideology; and require it to accept Russian as a second state language. Not surprisingly, the Kyiv Government has dismissed this modest proposal, describing it as an 'ultimatum'.

For Putin, Ukraine is at once the jewel in the crown and, as he said to George W. Bush, not a real country. Its Ukrainian inhabitants are little brothers when they behave nicely and, particularly, when they speak Russian or identify as ethnic Russians (as some 17 per cent do), or fascists and Banderists when they look westwards. He covets Ukraine's extensive Soviet-legacy defence industries, which could be vital to his huge military buildup. A recent article in a Russian specialist publication, Sovershenno Sekretno magazine, went so far as to suggest Ukraine's defence industries were vital to the Russian 
defence complex's functioning. Putin would also be glad of the infusion of 46 million Slavs with a relatively small Muslim community. In Russia, at least 15 per cent of the population is made up of Muslims, many of whom are increasingly alienated by government crackdowns on Muslim migrants in Russia's big cities and harsh counterinsurgency operations in the North Caucasus.

Russia is going through a demographic trough where the cohorts of young people in the right age group for employment and military recruitment are very low. The establishment of a compliant, proMoscow government in Kyiv, happy to join the Moscow-led Eurasian Customs Union and post-Soviet security structures, and with guaranteed autonomy for the Russophone regions of eastern Ukraine, would be a big step forward from Moscow's point of view. And it is possible that possession of Crimea and parts of eastern Ukraine will not exhaust Putin's territorial demands. Clearly, plans are afoot for Moldova. And he may not yet have given up on Georgia, where Russia already de facto occupies some 17 per cent of the country and half its Black Sea coastline.

Moldova and Georgia are keen to conclude Association Agreements (AAs) with the European Union this year in a search for security. Moscow will want to torpedo any such development one way or another. Even the Baltic states, despite their NATO and EU membership, may not yet be safe. Estonia and Latvia each have large populations of supposedly suffering Russians who - strangely - do not want to leave. In 2007, Russia conducted an aggressive campaign against Estonia over the removal of a Soviet statue from central Tallinn to the suburbs, with extensive cyberattacks on government institutions and a sudden outburst of angry demonstrations by aggrieved Russians in Estonia.

This week a Russian diplomat in Geneva drew an ominous parallel between discrimination against Russians in eastern Ukraine and Estonia. Aggressive and extensive Russian-Belarusian military exercises and aerial patrols in the Baltic-Nordic area have become regular events in recent years.

For too long the Western responses to these provocations have been tepid and tactful. It is high time they became more emphatic. 



\section{6}

\section{Ukraine: Time to cut a deal?}

On 7 May 2014, after months of unrelenting economic, military and propaganda campaigns against his fraternal neighbour, Ukraine, President Vladimir Putin suddenly signalled what appeared to be a change in direction. He called on the 'pro-Russian' separatists in the eastern Ukrainian provinces of Donetsk and Luhansk to postpone their referendums on independence, and declared that the presidential elections scheduled by Kyiv for 25 May were a 'step in the right direction'.

Earlier, on 28 April, Russian Defence Minister Sergey Shoigu had claimed that the Russian forces deployed on the Ukraine border for months had returned to their bases, a claim Putin repeated on 7 May. As became clear in each case, no such withdrawals were observed by anyone able to do so, which seemed to suggest that any softening of the Kremlin's line on Ukraine was an optical illusion.

Seemingly in defiance of Putin's calls for a postponement, the separatists in Donetsk and Luhansk held their hastily scheduled 'referenda' on 11 May, with slightly farcical claims of huge turnouts and Soviet-style electoral margins in their favour. But their appeal for Moscow to annex them, as it had earlier annexed Crimea, elicited no response. Putin has since declared again his readiness to accept the results of the Ukrainian presidential poll and repeated his assurance that the troops on the Ukrainian border would be withdrawn; and this

1 First published in Inside Story, 30 May 2014, insidestory.org.au/ukraine-time-to-cut-a-deal. 
time there are indications that the troops may indeed be embarking on a drawback (though many of the units could be redeployed within a couple of days).

Despite the more conciliatory tone, Putin has continued to make ominous pronouncements, including renewed threats of another gas price war to force Ukraine to pay the abrupt increase Gazprom is demanding; claims that Ukraine is in the grip of a civil war; and the suggestion that his close friend Viktor Medvedchuk (Putin is godfather of one of Medvedchuk's children), the most pro-Kremlin politician in the Ukrainian political class, should become the mediator between the Kyiv Government and the 'rebels' in the eastern provinces. But to Western capitals, desperately eager to find a solution to the problem, any change of tone will be grasped as a sign that Putin is finally ready to 'de-escalate', and just needs an 'off-ramp' to do so.

Though tactically flexible under pressure, Putin is not given to backward steps, much less sudden about-turns. In the matter of Ukraine, he has shown a particular determination to prevail from well before the military operation against Crimea. So what are we to make of Putin's unexpected amiability? What brought it about, how genuine is it, and how long will it last? Have his objectives changed, or is this merely a tactical shift?

The recent heavy media coverage of the Ukrainian issue has probably made its fundamental grammar and vocabulary more familiar to the general reader. But, to judge by commonly recurring omissions and misconceptions in public discussions, some salient facts are worth recalling.

While Russians and Ukrainians are ethnically, linguistically, religiously and culturally close, there are important differences between them that have only been partly flattened out by tsarist and Soviet conditioning. And those differences are apparent within Ukraine itself. For historical reasons, central and western Ukraine have come under the influence over centuries of the Austro-Hungarian Empire and Poland. A substantial minority concentrated in the west are Uniate Catholics by belief or tradition, whose homelands had never formed part of Russia before the end of World War II. Though Orthodoxy is the religion, at least nominally, of the overwhelming majority, there is an important difference between the followers of the 
Moscow and Kyiv patriarchates of the Orthodox Church. Moscow and its Ukrainian loyalists have always favoured the Moscow Patriarchate, but the more nationalist Kyiv Patriarchate may actually have a larger following within Ukraine - and their relationship is troubled. There is also a much smaller Autocephalous Ukrainian Orthodox Church.

Moscow rulers have often sought to suppress Ukrainian language and culture. The Soviet leadership in its early years was more liberal in such matters but, for much of its subsequent history, it was also very oppressive. Even since Ukraine became an independent state, Russia has refused to tolerate more than the most minimal cultural facilities for the millions of Ukrainians living in Russia. In Moscowruled Ukraine, by contrast, Russians enjoyed a privileged status and the use of Ukrainian was informally or formally tabooed. Independent Ukraine has taken modest steps to improve the relative position of Ukrainian within the state, which has angered some Russian speakers.

But the use of Russian is under no serious threat, and repeated suggestions in the media that the government that emerged after the Maidan Nezalezhnosti (Independence Square) protests wants to ban Russian are misinformed. The bill in question, though politically foolish given its timing, was aimed not at 'banning' Russian, an impossible objective, but, rather, at restoring greater official status to Ukrainian in an attempt to partially rebalance the wrongs of the past. It was, anyway, very quickly vetoed by provisional president Oleksandr Turchynov and withdrawn.

The Soviet period was a series of demographic disasters for most of the country. But it was worst of all for the 'bloodlands' ${ }^{2}$ of Ukrainian, Belarusian, Baltic and Polish settlement. Per capita, Jews, but also Ukrainians and Belarusians, suffered far more than Russians. Slips of the mind equating Soviet citizens with 'Russians' and loose references to 25 or 30 million Russian dead in World War II serve to erase a universe of suffering sustained in the west of the country, in which Stalin's regime was complicit as a perpetrator. Similarly, in the 1930s, Ukrainians were among those national groups, together with Jews and Poles, who suffered disproportionately in the purges.

2 Timothy Snyder, Bloodlands: Europe between Hitler and Stalin (New York: Basic Books, 2010). 
The early Bolshevik leadership encouraged strong development of the languages and culture of the national minorities, to win their loyalty and ensure victory over the Whites in the civil war of 1917-22. The Ukrainian communist leadership of the 1920s was active in pursuit of nationalist Ukrainian objectives. From the late 1920s, however, Stalin brutally reversed this policy to favour Russian, and the emergent generation of Ukrainian national communist leaders and cultural activists was decapitated.

Worst of all, in the process of brutally collectivising agriculture in Ukraine (which had been the breadbasket of the empire), and then extracting grain from it for export, Stalin inflicted terrible casualties. The culmination was the artificial famine of 1932-33, which led to mass starvation and innumerable acts of cruelty aimed at preventing the victims from securing any relief. Historians debate both the numbers of dead and the Kremlin's precise intent in manufacturing this holocaust (known in Ukrainian as holodomor), but whether it was genocide by some definition or not, at least 3 million Ukrainians perished (and some estimates go much higher).

The Soviet regime suppressed discussion of these monstrous events and succeeded in largely obliterating them not only from the public domain but also, to a considerable degree, from popular awareness. The Russians who were encouraged to migrate into depopulated parts of Ukraine have even less awareness of the past. Through discreet and, indeed, politically hazardous family communication, Ukrainians have retained at least a fragmented folk memory of the great famine, which naturally doesn't always dispose them positively to Moscow. For its part, the Putin regime greatly resented pro-Western President Viktor Yushchenko's attempts to restore a basic historical understanding among Ukrainian citizens of the holodomor, which was at odds with Putin's policy of progressively rehabilitating Stalin and his works. When Viktor Yanukovych succeeded Yushchenko in 2010, he moved quickly to de-emphasise the issue and defang it of any anti-Russian accents, a difficult exercise in the circumstances.

Until recently, despite the burden of history, Ukrainians and Russians have continued to get on reasonably well with one another in Ukraine. Ukrainians living side by side with Russians in other parts of the post-Soviet sphere mingle easily, intermarry with Russians, and often adopt Russian ethnicity and the Russian language. The same has been 
largely true of Ukraine itself. It was not the case, Kremlin propaganda notwithstanding, that ethnic Russians faced any threats of persecution from Ukrainian fellow citizens in the east of Ukraine before the invasion of Crimea. At most they might experience irritation at the public use of what they regarded as an inferior but basically comprehensible rustic dialect in public places or on street signs.

The main resentments of Russians in eastern Ukraine centred on the fact that the central government in Kyiv, controlled by the Donetskbased Yanukovych clan, had done nothing to improve their standard of living, rather the reverse. Meanwhile, as they were keenly aware, he and his notorious familia were dipping into the public trough right up to their armpits. Because of the cultural and historical differences between the east and west of the country, some political polarisation also existed, reflected in differing regional levels of support for the main political parties.

But the differences were less than virulent and, in the 20-odd years since independence, they were successfully managed by elections that tended to produce regular alternation between eastern-oriented and western-oriented presidents. Eastern Ukrainians were mostly unenthusiastic about the pro-Western Orange Revolution of 2004-05 and the Maidan protests of 2013-14, though a substantial minority in the east, including Russians and Russian-speakers, supported them as movements that might improve their standards of living and increase probity in public life.

In fact, there was a degree of structural pluralism in Ukrainian society, which contributed to the retention of more democratic freedoms in the country than in neighbouring Russia or Belarus, for example. In that sense, Ukraine was a more democratic polity than any other part of the former Soviet Union, apart from the Baltic states and Georgia, and remains so, despite the current artificially induced turbulence.

But, if it is a little more democratic than the others, it is certainly not more economically functional than they are. Russia, with its huge resource endowment, has done better than Ukraine economically, and so too have Belarus (with its huge Russian subsidies) and Kazakhstan, for example. For many Ukrainians, however, the most telling comparison was with its western neighbour Poland, which was on the same level as Ukraine in 1990 but has since leapt far ahead, particularly after 
it joined the European Union in 2004. Its per capita GDP is now over three times the size of Ukraine's, and with Russia's ongoing military and economic aggression against Ukraine, that disparity is increasing sharply. ${ }^{3}$ The numerous Ukrainians who travel to Poland in search of short-term work can see and feel the difference and want to follow Poland's example.

The European Union, therefore, had strong appeal in Ukraine, reinforcing the Western orientation of those already so inclined but also attracting many others. The idea of seeking some degree of economic integration with Europe came to enjoy significant support both in the population as a whole (though only a minority in the east), and in the political and other elites. As a result, Ukrainian leaders mostly tried to couple good relations with Russia with some degree of rapprochement with Europe. Recent opinion polling has regularly shown a strong plurality in the country favouring an Association Agreement (AA), with Brussels, well ahead of the numbers supporting Putin's geopolitically motivated Eurasian Customs Union.

Yanukovych disappointed some of his eastern followers by working towards an AA, and Russian propaganda was able to effectively capitalise on the issue. Russian TV, heavily favoured by Russians in the eastern provinces, pushed the line that the AA would be the road to ruin for those provinces whose trade was directed more towards the Russian market. Moscow repeatedly threatened to penalise Ukraine's trade with Russia in retaliation for Kyiv's concluding any deal with Brussels. And, in 2013, not for the first time, it did indeed conduct a trade war against Ukraine, closing off its border to Ukrainian exports for more than a week in summer, and selecting as one of its key targets the chocolates produced by Roshen, the large confectionery concern owned by the 'Chocolate King' (and, since 25 May, the Ukrainian President), Petro Poroshenko, whose TV station was strongly advocating adoption of the Western vector.

Kyiv's negotiations with Brussels were undoubtedly a blow to Putin's hope of restoring a Soviet Union-lite, dominated by Moscow. Once he realised that there was a serious danger that the AA might happen,

3 See Simon Tilford, 'Poland and Ukraine: A tale of two economies', Centre for European Reform, 31 Mar. 2014, www.cer.org.uk/publications/archive/bulletin-article/2014/poland-andukraine-tale-two-economies. 
his hostility became explicit. Some Western observers, lobbyists and officials - of the kind widespread in Germany, where they are known as Russlandversteher (those who understand Russia) - suggest that the European Union should have conciliated Russia by involving it closely in the tortuous negotiations that took place with Kyiv over the AA. This would, they argued, have reassured Russia and dealt with any objections it might have had.

Unlike Putin's negotiations with Kyiv, however, the European Union's dealings with Ukraine were largely transparent, and conducted according to well-enunciated principles. There was no compelling reason to suppose that increased trade with Europe would make Ukraine a worse partner for Russia. Poland, for example, greatly increased its trade with Russia after joining the European Union and, in general, developed better relations with Moscow.

The reason why Moscow did not like the idea of Ukraine joining was that it wanted Kyiv to remain a subordinate partner contributing to Moscow's geopolitical objectives and responding cooperatively to its decisions and initiatives. Any attempt to involve Moscow in the negotiations would have been abortive, leading swiftly to a Russian demand for a de facto right of veto on anything that might ever be agreed. Putin's attitude to this has been eloquently expressed by the measures he took against Ukraine once it did attempt to fly the coop.

Eastern Ukrainians, anxious about their economic prospects, had good reason to fear EU integration. But, the real danger to them was that, as they had been warned, Moscow would launch punitive countermeasures to any Ukrainian decision for EU integration, based not on economic but on geopolitical considerations. They could sense that failing to accept the offer that couldn't be refused would lead to trouble first and foremost for their rust-belt industries. Not surprisingly, a majority of respondents in the eastern provinces regularly told opinion pollsters that they favoured Moscow's Customs Union, not the AA with Brussels. This gave Moscow valuable material to work with.

It was never the case, however, that the Russians and Russian speakers in eastern Ukraine wanted to become part of Russia. Opinion polling over the years has shown that a great majority of eastern Ukrainians including many who speak Russian by preference or, indeed, identify 
themselves as Russians - want their region to remain part of Ukraine. There is a regional national identity, as well as an ethnic one. And even in Crimea, up to the invasion, a majority of the inhabitants declared to opinion pollsters that they wished to remain in Ukraine. Despite this, the phoney referendum that the new post-invasion bosses conducted showed an implausible turnout with a huge majority supporting annexation.

Western commentators are used to spin in their own political systems and are growing increasingly fed up with it. They are not, however, used to dealing with what the Russians call vranyo (roughly, lies of a particularly brazen and shameless kind). Vranyo was one of the basic pillars of the Soviet regime, and it continues to play a major and indeed an increasing role in the Putinist system. When someone reports electoral results affected by vranyo to Western listeners, however, they are inclined to assume that those results must be somewhere near the mark, spun a bit, perhaps, but otherwise okay, and certainly indicative of something. In this case they were wrong, yet we all heard and read phrases in our media implicitly accepting that the results of the fraudulent referenda had some meaning. They did of course have a meaning, but it was not as a test of public opinion.

Events since the invasion and annexation of Crimea, up to and including Putin's recent shift of tack, need to be considered in the light of the above. Western reporting and comment have sometimes fallen victim to their practitioners' sincerely held principles - the belief, for example, that the truth must be somewhere in the middle, or that the object of widespread criticism, in this case Russia, is some kind of underdog, so let's try to understand it. Russians are talented people and one of their traditional strengths, in which they are again excelling, is propaganda. They have run a crudely mendacious but effective and skilfully differentiated information war against Ukraine and its Western supporters over the past few months, which has done a great deal to reduce the international fallout from their seizure of Crimea and destabilisation of Ukraine's eastern provinces.

How, then, do recent events in and around Ukraine look if they're summarised with considerably less vranyo? Russia's conquest of Crimea was indeed a masterly operation displaying a great deal of ingenuity and originality, and making adroit use of some historical precedents. Following up its trade war skirmishes, but with assurances that it had 
no aggressive intentions, Moscow conducted very large military exercises in the west of Russia near the Ukrainian border, deploying up to 150,000 troops. These provided cover for the preparation of a detailed invasion plan for Crimea, which was then implemented with considerable strategic surprise. The invasion saw deployed a modest number of highly trained Russian spetsnaz (special forces) and military units based in Crimea in accordance with, but now grossly violating the terms of, the Black Sea Fleet Agreement with Kyiv. Putin initially denied that any Russian forces were involved, but later, after the triumph, acknowledged that there had been.

The weak and somewhat demoralised Ukrainian forces on the peninsula, like the new Kyiv Government, were taken unawares. Any serious response was beyond their immediate capacity and, in any case, they feared that any armed resistance they attempted would provoke Moscow to stage a wider incursion using the massed forces just beyond the border. The invading forces wore masks and no military insignia (another of many breaches of international law) and liaised closely not just with other Russian units, but also with local militias and politicians who had clearly, under cover of the heavy Russian presence on the peninsula, been thoroughly prepared to perform their roles.

One of Yanukovych's first acts in 2010 had been to extend the Russian fleet's tenure in Crimea and resume the traditional military and security cooperation with Russia that his pro-Western predecessor Yushchenko had been trying to minimise. Moscow used the cooperation of the Yanukovych years to good effect. Sergey Aksyonov, a marginal Crimean politician with 4 per cent support, Kremlin links, a criminal record (like Yanukovych), and money and connections to lend to the task, was parachuted into the role of 'premier' of the new entity. His 'government' then proclaimed its desire to join Russia and conducted a rushed and fraudulent 'referendum', which produced an allegedly large turnout and huge majority ratifying this new reality. Monitors from the Organization for Security and Co-operation in Europe and other Western observers were bullied, harassed and excluded, though exceptions were made for some Kremlin-friendly right-wing and left-wing European extremist groups to observe and enthuse about the referendum. 
After hinting first that he would not quickly accede to the Aksyonov government's request, Putin then abruptly staged a huge annexation ceremony in the Kremlin to mark this momentous development. There, he made a stirring patriotic speech reaffirming the new Russian doctrine that any people anywhere who spoke Russian would be regarded by Moscow as people it had a responsibility to regard as its own citizens and to protect against any harm that might come their way. This doctrine is one of the key items that induced a wide variety of Western observers, including Hillary Clinton and the Prince of Wales, to comment on the parallels with Nazi Germany in the late 1930s. The entire Crimean operation was accomplished within no more than three weeks.

Western experts had made critical appraisals of Russia's military performance in their crushing of Georgia in 2008. This time, however, after getting over their initial surprise, they acknowledged that, technically, the takeover of Crimea was a classy performance, and one that indicated that Putin's big military buildup - to which EU and NATO countries have totally failed to respond - is yielding impressive results.

Indeed, Western countries appeared to be as much taken by surprise as the Ukrainians themselves. They spoke of costs and consequences for Russia, but were unable to agree on imposing any severe enough to worry Putin greatly. While Western countries have said that they would never recognise the annexation as legal, there is a strong sense that most of the Europeans, at least, have accepted it as a fait accompli. There seems to be an unstated but widespread assent to Putin's argument that Nikita Khrushchev's decision to allocate Crimea to Ukraine was a silly misunderstanding that should be put aside. Crimea is Russian, end of story.

It should be emphasised again that reputable opinion polls showed that, right up to the invasion and despite the fact that some 58 per cent of Crimeans identified themselves as Russians, there was not a majority that favoured Crimea's joining Russia. The Crimean Tatars (some 12 per cent of the population), who had been deported by Stalin towards the end of World War II with huge casualties, were particularly emphatic in their opposition. After making one or two conciliatory gestures in their direction, the Kremlin seemed to abandon the attempt and resumed their policy of persecution. Many thousands of Crimean 
Tatars have now chosen exile in central and western Ukraine. Their leader, Mustafa Dzhemilev, has been banned from entering 'Russia', and their main political organ has been threatened with closure as an 'extremist organisation'.

These events recall much that was done in the Stalinist era by way of territorial acquisition and the erection of totalitarian structures. The human casualties, it should be noted, have been much fewer; although it was carried out by highly armed and menacing troops, the Crimean operation was not gratuitously violent. But the parallels with the 1940s are nonetheless striking.

Meanwhile, Moscow and its fifth column in Ukraine have continued their work destabilising the provinces of eastern Ukraine where proRussian sentiment is strongest. At first glance, the modus operandi mirrored the Crimean operation: heavily armed men in anonymous military fatigues with full face masks and no insignia; strong evidence of a controlling Russian presence; and detachments of local sympathisers helping out, including civilian and babushka groups to provide a human shield for the operations and a local legitimation.

Again there was a high degree of coordination between assaults on public buildings of strategic importance in various major eastern centres, as the violence 'spread' to different targeted cities, which formed a neat and strategic band running through eastern Ukraine down to the Black Sea. As Putin and others spoke ominously of Novorossiya (the tsarist name for most of eastern and southern Ukraine), attempts were made to extend the insurgency into the Black Sea provinces stretching across the south of Ukraine.

Armed groups of militiamen and toughs roamed the towns looking for useful work for themselves. They particularly concentrated their violence and intimidation on locals who spoke Ukrainian, flew Ukrainian flags or took part in pro-Maidan demonstrations. They were helped in their activities by the passivity or even collusion of the police and security forces in the east, which had become wholly dominated in recent years by Yanukovych's Party of Regions machine, and appeared to be happy for the pro-Russian militias to take over control of the region. The object of all this activity seemed to be to weaken resistance to the new order that was about to be instituted, as in Crimea. 
But differences between the two campaigns became more apparent as time went on. Some targeted cities were effective in resisting, even where there seemed to be a strong pro-Russian element in the population. Recovering from their initial shock, the Kyiv authorities began to resist with armed force, using such loyal military and security units as they could muster to take the fight back to that new and suddenly very well-armed ethnic category, the 'pro-Russians' in the east. Casualties began to mount. Local residents sometimes became angry with the militiamen who were undermining their way of life and behaving in an increasingly lawless way.

Key oligarchs, who had mostly been playing a waiting game or even colluding with the troublemakers, joined the resistance. Some of them, who had been recruited as local governors by Kyiv, used their economic power against the separatists. When Ukraine's richest man, Rinat Akhmetov, who had initially been virtually invisible, suddenly deployed some of his vast workforce to challenge the thugs and police the streets instead of them, there was a sense that the tide was turning.

The morale and discipline of the attackers slackened and they increasingly involved themselves in common criminal activity, which was often directed against minority groups, especially Roma. As with Yanukovych's crowd-dispersal operations on the Maidan, groups of titushki (hired thugs) appeared to be involved in the action, with some of them admitting that they were being paid to inflict violence on pro-Kyiv Ukrainians. Media reporting began to focus on the criminal element in the east, as did the UN Human Rights Monitoring Mission, whose second report ${ }^{4}$ on the situation laid the burden of responsibility heavily on the pro-Russian camp for the killings, abductions, beatings and harassment that they were observing.

Clearly, if Putin's intention had been to overrun some of the eastern provinces as a preliminary to annexation, things were no longer running smoothly. Destabilisation was relatively easy; pacifying and then holding new territories in the east would be more difficult, even in Yanukovych's home territory of Donetsk and Luhansk, where the 'pro-Russians' were much stronger than elsewhere. It needs to be emphasised again that, while there are more Russians and more

4 UN Human Rights Monitoring Mission Report, 15 May 2014, www.un.org.ua/images/ stories/Report_15_May_2014_en.pdf. 
pro-Russian sentiment in the eastern provinces, before the Russian intervention, strong majorities there, including in Donetsk and Luhansk, favoured remaining part of Ukraine.

This was no doubt one of the reasons why Putin reacted as he did when the Donetsk and Luhansk leaders organised referendums and declared themselves sovereign 'people's republics' (another bizarrely nostalgic formulation from the Stalinist past). He decided first to advocate that the votes be abandoned, and then to decline their request to be annexed. As well as distancing himself from his own agents and their zealot followers, he began to reach out to what looked increasingly likely to be a new leadership group in Kyiv after the presidential elections on 25 May. While the sanctions to date had not seemingly made a huge impression on him, he was painfully aware that the Russian economy, stagnant already for some time, was heading into recession, and the possibility of more resolute sanctions being imposed, as had been threatened if he tried to disrupt those elections, was a serious potential danger.

As it became increasingly evident that the new president, with a huge and convincing majority, would be Poroshenko, maintaining the fiction that Yanukovych was still the legitimate leader was becoming more difficult. Putin has recently repeated the claim that Yanukovych was still the rightful leader, but he has also said several times that he is prepared to engage with Poroshenko. He may well see in Poroshenko an opportunity as well as a challenge.

Poroshenko has emphasised his pro-Maidan credentials recently and declared his full commitment to European integration and the recovery of Crimea. But he is an oligarch who has become a billionaire mainly through his Russian trade links and investments and has, in the past, been associated with Yanukovych and his Party of Regions, as well as with more pro-Western political formations. He mingles easily with Russians, has a Russian daughter-in-law and has emphasised his readiness to negotiate with Moscow - and with Putin personally, of whom he has spoken publicly with diplomatic respect. In a word, Putin may have felt that Poroshenko is more his kind of Ukrainian than any of the other post-Yanukovych leaders, like Prime Minister Arseny Yatseniuk or the former provisional president, Turchynov. 
If so, he may be heading for something of a disappointment. Poroshenko is a tough and experienced politician with a huge majority behind him, including wins in the eastern provinces. And he has begun his administration forcefully. Responding to a heavily armed ambush on a Ukrainian army checkpoint south of Donetsk, where the well-trained raiders' objective was clearly to kill as many as possible (16 died and many more were injured), and the armed seizure of Donetsk airport several days later, Poroshenko ordered a major armed assault to recapture the airport, resulting in the deaths of nearly 50 separatists. And he repeated that he did not regard EU integration and Crimea as negotiable.

Russia's sustained coercive pressure on Ukraine - the manipulative gas pricing, the trade boycotts, the collusion with pro-Russian elements in Ukraine, the seizure of Crimea, and the destabilisation of eastern Ukraine - all look like neo-imperial aggression. And it is neo-imperial aggression by a country with a very bad record in that respect. At a time when other European imperial powers have long since withdrawn from their imperial possessions, whether in Europe or beyond it, such behaviour seems anachronistic as well as unconscionable. Hence Obama's lectures about Russia being on the wrong side of history not terribly effective as a way of influencing Moscow's behaviour, but an understandable sentiment.

The Ukrainians have been invaded and had a vicious civil war artificially inseminated in their eastern provinces. Notwithstanding a surprising flow of Western commentary in their defence, the Russians are in breach of numerous international instruments, including the 1994 Budapest Memorandum on Security Assurances, whereby Ukraine agreed to divest itself of its nuclear weapons in exchange for assurances offered to it by the United States, Britain, Russia and, later, France that it would not be subjected to any military or economic coercion by anyone. Yet it has been subjected to both many times.

Can that do anything positive for the international nuclear nonproliferation regime? And what does this portend for other countries with large Russian imperial minorities? What of Moldova, Kazakhstan or Belarus's surviving sovereignty? And what, even, of NATO members like Estonia (already in 2007 subjected to a cyberwar backed 
up by organised turbulence within its Russian minority) and Latvia (many of whose ethnic Russian citizens have told opinion pollsters that they support Russia's invasion of Crimea)?

Yet Russia's view of the whole saga, especially the last few months of it, has been taken up by numerous Western commentators who are eager to set out what they obviously believe to be the deeper reality behind the seemingly blindingly obvious: that Russia's behaviour is aggressive and unjustifiable, and must be restrained. There are some who blame the victim, pointing to the poor management of successive Ukrainian governments and suggesting that they are so irredeemably incompetent and corrupt that nothing better can ever be expected from them. In any case they are in Russia's sphere of influence, so let them beg Moscow for mercy.

Another school of thought sees this as yet another case for which the United States must take the blame, with its endless malevolent interference in other people's affairs. It failed to give the new Russian democracy of the early 1990s any support and brazenly expanded NATO practically up to Moscow's door. Any Russian leader would have reacted badly to that, justifiably fearing that Washington was trying to destroy it. Some of these thinkers seem to be guided by the principle that wherever the United States takes a stand, the decent or insightful should position themselves on the other side.

Then there are the economists who argue that Russia has given its neighbours generous discounts, which, in Ukraine's case, have been frittered away. Saving Ukraine from itself would be ruinously expensive for the West, so it's fortunate that Russia wants to take it over. If we agree to their doing so, we will save ourselves billions of dollars, and how good is that? This line of thought is a subset of the blame-the-victim thinkers, and it shares their lack of interest in any possible security downsides of a Russian takeover.

Yet another prominent group is made up of what might be termed the perpetual friends of Russia. Often these are durable lefties who've retained a sympathy for Russia through all the purges, Hungaries, Czech Springs, Cubas, North Koreas and Venezuelas, all the way to the collapse of communism and beyond, and who still see Russia as a country to be protected from its enemies. Sometimes to be found on the pages of The Guardian or The Nation, they are typically a subset 
of the blame-the-Americans school, despite Washington currently having its most liberal administration since at least Jimmy Carter's, and possibly beyond.

Let us not forget the realists, who also see what Putin has done as what any Russian leader would have done. For them, there's no point in being indignant; nature has taken its course and resistance would at best be futile, or at worst be dangerous folly. Despite their 'realism', these thinkers are strangely insouciant about the strategic downsides of Russia being thus encouraged to make further land-grabs from other of its neighbours, till it finally reaches the next circumference of hostile encircling states which will also need to be dealt with. The explanation for this paradox is probably that the morbid realists haven't, for one reason or another, any affection for the current victims of the bear (a furry image they like to deploy to make Russian aggression seem more cuddly). If we give some of them to the Russians, the bear will be sated and we'll all be able to enjoy some realistic peace in our time.

Both of the preceding two categories overlap with the left, particularly of course the friends of Russia, and sometimes the hard left. They are often particularly susceptible to the Kremlin propaganda line, which has stated from the outset of its aggression that Ukraine is mortally threatened by vicious Ukrainian anti-Semites and neo-Nazis. This line has actually been running since Moscow took over much of Eastern Europe at the end of World War II, and still earns the Kremlin handsome rewards. People with a weak understanding of recent Ukrainian developments (and Russian for that matter) are particularly susceptible to it.

It is not a matter of debate that Ukraine, like many other European countries, has seen in the past a great deal of anti-Semitism, some of it violent and nasty. And it is true that the Svoboda party and other smaller groups in the Maidan coalition were not free of it. But it was a weak component, given great prominence mainly by the fact that, as Yanukovych increasingly resorted to violence, the hard men in the opposition who were prepared to use physical violence gained greater prominence. But the issue was grossly overestimated in some instant Western commentary, while there was an equivalent underestimation of the presence of similar forces in the east. In fact, Jews were strongly 
represented in the Maidan coalition, and senior rabbis have repeatedly emphasised that they did not feel seriously threatened in Ukraine either east or west.

Given Ukraine's history, the amount of anti-Semitism, as opposed to militant nationalism (not the same thing, and not necessarily always 'far right'), is at present modest. And, as for the political representation of such forces in the country, the best measure is provided by the European parliamentary elections on 22-25 May: in France, Denmark and Austria, the far right got 20 per cent or more of the vote; in Ukraine it received only 2.2 per cent, despite the fact that Russia's actions were the ideal catalyst for more of it to have developed.

Finally, in this incomplete list of Russlandversteher, we have the hardright extremists. Recently the director of Sydney's Lowy Institute, Michael Fullilove, deplored the relative absence of the left from the ranks of those deeply concerned about the events in Ukraine. He made a good point, and could perhaps with due qualifications have extended it beyond Australia, which was his primary concern. But some excellent pieces have also appeared in left-wing publications. ${ }^{5}$

It is the hard right's enthusiasm for Putin and all his works, however, that is perhaps even more dismaying, particularly in the light of their stellar performance in the elections to the European Parliament. While Putin has many Soviet characteristics, he has increasingly been selling himself and his regime as exemplars of traditional 'conservative' values, while continuing to clutch the gullible old left to his bosom.

Putin's conservative values include suppressing democracy, empowering the reactionary and KGB-subservient Russian Orthodox hierarchy, encouraging people calling themselves Cossacks to undertake bully-boy roles in public (including whipping Pussy Riot performers), denouncing and oppressing gays, and pursuing territorial aggrandisement. The European hard right reciprocates warmly. Marine Le Pen, for example, has twice visited Moscow recently and seemed to get on famously with the relentlessly aggressive nationalist with KGB connections, Deputy Prime Minister Dmitry Rogozin. Representatives from such parties were invited to observe the Crimean referendum to

5 See, for example, Brendan Simms, 'Defend the West: Is it time to re-arm?', New Statesman, 3 Apr. 2014, www.newstatesman.com/politics/2014/03/defend-west. 
attest to its strict conformity with best democratic practice, a function that they performed enthusiastically. I was always taught that hard left and hard right have more in common than either would wish to acknowledge. In this case, it would certainly seem so.

But Putin and his Foreign Minister, Sergey Lavrov, are now sounding more reasonable. Is this a good thing? Well it's an improvement on Putin's annexation sabbath in the Kremlin. And perhaps some good will come of it. But only if Western leaders can show a little more resolution and unity than has been evident so far.

It has always seemed that Moscow's minimal demand, beyond seizing Crimea, is that Ukraine be constitutionally restructured to create a federal or even a confederal state in which the eastern provinces, and through them Moscow, would have an effective veto on major decisions, especially regarding the country's external orientation. Alternatively, perhaps, Moscow might wish to see immutable constitutional provisions directly inserted that would preclude Ukraine from seeking membership of NATO or the European Union or any equivalent international arrangement (an AA through the Eastern Partnership program, for example). Moscow also urges that the Russian language must have guaranteed status as a state language. It is evident, moreover, that it aspires to have these sorts of constitutional provisions guaranteed by some international instrument.

Finlandisation is also being proffered by generous Western cheerleaders, free with other people's favours, as the ideal solution for Ukraine, just at the time when Ukrainian events have led to another wave of anxious discussion in neutral Finland and Sweden as to whether their security arrangements are adequate for present circumstances. Ukraine's postYanukovych leadership has repeatedly indicated a readiness to discuss greater devolution of powers to the provinces, but within the bounds of a unitary state.

Federalisation of the kind that Moscow would like is not popular outside the separatist movements in eastern Ukraine. It's hard therefore to see it being accepted by any credible domestic democratic process in Ukraine. Just how Moscow would be able to get what it wants is therefore unclear. Presumably it would respond to its disappointment with the outcome of any domestic or international process in such matters in the usual way, by renewing its destabilisation of the 
eastern provinces or by inflicting another gas war or heavy-handed trade boycott on Ukraine. Similarly, if Poroshenko proves to be less amenable to pressure than Moscow is hoping (he says he is going to divest himself of much of his business empire), it may think better of having agreed to engage with him in the first place. Russia has a wide range of punitive measures to draw on in any such contingency.

By their invasion and destabilisation campaigns, the Russians have in large measure discredited themselves with the Ukrainian mainstream, for the immediate future at least. If they can't annex part of eastern Ukraine, or secure special constitutional prerogatives for their proxies there, they will be facing a poor outlook. This leaves one with the suspicion that, if the current tone of sweet reason does not yield adequate rewards, some incident may occur or be devised that will overturn the chessboard and confront Kyiv with a renewal of outright violence or economic blackmail. 



\section{7}

\section{Russian disinformation and Western misconceptions ${ }^{1}$}

A few weeks after Russian proxies in eastern Ukraine shot down a Malaysian airliner on 17 July, Russia infiltrated some 6,000 more of its regular forces, including crack troops armed with high-tech weaponry, across the still porous Ukrainian border. Whether it was an invasion or merely an incursion, as some have argued, this operation sharply reversed the direction of the conflict in eastern Ukraine, which had been running increasingly in Kyiv's favour, and inflicted heavy losses on the Ukrainian forces. Western governments are in no doubt about what has happened. And, yet, many Western media, and some in the commentariat, continue to treat these events as a mystery about which little is definitively known.

Under Vladimir Putin, Russia has wielded its 'political technology' very effectively. (Roughly translated, this technique involves liberal doses of manipulation, deception, disinformation and outright lies to achieve a particular political objective.) Perhaps its crowning achievement is what has become known as 'hybrid warfare', which has been on display in Ukraine, particularly since the lightning operation in Crimea over three weeks in February and March this year. In this 
kind of war, violence is relatively limited, and is cloaked behind a thick veil of information warfare (propaganda) to conceal not only its real perpetrators but also its purpose and objectives. ${ }^{2}$

In the Crimean case, masked 'little green men', in fatigues without insignia, conducted surgical strikes on key enemy targets with no warning or declaration. This was implausibly presented to a gullible international audience as a spontaneous outburst of resentment by mistreated ethnic Russians suffering under the heel of a 'fascist' dictatorship set up by an illegal coup in Kyiv.

The Kremlin has been labelling its enemies and victims as fascists for decades, seldom accurately but often with a high degree of success. Western media, with their ethic of 'balance' ('the West says this, the $\mathrm{X}$ says that; we're not sure which to believe, we're just reporting the established facts') always run the risk of blurring or even suppressing the real story that should be obvious to anyone with a passing familiarity with the region and the situation. What we get is along the lines of: 'Armed men in unmarked battle fatigues have seized key buildings and installations on the Crimean peninsula. Western governments are accusing Moscow of being behind the raids, a charge which Moscow strenuously denies.' Six months later, the same convention continues to be followed.

Western publics are becoming increasingly familiar with and irritated by 'spin' from their own governments, for which they are developing sensitive antennae. They find it more difficult to handle outright lies and deliberate disinformation (a semi-truthful narrative, with big lies embedded in it at strategic points) from sources far less scrupulous than governments of open democracies.

The same sometimes goes for Western officials, particularly of the post-Cold War generation. Most EU officials and politicians, for example, are used to tough and complex bargaining and the lengthy hammering out of difficult compromises. But this all takes place within a peaceful atmosphere, following clear rules, with limited corruption or outright dishonesty. They can be tough on trading

2 For an early and apt description and analysis of 'hybrid warfare', see Jānis Bērziňšs paper, 'Russia's new generation warfare in Ukraine: Implications for Latvian defense policy', National Defence Academy of Latvia, Center for Security and Strategic Research, Policy Paper No. 2, Apr. 2014, www.naa.mil.lv/ /media/NAA/AZPC/Publikacijas/PP\%2002-2014.ashx. 
issues, but they are typically less confident and effective in dealing with seriously unscrupulous purveyors of security challenges. Theirs is a fine civilisation, configured for peace, but suddenly confronted with war. As in the 1990s with the Yugoslav wars, EU officials seem a bit lost. It must be seriously doubted that they are equal to the task of dealing with Putin's Russia.

There are two key reasons why Russian aggression and mendacity have worked so well thus far. First, there was the shock factor. Western leaders, officials and commentators were taken by surprise by the Crimean invasion, and only after further surprises are they starting to realise what they're up against.

Second, there's the ignorance factor. The global West has, by and large, always had a poor understanding of Russia. Putin's neo-Soviet yet postmodern modus operandi has reinforced that longstanding state of affairs. Since declaring victory in the Cold War, which was largely won for them by brave Russian reformers and their Eastern European counterparts, the West has been content to relegate Russia and its neighbourhood to the easy basket.

When conflict between Russia and Ukraine first entered the Western public awareness earlier this year, and Australian media were looking to bone up quickly, I noticed that a lot of the questions directed to me reflected very serious, even crippling misunderstandings. I was frequently asked not to discuss the overall situation or some important development, but rather the threat posed by the neo-Nazis known to be dominant in Kyiv. Or could I please comment on and explain the reasons why Russians were in fear of their lives in Eastern Ukraine, where most people were Russian or pro-Russian and were in despair because use of the Russian language had been banned? Was it not the case that we'd been given fair warning of all this because the Maidan demonstrations had, after all, been dominated by violent, far-right anti-Semites? The questions were often so wide of the mark it was hard to know where to begin.

Sometimes the questions carried the unstated implication that these alleged social pathologies not only existed, but also were peculiar to the West of Ukraine and therefore presumably absent from Eastern 
Ukraine or Russia itself. Moscow was assumed to be looking on from a distance with understandable dismay - suggesting that we should be supporting the Kremlin in its stalwart opposition to 'the fascists'.

Some reporters rightly grasped that corruption was a massive problem in Ukraine. But they did not pick up the fact that resentment of corruption was probably the biggest factor in the Maidan protests in Kyiv, that disgraced president Viktor Yanukovych had been responsible for a huge increase in the problem in Ukraine, or that corruption was an equally great or greater problem in Russia.

Many were also understandably sharply focused on Ukraine's economic fragility, and wanted to draw an inference that any Western involvement would be a waste of money and effort. Let the Russians take over the problem and bear the costs of it; why should the West get involved? They seemed unaware that Yanukovych had sharply accentuated Ukraine's economic debacle, not least by his own entourage's theft of mega-billions; or that the seizure of Crimea would make things much worse; or that 'giving Ukraine to the Russians' might amount to the trashing of the entire post-Cold War security system in Eurasia.

From the early media coverage it became apparent, in short, that some interlocutors had swallowed whole some of the cruder falsifications of Russian propaganda. Little of the commentary betrayed an adequate awareness of the degree to which, since Putin's return to the presidency in 2012, Russia was rapidly becoming a police state with increasingly fascist as well as neo-Soviet characteristics. Putin has become even more the Mussolini-style strongman with slightly flabby but muchexposed pectorals, heading what is essentially a one-party state; the rubber-stamp parliament, with grotesque stooge parties on the sidelines, has passed reams of repressive legislation while chorusing anti-Western slogans; all the human rights gains of the 1990s have been eliminated; Stalin and Stalinism have been restored to a place of public respect; and a uniform view of history and the world has been imposed on the media and the education system.

Since the fall of communism, Russia has of course become a society with gross inequality and increasingly run-down health and educational infrastructure. Under Putin, together with the Soviet flourishes, there has emerged a supplementary hard-right official ideology, sometimes 
misleadingly touted as 'conservatism'. This comes complete with siren calls directed at the extreme right that is currently blossoming in many Western countries. This bizarre Putinist embellishment of the last few years, still scarcely noticed by many Western commentators, has featured, for example, visits from the French National Front's Marine Le Pen to Moscow, where she was feted by senior members of the regime, including Deputy Premier Dmitry Rogozin; xenophobic treatment of Russia's own internal 'immigrants'; gay-bashing, both literal and metaphorical, by tolerated vigilante groups and senior regime spokesmen respectively; and, elevation of the unreconstructed and KGB-penetrated Russian Orthodox Church to the role of joint arbiter with the state of public and international morals.

These persistent misconceptions of what Russia currently represents owe a lot to what the late strategic analyst Arthur Burns once memorably called 'culpable innocence' - in other words, wilful ignorance by those presuming to instruct the vox populi - but also to Moscow's skilful injection of huge amounts of well-crafted and adroitly directed propaganda. Russian propaganda now has a Goebbelsian supremo, Dmitry Kiselyov, who once proclaimed exultantly to his prime-time television audience, 'Russia is the only country in the world that can reduce the United States to radioactive cinders'. In fact, nuclear intimidation has become a staple of Putinist propaganda, and not just at dog-whistle pitch. The buffoonish Vladimir Zhirinovsky, head of the Liberal Democratic Party (which is neither liberal nor democratic and scarcely a party, rather an officially cosseted Greek chorus), recently spoke publicly of a forthcoming major war in which Poland and other countries would be wiped off the map. Putin himself has reminded the world publicly that Russia is a well-armed nuclear power and that no one should 'mess with it'.

Crude as its message often is, Russian propaganda is nonetheless skilful and effective, much more so than its late-Soviet equivalent. It has acquired a mass international following through the external propaganda television network, Russia Today or RT, a fact of which many Western officials remain unaware. There are, allegedly, 86 million subscribers to RT in the United States alone (though this figure in itself may be disinformation). ${ }^{3}$ With a large and expanding budget,

3 See 'History', Russia Today, www.rt.com/about-us/history/. In 2009, Russia Today changed its name to RT, seemingly to conceal its sponsorship. 
RT employs as presenters many Western native speakers who are enthusiastic critics of their own societies and enjoy the opportunity to go global, something few would have achieved on their home turf. Some of them are problematical, like a German 'expert' who is editor of a neo-Nazi publication and one Karen Hudes, presented as a World Bank whistleblower, but who specialises in off-the-planet urban myths. ${ }^{4}$

But RT has also recruited more resounding names, including Julian Assange and Larry King. The formula is not to sing paeans of praise to Russia so much as to denigrate the alternatives. As the distinguished English Russia-watcher Oliver Bullough wrote in an excellent article on Russia Today, 'Deep into his fourteenth year in power, the President seems to have given up on reforming Russia. Instead he funds RT to persuade everyone else that their own countries are no better. ${ }^{5}$

Domestic Russian propaganda follows a similar strategy, with a strong and often xenophobic emphasis on the sins of other countries, especially in the West. As befits a KGB-run state, spymania is everywhere and, recently, there has been a dismaying enthusiasm for finding and denouncing internal enemies (usually liberals and intellectual critics) and asserting that they are in league with foreign enemies. Many Russian intellectuals are becoming deeply anxious about what they see as a reversion to the atmosphere of the 1930s.

It has now been reported that a new series on predateli (traitors) has been launched on Russian state television (where 85 per cent get their news), hosted by one Andrei Lugovoi, who is seen by British police as having been responsible for the polonium poisoning of the Kremlin critic Alexander Litvinenko. ${ }^{6}$ The Kremlin refused to extradite Lugovoi for questioning, then turned him into a national hero and made him a member of the Duma with immunity from prosecution. In keeping with his valiant service to Russia, host Lugovoi is introduced to his $\mathrm{TV}$ audience as chelovek-legenda (a living legend). Two days after

4 James Miller, 'Throwing a wrench in Russia's propaganda machine', The Interpreter, 18 Jun. 2014, www.interpretermag.com/throwing-a-wrench-in-russias-propaganda-machine/.

5 'Inside Russia Today: Counterweight to the mainstream media, or Putin's mouthpiece?', New Statesman, 10 May 2013, www.newstatesman.com/world-affairs/world-affairs/2013/05/ inside-russia-today-counterweight-mainstream-media-or-putins-mou.

6 Steven Rosenberg, 'Traitors in Putin's Russia', BBC News, 15 Sep. 2014, www.bbc.com/ news/world-europe-29202789. 
reporting about the new program, the $\mathrm{BBC}$ reporter responsible and his team were beaten up and detained for four hours in a provincial town in Russia.

The West, meanwhile, has sharply downsized its own information outreach to Russian speakers over the past two-and-a-half decades. Radio Free Europe/Radio Liberty and the BBC World Service, which once beamed effective alternative versions to Soviet-bloc propaganda, have lost much of their erstwhile coverage and prestige and, even if they were to be restored, might struggle for at least some time to gain any traction.

The lies and half-truths that Moscow launched to justify its invasion of Crimea and eastern Ukraine have faded somewhat from Western media, but retain a tenacious half-life. Some journalists and commentators seem to have ideological or programmatic reasons for sticking with parts of the Russian narrative. Others may simply feel the need to observe 'balance' and, as long as Russia is still cranking up parallel narratives to put into circulation, they are at pains to remain agnostic about which version of reality is the truth. ${ }^{7}$

There are some interesting subcategories of observers who advance the Kremlin's cause. A distressingly large number of academics and former officials, including retired diplomats suffering from what is known in the trade as localitis (a tendency to become an advocate for the country in which they serve rather than their own), seem to be conscious supporters of the Russian narrative. In some cases they have picked up a secondary complication from what Gareth Evans once luminously described as 'relevance deprivation syndrome', or RDS.

Moscow liberals, for example, see Henry Kissinger as having fallen victim to RDS. He has continued to visit Moscow regularly, where he is given elaborate red carpet treatment. His comments on Russian matters always seem to display warm empathy for the dilemmas of his Kremlin friends. For example, he has been undertaking to do all he can to ensure that Ukraine does not choose any Westward

7 On the Western media's devotion to 'balance', and Russian propaganda more generally, see the excellent article by the doyen of Western commentators on Soviet and post-Soviet nationalities issues, Paul Goble, 'Hot issue - lies, damned lies and Russian disinformation', Jamestown Foundation, 13 Aug. 2014, www.jamestown.org/single/?tx_ttnews\%5Btt_news\%5D=42745\#. Vej35k1-_cs. 
orientation, even though that is what a majority of its population now emphatically wants. Kissinger and former US ambassador to Russia Jack Matlock came in for some lethal sarcasm from prominent Moscow political scientist Lilia Shevtsova for such pronouncements, which, as she points out, closely parallel the Kremlin's own declarations. ${ }^{8}$

Some academic strategists follow similar lines of reasoning and activism, seeking to explain why certain victims have to be victims and certain bullies have to be bullies. They deploy their acumen rather like the RDS diplomat by setting out their close understanding of the mindset of the adversary: Mr Putin's objectives are understandable, they argue, and surely should be accommodated. No similar understanding or empathy is apparent for the victims.

The intentions of these strategists may be good, and it is certainly important to understand the enemy in order to respond to him more effectively. But at a certain point, perhaps, the important thing becomes not how to understand Putin, but how to stop him before he destroys all the agreements and understandings on which the international security system rests.

Otherwise, the strategist may fall prey to one of the Kremlin's most tried and true negotiating principles: 'what's ours is ours, and what's yours is negotiable'. In the Ukrainian case, this becomes 'what's now already ours is clearly ours (Crimea and perhaps much else besides) and you and we can negotiate between ourselves about what should be left for (in this case) the Ukrainians, over their heads and in their absence'.

Recently, a group of empathetic US luminaries arranged to meet with some of their old Russian colleagues to discuss a peace plan for Ukraine. Without going into the merits of their plan, the idea that a group of Americans should presume to launch such an initiative, at a time when Russian aggression had ratcheted up further, and without seeking ${ }^{9}$ the participation of a single Ukrainian representative, was emblematic of their appeasement mindset.

8 Lilia Shevtsova, 'Ukraine as a challenge of perception', Carnegie Moscow Center, 11 Mar. 2014, carnegie.ru/eurasiaoutlook/?fa $=54867$.

9 Uri Friedman, 'A Ukraine peace plan that excludes Ukrainians is unacceptable', The Atlantic, 1 Sep. 2014, www.theatlantic.com/international/archive/2014/09/response-boisto-peace-planukraine-russia-us/379428/. 
The line of argument of the Russlandversteher (those who understand Russia) is typically that Putin is the ruler of a very large nucleararmed country, which they like to affectionately call 'the bear', whose concerns about Western policy are entirely reasonable. In any case, they argue, irrespective of how reasonable they are, we should be very wary of 'poking the bear'. NATO's expansion to the east was an intolerable threat to Russia, and Moscow is attacking its neighbours not because it has a revanchist program to reinstitute a Soviet Union-lite, but because of its understandable hostility to Western intrusions into its 'backyard'.

The sensitivities of 140 million Russians are paramount in this train of thought, not the interests of the 160 or so million Eastern Europeans who live between Russia and core Europe. That NATO expanded not because of NATO's desire to threaten Moscow but in response to the desperate desire of many Eastern Europeans to be freed from wouldbe autocrats-for-life like Lukashenka or Yanukovych, or from renewed Russian aggression, is not seen as relevant.

The expansion of NATO was, they assert, a breach of solemn promises to Moscow. Oral reassurances about NATO's future intentions were certainly made in cautious language at a certain point, but in the very different context of prospective German unification, and before the peoples of the region had fully had their say. Once they had, new states emerged whose sovereignty and integrity Moscow duly agreed to respect. For wholly natural and legitimate reasons, many such states have chosen to pursue some sort of Western vector. Outraged by these sovereign choices, Moscow has repeatedly breached its undertakings to respect their sovereignty. On the issue of the West's supposed undertakings to help sustain Russia's Eastern European sphere of influence, see the recent discussions by Mary Elise Sarotte ${ }^{10}$ and Ira Louis Straus. ${ }^{11}$

10 Mary Elise Sarotte, 'A broken promise? What the West really told Moscow about NATO expansion', Foreign Affairs Sep./Oct. 2014, www.foreignaffairs.com/articles/141845/mary-elisesarotte/a-broken-promise.

11 Ira Louis Straus, 'The myth that NATO committed to having no permanent troops in Eastern Europe', Atlantic-community.org, 4 Sep. 2015, www.atlantic-community.org/-/the-myth-thatNATO-committed-to-having-no-permanent-troops-in-eastern-europe. 
On the other hand, Ukraine did actually receive some written assurances, which, unlike the promises allegedly made to the Russians, are on the public record. In 1994, under pressure from Moscow and the Western powers, in accordance with the provisions of the Budapest Memorandum, Kyiv agreed to divest itself of its nuclear weapons in exchange for written assurances that it should never become the subject of economic or military coercion and that Russia, the United States, Britain and France would stand ready to defend it in any such event. Those assurances have proven worthless.

The argument that NATO's expansion to the east is an intolerable provocation to Moscow is, in any case, inherently unpersuasive. If Moscow was indeed so afraid of NATO expansion, why was it not reassured by the fact that, for many years, NATO has observed the self-denying ordinance, inscribed in the NATO-Russia Founding Act of 1997, not to deploy any significant military hardware or personnel in the new member states. It is clear that the new members are the ones threatened by Russia's aggressive revanchism under Putin, not the reverse. On 18 August 2014, during a visit to Riga, Angela Merkel reaffirmed that the Act meant that even now, despite Moscow's multiple aggressions and transgressions, there would be no permanent bases in the Baltic states regardless of their allied status or their desperate pleas.

Russia, meanwhile, has continued its aggressive overflights near the borders of its western neighbours, NATO and non-NATO members alike, particularly though not only in the Baltic/Nordic region. It conducted a cyberwar with backup action by elements of the Russian minority against Estonia in 2007, and on 5 September 2014, the FSB apparently abducted an Estonian security official from Estonian sovereign territory, just two days after President Obama visited Tallinn to reassure Estonia that it would not be left to stand alone if it were subjected to attack. ${ }^{12}$ The invasion of Georgia by Russia in 2008 - after a long history of aggressive provocation by Moscow and its proxies in Abkhazia and South Ossetia - and the huge military exercises up against western neighbours' borders in 2009 and $2013-$

12 See Julian Borger, 'Russians open new front after Estonian official is captured in crossborder raid', Guardian, 8 Sep. 2014, www.theguardian.com/world/2014/sep/07/russia-paradesdetained-estonian-police-officer. 
one of which concluded with a simulated nuclear strike on Warsaw - all have a similar resonance. So too, of course, do the frequent trade wars that Russia has unleashed against erring former vassals.

The confidence with which it pursues these aggressive policies strongly suggests that, while Russia may be angry about NATO's expansion, it is not afraid of it. Moscow regards its territorial acquisitions under the Molotov-Ribbentrop Pact of 1939, whereby Hitler and Stalin divided up Eastern European countries between them, as still valid. Its stridently aggressive behaviour suggests that it wants to restore them to its patrimony, and that it regards NATO as not much more than a paper tiger in the region. Yet, despite this sustained aggression, the compassion of the Russlandversteher for Russia's imperial phantom limb syndrome knows no bounds.

Another frequent line of justification by Western commentators for Russia's pursuit of its neo-imperial objectives is that we must be more sympathetic towards Russian policies because, if we're not, they'll gravitate even closer to China. Official Russian spokesmen and patriotic scholars have deployed this argument for decades through all kinds of vicissitudes in Russo-Chinese relations. On one legendary occasion, a Soviet official in Canberra, enraged by what he perceived to be an attempt by local interlocutors to exploit the then Sino-Soviet divide to threaten Moscow with bad outcomes in Afghanistan, responded, 'Just you wait - one day we'll get back into bed with our Chinese comrades and $\mathrm{f}-\mathrm{k}$ you from both ends'. More cerebral versions of this argument have been heard increasingly from Moscow propagandists in recent months, adjusted to fit the circumstances of the time. And, predictably, some Western commentators have adopted it.

A common Western counterstrike has latterly been to hint that Russia's growing strategic partnership with China will lead to its becoming China's junior partner, or even its neo-colonial vassal loyally supplying raw materials. Russian polemicists are even beginning to deploy this argument in attack mode to argue that if Moscow does indeed become junior partner to Beijing, that will be the West's fault, and to its detriment above all.

Western experts on the region are likely to have a better grasp of Russian than of Georgian, Moldovan, Estonian or Ukrainian affairs. As a result, they often acquire a bad case of secondary Russian 
chauvinism, unconsciously taking on something of the dismissive attitude of the vast majority of Russians, both the highly educated and the bovver-boys on the street, towards smaller ethnic groups within Russia and on its borders. This makes them vulnerable to Russian propaganda, even though they are of course aware of that phenomenon in general terms and would believe that they were making adequate allowance for it. It also makes them more receptive to the thought that any troublesome smaller neighbour should, if necessary, be put back in its box to keep the bear contented and friendly.

That doing so might not only undermine the post-1990 security system, but also help to recreate an aggressive, confident, antiWestern and expansionary Russia, does not seem to trouble them. Likewise, that it might lead to an unravelling of the Western strategic community, with countries betwixt and between Russia and the European Union increasingly choosing to accommodate Moscow's aggressive or seductive overtures because they can see no prospect of its being resisted by anyone. Some Eastern European NATO members, including Hungary, Slovakia and Bulgaria, seem to be already flirting with just such a fundamental reorientation.

Working journalists are less likely to be involved in working creatively towards peace in our time by launching hands-across-the-BeringStrait initiatives. After a scramble to catch up at the outset of the Crimean invasion, for the most part they are doing a pretty good job. But the language used to describe the unfolding events in Ukraine continues to be impregnated with assumptions and misconceptions stemming ultimately from Russian disinformation, and above all from its remarkably successful efforts to convince the uninformed majority of its non-involvement in the conflict in Ukraine.

'The civil war in Ukraine', 'the Ukrainian crisis', 'separatists', 'proRussians', 'rebels' - terms like these are loaded with semantic baggage that helps Moscow to maintain, even now, that it is only a concerned bystander, worried about the tragic fate of its sootechestvenniki (fellow countrymen) and seeking to find an honourable way out for all concerned. Even before the attack on Crimea, Russia was working hard through trade boycotts, manipulation of energy pricing and heavy pressure on its wayward protégé Yanukovych to force Kyiv to abandon its arduously negotiated Association Agreement (AA) with the European Union. 
When Yanukovych finally complied with Putin's insistently repeated wishes, and huge demonstrations broke out in response on what came to be known as the Euromaidan, Putin pushed him to introduce police state legislation modelled closely on Russia's own. When that in turn failed, Yanukovych resorted to mass shootings in an effort to suppress the protests. Such actions had not previously been part of his repertoire, so this was probably also a response to pressure from Moscow. And when that too failed, he fled, leaving Kyiv to the Maidan coalition.

The Crimea operation bore even more of Moscow's fingerprints. Despite the unmarked uniforms, it was clear that Russian special forces were heavily involved, as well as the armed Russian units stationed on the peninsula (obviously all a crass violation of the Black Sea Fleet Agreement with Kyiv). There was also an admixture of local Russian patriots and compliant politicians and administrators, some local and some spirited in from across the border. Russia's Federal Security Service (FSB), the domestic successor organisation to the $\mathrm{KGB}$, quickly established its presence by calling on the population to denounce any of their neighbours who had supported the Maidan revolt. In the months since the annexation, Crimea has descended into an economically depressed police state, complete with aggressive homophobia and all the other hallmarks of loyal, provincial Putinism.

A fortnight after the annexation, a similar pattern of events began to be enacted in the Donbas and other regions in Ukraine's south-east. Here, again, Russians from Russia were conspicuous in the leadership, and the military professionalism of most of the attacks made it clear that Russia was directly implicated in precipitating, staffing and managing the takeovers. The proportion of local zealots participating in the events, however, was greater than in Crimea, which contributed to the indiscipline of the proxy forces and perhaps also to their penchant for common criminality and gross human rights abuses (abductions, beatings, disappearances, arrests) against local residents.

As Kyiv recovered its composure and managed to improvise an effective military response, the polarisation of the population between Eastand West-oriented naturally increased. But that does not make the conflict that resulted a civil war. Before Yanukovych began shooting protesters, and before Putin launched his hybrid war against Ukraine, there had been very little loss of life through politics in the quarter- 
century of Ukraine's independence. There were certainly political differences between many in the west and east of the country, but they had essentially been regulated through the ballot box.

Insofar as the conflict has or may become something more like a civil war, if with decisive interference and involvement from Russia, it will be a civil war conceived by artificial insemination. Nor can it properly be called a 'Ukraine crisis'. Perhaps the later and violent phases of the Maidan could be so described but, once Yanukovych chose to flee, the crisis was over. What followed was not a crisis, and certainly not a Ukrainian crisis, but an invasion of Ukraine by Russia coupled with active and violent destabilisation, in which local recruits, stiffened and led by Russian troops and administrators, were carefully steered towards Moscow's objectives.

Nor can the combatants of Russian persuasion accurately or properly be referred to as 'separatists' or 'rebels'. While the exact proportions are difficult to determine, it is Russians from Russia who have been calling the shots, while cross-border reinforcements of weapons, supplies and personnel have been maintained throughout. To be a separatist you have to be in your own country and trying to detach part of it to form an independent entity. The so-called 'separatists' in eastern Ukraine may be irredentists, but their movement cannot be considered as genuinely separatist. For similar reasons, a foreign soldier cannot be classed as a rebel.

There is a genuine terminological difficulty here, but the solutions in common use in the West are tendentious and serve to conceal Moscow's decisive involvement. In other such cases, the fighters might well be described as 'fifth columnists' or even simply as traitors. There is, moreover, evidence that quite a number of the combatants are not 'volunteers' but paid mercenaries, originating often from the Russian North Caucasus and shipped in across the border.

Such terms as 'fifth columnists' (now routinely used by Russian officials to describe its own liberal dissidents, by the way) might seem harsh or not fully accurate given the authentic strength of local proMoscow sentiment in south-east Ukraine, and past vicissitudes and disputes relating to state boundaries. But 'rebels' and 'separatists' are not appropriate, and nor should a militiaman who has allowed himself to be recruited to fight for a foreign imperial power be entitled to 
any other semantic fig leaves. It is striking that Kyiv's preferred term 'terrorists' is studiously avoided by the Western press, even though a much better case can be made for that than for most of the locutions actually used (violence against legitimate institutions and civilians, mass abuse of human rights, avoidance of identifying insignia, deployment of weapons in residential areas, and so on).

The terminological difficulty has led to the widespread use of the term 'pro-Russian', usually as an adjective, but sometimes even as a noun to describe those fighting against the Ukrainian armed forces and their volunteer militia supporters. But that, too, is inadequate. Many of them are quite simply Russians, for starters. Why not 'pro-invaders'? I favour 'proxies' or even simply 'Russians', which is what most would identify as, and which describes exactly where they stand. The only difficulty with 'Russians' is that many ethnic Russians in Ukraine do not want to betray their country or see their home region attached to Russia.

The most recent turn of events in the fighting has unleashed a further avalanche of misleading descriptions, which again have the effect of concealing Russia's real role. As will be recalled, there was a time in the early months when the proxies seemed to be sweeping all before them, the Ukrainian armed forces were demoralised as well as hopelessly ill-equipped, and the local populations in the east were not fighting back against the proxies, despite opinion polling showing that, even in Crimea, a majority of the population did not want to become part of Russia.

Then the Ukrainian armed forces began to find their feet, supported by volunteer militias and the financial contributions of many ordinary Ukrainians, as well as some key oligarchs. From May to mid-August, the Kyiv forces gradually took control of the situation, forcing the proxies back, and even recapturing much of the lost ground in Donetsk and Luhansk provinces.

They faced difficult dilemmas in doing so. With the Russian forces well dug in, winkling them out in urban areas would inevitably require aerial and artillery bombardment to reduce the need for bloody street fighting. In addition, Kyiv would need to solicit and maintain the support of the oligarchs where possible, and also the enthusiastic but sometimes problematical volunteer detachments. 
All such steps could increase the suffering and bitterness of both fighters and civilians in the disputed east. The pro-Kyiv militias, like those on the other side, were in some cases led and/or manned by militant nationalists with hardline political views. Over the longer term, this could create a security problem for the Kyiv Government and reactivate the familiar Russian propaganda trope of 'the fascists and Banderovtsy in the Kyiv junta and Western Ukraine'.

A particularly worrying formation for Ukrainian President Petro Poroshenko has been the force led by the populist nationalist Oleh Lyashko. Lyashko has been using his militia not only against the enemy, but also as a tool in his campaigns for the presidency (where he did dismayingly well, finishing a distant third behind Poroshenko, but third nonetheless) and in the parliamentary elections scheduled for 26 October, where polling suggests his Radical Party will do well. $\mathrm{He}$ and his militiamen have been involved in kangaroo courts, direct actions of dubious legality and other abuses of human rights.

Though not a fascist in the ideological sense, Lyashko is certainly an extremely dubious asset for Poroshenko. With a shady past, including a criminal record and one-time connections with Yanukovych's party, his prominence in the war has enabled him to issue aggressive political challenges to the Poroshenko bloc. Fortunately, his popularity seems to be declining, but it remains uncomfortably high.

Another very mixed blessing for Poroshenko is the Azov Battalion, ${ }^{13}$ which has fought bravely but displays neo-fascist insignia and has members given to hard-right pronouncements. Lyashko himself is from Luhansk and, interestingly, a lot of the recruits to such hardline proKyiv detachments are ethnic Russians from the east of the country. ${ }^{14}$

Armed conflicts have a tendency to generate irregular forces like these, particularly at critical junctures, in immature semi-democracies like Ukraine's. Ukraine is fighting for its independence, perhaps even ultimately for its existence, with no reliable allies and an enemy that is much stronger and better equipped than itself. There are many more

13 Shaun Walker, 'Azov fighters are Ukraine's greatest weapon and may be its greatest threat', Guardian, 10 Sep. 2014, www.theguardian.com/world/2014/sep/10/azov-far-right-fightersukraine-neo-nazis.

14 For a balanced appraisal of hard-right militias generally in Ukraine, see Alina Polyakova, 'The far-right in Ukraine's far-east', Carnegie Moscow Center, 12 Sep. 2014, carnegie.ru/ eurasiaoutlook/?fa $=56604$. 
such militant and extremist formations in Russia and on the Russian side of the fight in Ukraine but, while Moscow doesn't choose to rein them in for the most part, it undoubtedly can do so when it so wishes. Poroshenko, despite his strong presidential mandate, doesn't enjoy a similar capacity and has many other urgent problems with which to deal.

So why do Western commentators focus so disproportionately on the pro-Kyiv bad guys? They may represent some sort of threat to their local Russian enemies, but not to the Russian regular army, which can and has inflicted devastating damage on them. Even less do they threaten the Western countries, whose commentators focus on them with such keen attention. The hardline nationalist militias and their political allies remain a country mile behind Poroshenko in public opinion ratings. The only thing that might make them serious contenders would be if Russia continues to inflict defeat, destruction and yet more trade wars on the elected Kyiv authorities while the West continues to look on disapprovingly, but does nothing effective to save them.

With some observers, it's difficult to avoid the impression that, for whatever reasons, they want to exculpate the aggressor by blaming the victim. The blame-the-victim commentators are not much interested in the fact that the victor by an overwhelming margin in the recent presidential election was a moderate nationalist ready for compromises to preserve peace - perhaps even too ready in the view of some; or that the Ukrainian Prime Minister Arseny Yatseniuk, for example, is a pro-Western liberal economist and democrat, said by some to be of partly Jewish heritage; or that the man who for a time took over as acting prime minister from Yatseniuk was a senior regional administrator called Volodymyr Groysman, a Jew; or that, at a time when the European Union is in considerable economic and political difficulty and losing much of its erstwhile allure, virtually the entire Kyiv political class in its present configuration is desperate to join it.

By contrast with such groups as the Azov Battalion, the spectacularly bad guys among the Russian military colonists and their local supporters attract little enough media scrutiny. Take, for example, Igor Girkin (aka Strelkov), a Russian from Russia, former supremo of the self-styled Donetsk People's Republic, the very name of which reeks of Stalinism. In his long career as a soldier of fortune pursuing 
Russian imperial causes in the most expansive sense, Strelkov has been reported to have involved himself with Bosnian-Serb forces in ethnic cleansing of Bosnian Muslims during the Yugoslav wars. He is undoubtedly a Russian fascist, but also a nostalgic Stalinist, which makes him one of a hybrid type that is widespread in Russia at the moment.

Then there is the former Russian criminal, Sergey Aksyonov, who is presiding over the communising of Crimea, a circumstance that is also ignored by most of the West. Or take Aleksandr Borodai, another Russian from Russia, who miraculously emerged as the supremo in Donetsk and remained there till Moscow found it expedient to replace him with a local called Aleksandr Zakharchenko, a true-red loyalist to Moscow, but with a usefully Ukrainian-sounding surname. And, probably most tellingly, there is Vladimir Antyufeyev, the grey KGB eminence of Transnistria, and as of recently, of eastern Ukraine. Why is no one particularly aghast at their prominence?

Antyufeyev in particular gets minimal attention in the West, yet his role as Moscow's de facto viceroy in south-east Ukraine is obvious. It is clearly reflected in a recent picture of Strelkov holding court with his imperialist freebooters back in Russia where he is 'on leave', a photograph of Antyufeyev on the wall in the background, where Stalin might once have been. ${ }^{15}$

Despite the country's overwhelming burdens, for months the Kyiv forces continued to make steady progress towards their objective of encircling Donetsk and Luhansk cities with a view to cutting them off from resupply across the Russian border. Moscow responded by changing their proxies' leaders and providing more high-tech weaponry. This led to some spectacular victories in local skirmishes by the Russians as well as to rapidly growing downings of Ukrainian aircraft. But, it also led to the MH17 disaster, which was obviously not a triumph for Moscow. Until well into August, and despite the successive waves of Russian intervention, Kyiv's steady counterinsurgency progress seemed to be maintained.

15 Not long after this article was written, Antyufeyev became involved in one of eastern Ukraine's frequent political brawls, and seems to have been withdrawn. But there is no reason to doubt that Russia's paramount sway in eastern Ukraine continues. 
Then suddenly came a 180-degree shift in the fortunes of war. Russia introduced into Ukraine a large number of its regular troops, probably some 6,000 or so all up, including crack special forces, and with more high-tech weaponry. Abruptly, wholly against the flow of play, the beleaguered 'rebel' forces turned their increasingly dire situation around. The siege of Donetsk was broken, and a large concentration of mainly volunteer pro-Kyiv units near the strategic town of Ilovaisk was forced to retreat. As they retreated, responding apparently to an invitation to exit via a 'humanitarian' corridor, they were ambushed by Russian forces with greatly superior weaponry, resulting in a massacre of hundreds of men and total destruction of their weapons and military transport.

The survivors of the Ilovaisk massacre ${ }^{16}$ are bitter that they did not receive more backup from Ukrainian forces, a resentment that may create strains as volunteer militias come to be reintegrated in the armed forces or civilian society of any post-conflict Ukraine. It was an attack well executed and well directed in every sense by highly professional Russian troops, part of a broader intervention that forced Poroshenko to sue for a ceasefire. He has been on the back foot ever since, offering concessions to the 'separatists' and desperately pleading, largely in vain, for more help from the European Union and NATO.

Western countries, Amnesty International and other authorities have all said that this turnaround was the result of a clandestine but large cross-border deployment of Russian troops and armour. Russian internet sources and surviving independent Russian media and blogs accept the sharply increased Russian involvement as the cause of the sudden 'rebel' triumph. The Russian Committee of Soldiers' Mothers, one of the few politically engaged NGOs in Russia that still works effectively, has claimed that some 200 soldiers from regular Russian formations have now perished in the fighting in Ukraine. For making such a damaging claim, the St Petersburg branch of the NGO has already been denounced by the regime as a 'foreign agent' (translated from the 1930s Stalinese, 'spy' or 'traitor').

16 Tim Judah, 'Ukraine: A catastrophic defeat, New York Review of Books blog post, www. nybooks.com/blogs/nyrblog/2014/sep/05/ukraine-catastrophic-defeat/. 
Among the Russian casualties there have been members of the crack Pskov Paratrooper Division. A (legal) opposition politician in Pskov who attempted to view the graves of anonymously buried special forces soldiers there was beaten up by 'unknown assailants' - a trademark of the FSB - and left unconscious with a fractured skull. ${ }^{17}$ The war is increasingly unpopular in Russia, and Putin is continuing to keep it hush-hush, both for that reason, and to maintain the threadbare fiction of Russia's non-involvement.

The current shaky armistice, which the Russian side in particular has been breaking in an attempt to regain control of Donetsk airport and other strategic targets, is unlikely to be sustained. Poroshenko's effort to shore it up by offering further concessions to the 'separatists' may give Kyiv some further respite, but that too is unlikely to remain stable for long. All he can do to ensure stability is further surrender Ukrainian sovereignty, recognising the 'rebels' as a legitimate Ukrainian force representative of the local populations (which they never have beentheir referenda were farcical), and accepting Russia as the paramount guarantor of stability in the region; in other words, in addition to the loss of Crimea, accepting that Ukraine would now have a large frozen conflict $^{18}$ in its industrial heartland.

Even that would almost certainly not be the end of it, judging by the experience of frozen conflicts elsewhere in the post-Soviet area. The corresponding parts of Moldova and Georgia have been used as tools to try to block any Westward movement by those countries. A frozen conflict can also, if and/or when the need or opportunity presents, be rapidly unfrozen to form a bridgehead in a wider irredentist push. Georgia presented a classic case in 2008 and Moldova may soon provide another.

Russia's diplomatic vehicle of choice to establish a frozen conflict is the Organization for Security and Co-operation in Europe (OSCE), where, in recent times, US influence in relation to events in Russia's western borderlands seems to have been weaker, and where Russia has made good use of its veto power to make the OSCE's work difficult and,

17 See Alexey Eremenko, 'Inquisitive Pskov lawmaker beaten unconscious', Moscow Times, 31 Aug. 2014, www.themoscowtimes.com/news/article/russian-lawmaker-beaten-unconsciousafter-questioning-reports-of-paratroopers-in-ukraine/506156.html.

18 Patrick Jackson, 'Ukraine crisis: "Frozen conflicts" and the Kremlin', BBC News, 9 Sep. 2014, www.bbc.com/news/world-europe-29078541. 
at times, impossible. The recent peace discussions brokered by the OSCE are unlikely to deliver either a permanent settlement or a just one. The OSCE is not in the business, for example, of suggesting that Russia was not a legitimate player in the 'peace process' to begin with.

The OSCE format was publicly launched by Putin in May, when he welcomed in Moscow a visit by the Swiss President and chairman of the OSCE for 2014, Didier Burkhalter, and an OSCE blueprint for a settlement that Burkhalter brought with him. At that time, the Kyiv forces had started to turn the tide against the Russian proxies, and Putin clearly was looking to hit the pause button before things got any worse for his proxies. The OSCE format has been shaped to keep the United States out of the front line of the Ukraine issue, and the formation of an OSCE Contact Group consisting of a Swiss OSCE chair, Russia, the Donetsk and Luhansk so-called People's Republics and Ukraine has enabled Putin to set negotiations with Poroshenko in what is for Moscow a very favourable context, with the proxies legitimised as interlocutors and Kyiv outnumbered.

Russia's frequent use of its veto to pressure the OSCE and the lack, over time, of any effective US or Western pushback on OSCE involvement in frozen conflicts have ensured that the OSCE is now very sensitive to Russia's priorities. Germany and France, who happen to be two of the EU/NATO countries most understanding of Russia's security requirements, have had a modest involvement in the Contact Group process, mainly in pressing Ukraine to become engaged. But Britain, like the United States, is not involved. Thus Berlin's Russlandversteher approach is virtually the only Western game in town. The Contact Group is headed by Swiss diplomat Heidi Tagliavini, who produced a report on the Georgian war of 2008 that, in the view of some observers, tended to tread lightly over much of Russia's responsibility for that event and for the extensive destruction it visited on Georgia.

Not being comfortable in situations where force has been or may be deployed, Germany is looking for a peaceful solution and is happy to entrust the task of mediation between aggressor and victim to the OSCE. Kyiv, however, is clearly at a disadvantage. At one point, the Contact Group even brought into the talks as a separate participant 
one Viktor Medvedchuk, a close friend of Putin's and the most proMoscow politician in Ukraine, where he has almost no popular support. ${ }^{19}$

For Putin, as in May, the purpose is to present Russia again as a concerned, peace-loving observer while this time locking in his sudden gains on the battlefield. The timing of his back-of-the-envelope peace proposal, reportedly sketched out on a flight to Mongolia, was also meant to weaken and further divide the leaderless and irresolute Western leadership just as NATO was holding a crucial summit on 4-5 September in Wales and the European Union was struggling to reach agreement on another round of sanctions.

In this, Putin was highly successful. Again the huge advantages of a single, autocratic leadership over broad coalitions of poll-ridden democracies were in evidence. After protracted agonies about whether to impose further sanctions on Russia for again invading Ukraine, the European Union finally approved a package, but in the same breath said that the sanctions might be reviewed within weeks if the ceasefire holds. That the 'ceasefire' followed another damaging Russian military expedition into Ukraine was, like the Crimean annexation, seemingly forgotten or forgiven.

Brussels also mysteriously suspended till the end of 2015 the implementation of the Deep and Comprehensive Free-Trade Agreement (DCFTA) with Ukraine, to which it had previously accorded accelerated passage. The reason for this unexpected additional reward for Russia's bad behaviour was seemingly to enable further exhaustive discussions aimed at accommodating the Russians' objections to the free-trade deal. Moscow has demanded a virtual rewrite of roughly a quarter of the huge and exhaustively negotiated agreement.

The European Union has previously maintained that the agreement would not damage Russia's trade and, more generally, that it could not, as a matter of principle, allow third parties to interfere in its negotiations with other countries. The Poroshenko Government agreed to the postponement, reportedly because it feared that, otherwise,

19 See, for example, the typically incisive analysis of Vladimir Socor in 'The Contact Group in Ukraine weighted toward Russia', Eurasia Daily Monitor, 18 Jul. 2014, www.jamestown.org/programs/edm/single/?tx_ttnews \% 5Btt_news \% 5D=42645\&tx_ ttnews \%5BbackPid\%5D=756\&no_cache=1\#.VekVsk1-_cs. 
Moscow was planning to hit it with a crippling all-out trade war. The European Union has cushioned the blow of the postponement by extending trade concessions to Ukraine over the intervening period.

Nonetheless, the postponement sends yet another discouraging signal to Ukrainians and other countries under Russian pressure. A deputy Ukrainian foreign minister resigned over the issue, which is not reassuring on the question of what backroom deals were struck to secure Poroshenko's agreement. The postponement also offers further encouragement to Russia to maintain its present aggressive stance towards the countries to its west, and their Western friends.

NATO, for its part, stalwartly reaffirmed that it would not permanently deploy any boots on the ground on the territory of the new members, but that it would provide 'reassurance' in other ways. It also confirmed that it would continue not to supply any serious weapons to the beleaguered Kyiv administration. It undertook, on the other hand, to provide non-lethal aid worth US $\$ 20$ million. Subsequently, the Ukrainian Defence Minister asserted that some individual NATO countries were undertaking to supply weapons to Ukraine, but the countries he mentioned have denied it.

On 17-18 September, Poroshenko visited the United States where he renewed his appeal to the Obama administration for lethal aid to resist Russian aggression on his country. He was well received, particularly in Congress, but his appeal was unsuccessful, though he did receive a further US $\$ 53$ million in non-lethal aid. As he said when he addressed Congress, 'Please understand me correctly. Blankets, night-vision goggles are also important. But one cannot win the war with blankets ... Even more, we cannot keep the peace with a blanket.'

Short of another muscular intervention from Moscow, a trade war alternative is always near to hand. Recently, Russia sharply reduced its gas exports to Poland, putting a stop to reverse-flow imports by Ukraine through Poland and Slovakia to replace the flows through Ukrainian pipelines that Russia blocked last June. If Poroshenko does not give satisfaction in the peace talks, the economic stranglehold on Ukraine can be strengthened at will, a far more immediate and deadly weapon than any Western sanctions that have yet been devised against Russia. 
Conscious of his weak hand internationally and the forthcoming elections domestically, Poroshenko is bending over backwards to stay out of trouble. Following up on the Minsk ceasefire agreement of 5 September, he managed to push through legislation on 16 September offering a guarantee of autonomy for three years to local government in areas of Donetsk and Luhansk controlled by the proxies. The law is carefully drafted to avoid legitimising the authority of the 'people's republics', but is domestically costly for Poroshenko even so, and will increase the criticism of him from radical rivals in the run-up to the vital parliamentary elections on 26 October. It is also unlikely to satisfy Moscow or most of its proxies, who are continuing military actions to seize more territory beyond the ceasefire lines.

Meanwhile, Russia is at work in the Baltic states. ${ }^{20}$ Despite Obama's visit to Tallinn, where he delivered a ringing address - a genre in which he excels - Moscow has launched a concerted series of provocations, beginning two days later with the abduction from Estonian territory of the Estonian anti-corruption official, and his almost immediate parading before Russian TV cameras as a spy.

Soon after, a senior Moscow official responsible for 'human rights', Konstantin Dolgov, visited Riga where he delivered an aggressive speech denouncing Latvian 'fascism' and alleged mistreatment of the Russian minority, and calling on the Latvian Russians to show their 'martial spirit'. (In fact, they are already doing so; a high proportion of Latvian Russians support the annexation of Crimea, and there have been reports that some are being recruited to fight in Ukraine.) Given the atrocities committed by Moscow against the Baltic peoples after the Molotov-Ribbentrop Pact of 1939, these are remarkably brazen and threatening claims.

Russia has recently revived and is pursuing through Interpol arrest warrants against Lithuanian citizens who refused to serve in the Soviet/Russian army at the time of Lithuanian independence. Then, it will be recalled, Moscow despatched military raids against the Lithuanian capital Vilnius and other localities, resulting in 16 civilian deaths and many hundreds of injuries. And it has in the last few days

20 Julian Borger \& Luke Harding, 'Baltic states wary as Russia takes more strident tone with neighbours', Guardian, 19 Sep. 2014, www.theguardian.com/world/2014/sep/18/baltic-stateswary-russia-strident-estonia-latvia-lithuania-NATO. 
seized a Lithuanian fishing vessel, which the Lithuanians allege was in international waters at the time, and tugged it off to Murmansk with 28 people on board.

So, a Baltic trifecta. Regardless of how these events develop further, their common purpose appears to be, at the very least, to suggest to the Baltic governments that their distinguished visitors and supporters live far away and can't or won't do much to help them.

With Western attention again becoming absorbed in very difficult Middle Eastern issues, it is hard to be optimistic about the further outlook for Ukraine - or for the future of European values in the postSoviet space. 



\section{8}

\section{Putin's parallel universe ${ }^{1}$}

After a conversation with Vladimir Putin following his country's occupation of Crimea earlier this year, German Chancellor Angela Merkel was heard to remark that the Russian President was 'out of touch with reality' and 'living in another world' ${ }^{2}$ An Australian official made a similar observation rather earlier, during a briefing in Canberra about seven years ago. The briefers had set out the characteristic features of the world of Vladimir Putin, whose increasingly aggressive demeanour and systematically anti-Western nationalism had already caught the attention of many Russia-watchers. Having begun the discussion in a jovial mood, the official became serious and reflective; at its end, he said gravely, 'He's living in a parallel universe, really, isn't he?'

In what follows, I try to set out some of the main reasons why this parallel universe came into existence. What were the main factors favouring the re-emergence of a xenophobic autocracy in Russia and the high degree of acceptance it received from a stunted and passive civil society? I am not suggesting that there was anything inevitable about Putinism. Had oil and gas prices stayed higher for Mikhail Gorbachev and the early Yeltsin reformists, things might have turned out differently, despite the strength of the reactionary

1 First published in Inside Story, 20 Nov. 2014, insidestory.org.au/putins-parallel-universe.

2 See 'Ukraine crisis: Vladimir Putin has lost the plot, says German chancellor', The Guardian, 3 Mar. 2014, www.theguardian.com/world/2014/mar/03/ukraine-vladimir-putinangela-merkel-russian. 
back-to-the-USSR constituency. Had Boris Yeltsin finally settled for some successor other than the KGB half-colonel from Petersburg Vladimir Vladimirovich Putin, Russia might not have become a police state domestically and a rogue state externally. Had some Moscowbased clique, say, successfully resisted the takeover of the state by a Leningrad push that originated in a dubious enterprise known as the Ozero Dacha Cooperative in the 1990s, things might have progressed otherwise, though not necessarily greatly for the better.

But the political culture of a country does not normally change quickly or easily. Changing it for the better requires favourable winds and good leadership. Neither factor was prominent in Russia's abortive transition from state socialist empire towards market democracy.

Putin's view of the world was no doubt imbibed from a very early age in the heavily ideological Soviet environment that led him, still a teenager, to attempt to volunteer for training as a KGB officer. But perhaps the most lasting influence on his attitudes was the turbulence in East Germany that led to the collapse of the hardline East German communist regime.

On 9 November 2014, much of the world marked the 25th anniversary of the fall of the Berlin Wall. Putin wasn't among those celebrating. When the wall fell he was a middle-ranking KGB officer in the East German city of Dresden, and the breaching of the wall and the collapse of the German Democratic Republic were both a personal and professional disaster. By his own account, he was forced at one point to defend his KGB building from an angry crowd who were demanding with boundless impudence to know what was going on inside this anonymous structure in their city.

To paraphrase Graeme Allison, where you stand depends on where you were sitting - or standing - at the relevant time. For the overwhelming majority of Europeans East or West, the fall of the Wall was a joyous surprise. But for Putin, a Soviet true believer, it was a trauma.

Even worse followed for Putin when, two years later, the Soviet Union disintegrated - an event that gave rise to his famous observation that the break-up of the Soviet Union was the greatest geopolitical 
catastrophe of the century' ${ }^{3}$ For most of the people in the non-Russian republics of the old Soviet Union who were not ethnic Russians, as for the overwhelming majority of Europeans, East and West, the collapse was a blessed relief.

Since Putin has become the leader of one of the world's most incorrigible autocracies, those differences of perception have taken entrenched and institutional forms. Russia's increasingly ideologised public domain is now dominated by the official Putinist view of everything, and the area of free expression is contracting to a few elite outlets and the internet (and even the internet is being squeezed). Opinion polling shows that, after a brief euphoric period in the early 1990s, during which they were encouraged to feel - and indeed felt - more positively about the West, Russian attitudes have become reserved or even hostile. Although this owes a lot to increasingly wallto-wall propaganda, Putin has not pushed his personal perspective on an entirely unwilling Russian public.

For most Russians, the huge economic disruptions of the years of Yeltsin's presidency were traumatic. Yeltsin's young economic reformers used 'shock therapy' to convert Russia's communist economy into a market-based system, abolishing price controls and rapidly privatising state enterprises to forestall any attempt to restore the old order. They sharply downsized the huge Soviet military-industrial complex and tried to reorient the economy towards the needs of consumers. But it was a risky experiment and they had little by way of experience to guide them.

Shock therapy had been applied in Poland and in other Eastern European states, but in each case the economies were smaller and less heavily imbued with Soviet habits and attitudes. No one had any proven blueprint there either, of course, but after a very uncomfortable transition period the reforms began to pay dividends. There were winners and losers, to be sure, but for most people in Eastern Europe the increased freedoms and economic opportunities, and the new focus on the needs of ordinary consumers, made the pain worthwhile. And for all of the post-communist countries other than Russia, gaining national independence was a source of huge satisfaction in

3 Mike Eckel, 'Putin calls Soviet collapse a "geopolitical catastrophe"', Union-Tribune SanDiego, 25 Apr. 2006, www.utsandiego.com/uniontrib/20050426/news_ln26russia.html. 
itself. For the Russians, by contrast, the economic disruptions were much more severe, and the escape of their imperial subjects was an additional trauma superimposed on the privation.

Ostalgie of the Goodbye Lenin ${ }^{4}$ variety certainly exists in East Germany, and perhaps, to a lesser extent, in other post-communist countries. But in Russia it is a much more mainstream phenomenon. For many Russians the transition was an economic disaster, a time when life savings and jobs were often lost. An offensive caste of grotesquely rich nouveaux riches - the new Russians - suddenly appeared, made wealthy (as it was often correctly assumed) by the fruits of corruption. Freedoms undoubtedly expanded, and these were valued at first, but for most Russians they did not outweigh the pain. Few understood that perhaps the main cause of their economic difficulties was the sustained slump in the oil and gas prices on which Russia's economy rested.

Then, after the default and devaluation of 1998, the price of energy products began to rise rapidly, as if on cue for the appearance of the hitherto obscure Putin as Yeltsin's successor. Together with his bloody but popular war against Chechnya in 1999-2000, the sudden prosperity established Putin's reputation as a great tsar. The heavy loss of life in Chechnya, including among Russian residents, the long insurgency that followed the war, and the periodic bloodshed and terrorist incidents on Putin's watch have not seriously tarnished that reputation. The economic reverses since the global financial crisis and the largely intelligentsia-based revolt against election fraud and Putin's growing authoritarianism in 2011-12 threatened his approval ratings, but a combination of intense propaganda and the nationalist euphoria of 'Crimea is Ours' (Krymnash) have restored them this year to almost Soviet levels.

During the 1990s, ordinary Russians largely lost the interest they had briefly felt in the crimes of communism, which had been such a talking point during Gorbachev's glasnost. Despite the fact that they touched the lives of most Russian families, those crimes have progressively been swept under the carpet. And yet, the first steps of the new tsar raised similar concerns about the ruthless contempt of the state

4 Peter Bradshaw, 'Review of Goodbye Lenin!', Guardian, 26 Jul. 2003, www.theguardian.com/ culture/2003/jul/25/artsfeatures.dvdreviews. 
for the lives of its citizens. The casus belli of the war in Chechnya, for instance, was a series of mysterious bombings of apartment blocks in Russian cities in September 1999, which were officially judged to be the work of Chechen terrorists. But strong evidence suggests that at least some of those attacks, which caused heavy casualties, may have been provokatsii staged by the FSB (the Federal Security Service, the domestic successor organisation of the KGB, which the future president had briefly headed on his rise to the top job).

Those who tried to investigate the bombings tended to die of unnatural causes - they include Alexander Litvinenko, poisoned by polonium in London, and the fearless investigative journalist Anna Politkovskaya ${ }^{5}-$ and the enthusiasm for doing so naturally diminished. More generally, though, Russians seem to have been so consumed by the difficulties of daily life in the 1990s, then so gratified by the sudden improvement in living standards in the 2000s, that they were happy to slip back into the attitude of cautious discretion that had been their default position before Gorbachev.

Even fewer Russians continued to take any interest in state crimes perpetrated against ethnic minorities in the Soviet Union or their erstwhile vassals in the Warsaw Pact countries. When Putin reassured them that these had always been marginal phenomena, common to all countries, and not something to be ashamed of, they seemed quite happy to believe him. Recently he has even attempted to justify the Molotov-Ribbentrop Pact, ${ }^{6}$ whereby Hitler and Stalin secretly agreed to divide much of Eastern Europe between them, paving the way for the outbreak of World War II.

One of the most dismaying recent developments in Putin's police state is an operation aimed at banning outright ${ }^{7}$ the heroic and beleaguered human rights organisation Memorial, which has tried to investigate Soviet crimes and to find the remains of the victims and erect memorials

5 See Maria Tumarkin, 'What it means to be a real journalist', Inside Story, 28 Apr. 2010, insidestory.org.au/what-it-means-to-be-a-real-journalist.

6 See Timothy Snyder, 'Putin's new nostalgia', New York Review of Books blog post, 10 Nov. 2014, www.nybooks.com/blogs/nyrblog/2014/nov/10/putin-nostalgia-stalin-hitler/.

7 See Daisy Sindelar, 'Russian human rights group faces threat of closure', Guardian, 15 Oct. 2014, www.theguardian.com/world/2014/oct/14/russian-human-rights-group-faces-threatclosure, first published as 'Five important things that Memorial's done (and is still doing) for Russia', Radio Free Europe/Radio Liberty, 13 Oct. 2014, www.rferl.org/content/russia-memorialfive-things/26635356.html. 
to them. Long persecuted by the Putin regime, Memorial is now the subject of an Orwellian demand by the Russian justice ministry that the Russian supreme court disband the organisation. With characteristic servility, the court immediately listed the matter, but has now postponed the hearing, perhaps in response to a flood of international disapproval. The Kremlin may yet decide that an outright ban would be bad PR, and that it would be better to let Memorial struggle on under constant harassment. The collective amnesia of Russians about these matters is both amazing and depressing. ${ }^{8}$

In addition to seeing their pay packets expand, and presumed Chechen terrorists justly chastised, the Russian public had further cause to appreciate Putin. Russians are an imperial people, just as the British and some other Europeans once were. People in modest walks of life are devoted to the idea of national greatness. The loss of empire was painful for Russians, and still is. Like the Germans after World War I, they felt the victory that was rightfully theirs in the Cold War had been plucked from their grasp by some kind of treachery or trickery. They must have been stabbed in the back by someone. And they were ready to believe that it was the West, which they'd been taught to hate from mother's milk onwards. Nowhere was this sentiment more pronounced than in the ranks of the KGB, Putin's finishing school and adult vocation.

Similarly, Russia's economic misfortunes must surely be the result of the Western ideas - market reforms and democracy in particular - that flooded into the country with perestroika and glasnost. Demokratiya (democracy) was dubbed by some Russian wit as dermokratiya (shitocracy), and privatizatsiya (privatisation) rebranded sardonically as prikhvatizatsiya (grabitisation), an allusion to the widespread corruption that was observed at the time. Both forms of social organisation became identified in the popular mind with economic chaos and imperial loss.

That loss was all the greater because more than 20 million ethnic Russians suddenly found themselves living in new countries where local nationalisms, hitherto kept under strict limits, were burgeoning and, in some cases, making them feel uncomfortable. The large Russian

8 On the reasons for that amnesia see David Satter, It Was a Long Time Ago, and It Never Happened Anyway: Russia and the Communist past (New Haven, CT: Yale University Press, 2012). 
diasporas in the other republics of the Soviet Union had grown used to enjoying a higher status than the natives; now, stripped of that status, many of them chose to return to Mother Russia, where they found privation and disruption. The new freedoms, including the freedom to travel, were all enveloped in bitter experiences.

I have tried to set out here what might be regarded as the canonical Russian view of the transition from communism, the view that is constantly drummed into Russians who watch television (where over 80 per cent get their news). Understanding that narrative helps us grasp the nature of the growing standoff between Russia and the global West, which turns on diametrically opposed views of the key developments in Russia's recent history. Someone coined the term 'values gap' to characterise the growing mutual estrangement between Russia and the West; since Putin returned to the presidency in 2012, that gap has become a chasm. It has been deepened further by Putin's touting of Russia as the true custodian of traditional European religious and family values, an ideological innovation aimed both at attracting the far right to his cause, in Europe and elsewhere, and pillorying his supposedly 'effete' domestic opponents.

But the values gap was not apparent at first. While most in the West rejoiced at the demise of communism and the end of the Cold War, the reactions of key Western leaders to the implosion of the Soviet empire were not what one might have expected or what Russian propaganda now maintains. It is true that Ronald Reagan called on Gorbachev to 'tear down this wall' in Berlin in 1987. ${ }^{9}$ But many Western commentators and officials were dismayed at the time by what they saw as a grossly provocative, even reckless, public statement by the US President.

And when, two years later, the people of Berlin took up Reagan's suggestion, some Western leaders seemed almost as much taken aback as the Russians. The French President François Mitterrand and British Prime Minister Margaret Thatcher were both sorely troubled by the prospect of German reunification, Mitterrand joining many others in quoting the bon mot of the senior statesman of French letters, Francois Mauriac: 'I love Germany so much that I'm glad there are two of them.' I can recall trying to reassure a slightly anxious meeting of Australian

9 See www.au.af.mil/au/awc/awcgate/speeches/reagan_berlin.htm. 
officials that reunification was not something to be worried about, and that West German democracy was hardy, moderate, reliable and very much in our interests.

In any case, reunification was all but unavoidable once the wall and communism had both fallen. Whether a reunited Germany could continue to be a member of NATO loomed as a difficult issue, and Western leaders felt called on to assure Moscow, in private, that there would be no NATO deployments further east as a result. This has given rise to the belief in Moscow's political class that a binding commitment had been given that NATO would never deploy further to the east, and that any expansion of NATO was therefore a breach of faith. No such commitment was ever entered into, though NATO has continued to avoid stationing troops or weaponry in the new member states.

As the rot spread from Eastern Europe to the Soviet Union itself, Western leaders became even more concerned about the instability that might result. They feared that this would be bad for their highly valued partner Gorbachev, that it could lead to serious bloodshed, and that it might even compromise control of the Soviet nuclear arsenal. The signs of impending break-up in Yugoslavia were another cause of great concern. Some Western leaders, like US President George $\mathrm{H}$. Bush, worried that the example of a fragmenting Yugoslavia might exert a regrettable influence on similar trends that were already evident in the Soviet Union.

Bush senior also deplored the emergence of forces in Ukraine pressing for national independence, warning the Ukrainians in his celebrated August 1991 'Chicken Kyiv' speech against 'suicidal nationalism', a phrase highly offensive to Kyiv that Bush himself had added to the final version of his remarks. ${ }^{10}$ So not only was the role of Western governments in the break-up of communism and the Soviet Union extremely modest, they were actually more dismayed than triumphalist about what was happening.

10 'Bush Sr. clarifies “Chicken Kiev" speech', Washington Times, 23 May 2004, www.washingtontimes.com/news/2004/may/23/20040523-101623-2724r/. 
Despite all this, Putin and his followers have imposed a narrative, currently accepted by most Russians, that the United States and its satellites are the eternal enemies of Russia, always scheming to cut it off from its natural sphere of privileged interests (its empire). Moreover, the narrative continues, NATO has deceptively drawn the nations of Eastern Europe into NATO, expanding the organisation aggressively right up to Russia's borders in breach of binding commitments not to do so. Putinist patriots never acknowledge that the central reason for the enlargement of NATO was not aggressive Western expansionist recruitment but, rather, the desperate desire by Eastern European nations to avoid a return to Moscow's rule.

Nor is the Putin narrative a good fit for the early years of the postcommunist era. Initially, much of the Russian political class rejoiced in unison with their Western colleagues, looking forward to a new era of amity and cooperation. Australian diplomats in Moscow at the time recall a veritable explosion of mutual goodwill, trust and understanding, and a desire to socialise freely without any of the traditional constraints. The new Russian Foreign Minister in the early Yeltsin years, Andrei Kozyrev, was probably the most pro-Western foreign minister Moscow has ever had.

I recall seeing a government document at that time that dared to hope for the possible emergence of a new zone of shared values and common strategic purpose extending from Vancouver to Vladivostok - not in any spirit of triumphalism, rather one of warm welcome to a Russia returning to its European values. Coral Bell and some other Western strategic thinkers spoke at the time about the possibility not just of close cooperation, but also of inviting Russia into NATO itself.

But it was not to last. The first symptoms of Russia's disillusionment with its new Western friends and the unfamiliar ways of market democracy became apparent well before the end of the Yeltsin era. With a few fluctuations, the sense of grievance has persisted ever since, deepening over time. The same people who had presented as bornagain democrats in the Gorbachev and early Yeltsin era re-emerged a few years later as among the most aggressively anti-Western of the Kremlin-friendly apologists of the Putin era - among them the political scientists Sergey Markov, Andranik Migranyan (now the head of an official propaganda unit in New York) and Aleksei Pushkov (now a senior figure in the extravagantly anti-Western Russian Duma). 
Even the most intelligent and moderate establishment commentators like Dmitry Trenin and Fyodor Lukyanov now find it extremely difficult to say anything that deviates from the aggressive orthodoxy of the current Putin presidency. Russia and its political class seem to have fallen victim to a collective case of relevance deprivation syndrome. Their insistent demand for respect appears to reflect above all a need, even a longing, to be feared.

Already in the 1990s some Western Russia-watchers worried about what was sometimes referred to as Weimar Russia: a Russia that, like post-imperial Germany, had lost its empire and had convinced itself that some foreign enemies and/or homegrown traitors must have betrayed it. Some observers feared that something not too unlike the Nazi regime might emerge in Russia: that severe economic distress would lead to domestic tyranny, cultivated xenophobia and external aggression aimed at restoration of empire. Despite some worrying symptoms, under Yeltsin and the early Putin this did not seem to be coming to pass. But, perhaps, in a longer retrospect, the Weimar Russia theory is now being at least partially borne out.

In their current state of aggressive self-righteousness, the Putinists see themselves as incapable of doing any wrong. Stalin's crimes are increasingly whited out, as are the democratic achievements and important liberal economic reforms of the Yeltsin period. In all the regime's rhetoric, media, propaganda and increasingly also in educational materials, Russia's 1990s are presented as an unredeemed disaster caused by the false Western gods of democracy and the market and their misguided or malign Russian disciples.

In recent years, Western defence budgets have been almost everywhere in decline: only three European members of NATO are currently maintaining military expenditure at or above 2 per cent of GDP. By contrast, the Kremlin has sharply increased its outlays, embarking on an ambitious rearmament program that will have cost US $\$ 750$ billion by the end of the decade. In 2015 alone, expenditure on the Russian military is to increase by 35 per cent. To paraphrase Robert Kagan, Russians, it seems, are from Mars, while Westerners, especially Europeans, are from Venus. 
Outlays on domestic security have also risen sharply under Putin, and the Russian bureaucracy has expanded greatly since the early postcommunist years. Education and health, on the other hand, have been increasingly squeezed, despite Russia's poor performance in both of those areas. Spending on propaganda is rising sharply from already high levels, with a recently announced increase of over 40 per cent for the external propaganda arm Russia Today. ${ }^{11}$ A new network of foreign-language propaganda outlets called Sputnik ${ }^{12}$ was launched earlier this month, with bureaus in over 30 countries, all built on the bones of what was till recently Russia's last surviving professional news agency, RIA Novosti.

These are not the policy patterns of a country at peace with itself and its neighbours, bent on cooperation and spreading sweetness and light. Yet, even now, much of the public Western discourse continues to be directed towards showing Russia greater understanding, accepting that it is primarily the West that has been at fault, and arguing that Moscow's demands should be met at least halfway or better. Many are the calls still to 'reset the reset' or 'repair the damaged relationship'. But do such well-meaning Western opinion leaders really have a partner ready for honest and creative dialogue?

Among most Western policymakers, there has only been slow recognition of the nature of their adversary. The invasion of Ukraine and particularly the downing of MH17 - a totally adventitious event on the path of policy development - have brought a greater sense of realism and a slightly greater readiness to face up to Moscow's reckless behaviour. But, after the Russian assault on Georgia in 2008, with destruction inflicted well beyond the area allegedly requiring Russian 'peacemaking', and Russia's occupation and de facto annexation inter alia of half of Georgia's Black Sea littoral, EU countries were quick to forgive, forget and resume business as usual. Now, too, despite Russian support for absurd 'elections' in the 'people's republics' of Donetsk and Luhansk, and clear evidence of further Russian armed incursions

11 See Paul Goble, 'Moscow to dramatically increase spending on "Russia Today"', Window on Eurasia, 30 Sep. 2014, windowoneurasia2.blogspot.com.au/2014/09/window-on-eurasiamoscow-to.html.

12 Marc Bennetts, 'Russia launches Sputnik to silence dissent, combat West's “information war" against Putin', Washington Times, 16 Nov. 2014, www.washingtontimes.com/news/2014/ nov/16/sputnik-launched-by-russia-to-silence-dissent-comb/?page=all. 
into Ukraine, members of the European Union are looking eagerly for any hint of Russian 'de-escalation' that would permit sanctions to be eased. ${ }^{13}$

Shortly after Russia's dismemberment of Georgia, the new administration of Obama embarked on its 'reset' of relations with Russia, which implicitly accepted both Moscow's behaviour in Georgia and the justice of Russian reproaches about the policies of the Bush administration. For its part, Germany has continued until very recently ${ }^{14}$ to regard an updated version of Willy Brandt's Ostpolitik as the model for Western policy towards Russia. The original version was a timely and well-judged policy that, together with US/NATO containment of Russia, the bravery of communist-bloc dissidents and opposition movements and other factors not applicable to the present situation, contributed to bringing about the fall of the Berlin Wall and the reunification of Germany.

Ostpolitik II has involved endless dialogue, diplomacy and partnership for modernisation that Berlin hoped would bring about an inevitable convergence; and, sotto voce, the belief that German reunification is something for which we should all be eternally grateful to Gorbachev and Russia, and which must not be risked by the West's being too assertive towards the Kremlin. But Putin is not Gorbachev. Obama is not Reagan. And 'diplomatic solutions' are not an adequate response to aggressive wars of coercion and territorial acquisition.

This sort of unrequited friendliness has long been characteristic of the West's approach to post-communist Russia. Even its supposedly ruthless expansion into Russia's backyard took place apologetically. At first hesitantly, the key Western institutions, NATO and the European Union, entered into communion with the former satellites through the softcore medium of the Partnership for Peace program that was launched in early 1994. Later they began to accede to the insistent efforts of former Warsaw Pact countries to become members.

13 See Daniel Tost, 'Mogherini, Steinmeier denounce black-and-white foreign policy', EurActiv, 12 Nov. 2014, www.euractiv.com/sections/global-europe/mogherini-steinmeierdenounce-black-and-white-foreign-policy-309925; see also, Andrew Rettman, 'EU countries keen to rebuild Russia relations', EUobserver, 17 Nov. 2014, euobserver.com/foreign/126550.

14 See Nikolaus Blome et al., 'Merkel concerned about Russian influence in the Balkans', Spiegel Online, 17 Nov. 2014, www.spiegel.de/international/europe/germany-worried-aboutrussian-influence-in-the-balkans-a-1003427.html. 
At the same time, they tried to allay Russian resentment of the process by strengthening links with Moscow. Russia, however, claimed with increasing stridency that any expansion of Western institutions was a grave threat to its security.

In deference to Russia's concerns, and in accordance with the NATO/ Russia Founding Act of 1997, NATO refrained from deploying significant weaponry or troops on the ground in the new member states. A variety of other bilateral instruments were concluded between the two in which it was always emphasised that neither partner saw the other as an adversary. While Russia's aggressive hostility to the West and to Eastern Europe was palpable by 2007, if not before, most Western countries continued until very recently to have the greatest difficulty in seeing Russia as a real adversary, much less an enemy.

When Mitt Romney suggested in the 2012 presidential race that Russia had become the United States's enemy number one, this was widely held to be a gaffe. When Hillary Clinton finally declared that Russia was embarking on the attempted re-Sovietisation of its western neighbours, this was also deemed a bit hardline, and she only ventured to say it when she was about to leave office. Yet, to most Russia watchers who've been following events unfold under Putin, the unambiguous enmity felt by the Kremlin and Putin's resolve to reverse the greatest catastrophe of the twentieth century have been clearly evident for many years.

One of the key reasons for the West's tolerance of Russia's increasingly revisionist and aggressive behaviour is that Western leaders and publics have difficulty in seeing how aggressive it is. They seldom know Russian well enough to have direct exposure to the combative and mendacious propaganda that Moscow emits, and they continue in mirror-imaging their own conciliatory attitudes on to Russia. How could Russia not wish to reduce dangerous levels of nuclear armaments (Obama)? How could Russia not wish to pursue modernisation through closer integration with advanced Western economies (successive German governments)? Despite occasional relapses, surely Russia will sooner rather than later recognise that the legacy of one of the most bloodthirsty tyrannies of the twentieth century, Stalinism, is best abandoned and regretted? Surely Russia will accept the need for welloff first-world countries to use their diplomatic and military capabilities to curb brutal and genocidal conflicts or regimes - Syria, for instance, 
or Islamic State - in accordance with the doctrine of the Responsibility to Protect? ${ }^{15}$ Despite constant disappointments, the persistent belief that Russia can be a valuable partner for the West in the world's worst trouble spots motivates Western governments to avert their gaze when the Kremlin yet again chooses to bully a neighbour or to block efforts to check egregious behaviour somewhere.

Despite all the determined good will, Russia was not to be conciliated, cajoled or co-opted into the Western consensus. Perhaps the earliest striking illustration of this came in 1999 in the former Yugoslav province of Kosovo. Russia's angry attempts to block or condemn NATO's efforts to put an end to bloodshed in the province are worth recalling because they illustrate much about the antagonistic relationship with the West that was already beginning to emerge.

The Serbs - whose position in the former Yugoslavia bore strong similarities, if on a much smaller scale, to Russia's in the Soviet Union - have always seen Kosovo as the historic heartland of their state because of its role as the centre of Serbian culture in medieval times. (The parallel with Russian views of Kyiv and Ukraine immediately suggests itself.) Despite having strong views on Kosovo, modern Serbs tend to have slightly hazy ideas about what has been going on in their historical heartland in more recent times, just as Russians are vague about developments in Ukraine.

When I lived in Belgrade in the late 1960s, my Serbian friends would often provide me with history lessons about the province and passionately explain its crucial importance to their homeland and themselves. I visited Kosovo on multiple occasions to photograph and admire the historic Serbian monasteries there, many articles about which I'd read or translated. On my return, some friends were somewhat puzzled to learn that I'd been to Kosovo at all, and when asked, often acknowledged that they'd never been there themselves.

Despite the efforts of successive Belgrade governments over decades to strengthen the Serbian ethnic presence in Kosovo, sustained emigration and differential fertility trends meant that the Albanian majority, which had been dominant since at least the

15 Philip Cunliffe (ed.), Critical Perspectives on the Responsibility to Protect: Interrogating theory and practice (Abingdon, Oxon: Taylor \& Francis, 2011). 
nineteenth century, rapidly became overwhelming. Serbs were emigrating to escape the relative poverty and the ethnic tensions. Given the strength of ethnic Albanian nationalism and the extensive territories of Albanian settlement adjoining Kosovo, Serbian control of the province was fraught with uncertainty.

Tito's solution to this dilemma in his later years had been to follow a conciliatory policy towards the Albanians, granting greater local autonomy to Kosovo and allowing ethnic Albanians to secure a powerful position in the local party/state hierarchy. Not surprisingly, the Serbs, who had been the paramount force in Kosovo life over many decades, saw this as a threat to their position.

Slobodan Milošević, the Serbian nationalist and emerging strongman of Yugoslavia in its last years, made his career out of the Kosovo dilemma, appealing directly, in a divisive and populist way, to the ethnic Serbs in the province and throughout Yugoslavia. In 1989 he abruptly rescinded Kosovo's autonomous status. This made him immensely popular in Serbia and put him in a powerful position to pursue ethnic Serbian interests during the fragmentation of Yugoslavia that was to follow.

As various commentators wrote in the 1970s, with the ethnic Albanians increasingly dominant demographically, crude coercion seemed unlikely to be viable over the longer haul. ${ }^{16}$ In Milošević's time, Belgrade actually had a potentially constructive ethnic Albanian partner in the Kosovo Democratic League (KDL). The KDL, the largest ethnic Albanian party, was committed to non-violent methods, as was its undisputed leader, the poet and pro-European intellectual Ibrahim Rugova. But Milošević had no intention of reaching any understanding with Rugova. Both Rugova himself and the policy of non-violence were discredited by Milošević's coercive policy choices. This contributed to the radicalisation of the Albanians and the emergence of more militant and even terrorist groups, which coalesced to produce the Kosovo Liberation Army (KLA). The KLA increasingly took precedence over the KDL as the dominant Albanian force in the struggles that followed.

16 See, for example, John Besemeres, 'The demographic factor in inter-ethnic relations in Yugoslavia', Southeastern Europe, vol. 4, no. 1 (1977): 1-31. 
At the outset of the Yugoslav wars, Milošević still enjoyed support from some important countries in the Western alliance. But he used brutal methods, especially so-called 'ethnic cleansing', in his campaign to convert the strong ethnic Serb presence in parts of Croatia and Bosnia into a dominant political and military position. By 1999, a strong consensus had developed among the Western allies that, while there were many guilty parties, Milošević and the Serbs were the worst offenders and the main source of the problems in Yugoslavia. Such atrocities as the Vukovar Hospital massacre in Croatia, the shooting of 8,000 men and boys by General Mladic's Bosnian Serb forces at Srebrenica and the lengthy siege of Sarajevo, which involved huge civilian casualties, decisively shaped Western opinion. Despite the growing hostility towards him among Western governments, Milošević nonetheless managed to secure for the Serbs - who only made up a third of Bosnia's population - a 49 per cent share of Bosnian land as determined by the Western-brokered Dayton settlement of November 1995.

But in 1999, when Milošević seemed to be bent on pursuing a violent solution for the KLA insurgency in Kosovo, including much more ethnic cleansing, Western leaders decided that enough was enough. NATO forces were directed to launch a campaign of air strikes on Serbian military and infrastructure assets, including propaganda outlets and other facilities in Belgrade. Milošević responded by driving much of the 90 per cent majority Albanian population out of Kosovo, with heavy casualties.

The air campaign was a blunt instrument inflicting great damage on Serbian infrastructure. Despite efforts to limit the human costs, it also caused some 500 civilian casualties and, in the end, the Serbs had to concede defeat. This was the beginning of the end for Milošević, who was finally deposed by a people power rebellion in October 2000. It also pretty much brought an end to the wars of the Yugoslav succession, though some sporadic violence continued afterwards, mainly involving ethnic Albanians in Kosovo and offshoots of the Kosovo conflict in adjacent territories of Macedonia and Serbia proper.

The NATO action was not an ideal solution, but its results were seen by Western countries as on balance positive. Serbs, particularly in Belgrade, have naturally condemned the bombing campaign, but tend to forget that their 500 fatalities were dwarfed by the victims 
of Belgrade-supported Bosnian-Serb violence at Srebrenica, or the 14,000 dead in the siege of Sarajevo, including 5,400 civilians. Infrastructure damage to Serbia was great, but there had also been very severe destruction as a result of earlier fighting in many other parts of Yugoslavia, where in the early stages the Serbs had superior weaponry and were able to prevail. Serbia, though a key instigator of the wars, had until the Kosovo campaign largely avoided damage to its own territories and residents outside Kosovo province.

Moscow was furious that NATO had acted without the approval of the UN Security Council, thus bypassing any Russian veto. It introduced a resolution of condemnation in the UN Security Council, but the resolution was only supported by China and Namibia, reflecting the widespread feeling that, for all its obvious downsides, the air campaign was a legitimate response to a difficult situation where further humanitarian disasters needed to be forestalled.

In the wake of the air campaign, Western leaders included Russia in the peacekeeping arrangements for Kosovo. But Moscow was offended that it was not given its own area of the province as a separate command. NATO leaders blocked that proposal, thinking that Moscow might seek to convert an occupation of Serb-populated areas in northern Kosovo into something more substantial, in a smallscale replay of East Germany and similar arrangements in the wake of World War II. Frustrated by this blocking of what they saw as their legitimate entitlements, Moscow ordered some of its forces in the area to carry out a unilateral seizure of Priština airport. With the support of surrounding states, NATO managed to block any reinforcement and resupply of the Russian contingent at the airport, and a compromise solution was finally reached. The Priština airport incident was a good example of the increasingly adversarial nature of Russian foreign policy that was already evident under the later Yeltsin, and was a pointer to future Russian tactics in Yugoslavia and elsewhere.

Moscow maintained and intensified its denunciations of NATO's actions in Kosovo with ever greater intensity in the Putin period. Putin and the Moscow elite clearly identify with Serbian nationalist opinion, and vice versa. If Russia found it necessary to kill tens of thousands of people (estimates vary wildly) in its Second Chechen War, then it is its sovereign right to do so. In the Russian view, the Responsibility to 
Protect, like other human rights doctrines, is hypocrisy and humbug, used instrumentally by the West to undermine Russian (or Serbian, or Syrian) sovereignty and interests.

Moscow has also repeatedly waved the Kosovo argument in the air as justification for various self-interested neo-imperial ventures of its own. Western visitors to Moscow before the Russo-Georgian War of 2008 were often informed that, since NATO had attacked Serbia in support of Albanian secessionism, everything was now permitted, and it would be only natural for Abkhazia or South Ossetia, for example, to secede from Georgia (though not of course for Chechnya to secede from Russia). Unlike Russia in relation to Georgia's breakaway territories (which Russia itself had sponsored and nurtured), no European country was waiting eagerly to annex Kosovo to its own territory, or otherwise to profit from the operation. Kosovo was an onerous international policing burden undertaken to relieve and, it was hoped, curtail the humanitarian disaster that had unfolded in Yugoslavia. In a similar spirit, Euro-Atlantic institutions have accepted the responsibility of trying to ensure the peaceful postwar development of Kosovo and its reconciliation with Serbia.

Why preventing a further bloodbath in the former Yugoslavia was damaging to the security or other legitimate interests of Russia, a country whose borders were by that time remote from Kosovo, is not obvious. The Russian point of view in relation to US or Western interventions in Iraq, Libya or Syria, three other cases that figure constantly in the Putinist bill of indictment, is slightly easier to understand. Moscow stood to lose money and privileged access in all those countries, and arguably, given its large, restive Muslim minority, could potentially have been exposed to some kind of terrorist blowback from any Western intervention. But their own brutal policies in the North Caucasus were a much more likely potential trigger for any such development. And again, despite Putin's emotional reaction to the death of Colonel Gaddafi, there wasn't really any convincing threat involved to Russian security in the Libyan intervention. Whether US/ Western involvement in all those cases was wise and/or in their own interests is another matter, but not one that need detain us here.

Under Putin, Russia's most explicit concern has been with NATO expansion, which took a further leap in 1999, the same year as the Kosovo intervention, when Poland, the Czech Republic and Hungary 
all joined the alliance at the NATO summit in March, and several other countries including the three Baltic states were given Membership Action Plans. Most of these countries, including the Baltic states, subsequently joined NATO in 2004. Russia's postwar claim to the Baltic states ultimately rested on military conquest (followed by severe genocidal atrocities), and the Molotov-Ribbentrop Pact secret protocol, as well as the Yalta settlement. From that point of view, Putin's recent public justification of the Molotov-Ribbentrop Pact is a particularly grim signal to the Baltic states, and illustrates graphically why they were so desperate to join NATO and the European Union.

By 2008, Russian anger and indignation that more former republics of the USSR were following the Baltic example of seeking a haven in NATO was heading towards a climax. Putin had launched his own anti-Western crusade with his bellicose speech at the Munich Security Conference in February 2007. At the same time, relations between the Bush administration and some leading countries of the European Union were seriously strained. Georgia and Ukraine, two former republics of the USSR under strongly pro-Western and anti-Russian leadership were, meanwhile, seeking a membership path to NATO.

Bush lobbied hard for a Membership Action Plan to be granted to the two countries at the Bucharest NATO Summit of April 2008. Moscow expressed emphatic opposition to any such development both before and at the summit, which Putin attended. Key Western European NATO members were also opposed, largely because they didn't want to antagonise Russia, and the pleas from Kyiv and Tbilisi were duly rejected. In reaction to cries of alarm from some new Eastern members, NATO issued an anodyne statement without any dates (and without much credibility) that Georgia and Ukraine would at some time become members.

Putin was undoubtedly enraged by this statement, but he was certainly not deterred by it. Russia has since invaded both countries and annexed or de facto taken control of significant parts of their internationally recognised sovereign territories. Western resistance in each case was mainly rhetorical, and certainly not military, as Russia would have very confidently known in advance. There were significant arguments against extending Membership Action Plans to either applicant country, in the case of Ukraine not least because, at that time, there was nothing like a majority within Ukrainian 
public opinion in favour of such a step. But Russia's opposition to the enlargement was clearly founded not on fear for its own security, but on concern that NATO membership might possibly make it harder for it to regain by force a position of dominance in the two countries in question.

The Bucharest Summit is generally seen as marking an end to further NATO enlargement to the east against Russian opposition, especially in the case of countries that had formerly been part of the USSR. And the new European Commission President Jean-Claude Juncker ${ }^{17}$ has made clear that there will be no further enlargement of the European Union on his five-year watch. So those urgently pursuing EU membership as a softer alternative to NATO to counter Putin's mounting belligerence are not likely to make much progress. The message for Moscow seems to be that aggression works, so why would one resile from it?

17 See Jean-Claude Juncker, 'A New Start for Europe: My Agenda for Jobs, Growth, Fairness and Democratic Change', Opening Statement in the European Parliament Plenary Session, Strasbourg, 15 Jul. 2014, www.eesc.europa.eu/resources/docs/jean-claude-juncker---politicalguidelines.pdf. 


\section{9 \\ Putin's Westpolitik: Back to the USSR ${ }^{1}$}

Over the past two years, Vladimir Putin's aggressive policies towards his western neighbours have reached a crescendo, extending now also to the Western strategic community as a whole and even including non-NATO members like Sweden and Finland. The Russian President makes tactical concessions to more susceptible European countries like Germany, France, Italy, Greece, Cyprus, Hungary and Slovakia sadly, not an exhaustive list - with a view to keeping the European Union and NATO divided. His 'energy diplomacy' - manipulating vital supplies and prices to pressure vulnerable ex-vassals into returning to the tent, or to punish or persuade countries further afield - has a continuing role. But now it is more frequently coupled with military intimidation or outright coercion.

A sharp rise in military expenditure has been accompanied by evergreater missile rattling and threatening 'exercises'. Aggressive and frequent overflights near or even occasionally into Western countries' airspace have become a threat to civilian aircraft and indeed to peace itself. Those policies are backed by blanket anti-Western propaganda at home, and skilfully crafted and targeted disinformation abroad, all of it at levels of expenditure, reach, toxicity and effectiveness that are far greater than any later Soviet equivalents. To say that we

1 First published in Inside Story, 17 Dec. 2014, insidestory.org.au/putins-westpolitik-back-tothe-ussr. 
have a return to the Cold War is not an exaggeration. In some ways it is worse in that during the Cold War, there were clearer rules and understandings regulating East-West relations.

Putin's primary objective is to re-establish a version of the Soviet sphere of influence. In the first instance, that means not just halting NATO expansion, which he's already achieved, but also blocking the European Union from integrating any more former dependencies of the USSR. It seems unlikely that he will stop there of his own volition without attempting to roll back some of his earlier 'losses'. He views his Western adversaries as weaklings who can be set against one another and intimidated. An enthusiastic if ungifted student of history, he sees himself as the successor to Catherine and Peter the Greats as well as Stalin, destined to gather together all the Russian lands, very broadly understood. His actions suggest he certainly has designs on the Baltic states, for example, and may have ambitions beyond them.

He also seems to be working towards systematic weakening not just of NATO, but also of the European Union as an institution. Moscow's traditional support of the hard left in the West, as well as Russophiles of all stripes, has now been extended to diligent courtship of the hard right, especially the Eurosceptic hard right. This has been going on for some time with minimal attention from Western publics, but now the West is at last starting to notice. The recent scandal involving a €40 million loan from a Moscow bank to Marine Le Pen's National Front war chest for the French presidential and parliamentary elections, due in 2017, has focused greater attention on this aspect of Moscow's Western policy. ${ }^{2}$ That handsome gesture, part of a wider pattern that includes official visits to Russia by Le Pen herself, tends to confirm that the intention is to destabilise the European Union as a whole by promoting all forms of Euroscepticism, of whatever provenance.

The Kremlin hasn't always been so hostile to the European Union. In fact, it was long thought that Russia objected only to its former satellites having any connection with NATO. By 2008 Putin's hostility to NATO expansion had become so emphatic that European members of the alliance were reluctant to test him further. At the April 2008 Bucharest summit of NATO, the pleas of the pro-Western leaderships

2 See Andrew Rettman, 'Mediapart: National Front's Kremlin loan is worth €40mn', EUobserver, 27 Nov. 2014, euobserver.com/foreign/126693. 
of Georgia and Ukraine to secure a Membership Action Plan for NATO were rebuffed. After the summit, and after the weak Western response to the Russian invasion and annexation of parts of Georgia that followed soon after, it was generally accepted that there would be no further eastward expansion of NATO within the foreseeable future.

The European Union's Eastern Partnership scheme, launched by the European Union in 2009, was an attempt to offer former Soviet republics a softcore alternative to NATO with a form of EU integration, that fell well short of full membership. Some new EU members hoped that this process would be a stepping stone to full EU membership for their eastern neighbours, but older EU members explicity opposed any such connection being made.

The Eastern Partnership scheme seemed well designed to assuage Russia's sensitive nature. But, as all the former western republics of the Soviet Union became involved to some degree in the scheme, Moscow's hostility became apparent. The European Union has tried to draw Russia itself into a similar process of progressive 'modernisation' through partnerships of various kinds. But Russia has been proof against any such inducements, preferring to revert increasingly to its own highly successful sociopolitical models.

In 2010, in response to the Eastern Partnership scheme, Russia set up its own nascent version of the European Union in the form of the Eurasian Customs Union, which from the beginning of next year is to morph into the Eurasian Economic Union, aka the Eurasian Union. Putin has said in the past that he wants to draw all the former republics into membership, including the Baltic states. His actions to date, and the example of the statelets set up in the various 'frozen conflicts', tend to suggest that Russia would prefer all its former vassals not only to join the Eurasian Customs Union but also to follow its own neoSoviet, sociopolitical model.

The Customs Union and the Eurasian Union have not exerted much genuine attraction on the six Western republics, apart from Belarus. But all six displayed some interest in cooperating with the Eastern Partnership scheme, though for various reasons Belarus and Azerbaijan never pursued an Association Agreement (AA), and Armenia reversed its decision to do so. The other three - Ukraine, Georgia and Moldova - have now all negotiated and recently signed AAs. For all three it has 
been a tortuous process, with Russia employing every means it can, including military force, to block any progress. Even post-signature, full and sustained implementation promises to be very difficult.

Putin seems to think he can stare down the AA candidates by a mixture of violence, propaganda, trade boycotts and intermittent invitations to Brussels to seek a 'political solution' to the 'problems' in Ukraine, Moldova or wherever else. We may soon see whether he's right.

Despite some wobbles caused by Brussels's objections to their highly undemocratic systems, Belarus and Azerbaijan continue to be lowgrade participants in the Eastern Partnership scheme and both use the connection as a hedge against Russia and a means to pursue mutually advantageous trading and other links with the European Union. While Azerbaijan has hitherto leaned more to the West, Belarus is Russia's closest ally, despite President Alexander Lukashenka's tiffs with Moscow and fear of Russian domination. There is no interest in either case or from either side in an AA. Nonetheless, Moscow is constantly working to draw both countries into closer communion with itself and to sever the Brussels connection.

Belarus joined Putin's Customs Union, and will be a founding member of the Eurasian Union. Although Lukashenka wriggles at times as he observes the increasingly dictatorial behaviour of the Putinist regime towards its neighbours, he does not want to meet the European Union's minimal requirements on governance or most other things. So Belarus is probably destined to be dragged further into Moscow's embrace.

Azerbaijan's dictator Ilham Aliyev is the son and dynastic heir of Heydar Aliyev, a former head of the republican KGB, who was Azerbaijan's communist and then post-communist boss. The younger Aliyev has continued his father's pragmatic autocracy, vying strongly with Russia in domestic oppression, but seeking links with the European Union as far as his own domestic imperatives permit, and particularly in trade and investment. The European Union, for its part, has a strong interest in Azerbaijani energy exports as an offset for its dependency on Russia, a policy direction that Moscow has been trying, with some success, to block. But, during 2014, Aliyev has shifted ground. Sensing EU weakness and Russia's growing resort to hard power, he has tilted markedly back towards Moscow. 
Armenia, though not a model of democracy, is slightly more prepossessing in that respect than Belarus or Azerbaijan. It is heavily dependent on Moscow for security against Turkic Azerbaijan (from which it seized by military force the mainly Armenian territory of Nagorno-Karabakh in the early 1990s) and against the Turks, the authors of its greatest historical disaster, the Armenian genocide of 1916. Nonetheless, Armenia, which has one of the most ancient Christian churches still in existence, sees itself as belonging to the West in some general sense. It also has a large Western diaspora (including up to an estimated 50,000 Australian residents claiming Armenian ethnicity).

For an extended period, Armenia was active in the Eastern Partnership and seemed to be working steadily towards an AA. Then, in a single day, Armenia abruptly changed course. Putin had earlier applied heavy pressure, agreeing to sell the Aliyev regime weaponry to the value of US\$4 billion. Without prior announcements, on 3 September 2013, Putin received Armenian President Sargisian in Moscow, where they jointly announced that Armenia was withdrawing from negotiations for an AA and seeking to join Putin's Customs Union instead. Russia's threats and inducements were not made public, but they were clearly persuasive.

Putin sees the Eurasian Union as becoming a fully fledged equivalent of the European Union, part of a multipolar world system in which the poles will include the United States, the European Union, the Eurasian Union, China and India. Not only will it be able to pre-empt integration into European Union structures by any former Soviet republics, it may even, in the Kremlin's eyes, be capable of attracting into its orbit other prospective members. But at this stage the Eurasian Economic Union has done little to enhance the dwindling trade among its members and is still generating disputes, even conflicts, about basic, yet-to-beagreed trading provisions. And, with the economic slump in Russia, the attractions of the Eurasian Economic Union decline further. It's hard to avoid the conclusion that its whole rationale is much more imperial-political than economic.

While the other three Eastern Partnership members - Ukraine, Moldova and Georgia - have all now signed AAs with Brussels, Putin is not giving up on blocking any of them. In 2013, both before 
and after his Armenian triumph, he was progressively stepping up pressure on Ukraine to withdraw from its laborious but well-advanced AA negotiations with Brussels.

President Yanukovych was hoping he could somehow gain advantage from both sides without fully committing to either. Putin was not, however, going to give him that chance. On 21 November 2013, Yanukovych suddenly followed Sargisian's lead, performing a 180-degree turn without any prior attempt to prepare the Ukrainian public.

Ukraine's civil society proved less submissive than Armenia's. In response to Yanukovych's abrupt change of course, several months of demonstrations in Kyiv - the so-called Maidan or Euromaidan began that night. In the weeks that followed, as the protests persisted, the regime began to resort to 'disappearances', arrests and forceful crowd control tactics against demonstrators. All this was a shock for public opinion as, hitherto, there had been relatively little lethal violence of that sort in Ukrainian politics. But the shock only served to radicalise and strengthen the protest movement, which maintained its pressure until Yanukovych finally fled the capital on 21 February. As his ruling Party of Regions began to crumble, a reformist and pro-European successor government was quickly formed. Despite Russian propaganda that this was a 'fascist coup', the legitimacy of the transition has never been seriously challenged and has been fully confirmed since by early and orderly elections to the presidency and parliament.

Putin's response was so quick, it clearly had been well rehearsed and prepared. Within a month, Crimea had been invaded and 'annexed'. The story in Crimea since the annexation, however, has been bleak: steep economic decline, loss of most links to the Ukrainian hinterland, forced and disruptive adoption of detailed Russian administrative routines, corruption and criminality, ${ }^{3}$ petty tyranny, and persecution of non-Russians (notably the Crimean Tatars, who had been deported

3 See Laura Mills \& John-Thor Dahlburg, 'Change of leadership in Crimea means property grab', Salon, 2 Dec. 2014, www.salon.com/2014/12/02/change_of_leadership_in_crimea_means_ property_grab/. 
by Stalin with mass casualties during World War II). ${ }^{4}$ Appropriately, the new 'prime minister' gifted to Crimea by Moscow was Sergey Aksyonov, a Russian patriot from Moldova who originally came to Crimea as a teenager hoping to join the Soviet military, but transited into criminal activity and then politics, where he led a minor party with 4 per cent support at the last free Crimean elections. ${ }^{5}$

Having subdued Crimea, Moscow instituted similar operations in much of south-eastern Ukraine. But there, unlike in Crimea, Russia had no regular forces stationed, and the ratio of local zealots and crossborder volunteers to Russian professionals in anonymous uniforms was greater. This often led to administrative chaos and crude abuses and criminality by the Russian and proxy forces, stiffening local resistance as well as military pushback from the new Ukrainian Government.

Over time, the grossly underfunded and ill-equipped Ukrainian forces managed to mobilise their resources and, with the support of volunteer detachments and much help from the public, began to gain the upper hand over the so-called 'separatists'. By August 2014, they had pushed the Russians out of most regions in the east, and were even making big inroads into the two most pro-Russian provinces, Donetsk and Luhansk. Faced with the possible defeat of their proxy forces, Moscow decided on another large injection of perhaps 6,000 crack troops with high-tech weaponry. Within a few days, this further cross-border incursion had completely changed the course of the conflict.

Under growing pressure from Western sanctions, which had sharpened appreciably in late July after the downing of Malaysian flight MH17, and having recouped the situation of his proxy forces, Putin was now disposed to agree to a ceasefire. For his part, President Petro Poroshenko had realised that Moscow would not allow him to restore Kyiv's authority in the east by force and that, given the dire state of Ukraine's economy, he could no long afford the casualties or the destruction the conflict was generating.

4 See Paul Goble, 'Volga Tatars demonstrate against Russian persecution of Crimean Tatars', Window on Eurasia, 28 Sep. 2014, windowoneurasia2.blogspot.com.au/2014/09/window-oneurasia-volga-tatars.html.

5 See Simon Shuster, 'Putin's man in Crimea is Ukraine's worst nightmare', Time, 10 Mar. 2014, time.com/19097/putin-crimea-russia-ukraine-aksyonov/. 
Hence, the ceasefire that never really was, brought about by the socalled Minsk Protocol of 5 September. In fact there were, by December 2014, over 1,000 further fatal casualties, with armed clashes occurring on a daily basis. The proxies have been attacking strategic points in Ukrainian hands, especially Donetsk airport and the major port city of Mariupol. The pattern of their attacks suggests Moscow would like at least to establish a secure land corridor to Crimea, and could be contemplating a further major incursion into Ukrainian territory. During November, Russian forces and high-tech weaponry were again infiltrated across the porous border. Hardline nationalist circles in Russia continue to speak threateningly of 'Novorossiya', ${ }^{6}$ a historical term for a large part of southern and eastern Ukraine, the seizure of which official Moscow has occasionally hinted at broadly as an objective. If Russia were to do this, it could leave Ukraine landlocked, with Russia taking over its entire Black Sea littoral. This would also enable Moscow to link up with its protectorate of Transnistria in Moldova, further threatening Moldova's fragile existence as a sovereign state and surrounding a rump Ukraine from three sides.

But the Ukrainians have managed to hold firm to their positions through the phoney peace. Feeling some pressure from Ukrainian military resistance as well as Russia's economic downturn, Putin seems again disposed to settle for at least a temporary lull in military proceedings. Poroshenko has reached an accommodation of sorts with the Donetsk and Luhansk leaders, and on 9 December Russian Foreign Minister Lavrov even spoke of a 'postwar phase'. Since that date, for the first time since the September ceasefire, there has been an unambiguous reduction in clashes.

Sensing he may never get adequate military or economic support from the West, and with the Ukrainian economy teetering ever closer to the abyss, Poroshenko has no choice but to grasp any ceasefire on offer. Though it is much stronger than Ukraine's, Russia's economy is also heading precipitately south. While sanctions have made some contribution, the plummeting oil price and rouble have been a great deal more important. Russia's Finance Minister, Anton Siluanov, recently estimated the cost to the Russian economy of the oil price

6 See Adam Taylor, “"Novorossiya”, the latest historical concept to worry about in Ukraine', Washington Post, 18 Apr. 2014, www.washingtonpost.com/blogs/worldviews/wp/2014/04/18/ understanding-novorossiya-the-latest-historical-concept-to-get-worried-about-in-ukraine/. 
slump at up to US $\$ 100$ billion, compared with US $\$ 40$ billion for the current sanctions. ${ }^{7}$ While Putin likes to declare that his loyal subjects will suffer as heroically as their forebears have often done, he seems reluctant to push them too hard.

All Moscow really needs at this stage in pursuit of its core objectives is a secure 'frozen conflict' in eastern Ukraine, like the ones it established in the early 1990s in Georgia's Abkhazia and South Ossetia, and in Moldova. These structures enable Moscow to exert great influence on the involuntary host country, deploying 'peacekeeping forces' there to support the 'rebels', and blocking national governments from joining the European Union or NATO, neither of which want as new members countries in which there is an ongoing civil conflict or standoff. And, as in Georgia in 2008, such a bridgehead can easily be used at short notice in any all-out assault on the host country if the opportunity presents itself.

Ukraine is in a dire state, weakened by the incompetence and venality of past governments, and devastated and polarised by Putin's geopolitical vandalism. Its efforts to defend itself largely unaided against an infinitely stronger enemy have had a surprising degree of political and military success, as well as strengthening national identity and morale in much of the country. But they have also added to the damage and polarisation. At least it now has a fully legitimate and reasonably coherent administration to address these challenges.

Moldova's circumstances are complicated in a very different way. This small, impoverished state - despite high growth in recent years, it is still commonly described as the poorest in Europe - has an intricate ethnolinguistic makeup and eventful history. In modern times, its population has been predominantly Romanian, but with a substantial Russian-speaking minority enhanced since tsarist times by Moscow's encouragement for people from elsewhere in the empire to migrate there. Part of Romania between the wars, it was occupied by Moscow again in 1940 on the basis of the secret provisions of the Molotov-Ribbentrop Pact, whereby Hitler and Stalin divided Eastern

$7 \quad$ See ‘Russia loses $\$ 140$ bn with sanctions and falling oil prices - Finance Minister', Russia Today, 24 Nov. 2014, rt.com/business/208263-russia-losses-sanctions-oil/. 
Europe between them. Russia's control of the territory was brutally reimposed by the Soviet Army and NKVD secret police at the end of World War II but, with the collapse of the Soviet Union, Moldova became an independent state. Putin clearly wants it back, like other Molotov-Ribbentrop acquisitions. He is not too embarrassed by the defects in his deed of title, recently telling an audience of young Russian historians that he couldn't see anything bad about the Pact. ${ }^{8}$ Indeed, he appears to feel nostalgia for it. ${ }^{9}$

He has extensive material to work with in Moldova: a large Russianspeaking imperial minority; a heavy economic dependence on Russian trade and energy supplies; a high degree of dependence on remittances from an estimated 400,000 Moldovan migrant workers in Russia; a large communist party (still so-called) that tries to balance between the European Union and Russia but leans increasingly towards the latter; other large political parties financed or sponsored by Russia, one of which (the Socialists) unexpectedly topped the polls in the 28 November parliamentary elections; and Transnistria, an enclave between the Dniester River and the western border of Ukraine, where Russia has supported a corrupt breakaway regime of pro-Russian patriots and maintains a 'peacekeeping' force that acts, in fact, as an agent for Moscow.

The politics of Moldova are also complex but, since 2009, there has been a coalition government of ethnically Moldavo-Romanian parties that has charted a consistent course towards the European Union and has now signed and ratified an AA with Brussels. In the run-up to national elections last month, there were huge pressures from Russia aimed at convincing the public to support parties that favour joining Putin's Customs Union. Moscow has successively blocked Moldova's key agricultural exports on bogus sanitary grounds, issued Russian passports to its local supporters, and threatened both to expel its Moldovan guest workers (whose remittances are vital to Moldova's economy) and to arbitrarily curtail vital gas exports to Moldova in winter.

8 See Linas Linkevičius, 'Putin has defended the Nazi-Soviet pact. Time for the west to wake up', Guardian, 8 Nov. 2014, www.theguardian.com/commentisfree/2014/nov/07/vladimir-putindefended-nazi-soviet-pact-west-world-war-two.

9 See Timothy Snyder, 'Putin's new nostalgia', New York Review of Books blog post, 10 Nov. 2014, www.nybooks.com/blogs/nyrblog/2014/nov/10/putin-nostalgia-stalin-hitler/. 
Not content with the nuanced support of the Communist Party, which was, until the November elections, by far the largest party in the country, Moscow recently sponsored the emergence of two fully subservient pro-Moscow parties - the Socialists and Patria (Fatherland). Both were red-carpeted in Moscow, received generous subventions, and were authorised to promise the electorate that they could secure the lifting of Moscow's damaging trade boycotts and ensure the well-being of Moldovan guest workers. Their electoral bottom line was that joining the Customs Union would solve all the country's problems. Crucially, they were supported by heavy Russian TV propaganda coverage, beamed throughout Moldova.

Not to be outdone, the government responded by banning Patria from competing in the elections on the grounds that it had received illegal financial support from abroad. Patria does indeed look very much like a Kremlin project, even more so than the Socialists. But most of the Patria votes seem then to have been simply transferred to the Socialists. Using 'political technology' worthy of the Kremlin, the government also stacked the voting arrangements in the Moldovan guest worker diaspora so that it would be much harder for Moldovans in Russia to vote than their compatriots in Italy and elsewhere who usually favoured Western integration. Thus, while international observers gave the election procedures in country the thumbs-up, neither side played fair. But Russia's involvement was much greater, more menacing and unscrupulous, and also more effective.

The 30 November 2014 elections gave the three main pro-EU parties fewer votes than last time, but they did scrape through to a narrow majority of seats in the parliament. If the very pro-Russian Socialists can combine effectively with the merely pro-Russian Communists, however, they may be able jointly to defeat some key parliamentary votes, including for the presidency in 2016. Both sides of politics are fractious, but the pro-Europe bloc perhaps more so, and Russia is much better than Brussels at wielding carrots and sticks. With the Socialists already agitating for votes on rescinding the AA with Brussels and joining the Customs Union instead, implementing the agreement could prove difficult or even impossible.

Moldovans have had rich experience of brutal imperial and military occupation. The election results suggest Moscow's blunt messages about cutting off gas supplies and deporting Moldovan guest workers 
gained traction. Either manoeuvre could inflict great damage on the economy, and many Moldovans have obviously decided that supporting the Customs Union may be the better part of valour. The latest opinion polls suggest that support for the Customs Union may have edged slightly ahead of support for the AA, despite the European Union's efforts to frontload the trading and visa-free travel benefits of the AA. From Moldova, Brussels looks much further away than Moscow.

In case Moldovans haven't yet got the message sufficiently, Russia is apparently preparing similar actions to the ones it has taken in Ukraine. It has been reliably reported that Moscow has recruited groups of pro-Russian enthusiasts in Moldova to travel to Russia for special paramilitary training in the civic arts of destabilisation, urban guerilla warfare and the seizing of public buildings. ${ }^{10}$ As in Ukraine, Russia could artificially stimulate conflict in Moldova by paramilitary intervention, then deploy its forces stationed in Transnistria or infiltrated into the country to act as a force-multiplier for its preferred partisans, and present its proxies later to the Organization for Security and Co-operation in Europe (OSCE) as legitimate combatants.

The elections may not have decided the issue one way or the other. Formation of a pro-EU government based on a parliamentary majority may only lead to the outbreak of disturbances and demands for secession from Transnistria and other pro-Russian enclaves in the country. We could see further and more decisive action in and against Moldova quite soon.

To many Westerners, Moldova and Transnistria sound like places from a musical comedy, a kind of Ruritania suddenly come bizarrely to life. But a successful hybrid war in Moldova could be seriously bad news not just for Moldova, but also for Ukraine, which would then be more vulnerable to a full-on Russian attack at some propitious future moment. And the European Union's credibility, soft power and capacity for spreading peace and stability on the continent, already seriously damaged, would be dealt a further heavy blow.

10 See Stanislav Secrieru, 'How to offset Russian shadow power? The case of Moldova', PISM (The Polish Institute of International Affairs) Bulletin, No. 125 (720), 31 Oct. 2014, www.pism.pl/ files/?id_plik=18536. 
Georgia has also signed an AA with Brussels, despite or perhaps because of its intensely sobering recent experiences with Russia. After Georgia regained its independence in 1991, Russia quickly stepped in to foster the breakaway regions of Abkhazia and South Ossetia, encouraging and actively supporting the violent expulsion of ethnic Georgians from both regions (in Abkhazia, ethnic Georgians had actually been a majority before the Russian-supported expulsions). In 2008, after failing to win any real prospect of NATO membership, the pro-Western reforming President Mikheil Saakashvili unwisely tried to use armed force to put an end to the ongoing ethnic cleansing of Georgian villages in South Ossetia, perhaps mistakenly thinking the West would support him. Moscow quickly seized on this pretext to invade the country, destroying much of its modest military capability and inflicting heavy damage on its infrastructure.

Russia increased its military presence in Abkhazia too, even though the Georgians had not taken action in Abkhazia to restore to their homes over 200,000 internally displaced ethnic Georgians from Abkhazia. The two enclaves were then encouraged to declare their independence, which Moscow actively urged close allies and the international community to recognise, but with almost no success. Only one or two old Latin American friends of Moscow and a couple of Pacific Island states extended recognition to the newly cobbled entities, the latter in return for financial incentives. Even Belarus, seeing a dangerous precedent for itself, failed to recognise them, despite heavy pressure from Moscow.

Saakashvili limped on for a few years beyond his 2008 fiasco but, in October 2012, he and his United National Movement party were defeated in what were, by post-Soviet standards, unusually free and fair elections. The victor was an ad hoc coalition of forces called Georgian Dream, led by a (then) Russian citizen and billionaire Bidzina Ivanishvili, who had devoted his vast wealth earned in Russia to the campaign to bring down the Saakashvili administration. Since taking office, the Georgian Dream-led coalition has pursued a sustained campaign of repression against members of the former administration, despite their remarkable achievements in economic reform and suppression of corruption. At the same time, Ivanishvili has broadly continued his predecessors' pro-Western external policies, and retained some strongly pro-Western groups in his governing coalition. But he has also extended conciliatory feelers towards Moscow and 
there are some observers who suspect him of being a Kremlin project. The defeat of Saakashvili was certainly cause for great celebration in Moscow.

The pursuit of Saakashvili and his United National Movement colleagues has continued to the present and, sometimes, looks like selective justice aimed against anyone pushing a strongly Atlanticist line. In early November 2014, the very popular, pro-Western Defence Minister Irakli Alasania was dismissed after several of his senior officials were purged against his wishes. Foreign Minister Maia Panjikidze, together with four deputy foreign ministers and the minister responsible for relations with Europe, resigned in response, claiming that the country's Western orientation was under threat. Though strongly pro-Western, neither Alasania nor Panjikidze belonged to Saakashvili's party, which suggests that their main offence may have been to be too pro-Western.

President Giorgi Margvelashvili appears to share some of the concerns of the former ministers, whereas the current Prime Minister, Irakli Garibashvili, a close confidant of Ivanishvili, has dismissed the resignations and complaints as political stunts. Ivanishvili, who left the prime ministership in 2013, has retired from formal political office, but is widely believed to still control Georgia's political life from behind the scenes, acting mainly through his business protégé and right-hand man, Garibashvili. Georgia's Western interlocutors were dismayed by the loss of the key officials who lent credibility to the Tbilisi Government, and have repeatedly urged Ivanishvili and his allies not to continue the campaign of selective justice, but clearly to no avail.

It seems likely that Georgia, a strongly independent country very conscious of its European identity, will continue its path towards implementation of the AA with Brussels, if with less commitment than some in Georgia and Europe would like. But regardless of any contingency plans the secretive Ivanishvili may have (he once told an interviewer that he might favour the Customs Union if that seemed the right decision for Georgia), Russia has many assets at its disposal in Georgia, including client politicians, the conservative Georgian Orthodox Church and expanded military bases in both enclaves. And it is further strengthening its presence in Abkhazia after a Moscowfacilitated coup last May, which led to a more independent Abkhazian 
leader being replaced by a former KGB officer, Raul Khajimba, who is seen very much as Moscow's man. On 24 November, Putin and Khajimba signed a far-reaching 'bilateral' agreement that provides for close integration of defence, border control, customs policy, social policy and law and order.

All but the last vestiges of Abkhazia's separate existence are removed by this 'treaty'. It is likely that a similar arrangement will soon be concluded with the smaller and more subservient South Ossetia. Russian forces are already in close proximity to Georgia's capital, Tbilisi, and could be easily and quickly reinforced, if that were judged expedient. So, when the time is right, Russia could easily complete the job begun in 2008. There has been some semi-muffled debate within the Moscow establishment in the past about whether it should have gone the last few dozen kilometres to Tbilisi in 2008, and about whose fault it had been (Medvedev's) that it had not already done so.

Russia's threatening posture towards its Western periphery is primarily aimed at preventing further defections by former vassals to Western institutions. But it is also increasingly aggressive towards the entire global West, even including Japan, despite a shaky mini-thaw with the Shinzo Abe administration.

This aggressive behaviour is not new, though it has sharply increased in the last year or so. In 2009 and 2013, Russia conducted very large military exercises entitled Zapad 2009 and Zapad 2013 (or West 2009 and West 2013), with aggressive scenarios. The 2009 scenario, for example, assumed Polish support for 'terrorism' in Belarus and concluded with a nuclear strike on Warsaw. Overflights necessitating defensive reactions have also been increasing for some time but, during recent months, these have escalated. ${ }^{11}$ Many have been directed at vulnerable NATO members, especially the Baltic states, and at the Nordic nonNATO members, Sweden and Finland. And Putin has recently made repeated threatening references to Russia's nuclear capabilities,

11 See Thomas Frear et al., 'Dangerous brinkmanship: Close military encounters between Russia and the West in 2014', European Leadership Network Policy Brief, Nov. 2014, www. europeanleadershipnetwork.org/medialibrary/2014/11/09/6375e3da/Dangerous\% 20 Brinkmanship.pdf. 
continuing a trend of nuclear intimidation that was always present in Soviet times, if usually sotto voce, but has become more audible during his presidency.

This aggression has run in tandem with constantly expanding attacks on human rights and freedoms within Russia itself; and there is a clear link between the two. Putin has also enunciated an unattractive new principle for the conduct of foreign policy: that Russia has a right, even an obligation, to protect the rights of supposedly ill-treated Russian populations in neighbouring states, or indeed anywhere in the world. This doctrine echoes Hitler's assertion of a similar right in pursuing the Anschluss of Austria and coming to the rescue of supposedly oppressed Germans in Czechoslovakia and then Poland. It is in pursuit of this principle that Russia has been adopting the practice of distributing Russian passports to its 'fellow countrymen' (sootechestvenniki), for whose protection they might be later justified in interfering in the internal affairs of their country of residence.

Russian nationalists argue that because the break-up left over 20 million ethnic Russians in the former republics that then became independent countries, such policies are entirely natural. This was undoubtedly a misfortune for many of them, though not necessarily the greatest catastrophe of the twentieth century. It should be remembered, however, that over the centuries many more non-Russians had become involuntary citizens of the Russian, then the Soviet empire, often in severely traumatic circumstances and with massive loss of life at the hands of Russian military and political police formations.

Russian nationalists seem unable to absorb the broader context of this issue, which can in any case scarcely justify comprehensive aggression towards the new states of the kind that is now unfolding. Moscow has been happy in the past to encourage the return of ethnic Russians to the homeland, where severe demographic problems are judged to have rendered the existing population less than sufficient. But, for now, the policy of using the diaspora as a political asset in creating some lesser version of the Soviet Union under Moscow's direction seems firmly on the agenda, with alarming implications for the new postSoviet states and European security more generally. 
Until recently, it had been assumed in the West that the safety of the Baltic states was assured by their having become successful members of the European Union and NATO. But, since the almost certainly Russian-inspired cyberwar against Estonia in 2007, and the accompanying campaigns of destabilisation undertaken by ethnic Russians in Estonia, their position has seemed less secure. Russian economic coercion and outright aggression against Ukraine over the last year or so has reinforced Baltic anxiety. Lithuania has substantial Russian and pro-Russian minorities, while Latvia and Estonia have very big Russian diasporas, about a quarter to a third of the population in each case, and more if Russophone minority groups are included.

Most of the current Baltic Russian population is a result of immigration and border changes imposed by Moscow decision-makers in Soviet times. Many are military and KGB retirees and their descendants. They often have attitudes to the war on Ukraine similar to those of Russians in Russia itself. There are areas of local majority Russian settlement near the borders of both countries with Russia, where there have been signs of unwelcome activity, including recruitment of Russians to fight in the Ukrainian conflict. And the increasingly chauvinist propaganda of Russian TV stations has been beaming into all three countries in recent years. Since the invasion of Ukraine, the Baltic states have been developing countermeasures, but their efficacy is yet to be tested.

What worries the Baltic peoples most is that, though they are NATO members, the techniques used by Russia to subvert Ukraine could easily be employed against them: recruitment and covert training of co-ethnics and any other sympathisers to take subversive action in the country on signal from their controllers; export of corruption to the country with political strings attached; encouragement or indeed systematic incitement of ethnic Russian organisations to make increasingly radical and politicised demands on national or regional authorities; intense espionage facilitated by the presence of large pools of bilingual talent; creation of 'provocations'; or artificial incidents that Moscow could use as evidence of damage to 'legitimate Russian interests' or mistreatment of Russian co-ethnics; infiltration of crack Russian forces ostensibly to protect the threatened Russians but, in fact, to lead and mobilise local collaborators; unleashing propaganda campaigns against the victim country, complete with grains of truth and half-truth and larger dollops of outright lies, all to suggest that 
the victims were in reality the 'fascist aggressors'; and, deploying large and intimidatory Russian forces near the border, aggressive overflights of contiguous space, and nuclear sabre-rattling.

These tactics might be more difficult to deploy in the Baltic states than over the long and porous Russian/Ukrainian border, and more difficult to use against countries with stronger allies, better organised defence and intelligence agencies, and a clearer understanding of the lessons of 'hybrid warfare'. As against that, the Baltic countries have virtually no strategic depth. And, while they have powerful allies, large sections of the publics in those allies, including in Germany, have little stomach for coming to the aid of the Baltic states. As Paul Roderick Gregory asked, setting out an all-too-plausible scenario: if Russia does make a carefully crafted move against a Baltic state, which is less than a conventional military assault, and NATO does not rise adequately to the occasion, what will remain of NATO's credibility? ${ }^{12}$

Russia's largely successful aggression against Ukraine has had other bad effects on the security environment in Eurasia. In Ukraine, Russia has undermined, with Western connivance, a number of international agreements, perhaps most relevantly the Budapest Memorandum of 1994. The example effect for would-be nuclear countries of the flouting of the Budapest Memorandum may be difficult to assess, but can hardly be positive.

The sustained aggression encountering only a modest Western response has made Russia, whose economy is less than one-fifteenth the size of the Western economies, look the strategic equal of any or all of them anywhere near its home turf. Several Western European countries have appeared to place business-as-usual with Russia ahead of the security of fellow EU or NATO members and not just victim countries beyond the European Union's borders. Despite the political skill and patient determination of the German chancellor, Angela Merkel, many in the elites of the European Union's leading country continue to suffer from an anachronistic devotion to Russophilia, heedless of Russia's actions.

12 See Paul Roderick Gregory, 'Ukraine is more of an existential threat than ISIS, because it could destroy NATO', Forbes, 23 Sep. 2014, www.forbes.com/sites/paulroderickgregory/2014/09/23/ ukraine-is-more-of-an-existential-threat-than-isis-because-it-could-destroy-NATO/. 
Russia's successful trashing of 'a Europe whole and free' has also led new democracies in post-communist Eastern Europe to reconsider their commitment to the Western strategic community and its values. Hungary (a right-wing autocracy with crypto-fascist tendencies) and Slovakia (a centre-left populist government) have both wobbled on Ukraine, and there are strong pro-Russian constituencies in many other new member states. Czech President Miloš Zeman, for example, supports Russia's invasion of Ukraine, has told Kazakh interlocutors that support for Russia's stance on Ukraine is building in Europe (not necessarily what his hosts would have wanted to hear) and has called on his Western allies to curtail sanctions and recognise Crimea's annexation. ${ }^{13}$ The Washington Post has described Zeman as a 'virtual mouthpiece' for Putin. Serbia, a prospective member of the European Union, supports Russia on Ukraine, opposes sanctions and, in general, seems to calculate that it can have excellent relations with Russia while continuing on a path towards EU membership. Serbian President Tomislav Nikolić seems to see Serbia's relationship with Russia almost as a love affair. ${ }^{14}$

The events in Ukraine have demonstrated the weakness and divisions within the EU and Western alliance. The sanctions have been difficult for Brussels to coordinate, and have been contentious at every point. Without the wake-up call of MH17, it's unlikely that the European Union would have mobilised even as much consensus as it has done. Despite Russia's renewed incursions into Ukraine in November, the European Union could only manage to come up with a few Ukrainian 'separatists' to add to its sanctions list. Moscow is now intent on finding sympathetic or self-interested EU members ready to veto further extension of the sanctions packages as they reach their expiry dates in mid-2015. ${ }^{15}$

Even the MH17 seems to evoke embarrassment rather than plain speaking. No one close to the events in the West is in any doubt about what happened, and yet the tone is often hyper-cautious, 'balanced'

13 See Piers Lawson et al., 'Buckwheat panic grips Russia, Czech leader urges "Finlandization" of Ukraine', Transitions Online, 27 Nov. 2014, www.tol.org/client/article/24582-buckwheatpanic-grips-russia-czech-leader-urges-finlandization-of-ukraine.html.

14 See Tim Judah, 'To Russia with love', The Economist, 18 Sep. 2012, www.economist.com/ blogs/easternapproaches/2012/09/russia-and-serbia.

15 See Andrew Rettman, 'Russia targets Cyprus, Hungary, and Italy for sanctions veto', EUobserver, 11 Dec. 2014, euobserver.com/foreign/126879. 
and euphemistic. The Dutch are saying that any report elucidating the causes is still far off. In the meantime, the Kremlin's various implausible counter-narratives are still treated with more respect than they deserve, even after the recent exposure of Russian TV's fake footage purporting to demonstrate that a Ukrainian plane was responsible.

Putin's 2014 has been a little less miraculous than his serial triumphs in 2013. He has had some triumphs, but also some serious reverses, including some - like his growing embrace of China and his disciplining of Ukraine - that he no doubt sees as being at the very least qualified successes. Western responses remain weak, but if the sanctions can be maintained at least until the point where, as Timothy Snyder remarked, they 'start a conversation' in Russia, that could yet lead to some restoration of sanity in Moscow. 


\section{0 \\ Peace in our time}

The 'Minsk II' agreement, signed in the Belarusian capital, Minsk, on 12 February 2015 was welcomed in Western media as a promising step towards a more stable peace in eastern Ukraine. But the optimism seems misplaced: the fine print of the ceasefire deal has some disturbing elements, and there has been at best patchy observance of the ceasefire by Russia's proxy forces. The agreement was signed not only by the representatives of Russia, Ukraine and the Organization for Security and Co-operation in Europe, but also by the leaders of the Donetsk and Luhansk 'people's republics'. Thus Minsk II does much to legitimate the credentials of the proxy leaderships installed and propped up by Moscow. Strangely, too, the ceasefire was only scheduled to take effect three days after the agreement was signed, which gave the proxy forces time to further their assault on the Debaltseve salient, with its strategic railway hub connecting Donetsk and Luhansk cities. That assault was continued beyond the ceasefire till Kyiv was compelled to order its forces to withdraw from Debaltseve with severe losses of life and materiel.

Having achieved that key objective, the proxies did indeed become more compliant and some diminution of the fighting ensued. But, on 6 March, the Ukrainian envoy told the United Nations that Ukraine had registered 750 attacks $^{2}$ by the 'separatists' since 12 February, killing 64 Ukrainian soldiers and wounding 341 people. The West

1 First published in Inside Story, 23 Mar. 2015, insidestory.org.au/peace-in-our-time.

2 See Gorshenin Weekly, 9 Mar. 2015, p. 6, gorshenin.eu/programs/weekly?offset=50. 
has now largely accepted the Debaltseve fait accompli despite the serious and blatant violation of Minsk II that was involved. Nor does it seem over-concerned by other violations - near the large and strategic southern city of Mariupol, for example - or the continuing terrorist bombings in Kharkov and Odessa. And, while Minsk II was supposedly intended to confirm and reinforce the ceasefire provisions of the armistice agreements of 5 and 19 September last year (Minsk I), the German and French leaders accepted the territorial gains the Russian side had made by serial violations of that ceasefire in the intervening months, and presumably then persuaded the Ukrainian President, Petro Poroshenko, that this was the best deal they could get for him.

The Minsk II agreement uses lots of soothing words like Ukrainian sovereignty and 'in accordance with Ukrainian law'. But, tucked away in the text and an accompanying declaration are some significant concessions to both the proxies and their Russian sponsors. To mention a few:

- A blanket amnesty has been extended to all the pro-Russian forces and, by implication, to the often thuggish local regimes they've set up in Donetsk and Luhansk. The amnesty seems on the face of it to extend even to those who shot down MH17.

- Ukraine is required to reach agreement with the 'representatives' of Russia's proxies in eastern Ukraine (legitimating them as negotiating partners for Kyiv's elected government) on constitutional changes that would decentralise government. This is thus a condition of Kyiv's regaining access to that part of its eastern border that is now controlled, in tandem, by the proxy forces and the Russian army.

- The proxies are given the freedom to form cross-border cooperative arrangements with Russian authorities.

- The proxy 'authorities' will be involved in all policing, judicial and other legal appointments within their 'people's republics', an apparent legitimation of their clear intention to consolidate the abusive police state regimes they already have in place.

- Kyiv is required to undertake 'full resumption of socioeconomic ties, including social transfers such as pension payments' and 'timely payments of all utility bills ... within the legal framework of Ukraine'. The point at issue here is that Russia's actions have resulted in huge damage, for which Ukraine is now expected to 
pay, while Moscow pockets the geopolitical advantages. Kyiv had suspended a range of transfer payments, basically because it was broke. But it also took the not unreasonable position that as Russia had at that point already introduced 16 'humanitarian convoys', of whose contents no one but Moscow and its proxies have any knowledge, it should accept responsibility for supporting the living expenses of the local residents whose lives and livelihoods it had severely disrupted.

Chancellor Angela Merkel and French President François Hollande who initiated the negotiations with Russian President Vladimir Putin, apparently on Ukraine's behalf, as 'the last chance to end the fighting in Ukraine' - also persuaded Poroshenko to sign an accompanying political declaration that seems to call on Ukraine to make additional concessions to Russia. This document aligns Poroshenko with the Merkelist doctrine that 'there is no alternative to an exclusively peaceful settlement' to the Ukraine situation, despite the fact that, for a year, Moscow has been imposing military solutions on a daily basis. The declaration also states that 'the Normandy format' of Germany, France, Russia and Ukraine should be responsible for oversight of this latest 'ceasefire', thus providing for the continued non-participation of the United States, Britain and Poland (neighbour to both Russia and Ukraine and prominent earlier in EU deliberations on Ukraine).

\section{Trade war morphs to hybrid war}

Perhaps most worryingly from Kyiv's point of view, the accompanying declaration says that the group endorses trilateral EU-Ukraine-Russia talks to achieve 'practical solutions to concerns raised by Russia' in relation to the free-trade agreement that Ukraine signed with the European Union in June 2014. The Maidan protests were sparked by Yanukovych's retreat, after years of laborious negotiations, from signing essentially the same agreement. The post-Maidan government was hoping that its signature on the package (comprising an Association Agreement (AA) and a Deep and Comprehensive FreeTrade Agreement (DCFTA)) would at last launch it on a process of EUsupported reform and integration with Europe. 
In response to further Russian pressure and threats, the European Union had already postponed implementation of the agreement for 12 months. Now, it seems, Russia can use that period to seek to veto any parts of the DCFTA that it doesn't like - and Moscow has made clear it would like to rewrite large slabs. Independent observers have analysed the Russian objections and find them largely specious. ${ }^{3}$ What Russia really doesn't like about the AA, and the free-trade deal embedded in it, is that Ukraine signed it at all, rather than joining Putin's Eurasian Customs Union.

Why would Kyiv have agreed to such an unbalanced pair of documents? The answer, basically, is because it had no choice. It could see that it would not receive much military support from its Western friends, despite again having been defeated on the battlefield by a further injection of high-tech weaponry and skilled manpower from Moscow. And its economy, blighted by decades of mismanagement, especially in the Yanukovych years, was and continues to be on the brink of collapse. It is also acutely conscious that fighting 'separatists' entrenched in residential areas in the Donbas can only deepen the alienation of Ukrainian citizens literally caught in the crossfire. But for the Ukrainians not to return fire, even with their inaccurate and obsolescent weapons, would concede the terrain to Russia. This has been one of Kyiv's worst dilemmas from the outset.

Even without Russian trade wars and military aggression, the new government had much to do to repair and reform the economy. But the disruption and destruction in eastern Ukraine - a rust belt area but, also, the location of much of Ukraine's industrial and export capacity - have all but tipped the economy over the edge. Ukraine's economy has normally relied heavily on its foreign trade for much of its GDP, and that trade collapsed abruptly in the second half of the 2014 - by 32 per cent in December alone. This was almost entirely due to the war in the Donbas and Russia's punitive trade restrictions. ${ }^{4}$ The International Monetary Fund (IMF) has assessed that Ukraine's GDP declined by 6.9 per cent in 2014 , and it expected a further decline

3 See Nicu Popescu, 'Eurasian Union: The real, the imaginary and the likely', European Union Institute for Security Studies Chaillot Papers, No. 132, 9 Sep. 2014, www.iss.europa.eu/ publications/detail/article/eurasian-union-the-real-the-imaginary-and-the-likely/.

4 See Tadeusz Iwański, 'The collapse of Ukraine's foreign trade', Centre for Eastern Studies/ Ośrodek studiów wschodnich, 18 Mar. 2015, www.osw.waw.pl/en/publikacje/analyses/2015-03-18/ collapse-ukraines-foreign-trade. 
of 5.5 per cent in 2015. But the Kyiv Government's own prognosis for 2015 had worsened from -5.5 per cent (as assessed at the end of 2014) to -11.9 per cent by March of this year, with inflation expected to be somewhere between 27 per cent and 43 per cent. And those trends could worsen further.

Russia's economy has also been sliding badly, in response to the fall in the oil price, the consequential slump in the rouble, and Western sanctions. ${ }^{5}$ Estimates of Russia's likely GDP decline in 2015 usually range between -3 and -5 per cent. Its sovereign wealth funds, the Reserve Fund and National Wealth Fund, are being raided to fill budgetary holes. But, despite Putin's irresponsible stewardship, Russia's international currency reserves are - though under pressure still among the highest in the world, at US $\$ 356$ billion, whereas, before Ukraine received the first tranche of its recent US\$17.5 billion IMF bailout, its reserves had slumped to some US\$6 billion, not enough to cover two months of imports. And in February Ukraine's economic freefall had become markedly more precipitate and damaging than Russia's.

Whatever financial respite Kyiv had been hoping for, Minsk II didn't provide it. Russia's stock market went up at the news of the agreement; Ukraine's fell further. Despite the announcement of the IMF package having been timed to coincide with (and to be seemingly conditional on Kyiv's acceptance of) Minsk II, the Ukrainian hryvnia collapsed spectacularly, causing panic in the population. Desperate measures by the National Bank of Ukraine, a flurry of economic reform legislation and the arrival of the first IMF tranche recouped the position somewhat in early March, but the hryvnia has only been shakily stabilised at 23 to the US dollar, roughly one third of its value a year earlier. The extreme fragility of the Ukrainian economy was exposed and, with it, its vulnerability to further Russian geopolitical blackmail.

Kyiv's prospects for financial stabilisation, foreign investment and continued disbursement of IMF funds depend on whether Russia chooses to refrain from further military or economic attacks on

5 See Ian Bond, Christian Odendahl \& Jennifer Rankin, 'The politics and economics of sanctions against Russia', Centre for European Reform, Mar. 2015, www.cer.org.uk/sites/default/ files/publications/attachments/pdf/2015/frozen_sanctions-10787.pdf. 
Ukraine. A gas war, a wider ranging trade boycott, or major further military offensives against eastern Ukraine would possibly be enough to push the national economy over the cliff, despite what has been achieved. Even with the IMF bailout secured and without any further Russian coercion, there would be serious doubts as to whether Kyiv will be able to secure enough financial support to stave off default and disaster. Western support outside the IMF framework has been modest, and the Ukrainian Government has been required by the IMF to try plugging an imminent US $\$ 15$ billion funding gap by restructuring its debt to private investors via agreed 'haircuts' and extensions. That includes US\$3 billion owed to Russia and due for repayment in December 2015. Under the terms of that agreement, Russia has the right to call the loan in early and has repeatedly threatened to do so. It may choose its moment to good effect.

\section{Back to Yalta}

Moscow clearly has further plans for strengthening its position in Ukraine. With Minsk II's legitimisation of its pseudo-statelets of the Donetsk and Luhansk People's Republics, it has already achieved its minimal objective of establishing a frozen conflict in East Ukraine. Its ultimate objective is a compliant government in Kyiv, and probably further territorial acquisitions, in which the Donetsk and Luhansk statelets could play a useful role. But just for the moment, itself troubled by serious economic decline, the Kremlin may be content to leave the statelets in eastern Ukraine as they are. This it can use to veto any European integration by Kyiv while it continues working to undermine the very fragile EU consensus on sanctions.

It was reported earlier this month that, despite the successful proxy advances in Debaltseve and Donetsk airport, the European Union would not impose any further sanctions at this point because they might upset the delicate Minsk II ceasefire. ${ }^{6}$ Though the EU Summit on 18 March was a little more robust on Russia than expected, that

6 See 'No new EU sanctions against Russia as ceasefire holds', EurActiv, 13 Mar. 2015, www.euractiv.com/sections/global-europe/no-new-eu-sanctions-against-russia-ceasefireholds-312895. 
prediction was confirmed. For his part, to strengthen the chances of Minsk II succeeding, Obama has cancelled an innocuous US training program for the Ukrainian military.

Moscow has learnt from such reactions that ceasefires can be abused without further penalties. Different views are evident within the broader Russian leadership elite about how far and how fast Russia can and should go in Ukraine, and some of those views are radical. So any sudden opening of another front in Ukraine - for example an all-out attack on Mariupol - should not surprise us. Putin thinks that, with current Western leaderships in place, he need not fear pushback that would cost Russian lives. He does worry that Russian military losses would affect his popularity and, partly for that reason, has gone to absurd lengths to pretend that Russia is not involved militarily in East Ukraine. But he probably calculates that if the divided Obama administration again seemed to be tilting towards arming Ukraine, an emphatic warning of marked further escalation, followed by the offer of talks on a Minsk III, would be enough to see off the threat.

Putin is certainly seeking to restore a sphere of influence over most of the territory of the former Soviet Union. But he seems to want to go beyond that, if he can, to restore a sphere of influence within Europe as well, including in NATO and EU member states. What he probably wants most after some more Minsk Is and IIs would be the creation of a new European security architecture modelled on the Yalta settlement of February 1945, where Roosevelt and Churchill conceded to Stalin control over much of Central and Eastern Europe. Russian media and some senior officials have been warmly praising Yalta recently.

By February 1945, Stalin had a dominant military grip on most of what he was claiming in Central-Eastern Europe, and there was not very much that the Anglo allies, despite their formidable military, could do to wrest it from him or prevent him from communising it. Despite his huge military buildup in progress this decade, Putin is unlikely ever to cast the shadow that Stalin's conventional forces once did over the Eurasian continent. But the Western alliance he is facing is also relatively much less formidable. Though boasting a larger number of members than the Western alliance of the Cold War era, the Europeans are disunited, lack adequate security leadership, and are disinclined to pay much for their own defence. In many cases, they would be 
very happy to return to business as usual with Moscow, as long as it restricts itself to bullying and grabbing land from other countries and not from them.

Chancellor Merkel, Europe's most energetic and capable leader, works the EU system very well, and has achievements also in the security domain. She has succeeded in keeping sanctions in place, despite the objections of the more pro-Russian EU members and the Russophile sentiments prevalent among influential elites within her own country, including two of her predecessor chancellors, Gerhard Schroeder and latterly, after a valedictory visit to the Kremlin at the age of 94, Helmut Schmidt. ${ }^{7}$ Even though Germans generally are starting to lose their enthusiasm for the Putin regime, the foreign country they often seem most worried about is the United States. Der Spiegel recently ran a major article about the extreme anxiety and hostility evoked in the German foreign and defence policy elite by NATO's European Commander, General Philip Breedlove, for his supposedly provocative bellicosity towards Russia. ${ }^{8}$ The article seems to suggest that official Germany sees Breedlove as a bigger threat to peace than Putin.

While Merkel has spent many difficult hours trying to persuade Putin to modify his behaviour, she's had little success so far. She tirelessly repeats her favourite verity about Ukraine - that there can be no military solutions to this crisis - while her principal interlocutor, Putin, continues to freely deploy them, including, right under her nose, last month before the ink on Minsk II was dry.

Merkel's second-in-command in the Minsk negotiations, President Hollande, appeared not to be playing a major role. And perhaps that was just as well. Hollande has occasionally been forceful on African and Middle Eastern issues and commands one of the two strongest armed forces in Europe. But on Ukraine, to put it charitably, he has been wobbly. He was, for example, the first Western leader to visit Putin in the Kremlin after the annexation of Crimea. France often seems hopeful that sanctions can be rolled back, and that it can at

7 See 'Meeting with Helmut Schmidt', President of Russia, 11 December 2013, en.kremlin.ru/ events/president/news/19822; see also 'Russia's actions in Crimea "completely understandable" - German ex-chancellor', RT, 28 March 2014.

8 See Matthias Gebauer et al., 'Breedlove's bellicosity: Berlin alarmed by aggressive NATO stance on Ukraine', Spiegel Online, 6 Mar. 2015, www.spiegel.de/international/world/germanyconcerned-about-aggressive-NATO-stance-on-ukraine-a-1022193.html. 
last sell its Mistral-class amphibious attack vessels to the Russians, despite the fears of Russia's neighbours bordering the Baltic and Black Seas. On 13 February, immediately after signing Minsk II, Hollande told journalists that while it was not yet time to do so, he hoped that France would be able to deliver the Mistrals to Russia. ${ }^{9}$

Perhaps as significant as who was involved on the Western side at Minsk are the absentees ensured by the Normandy format, a constraint that Putin clearly relishes. ${ }^{10}$ With Obama having apparently outsourced the management of Western security interests in Ukraine to Merkel and the European Union, the United States has been consistently missing from Ukrainian negotiations over the last year. ${ }^{11}$

A second noteworthy absentee has been Britain, the other major military power in Europe. The British Government under David Cameron began by seeking its own reset with Russia, and has sharply lowered Britain's defence budget. But, latterly, it has become more forceful in response to Russia's aggressive policies, instigating a public enquiry into the Alexander Litvinenko case, identifying Russia as its key security threat, and talking of providing defensive weapons and training to Ukraine. Britain might have been able to strengthen the EU response to Russia's growing belligerence but, with domestic euroscepticism growing in strength and Cameron not doing a great deal to contain it, along with the distraction of the Scottish independence movement, London's influence in EU counsels has greatly diminished.

Likewise, Poland and former prime minister Donald Tusk have played a less prominent role in the EU response to Russia's activities in Ukraine than used to be the case, despite Poland's close knowledge of the Russian target, its size and common borders with Russia and Ukraine, and Tusk's having recently ascended to the role of president of the European Council.

9 See Ian Bond, 'Russia's war in Ukraine: Is Minsk the end, or just the start?', Centre for European Reform, 13 Feb. 2015, www.cer.org.uk/insights/russias-war-ukraine-minsk-end-orjust-start. President Hollande was finally, in July 2015, forced to accept that he would have to pay compensation to Russia for non-delivery of the Mistrals and seek instead to find another buyer for them.

10 Later in 2015, Putin found it might be better to draw Obama and the US State Department into the task of pushing Kyiv into carrying out the unfavourable Minsk provisions that the Normandy format imposed on Ukraine.

11 See Anne Applebaum, 'The risks of putting Germany front and center in Europe's crises', Washington Post, 20 Feb. 2015, www.washingtonpost.com/opinions/germanys-centralrole/2015/02/20/d1119cd4-b8f8-11e4-aa05-1ce812b3fdd2_story.html. 
Since the fading of his reset policy, Obama has been publicly contemptuous of Putin on occasion. But he seems to wish to cling to whatever remains of the policy to pursue supposedly shared multilateral objectives, like curbing Iran, North Korea and Islamic State as well as chasing after the fata morgana of nuclear disarmament. Whether Russia has a strong and disinterested commitment to all or any of these objectives, especially nuclear disarmament, may be questionable but, for Obama, they appear to have precedence over Ukraine, the Budapest Memorandum or the security of the European side of the Transatlantic alliance. To its credit, the Obama administration has taken a strong and leading role on sanctions, seeking to keep pressure on the European Union to match it step for step. But it should be remembered that, for the United States, a single country with a single decision-making process (however complex) and limited trade with Russia, sanctions are a much easier option than for the Europeans.

Though he recently approved a US $\$ 75$ million package of non-lethal aid for Ukraine, Obama has not shown much appetite for supporting Kyiv's armed forces, and has repeatedly ruled out providing defensive arms. Recently, many senior figures in the Obama administration have publicly mooted supplying lethal aid to Ukraine, and there is strong and growing support for such a step in Congress. Nonetheless, Obama remains emphatically opposed. One reason for Obama's hesitation is a perceived need to keep in step with the EU leadership's doveish policy in this respect. Merkel's sense of urgency about again engaging Putin in the Minsk II negotiations was widely understood to stem from her concern that Washington might provide defensive weapons to Ukraine, with what Berlin is convinced would be disastrous consequences.

Even without any such 'provocation', Putin escalated again. After more than a year of Russia's serial aggressions, it remains unclear whether the Obama administration will ever do anything to equip Ukraine to resist Moscow's superior weaponry, but it seems unlikely. As mentioned, Washington recently cancelled a modest training program for the Ukrainian military in order not to provoke Putin or give Moscow a chance for propaganda about American interference. 
The training, far from the front line, involved such provocative activities as battlefield first aid, combating enemy radio-jamming and surviving heavy artillery fire from the 'separatists'. ${ }^{12}$

The question of whether defensive weapons should be provided to Ukraine has been discussed heatedly and at length in Western countries since early in the Russian intervention. ${ }^{13}$ It is not an easy issue, and one of the key arguments adduced against doing so is that it would lead supposedly to immediate Russian escalation and more death and destruction in Ukraine. But, at present, one side is being handsomely supported - with repeatedly decisive and escalatory effects - by its generous Russian backers. This has taken the form of high-tech weaponry, substantial numbers of 'volunteers' and highly skilled special forces, intelligence, massive propaganda and diplomatic threats and persuasion. Meanwhile, the other side is receiving some economic and diplomatic support, though not enough to safeguard it or its economy, but only modest material support for its armed forces - blankets rather than anti-tank weapons.

As the strategic analyst Phillip Karber of Georgetown University has commented in a study of Russia's so-called hybrid warfare in Ukraine:

While Russia has introduced thousands of weapons into the conflict, European and American political hesitation in helping Ukraine acquire replacements for its losses (and the political message it sends to others who would like to help) serves as a virtual military embargo on Ukraine. Ironically the most successful Western sanction has been in preventing a friendly country from defending itself. ${ }^{14}$

Despite the undertakings given in the Budapest Memorandum of 1994 to ensure that Ukraine would be free from military or economic coercion in exchange for relinquishing its nuclear weapons, the signatories have failed to deliver. Signatory Russia has attacked Ukraine for attempting

12 See Philip Shishkin, 'US delays Ukraine military training, general says', Wall Street Journal, 17 Mar. 2015, www.wsj.com/articles/u-s-delaying-ukraine-military-training-generalsays-1426631033.

13 See Kirk Bennett, 'The realist case for arming Ukraine', The American Interest, 20 Feb. 2015, www.the-american-interest.com/2015/02/20/the-realist-case-for-arming-ukraine/.

14 See Phillip Karber, 'Russia's hybrid war campaign', Center for Strategic International Studies Russia and Eurasia Program, 10 Mar. 2015, willzuzak.ca/cl/videolinks/karber20150310CSIS.html. 
to reach a non-military bilateral agreement with the European Union, while the leaders of the Western world - the United States, Britain and France (also signatories) - have failed to protect it.

So, while Putin is less powerful than Stalin was at Yalta, he must nonetheless feel increasingly confident that a little determination and guile on his part will be enough to brush aside Western opposition to his plans for perestroika of the post-1990 European security architecture. It is apparent that he has a certain amused contempt for Europe, its complicated decision-making structures, its unreadiness to pay for its own defence, and its 'decadent' social fashions. He sees it as increasingly divided and lacking authoritative leadership, and is very conscious that several EU members are either sympathetic to his strategic objectives or at least afraid to contest them for fear of reprisals.

While Russia's own economy was on a steady downward slide well before the imposition of sanctions, Putin also takes great heart from the sustained malaise in many EU economies, and the social distress and political volatility that malaise has engendered. Sanctions and the sharp drop in oil prices and the rouble are a constraint on his freedom of manoeuvre for the moment, but he feels confident that the increasingly compliant Russian population will endure the necessary belt-tightening until such time as Ukraine is put in its proper place. As soon as the economy starts to recover, if not before, he will probably feel ready to pursue further strategic gains.

If Ukraine, the largest country in continental Europe, is finally brought undone economically, politically or militarily by the battering it has suffered, that will also sound a potent message to any neighbouring country unwise enough to attempt to resist Russia's designs for it. Already Ukraine's economy is undermined, and not surprisingly, the Kyiv Government's high popularity is ebbing rapidly.

\section{Appeasement springs eternal}

Appeasement is a rhetorical rather than an analytical term. One man's appeasement is another's judicious pragmatism. Western countries are often reproached by critics for their alleged hypocrisy in criticising Russia where they would not criticise, say, Saudi Arabia for similar 
offences. There is often some abstract justice in the criticism, although it seems to imply that Western countries have an absolute obligation to lead with their chins in policing the world without any regard to their own interests. Decisions whether to criticise, impose sanctions or intervene militarily are always the product of some combination of geopolitical interests, moral outrage, fear of retaliation, alliance or treaty obligations, domestic political pressures and other factors. But, usually, when the term is invoked in Western countries, it is because the invoker claims to see some point of comparison with the classic appeasement of Hitler in the 1930s.

Russian patriots and Western Russlandversteher become particularly enraged when any parallel between contemporary Russia and Nazi Germany is suggested. Nazi collaborators and alleged collaborators are denounced by Moscow as 'fascists', but so too are almost any other classes of humanity that the Kremlin wishes to discredit. To turn that longstanding weapon of hybrid warfare on its head against its inventors strikes Putinists and their sympathisers as particularly perfidious.

But the parallels are striking nonetheless: domestic xenophobia and revanchist irredentism; a charismatic autocrat whose constantly trumpeted superhuman qualities make him immensely popular among the masses; militarisation of society and the budget; relentless, mendacious propaganda; elephantiasis of the security organs; mass invigilation of the population and widespread repression of human rights; extensive regulation and uniformity of views in nearly all media outlets; a mobilised population that hates as it is told; a foreign policy that asserts the right to protect people of the same ethnicity, or even the same language, by interfering with force in their countries of residence; a seemingly expanding appetite for further territorial conquest even after irredentist claims are satisfied ... the list goes on.

Even Putin's latest version of the Russian invasion of Crimea to protect Russians supposedly in danger in Crimea and save the life of Yanukovych, all of which necessitated urgent military intervention and nuclear threats - starts to bear a resemblance to the 1939 Gleiwitz Incident, stage-managed by the high-ranking Nazi official Reinhard Heydrich to justify Germany's attack on Poland. 
To draw attention to such features is not to imply that Putin's Russia will necessarily commit crimes of even remotely comparable magnitude to those of Nazi Germany. In addition to using the parallels to critique Putinism, such critics usually have one overriding objective in mind, namely to suggest that if Putin is not stopped, he will attempt to subvert or even attack all neighbours who were ever part of Moscow's empire, and quite possibly other countries as well. Attempts to conciliate him at other people's expense are not only naïve or unworthy and in breach of the appeasers' international obligations; they are also self-destructive, in that an appeased autocrat will simply pocket whatever he is given, and pursue further conquests.

A quote from Churchill is usually called for at this point. In a joint appeal to Europe to not betray the ideals on which the European Union is based, a former Czech ambassador to Moscow and a senior Slovak Green politician quoted Churchill: 'You were given a choice between dishonour and war. You have chosen dishonour and will get war. ${ }^{15}$ Cameron, Hollande, Merkel and Obama, they said, have chosen dishonour: 'But now it is Ukraine that is getting the war, while Europe stands aside, even as its security is undermined and its values mocked.'

The proportions here have to be measured carefully, and an EU advocate would be quick to argue, among other things, that Ukraine is not a member of the European Union or NATO and that therefore no duty is owed it. But Putin's behaviour to date is certainly not inconsistent with the above line of analysis, and much of the public patriotic rhetoric in Russia goes further. In the face of Russia's trashing of the post-1990 security architecture, its repeated brandishing of its nuclear weapons and its huge preponderance in tactical nuclear weapons over the Western alliance in the Eurasian theatre, Western Europe should at least be worrying about the risk of further whetting Putin's appetite. ${ }^{16}$

15 See Petr Kolář \& Juraj Mesík, “From Munich to Kyiv', Project Syndicate, 13 Mar. 2015, www.project-syndicate.org/commentary/west-dishonor-ukraine-by-petr-kolar-and-jurajmesik-2015-03.

16 See Rebeccah Heinrichs, 'NATO's nuclear nightmare over Ukraine', Real Clear Defense, 27 Feb. 2015, www.realcleardefense.com/articles/2015/02/27/NATOs_nuclear_nightmare_over_ ukraine_107670.html. See Matthew Kroenig, 'Statement', Hearing on 'Regional nuclear dynamics', United States Senate Armed Services Committee, 25 Feb. 2015, www.armed-services.senate.gov/ imo/media/doc/Kroenig_02-25-15.pdf. 
If it is unprepared to supply defensive weapons to countries that are under Russian attack, it should be ready to deploy sanctions with vigour and determination, and escalate in response to any escalation. So far it is not obviously doing so. The sanctions have been deployed slowly and reluctantly. Without the downing of Flight MH17, EU sanctions that really bite may not have materialised. Having materialised, the European Union collectively, and many EU member states individually, are continually undermining them by broaching the issue of their early release, or even denouncing them as own goals. Any prospect of their early withdrawal should be removed from the table for the time being.

Putin will always be encouraged by the sight of EU seniors again deciding not to strengthen sanctions, as recently, or discussing instensely whether or not the most effective sanctions in place should be extended. As to the latter, they finally declared that they would be extended till the end of 2015 and, moreover, that their lifting would be made conditional on fulfilment by Russia of its obligations under Minsk II. Passing the necessary legal instruments for doing so, we are assured, will occur nearer the time. The Russian propaganda outlet, RT (formerly Russia Today), is claiming that extension of those sanctions that are due to expire in July to the end of the year is not yet a done deal. And a German Deutsche Welle commentator has suggested that a single pro-Russian member country could block the extension by a determined veto. While theoretically possible, this is unlikely, but there are a number of dissenting member states who are being eagerly courted by Moscow, so some doubt must remain.

Naturally, the Ukrainians find all these deliberations unsettling. Another to find them so is evidently Donald Tusk. After a visit to Washington, he declared to Western media, while the issue was still evidently moot, that Europe must maintain broad economic sanctions against Russia until Ukrainian control of its border with Russia is restored or risk a crisis with the White House. ${ }^{17}$ 'Putin's policy', he said, 'is much simpler than our sophisticated discussions. The only

17 See Ian Traynor, 'Donald Tusk: Putin's policy is to have enemies and to be in conflict', Guardian, 16 Mar. 2015, www.theguardian.com/world/2015/mar/15/donald-tusk-putins-policyenemies-conflict-european-council-sanctions-russia. 
effective answer to Putin's clear and simple policy is pressure.' Putin's policy, he said, is 'simply to have enemies, to be stronger than them, to destroy them and to be in conflict'.

According to Tusk, Obama was not expecting the Europeans to step up sanctions (that issue was evidently already decided), just to maintain those already in place. 'The comparison with appeasement applies ...', he said, 'about the approach of some politicians who say Ukraine is too far from us, not our business ... You know the melody.'

Whatever these comments may lack in subtlety in relation to the various categories of Russian sympathisers or appeasers in the European Union, whose views Tusk has the remit of endeavouring to bring into alignment with a broad EU consensus, they certainly lack nothing in clarity. In the event, at the EU Summit last week, Tusk and his close colleague Merkel seem to have carried the day. But more such deliberations will surely arise in response to Russia's studiedly ambiguous hybrid warfare against its largest Western neighbour. There will remain in the approaches of both the Obama administration and the European Union much that will continue to unsettle the Eastern Europeans. 


\section{1 \\ Ukraine conflict exposes Western weakness on Russia}

The European Union has colossal achievements to its credit in stabilising and integrating post-communist countries after 1990 by a mixture of carrots, civilisational attraction, and economic incentives and penalties. But the Yugoslav crises of the 1990s and now Russia's war on Ukraine have highlighted the limitations of the European Union's security capabilities. After centuries of conflict originating in Europe, often radiating effects far beyond, the European Union has sought to abolish conflict. Confronted by a rogue state that thrives on conflict, its policy toolkit looks painfully depleted.

The economic malaise of the years since the global financial crisis of 2008-09 has significantly vitiated the European Union's capacity to attract and influence its members, and to project itself to neighbours and would-be members as a compelling role model. Moreover, although many countries to its east would still prefer to integrate with the European Union rather than with Russia, the European Union's enthusiasm for further enlargement has also greatly declined.

Russia now explicitly and aggressively objects to enlargement of any kind, not just of NATO but also of the European Union, and in any form. It claims to be afraid of being encircled by hostile states,

1 First published in The Interpreter, 10 Apr. 2015, www.lowyinterpreter.org/post/2015/04/10/ The-Wests-abject-weakness-on-Russia.aspx $?$ COLLCC $=884734376 \&$. 
and to have been humiliated by the West's supposedly triumphalist expansion into its backyard (its 'sphere of privileged interests'). This is largely a propaganda myth; the Western expansion was reluctant and apologetic and caused, above all, by the desperation of former Soviet vassals for protection from any Russian recidivism. Russia's volatile opinion polls suggest, however, that after years of intense propaganda most of Vladimir Putin's subjects have come again to believe the hostile encirclement narrative, which closely follows a tradtional Soviet propaganda theme.

Some who spend a lot of time talking to Russian officials and propagandists start to repeat these claims of encirclement and humiliation, and present them as their own superior insight into the Russian mind. They would do better to reflect on them more critically. Why, for example, has Germany never felt 'threatened' or 'encircled' by its inclusion in multilateral organisations of countries on its borders, set up to 'keep it down', and which include as members several countries that had secured territory from Germany in recent conflicts?

In response to Russia's coercive approach to its neo-imperial restoration project, the European Union has tried above all to use diplomacy and persuasion. When it felt forced by Russia's increasingly brazen actions to turn to sanctions, it found consensus difficult to achieve. Were it not for the downing of Flight MH17, serious EU sanctions might never have been enacted. And even those sanctions might not have made much difference to Russia were it not for the unrelated fall in the price of oil and its consequential effect on the stability of the ruble.

It is also apparent that, as each successive sanctions package was adopted, there were dissenting voices from EU member states and among senior politicians, who in some cases embrace publicly Russophile positions. Federica Mogherini, the successor to Catherine Ashton as the 'foreign minister', leans towards that camp. Going beyond sanctions to use force, even to the extent of supplying Kyiv with weapons to defend itself against the heavy weaponry supplied to the 'separatists' by Russia (along with special forces, 'volunteers', intelligence and huge diplomatic and propaganda support), is anathema to Brussels and Berlin. 
Putin can see the hesitation and the divisions in EU decision-making, and feels confident that by divide-and-rule tactics he will sink sanctions well before they seriously damage him.

Since the global financial crisis, de facto leadership of the European Union has settled decisively on Chancellor Angela Merkel, as leader of the biggest and healthiest EU economy. After long decades of erring on the side of militarism, Germany has now become a programmatically pacifist power. Most Europeans are glad of this, as are most Germans. But, how does that square with being in a leadership role dealing with a severe security challenge from an aggressive would-be superpower in the East?

President Obama, having 'pivoted' to Asia and struggling with Middle East problems from which he has undertaken to extract the United States, has been keen to outsource the lion's share of the Russian security problem to Brussels.

Europeans have learned to find laborious compromises to solve all their internal and most of their external problems. They have great experience in such processes, and are very good at them. But they rely on their partners to refrain from violence and practise honesty. The Putin regime, on the other hand, makes threats and uses force and lies (not spin or misrepresentation, but constant outright, barefaced lies).

Thus, for example, Moscow claimed emphatically, if implausibly, that it wasn't involved in the invasion and occupation of Crimea, merely in its annexation. Putin later acknowledged Russia's role, once the lies had served their purpose. But the Kremlin has continued to lie endlessly about its involvement in East Ukraine, lies that are essential to Russia's strategy for disabling the Ukrainian state and bedding down its own violently established occupation, directly or by proxy, of a significant part of the country. Amazingly, mainstream Western media continue to slavishly repeat those denials as though they represent a genuine point of view and not unscrupulous propaganda.

EU leaders still behave as though they assume Putin shares their interest in peaceful solutions. But, while he may sometimes welcome a short-term ceasefire, Putin has no interest in peace, per se. What he 
wants is victory and a wholesale restoration of the post-Yalta security system. He regards major loss of life and total dishonesty as legitimate tools of statecraft in the pursuit of these lofty patriotic goals.

Worst of all, many in the European Union seem to be checkmated by Russia's increasingly naked nuclear intimidation. These champions of compromise, who would like to solve the Russia problem by offering it inducements to be nice, work towards dismantling sanctions or, with their NATO hats on, to block or dilute measures of security 'reassurance' to exposed member states. This activity, increasingly conducted openly by visits to and from Moscow, gives Putin ample opportunity to drive wedges into the European Union.

Merkel has worked tirelessly and, so far, apparently successfully, to defend the EU sanctions regime from would-be diluters, including at the EU summit on 3 March. But it was also she who told Baltic leaders that they would not be getting permanent NATO boots on the ground. And it is she who endlessly repeats the incantation that 'there can be no military solution' to Ukraine's problems. The Kremlin, while maintaining the pose of a well-meaning mediator in someone else's conflict, begs to differ, repeatedly sending nuclear-capable aircraft into European civilian airspace with transponders turned off, to underline the message.

EU weakness is part of a broader Western weakness on Russia. The Obama administration enacted effective sanctions earlier than the European Union, and has worked hard to hold Brussels's feet to the fire to maintain and extend them. But that is easier for one decisionmaking structure than for a federation of 28. And Washington has been missing from much of the diplomatic action on Ukraine. Despite what looks to the naked eye like overwhelming advice from senior military figures and bipartisan support in Congress in favour of arming Ukraine, the administration continues, after well over a year, not to do so. Various arguments are heard, perhaps most often that arming Ukraine would only provoke a further escalation from Moscow and increase Ukraine's suffering.

If that is true, it would seem that the only remaining option is to sit down and discuss the terms under which Putin can continue to rearrange the post-1990 security order to his own liking. The rest 
of Ukraine, the largest country in continental Europe, is there for the further dismembering, as are Georgia and Moldova. Even the Baltic states, despite being both NATO and EU members, may not be immune.

In a more robust scenario, it would be made abundantly plain to Putin that any further moves against Ukraine would lead to lethal military supplies to Kyiv sufficient to nullify any advantage Russian-backed forces had gained, full disclosure of the Putin entourage's financial interests, with other measures threatened offstage but held in reserve. The European Union should also be sending a message to those dissenting members who would betray European values by overtly cheering for Putin, like Hungarian Prime Minister Viktor Orban and Czech President Miloš Zeman, that the gates of the main capitals of Europe will be closed to them till further notice. But we shouldn't be holding our breath. 



\section{2 \\ Bling and propaganda in an ethics-free zone ${ }^{1}$}

According to a story circulating around the turn of the millennium, the CEO of a big company with investments in post-Soviet Russia felt that his company was just not finding the right sort of Russian trainee execs. Their computer and language skills were excellent, their understanding of capitalist economics and international business was surprisingly good, and they had ambition and a nose for money. But they had no ethics, neither business ethics nor seemingly any other kind. Company seniors were sternly directed to greatly strengthen their emphasis on these values in their recruitment and training.

The anecdote illustrates something significant about the post-Soviet Russia Peter Pomerantsev moved to early in the Putin years, which is reflected in the sharply observed vignettes that make up his book. This was a society stripped of its moorings, suddenly characterised by a few winners and many more losers. The glamour, pizzazz and cornucopia of (mostly theoretical) choices would have been unthinkable in Soviet times, but alongside these was a lack of security or predictability.

$1 \quad$ First published as a book review of Peter Pomerantsev's Nothing is True and Everything is Possible: Adventures in Modern Russia (Faber \& Faber, 2015) in Inside Story, 15 Jun. 2015, insidestory.org.au/bling-and-propaganda-in-an-ethics-free-zone. 
The Wild West capitalism set in train by the abrupt transition from command economy to free market in the early 1990s had precipitated a torrent of inflation, sharp declines in production, nakedly corrupt mass privatisations, a widespread loss of personal savings, a crime wave seemingly linked to the new economic model, conspicuous consumption by the newly rich 'new Russians', and conspicuous poverty among pensioners and professors alike, who were reduced to selling their family possessions on the streets to get by. This was the chaos that Vladimir Putin has persuaded Russians was an unnecessary and unalloyed disaster visited on them by Boris Yeltsin and the reformers, who had senselessly dismantled the Soviet Union and everything its ordinary, loyal citizens held dear.

It's true that the shock therapy was not optimal in either conception or execution. But transforming a faltering command economy centred on a huge military/police apparatus into a functioning market economy was never going to be easy or quick. In fact, a major cause of the 1990s downturn was the sustained slump in the price of Russia's oil and gas exports (just as it had precipitated the economic decline in the second half of the Gorbachev-era 1980s). And the spectacular economic recovery that largely coincided with Putin's meteoric rise and first two presidential terms (for which most Russians still thank him) owed much to a boom in energy prices and those painful reforms of the 1990s.

Putin's main contribution to this serendipitous outcome was to enable a group of liberal economic advisers from his Leningrad entourage to make some judicious adjustments to Russian economic policy in his early years in power. He still has competent economic advisers in his service but, as the years have worn on, their capacity to influence policy has been greatly reduced. And, since 2011, the most influential of them, the liberal and principled former Deputy Prime Minister Aleksei Kudrin, has been rusticated from the power elite to the moderate opposition. ${ }^{2}$

The elite that had emerged in the 1990s embraced not only the freedom of speech and freedom to participate in politics but, also, and more particularly, the freedom to become grotesquely, obscenely

2 After holding out for a few years as the head of a liberal think tank founded by himself, Kudrin has in 2016 acceded to oblique requests from Putin to return to an official establishment think tank. He continues to express similar views, but it is not clear that his influence has increased greatly as a result. 
and publicly wealthy. In the 1990s, large black limousines would roar at terrifying speed down Moscow's broad boulevards and through pedestrian crossings at 80 kilometres an hour while pedestrians cowered at the road's edge waiting to attempt a crossing. These were not always, as in Soviet times, office-bearers with a fleet of vehicles and the capacity to close off roads at peak traffic hours; in many cases, they were 'new Russians' asserting and enjoying their ascent to traditional Russian privilege as they understood it.

Among the new entrepreneurs who seized the opportunity to make millions and then billions were many former members of the nomenklatura, including KGB operatives, who had privileged access to the new opportunities, and often also to funds that were cunningly squirrelled away by the old regime. Several underworld figures also became prominent in the emergent plutocracy.

As in the Soviet period, there was a symbiosis between crime, corrupt economic activity and the security organs. An analyst probing the transmogrification of organised crime dons and secret policemen into tycoons in the 1990s told a group of listeners that it wasn't clear whether what we were witnessing was 'the mafia-isation of the KGB or the KGB-isation of the mafia in Russia'. The accession of ex-KGB officer Putin to the top job did not, of course, do anything to diminish the prominence of ex-KGB figures in business. ${ }^{3}$

Corruption also flowered beyond the circles of well-placed apparatchiki. Many business success stories involved people without Soviet-era connections who had talent, drive and an eye to the main chance in a ruthless dog-eat-dog environment. Respect for property rights hadn't been a feature of most communist societies - in fact, ordinary people were often unconscious followers of the French anarchist Pierre-Joseph Proudhon's doctrine that all property is theft, and most assumed that other people's property had probably been illegitimately acquired in the first place. Because the difficulties of daily life could only be overcome by corruption, a certain amount of it was in any case widely regarded as unavoidable and perfectly reasonable.

3 The connections between crime, oligarchy, the state and President Putin are covered very well in Karen Dawisha's 2014 book Putin's Kleptocracy (New York: Simon \& Schuster). 
Following a visit to his country by a delegation of Supreme Soviet members in the late Gorbachev period, a Western official with extensive experience of the Soviet Union described how shocked he had been to learn that nearly all members of the delegation had not only laid waste to the hotel minibars without paying for any of it (which might have been a naïve mistake in some cases), but had also removed quite a lot of the fittings in their rooms. He had been particularly dismayed that one strongly reformist deputy with a fine record as a dissident had been one of the more conspicuous offenders. Many Russians were thus well equipped for the conditions that emerged after the dismantling of the command economy.

The Putin years saw sharp improvements in living standards, but much more of the same as far as Wild West capitalism was concerned, with the rapid expansion of the economy throwing up even greater opportunities. Putin is sometimes credited with having brought the oligarchs under control; all he did, in fact, was to jail or exile a few who impertinently aspired to take part in the county's political life or were resisting his policies. Oligarchs continued to flourish, though their previous security of tenure and ability to make political choices were curtailed. Those who prospered were increasingly those who were responsive to Kremlin requirements and directives. Within those broad-enough parameters, they could usually enjoy their wealth in any way they wished.

This, then, was the freewheeling world that Pomerantsev came to early in Putin's reign. The son of Russian dissidents who had managed to emigrate to London in 1978, raised in England but having lived in various other European capitals, Pomerantsev arrived in Moscow in his 20s, looking for work and a bit of exotic adventure. Western visitors and expatriates were still welcome, even sought after, in Moscow at that time, and he was able to find work as a director of television documentaries, exploring the extravagance, the giddy variety and the dark nether regions of the new Russia. Provided he managed to ensure a degree of 'balance' by including some positive content in his films, his commissioners and producers were happy to run with politically more risqué material. At least at first, that is, for their resistance to his investigative zeal increased over time, and Pomerantsev began to feel progressively less welcome. 
He returned to London from Moscow in 2010. After a briefly difficult transition, vividly described in his essay 'In between tortures', Pomerantsev quickly made a name for himself in Britain and the West generally as a commentator on contemporary Russian politics and society. He first came to the notice of many with his 2011 London Review of Books essay on Vladislav Surkov, the erstwhile éminence grise of Putin's Kremlin, memorably entitled 'Putin's Rasputin'. He has also written persuasively on Russian propaganda techniques. ${ }^{5}$

Nothing Is True and Everything Is Possible is based mainly on his documentary films. The events and sociopolitical backdrop he describes are essentially those of Putin's first two terms as president, not the economically stagnant and more oppressive and xenophobic Russia that emerged after Putin announced in 2011 that he intended resuming the presidency. The book should not be regarded as a portrait of the grim police state seemingly bent on unremitting confrontation with the West that Putin has since created, but of something rather less malign. Some of the sour flavour of the most recent Putin years does come through in postscript chapters describing Pomerantsev's contacts after 2010 with the upper echelons of Londongrad's hugely wealthy Russian diaspora. His interesting interviews with William Browder and Jamison Firestone about the tragic Sergey Magnitsky case, for example, dramatically illustrate much of the ugly and worsening symbiosis between crime, wealth and state corruption in Russia.

But much of that earlier Putinist landscape was grim enough. Pomerantsev gives us gripping eyewitness accounts of some major political events, including the Chechen terrorist theatre siege in Moscow of October 2002 in which over 170 people, including 129 of the hostages, perished, largely because of the brutality and incompetence of security officialdom. He gives us sometimes chilling portraits of significant players in Russian political life - people like Alexei Weitz, one of the leaders of Putin's favourite patriotic bikie gang, the fascist-style Night Wolves.

4 Peter Pomerantsev, 'In between tortures', Zeitzug, www.zeitzug.com/autoren/pomerantsevpeter/in-between-tortures.html; 'Putin's Rasputin', London Review of Books, vol. 33, no. 20 (20 Oct. 2011): 3-6, www.lrb.co.uk/v33/n20/peter-pomerantsev/putins-rasputin.

5 Peter Pomerantsev and Michael Weiss, The Menace of Unreality: How the Kremlin weaponizes information, culture and money, The Institute of Modern Russia, 2014, www.interpretermag.com/ the-menace-of-unreality-how-the-kremlin-weaponizes-information-culture-and-money/; see also Peter Pomerantsev, 'Inside the Kremlin's hall of mirrors', The Guardian, 9 April 2015, www. theguardian.com/news/2015/apr/09/kremlin-hall-of-mirrors-military-information-psychology. 
Pomerantsev depicts features of Russian life that are well known to specialists and expats but still startling in vivid close-up: the monstrous bullying of Russian military recruits and the extraordinary efforts undertaken by their families, typically their mothers, to help them dodge the draft; the ubiquitous need to bribe officials at many levels, especially the police who randomly check pedestrians' documents or arbitrarily pull over motorists, primarily if not exclusively to enhance their own incomes; the remarkably stylised and seemingly almost compulsory system for bribing your way through a driver's licence test regardless of your level of competence; and the heroic, but ultimately futile efforts of the brave heritage architect Alexander Mozhaev and his hardy circle of followers to save historic buildings in central Moscow that are subject to mindless destruction in favour of huge and corruptly approved redevelopment projects. ('Over three years they have saved three buildings out of three thousand', reports Pomerantsev.)

One particularly absorbing story recounts a businesswoman's experience of a practice known incongruously in Russian as reiderstvo ('raiding'), whereby a person in a position of power, often an official, steals the victim's property by having him or her arrested by compliant police and condemned by a venal judge (99 per cent of all accused are convicted in Russia). The victim then rots in jail while their documents of ownership are purloined by more compliant 'investigators' and handed over for a consideration to the 'raider'. Remarkably, this is a widespread phenomenon in Russia, and large numbers of small and medium entrepreneurs are in jail at any one time, which contributes significantly to Russia's dismal investment climate and sagging growth rates.

The portraits of largely unknown people that Pomerantsev uses to illustrate the lives and fates of typical categories of Russian humanity are another absorbing feature of the book. The intelligent and literate Vitaly, a Siberian mafia gangster with a brutally disciplined retinue in tow, makes documentary films about himself and goes on to write picaresque bestsellers based on his life. Oliona, the professional mistress, has trained herself at considerable expense to have the necessary qualities in addition to natural beauty to win the patronage - typically transient - of seriously wealthy oligarchs. Benedict, the Western 'lapsed economist', came to Russia with a poor understanding of the country or the language but found employment 
in various places, including as a consultant for various well-meaning Western acronyms; he writes reports instructing Russian institutions on how to adopt Western organisational and business practices but is slow to recognise that their resistance to foreign ideas and desire to make corrupt use of any funds or schemes that come their way are undermining the whole purpose of his activity.

Then there's Grigori, the wealthy businessman who throws rampantly extravagant parties that Pomerantsev delights in attending. He is a brilliant mathematician and computer scientist who built his flourishing business honestly enough and from scratch, and pours much of his wealth into supporting the arts. He also supports and funds a mendicant yurodivy ('holy fool', a traditional Russian social category), whose dismaying personal hygiene Pomerantsev describes all too clearly, but whom Grigori earnestly regards as a seer who will become the saviour of Russia. And various dissident performance artists from the milieu out of which Pussy Riot emerged also make their appearance intermittently in the narrative.

Some of the descriptions of conspicuous wealth and consumption start to weary the reader a little, as could Pomerantsev's interest in the often tragic stories of beautiful young women (roughly 60 pages out of 282) who are preyed on by wealthy and powerful males, or the numerous lunatic sects that emerged in the post-Soviet period. But, while he tends to neglect ordinary, less telegenic Russian citizens and their daily struggles, he focuses effectively on many of the key features of Putinist society - the harshness, the lawlessness, the impunity - and he has a deadly eye for the telling detail.

The longer Pomerantsev stayed in Russia, the more it became apparent to him, as it does to the reader, that the country's political system was heading towards greater domestic oppression, and that lies and xenophobia were once again key guiding principles. One of Pomerantsev's favourite subjects is Surkov, who was the high priest of the earlier 'soft authoritarian' phase of Putinism, during which people were manipulated into compliance with relatively less crude coercion. 
Surkov is shown devising ingenious but mendacious reasons for supporting the regime, which he invites intellectuals to adopt. Surkov himself flirted with performance artists and dissident ideas, and even published a book under a transparent pseudonym with somewhat subversive content. But the flirtation was ultimately all part of the radical relativism encapsulated wittily in the title Pomerantsev gave his book, and used instrumentally by Surkov and the regime to justify their grip on power and fuel their struggle against the decadent democracies of the West.

Beneath the intellectual brilliance and sophisticated facade, however, the real Surkov - himself of Chechen origins - is a good friend of the exceptionally brutal Chechen strongman Ramzan Kadyrov, who keeps the rebellious province under tight control on the Kremlin's behalf as well as his own. Though partly sidelined within the Kremlin in recent years, Surkov has been closely involved in the planning of Russian operations in Ukraine. He might have attractive qualities against the backdrop of the thugs he moves among, but it's difficult to class Surkov as a good guy.

The reader thus needs always to bear in mind that, over the last four years, Putin's regime has morphed into something markedly less engaging than Pomerantsev's in-country adventures depict. Pomerantsev is fully aware of these developments of course, as his other recent writings make clear. Surkov's lighter domestic touch, which gelled reasonably well with the declaratory liberalism of Dmitry Medvedev's presidency (2008-12), has been supplanted by the more traditionally Soviet head-kicking style of Surkov's successor as first deputy head of the presidential administration, Vyacheslav Volodin.

It was Volodin who gave us the lapidary formulation, 'if there is no Putin there is no Russia'. Together with the hyperactive and hyperzealous but rubber-stamping Duma, the Putin administration is producing a never-ending avalanche of repressive neo-Stalinist domestic legislation and adopting a stridently aggressive antiWesternism both domestically and externally. A Peter Pomerantsev would have great difficulty finding work in Moscow media today, except as a Lord Haw-Haw. 


\section{3}

\section{Making nice and making enemies ${ }^{1}$}

Ukraine has largely disappeared from our antipodean media in recent months, and is much less prominent even in Europe and North America. In this case, though, no news is not necessarily good news. At best, the shaky Minsk II ceasefire of 12 February 2015 somewhat reduced the fighting in eastern Ukraine. Then, suddenly, on 1 September, following a third agreement between the parties, it morphed into a genuine ceasefire just as Russian forces began moving into Syria. Vladimir Putin decided to change the subject by intervening in Syria and calling for a broad alliance with the Western powers against Islamic State. To improve Russia's standing, he prevailed on his truculent proxies in the 'people's republics' of Donetsk and Luhansk to refrain till further notice from making aggressive statements, attacking Ukrainian positions or holding phoney elections outside the Minsk agreements.

The underlying situation in Ukraine did not improve, but the steady drip of casualties suddenly halted. For many Western commentators and politicians, this fuelled a hope that lasting peace was not far off. Few sufficiently noted the point made by political scientist Alexander Motyl that the sudden suspension of the proxy aggression against Ukraine showed that Russia's claims that it hasn't been involved in

$1 \quad$ First published in Inside Story, 10 Dec. 2015, insidestory.org.au/making-nice-and-makingenemies. 
Donbas were absurd. What can be so easily turned off, however, can easily be turned back on again - and, towards the end of 2015, has been.

Other crises affecting Europe have been competing with Ukraine for space. The many permutations of the Greek insolvency crisis were sorely preoccupying EU leaders as well as attracting media attention, until it was pushed into the background by the growing avalanche of migrants. Increasing numbers were coming from Syria (and elsewhere) via refugee camps in Turkey, Jordan and Lebanon, and crossing from Turkey to adjacent Greek islands rather than taking the longer and more hazardous journey from North Africa. Then, while the European Union was struggling with its migration crisis, Russia launched itself forcefully into the already crowded Syrian war zone.

Next came the downing of the Russian Metrojet passenger plane over the Sinai Peninsula, followed by the terrorist atrocities in Paris, both claimed by ISIS, with the latter event exerting the usual hypnotic effect on Western publics. Most recently, the shooting down of a Russian military aircraft on the Turkish-Syrian border, after its incursion into Turkish airspace, led to yet another international crisis involving an aggrieved and aggressive Russia.

All of these things relate to Ukraine's still precarious position in significant ways. Not only do they occupy column inches, they also take a heavy toll on the attention spans, financial resources, political capital and collective resolve of Western decision-makers, all necessarily at the expense of other priorities. From Putin's point of view, they offer a golden opportunity to transform the international manoeuvring over Ukraine and sanctions.

Most independent Russian observers thought that pursuing a better settlement in Ukraine and relief from sanctions was probably the most important motivation for Moscow's Syrian intervention. But it was clearly also aimed at other objectives: to shore up Russia's oldest ally in the Middle East, to lay claim to great power status and a place at any negotiating tables, to demonstrate that Putin, unlike Obama, is loyal to his friends (compare Bashar al-Assad with Hosni Mubarak), and to defend and extend Russia's only military base in the Middle East and the Mediterranean. The intervention may even have been motivated in part by a desire to take on ISIS, as Putin proclaimed at the outset, 
though for weeks 90 per cent of Russia's attacks ignored ISIS targets and were aimed rather at Western allies among the anti-Assad forces. It was certainly intended to impress on Western minds that Russia was a necessary ally against ISIS, an ally worth placating to bring on board.

After it became clear that Western governments rejected Putin's pretence to be taking on ISIS, and particularly after the attacks in Paris, Moscow changed its line, belatedly acknowledging that the Russian passenger jet had been blown up by ISIS, which till then it had energetically denied, and offering sympathy and armed support to French President François Hollande. Russia summoned other countries to join a united front against terrorism, which it presented as analogous to the wartime alliance against Nazi Germany, a line it has been pushing since well before its Syrian intervention. These siren calls often explicitly proposed that Western countries put issues like Ukraine behind them. But, while indicating a readiness to coordinate efforts against ISIS, most Western majors made clear that they were not ready to overlook other issues dividing them from Russia. The politically beleaguered Hollande, by contrast, responded with alacrity and enthusiasm to Moscow's appeal, raising further doubts about the strength of his commitment to a strong line on Ukraine.

Like the Metrojet disaster, the Turkish shooting down of a Russian bomber was a severe reverse for Putin. This time he immediately went on the front foot, moving more forces into the region, launching the usual Russian trade war, despite the considerable cost to Russian consumers, tourists and small businesses, and demanding a public apology from Turkish President Recep Tayyip Erdoğan. A rising crescendo of propaganda was directed against this new enemy, much of it personal to Erdoğan. All this was probably an expression of Putin's personal feelings of humiliation, but clearly such an affront could not be tolerated by a great power. Russia is maintaining its rage, and further escalation is possible, though unlikely.

The rights and wrongs of the incident may take some time to become fully clear, but it should be remembered that Putin has been repeatedly deploying aircraft close to, or in, other countries' airspace for well over a year. These overflights typically seem deliberately provocative or intimidatory. The Russian aircraft fly with their transponders either turned off or not installed in the first place, so that 
the air defence and air traffic control systems in targeted countries cannot contact the pilots. Nor was this the first time that Russia had treated Turkey in this way during the current operations. The Turkish claim that the Russian crew had not responded to successive warnings is, therefore, plausible. Moreover, the bombers were attacking ethnic Turkish anti-Assad forces rather than ISIS. Putin has made much of Russia's supposed right and duty to protect anyone who can be classed as belonging to the rubbery entity known as the Russian world (Russky Mir) - ethnic Russians, that is, or even just Russian speakers in foreign countries. Why should Turkey not feel some responsibility for its own co-ethnics?

While it may not have been the primary purpose of these dangerous operational procedures near the Turkish border, Russia has shown signs of satisfaction with the nervous NATO response the border incident evoked. This seems to have been the first time a NATO member state has shot down a Russian or Soviet aircraft. Moreover, Erdoğan is not flavour of the month with either NATO or the European Union. Though Brussels is offering Ankara some US $\$ 4$ billion in funding and other concessions to persuade it to cooperate in stemming the vast flow of would-be migrants who have come through Turkey, this is a sign of EU desperation rather than esteem.

NATO is, of course, obliged under Article 5 of the NATO treaty to consider what it can do to aid any member whose security is under threat. But some NATO members will be asking themselves whether they want to come to the aid of a Turkey that feels emboldened in ambiguous circumstances to shoot down a Russian aircraft. Russian commentators are clearly hoping this will prove to be the case.

What these events illustrate is that while Moscow may not have provoked or planned these situations, it has been quick to turn them all to its strategic advantage. If Russia deals with Turkey in a contemptuous and threatening manner and NATO responds mainly by declaratory support and mediation efforts, tempered by evident unease, this may suggest that NATO membership is of uncertain value. And if the Paris atrocities in tandem with the Metrojet disaster generate a wave of sentiment in favour of a new alignment with Russia, that may well weaken Western solidarity in defence of Ukraine. Divisions and uncertainty within NATO or the European Union are always welcome in Moscow. 
Even Moscow's involvement in the Grexit issue was clearly aimed at more than simply supporting a traditional Russian ally. Mutual highlevel visits between Moscow and Athens, and symbolic gestures of support were timed in such a way as to encourage Athens's resentment of the tough conditions attached to the EU bailout. Of course, Russia itself was not able or prepared to come to the financial rescue, given the vast sums involved. But the purported contrast between warmhearted, sympathetic Russia and mean, hard-hearted Berlin and Brussels was good political theatre and stirred up extra trouble in the European Union. In the end, however, Greek Prime Minister Alexis Tsipras proved more soberly calculating than Putin had hoped, and he did not withhold his support for extending EU sanctions.

Though some Eastern European commentators believe otherwise, Putin appears to have had no significant role in initiating the migration tidal wave in Europe. But his intense bombing raids in Syria will add to it and perhaps partly reflect a desire to bring about such an increase. And Russia has indeed facilitated a rapidly increasing flow of some 5,000 would-be migrants into Norway across the remote northern border linking the two countries, overwhelming Norwegian reception facilities. Oslo has demanded an explanation and amended its regulations to stem the flow. The numbers are small at this stage, but the intent is clear. Russia has also exerted similar pressure on Finland.

Putin would be delighted with the spectacle of EU embarrassment and disarray in the face of this human rights policy debacle. The migration issue threatens to open up a new and damaging divide between 'core Europe' and new members in the east who are vigorously resisting efforts to make them accept allocations of refugees for resettlement. The refugee crisis is also a gift for Putin's allies and admirers on the European hard right, including Marine Le Pen and her National Front in France. Le Pen is frequently invited to visit senior figures in the Kremlin, and her party has received funding from a Kremlin-friendly, Moscow-based bank. Moscow supports all hard-right Eurosceptic parties, as well as hard-left parties, valuing their disruptive role in a European Union that is staggering under the weight of successive crises. The migration issue promises to be the mother of all of them, and of long duration. 
Russia itself has a severe problem with its increasingly radical Muslim communities, which comprise over 20 million in a total population of 144 million if migrant workers from the '-stans' of former Soviet Central Asia are included. This may have been a key factor inclining Putin initially to avoid stirring up ISIS unduly in Syria, as that organisation was recruiting substantial numbers of Muslim radicals from Russia, especially from the turbulent North Caucasus. Stalin committed barbarous crimes against some of those national groups, including the Chechens, and also the Turkic-speaking Crimean Tatars who have strong links with and enjoy official and public sympathy in Turkey. The Chechens and Crimean Tatars, like the overwhelming majority of Russian Muslims, are Sunni.

For all these reasons the Sunni Erdoğan keenly resents Putin's annexation of Crimea, and his support for Shiite regimes in Damascus, Tehran and Baghdad, as well as for Hezbollah in Lebanon. In fact, Putin himself has done much to fan the flames of Muslim resistance in Russia and to push it in an increasingly Islamist direction, by his violent repression in the North Caucasus, especially in Chechnya. Having conducted a brutal war to pacify the province at the outset of his presidency (a war that greatly boosted his popularity), he has increasingly outsourced rule in Chechnya to the brutal but efficient and increasingly Islamist dictator, Ramzan Kadyrov.

So Putin has a serious problem with radical Islam domestically, which is one reason why he until recently steered clear of armed involvements in the Middle East. The Soviet regime tended to support supposedly 'modernising' anti-Western autocracies and movements in the region, including Gamal Abdel Nasser in Egypt, Saddam Hussein in Iraq, Muammar Gaddafi in Libya, and the Baathist regime of the Assads in Syria. In the post-Soviet period, at least until recently, Russia has been less actively engaged in the Middle East, but Putin now seems ready to risk greater involvement.

Especially since Putin came to power, Russia has deeply resented Western support for regime change not just in former communist states in Eastern Europe, but also in Afghanistan, Iraq and Libya (where Putin seemed to take the fall and execution of Gaddafi personally). Moscow was, perhaps wisely, sceptical that the Arab Spring would lead to any kind of sweetness and light. Putin is convinced that the 
real Western motivation there is not to solve humanitarian problems or promote democracy, but rather to strengthen its influence in the region at the expense of Moscow's political and economic interests.

And he is apparently genuinely mystified that the West should repeatedly invest so much blood and treasure in such dangerous and volatile situations. It is not just damaging to Russia, it is damaging to the West as well, so why do it? To quote the rhetorical question in his UN address in September 2015 referencing Western-led regimechange operations in the broader Middle East: 'Do you at least realise what you've done?!' It's not an unreasonable question. Yet he now seems on the brink of a dangerous double investment of his own, first in the whole Middle Eastern Sunni-Shia civil war, and second in a vengeful feud with a man after his own heart, Erdoğan, which could severely damage his carefully cultivated relationship with Turkey, and possibly much more besides.

Russians generally, including opposition voices, find the Western attitude to the wider Middle East, and particularly to Muslim immigrants in their midst, deeply strange. The once prominent Russian banker Elena Kotova, writing about the Paris atrocities for the independent Russian online publication Snob, expressed amazement that Western elites react to all Islamist terrorist attacks in Western countries with the same clichés about solidarity, tolerance, courage, civilised values inevitably triumphing, and so on. ${ }^{2}$ After years of changing reality, she wrote, the tolerance mantras remain the same. They defy common sense, she argued, but more importantly they defy the wishes of the majority of ordinary citizens of Europe. And she went on to make some mordant observations about the tyranny of political correctness in Western Europe.

The common thread in all these recent headline issues from the Putinist perspective is that they carry the promise of, or present opportunities for, the weakening of NATO and the European Union, and the West generally. As Putin once frankly told a secretary-general of NATO, his mission was not to build a better relationship with NATO, but

2 Elena Kotova, 'Topor Miasnika' (The Butcher's Axe), Snob, 16 Nov. 2015, snob.ru/ profile/23854/blog/100760. 
to destroy it. And his attitude in recent years towards the European Union, especially its trade and governance outreach to its eastern neighbours, has become similarly hostile.

For Putin generally, as for his senior colleagues, the objective of policy is not to reach an honourable compromise, or to achieve peace as such, but to be in conflict with and defeat his numerous adversaries. All relationships are zero-sum games, and win-win solutions are an illusion - or would be if Russian had a word for them. What he wants is victory, not peace, domination not partnership (despite his frequent sly references to his Western enemies as 'partners'). Kto kogo ('who will dominate whom'), as Lenin famously said; the weak get beaten, as Putin himself said. And he assumes that behind their hypocritical facades everyone else operates in the same way.

Because of the dismal state of Western education about the Soviet and post-Soviet operational code, Western foreign policymakers (and often commentators, too) cannot internalise these sorts of basic Russian realities. They continue to try to create resets or peaceful winwin solutions, to 'rebuild the relationship', to reach out, until their patience runs out, or they lose the election, or they are replaced by a democratic party colleague with superior insight into the nature of things, who will also see a need to rebuild the relationship supposedly damaged by her predecessor. 


\section{4 \\ Ukraine, out of sight ${ }^{1}$}

Vladimir Putin's recent excursion into the heat and turbulence of Middle Eastern conflicts was undertaken for a number of reasons. But, probably key among them, was the desire to improve his standing with the West enough to weaken or eliminate sanctions and secure his acquisitions in Crimea and eastern Ukraine. Russia's active military involvement in Ukraine has moderated in recent months, though it has not ceased, and it could resume at short notice. Where does that leave the Ukrainian struggle for independence and closer relations with the West?

Even if the gunfire has fallen silent or become merely intermittent, Western policymakers need to remind themselves that a Leninist $k$ to kogo struggle (who is defeating or dominating whom) is still being fought by the other side, and in a variety of ways. Putin wants to win, not to settle for an honourable draw, and his attention span is much longer even than German Chancellor Angela Merkel's, and certainly than French President François Hollande's.

War is the continuation of politics by other means, while, for the Leninists and their modern legatees, the Putinists, politics (and information, culture, trade, population movements, etc.) is the continuation of war by other means. They see many different paths to victory, and so it is with Ukraine.

1 First published in Inside Story, 21 Dec. 2015, insidestory.org.au/ukraine-out-of-sight. 
In recent years, Moscow has essentially been replicating in countries to its west the sorts of operations it undertook at the end of, and just after, World War II to communise Central and Eastern Europe. This time the target countries are former Soviet republics rather than what were once Warsaw Pact countries-to-be, though Ukraine fits into both camps. The ideological bait and the mix of preferred instruments are also slightly modified to suit the times and, happily, the use of military conquest and the violent repression of ungrateful new subjects are so far much less massive in scale.

But the pattern is broadly similar: outright invasion and seizure of territory; deployment of freshly minted partisan militias under Kremlin auspices; creation of pseudo-state structures, often with tell-tale Stalinist monikers like 'people's republic'; police state methods against whole categories of dissenters; international negotiations on the basis of these faits accomplis; intensive propaganda to discredit the victims ('fascists'), legitimise the proxies ('rebels', 'separatists'), and reduce the outside world's readiness to resist the new dispensation; and trade wars, using arbitrary and crippling sanctions for no legitimate reason to undermine the target country's economy or generate coercive pressure (by cutting off sources of heating in winter, for example).

Also in the mix are exported corruption, especially bought or hired politicians; subverting and destabilising target states by organising violent takeovers of media outlets, administrative buildings and so on; bankrolling receptive parties; setting up pseudo-independence movements in areas where a military incursion might lend wings to a 'national liberation movement' that is otherwise incapable of independent flight; and recruiting neighbouring states or peoples who may wish to cooperate in a possible carve-up of territory. ${ }^{2}$

Though skirmishes have resumed in Eastern Ukraine in recent weeks, the outright military phase seemed to plateau at a lower level several months ago. Negotiations, manoeuvres and contacts have continued in various formats, but they seem to match Moscow's plans and desiderata less closely than before. Reinforced by the slump in oil and gas prices and Russia's overall economic malaise, sanctions are holding

2 On the postwar events and present-day similarities, see respectively Anne Applebaum's book Iron Curtain: The Crushing of Eastern Europe 1944-1956, New York: Doubleday, 2011; and her article 'Russia and the great forgetting', Commentary, 1 Dec. 2015, www.commentarymagazine. com/articles/russia-great-forgetting/. 
Moscow back from attempting to create further 'facts on the ground' in Ukraine. And Putin's costly insertion of his armed forces into Syria has yielded added complications that threaten further conflicts on multiple fronts and reduce his room for manoeuvre.

The Ukrainian armed forces and associated militias have continued to display unexpected resilience in defending the line of contact with Russian-dominated proxy forces. Even more surprisingly, the West's unity on the sanctions has proved greater than Russia, or indeed many Western observers, were expecting. But that unity is still precarious, and much of what Russia has been saying lately about the need for a new grand alliance against terrorism, in the spirit of World War II, points to the Kremlin's reasonable calculation that EU sanctions could be rolled back in the relatively near future.

The West has agreed on the line that relief from sanctions should be linked to implementation of the Minsk ceasefire agreements, which sought to end the fighting in Ukraine. But those agreements are unclear, and flawed, appearing to place more definite obligations on Kyiv than on Moscow or its proxies. Russia hopes that it will be able to persuade a few European friends and potential veto-wielders that it has more or less met the terms of Minsk. But it has not met the requirement to withdraw its forces and weaponry (indeed, it still pretends it has not deployed either), much less to concede control of its 'border' with the 'people's republics'. Few people really believe it ever will.

The last few months have seen renewed signs of pressure from the pro-Moscow camp in the European Union for a review of sanctions and a fresh 'engagement' with Russia, notably via statements from EU Commission President Jean-Claude Juncker and various senior national figures. But despite the growing agitation for a return to business as usual with Moscow, it is now clear that sanctions will nonetheless be extended for another six months when they expire at the end of January.

Because a unanimous decision is required to extend sanctions, a determined veto by even one EU member state would be enough, in theory, to revoke them. In practice, it doesn't work that way. But, if a stronger wave of sentiment were to develop with one or two senior and influential EU leaders behind it, the outcome may be different. In the second week of December, Italian Premier Matteo Renzi caused 
a brief sensation by twice appearing to demand a reconsideration of the sanctions issue at the EU summit on 17-18 December, taking more adequate account of Russia's 'help' in the Middle East.

As of 14 December, however, his Foreign Minister, Paolo Gentiloni, was 'clarifying' that Italy would not block extension of the sanctions. But Gentiloni did emphasise that EU states are increasingly keen to come to terms with Russia over Ukraine. So, if not now, perhaps sanctions will be lifted in six months. And Luxembourg Foreign Minister Jean Asselborn has reminded everyone that sanctions could end earlier if the situation in Ukraine improves. ${ }^{3}$ This is clearly a space to keep watching.

From the outset, the Minsk agreements had a number of disadvantages for Ukraine and the West. As the distinguished Chatham House expert on Russia and Ukraine, James Sherr, has commented, 'If Poroshenko, Merkel and Hollande received military advice when negotiating, there is no sign of it' ${ }^{4}$ To be fair, while Ukraine President Petro Poroshenko must have known that the deal had grave flaws from Kyiv's point of view, he had limited influence over the negotiating tactics and objectives of his Western supporters.

The central problem was that the agreements recognised the invaders and fifth columnists in eastern Ukraine as legitimate representatives of a domestic constituency rather than the placement of a foreign power that had annexed by force a large part of Ukraine and was manifestly intent on doing more of the same. Russia was treated not as a guilty participant but as an honest broker with 'legitimate interests' in the outcome of the 'conflict'. (Ukraine has experienced tensions during its 24 years of independence, but never violent subversion of the kind that conveniently 'broke out' across eastern Ukraine in the weeks immediately after the invasion of Crimea.)

3 See Andrew Rettman, 'Italy clarifies position on Russia sanction', EU Observer, 15 Dec. 2015, euobserver.com/foreign/131514.

4 See James Sherr, 'Russia's Minsk and Yalta projects', The Intersection Project: Russia/ Europe/World, 29 May 2015, intersectionproject.eu/article/russia-europe/russias-minsk-and-yaltaprojects. 
Under the Minsk agreements, Ukraine was required to change its constitution to guarantee autonomy to 'certain regions' in the Donbas - and to do this in a way that met with the approval of the Moscowcontrolled cliques in charge of the nascent police states of Donetsk and Luhansk. ${ }^{5}$

Most Ukrainians don't see why being attacked by Russians and their Trojan horses in the Donbas should mean that they must make constitutional changes that will shore up the position of the aggressors. Meeting this Minsk provision, therefore, requires Kyiv to take an extremely unpopular decision at a time when the governing parties' public standing is in steep decline. One of the key reasons for the decline is that they had to impose painful economic reforms on the population to clean up the fiscal mess left by predecessors, notably the deposed president Viktor Yanukovych, and meet the prerequisites for a desperately needed International Monetary Fund (IMF) bailout. While this has been going on, the Ukrainian economy has contracted by 7 per cent and a projected 12 per cent in 2014 and 2015, respectively, and incomes and living standards have slumped even more sharply. ${ }^{6}$ GDP seems likely to register a small increase in the current quarter, but any turnaround will be slow, and much damage has been done.

Given their own desperate situation, most Ukrainians have no desire to pay for the despoliation of the east of their country by Moscow and its proxies. Some even argue for cutting the people's republics loose and allowing them to secede de facto to Russia, forcing Moscow to pay for the damage it has caused, and leaving Ukraine reduced but more united. The Minsk agreements, however, gave Kyiv responsibility for the social security of the Donbas inhabitants and the rehabilitation of the war zone, presumably including the cost of mopping up after the looting and gratuitous damage the proxies inflicted on Ukrainian and foreign businesses, above and beyond the armed conflict. ${ }^{7}$

\footnotetext{
5 For a recent depiction of life there by a Russian reporter who has been on the ground throughout, see Pavel Kanygin's article, 'The Donbass war: Assessing the aftermath', Meduza, 14 Nov. 2015, meduza.io/en/feature/2015/11/13/the-donbass-war-assessing-the-aftermath.

6 See 'Ukraine: Reforms helped to stabilize economy, but continued and faster reforms are key', World Bank press release, 5 Oct. 2015, www.worldbank.org/en/news/press-release/2015/10/05/ ukraine-macroeconomic-update-october-2015.

7 See Michael Bird et al., 'The great looting of Donbass', EU Observer, 10 Dec. 2015, euobserver.com/investigations/131428.
} 
For reasons of its own, Russia wants the Donbas people's republics to be reintegrated into Ukrainian state structures but given such farreaching autonomy that they can block any westward moves by the Kyiv Government. And for any national government to acquiesce legally to further excisions from Ukraine's sovereign territory after Russia's military surgery in Crimea and elsewhere would be political suicide.

In fact, Kyiv has curtailed much of its support for the population that is still living in the people's republics. ${ }^{8}$ It is thereby pressuring a reluctant Moscow to come to the aid of the Donbas population. Some humane Ukrainian commentators deplore Kyiv's policy in this matter, saying it will lead to the permanent estrangement of the Donbas population, and reporting from the region suggests they are probably right. But the state's coffers are bare.

Two years on from the Euromaidan uprising, the population in Kyivdominated regions is growing impatient with the government's weak performance in tackling Ukraine's endemic corruption (a common feature of most of post-Soviet Europe, apart from the Baltic states and Georgia). Sympathetic Western leaders, notably from the United States, take a similar view and have been expressing it forcefully. Other major sources of public resentment include the notorious influence of powerful oligarchs and the failure to find and prosecute those responsible for the violent repression of protesters during the Maidan demonstrations.

Supporters of President Poroshenko and the Prime Minister, Arseny Yatsenyuk, argue that fighting a war, keeping a stricken economy afloat and implementing painful measures to restore the fiscal balance are exhausting their political capital, and that they cannot afford to alienate the powerful oligarchs and other influential figures they need to keep in the tent. As for prosecuting those responsible for the violent attacks on Maidan demonstrators, they claim nearly all of them have fled to Russia after destroying the evidence, making prosecutions hard to mount.

8 Current estimates, almost certainly on the low side, put war fatalities at more than 9,000, with at least three million displaced, one million of them to Kyiv-controlled Ukraine. 
A corruption scandal has recently engulfed the self-styled 'kamikaze' prime minister himself, whose popularity had already sunk through the floor. One of his close allies is being pursued by Swiss prosecutors for accepting bribes, and has been forced to resign his seat in the Verkhovna Rada (parliament). ${ }^{9}$

Earlier it was revealed that Poroshenko's personal wealth, despite punitive Russian measures in Russia and Ukraine, has surged above the US billion dollar mark since he took office, a point eagerly picked up by Russian propaganda outlets. He is also justly criticised for having failed to divest himself of much of his wealth, as he promised to do before assuming office. But while no clear evidence of corruption by the President or Prime Minister has emerged, the public is not convinced by the government's explanations for its failures, and impatience is growing.

Meanwhile, populist and nationalist solutions to complex economic and political issues are starting to gain traction in the Verkhovna Rada and more widely. A battle is being fought in the Rada and beyond over a populist counterproposal to the radical tax and budgetary package proposed by the highly competent American-Ukrainian Finance Minister Natalie Jaresko, in consultation with the IMF. The rival bill, which would bust Ukraine's precarious fiscal position, has elicited an IMF warning that its further support (without which the country may face default) could be withheld.

There is a serious risk that ambitious and irresponsible political groups could use or somehow precipitate violence in their efforts to exploit the current volatile political situation. The issue of the special autonomy to be bestowed upon the 'people's republics' in Donbas under the Minsk agreements has done so already, and could again be a trigger. Extreme turbulence accompanied the first stage of the relevant legislation's passage through the parliament on 31 August, despite the measures falling far short of the expectations of Moscow and its proxies. A violent hand-grenade attack outside the parliament, staged

9 See 'Switzerland officially confirmed case Martynenko. He faces 5 years', Ukrainian Crisis, 23 Oct. 2015, ukrainiancrisis.net/news/14573. 
by one of the militant nationalist parties, resulted in police casualties. ${ }^{10}$ Fisticuffs inside the parliament are not unknown, but violence of this kind is a most unusual and ominous development.

Given all this, the passage of legislation necessary even to meet Ukraine's Western supporters' expectations may yet prove beyond the Poroshenko administration's capacity. For their part, Russia and its proxies will almost certainly say that whatever legislation is passed is insufficient. They have been demanding not just decentralisation or autonomy, but effectively 'federalisation'. Cobbling together a parliamentary majority to pass the unpopular legislation will be very difficult, and could possibly even bring about the Kyiv Government's collapse.

Whatever their flaws, the Minsk agreements were presumably as much as Merkel and Hollande felt they could get from Moscow. With the absence of the United States from the negotiating process, Poroshenko had no alternative way of gaining the reduction in fighting that he desperately needed to rescue the gravely ill Ukrainian economy. Apart from the few weeks of calm after 1 September 2015, though, there never really has been a genuine ceasefire in place. And Russia has continued to supply heavy weaponry and infiltrate personnel through the over 300 kilometres of border that it jointly controls with its Donbas proxies.

Throughout the occupation, with Russian connivance, the proxies have denied international monitors from the Organization for Security and Co-operation in Europe (OSCE), access to the border and most other areas they hold. ${ }^{11}$ In recent months they have even been blocking international charitable organisations seeking to bring relief to the suffering civilian population in the Donbas, ${ }^{12}$ these charities are acting as hostile 'foreign agents', the proxies allege, in another loyal echo of one of the worst xenophobic features of Putinism. The Donetsk and Luhansk regimes, on the other hand, have been welcoming towards

10 See 'Death toll rises to three from grenade attack near Ukrainian parliament', Radio Free Europe/Radio Liberty, 1 Sep. 2015, www.rferl.org/content/ukraine-second-national-guardsmandies/27220213.html.

11 See Daniel Baer, 'Russia's ongoing violations in Ukraine', US Mission to OSCE, 3 Sep. 2015, osce.usmission.gov/sep_3_15_russias_violations.html.

12 See Halya Coynash, 'Why are the Kremlin's proxies in Donbas provoking a humanitarian catastrophe?', Kyiv Post, 28 Sep. 2015, www.kyivpost.com/opinion/op-ed/halya-coynash-whyare-the-kremlins-proxies-in-donbas-provoking-a-humanitarian-catastrophe-398863.html. 
selected Western journalists, enabling them to see, record and display to the world the damage and suffering the civilian population has sustained. Often the news reports uncritically present the devastation as being essentially Kyiv's fault, without saying much if anything about the real causes of the conflict or the thuggish behaviour of the journalists' hosts.

Russia has up till now sent 45 'humanitarian convoys' to proxy-held territory since the Donbas regions were seized, none of which they have allowed Ukrainian or OSCE officials to inspect. Many reports suggest that weaponry and other non-humanitarian cargo have been transported in this way. Russia has also provided financial support, but with its own economy under stress it doesn't seem to see repairing its damage in Ukraine as a high priority. It does maintain close political control of the regions, however.

As it currently stands, the Minsk outcome only meets the Kremlin's minimum requirements - to devastate the Ukrainian economy, and to seize enough territory to prevent the country from integrating with Western institutions. Even with the additional land the proxies grabbed after the Minsk II ceasefire supposedly came into effect last February, they occupy less than half of the Donetsk and Luhansk regions. Putin would like ideally at some point to take over both in their entirety, and more besides, but the present moment is not propitious. Efforts continue aimed at destabilising the two largest and most Russified regions of Kharkiv and Odessa, the scene of repeated, mysterious bombings that were never typical of Ukraine before the Russian aggression began. The Transcarpathian region of western Ukraine, bordering Slovakia, has also been subject to transparently Kremlin-inspired attempts to create a separatist movement.

Where does this leave Putin's Novorossiya project - the idea of seizing the entire eastern and southern regions of Ukraine, creating a land bridge to Crimea, and linking up with the Russian-sponsored breakaway territory of Transnistria in Moldova? This seems to have been the Kremlin's preferred option at one stage, but Ukrainian resistance, Western reactions and the slump in energy prices and 
the rouble forced a reappraisal. Putin has not publicly mentioned it for well over a year, and he seems to have settled, for now anyway, on another 'frozen conflict' in the Donbas. ${ }^{13}$

As the Georgian precedent indicates, the Kremlin could easily decide to 'unfreeze' the conflict at some opportune moment, but for the time being that seems unlikely. In recent months it has restrained some of its domestic hypernationalists, once tacitly encouraged, who have been calling for Moscow to invade Ukraine and condemning Putin for failing to do so. Keeping Ukraine a failed state and out of Western institutions is the minimal requirement. But what the Putin regime would like ultimately is a Ukraine subordinate to Moscow, with a compliant government in Kyiv, its economy integrated in the Eurasian Economic Union and Russian as an official, and effectively the dominant, language.

If the Ukrainians don't oblige, the Donbas front could always be reactivated and the destabilisation of other regions renewed. But there are other ways of exerting severe pressure. Trade boycotts, 'energy diplomacy' and manipulating prices have all been used repeatedly.

It is true that such measures may be starting to exhaust their potential. As Moscow has intensified its trade boycotts, Ukraine has been tearing itself away from its dependence on Russian imports and exports. Quite recently, Russian and EU trade with Ukraine were each roughly a third of the total, but Ukraine's trade with the European Union is now more than double that with Russia.

In an ideal world this would not be the optimal trade pattern between the two countries but, as Putin has turned trade - like culture and broadcasting - into a coercive weapon, Kyiv feels that it has no choice but to greatly reduce contact with Russia in all fields. If Putin's methods ultimately fail in the struggle to dominate Ukraine, he will have done severe and gratuitous damage to Russia as well as to his victim along the way.

But, while the economic weapons are starting to lose effectiveness because of gross overuse, they are still potent. Moscow has foreshadowed yet another cut-off of gas supplies during the coming

13 See Robert Orttung \& Christopher Walker, 'Putin's frozen conflicts', Foreign Policy, 13 Feb. 2016, foreignpolicy.com/2015/02/13/putins-frozen-conflicts/. 
winter; it has abruptly curtailed all agricultural imports from Ukraine; and when Ukraine banned civilian Russian flights into Ukraine on ostensibly national security grounds, Moscow quickly responded in kind. These recent measures build on nearly two years of a severe and punitive trade war waged by the Kremlin.

The gas weapon is less potent than it once was thanks to efforts by Ukraine to build up reserves and acquire more of its gas imports from other sources. But it has other vulnerabilities and Moscow will exploit them. As well as cutting off gas supplies, it has curtailed coal and nuclear fuel supplies. Kyiv is partly to blame for this: it failed to contain the blockade of Crimea, mounted by mainly Crimean Tatar activists and aimed at preventing essential supplies being delivered from Ukraine to the peninsula. The Crimean Tatars have suffered heavily from Russian imperialism in various forms, including genocide at the hands of Stalin and systematic persecution by the new regime installed since the Russian annexation last year. But the activists went from obstructing land exports to sabotaging electricity supplies and then preventing Ukrainian services from carrying out repairs. In failing to block the blockaders, however understandable given Moscow's behaviour in Crimea, Kyiv gave Putin an excellent excuse to retaliate painfully. The ban on coal supplies in particular could be very damaging to Ukraine during the winter.

After blandly lying that he would not impose further sanctions on Ukraine, Putin has now ordered the imposition of tariffs on Ukrainian exports when Kyiv's free-trade deal comes into force on 1 January 2016, on the grounds that without them, cheap EU goods would flood into Russia. EU officials and independent observers regard these Russian claims as groundless, and a smokescreen for measures aimed at preventing Kyiv from proceeding with its Association Agreement (AA) with the European Union. It has been estimated that the tariffs will cost Ukraine US\$1.5 billion annually. ${ }^{14}$

Moscow is trying hard to damage the battered Ukrainian economy in other ways too. Not widely reported in the Australian press has been Russia's unremitting campaign to use a US\$3 billion debt owed it by Ukraine to tip its unruly little brother over the economic precipice.

14 See Andrew Rettman, 'Russia imposes Ukraine trade measures', EU Observer, 17 Dec. 2015, euobserver.com/foreign/131564. 
The money, provided by Moscow to President Viktor Yanukovych just before he was deposed, has been described (not unfairly) by Prime Minister Yatsenyuk as a bribe to induce Yanukovych to abandon any thought of integration with the European Union.

As a condition for approval of a US $\$ 40$ billion bailout package from the IMF, the Poroshenko administration was required to secure a negotiated restructuring of the US $\$ 18$ billion owed to private creditors. After long and arduous negotiations, the creditors agreed to a 20 per cent haircut and some easing of the terms of repayment, which financial observers saw as a favourable outcome for the creditors in the circumstances. Russia refused to negotiate on its US\$3 billion share of US\$18 billion, maintaining that the debt was state-to-state, not private.

IMF policy has been not to disburse loans to states in arrears to other states. In this case, though, the IMF let it be known that it would continue to disburse tranches of the bailout even if Ukraine remained in arrears to Russia. No doubt it was also taking into account the fact that, as the IMF's president Christine Lagarde emphasised publicly, Kyiv had taken some heroic decisions to meet the fund's tough conditions. Perhaps it also saw as relevant the fact that Russia had invaded Crimea after making the loan, seizing land and resources worth many tens of billions of dollars, and had also implicated itself heavily in the tens of billions of dollars' damage done by the armed subversion of eastern Ukraine. All this suggested that Russia's bonds might ultimately be judged to be odious debt and unenforceable in the technical legal sense.

As the IMF mood seemed to be hardening against him, Putin attempted to step round this obstacle by declaring a readiness to accept the US $\$ 3$ billion over three years, plus interest, starting with an upfront US $\$ 75$ million and subject to guarantees of repayment by Western institutions. Although the 'offer' was conspicuously less generous than the deal accepted by the private creditors, it was widely hailed at first by ever gullible Western media as a sign of Russia's flexibility. Ukraine argued that it could not offer more generous terms to Russia than it had done to the other non-official creditors. 
Last week the IMF confirmed publicly that, in Ukraine's case, it was prepared to set aside its usual rule of not extending support to countries in arrears to another sovereign. ${ }^{15}$ But, shortly afterwards, the Fund announced that it had upheld Russia's contention that the US\$3 billion lent to Yanukovych by Putin was an official not a commercial debt, and called on Kyiv to negotiate with Moscow on repayment of the debt. This is unfavourable for Kyiv, which will refuse to pay; and the issue will probably become another matter between the two countries that will end up in court.

Another good example of Putin's methods is Gazprom's latest pipeline project, Nord Stream II, to be built in collaboration with big German and other Western European companies. Like Nord Stream I, it will cost at least US\$10 billion but has no economic justification. (Existing pipelines through eastern and central Europe could do the same job.) The purpose is geopolitical: to bypass the Eastern European countries, depriving them of transit fees and any leverage in price negotiations, and making it easy for Gazprom to cut off their gas supplies for punitive effect at any time. Western energy companies are apparently being drawn into a cosy deal with Gazprom to blackmail Russia's western neighbours and profitably monopolise gas supplies to much of Europe.

After lengthy controversy, the European Union seems to be preparing to decide whether it should disallow this project as contrary to its Third Energy Package and anti-trust policies. In a more amenable age, Nord Stream I slipped through the net quite smoothly, aided and abetted by former German chancellor Gerhard Schroeder. His influence is still detectable. When Merkel's Deputy Chancellor, Social Democrat leader Sigmar Gabriel, made a 'personal' trip to Moscow on 28 October 2016, he spent two hours with Putin and Gazprom head Aleksei Miller, during which time the visitor expressed the hope that the project would go through with as little 'outside interference' as possible. ${ }^{16}$ For her part, Merkel seems also to be a supporter, if more cautious, of Nord Stream II, while still envisaging some residual role for Ukraine as a transit state. Ukraine, Slovakia, Poland and other affected states have protested loudly against Nord Stream II, and EU

15 See 'IMF backstabs Russia by lifting loan ban vs. debt-dodging Ukraine', Covert Geopolitics, 10 Dec. 2015, geopolitics.co/2015/12/10/imf-backstabs-russia-by-lifting-loan-ban-on-ukraine/.

16 See Julia Smirnova, 'Gabriel spielt in Moskau den Gerhard Schroeder', Die Welt, 29 Oct. 2015, www.welt.de/politik/ausland/article148156440/Gabriel-spielt-in-Moskau-denGerhard-Schroeder.html. 
energy commissioner Maroš Ševčovič (a Slovak) has also expressed deep scepticism. At the EU summit on 17-18 December, strong opposition was expressed by a number of countries against allowing Nord Stream II to go ahead.

If, however, Nord Stream II does proceed, Ukraine will suffer a further loss of more than US\$2 billion in transit fees annually on top of what it lost earlier from the effects of Nord Stream I.

Given the desperate state of Ukraine's economy and public finances, and even with the IMF support that has raised its international reserves to a princely US $\$ 13$ billion, sums like US $\$ 2$ billion here and US $\$ 3$ billion there may be enough to bankrupt the country. ${ }^{17}$ Russia, by contrast, still has US $\$ 375$ billion in its reserves, despite the steady and damaging drain by Putin's various geopolitical projects.

While it has noted progress by Ukraine in its regular reports, the IMF usually adds the caveat that the country's already clouded outlook for economic recovery depends on no further worsening of the military situation in eastern Ukraine. For the moment, Moscow is constrained in that respect by its desire to obtain sanctions relief. But another 'outbreak' of fighting in eastern Ukraine at some point could be economically ruinous for Ukraine; and it would not be too difficult for Moscow to devise other punishments that would bring Ukraine financially undone.

Moscow's recent military restraint is thus not a sign of a newly felt moderation on the part of Putin and his colleagues, but rather a result of the pressure he is under because of low energy prices and Western sanctions on Russia's economy. GDP growth dwindled to close to nothing even before the sanctions were applied; a decline of some 4 per cent is expected this year, and if sanctions are not lifted, a further decline is likely next year. But with his heavy military commitment in Syria, and now his extensive economic sanctions against his latest enemy, Recep Tayyip Erdoğan's Turkey, Putin has demonstrated yet again that no economic price is too great for his adoring subjects to pay when his geopolitical projects demand it.

17 See Anders Åslund, 'Ukraine must not pay Russia back', Atlantic Council, 2 Nov. 2015, www.atlanticcouncil.org/blogs/new-atlanticist/ukraine-must-not-pay-russia. 
He would much prefer that sanctions be removed, of course, and he is working to that end with his numerous EU allies and sympathisers along the political spectrum - people like Sigmar Gabriel; Viktor Orban, the authoritarian right-wing Prime Minister of Hungary; Greece's present leadership and Cyprus, regardless of leadership; Miloš Zeman and Václav Klaus, President and former president of the Czech Republic; Slovak Prime Minister Robert Fico on some issues, though not on Nord Stream II; European Commission President Juncker; and EU 'foreign minister' Federica Mogherini and her patron, Italian Prime Minister Matteo Renzi. More broadly, there is a widespread and apparently growing desire among many European elites to get back to 'business as usual' with Russia, a sentiment that Juncker embodies, together with his perceptible distaste for US influence on European affairs.

To date, these currents have been held in check with great determination by Merkel. Now, however, the Chancellor's capacity to maintain support for sanctions against such widespread scepticism is coming under greater pressure from various quarters, both domestically and in the European Union more generally. Moreover, her own political position has been weakened by her quixotically generous response to the huge influx of would-be migrants into Europe, which, like many in the humanitarian German intelligentsia, she seems to see as a chance for Germany to put the seal on its European leadership role and to atone finally and decisively for sins past. This has damaged her domestic standing both in her party and the population.

The migration issue has also preoccupied many EU members desperate to find a short-term fix, and has created severe tensions and divisions between member states. While still trying to defend her initial position, Merkel is now championing the idea, most clearly enunciated by European Council President Donald Tusk, that preserving Schengen and beginning to repair the whole chaotic situation requires adequate protection of Europe's external borders, a radical diminution of the inflow and the safe return of those not found to be refugees.

Along the way, and via her serious further preoccupations with Putin in Syria, the Paris atrocities, and other migration/terrorism issues, the Chancellor's capacity and will to ensure that the European Union holds the line on sanctions may have been damaged. Rolling back sanctions while Russia is still ensconced in Ukraine would be a 
severe blow to EU and transatlantic unity and a huge boost for Putin's fortunes both domestically and internationally. Merkel, the pacifist and nuanced supporter of Putin's Nord Stream II operation, is arguably at this point a more crucial pillar of Western resistance to Russian aggression in Europe than NATO itself. 


\section{Select bibliography ${ }^{1}$}

Allenova, Ol'ga, 'Viktor Yanukovich vzoidet na zapade', Kommersant, 26 Feb. 2010.

Ananicz, Szymon, 'Armenia turns away from the EU', Centre for Eastern Studies (Warsaw) Eastweek, 4 Sep. 2013.

Applebaum, Anne, 'Russia and the great forgetting', Commentary, 1 Dec. 2015, www.commentarymagazine.com/articles/russia-greatforgetting/.

- 'The risks of putting Germany front and center in Europe's crises', Washington Post, 20 Feb. 2015, www.washingtonpost.com/ opinions/germanys-central-role/2015/02/20/d1119cd4-b8f8-11e4aa05-1ce812b3fdd2_story.html.

- 'The myth of Russian humiliation', Washington Post, 17 Oct. 2014, www.washingtonpost.com/opinions/anne-applebaum-natopays-a-heavy-price-for-giving-russia-too-much-credita-trueachievement-under-threat/2014/10/17/5b3a6f2a-5617-11e4809b-8cc0a295c773_story.html.

- Iron Curtain: The crushing of Eastern Europe 1944-1956, New York: Doubleday, 2012.

Åslund, Anders, 'Ukraine must not pay Russia back', Atlantic Council, 2 Nov. 2015, www.atlanticcouncil.org/blogs/new-atlanticist/ ukraine-must-not-pay-russia.

1 The online sources cited were usually accessed in the month before the original publication of the article in question. A small number of them may not be still available. Articles on the internet critical of Russian policies are sometimes subjected to cyber attacks. 
Asmus, Ronald, 'Finlandization of Georgia and Ukraine', Moscow Times, 3 Mar. 2010.

'Bad decisions', Kyiv Post, 18 Mar. 2010, www.kyivpost.com/opinion/ editorial/bad-decisions-62055.html.

Baer, Daniel, 'Russia's ongoing violations in Ukraine', US Mission to OSCE, 3 Sep. 2015, osce.usmission.gov/sep_3_15_russias_ violations.html.

Barry, Ellen, 'Rousing Russia with a phrase', New York Times, 9 Dec. 2011, www.nytimes.com/2011/12/10/world/europe/the-saturdayprofile-blogger-Aleksey-navalny-rouses-russia.html?_r=1\&.

Bennett, Kirk, 'The realist case for arming Ukraine', The American Interest, 20 Feb. 2015, www.the-american-interest.com/2015/02/20/ the-realist-case-for-arming-ukraine/.

Bennetts, Marc, 'Russia launches Sputnik to silence dissent, combat West's "information war" against Putin', Washington Times, 16 Nov. 2014, www.washingtontimes.com/news/2014/nov/16/ sputnik-launched-by-russia-to-silence-dissent-comb/?page=all.

Bērziņš, Jānis, 'Russia's new generation warfare in Ukraine: Implications for Latvian defense policy', National Defence Academy of Latvia, Center for Security and Strategic Research, Policy paper no. 2, April 2014, www.naa.mil.lv/ /media/NAA/AZPC/Publikacijas/ PP\%2002-2014.ashx.

Besemeres, John, 'The demographic factor in inter-ethnic relations in Yugoslavia', Southeastern Europe, vol. 4, no. 1 (1977): 1-31.

Bidder, Benjamin, 'Controlling the press', Spiegel Online, 17 Feb. 2012, www.spiegel.de/international/world/controlling-the-press-echoof-moscow-under-pressure-in-russia-a-815731.html.

Bird, Michael et al., 'The great looting of Donbass', EU Observer, 10 Dec. 2015, euobserver.com/investigations/131428.

Blinova, Ekaterina, 'Who controls the past controls the future: Why does West hate Stalin?', Sputnik, 25 Aug. 2015, sputniknews.com/ politics/20150825/1026165590/why-does-west-hate-stalin.html. 
Blome, Nikolaus et al., 'Merkel concerned about Russian influence in the Balkans', Spiegel Online, 17 Nov. 2014, www.spiegel.de/ international/europe/germany-worried-about-russian-influencein-the-balkans-a-1003427.html.

Bodner, Matthew, 'Putin tightens grip on Russian defense industry', Moscow Times, 10 Sep. 2013, www.themoscowtimes. $\mathrm{com} /$ business/article/putin-tightens-grip-on-russian-defenseindustry/506803.html.

Bohm, Michael, 'The 5 biggest events that shaped Putin's 2013', Moscow Times, 30 Dec. 2013.

Bond, Ian, 'Russia's war in Ukraine: Is Minsk the end, or just the start?', Centre for European Reform, 13 Feb. 2015, www.cer.org.uk/ insights/russias-war-ukraine-minsk-end-or-just-start.

Bond, Ian, Christian Odendahl \& Jennifer Rankin, 'The politics and economics of sanctions against Russia', Centre for European Reform, Mar. 2015, www.cer.org.uk/sites/default/files/publications/ attachments/pdf/2015/frozen_sanctions-10787.pdf.

Borger, Julian, 'Russians open new front after Estonian official is captured in cross-border raid', Guardian, 8 Sep. 2014, www. theguardian.com/world/2014/sep/07/russia-parades-detainedestonian-police-officer.

Borger, Julian \& Luke Harding, 'Baltic states wary as Russia takes more strident tone with neighbours', Guardian, 19 Sep. 2014, www. theguardian.com/world/2014/sep/18/baltic-states-wary-russiastrident-estonia-latvia-lithuania-NATO.

Bradshaw, Peter, 'Review of Goodbye Lenin!', Guardian, 26 Jul. 2003, www.theguardian.com/culture/2003/jul/25/artsfeatures.dvd reviews.

Brzezinski, Zbigniew, 'The premature partnership', Foreign Affairs, Mar./Apr. 1994, www.foreignaffairs.com/articles/russian-federation/ 1994-03-01/premature-partnership. 
Bullough, Oliver, 'Inside Russia Today: Counterweight to the mainstream media, or Putin's mouthpiece?', New Statesman, 10 May 2013, www. newstatesman.com/world-affairs/world-affairs/2013/05/insiderussia-today-counterweight-mainstream-media-or-putins-mou.

Bush, Jason, 'Price of victory may be too high for Putin', Reuters, 5 Mar. 2012, www.reuters.com/article/2012/03/05/us-russiaelection-promises-idUSTRE8240EQ20120305.

'Bush Sr. clarifies "Chicken Kiev" speech', Washington Times, 23 May 2004, www.washingtontimes.com/news/2004/may/23/2004 0523-101623-2724r/.

Ciochina, Simion, 'Moldovan migrants denied re-entry to Russia', Deutsche Welle, 21 Dec. 2014, www.dw.com/en/moldovanmigrants-denied-re-entry-to-russia/a-18144394.

Coynash, Halya, 'Why are the Kremlin's proxies in Donbas provoking a humanitarian catastrophe?', Kyiv Post, 28 Sep. 2015, www.kyivpost. com/opinion/op-ed/halya-coynash-why-are-the-kremlins-proxiesin-donbas-provoking-a-humanitarian-catastrophe-398863.html.

_ - 'Russia says Poland, not USSR, was Hitler's ally and responsible for Holocaust', Prava Lyudiny v Ukraini (Human Rights in Ukraine), 25 Sep. 2015, khpg.org/index.php?id=1443091855.

Cunliffe, Philip (ed.), Critical Perspectives on the Responsibility to Protect: Interrogating theory and practice, Abingdon, Oxon: Taylor \& Francis, 2011.

Dahlburg, John-Thor \& Robert Burns, 'NATO ministers approve new force for Eastern Europe', Globe And Mail, 10 Feb. 2016.

Davies, Norman, Rising '44: The battle for Warsaw, New York: Macmillan, 2003.

Dawisha, Karen, Putin's Kleptocracy, New York: Simon \& Schuster, 2014.

'Death toll rises to three from grenade attack near Ukrainian parliament', Radio Free Europe/Radio Liberty, 1 Sep. 2015, www.rferl.org/ content/ukraine-second-national-guardsman-dies/27220213.html. 
'Delegatura rzadu na kraj', Slownik historii Polski, Warsaw: Wiedza Powszechna, 1969.

De Luce, Dan, 'If Russia started a war in the Baltics, NATO would lose - quickly', Foreign Policy, 3 Feb. 2016.

Eckel, Mike, 'Putin calls Soviet collapse a "geopolitical catastrophe"', Union-Tribune San-Diego, 25 Apr. 2006, www.utsandiego.com/ uniontrib/20050426/news_ln26russia.html.

'Emotional Putin wins election as opposition cries foul', EurActiv, 5 Mar. 2012, www.euractiv.com/europes-east/emotional-putinwin-election-opposition-cries-foul-news-511273.

Eremenko, Alexey, 'Inquisitive Pskov lawmaker beaten unconscious', Moscow Times, 31 Aug. 2014, www.themoscowtimes.com/news/ article/russian-lawmaker-beaten-unconscious-after-questioningreports-of-paratroopers-in-ukraine/506156.html.

Erlanger, Steven, 'Putin, at NATO meeting, curbs combative rhetoric', New York Times, 5 Apr. 2008, www.nytimes.com/2008/04/05/ world/europe/05nato.html?_r=0.

Felgenhauer, Pavel, 'Vyrastet li Yalta na oblomkakh Sirii?', Novaya Gazeta, 21 Sep. 2015, www.novayagazeta.ru/politicvs/70024. html?print $=1$.

- 'Jubilant Medvedev praises Yanukovych and threatens Lukashenka', Eurasia Daily Monitor, 22 Apr. 2010.

- 'France fears the loss of Mistral sale', Eurasia Daily Monitor, 4 Mar. 2010.

Frear, Thomas et al., 'Dangerous brinkmanship: Close military encounters between Russia and the West in 2014', European Leadership Network Policy Brief, Nov. 2014, www. europeanleadershipnetwork.org/medialibrary/2014/11/ 09/6375e3da/Dangerous\%20Brinkmanship.pdf.

Friedman, Uri, 'A Ukraine peace plan that excludes Ukrainians is unacceptable', The Atlantic, 1 Sep. 2014, www.theatlantic. com/international/archive/2014/09/response-boisto-peace-planukraine-russia-us/379428/. 
Gebauer, Matthias et al., 'Breedlove's bellicosity: Berlin alarmed by aggressive NATO stance on Ukraine', Spiegel Online, 6 Mar. 2015, www.spiegel.de/international/world/germany-concerned-aboutaggressive-NATO-stance-on-ukraine-a-1022193.html.

Gmitruk, Janusz, Stanislaw Mikołajczyk: trudny powrót, Warsaw: Muzeum Historii Polskiego Ruchu Ludowego, 2002.

Goble, Paul, 'Moscow to dramatically increase spending on "Russia Today"', Window on Eurasia, 30 Sep. 2014, windowoneurasia2. blogspot.com.au/2014/09/window-on-eurasia-moscow-to.html.

_ - 'Volga Tatars demonstrate against Russian persecution of Crimean Tatars', Window on Eurasia, 28 Sep. 2014, windowoneurasia2. blogspot.com.au/2014/09/window-on-eurasia-volga-tatars.html.

- ' 'Hot issue - lies, damned lies and Russian disinformation', Jamestown Foundation, 13 Aug. 2014, www.jamestown.org/ single/?tx_ttnews $\% 5 \mathrm{Btt} \_n e w s \% 5 \mathrm{D}=42745 \#$.Vej35k1-_cs.

Gotev, Georgi, 'Slovak PM calls Nord Stream expansion deal "a betrayal", EurActiv, 10 Sep. 2015, www.euractiv.com/ sections/energy/slovak-pm-calls-nord-stream-expansion-dealbetrayal-317531.

Gregory, Paul Roderick, 'Ukraine is more of an existential threat than ISIS, because it could destroy NATO', Forbes, 23 Sep. 2014, www. forbes.com/sites/paulroderickgregory/2014/09/23/ukraine-ismore-of-an-existential-threat-than-isis-because-it-could-destroyNATO/.

Gressel, Gustav, 'Understanding eastern European attitudes on refugees', European Council on Foreign Relations, 11 Sep. 2015, www.ecfr.eu/article/commentary_understanding_eastern_ european_attitudes_on_refugees4019.

Gross, Jan T., Neighbors: The destruction of the Jewish community in Jedwabne, Poland, Princeton University Press, 2001.

Gross, Jan Tomasz \& Irena Grudzinska-Gross, Golden Harvest, New York: Oxford University Press, 2012.

Harding, Luke, The Snowden Files, London: Vintage, 2014. 
Heinrichs, Rebeccah, 'NATO's nuclear nightmare over Ukraine', Real Clear Defense, 27 Feb. 2015, www.realcleardefense. com/articles/2015/02/27/NATOs_nuclear_nightmare_over_ ukraine_107670.html.

Hoffman, Stephen, 'The power vertical and its chilling effect on democracy', Human Rights in Russia, 5 Mar. 2012, www. rightsinrussia.info/archive/blog/hoffman/power-vertical.

Hokovský, Radko, 'What Central Europeans want to know about the refugee crisis', EU Observer, 18 Sep. 2015, euobserver.com/ opinion/130321.

Holmes, Stephen \& Ivan Krastev, 'The weakest strongman', The New Republic, 11 Jan. 2012, www.newrepublic.com/article/world/ magazine/99527/strongman-putin-march-kremlin.

Horvath, Robert, 'Putin's fiasco', Inside Story, 11 Dec. 2014, insidestory. org.au/putins-fiasco.

'IMF backstabs Russia by lifting loan ban vs. debt-dodging Ukraine', Covert Geopolitics, 10 Dec. 2015, geopolitics.co/2015/12/10/imfbackstabs-russia-by-lifting-loan-ban-on-ukraine/.

Inayeh, Alina, 'Ukraine and the EU: A family portrait', The German Marshall Fund of the United States Focus on Ukraine, 27 Jan. 2010, www.gmfus.org/publications/ukraine-and-eu-family-portrait.

International Centre for Policy Studies, 'Yanukovych uncovered', Inside Ukraine [special issue], Feb. 2010

Ioffe, Julia, 'Taking it off for Putin', The New Yorker, 21 Jul. 2011, www.newyorker.com/news/news-desk/taking-it-off-for-putin.

Iwański, Tadeusz, 'The collapse of Ukraine's foreign trade', Centre for Eastern Studies/ Ośrodek studiów wschodnich, 18 Mar. 2015, www. osw.waw.pl/en/publikacje/analyses/2015-03-18/collapse-ukrainesforeign-trade.

Jackson, Patrick, 'Ukraine crisis: "Frozen conflicts" and the Kremlin', BBC News, 9 Sep. 2014, www.bbc.com/news/worldeurope-29078541. 
Janke, Igor, 'Igor Janke o kulisach pertraktacji z Rosja w sprawie gazu', Rzeczpospolita, 2 Apr. 2011, beta.rp.pl/artykul/636014-IgorJanke-o-kulisach-petraktacji-z-Rosja-w-sprawie-gazu.html.

Judah, Tim, 'Ukraine: A catastrophic defeat, NYRB Blog, www. nybooks.com/blogs/nyrblog/2014/sep/05/ukraine-catastrophicdefeat $/$.

-, 'To Russia with love', The Economist, 18 Sep. 2012, www. economist.com/blogs/easternapproaches/2012/09/russia-andserbia.

Kanygin, Pavel, 'The Donbass war: Assessing the aftermath', Meduza, 14 Nov. 2015, meduza.io/en/feature/2015/11/13/the-donbass-warassessing-the-aftermath.

Karatnycky, Adrian, 'Reintroducing Viktor Yanukovych', Atlantic Council, 8 Feb. 2010, www.acus.org.

Karber, Phillip, 'Russia's hybrid war campaign', Center for Strategic International Studies Russia and Eurasia Program, 10 Mar. 2015, willzuzak.ca/cl/videolinks/karber20150310CSIS.html.

Khodasevich, Antoniya, 'Minsk prikidyvayet kak obmanut' soyuznika', Nezavisimaya Gazeta, 5 Sep. 2012, www.ng.ru/ cis/2012-09-05/7_minsk.html.

Kobos, Andrzej M., 'Witold Pilecki w piekle XX wieku', www.zwojescrolls.com/zwoje09/text02p.htm.

Kochanski, Halik, The Eagle Unbowed: Poland and the Poles in the Second World War, Penguin, 2012.

Kolář, Petr \& Juraj Mesík, 'From Munich to Kyiv', Project Syndicate, 13 Mar. 2015, www.project-syndicate.org/commentary/westdishonor-ukraine-by-petr-kolar-and-juraj-mesik-2015-03.

Kotova, Elena, 'Topor Miasnika' (The Butcher's Axe), Snob, 16 Nov. 2015, snob.ru/profile/23854/blog/100760.

Kramer, Andrew E, 'Gas deal with Belarus gives control of pipeline to Russia', New York Times, 25 Nov. 2011, www.nytimes. com/2011/11/26/world/europe/in-deal-with-belarus-russia-getscontrol-of-yamal-europe-pipeline.html?_r $=0$. 
Kroenig, Matthew, 'Statement', Hearing on 'Regional nuclear dynamics', United States Senate Armed Services Committee, 25 Feb. 2015, www.armed-services.senate.gov/imo/media/doc/ Kroenig_02-25-15.pdf.

Kublik, Andrzej, 'Rosja podbija Ukrainę', Gazeta Wyborcza, 28 Apr. 2010.

Kuzio, Taras, 'Yushchenko versus Tymoshenko: Why Ukraine's National Democrats are divided', Demokratizatsiya, vol. 21, no. 2 (Spring 2013): 215-40, www.taraskuzio.net/Comparative\%20 Politics_files/Kuzio_YuliaVersusViktor.pdf.

- 'Judges mock justice with their useless or corrupt rulings', Kyiv Post, 8 Apr. 2010, www.kyivpost.com/article/opinion/op-ed/ judges-mock-justice-with-their-useless-or-corrupt--63477.html.

- 'Yushchenko and Yanukovych forge an electoral alliance', Jamestown Foundation Eurasia Daily Monitor, 5 Jan. 2010.

Laqueur, Walter, The Terrible Secret, New York: Owl Books, 1998.

Lawson, Piers et al., 'Buckwheat panic grips Russia, Czech leader urges "Finlandization" of Ukraine', Transitions Online, 27 Nov. 2014, www.tol.org/client/article/24582-buckwheat-panic-grips-russiaczech-leader-urges-finlandization-of-ukraine.html.

Linkevičius, Linas, 'Putin has defended the Nazi-Soviet pact. Time for the west to wake up', Guardian, 8 Nov. 2014, www.theguardian. com/commentisfree/2014/nov/07/vladimir-putin-defended-nazisoviet-pact-west-world-war-two.

Litvinenko, Alexander \& Yuri Felshtinsky, Blowing up Russia: Terror from within, Geoffrey Andrews and Co (trans.) London: Gibson Square Books, 2007 (2002).

Loiko, Sergei, 'Russians are leaving the country in droves', Los Angeles Times, 14 Nov. 2011, articles.latimes.com/2011/nov/14/world/lafg-russia-emigration-20111115.

Lucas, Edward, The Snowden Operation, Amazon Kindle Single, 2014. 
Marone, J., 'Russia's interest in warships worrisome', Kyiv Post, 4 Mar. 2010, www.kyivpost.com/article/content/ukraine/russias-interestin-warships-worrisome-61057.html.

Marples, David, 'The great game', Eurasia Daily Monitor, 31 Mar. 2010.

Marson, James, 'Putin to the West: Hands off Ukraine!', Time, 25 May 2010, www.time.com/time/world/article/0,8599,1900838,00.html.

Mayr, Walter, 'Walking the thin line with Catherine Ashton', Spiegel Online, 8 Mar. 2010, www.spiegel.de/international/europe/ european-union-foreign-policy-walking-the-thin-line-withcatherine-ashton-a-682339.html.

Michnik, Adam, In Search of Lost Meaning: The new Eastern Europe, Irena Grudzinska Gross (ed.), Roman S. Czarny (trans.), University of California Press, 2011.

Miller, James, 'Throwing a wrench in Russia's propaganda machine', The Interpreter, 18 Jun. 2014, www.interpretermag.com/throwinga-wrench-in-russias-propaganda-machine/.

Mills, Laura \& John-Thor Dahlburg, 'Change of leadership in Crimea means property grab', Salon, 2 Dec. 2014, www.salon. com/2014/12/02/change_of_leadership_in_crimea_means_ property_grab/.

Monaghan, Andrew, 'The Russian Vertikal: the tandem, power and the elections', Jun. 2011, Chatham House Russia and Eurasia Programme Paper, www.chathamhouse.org/sites/files/chathamhou se/19412_0511ppmonaghan.pdf.

Neef, Christian \& Matthias Schepp, 'The return of Uncle Joe: Crisisstricken Russians nostalgic for Stalin', Spiegel Online, 6 May 2010, www.spiegel.de/international/world/the-return-of-uncle-joecrisis-stricken-russians-nostalgic-for-stalin-a-692971.html.

'No new EU sanctions against Russia as ceasefire holds', EurActiv, 13 Mar. 2015, www.euractiv.com/sections/global-europe/no-neweu-sanctions-against-russia-ceasefire-holds-312895. 
Orttung, Robert \& Christopher Walker, 'Putin's frozen conflicts', Foreign Policy, 13 Feb. 2016, foreignpolicy.com/2015/02/13/putinsfrozen-conflicts/.

'Österreichs Kanzler vergleicht Orbáns Flüchtlingspolitik mit Holocaust' (Austria's chancellor compares Orban's migration policy with the Holocaust), Spiegel Online, 12 Sep. 2015, www. spiegel.de/politik/ausland/werner-faymann-ueber-ungarnfluechtlingspolitik-erinnert-an-holocaust-a-1052448.html.

Pancevski, Bojan, "Moral" Germany cracks as the world turns up on its doorstop', Sunday Times, 20 Sep. 2015.

Pankowski, Rafal, The Populist Radical Right in Poland: The patriots, Abingdon: Routledge, 2010.

Pifer, Steven, 'Curing "Ukraine fatigue"”, New York Times, 9 Feb. 2010, www.nytimes.com/2010/02/10/opinion/10iht-edpifer.html?_r=0.

Pilecki, Witold, The Auschwitz Volunteer: Beyond bravery, Jarek Garliński (trans.), Aquila Polonica, 2012.

Polonsky, Antony, Politics in Independent Poland 1921-1939, Oxford University Press, 1972.

Polyakova, Alina, 'The far-right in Ukraine's far-east', Carnegie Moscow Center, 12 Sep. 2014, carnegie.ru/eurasiaoutlook/?fa $=56604$.

Pomerantsev, Peter, Nothing is True and Everything is Possible: Adventures in modern Russia, Faber \& Faber, 2015.

Pop, Valentina, 'Merkel caves in on Russia appointment', EU Observer, 10 Jan. 2014, euobserver.com/foreign/122680.

Popescu, Nicu, 'Eurasian Union: The real, the imaginary and the likely', European Union Institute for Security Studies Chaillot Papers, no. 132, 9 Sep. 2014, www.iss.europa.eu/publications/detail/ article/eurasian-union-the-real-the-imaginary-and-the-likely/.

Rettman, Andrew, 'Russia imposes Ukraine trade measures', EU Observer, 17 Dec. 2015, euobserver.com/foreign/131564.

- 'Italy clarifies position on Russia sanction', EU Observer, 15 Dec. 2015, euobserver.com/foreign/131514. 
- ' 'Russia targets Cyprus, Hungary, and Italy for sanctions veto', EUobserver, 11 Dec. 2014, euobserver.com/foreign/126879.

- ' 'Mediapart: National Front's Kremlin loan is worth €40mn', EUobserver, 27 Nov. 2014, euobserver.com/foreign/126693.

- ' 'EU countries keen to rebuild Russia relations', EUobserver, 17 Nov. 2014, euobserver.com/foreign/126550.

Rolofs, Oliver, 'Ein Hauch vom Kaltem Krieg' (A breath of Cold War), Munich Security Conference, 2007, www.securityconference.de/ de/ueber-uns/muenchner-momente/ein-hauch-von-kaltem-krieg/.

Rosenberg, Steven, 'Traitors in Putin's Russia', BBC News, 15 Sep. 2014, www.bbc.com/news/world-europe-29202789.

'Russland in politikbezogenen länderrankings', Russland-analysen, no. 197, 26 Feb. 2010, www.laender-analysen.de/russland/pdf/ Russlandanalysen 197.pdf.

Sarotte, Mary Elise, 'A broken promise? What the West really told Moscow about NATO expansion', Foreign Affairs Sep./Oct. 2014, www.foreignaffairs.com/articles/141845/mary-elise-sarotte/abroken-promise.

Satter, David, It Was a Long Time Ago, and It Never Happened Anyway: Russia and the Communist past, New Haven, CT: Yale University Press, 2012.

Schindler, John R., 'Snowden in the U.S-Russian "SpyWar", The National Interest, 27 Jun. 2013.

Schuller, Konrad, 'Neuer Schnee auf altem Schmutz', Frankfurter Allgemeine Zeitung, 15 Feb. 2010.

Schwartz, Robert, 'Visa-free travel for eastern Europe, but with a lot of question marks', DW, 26 Dec. 2015, www.dw.com/en/ visa-free-travel-for-eastern-europe-but-with-a-lot-of-questionmarks/a-18933243.

Schwirtz, Michael, 'Belarus says suspects confessed to subway bombing', New York Times, 13 Apr 2011, www.nytimes. com/2011/04/14/world/europe/14belarus.html?_r=0. 
Secrieru, Stanislav, 'How to offset Russian shadow power? The case of Moldova', PISM (The Polish Institute of International Affairs) Bulletin, No. 125 (720), 31 Oct. 2014, www.pism.pl/files/?id_ plik $=18536$.

Semotiuk, Andriy, 'The Stepan Bandera quandary', www.kyivpost. com/news/opinion/op_ed/detail/64386.

'Semynozhenko wants discussion of idea of union of Ukraine, Russia, Belarus', Kyiv Post, 28 Mar. 2010, www.kyivpost.com/content/ ukraine/semynozhenko-wants-discussion-of-idea-of-unionof--62662.html.

Sestanovich, Stephen, 'What's at stake in Putin's Culture War' (interview with Jeanne Park), Council on Foreign Relations, 17 Aug. 2012, www.cfr.org/russian-federation/stake-putinsculture-war/p28814.

Sherr, James, 'Russia's Minsk and Yalta projects', The Intersection Project: Russia/Europe/World, 29 May 2015, intersectionproject. eu/article/russia-europe/russias-minsk-and-yalta-projects.

- 'Ukraine's elections: Watershed or new stalemate?', Chatham House REP Paper 2010/01 (Feb. 2010), www.chathamhouse.org/ sites/files/chathamhouse/public/Research/Russia\%20and \% 20 Eurasia/pp0210ukraine.pdf.

Shevtsova, Lilia, 'Ukraineas a challengeof perception' , Carnegie Moscow Center, 11 Mar. 2014, carnegie.ru/eurasiaoutlook/?fa=54867.

Shishkin, Philip, 'US delays Ukraine military training, general says', Wall Street Journal, 17 Mar. 2015, www.wsj.com/articles/u-sdelaying-ukraine-military-training-general-says-1426631033.

Shlapak, David A. \& Michael Johnson, 'Reinforcing deterrence on NATO's eastern flank: Wargaming the defense of the Baltics', www. rand.org/pubs/research_reports/RR1253.html.

Shuster, Simon, 'Putin's man in Crimea is Ukraine's worst nightmare', Time, 10 Mar. 2014, time.com/19097/putin-crimea-russia-ukraineaksyonov/.

, 'Why young entrepreneurs are fleeing Russia', Time, 18 Jul. 2011, content.time.com/time/world/article/0,8599,2080414,00.html. 
Silke, Andrew, 'EU embrace of Ukraine fuels Russia tensions', BBC News, 15 Oct. 2013, www.bbc.com/news/world-europe-24532292.

Simmons, Katie, Bruce Stokes \& Jacob Poushter, 'NATO public opinion: Wary of Russia, leery of action on Ukraine', Pew Research Center, 10 Jun. 2015, www.pewglobal.org/2015/06/10/1-nato-publicopinion-wary-of-russia-leary-of-action-on-ukraine/.

Simms, Brendan, 'Defend the West: Is it time to re-arm?', New Statesman, 3 Apr. 2014, www.newstatesman.com/politics/2014/03/ defend-west.

Sindelar, Daisy, 'Russian human rights group faces threat of closure', Guardian, 15 Oct. 2014, www.theguardian.com/world/2014/ oct/14/russian-human-rights-group-faces-threat-closure.

Smirnova, Julia, 'Gabriel spielt in Moskau den Gerhard Schroeder', Die Welt, 29 Oct. 2015, www.welt.de/politik/ausland/article148156440/ Gabriel-spielt-in-Moskau-den-Gerhard-Schroeder.html.

Snyder, Timothy, 'Putin's new nostalgia', New York Review of Books blog post, 10 Nov. 2014, www.nybooks.com/blogs/nyrblog/2014/ nov/10/putin-nostalgia-stalin-hitler/.

- ' 'Ukraine: The new dictatorship', New York Review of Books blog post, 22 Jan. 2014.

- Bloodlands: Europe between Hitler and Stalin, New York: Basic Books, 2010.

- 'The causes of Ukrainian-Polish ethnic cleansing 1943', Past and Present, vol. 179, no. 1 (May 2003): pp. 197-234.

Socor, Vladimir, Eurasia Daily Monitor, 10, 14, 15, 17, 21 Sep. 2015, www.jamestown.org/programs/edm/.

- 'The Contact Group in Ukraine weighted toward Russia', Eurasia Daily Monitor, 18 Jul. 2014, www.jamestown.org/ programs/edm/single/?tx_ttnews \%5Btt_news \% 5D=42645\&tx_ ttnews $\%$ 5BbackPid \%5D=756\&no_cache=1\#.VekVsk1-_cs. 
Solonyna, Yevhen, 'Russia's plan for Ukraine: Purported leaked strategy document raises alarm', Radio Free Europe/Radio Liberty, 20 Aug. 2013, www.rferl.org/content/russia-ukraine-leakedstrategy-document/25081053.html.

Solovyov, Vladimir, 'Konfeta po-Kyivski', Kommersant Vlast, 22 Feb. 2010, www.kommersant.ru/doc/1323691

-, 'Viktor Yanukovych vygliadel vazhnym i politicheskim', Kommersant, 6 Mar. 2010, www.kommersant.ru/doc/1333717.

—, 'Iz Ukrainosti v krainost', Kommersant, 22 Apr. 2010, www. kommersant.ru/doc/1358173.

_ ' 'Viktor Yanukovych proyavil mnogovektornuyu priznatel'nost', Kommersant, 28 Apr. 2010, www.kommersant.ru/doc/1361403.

Solovyov, Vladimir, Natalya Grib \& Oleg Gavrish, 'Vyrvi gaz', Kommersant, 5 Mar. 2010, www.kommersant.ru/doc/1331939.

Solovyov, Vladimir \& Valerii Kucheruk, 'Viktor Yanukovych razrubaet morskoi uzel', Kommersant, 23 Apr. 2010, www.kommersant.ru/ doc/1358706.

Subtelny, Orest, Ukraine: A history, Toronto, 1988.

Svanidze, Tamar, 'Visa-free travel with EU: Green light to Georgia, but not for unlimited travel', Georgia Today, 29 Jan. 2016, georgiatoday. ge/news/2804/Visa-Free-Travel-with-EU\%3A-Green-Light-toGeorgia,-but-not-for-Unlimited-Travel.

'Switzerland officially confirmed case Martynenko. He faces 5 years', Ukrainian Crisis, 23 Oct. 2015, ukrainiancrisis.net/news/14573.

'Tarasiuk: Russia proposes terms contradicting Ukraine's interests in exchange for reduction in gas price', Kyiv Post, 20 Apr. 2010, www.kyivpost.com/content/ukraine/tarasiuk-russia-proposesterms-contradicting-ukrai-64522.html.

Tausendfreund, Rachel Herp \& Bettina Vestring, 'On Ukraine, the EU has made too many misjudgements', Deutsche Gesellschaft für Auswartige Politik, 12 Dec. 2013, ipjournal.dgap.org/en/ article/24666/print. 
'The myth that NATO committed to having no permanent troops in Eastern Europe', Atlantic-community.org, 4 Sep. 2015, www. atlantic-community.org/-/the-myth-that-NATO-committed-tohaving-no-permanent-troops-in-eastern-europe.

Tilford, Simon, 'Poland and Ukraine: A tale of two economies', Centre for European Reform, 31 Mar. 2014, www.cer.org.uk/publications/ archive/bulletin-article/2014/poland-and-ukraine-tale-twoeconomies.

'Top German prosecutor considers NSA investigation', Spiegel Online, 20 Jan 2014.

Tost, Daniel, 'Mogherini, Steinmeier denounce black-and-white foreign policy', EurActiv, 12 Nov. 2014, www.euractiv.com/ sections/global-europe/mogherini-steinmeier-denounce-blackand-white-foreign-policy-309925.

Traynor, Ian, 'Donald Tusk: Putin's policy is to have enemies and to be in conflict', Guardian, 16 Mar. 2015, www.theguardian.com/ world/2015/mar/15/donald-tusk-putins-policy-enemies-conflicteuropean-council-sanctions-russia.

Tumarkin, Maria, 'What it means to be a real journalist', Inside Story, 28 Apr. 2010, insidestory.org.au/what-it-means-to-be-a-realjournalist.

'Tyhypko poprosiv, shtob iomu ne zakrivali rot', Unian, 16 Mar. 2010, www.unian.ua/politics/335821-tigipko-poprosiv-schob-yomu-nezakrivali-rot.html.

'Ukraine: l'OSCE reconnaît la bonne tenue de l'élection', Le Monde, 8 Mar. 2010.

'Ukraine: Reforms helped to stabilize economy, but continued and faster reforms are key', World Bank press release, 5 Oct. 2015, www.worldbank.org/en/news/press-release/2015/10/05/ukrainemacroeconomic-update-october-2015.

Umland, Andreas, "Tushki" and the decline of Ukrainian representative democracy', Kyiv Post, 24 Mar. 2010, www. kyivpost.com/article/opinion/op-ed/tushki-and-the-decline-ofukraines-representative--62429.html. 
UN Human Rights Monitoring Mission Report, 15 May 2014, www. un.org.ua/images/stories/Report_15_May_2014_en.pdf.

Walker, Shaun, 'Azov fighters are Ukraine's greatest weapon and may be its greatest threat', Guardian, 10 Sep. 2014, www.theguardian. com/world/2014/sep/10/azov-far-right-fighters-ukraine-neo-nazis.

Weir, Fred, 'Ukraine struggles to balance lure of Europe, pull of Russia', Christian Science Monitor, 13 Apr. 2011, www.csmonitor. com/World/Europe/2011/0413/Ukraine-struggles-to-balance-lureof-Europe-pull-of-Russia.

Wilson, Andrew, Belarus: The last European dictatorship, New Haven, CT: Yale University Press, 2011.

- 'Dealing with Yanukovych's Ukraine', European Council on Foreign Relations Policy Memo, Mar. 2010, p. 4.

— The Ukrainians: Unexpected nation, 3rd edn, Yale UP, 2009.

Wood, E. Thomas \& Stanisław M. Jankowski, Karski: How one man tried to stop the Holocaust, New York: Wiley, 1994.

Zawadzki, Mariusz, 'Janukowycz: Ukraina będzie bliżej UE', Gazeta Wyborcza, 11 Feb. 2010. 



\section{Further reading}

This bibliography attempts to do two things. Firstly, to help general readers with modest familiarity with the region, but some curiosity about it, to bone up on some of the basics, which often seem to escape Western intellectuals, and are seldom now taught adequately, if at all, in Australian schools or even universities. Secondly, it aims to provide regular observers of Russia and East-Central Europe with some reminders about material available that elaborates on the contemporary issues addressed in this book.

Prejudice is obviously bound to inform any select bibliography. One prejudice that I was certainly applying, and consciously, was to favour, though not exclusively, authors who seemed to have an awareness not just of the views and interests of the Russians and their official representatives, but also of the attitudes and experience of the nations to Russia's west. An absence of any such awareness is not uncommon in Western writers, and in my view can vitiate, sometimes cripplingly, the value of their work.

Anderson, Perry, 'Incommensurate Russia', New Left Review, Jul.-Aug. 2015, newleftreview.org/II/94/perry-anderson-incomm ensurate-russia.

Andrew, Christopher \& Oleg Gordievsky, KGB: The inside story of its foreign operations from Lenin to Gorbachev, London: Hodder and Stoughton, 1990.

Andrew, Christopher \& Vasili Mitrokhin, The Mitrokhin Archive: The KGB in Europe and the West, London: Allen Lane, 1999.

Applebaum, Anne, Iron Curtain: The crushing of Eastern Europe 19441956, New York: Doubleday, 2012. 
—, Gulag: A history, Random House, 2003.

Aron, Leon, 'Putinology', The American Interest, 30 Jul. 2015, www. the-american-interest.com/2015/07/30/putinology/.

Ascherson, Neal, The Polish August, London: Allen Lane, 1981.

Barrass, Gordon, The Great Cold War, A Journey Through the Hall of Mirrors, Stanford University Press, 2009.

Bennett, Kirk, 'The myth of Russia's containment', The American Interest, 20 Jan. 2016, www.the-american-interest.com/2015/12/21/ the-myth-of-russias-containment/.

Bērziṇš, Jānis, 'Russia's new generation warfare in Ukraine: Implications for Latvian defense policy', National Defence Academy of Latvia, Center for Security and Strategic Research, Policy paper no. 2, April 2014, www.naa.mil.lv/ /media/NAA/AZPC/Publikacijas/ PP\%2002-2014.ashx.

Besemeres, John F., Socialist Population Politics: The political implications of demographic trends in the USSR and Eastern Europe, White Plains, New York: M.E. Sharpe, 1980.

Bethell, Nicholas, The Last Secret, London: Deutsch, 1974.

Bild exclusive, 'How Russia finances the Ukrainian rebel territories', Bild, 16 Jan. 2016, www.bild.de/politik/ausland/ukraine-konflikt/ russia-finances-donbass-44151166.bild.html.

Brown, Archie, The Rise and Fall of Communism, London, 2009.

—, The Gorbachev Factor, Oxford University Press, 1996.

Bugajski, Janusz \& Peter B. Doran, 'Black Sea rising: Russia's strategy in Southeast Europe', CEPA (Centre for European Policy Analysis), Feb. 2016, cepa.org/files/?id_plik=2096.

Bullough, Oliver, The Last Man in Russia: The struggle to save a dying nation, New York: Basic Books, 2013.

Caldwell, Christopher, Reflections on the Revolution in Europe: Immigration, Islam and the West, London: Allen Lane, 2009.

Carrère d'Encausse, Hélène, L'Empire éclaté, Flammarion, 1978. 
Charlton, Michael, The Eagle and the Small Birds, London: BBC, 1984.

Chawrylo, Katarzyna, The Altar and Throne Alliance, Warsaw: OSW Studies no. 54, Dec. 2015.

Conquest, Robert, The Harvest of Sorrow: Soviet collectivization and the terror-famine, Oxford University Press, 1986.

- The Nation Killers: The Soviet deportation of nationalities, London: Macmillan, 1970.

— The Great Terror, London: Macmillan, 1968.

Cviić, Christopher, Remaking the Balkans, London: Chatham House, 1991.

Davies, Norman, Europe At War 1939-1945: No simple victory, London: Macmillan, 2006.

—, Rising '44: The battle for Warsaw, New York: Macmillan, 2003.

- Europe: A history, Oxford University Press, 1996.

- God's Playground: A history of Poland, vol. 2, 1795 to the Present, Oxford University Press, 1981.

Dawisha, Karen, Putin's Kleptocracy, New York: Simon \& Schuster, 2014.

Delcour, Laure \& Kataryna Wolczuk, 'Spoiler or facilitator of democratization? Russia's role in Georgia and Ukraine', Democratization, May 2015.

Dugin, Aleksandr, 'Geopolitics of Russia', lecture delivered to the Institute of International Relations in Athens, Aug. 2013, www. youtube.com/watch? $\mathrm{v}=\mathrm{XUOSHO} 4 \mathrm{hDgo}$.

- Foundations of Geopolitics (Osnovy geopolitiki Arktogeya), Moskva, 2000

Dunlop, John, The Faces of Contemporary Russian Nationalism, Princeton 1985. 
'Aleksandr Dugin's Foundations of Geopolitics', The Fourth Political Theory, www.4pt.su/en/content/aleksandr-dugin\%E2\% $80 \% 99$ s-foundations-geopolitics.

Frear, Thomas, Łukasz Kulesa, Ian Kearns, 'Dangerous brinkmanship: Close military encounters between Russia and the West in 2014', European Leadership Network, Policy Brief, Nov. 2014.

Fainsod, Merle, How Russia is Ruled, Harvard University Press, 1953.

Falkowski, 'Maciej, 'Georgian drift: The crisis of Georgia's way Westwards', OSW Warsaw, 22 Feb. 2016, www.osw.waw.pl/en/ publikacje/point-view/2016-02-22/georgian-drift-crisis-georgiasway-westwards.

- 'Ramzanistan: Russia's Chechen problem', OSW Warsaw, Aug. 2015, www.osw.waw.pl/en/publikacje/point-view/2015-0825/ramzanistan-russias-chechen-problem.

Fedor, Julie, 'Chekists look back on the Cold War: The polemical literature', Intelligence and National Security, Dec. 2011.

Feshbach, Murray, Russia's Health and Demographic Crises: Policy implications and consequences, Washington, DC: The Chemical and Biological Arms Control Institute, 2003.

Figes, Orlando, Natasha's Dance: A cultural history of Russia, New York: Metropolitan Books, 2002.

Fitzpatrick, Sheila, On Stalin's Team: The years of living dangerously in Soviet politics, Princeton University Press, 2015.

Freedman, Lawrence, 'Ukraine and the art of exhaustion', War on the Rocks, 11 Aug. 2015, warontherocks.com/2015/08/ukraine-and-theart-of-exhaustion/.

,' 'Ukraine and the art of limited war', War on the Rocks, 8 Oct. 2014, warontherocks.com/2014/10/ukraine-and-the-art-of-limitedwar/.

- 'Ukraine and the art of crisis management', Survival: Global Politics and Strategy, Jun.-Jul. 2014, pp. 7-42, www.iiss.org/en/ publications/survival/sections/2014-4667/survival--global-politicsand-strategy-june-july-2014-3d8b/56-3-02-freedman-6162. 
Funder, Anna, Stasiland, Melbourne: Text Publishing, 2002.

Gaddis, John, The Cold War: A new history, New York: The Penguin Press, 2005.

Garton Ash, Timothy, The File: A personal history, London: HarperCollins, 1997.

- The Polish Revolution: Solidarity 1980-82, New York: Scribner, 1984.

Gessen, Masha, The Man Without a Face: The unlikely rise of Vladimir Putin, New York, 2012.

Gilbert, Martin, The Righteous: The unsung heroes of the Holocaust, London: Doubleday, 2002.

Giles, Keir, 'Russia's 'new' tools for confronting the West: Continuity and innovation in Moscow's exercise of power', Chatham House, Mar. 2016, www.chathamhouse.org/publication/russias-new-toolsconfronting-west.

Gilsinan, Kathy, 'What happens if Aleppo falls?' The Atlantic, 11 Feb. 2016, www.theatlantic.com/international/archive/2016/02/syriaaleppo-assad-russia/462231/.

Glenny, Misha, The Balkans: Nationalism, war and the great powers, London, 1999.

- The Fall of Yugoslavia, London: Penguin, 1992.

Goble, Paul, 'Hot issue - lies, damned lies and Russian disinformation', Jamestown Foundation, 13 Aug. 2014, www.jamestown.org/ single/?tx_ttnews \%5Btt_news $\% 5 \mathrm{D}=42745 \#$.Vej35kl-_cs.

Górny, Grzegorz, Sprawiedliwi: Jak Polacy ratowali Żydów przed Zagłada, Warszawa, 2013.

Gressel, Gustav, 'Russia's quiet military revolution and what it means for Europe', European Council on Foreign Relations, 12 Oct. 2015, www.ecfr.eu/publications/summary/russias_quiet_military_ revolution_and_what_it_means_for_europe4045.

Gross, Jan T., Neighbors: The destruction of the Jewish community in Jedwabne, Poland, Princeton University Press, 2001. 
- Polish Society Under German Occupation: The Generalgouvernement, 1939-1944, Princeton University Press, 1979.

Gross, Jan Tomasz \& Irena Grudzinska-Gross, Golden Harvest, New York: Oxford University Press, 2012.

Gusarov, Vyacheslav, 'Russian private military companies as licensed tool of terror', InformNapalm, 24 Nov. 2015, informnapalm.org/ en/russian-private-military-companies-as-licensed-tool-of-terror/.

Harding, Luke, The Snowden Files, London: Vintage, 2014.

Higgins, Eliot, 'MH17: The open source evidence', 8 Oct. 2015, www. bellingcat.com/news/uk-and-europe/2015/10/08/mh17-the-opensource-evidence/.

Hill, Fiona \& Clifford G. Gaddy, Mr Putin: Operative in the Kremlin, Washington: Brookings Institution Press, 2013.

Honchar, Mykhailo, Oleh Gychko \& Maksym Nedrya, 'Russian-German nur geschäft, or strategy for bypassing sanctions', Euromaidan Press, euromaidanpress.com/2016/01/06/russian-german-nur-geschaft -or-strategy-for-bypassing-sanctions/\#arvlbdata

Horvath, Robert, Putin's Preventive Counter-Revolution: Post-Soviet authoritarianism and the spectre of Velvet Revolution, Routledge, 2014.

- The Legacy of Soviet Dissent: Dissidents, democratisation and radical nationalism in Russia, Routledge, 2012.

Hosking, Geoffrey, The Awakening of the Soviet Union, London, 1990.

- A History of the Soviet Union, London, 1985.

ICPS International Centre for Policy Studies (Kyiv), 'Inside Ukraine', 23 Oct 2015, icps.com.ua/assets/uploads/files/IU_52_ eng_2015_23_10_1350.pdf.

International Crisis Group, 'Russia and the Separatists in Eastern Ukraine', 5 Feb 2016, www.crisisgroup.org/en/regions/europe/ ukraine/b079-russia-and-the-separatists-in-eastern-ukraine.aspx. 
Jarosiewicz, Aleksandra, Azerbaijan: A growing problem for the West', OSW Warsaw, 15 Sep. 2014, aei.pitt.edu/57963/1/ commentary_146.pdf.

Järvenpää, Pauli, 'Zapad-2013: A view from Helsinki', The Jamestown Foundation, Washington, DC, Aug. 2014, www.jamestown.org/ uploads/media/Zapad_2013_View_From_Helsinki_-_Full.pdf.

Jones, Stephen, Georgia: A political history since independence, London, 2013.

Judt, Tony, Postwar: A history of Europe since 1945, London, 2005.

Kochanski, Halik, The Eagle Unbowed: Poland and the Poles in the Second World War, Penguin, 2012.

Laqueur, Walter, 'Détente Plus? How should the West deal with Russia?', World Affairs, Fall 2015, www.worldaffairsjournal.org/ article/d \%C3\% A9tente-plus-how-should-west-deal-russia.

- The Last Days of Europe: Epitaph for an old continent, New York, 2007.

— The Terrible Secret, New York: Owl Books, 1998.

Laruelle, Marlène, Inside and Around the Kremlin's Black Box: The new nationalist think tanks in Russia, Institute for Security and Development Policy, Stockholm, 2009.

Ledeneva, Alena V., Can Russia Modernise? Sistema, power networks and informal governance, Cambridge University Press, 2013.

Leslie, R.F., Antony Polonsky, Jan Ciechanowski \& Z.A. Pelczynski, The History of Poland since 1863, Cambridge University Press, 1980.

Liik Kadri, 'How to talk with Russia', European Council on Foreign Relations, 18 Dec. 2015, www.ecfr.eu/article/commentary_how_ to_talk_to_russia5055.

Litvinenko, Alexander \& Yuri Felshtinsky, Blowing up Russia: Terror from within, Geoffrey Andrews and Co (trans.), London: Gibson Square Books, 2007 (2002).

Lo, Bobo, Russia and the New World Disorder, London: Chatham House, 2015. 
- ' 'Russia's Eastern direction - distinguishing the real from the virtual', Russia/NIS Center, Jan. 2014, www.ifri.org/sites/default/ files/atoms/files/ifrirnr17boboloeasterndirectionjan2014.pdf.

- Axis of Convenience: Moscow, Beijing and the new geopolitics, London: Chatham House, 2008.

Lucas, Edward, 'The Coming Storm: Baltic Sea security', CEPA (Centre for European Policy Analysis) Jun. 2015, cepa.org/ index/?id=f3af38a9500cfc72614a7cb788e5a56b.

—, The Snowden Operation, Amazon Kindle Single, 2014.

—, Deception, Bloomsbury: London, 2012.

- The New Cold War: Putin's Russia and the threat to the West, Palgrave Macmillan 2008.

Malcolm, Noel, Kosovo: A short history, New York University Press, 1998.

— Bosnia: A short history, New York University Press, 1994.

Malia, Martin, Russia Under Western Eyes: From the Bronze Horseman to the Lenin Mausoleum, Harvard University Press, 1999.

Marples, David, 'Decentralization: Pros, cons and prospects', davidmarples.wordpress.com, 25 Jan. 2016, davidrmarples. word press.com/2016/01/25/decentralization-pros-cons-andprospects/.

Mefford, Brian, Ukraine Political Blog, Kyiv, www.brianmefford.net/ blog/.

Menkiszak, Marek (ed.), 'Late Putin: The end of growth, the end of stability', OSW (Warsaw) Point of View, Oct. 2015, www.osw.waw. $\mathrm{pl} / \mathrm{en} /$ publikacje/point-view/2015-10-05/late-putin-end-growthend-stability.

Miller, Robert F., Soviet Foreign Policy Today: Gorbachev and the new political thinking, London, 1991.

Minchenko Consulting, Politburo 2.0 i siriiski gambit (Sokrashchonnaya Versiya), 3 Nov. 2015, www.minchenko.ru/analitika/analitika_57.html. 
Montefiore, Simon Sebag, Stalin: The court of the Red Tsar, London: Weidenfeld and Nicolson, 2003.

Motyl, Alexander, 'Putin's Russia as a fascist political system', Communist and Post-Communist Studies, 49 (2016).

Myers, Steven Lee, The New Tsar: The rise and reign of Vladimir Putin, London: Simon and Schuster, 2015.

Nemtsov, Boris, Il'ya Yashin \& Ol'ga Shorina, 'Putin. Voina' (Putin. War), Moscow, May 2015, www.putin-itogi.ru/putin-voina/.

Oldberg, Ingmar, 'Russia's great power strategy under Putin and Medvedev', Swedish Institute of International Affairs (UI) UI Occasional Papers, no, 1, 2010, www.ui.se/upl/files/44240.pdf.

Pankowski, Rafal, The Populist Radical Right in Poland: The patriots, Abingdon: Routledge, 2010.

Pilecki, Witold, The Auschwitz Volunteer: Beyond bravery, Jarek Garliński (trans.), Aquila Polonica, 2012.

Piontkovsky, Andrei, 'Putin's Russia as a revisionist power', Journal on Baltic Security, vol. 1, issue 1, 2015, www.hudson.org/ research/11386-putin-s-russia-as-a-revisionist-power.

Plokhy, Serhii, The Gates of Europe: A history of Ukraine, Philadelphia, 2015.

Politkovskaya, Anna, A Russian Diary, London: Harvill Secker, 2007.

Polonsky, Antony, Politics in Independent Poland 1921-1939, Oxford University Press, 1972.

Pomerantsev, Peter, Nothing is True and Everything is Possible: Adventures in modern Russia, Faber \& Faber, 2015.

Pomerantsev, Peter \& Michael Weiss, 'The menace of unreality: How the Kremlin weaponises culture, information and money', Institute of Modern Russia, The Interpreter, 22 Nov. 2014, www. interpretermag.com/wp-content/uploads/2014/11/The_Menace_ of_Unreality_Final.pdf.

Pomianowski, Jerzy, Na wschód od Zachodu: Jak być z Rosją?, Warszawa: Rosner \& Wspólnicy, 2004. 
Popescu, Nicu, 'Eurasian Union: The real, the imaginary and the likely', European Union Institute for Security Studies Chaillot Papers, no. 132, 9 Sep. 2014, www.iss.europa.eu/publications/detail/article/ eurasian-union-the-real-the-imaginary-and-the-likely/.

Putin, Vladimir, Bol'shaya press-konferentsia Vladimira Putina, 17 Dec. 2015, kremlin.ru/events/president/news/50971.

Rayfield, Donald, Edge of Empires, London, 2012.

—_, Stalin and His Hangmen, New York: Random House, 2005.

Ruane, Kevin, The Polish Challenge, London: BBC, 1982.

_- To Kill a Priest: The murder of Father Popieluszko and the fall of communism, London, 2004.

Reddaway, Peter \& Dmitri Glinski, The Tragedy of Russia's Reforms: Market Bolshevism against democracy, Washington, 2001.

Roy, Olivier, The New Central Asia: Geopolitics and the birth of nations, London: I.B. Tauris 2000.

Rusinow, Dennison, The Yugoslav Experiment 1948-74, University of California Press, 1978.

Rutland, Peter, 'Back to the future: Economic retrenchment in Russia', Russian Analytical Digest, 23 Mar. 2016, www.isn.ethz.ch/DigitalLibrary/Articles/Detail/?id=196475.

Sakwa, Richard, The Crisis of Russian Democracy: The dual state, factionalism and the Medvedev succession, Cambridge University Press, 2011.

Sarotte, Mary Elise, 1989: The struggle to create post-Cold War Europe, Princeton University Press, 2009.

Sarrazin, Thilo, Deutschland schafft sich ab, Dt. Verlags-Anstalt, 2010.

Satter, David, It Was a Long Time Ago, and It Never Happened Anyway: Russia and the Communist past, New Haven, CT: Yale University Press, 2012.

Schapiro, Leonard, The Communist Party of the Soviet Union, London: Methuen, 1970. 
Sebastyen, Victor, Revolution 1989: The fall of the Soviet Union, London: Weidenfeld and Nicolson, 2009.

Sell, Louis, Slobodan Milošević and the Destruction of Yugoslavia, Duke University Press, 2002.

Serkelchyk, Serhy, The Conflict in Ukraine: What everyone needs to know, Oxford University Press, 2015.

Servettaz, Elena, 'Putin's Far-Right friends in Europe', Institute of Modern Russia, 16 Jan. 2014, www.theatlantic.com/international/ archive/2016/02/syria-aleppo-assad-russia/462231/.

Service, Robert, Comrades: Communism: A world history, London: Macmillan, 2007.

Seton-Watson, Hugh, The East European Revolution, New York: Praeger 1961 .

Shekhovtsov, Anton, 'Is transition reversible? The case of Central Europe', Legatum Institute Transitions Forum, Jan. 2016, www. li.com/activities/publications/is-transition-reversible-the-case-ofcentral-europe.

Sherr, James, 'The new East-West discord: Russian objectives, Western interests', Netherlands Institute of International Affairs, Clingendael, Dec. 2015, www.clingendael.nl/publicatie/new-eastwest-discord-russian-objectives-western-interests.

Sherr, James et al., 'The Russian challenge', Chatham House, 5 Jun. 2015, www.chathamhouse.org/publication/russian-challenge -authoritarian-nationalism.

Shevtsova, Lilia, 'How the West misjudged Russia: What do the normativists stand for?', The American Interest, 1 Jan. 2016, www. the-american-interest.com/2016/01/13/what-do-the-normativistsstand-for/.

- Putin's Russia, Washington: Carnegie Endowment for International Peace, 2003.

Shlapak, David A. \& Michael Johnson, 'Reinforcing deterrence on NATO's eastern flank: Wargaming the defense of the Baltics', rand. org/pubs/research_reports/RR1253.html. 
Snyder, Timothy, Bloodlands: Europe between Hitler and Stalin, New York: Basic Books, 2010.

- 'The causes of Ukrainian-Polish ethnic cleansing 1943', Past and Present, vol. 179, no. 1 (May 2003): pp. 197-234.

Subtelny, Orest, Ukraine: A history, Toronto, 1988.

Szporluk, Roman, Ukraine: A brief history, Detroit 1982.

'The politics of the Putin regime', Russian Analytical Digest, 14 Jul. 2015, www.isn.ethz.ch/Digital-Library/Publications/ Detail/?ots591=0c54e3b3-1e9c-bele-2c24-a6a8c7060233\&lng= en\&id=192579.

Tolstoy, Nikolai, Victims of Yalta, London: Hodder and Stoughton, 1977.

Trenin, Dmitri, 'Vnutrenni kontur vneshnei politiki' (The domestic contours of external policies), Moscow Carnegie Centre, 9 Dec. 2015.

Weiss, Michael \& James Miller, 'How we know Russia shot down MH17', The Daily Beast, 17 Jul. 2015, www.thedailybeast.com/ articles/2015/07/17/how-we-know-russia-shot-down-mh17.html.

Wilson, Andrew, 'Survival of the richest: How oligarchs block reform in Ukraine', ECFR Policy Brief, 24 Apr. 2016, www.ecfr.eu/ publications/summary/survival_of_the_richest_how_oligarchs_ block_reform_in_ukraine6091.

- ' 'No stability under occupation in Crimea', European Council on Foreign Relations, 18 Mar. 2016, www.ecfr.eu/article/commentary_ crimea_no_stability_under_occupation6042.

- Ukraine Crisis: What it means for the West, Yale University Press, 2015.

- Belarus: The last European dictatorship, New Haven, CT: Yale University Press, 2011.

- The Ukrainians: Unexpected nation, 3rd edn, Yale UP, 2009 (a new edition is to appear in 2016).

- Virtual Politics: Faking democracy in the post-Soviet world, Yale University Press 2005. 
Wood, E. Thomas \& Stanisław M. Jankowski, Karski: How one man tried to stop the Holocaust, New York: Wiley, 1994.

Yaffa, Joshua, 'The double sting: A power struggle between Russia's rival security agencies', The New Yorker, 27 Jul. 2015, www. newyorker.com/magazine/2015/07/27/the-double-sting.

Zamoyski, Adam, Poland: A history, London, 2009.

Zawodny, J.K., Nothing But Honour: The story of the Warsaw Uprising, 1944, London: Macmillan 1978.

- Death in the Forest: The story of the Katyn Forest Massacre, University of Notre Dame Press, 1962. 



\section{Index}

Abe, Shinzo 415

Abkhazia 4, 154, 159, 164, 171, 312, 313, 364, 398, 409, 413, 414-15 Afghanistan 99, 148, 160n.31, 175, $227,248,264,272,365,456$

Akhmatova, Anna 156

Akhmetov, Rinat 156-57, 346

Akimova, Iryna 157, 158n.27

Aksyonov, Sergey 343-44, 372, 407

al-Assad, Bashar 212, 307, 452

al-Assad, Hafez 307

al-Maliki, Nouri 309

Alasania, Irakli 414

Aliyev, Heydar 404

Aliyev, Ilham 404, 405

All-Russian National Front (ONF)

125-26, 201, 290

Anders, Władysław 42, 46, 72

Andreyeva, Nina 293

Angers (France) 51, 52n.4

Anschluss 416

Antyufeyev, Vladimir 372, 372n.15

Arab League 184

Arab Spring 125, 217, 226, 242, 243, 456

Arkhangelsk 114

Armenia 17, 113, 133, 298, 299, 303-04, 314, 315, 320, 322 Map

3, 403, 405-06

Armenian genocide of 1916405

Armia Krajowa (Home Army, AK)

$41,60,654$

Ascherson, Neal 33
Ashton, Catherine 99, 145n.9, 438

Assange, Julian 360

Asselborn, Jean 462

Atambayev, Almazbek 227

Auschwitz 50, 66-67, 68, 69-70, 71, 72, 73, 74, 75, 76

Auschwitz I (Stammlager) 66, 69,70

Auschwitz-Birkenau 68, 70

Austro-Hungarian Empire 37, 336

Autocephalous Ukrainian Orthodox

Church 276, 337

Azarov, Mykola (Nikolai) 157, 158,

161,304

Azerbaijan 17, 133, 228, 298, 303,

314, 320, 322 Map 3, 403, 404,

405

Azov Battalion 370, 371

Baghdad 309, 456

Bakiyev, Kurmanbek 160n.31

Baltic region 11, 17, 32, 81, 333, 337,364

Baltic Sea 21, 95, 148, 277, 429

Baltic states 8, 12, 15, 36, 77, 100, $106,147,176,177,222,255$,

$313,314,321,333,339,364,378$

$-79,399,402,403,415,417-18$,

$440,441,464$

Bandera, Stepan 105, 144, 144n.7, 161

Barroso, José-Manuel 270-71

Bashkortostan 295 
Begin, Menachem 42

Belarus 8, 10, 11, 38, 126, 153, 167-

78, 181-82, 187-91, 225-26,

233, 257, 275-76, 280, 282, 284,

$339,348,421$

and Europe 133, 170, 175, 176,

$181,190-91,283,298,314$,

325,403

and Poland 99, 104, 113

and Russia 18, 31, 39, 99, 107,

$155,159,160,169-71,172$,

$174,175,177,178,181,182$,

185, 193, 195, 216, 223, 271,

275, 276, 277, 280, 298-300,

$301,314,317,333,333,403$,

404,413

and the United States 170

anti-semitism 177

democracy 108, 134, 168, $169,171,175,177,187-88$, 200, 225, 268, 281-82, 325,

404,405

economy 10, 108, 134, 172,

$182,188,216,225,281$

elections 10, 137, 167, 170-71, 172, 173, 178, 181,

$187,188,190,195,225,255$,

256-57, 281-82

energy subsidies 170, 173,

$256,274-75,277,280-81$

gas $95,171,226,227,278,280$

military 12

World War II 14, 177

Belgrade 394, 395, 396-97

Bell, Coral 389

Belovezhskaya Forest 31

Bełżec 53, 56

Berlin 32

Berlin Wall 31, 35, 81, 382, 387, 392

Berling, Zygmunt 42, 44, 74

Berlusconi, Silvio 176, 208, 249

Bertelsmann Transformation Index 155

Bierut, Bolesław 73
Bildt, Carl 317

Bishkek 227

Black Sea 203-04, 333, 345, 391, 408,429

Black Sea Fleet 147, 152, 153, 154, $161,162,163,165,276,301$, $319,343,367$

Bolotnaya (Muddy) Square 291

Bolsheviks 37, 64, 65, 217, 338

Borodai, Aleksandr 372

Borowski, Tadeusz 75

Bosnia 372, 396, 397

Bosnia \& Herzegovina vii Map 1

Breedlove, General Philip 428

Brexit 13

Brezhnev, Leonid 151, 227, 227n.3, 245, 288

Browder, William 114, 447

Brussels see European Union

Brzezinski, Zbigniew 159, 276

Budapest 32

Budapest Memorandum on Security Assurances 14, 348, 364, 418, 430,431

Bulgaria 146, 366

Bulgaria 121

Bullough, Oliver 360

Burkhalter, Didier 375

Burns, Arthur 359

Bush, George H. 246, 388

Bush, George W. 2, 3, 93, 146, 459n.30, 246, 300, 332, 392, 399

Carter, Ash 12

Carter, Jimmy 350

Cathedral of Christ the Saviour (Moscow) 260-61

Catherine the Great 402

Catholicism 33, 52n.4

Ceauşescu, Nicolae 207, 208

Central Electoral Commission (Russia) 210, 219, 240

Chavez, Hugo 290

Chechnya 210, 217, 249, 260, 268, 308-09, 384-85, 398, 456 
Chekhov, Anton 156

Chirac, Jacques 93, 135n.2, 176

Christian Democrats (Germany) 325

Churchill, Winston 44, 45, 54, 427, 434

Churov, Vladimir 210, 219, 220, 230, 232

Civic Platform (Poland) (Platforma Obywatelska) 8, 82, 92-93, 94, 95, 96, 97-98, 103, 104, 105, $112,120,129,130,131,132$, $133,198,200$

Clinton, Bill 147n.13, 195, 261

Clinton, Hillary 108, 220, 248, 297, 344, 393

Cohen, Stephen F. 246

Collective Security Treaty Organization 18, 226

Commission for Difficult Matters 94

Committee of Soldiers' Mothers (Russian) 373

Common Economic Space 172

Commonwealth of Independent States 164

communism $60,76,83,87,92,131$

fall of 5, 11, 31, 32, 35, 75, 84, 103, 107, 119, 169, 219, 308, $349,387,388$

Cracow 69, 96, 119

Crimea 8, 16, 147, 152-53, 155, 164, 264, 276, 305, 319, 331, 342, $343,344-45,351-52,367,372$, 407, 433, 456, 467, 469 annexation by Russia 14, 16, $329,330,333,335,336,339$, $342-43,344,345,347,348$, $349,352,355-56,357,358$, $361,352,366-67,374,376$, 378, 381, 406-08, 419, 428, 433, 439, 456, 459, 462, 464, 469,470

naval facilities, lease by Russia 8, 152, 163, 172, 226, 277, $301,319,343$
'Crimea is Ours' (Krymnash) 384

Croatia vii Map 1, 396

Cuba 222, 349

Curzon Line 44

Customs Union see Eurasian Customs Union

Cyprus 286, 289, 295, 401, 473

Cyrankiewicz, Józef 52, 58-59, 73-74

Czech Republic 94, 126, 191, 398-99, 419, 434, 441, 473

Czechoslovakia 36, 227n.3, 349, 416

Dačić, Ivica 271

Damascus 456

Dayton settlement 396

Deauville 176

Debaltseve 421-22, 426

Deep and Comprehensive FreeTrade Agreement (DCFTA) 193, 194, 314, 376, 423-24

Deep and Comprehensive FreeTrade Area 315

Democratic Left Alliance (DLA) (SLD) 92, 93, 94, 103, 129, 103 demokratiya (democracy) 386 dermokratiya (shitocracy) 386 Deutscher, Isaac 76 Dmitriyeva, Oksana 220

Dnepropetrovsk 151

Dniester River 410

Dobrushin, Roland Lvovich 123

Dolgov, Konstantin 378

Donbas 158, 159, 367, 424, 451-52, 463-64, 465, 466-67, 468

Donetsk 16, 19, 151, 156, 158, 191, $319,335,339,346,347,348$, 369, 372-73, 374, 375, 378, 391-92, 407, 408, 421, 422, 426, 451, 463, 466-67

Donetsk People's Republic 371-72

Dresden 264, 330, 382

Dubček, Alexander 32, 227n.3

Dzhemilev, Mustafa 345 
East Germany / German Democratic

Republic 35, 131, 264, 325, 330,

$382,384,397$

Eden, Anthony 54

Ekho Moskvy (Echo of Moscow) 234

Erdoğan, Recep Tayyip 453, 454, $456,457,472$

Erler, Gernot 326

Estonia 2-3, 272, 333, 348-49, 364, $365,378,417$

Russia's cyberwar against 2, 4, 8, 185, 215, 272, 297, 312, 333, 348-49, 364, 417

Eurasian Commission 18

Eurasian Customs Union / Customs

Union 18, 157, 171, 182, 193, 222, 277, 298, 304, 312, 333, $340,403,405,424$

Eurasian Economic Union / Eurasian Union 18, 19, 208, 222-23, 227, 254, 270, 271, 277, 282, 283, 298, 312, 403, 404, 405, 468

Euromaidan see Maidan Nezalezhnosti (Independence Square) protests

European Commission 137n.10, 270-71, 275, 400, 473

European Council on Foreign Relations 148n.16, 429, 473

European Court of Human Rights 278

European Parliament 105, 145, 154, 311,351

European Union 4, 8, 9, 10, 13, 14, 17-18, 22, 94, 95, 99, 113, 126, $130,134,146,151-52,161,169$, $170,194,212-13,222,228$, 270, 271, 274, 275, 279, 280-81, 283, 298, 301, 302, 304, 311, 313, 314-16, 318-20, 332, 340, 341, 366, 376, 392-93, 399, 401, 402, 403, 404, 405-06, 409, 410, 411-13, 414, 417, 424, 434, 437, $439,441,454,455,457,471,473$ and Armenia 133, 298-99, 314,320

and Azerbaijan 133, 298, 314,404

and Belarus 10, 126, 168-69, $170,172,175,181,182,225-$ 26, 256, 280, 283, 298-99, 314,404

and Bulgaria 146

and Cyprus 289, 295

and Georgia 4, 103, 298, 314,

$320,321,333$

and Greece 455

and Kazakhstan 298-99

and Kyrgyzstan 298-99

and Lithuania 299

and Moldova 17, 23n.16, 113,

126, 133, 147, 270, 271, 298, $303,314,315,320,323,324$, 333, 403-04, 405, 410, 412

and Poland 8, 9, 93, 94, 101, 113, 130, 132, 133, 183, 198, 200, 314, 339-40

and Romania 146

and Russia 11, 12, 20, 22, 100, $101,109,168-69,175,182$, $183,193,208,217,223,228$, 248, 275, 295, 297, 298, 300, 303, 305, 310, 311, 315, 330, $332,341,376,401-02,403$, $418,419,426,435,436,437$, $438,440,457-58,461$

and Serbia 419 and Sweden 314 and Tajikstan 298-99 and Turkey 454 and Ukraine 7, 10, 12, 25, 133, 134, 143, 147, 151, 153-54, 157, 160, 168-69, 170, 172, 182, 191, 192, 193, 194, 195, 223-25, 258, 277, 278, 279, 283, 298, 299, 305, 311, 314, $315,316,318,319,324,325$, $326,340,341,352,366,371$, $373,377,392,419,423,429$, $430,431-32,434,468,469-70$ 
Association Agreement (AA) 13, $14,303,340$

and Ukraine 13, 14, 21, 134, 154, 193, 195, 223, 225, 299, 301, 304, 311, 315, $318,340-41,352,366$, 403-04, 406, 423-24, 469 and Armenia 304, 320, 321, 403, 405

and Azerbaijan 403 and Belarus 403, 404 and Georgia 333, 403-04, 413,414

and Moldova 271, 324, 333, 403-04, 410-12

Eastern Partnership (EaP) 9, 11, 103, 133-34, 298-99, 301, $314-15,322,324-26,352$, 403, 404, 405

economic performance 17 expansion of $7,8,11,12$, $134,146,283,313,400,437$ migration $24-25,24 \mathrm{n} .18,452$ eurozone 116, 268

ExxonMobil 205

Fajner, Leon 53

Faymann, Werner 24

Federal Security Service

(Federalnaya Sluzhba

Bezopasnosti, FSB) 107, 161-62,

$185,211,235,266,267,385$

Fico, Robert 21, 473

Filat, Vlad 270

Finland 15, 222, 272, 352, 401, 415,455

Firestone, Jamison 447

Firtash, Dmytro 152, 157, 158

Forward Ukraine 259

France 37, 99, 223, 313, 348, 364, 423, 455

and Russia 176, 428-29

and the European Union 20, 105, $351,375,401,432$ and World War II 39, 41, 51, 53
Frankfurter, Felix 55, 56

Freedom House 151, 199

Front for the Rebirth of Poland 59

Fullilove, Michael 351

Gabriel, Sigmar 471, 473

Gaddafi, Muammar 184, 220, 242, 308, 398, 456

Garden of the Righteous Among the Nations (Yad Vashem) 87

Garibashvili, Irakli 414

Garliński, Jarek 71, 75

Garliński, Józef 75

Gauck, Joachim 264, 325

Gazeta Wyborcza 82, 87, 130, 234

Gazprom 21, 152, 158, 161, 192, 198-99, 224, 225, 226, 227, 234, 274-75, 277, 280, 304, 317, 325, 336,471

Gazprom-Media 234

Gdańsk 31, 32, 81, 95

Gentiloni, Paolo 462

Georgia 93, 94, 103, 155, 162, 174, 248, 305, 322 Map 3, 339, 414,464 and NATO 3, 103, 176, 312, 399, 402-03

and Russia 3-4, 11, 17, 108, 148, 169, 185, 205-06, 222, 270, $312,313-14,320-21,333$, 374, 375, 391-92, 398, 409, 413, 414-15, 441, 468 invasion of Georgia 7, 8, 16 , 20, 94, 99-100, 108-09, $147,171,175,263,272$, 273, 288, 297, 320, 322, $324,333,364,374,403$, 409,413

and the European Union 4, 17, 20, 23, 23n.16, 103, 113, 133, 147, 298, 314, 315, 320, 403-04, 405, 413, 414 and the West 3,4,17, 104, 165, $273,297,344,365,414$ 
elections 108, 270, 321, 413

Georgian Dream 321, 413

Rose Revolution 103, 242

United National Movement 321, 413,414

Germany 21, 38, 106, 125, 135n.2,

$157,223,239,249,286,289$, $310,324-26,360,386,387-88$, $390,439,459,473$

and Belarus 170, 171, 175 and NATO 12, 148, 176, 313, $363,375,428$

and Poland 93, 94, 95, 105, 113, 130-31

and Russia 99, 121, 126, 148, 175-76, 184, 264, 325-26, 330, 341, 375, 381, 392, 397, 401, 418, 422, 423, 428, 436,438

and the European Union 20, 324, $325,341,375,418,439$ and the United States 12 and World War II 1, ln.1, $38-41,42,43,46,49,50,51$, 52-54, 55-56, 57, 59, 65-66, 67, 69-70, 71-72, 73, 75, 97, $95,144,344,416$

Bundestag elections 325 energy 21, 95, 227, 278, 471 Free Democrats 325 immigration 23-25 Nazism 24, 40, 41, 5ln.3, 59, $63,73,76,77,80,86,91$, $95,97,105,175,344,390$, 433-34, 453

Social Democrats 21, 34, 325

Giedrojc, Jerzy 103

Gierek, Edward 32, 81

Girkin, Igor (Strelkov) 371

glasnost 34, 230, 243, 384, 386

Glazyev, Sergey 295

Gleiwitz Incident 433

Gmail 185

GOLOS Russian election monitors $215,240,273$
Gomułka, Władysław 80-81, 117

Gongadze, Hryhorii 195

Gorbachev, Mikhail 2, 5, 34, 35-36, 77, 124, 175, 176, 184, 211, 228, 230, 234, 249, 290, 381, 384, $385,387,388,389,392,444,446$

Greece 25, 147, 176, 401, 452, 455,473

Gref, German 245

Gregory, Paul Roderick 418

Grexit 455

Gross, Irena Grudzinska 85-86

Gross, Jan Tomasz 85-86, 87

Groysman, Volodymyr 27n.22, 371

Grybauskaite, Dalia 299

Gudkov, Gennady 262

Hagel, Chuck 295

Hanson, Pauline 293

Havel, Václav 126

Herman, Hanna 157

Hermitage Capital Management 114 Heydrich, Reinhard 433

Hezbollah 308, 456

Hitler, Adolph 1n.1, 40-41, 42, 53, 63, 65-66, 69, 71, 76, 77, 125, $171,365,385,409-10,416,433$

Hitlerjugend 53

Hohenzollerns 37

Hollande, François 20, 21, 423, 428, 429, 429n.9, 434, 453, 459, 462,466

holodomor 305, 338

Hotmail 185

Hromadske Ukranian internet TV station 305

Hudes, Karen 360

Hull, Cordell 55

Human Rights Council (Russia) 114 Hungarian Socialist Workers' Party 35

Hungary 23, 32, 34, 35, 51, 147, 222, 366, 398-99, 401, 419, 473

Hussein, Saddam 135n.2, 308, 456 
hybrid warfare $3,8,16,355,356 \mathrm{n} .2$, $367,372,412,418,423,431$,

433, 436

Ilovaisk 373

Intergovernmental Aviation

Committee 115-16

Interpol 378

Iran 4, 15, 99, 148, 167, 171, 175,

$212,271,430$

Iraq 15, 135n.2, 309, 398, 456

ISIS 452-53, 454, 456

Islamic State 15, 22, 394, 430, 451

Italy 12, 176, 278, 401, 411, 462

Ivanishvili, Bidzina 4, 321, 324,

413,414

Ivanov, Sergey 251, 296

Jackson-Vanik Amendment 273

Jagiellonian Eastern Policy 103, 106

Japan 330, 415

Jaresko, Natalie 465

Jaruzelski, Wojciech 33-34, 81, 82, 83-84, 84n.2

Jedwabne 83, 86

Jordan 24, 452

Juncker, Jean-Claude 13, 400, 461,473

Kaczyński, Jarosław 8, 82, 83, 84-85, 92-93, 96, 97, 98, 113, 129-30, 131, 183, 196-97, 198, 199

Kaczyński, Lech 8, 9, 82, 83, 84-85, 91, 92-93, 94, 95, 96, 97, 98, 113, $115,130-31,132,183,197,199$

Kadyrov, Ramzan 232, 308-09, 450, 456

Kagan, Robert 390

Kamińska, Ida 57

kapos (prisoner trusties) 67, 75

Karaganov, Sergey 106-07

Karber, Phillip 431

Karski (Kozielewski), Jan 49-61, 70,74
Katyn massacre 9, 40, 42, 50n.2, $55,56,91,94,95,96,97,100$, $101,102,106-07,115,183,185$, 197, 200

Kazakhstan 153, 172, 182, 193, 195 , 223, 226, 270, 272, 277, 298-99, $301,339,348$

Khajimba, Raul 415

Kharkiv 153, 157, 162, 163, 305, 467

Khodorkovsky, Mikhail 85, 114 , $168,186,205,214,230,251$

Kholmanskikh, Igor 292

Khrushchev, Nikita 107, 184, 344

Kielce pogrom 86, 87

King, Larry 360

Kirill, Orthodox Patriarch 154, 192, 260

Kiselyov, Dmitry 359

Kissinger, Henry 361-62

Kiszczak, Czesław 83, 84

Klaus, Václav 473

Klitschko, Vitali 259, 305

Kochanski, Halik 38-41, 46-47

Kołakowski, Leszek 79-80

Kolomiyets, Oleksiy 195-96

Kolyma 40

Kommersant 151-52, 161-62

Komorowski, Bronisław 92, 97, 129, 131-32, 138, 197, 198

Korolevska, Natalia 259

Kosovo vii Map 1, 212, 271, 394-99

Kosovo Democratic League (KDL) 395

Kosovo Liberation Army (KLA) 395-96

Kossak, Zofia 59

Kotova, Elena 457

Kouchner, Bernard 108

Kozyrev, Andrei 389

the Kresy 46-47

krokodil 120

Kuchma, Leonid 150, 153, 157, 163-64, 195 
Kudrin, Aleksei 206, 212, 231, 236, 241, 244, 245, 253, 263, 265, $444,444 \mathrm{n} .2$

Kultura 103

Kuroń, Jacek 79

Kwaśniewski, Aleksander 83, 84, 86,94

Kyiv 152, 161, 163, 164, 182-83, 192, 195, 223, 226, 264, 276, 283, 304, 318, 319, 358, 406

Kyiv Patriarchate 192, 276, 337

Kyrgyzstan 160n.31, 169, 174, 193, 223, 227, 272, 299

Lagarde, Christine 470

Lanzmann, Claude 57

Lavrov, Sergey 99, 106, 247-48, 352

Le Pen, Marine 351, 359, 402, 455

League of Polish Families 93

Lebanon 24, 452, 456

Lebedev, Alexander 234

Lebedev, Platon 114-15

Lepper, Andrzej 94

Levada Centre 243, 294

Levi, Primo 75

Liberal Democratic Party (Russia) 209, 359

Libya 184, 220, 242, 249, 288, 398, 456

Lipski, Jan Józef 79

Lithuania 64, 104, 270, 277, 299, $315,378-79,417$

Litvinenko, Alexander 235, 260, 385,429

Łódź 50

Lowy Institute 351

Lugovoi, Andrei 360

Luhansk 19, 158, 335, 346-47, 369, $370,372,375,378,391,407,408$, $421,422,426,451,463,466,467$

Lukashenka, Alexander 10-11, 99, 104, 108, 134, 137n.9, 137n.10, 155, 160, 160n.31, 167, 169-75, $177,178,181-82,187-97,200$, $216,225-26,227,233,256-57$, 280-82, 314, 363, 404
Lukyanov, Fyodor 390

Lutsenko, Yuriy 150n.19, 168, 278, 279

Luxembourg 462

Luzhkov, Yury 101, 122, 159n.25

Lyashko, Oleh 370

Lyovochkin, Serhiy 157

Macedonia vii Map 1, 396

Magnitsky Act 289, 294

Magnitsky, Sergey 114-15, 273, 447

Maidan Nezalezhnosti (Independence Square, Kyiv) protests 304-05, 337, 339, $345,346,347,350-51,357-58$, $367-68,406,423,464$

Makarov, Nikolai 272

'March events' (Poland) 80

Margvelashvili, Giorgi 414

Mariupol 408, 422, 427

Markov, Sergey 389

Matlock, Jack 362

Matviyenko, Valentina 203

McFaul, Mike 264, 294

Medvedchuk, Viktor 336, 376

Medvedev, Dmitry 6, 99, 100, 107, 108, 113-15, 122, 125, 126, 151, $152,153,161,162,163,168$, 174, 176, 183-87, 196, 197, 200, 201-02, 203, 204-06, 208, 212, 213, 215, 216-17, 219, 221-22, 228, 229, 230, 231, 236, 241, 244, 247, 249, 251-52, 260, 26364, 265, 269-70, 273, 287-88, 289, 290-91, 294, 295, 415, 450

Merkel, Angela 3, 20-21, 95, 99, 102, 130-31, 264, 310, 325-26, $330,364,381,418,423,428-29$, 430, 434, 436, 439, 440, 459, $462,466,471,473-74$

MH17 16, 372, 391, 407, 419-20, $422,435,438$

Michnik, Adam 79-88, 130

Miedzeszyn 117-18

Migranyan, Andranik 389 
Mikołajczyk, Stanisław 44, 45, 58

Miller, Aleksei 471

Miller, Jerzy 115-116

Milošević, Slobodan 271, 395-96

Minsk 167, 171, 182, 189, 225

Minsk I agreement 19, 20, 378, 408, $422,427,451,461,462-63,465$, 466,467

Minsk II agreement 19-20, 421-22, 425, 426-27, 428-29, 429n.10, 430, 435, 451, 461, 462-63, 465, 466,467

Miracle on the Vistula 38

Mironov, Sergei 202-03, 220

Mistral-class amphibious assault vessels 148, 176, 429, 429n.9

Mitterrand, François 387

Mladić, Ratko 396

Moczar, Mieczysław 80, 81

Modzelewski, Karol 79

Mogherini, Federica 438

Mokotów 63-64, 65, 74

Moldova 323-24, 329, 365, 407, 409-12, 467

Alliance for European Integration 320

and Europe 17-18, 108, 126, $165,222,270,303,312,320$, 323-24, 333, 403-04, 405, 410,412

and migration $223,323,410,411$ and Russia 17-18, 108, 126, $165,222,270,303,312,320$, 323-24, 329, 333, 348, 374, 404, 405, 408, 409 elections 108, 410-12 Party of Communists 233 Patria (Fatherland) 411

Transnistria 108, 159, 270, 312, $323,324,329,372,408,410$, 412,467

Molotov-Ribbentrop Pact 15, 39, $50,65,95,365,378,385,399$, 409-10

Mongolia 376
Monte Cassino 43

Montenegro vii Map 1, 222

Morsi, Mohamed 309

Moscow Patriarchate 276, 319, 337

Motyl, Alexander 451

Możejki 104

Mozhaev, Alexander 448

Mubarak, Hosni 242, 452

Munich Security Conference 2, 399

Murmansk 379

Muslim Brotherhood 309

Nabucco project 227-28

Naftohaz 152, 192, 225

Nagorno-Karabakh 320, 405

Namibia 397

Narusova, Lyudmila 262

Naryshkin, Sergei 152

Nashi 243

Nasser, Gamal Abdel 456

National Bank of Ukraine 425

National Front (France) 359, 402,455

NATO 3, 11, 13, 22, 106, 176, 234, 247, 272, 287, 297, 298, 375, 376, 377, 388, 391, 392, 396-97, 399, 401, 402-03, 415, 417, 418, 427, 428, 434, 440, 441, 454, 457,474

2008 summit, Bucharest 3, 7, 11, 207, 313, 399, 400, 402-03 2010 summit, Lisbon 176 2014 summit, Newport, Wales 376

2015 summit, Riga 23

and Estonia 348-49

and Georgia 3, 103, 148, 176 and Poland 8, 61, 94, 98, 105, 106, 132 and Russia 2, 3, 8, 11, 99, 148, 175, 176, 192, 212, 228, 246, 248, 272-73, 303, 310, 313, $314,332,344,363,364-65$, 389, 393, 394, 397-400, 402, $437,440,454,457-58$ 
and Ukraine 3, 13, 105, 141,

$147,148,152,153,155,161$,

$163,192,303,352,373$

expansion 3, 7, 8, 11, 12-13, 99, 146-48, 274, 313, 314, 333, $349,363-64,366,388,389$, 399-400, 402-03, 409, 413, 437

Membership Action Plan 3, 147, 399,403

Nauru 154

Navalny, Aleksey 125, 214, 215 , $220,231,250,252,262,286$, 287, 292, 293

Nazarbayev, Nursultan 226-27

Neklyayev, Vladimir 167

Nemtsov, Boris 221

neo-Nazis 332, 350, 357, 360

new Russians 384, 444, 445

Nezavisimaya Gazeta 281

Nicaragua 154

Night Wolves (Nochnye Volki) 319, 447

Nikolić, Tomislav 271, 419

Nirenska, Pola 58

Nord Stream 21, 95, 152, 194, 227, 277, 325, 471-72

Nord Stream II 471-72, 473, 474

Normandy format 423, 429, 429n.10

North Africa 24, 452

North Caucasus 253, 266, 267, 268, 294-95, 308, 333, 368, 398, 456

North Korea 349, 430

North Rhine-Westphalia 102

Novaya Gazeta 234

Novorossiya see Putin

Obama, Barack 4, 11, 21, 25, 58, 99, 141, 148, 160, 170, 175, 222, 246, 247, 249, 264, 272, 273-74, 295, 297, 300, 326, 348, 364, $377,378,392,393,427,429-30$, 429n.10, 434, 436, 439, 440, 452

Okęcie 116
Onishchenko, Gennady 250

Operation Tempest 43

Orban, Viktor 23, 24, 441, 473

Organization for Security and Cooperation in Europe (OSCE) 20, 240, 248, 282, 374-75, 412, 466, 467

Orwell, George 76, 386

Ostalgie 384

Ostpolitik 175, 324-26, 392

Ozero Dacha Cooperative 382

Palikot, Janusz 129-30, 133

Panjikidze, Maia 414

Parliamentary Assembly of the Council of Europe (PACE) 164 Pavlovsky, Gleb 267

People's Republic of China 18, 19, 99, 126, 171, 178, 184, 216, 223, 228, 237, 270, 275, 279, 283, 298-99, 302, 312, 365, 397, 405,420

perestroika 5, 34, 77, 100, 108, 124, $174,175,230,290,293,386,432$

Peskov, Dmitry 251

Peter the Great 402

Philby, Kim 120

Pilecki, Józef 64

Pilecki, Witold 59, 63-77

Piłsudski, Józef 38, 50, 5ln.3, 59, 103

PKN Orlen 104

Plehve, Vyacheslav 330

Poland 31-36, 37-47, 49-61, 63-77, 79-88, 84-85, 91-109, 103n.5, $106,111-13,115-20,121$, 126-27, 129-34, 135-38, 144, 157, 183, 196-99, 198n.4, 337 and Belarus 8, 10, 99, 104, 170,

$171,173,177$

and France 37, 39, 41

and Georgia 94, 99, 103 
and Germany 1, 38-40, 41, 42,

$43,46,55,66,71-72,87,93$,

$95,103,131,415,433$

and Lithuania 104

and NATO 8, 98, 105, 132,

398-99

and Russia 1, 8-9, 15, 32, 38, $39,40-41,42-44,45,46$,

$52,55,56,65,71,72-73$,

85, 87, 91-92, 94-102, 103,

105, 103-07, 109, 112-13,

115-16, 130, 131, 181, 183,

185, 196-200, 222, 227, 232,

275, 298, 359, 377, 383, 415,

429,471

and Ukraine 8, 94, 99, 104-05,

133-34, 277, 318, 320, 336,

$339,340,341$

and the European Union 8, 9,

$11,23,93,94,95,98,101$,

$104,113,130,132,133-34$,

135-38, 198, 314, 423, 429

and the United Kingdom 37, 39,

$41,43,44,45,53,54,56$

and the United States 21,43, 44,

$45,56-57,106$

anti-Semitism 41, 47, 57, 58,

59-60, 63-64, 65, 76, 80, 83,

$85,86-87,93,132$

Catholic Church 35, 59, 93, 96,

$112,132,178$

communism 31-35, 36, 44, 45,

$52,58,60,63-64,72-73,74$,

75, 79-82, 83, 84, 86, 87, 92,

103, 112, 117, 119

constitution 95

democracy 85, 93, 116, 119

'Eastern Policy' (polityka wschodnia) 103, 106, 198

elections 34, 44, 45, 82, 83, 84,

91, 92, 93, 94, 95, 96, 97-98,

$105,111,112-13,120$,

129-33, 196-97, 198, 199
Law and Justice (LaJ) 8, 9, 82, 83, 84-85, 92-93, 94, 95, 96-98, 98n.2, 103, 104, 105, 113, 115, 119-20, 129, 130-33, 196, 197-98, 199

Polish armed forces 42, 45, 65, 72

Polish Socialist Party 58 PZPR (Polish United Workers' Party) 58, 63

Solidarity 31, 32, 33-36, 61, 81-82, 84, 92-93, 103, 119

Workers' Defence Committee 32

World War I 37, 64

World War II 1, 38-47, 49, 50, 50n.2, 51, 5ln.3, 52-56, 52n.4, 59, 60, 65, 67-68, 72$72,76,83,85,87,91-92,95$

Politkovskaya, Anna 234, 385

Pomerantsev, Peter 443, 446-50

Pope John Paul II 32

Pope Pius XII 54

Poroshenko, Petro 27n.22, 340, 347-48, 353, 370-71, 373, 374, $375,376,377-78,407,408,422$, 423, 462, 464, 465, 466, 470

Powązki Cemetery, Warsaw 75

Poznań 32

Prague 32, 119

Presidential Medal of Freedom (US) 58

prikhvatizatsiya (grabitisation) 386

Priština 397

privatizatsiya (privatisation) 386

Prokhorov, Mikhail 213, 220, 232

Pskov Paratrooper Division 374

Pushkov, Aleksei 389

Pussy Riot 260, 293, 351, 449

Putin 2, 114, 134, 171, 173, 174, 382, 420, 434, 435, 440, 458, 459 and Armenia 17, 303-05, 320, 405, 406

and Azerbaijan 17 
and Belarus 8, 10, 11, 170, 171, $173,174,175,176,188$,

216, 253, 257, 271, 275-76, 280-81, 282, 283

and Chechnya 235, 266, 268, 308-09, 384

and China 228, 275, 302, 420

and Crimea 330, 331, 333, 336, $342,343,344,346-47,367$,

$368,381,406-47,433$,

439,456

and Egypt 309

and Estonia 312

and Finland 272

and Georgia 4, 312, 321-22, 405, 415,468

and Germany 126, 264, 325-26, 428

and Iraq 309, 398

and Libya 183, 220, 249, 398

and Moldova 312, 320, 405, 409 and NATO 3, 8, 11, 17, 22, 212,

247, 248, 272, 310, 389, 397, 398-99, 400, 401, 457

and Poland 8, 85, 91, 93, 94, 95-96, 98, 101, 102

and Russia 1, 5-6, 14, 15, 16, $25,26,99,100,108,109$, $113,115,121,122,124$, 125, 126, 168, 170, 171, 176, 182, 183-87, 201-05, 206, 207-09, 210-18, 219-20, 221-23, 228, 229-33, 24044, 245-47, 248, 249-54, 255-56, 259, 260-64, 265, 266-67, 268, 269-70, 27172, 273, 283, 284, 285-93, 294-96, 295n.7, 307, 311, 329, 330-31, 342, 351, 355, $357,358-59,362,363,364$, 376, 381, 383, 384, 385-90, 391, 392, 393, 409, 415-16, 425, 438, 444, 444n.2, 445, 445n.3, 446-47, 449, 450, $453,454,456$ and Stalin 101, 125, 263, 294, 338

and Syria 22, 25, 25n.21, 249, $307,398,451,452-53,456$, 461

and the European Union 8, 11, $17,18,22,25,208,248,275$, $300,305,310,311,315,316$, $399,400,430,439-40,455$, $457,472-73$

and the United States 4, 101, 212, 246, 247, 248, 249, 263, 264, 269, 272, 274, 285, 293, $302,307,309,310,389$, 429n.10, 430

and the West 2, 8, 15, 16, 19, 22, 27, 100, 101, 109, 202, 208, $211,218,228,236,239,246$, 248, 252, 263, 264, 269, 287, $289,310,326,332,381,387$, $399,401,432,447,456-57$

and Ukraine 6, 8, 11, 16-17, 94, 141, 145, 152, 153, 156, 157, 159n.30, 161, 161n.33, $163,164,165,169,171,175$, $182,224,258,271,275-76$, $277,278,283,300,301,303$, 304, 305, 306, 311, 312, 315 , 316-18, 319-20, 331-32, $333,335-36,338,340,341$, $346-47,367,368,375,376$, 405, 406, 407, 408, 409, 420, 423, 424, 427, 441, 452, 468, $469,470,471,472$

energy diplomacy 222, 225, 256, $274,275,277,278,336,471$ imperialism 7, 8, 15, 17, 22, 26-27, 170, 196, 222, 297, 298-99, 300, 301, 302, 306, 340, 401, 403-04, 427, 467 Novorossiya 345, 405, 467

Quadriga 126 
Radio Maryja 93-94, 132

Ratajski, Cyryl 52, 52n.4

Reagan, Ronald 387, 392

Red Army 37

Renzi, Matteo 461-62, 473

RIA Novosti 391

Rice, Condoleezza 169

Riga 12, 23, 364, 378

Rogozin, Dmitry 212-13, 228, 234, 265, 268, 287, 295, 323, 351, 359

Rola-Żymierski, Michał 74

Roma 346

Romania 146, 207, 323, 409, 410

Romney, Mitt 264, 273, 393

Roosevelt, Franklin D. 44, 45, 55-56, 427

Roshen 340

Rosneft 186, 205, 288

Rospotrebnadzor 316

Rossiiskaya Gazeta 106

Różański, Józef 65

Rugova, Ibrahim 395

Russia 1-6, 13-19, 20, 21-22, $26,36,37,42,64,85,98-99$, 103n.5, 104, 108, 113-14, 118, $120,121-27,145,151,155$, 158, 168-69, 181, 200, 201-06, 207-18, 219-28, 229-37, 239-44, 245-54, 255-56, 257, 258, 259-68, 269-84, 285-95, 297-302, 303-06, 307-11, 312-15, 329-33, 335-53, 35579, 381-400, 401-20, 426-36, 440-41, 443-50, 451-58, 459-60 and Afghanistan 99, 148, 248, $272,365,456$

and Armenial7, 299, 303, 304, $315,320,404-05$ and Azerbaijan 303, 404 and Belarus 10, 11, 12, 13,

18, 104, 107, 134, 169-71, 172-73, 174-75, 177-78, $181,182,185,187-88,189$, 190-91, 193, 200, 216, 223,
225, 226, 227, 255, 257, 271, 274, 275, 276, 277, 278, 280-82, 314, 333, 348, 404, 413,415

and Chechnya 268, 308-09, 385, 397-98

and China 99, 302, 365

and Crimea 8, 16, 153, 155, 172, 226, 277, 301, 305, 329, 330, $331,333,335,336,342-46$, 348, 349, 352, 355-56, 361, $362,366,367,374,378,381$, 406, 428, 433, 439, 459, 462, $464,469,470$

and Cyprus 289 and Czech 419, 473 and Egypt 22, 309, 456 and Estonia 2-3, 4, 8, 20, 215, $272,297,312,333,348-49$, 364,417

and Finland 272, 401, 415, 455 and France 108, 148, 175, 176, $375,423,428-29,432$

and Georgia 3-4, 7, 8, 11, 17, 93, 99, 108-09, 148, 155, 165, 169, 171, 175, 270, 272, 273, 305, 312, 313, 314, $315,320-22,324,333,344$, 364-65, 374, 391, 392, 398, $403,405,409,413-15,468$ and Germany 20-21, 126, 148, 175, 176, 289, 325-26, 375, $392,423,428$

and Greece 455, 473 and Hungary 473 and Iran 99, 271 and Iraq 309, 456 and Italy 461-62, 473 and Kazakhstan 223, 226, 270, 272, 348

and Kosovo 394, 397, 398 and Kyrgyzstan 169, 227, 272, 299 and Latvia 333, 378, 417 
and Libya 184, 398, 456

and Lithuania 299, 378-79, 417

and Moldova 17, 108, 165, 270, $303,312,315,320,323-24$, $329,333,348,374,405,408$, 409-12, 467-68

and NATO 8, 8n.7, 11, 12, 99, $176,248,272,298,303,313$, 314, 344, 363, 364, 365, 366, 377, 388, 389, 392, 393, 392, 397, 398-400, 402-03, 409, 415, 434, 437-38, 440, 454, 457-58, 474

and Pakistan 271

and Poland 8-9, 21, 32, 38, 44, $56,79,85,87,91-92,93$, 94-96, 97-99, 101, 102, 103-04, 105, 106-07, 109, 111-13, 115-16, 130, 131, 134, 181, 183, 185, 196-99, $200,227,423,429$

and Serbia 271, 419 and Sweden 401, 415 and Syria 22, 25, 262-63, 271, 307-08, 393-94, 398, 451, $452,453,455,456$

and the European Union 8, 11,

12, 13-14, 20-21, 27, 99, $101,109,168,193,217,248$, 274, 275, 295, 297, 298, 306-08, 314, 324-25, 330, $332,341,344,348,357,375$, 376-77, 391, 400, 401, 402, 403, 404, 409, 412, 418, 419, 423-24, 426-28, 430, 432, $434,435,436,437-40,454$, 457-58, 461-62, 471, 473-74 and the United Kingdom 21, $423,429,432$

and the United States 4, 11, 21, 99, 101, 108, 109, 113, 114$15,148,170,175,176,177$, 227, 246, 247, 249, 263, 264, 271, 272-74, 294, 295-96,
$297,308,312,326,330,348$, $349,361-62,364,374,375$, $377,378,388,389,392,393$, 398, 423, 427, 429, 430, 432, $436,439,440,466$

and the West 1-2, 13-14, 15-16, $17,19,20,27,108,109$, $113,126,175,200,211,246$, 249, 263, 302, 330, 332, 333, $342,344,349,350,356,357$, $361,363-63,364,365-66$, $368,371,373,375,376,379$, 386, 387, 388, 389, 390, 392, 393, 394, 397, 408, 415, 418, 432-33, 434, 438, 453, 457, 459

and Turkey 453-54, 456, 457, 472

and Ukraine 1n.1, 4, 8, 11, 14, $16,17,19,20,21,22,27$, 93, 99, 100-01, 104-05, $107,134,141,142-43,147$, 151-55, 156-57, 159, 160, 160n.31, 161-62, 161n.33, 163-65, 169, 171, 181, 182-83, 185, 192-93, 194, $195,196,200,223,224,225$, $227,235,271,274,275$, 276-77, 278, 279-80, 282, 299, 300, 301, 303, 304-05, 306, 311, 312, 313-14, 31518, 319-20, 324, 331-33, 335-48, 349, 350, 352-53, 355-56, 357-58, 361, 362, 364, 366-74, 375-76, 377, $378,379,391,392,394$, 399-400, 405-08, 409, 412, 417, 418, 419-20, 421, 42224, 425-26, 427, 429, 430, 431-32, 433, 435-46, 437, 440, 441, 451-52, 459, 460, $461,462-67,468-71,472$ and Uzbekistan 272 
communism 107, 219, 308, 349, 384,387

Constitutional Court 150, 205 constitution 201, 209, 216, 288 Duma 114, 209, 210, 230, 231, 248, 251, 252, 260, 287, 290, $291,294,360,389,450$ economy 2, 5, 16, 18, 19, 99, 100-01, 108, 121, 124, 201, 211-12, 229, 232, 241, 244, 249, 253, 254, 263-64, 286, $330,347,383,384,386,390$, 408-09, 425, 432, 444-45, $446,460-61,472$

elections 115, 124, 125, 201-06, 208, 209, 210, 213, 214, 215, 216, 217, 220-21, 229-32, 233, 234, 235, 239, 240-42, 244, 245, 248, 249, 251, 252, 254, 255, 259, 262, 263, 264, 273, 280, 285, 286, 290, 293, 384

energy and energy diplomacy 2, 4, 6, 21, 95, 99, 107, 145, $146,152,157,161,164,170$, $171,172,173,183,187,192$, $193,198,205,222,225$, 227, 229, 234, 241, 253, 256, 263, 270, 274, 275, 277-78, 280, 281, 283-84, 286, 300, $312,326,366,381,384,401$, 408-09, 410, 425, 432, 444, 460-61, 468, 469, 471-72

Federation Council 203

Federal Security Service

(Federalnaya Sluzhba Bezopasnosti, FSB) 107, 161-62, 185, 211, 215, 216, $235,266,364,367,374,385$

'foreign agents' 260, 291, 317, 373, 466

imperialism 1, 15, 19, 26, 27, 107, 159, 159n.30, 390 People's Freedom Party 201 regional influence $17,19,21,22$, 25, 99-101, 105, 106, 107, $160,169,249,270,271,274$, 283-84, 297 repression 185, 216, 217, 234-37, 242-43, 255, 256, 259-62, 266, 270, 285, 290-94, 294, 295, 330, 331, $358,360-61,385-86,416$ Rodina (Motherland) 212 Russia Today (RT) 359-60, 391, 435

Russki Newsweek, 100, 101

Russky Mir (Russian World) 454

Russlandversteher 341, 351, 363, $365,375,433$

Rzeczpospolita 199

Saakashvili, Mikheil 3-4, 94, 108, 206, 270, 297, 313-14, 320-21, 413-14

Sakharov Prize 311

Sannikov, Andrei 167

Sarajevo 396-97

Sargsyan, Serzh 304, 320, 321

Schabowsky, Günter 35

Schockenhoff, Andreas 326

Schröder, Gerhard 21, 135n.2, 227, 249, 325

Sechin, Igor 186, 205, 288

Secret Polish Army 65

Seidler, Fritz 67

Serbia vii Map 1, 212, 222, 271-72, 394-98, 419

Sestanovich, Stephen 361

Ševčovič, Maroš 472

Sherr, James 462

Shevchenko, Andriy 259

Shevtsova, Lilia 362

Shoah 57, 58

Shoigu, Sergey 335

Shuvalov, Igor 236

Sikorski, Radosław (Radek) 51, 54, 59, 104, 133, 138, 138n.16, 171,173 
Silesia 66

silovik (securocrat) 186, 214, 236, 287, 288, 290

Siluanov, Anton 408

Skolkovo 202, 205

Slovakia 21, 51, 56, 366, 377, 401, $419,434,467,471-72,473$

Slovenia vii Map 1

Śmietański, Piotr 74

Snow, C.P. 123

Snowden, Edward 300, 309-11, 332

Snyder, Timothy ln.1, 41, 75, 77, $305,318,420$

Sobchak, Anatoly 2, 245, 250 261-62

Sobchak, Ksenia 250, 261-62

Sobyanin, Sergei 122, 236

Solzhenitsyn, Aleksandr 215

sootechestvenniki (fellowcountrymen) 17, 36, 416

South Ossetia 3-4, 154, 159, 164, 171, 297, 312, 313-14, 364, 398, $409,413,415$

South Stream 152, 194, 227-28, 277-78, 325

Soviet Union 1, 3, 5, 7, 9, 11, 17, 18 , $19,22,26,31,34,39,40,41,42$, 43-44, 45, 46, 49, 50, 50n.2, 53, $55,56,57,65,69,71,72,73,76$, $77,81,82,84,85,91,93,94,95$, 99, 101, 103, 105, 107, 114, 123, $125,133,146,151,153,158$, $159,160,162-63,168,169-70$, 173-74, 175, 176, 177-78, 184, $185,187,188,192,196,197$, 201, 203, 204, 208, 210, 217, 222, 223, 227n.3, 233, 235, 237, 246, 250, 252, 254, 255, 257, $258,260,265,270,271,272$, 274, 275, 277, 280, 283, 284, 287, 293, 295, 297, 298, 299. $301,302,303,308,310,311$ $312,313,314,315,319,320$ $321,325,326,329,330,332$, $333,335,336,337,338,339$,
$340,342,351,357,358,359$, $361,36 \ln .7,363,365,374,378$, $379,382-83,384,385,387,388$, 393, 394, 401, 402, 403, 405, 407, 410, 413, 416, 417, 427, 438, 443, 444, 445, 446, 449, 450, 454, 456, 458, 460, 464 Sovershenno Sekretno 332 Sovetskaya Rossiya 293 spetsnaz (special) forces 331, 343 Srebrenica 271, 396, 397

St Petersburg 2, 203, 209, 210, 220, 233, 241, 245, 261, 270, 373

Stalin, Joseph 1n.1, 15, 26, 42, 43-45, 56, 63, 71-72, 74, 76-77, 80, 100, 101-02, 107, 112, 115, $125,144,185,192,263,294$, $305,308,329,337-38,344,358$, $365,372,385,390,402,407$, 409-10, 427, 432, 456, 469

Stalinism 1n.1 6, 15, 40, 41, 45, 49, 63-64, 72, 76-77, 86, 87, 102, 106-07, 109, 119, 125, 177, 193, $185,187-88,197,200,207,225$, 260, 287, 293-94, 345, 347, 358, $371-72,373,393,450,460$

Stasi 21, 13

Steinmeier, Frank-Walter 325-26, 392

Stepashin, Sergei 243

Stępień, Jan 74

Surkov, Vladislav 213, 230, 234, 447, 449-50

Svoboda 350

Sweden 11, 133, 314, 352, 401, 415 Syria 13, 15, 22, 25, 212, 249, 262, $271,307,326,393-94,398,451$ 452, 453, 455, 456, 461, 472, 473 szmalcownik (ethnic Polish blackmailer of Jews) 52

Tagliavini, Heidi 375

Tajikistan 223, 272, 299

Tallinn 12, 272, 333, 364, 378

Tarasiuk, Borys 164 
Tatarstan (Volga region) 267, 295

Tbilisi 94, 108, 147, 320, 399, 414,415

Tehran 456

Thatcher, Margaret 387

The Nation 246, 247, 349

The National Interest 246, 247

Timchenko, Gennady 330

titushki (hired thugs) 305, 346

Transatlantic Free Trade Area 300

Transcarpathian 467

Transcaucasus 314

Transnistria see Moldova

Transparency International 251

Trenin, Dmitry 390

Tsipras, Alexis 455

tsiviliki (civilian lawyers and economists) 290

Turchynov, Oleksandr 337, 347

Turgenev, Ivan 120

Turkey 24, 320, 452, 454, 456, 457,472

Turkmenistan 228

Tusk, Donald 8, 82, 91, 92, 93-96, 98-99, 102, 103, 105, 112, 113 , $129,130-31,133,134,138,198$, $429,435-36,173$

Tyhypko, Serhiy 158, 158n.27, 195 Tymoshenko, Yulia 6-7, 94, 134, $141,143-44,145,149,150-51$, $152,153,157,168,191,224-25$, 257-59, 278-79, 299

Ukraine 141-46, 147-65, 182, 19196, 311-12, 315-20, 335-53, 437-41, 459-74

and Crimea 8, 14, 16, 147, 152-

53, 155, 164, 172, 226, 276, 277, 301, 319, 329, 331, 333, $336,339,342-43,344-45$, $348,352,355-56,358,361$, $362,366,367,369,374,376$, 406-07, 408, 419, 433, 439, $459,462,464,467,470$ and NATO 3, 13, 105, 141, 147, $148,152,153,155,161,163$, $192,303,352,373$ and Poland 8, 94, 99, 104-05, 133-34, 277, 318, 320, 336, $339,340,341$

and Putin 6, 8, 11, 16-17, 94, $141,145,152,153,156,157$, 159n.30, 161, 161n.33, 163, 164, 165, 169, 171, 175, 182, 224, 258, 271, 275-76, 277, 278, 283, 300, 301, 303, 304, 305, 306, 311, 312, 315, 316-18, 319-20, 331-32, $333,335-36,338,340,341$, 346-47, 367, 368, 375, 376, 405, 406, 407, 408, 409, 420, 423, 424, 427, 441, 452, 468, $469,470,471,472$

and Russia 1n.1, 4, 8, 11, 14, 16, $17,19,20,21,22,27,93,99$, 100-01, 104-05, 107, 134, $141,142-43,147,151-55$, 156-57, 159, 160, 160n.31, 161-62, 161n.33, 163-65, 169, 171, 181, 182-83, 185, 192-93, 194, 195, 196, 200, 223, 224, 225, 227, 235, 271, 274, 275, 276-77, 278, 279-80, 282, 299, 300, 301, 303, 304-05, 306, 311, 312, 313-14, 315-18, 319-20, $324,331-33,335-48,349$, $350,352-53,355-56,357-$ $58,361,362,364,366-74$, 375-76, 377, 378, 379, 391, 392, 394, 399-400, 405-08, 409, 412, 417, 418, 419-20, 421, 422-24, 425-26, 427, $429,430,431-32,433$, 435-46, 437, 440, 441, 451$52,459,460,461,462-67$, 468-71, 472 
and the European Union 7, 10,

$12,25,133,134,143,147$,

151, 153-54, 157, 160, 16869, 170, 172, 182, 191, 192, 193, 194, 195, 223-25, 258,

277, 278, 279, 283, 298, 299, 305, 311, 314, 315, 316, 318, $319,324,325,326,340,341$, 352, 366, 371, 373, 377, 392, 419, 423, 429, 430, 431-32, 434, 468, 469-70

anti-Semitism 350-51, 357

Association Agreement 13, 14, 21, 134, 154, 193, 195, 223, 225, 299, 301, 304, 311, $315,318,340-41,352,366$, 403-04, 406, 423-24, 469

constitution 16, 20, 149, 150, 150n.18, 154, 156, 158n.27, $162,168,191,332,352,353$, 422,463

elections 6, 19-20, 94, 134, 141, $145,146,148,149-50,152$, $155,156,158,160,168,169$, 182, 257-59, 277, 278, 279, $301,303,306,312,317,335$, $339,347,370,371,378,406$, 407,451

ethno-linguistic map 142 Map 2 Greek Catholics 154, 276

Orange Revolution 6, 94, 104, 134, 141, 143, 155, 160, 168, $169,11,220,224,242,257$, 312,339

Party of Regions 94, 143, 149, 154, 156, 162, 168, 193, 224, 258, 259, 279, 318, 345, 347, 406

Radical Party (Ukraine) 370

Uniate Catholics 336

Ukrainian Insurgent Army (UPA) 46 Ulyanovsk 248

UN Human Rights Monitoring Mission 346
UN Security Council 184, 211, 271, 397

Union of Military Organisation 69, 71

Union State of Russia and Belarus 170,280

United Kingdom 14, 21, 37, 43, 44, $45,114,348,364,375,423,429$, 432,447

United Nations 177, 307, 421, 457

United States 2, 4, 7, 11, 12, 14, 15, $19,21,22,25,27,37,44,45$, $54,55,56,57,58,60,85,93$, 94, 99 100, 101, 106, 107, 109, 113, 114, 115, 135n.2, 141, 143, 146-47, 148, 151, 160, 162, 170, $175,176,177,191,205,212$, 220, 222, 227, 228, 241, 244, 246, 247, 248, 249, 263, 264, $269,271,272-74,285,286,287$ 289, 293, 294, 295-96, 297, 298, 299, 300, 302, 306, 308, 309, $310,311,312,316,326,330$, $348,349,350,362,364,374$, $375,377,378,387,388,389$, 392, 393, 398, 405, 423, 427, 428, 429, 429n.10, 430, 431, 432, $434,435,436,439,440,451$, $452,464,465,466,473$

United Russia party 124, 125, 162, 187, 203, 204, 208, 209-10, 214, $215,216,220,229,230,239$, 245, 255, 260, 262, 285, 287, 290

US Agency for International Development (USAID) 273

Ushakov, Yury 100, 101

Uzbekistan 272

van Heuvel, Katerina 246

Venediktov, Aleksei 234

Venezuela 154, 171, 178, 222, 349

Vilnius 64, 104, 299, 304, 315, 316, $319,322,324,378$

Vladivostok 254, 389 
Volgograd 287

Volodin, Vyacheslav 234, 236, 450

vranyo (lies) 342

Wajda, Andrzej 91-92

Wałęsa, Lech 31, 34, 81-82, 84, 119 , 132

Warnig, Matthias 21

Warsaw 8, 32, 37, 43, 44, 45, 50, $51,52,53,56,58,63,65,66,69$, 70, 71-72, 74, 75, 79, 82, 92, 94, $101,103,105,111,112,113-16$, 118-19, 120, 122, 134, 196, 198, 365,415

Warsaw Pact 12, 14, 18, 32, 227n.2, $385,392-93,460$

Warsaw University 79-80

Warsaw Uprising 43, 44

Wawel Castle 96

Weimar Germany 38

Weimar Triangle 105

Weitz, Aleksei 447

Westerplatte 95

Westerwelle, Guido 171, 325

Wiesel, Elie 58, 61

Wilanów Palace 119

Wilno (Vilnius) 64, 104

Wilson, Andrew 203

Wilson, Woodrow 37

Winter Olympics 2014, Sochi 254, 305, 306, 325

Wise, Stephen 55

World Jewish Congress 55

World Trade Organization (WTO) 153, 164, 316

World War I 37, 64, 82, 386

World War II 1, 9, 14, 19, 49, 64, $83,85,95,144,175,177,329$, $336,337,344,350,385,397$, $407,410,460,461$

Yad Vashem Holocaust Museum 58, 87

Yalta conference 15, 45, 46, 399, $426,427,432,440$
Yanukovych, Viktor 6, 7, 8, 94, 105, 108, 134, 137n.13, 141, 143-44, 145, 146, 146n.11, 147, 148-53, 150n.18, 154, 155, 156-58, 159, $160,161,162,163,164-65,168$, $169,170,172,182,191,192$, 193, 194, 195-96, 223-25, 227, 235, 257-59, 264, 277-80, 282, 299, 301, 303, 304-05, 311, 312, 315-20, 338, 339, 340, 343, 345, $346,347,350,352,358,363$, 366-68, 370, 406, 423, 424, 433, $463,470,471$

Yatseniuk, Arseny 158, 258, 305, 347, 371

Yeltsin, Boris 2, 5, 31, 170, 176, 182, 197, 210-11, 246, 249, 261, 276, 280, 308, 381-82, 383, 384, 389, $390,397,444$

Yukos Oil 168, 186, 205

Yushchenko, Viktor 6-7, 94, 99, 105, 141, 143-45, 148, 150, 152, $154,155,161,162,164,168$, $191,192,257,303,319,338,343$

Zakharchenko, Aleksandr 372

Zapad (West) 2009 298, 415

Zapad 2013 298, 415

Żegota 59

Zeman, Miloš 419, 441, 473

Zhirinovsky, Vladimir 209-10, 232, 291, 359

Zyuganov, Gennadi 219, 232 
